\title{
BRINGING LIGHT INTO THE DARKNESS: \\ AN INTELLECTUAL HISTORY OF TIBET'S DARK AGE (842-978 CE)
}

\author{
Manuel López \\ Málaga, Spain
}

Master of Arts, University of Virginia, 2003

Bachelor of Arts, Universitat Pompeu Fabra, 1999

\begin{abstract}
A Dissertation presented to the Graduate Faculty
of the University of Virginia in Candidacy for the Degree of

Doctor of Philosophy
\end{abstract}

Department of Religious Studies

University of Virginia

August 2014 


\section{Table of Contents}

Table of Contents ............................................................................................................. 2

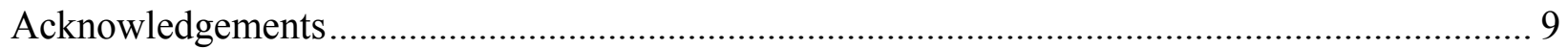

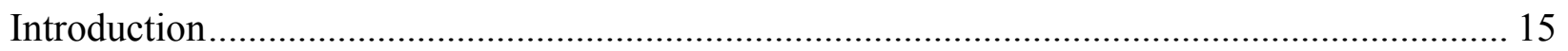

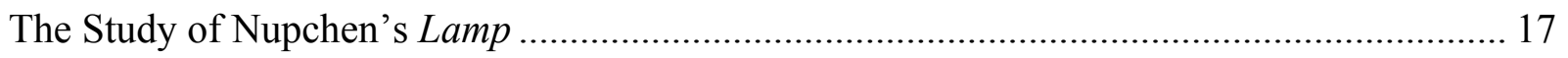

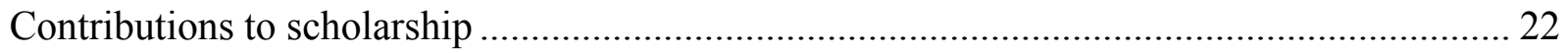

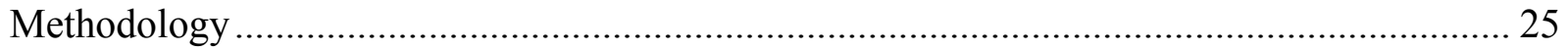

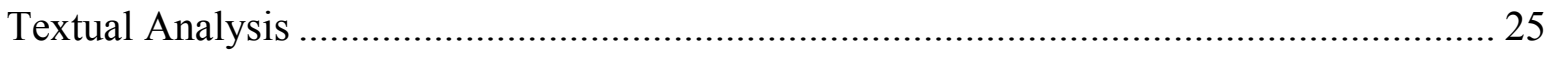

Historical Analysis........................................................................................... 26

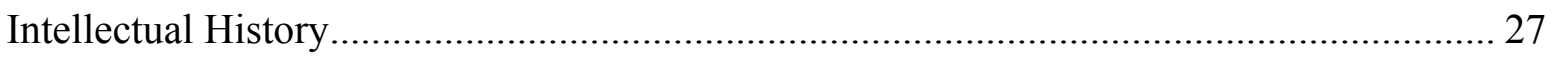

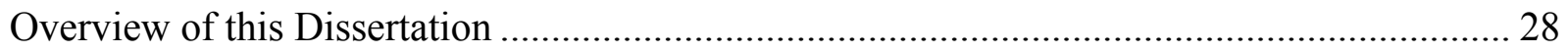

Chapter 1 - A Light in the Darkness: Nup Sangyé Yeshé and the Tibetan Dark Age............... 31

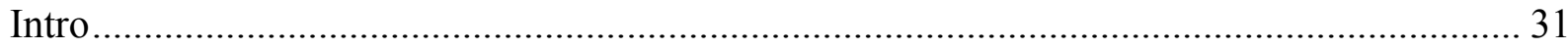

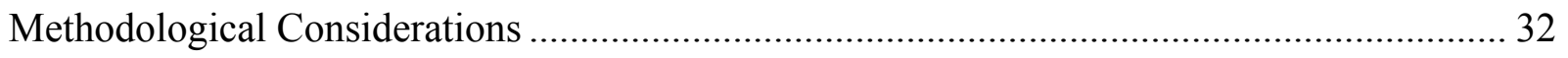

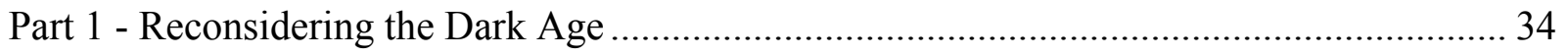

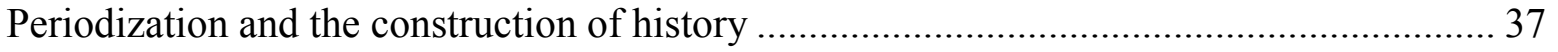

The End of an Era: The Collapse of the Tibetan Empire .............................................. 44

History as Narrative: the Creation of the Dark Age ..................................................... 55

Nupchen, the Dark Age, and the Tibetan Assimilation of Buddhism: A Reassesment....... 58 
Part 2 - The Unusually Long Life of Nupchen Sangyé Yeshé : Calendrical Issues, Lack of

Sources, and Turning a Problem into an Opportunity.

Autobiography, Biography, and Hagiography: Some Methodological Considerations ....... 71

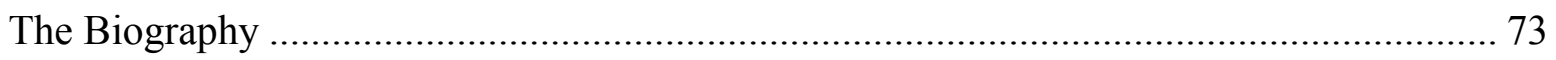

Birth and the Unexpected Role of a Chinese Monk ................................................. 73

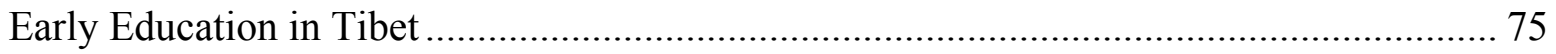

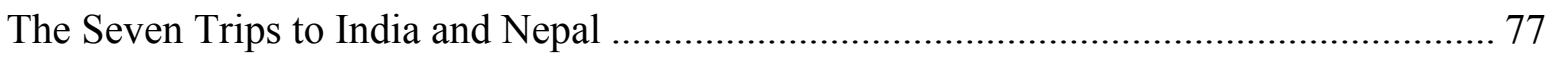

Return to Tibet and the Collapse of the Empire .......................................................... 77

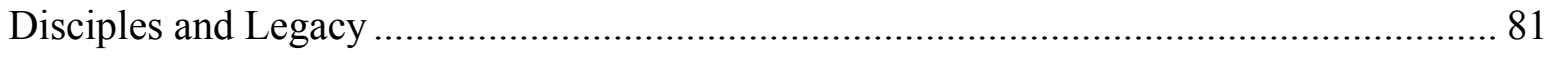

Part 3 - Nupchen's Works .................................................................................... 86

The Armor Against Darkness (Tib. Mun pa'i go cha) ..................................................... 89

Great Perfection Literature Commentaries: the Rig pa'i nyi ma and the rTse mo 'byung

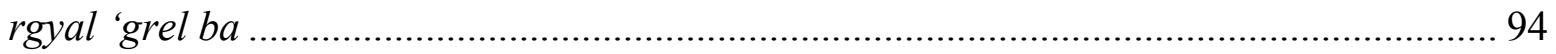

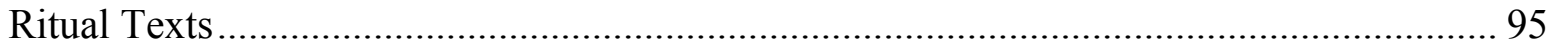

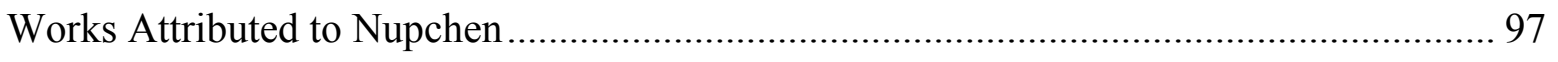

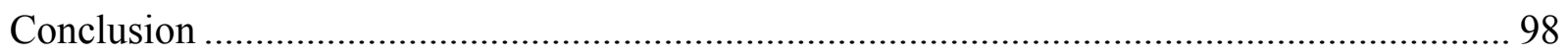

Chapter 2 - The Lamp for the Eye in Contemplation: Text and Contexts ............................... 99

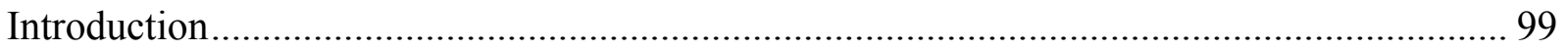

PART 1 - The Obscure Recension History of the Lamp for the Eye in Contemplation and the

Search for the Mysterious Lost Manuscript ................................................................. 100 
Recension History and Editions of the Lamp for the Eye in Contemplation..... 101

Authorship, Interlinear Notes, and the Transmission of the Lamp

PART 2 - A Text in Context: Buddhist Hermeneutics, Doxographies, and Order and

Creativity in the Lamp for the Eye in Contemplation

Doxographies: Solving a Buddhist Hermeneutical Problem

Early Tibetan Classifications 138

Nupchen's Lamp, the Emergence of the Great Perfection, and the Tibetan Assimilation of

Buddhism. 143

Why is Anuyoga not a Separate Vehicle in the Lamp?

Part 3 - A World of Texts: The Lamp for the Eye in Contemplation and the Textual World of the Dark Age Period 150

Intertextuality

Conclusion 155

Chapter 3 - Putting Meditation in Context: Practical Advice, Contemplative Techniques, and the

Final Goal 155

Introduction. 155

PART 1 - Getting Ready for a Meditation Retreat: Searching for the Ideal Place, Making a Commitment, and Removing Desires and Sorrows.

Where to Meditate: Sacred Geography and the Importance of the Retreat Location 159

Making a Commitment ..... 170

The Preliminaries (Tib. sngon du bya ba) 171 
Eliminating Desire and Overcoming Sorrow. 175

PART 2 - In Retreat: On Contemplative Methods, Teachers, Consorts, Books, and Servants.

The Various Contemplative Methods (Tib. thabs) .................................................... 176

The Four Harmonious Things to Rely On (Tib. mthun po bsten pa bzhi)...................... 181

Defeating Obstacles During Retreat and the Virtues of Meditation ............................... 186

PART 3 - The Essence of Meditation: Non-Conceptualization.......................................... 190

The Avikalpapraveśa-dhāraṇī and "Non-conceptuality" in Tibet .................................. 191

Non-Conceptuality and the Fourfold Structure of the Lamp for the Eye in Contemplation 195

Comparisson, Classification, and the Creation of Tradition....................................... 201

PART 4 - The Problem with Meditation............................................................................. 205

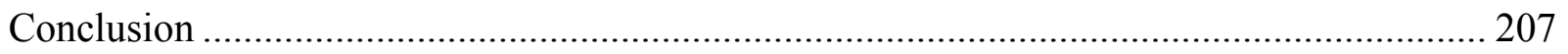

Chapter 4 - The Indian Gradual vs. the Chinese Sudden Traditions .................................... 208

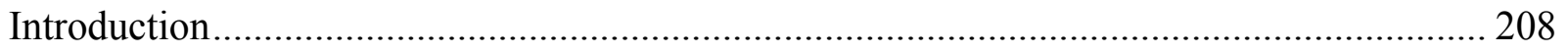

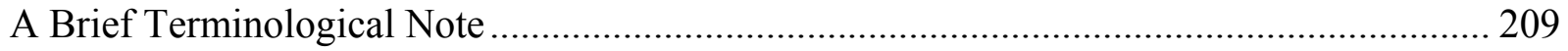

PART 1 - The Indian Gradual Tradition......................................................................... 210

Śāntarakșita and the Gradual Tradition in Tibet ............................................................ 210

Kamalaśîla and the Bhāvanākramas .................................................................... 216

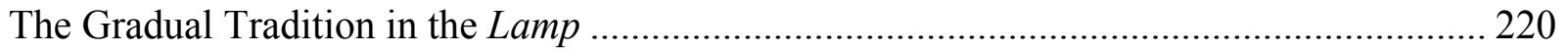

The Philosophical Views of the Indian Gradual Tradition (Tib. 1ta ba) ......................... 222 
Contemplative Practices in the Gradual Path (Tib. sgom pa) ...................................... 226

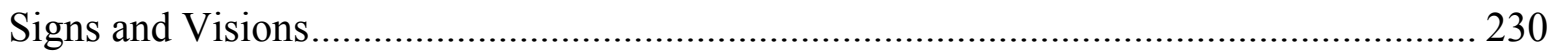

The Conduct (Tib. spyod pa) and the Result (Tib. 'bras bu) ........................................ 234

PART 2 - The Chinese Sudden Tradition ....................................................................... 235

The Arrival of Chan in Tibet .................................................................................. 235

The Dunhuang Library Cave and the Tibetan Chan Manuscripts .................................. 239

Reconstructing the Intellectual World of Chan in Tibet: Master Hashang Mahāyāna and

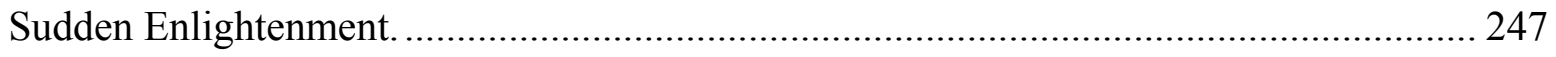

The Sudden Vehicle in the Lamp.................................................................................. 254

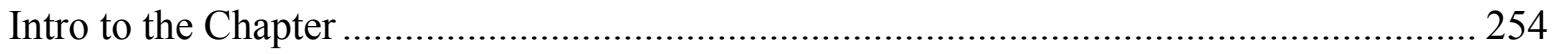

The Philosophical View of Chan (Tib. lta ba) ......................................................... 255

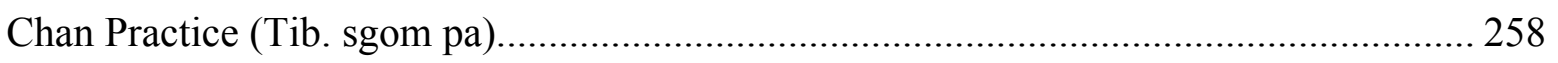

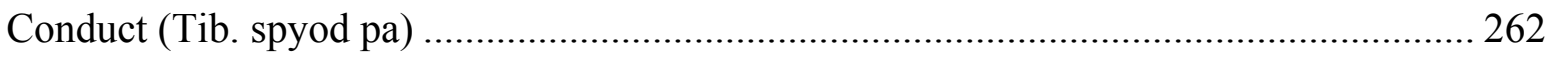

The Differences Between the Gradual and the Sudden .................................................. 263

The Samye Debate: Reexamining the Introduction of Buddhism in Tibet.......................... 265

Reconsidering Tibetan History: Demiéville's Le Concile de Lhasa ................................ 265

History or Historical Narrative?........................................................................ 269

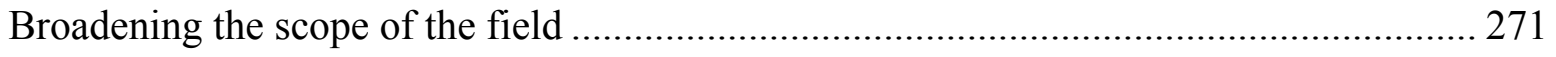

The Samye Debate in the Lamp for the Eye in Contemplation .................................... 273

Did Nupchen understand the Bhāvanākramas and Hashang Mahāyāna 's works? ................ 275 
Conclusion 277

Chapter 5 - The Triumph of Tantra and the Emergence of the Great Perfection Tradition in Tibet.

Intro. 278

Part 1 - Mahāyoga 281

The Emergence of Esoteric Buddhism in India 281

Pelyang's Six Lamps influence on Nupchen's understanding of Mahāyoga 290

Mahāyoga in the Lamp...... 296

The Philosophical View of Mahāyoga (Tib. lta ba) 298

The Contemplative Practices of Mahāyoga (Tib. sgom pa) 305

The Conduct and the Result (spyod pa and 'bras bu) 310

The Differences Between Mahāyoga and the Chinese Sudden Tradition

The Emergence of the Great Perfection Tradition in Tibet: An Alternative Approach to the Mystery of its Origins

The Complex Relationship of Atiyoga with Chan and Mahāyoga 315

The Need for a New Methodological Approach 320

The Great Perfection in the Lamp 325

Philosophical View (Tib. lta ba) 326

The Great Perfection's Contemplative Practices 340

The Conduct in Atiyoga (spyod pa) 344 


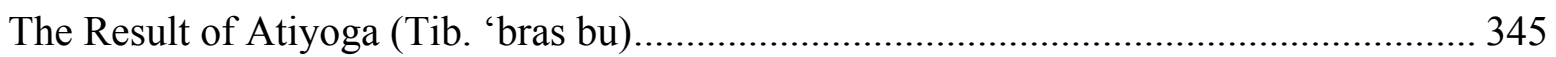

The Lamp and the Formation of the Great Perfection Literature Canon .............................. 348

The Story of the Eighteen Texts of the Mind ............................................................... 349

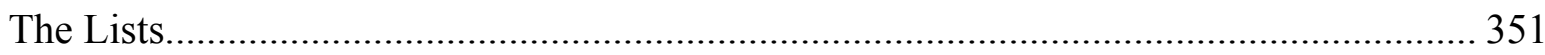

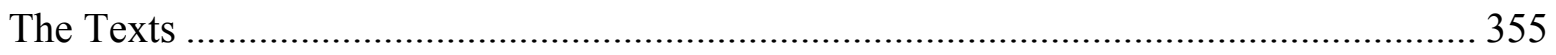

The Eighteen Texts of the Mind: Canon as an idea ................................................... 356

The Eighteen Texts of the Mind in the Lamp for the Eye in Contemplation ...................... 358

What is the Role of this Literature in the Early Development of the Great Perfection? .... 360

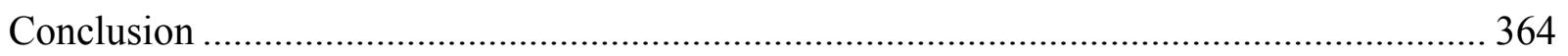

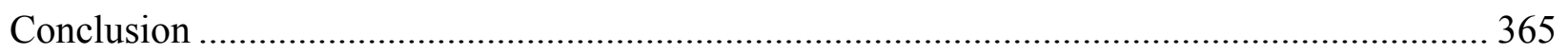

The Fate of Nupchen's Lamp for the Eye in Contemplation .............................................. 365

Nupchen's Lamp, the Construction of the Great Perfection Tradition, and the Tibetan

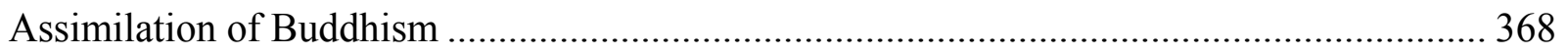

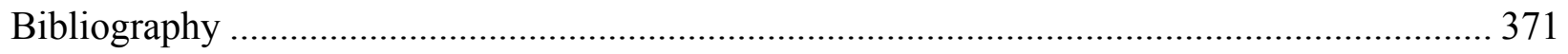

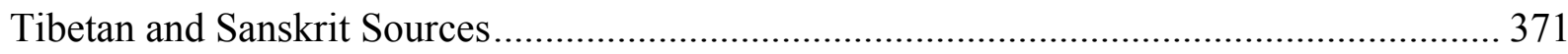

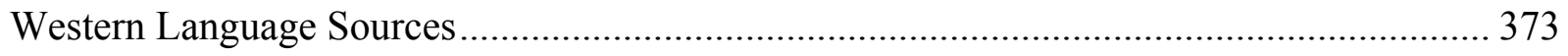




\section{Acknowledgements}

I, the beggar and novice Nup Sangyé Yeshé, have studied with many scholars from a wide variety of countries, such as many learned scholars from India, the King of Nepal, Vasudhara, and the translator from Brusha Chetsenkye [among others]. Having served and pleased them, I was able to obtain the permission [to learn from them], and by opening the treasure gate of their minds, [...] I became the King of the Esoteric Instructions. ${ }^{1}$

At the end of the Lamp, Nupchen thanks the many teachers who have helped him over the years with his studies in the far distant lands of India, Nepal, and Brusha (i.e. Gilgit). I will not claim, as Nupchen does, to have "opened the treasure gate of their minds," and needless to say, I have not become "the King of the Esoteric Instructions." I have had the privilege, though, of studying with a wide range of scholars all over the world, including my native Spain, India, Nepal, Tibet, China, and the United States, who have helped me with my understanding of Nupchen, his Lamp for the Eye in Contemplation, and the Great Perfection tradition.

First of all, I want to thank all of the members of my dissertation committee. Prof. Kurtis Schaeffer has offered to me incredible support and advice over the years. He read sections of the Lamp with me, and helped me navigate canonical sources in search of texts and quotes. I have never met anyone with his passion for Tibetan literature and his knowledge of Tibetan sources. In him I did not only find a mentor but, over the years, a friend. He is also a model of how to balanced academia and family life, while being good at both. Prof. David Germano has been instrumental in my understanding of the beauty and complexity of the early Great Perfection tradition. Incidentally, a class that I took with him in the Spring of 2002, in which four students

\footnotetext{
${ }^{1}$ Lamp 497.6-498.3: "bdag sprang po gnubs ban sangs rgyas ye shes rin po ches // rgya gar gyi mkhas pa paNDita mang po dang / bal po'i rgyal po ba su dh'a ra dang / gru zhwa'i yul gyi lo ts'a ba che btsan skyes la sogs pa rgyal khams so so'i mkhas pa mang po'i zhal brims te // mnyes pa phul bas paNDi ta rnams dgyes pa skyes te gnang ba thob pas / thugs kyi mdzod sgo phye nas / man ngag gi rgyal po dgongs don mthar gtugs pa bdag gis thob ste / bdag man ngag gi rgyal por gyur to/"
} 
met and read the work of the 14th century scholar Longchenpa once a week in his house, allowed me to know the most important person in my life, a fellow graduate student and my now wife, Pamela Novak. Prof. Paul Groner has always been supportive of my research, and given me helpful feedback not only on this dissertation, but on conference papers and job applications. With him, I have had the privilege of learning not only as his graduate student, but also as a teaching assistant for several of his courses. Prof. John Shepherd has been instrumental in expanding my understanding of religious phenomena, introducing me to a wide range of ethnographic and anthropological methodological approaches. Finally, the work of Prof. Jacob Dalton of University of California at Berkeley has been extremely influential in my understanding of Nupchen and the Dark Age period, and he has been incredibly generous in sharing his research and knowledge with me over the years.

Over the years, I have also been incredibly fortunate to have teachers, mentors, and friends that have made this project possible. In Spain, Prof. Dolors Folch of the University Pompeu Fabra (UPF) introduced me to the world of Chinese history and culture, a passion that has never left me. Prof. Amador Vega introduced me to the complex world of Asian religions, and was patient enough to suffer through my uncontrollable passion and innumerable questions. Prof. Ramon Prats, a visiting professor who also taught at UPF, introduced me to the world of Tibetan Buddhism. His passion and knowledge of the tradition opened up a world that I knew I needed to keep exploring, and that would, eventually, take me from my native Spain into a journey that lead to India, Nepal, Tibet, and the United States. At UPF I also met some incredible friends that shared my passion for Asian religions. First of all, I want to thank Ferran Mestanza, for being a friend and a partner during my early years in the field. We would spend hours discussing and trying to understand the intricacies of Tibetan religion in general, and of the Great 
Perfection in particular. With him I also did my first teaching retreat (with lama Namkhai Norbu) and my first trip to India and Nepal. Anna Busquets, a scholar of Chinese history, has always been a good friend, and was instrumental during my process of applying to the University of Virginia. She navigated the complexities of Spanish bureaucracy for me, while I was studying at Tibet University during the year 2000. During those early years in Spain, I also met fellow wandering scholar and friend, Antonio Terrone, an Italian student of Prof. Ramon Prats with whom I would cross paths over the years in Tibet, Nepal, and in the United States.

The faculty at the University of Virginia has always been supportive of my research in a variety of ways over the years. Prof. Karen Lang always had quick and good advice when I needed it. Prof. Larry Bouchard taught the most amazing seminar I have taken during my graduate years (Interpretation Theory), and what I learned during that class still influences the way I think about texts and religion. Professors Greg Goering, Matthew Hedstrom, Martien Halvorson-Taylor, Peter Ochs, Vanessa Ochs, Charles Matthews, Paul Jones, Jalane Schmidt, Heather Warren, and, in particular, Cynthia Hoehler-Fatton, offered great advice and support during the incredible stressful process of job hunting (as if writing this dissertation were not stressful enough!). The Religious Department staff also deserves to be acknowledged for their patience and help over the years: Elisabeth Smith solved ALL of my bureaucratic problems (and believe me, there have been many) on the spot and with a smile, and Doug Burgess and Mick Watson have always been patient when I brought my questions and problems to them.

At UVa, I have also been fortunate to meet an incredible group of young scholars and friends that have supported me over the years. Jann Ronis (the most talented graduate student I have ever met), Andres Montano (his online Tibetan dictionary is the single most important tool for any person trying to translate Tibetan), Chris Hatchell, Kimberly Dukes, Doug Duckworth, 
Carl Yamamoto, Tsering Wangchuk, Sarah Jacoby, William McGrath, Christina Robinson (with whom I co-founded the Buddhist Studies Group at the University of Virginia), Brenton Sullivan, David DiValerio, Gloria Chien, Rinchen Dorje, Benjamin McClintic (who enquired for me at the Calcutta University about the mysterious lost manuscript in which all present editions of the Lamp are based), Dominic Di Zinno (who also enquired about the lost original manuscript of the Lamp while studying at Sechen Monastery in Nepal), Alison Melnick, Ben Nourse, Natasha Mikles, Jed Verity, Michael Schuman (if you are looking for any Tibetan book, he has it!), and Tim Hartman (for his advice and support during the job hunting process).

During the six years (2003-2009) that I lived in Nepal working for the School for International Training (SIT), I was fortunate to have met an incredible group of scholars in the Tibetan studies field, including Hubert Decleer, Tashi Tsering (of the Amnye Machen Institute), Roberto Vitali, Lobsang Shastri (at the time head of the Tibetan Library of Works and Archives), and Lama Sonam (with whom I read the Great Perfection chapter of the Lamp in Tibetan for the first time). The staff working for SIT not only made my job easier, but made my love of Tibetan culture deepen even more: the language teachers in Dharamsala (Champa Chodron-la, Pema-la, Nyima-la, Tsering, and Tinley), Phuntsok (the best program assistant anyone could ask for), and Penba Tashi (the best tour guide in Tibet, bar none).

I do not want to forget other scholars who have helped me along the way. The late Gene Smith helped me early on with important textual sources on Nupchen, and even suggested while I was in Tibet studying the language for two years that I study at the University of Virginia. Prof. Jose Cabezón (University of California at Santa Barbara), one of the few people in the Tibetan Studies field with whom I can discuss Buddhism in Spanish, has always been supportive of my research. The research of Sam van Schaik, from the International Dunhuang Project at the British 
Library, has been crucial for my understanding of the Dark Age period, as well as of the early developments of the Great Perfection. Michael Sheehy, from the Tibetan Buddhist Resource Center (TBRC) helped me with my questions regarding the Nyingma collection, Extremely Extensive Spoken Teachings (Tib. bKa' ma shin tu rgyas pa). Kammie Takahashi's research on Pelyang has been very helpful for my understanding of Nupchen's nterpretation of Mahāyoga. I also want to thank the small but passionate group of scholars who have shared with me their passion for and research on Nupchen and the Lamp for the Eye in Contemplation. Otokawa Bunei, typed an electronic version of the Lamp that has been incredibly helpful during my study of the text (the transcriptions from the Lamp that I used in this dissertation come from his original input). Valeria Donati published a diplomatic edition and a translation of the Lamp in 2007, and answered my questions about her work early on in my research. Dylan Esler, who has been working on a critical edition of the Lamp, also shared some of his research with me and his dissertation will be a great addition to our knowledge of Nupchen's Lamp.

During my research year at Beijing's Minzu University, Prof. Tsering Thar and Prof. Yangmotso made time in their busy schedules and read Nupchen's biography with me. Prof. Drukhla read Kamalaśîla's Bhāvanākrama, and graduate student, Lobsang Thondup, helped me navigate Minzu University and read Nupchen's Lamp (in Beijing as well as in Charlottesville, during his year as a visiting scholar at UVa) with me, a text also at the heart of his dissertation research. During my two visits to Tibet, Karma Delek, the head of the Peltsek Reseach Center on Tibetan Language and Ancient Texts (Tib. dPal brtsegs bod yig dpe rnying zhib 'jug khang), in Lhasa, and one of the main Tibetan scholars who have studied the figure of Nupchen Sangyé Yeshé, was also extremely helpful and generous with his time. 
También quiero agradecer especialmente el apoyo de mis padres, Antonio López y Maribel Zafra, que me han apoyado todos estos años incluso cuando mi pasión por el Tibet me ha llevado lejos de mi país natal. Sé que no ha sido siempre fácil para vosotros el tenerme en tierras lejanas, aunque quiero que sepáis que la distancia no disminuye mi gratitud ni el amor que os tengo. Macu, que no sólo es mi mejor amiga y la hermana que nunca tuve (y my "best woman" en mi boda!), también ha jugado un papel muy importante en mi vida. Siempre me apoyó en tiempos difíciles cuando no tenía muy claro que camino debía tomar, y me ayudó a navegar periodos de confusión.

My American family has also been incredibly supportive over the years. I have the best in-laws anyone can ask for: John Novak and Rose Novak welcomed me into their family from the day they met me, and helped Pam and me over the years when we needed help the most (and this includes the birth of our three children and the writing of this dissertation). My sister-in-law, Emily Novak, and brother-in-law, Drew Waight, have always been welcoming in their apartments in New York and San Francisco when we needed a place to stay when coming back from Asia, or attending a conference.

Finally I want to dedicate this dissertation to my family. My wife, Pamela Novak, has been incredibly supportive and patient over the years. She is a true partner in love and life, with whom I have studied (at UVa), taught (at SIT), and traveled all across Asia. She also has been my unpaid editor and reader over the years (including this dissertation), and has suffered through my persistent grammatical mistakes. And to our three wonderful kids, Sophia, Dylan, and Isabel, for bringing craziness and sanity to my life... at the same time. 


\section{Introduction}

This dissertation is a textual, historical, and philosophical analysis of the The Lamp for the Eye in Contemplation ${ }^{2}$ (Tib. bSam gtan mig sgron), a $10^{\text {th }}$ century doxography (i.e. classification of philosophical views) written by the Tibetan scholar, Nupchen Sangyé Yeshé (Tib. gNubs chen sangs rgyas ye shes). Nupchen discusses and compares in the Lamp the main Buddhist traditions that had been imported into Tibet since the early introduction of Buddhism in the 7th century all the way to his own time. Those traditions, which Nupchen ranks hierarchically according to their soteriological effectiveness are: 1) the Gradual Approach (Tib. tsen men rim gyis 'jug pa), which describes the traditional Mahāyāna textual and scholastic tradition coming mainly from India; 2) the Instantaneous, or Sudden Approach (Tib. ston mun cig car 'jug pa), represented by Chinese Chan; 3) Mahāyoga (Tib. rnal 'byor chen po), the new tantric developments that had become popular during this period all across Asia, starting in the $7^{\text {th }}$ century; and, finally, 4) Atiyoga, or the Great Perfection (Tib. rdzogs pa chen po), a new and emerging tradition that presents itself, at least rhetorically, as a rejection of all types of practice.

I have two main goals in this dissertation. The first one is to offer an intellectual history of the period in which the Lamp was written, the so-called Dark Age period of Tibetan history (842-978 CE), and argue for its central role in the assimilation and transformation of Buddhism in Tibet. Buddhism was imported into Tibet as part of the great military, economic, and cultural transformation that the Land of Snows underwent during the Imperial era (618-842 CE), which culminated with the establishment of this foreign tradition as the official state religion in the $8^{\text {th }}$ century. The collapse of the Tibetan Empire in $842 \mathrm{CE}$ has been described in traditional Tibetan historiography, and by most contemporary scholars in the Tibetan Studies field, as a period of

\footnotetext{
${ }^{2}$ I will refer to the text from now on simply as the Lamp.
} 
intellectual decay, in which Buddhism almost disappeared from the Tibetan plateau. My dissertation will argue that the so-called Dark Age is a label that obscures more than illuminates the significant transformation that Buddhism underwent in Tibet during this period. The collapse of the Empire allowed Tibetans to transform what had been a foreign religion imposed by the state through a few monastic sponsored institutions, into a vehicle that was able to express genuine Tibetan religious ideas and concerns: Buddhism in the Dark Age became Tibetan Buddhism.

My second goal is to argue for the central role played by Nupchen and, in particular, by his Lamp, in the construction of the early identity of the new Great Perfection tradition. As the scholar of religion, Jonathan Smith, points out, "The world is not a given, it is not simply 'there.' We constitute it by acts of interpretation. We constitute it by activities of speech and memory and judgment. It is by an act of human will, through projects of language and history, through words and memory, that we fabricate the world and ourselves." ${ }^{3}$ This dissertation argues that Nupchen's Lamp is such a project of interpretation, and of construction of a new (Buddhist) worldview. While the Great Perfection had existed prior to Nupchen as a particular approach to contemplative practice within the Mahāyoga tradition, the Lamp is the first Tibetan text in which we find this tradition discussed as a different and separate Buddhist vehicle (Tib. theg pa), with its own philosophical view (Tib. lta ba), set of scriptures, contemplative practices (Tib. sgom pa), ethics (Tib. spyod pa), and soteriological goals (Tib. 'bras bu). ${ }^{4}$ The Lamp functions as a manifesto of sorts, in which Nupchen articulates the ideas of this new emergent movement and proclaims its superiority over all other previous Buddhist traditions. In the Lamp, Nupchen is

\footnotetext{
${ }^{3}$ Jonathan Z. Smith, "Playful Acts of Imagination," Liberal Education 73, no. 5 (1987), p. 14.

4 Sam van Schaik, "The Early Days of the Great Perfection," Journal of the International Association of Buddhist Studies 27, no. 1 (2004): 178.
} 
constructing a new and unique overview of the Buddhist path that responded to the unique historical, social, and intellectual context of 10th century Tibet.

\section{The Study of Nupchen's Lamp}

Scholarly attention on Nupchen's Lamp began in 1974, with the publication in India of a copy of the text that had survived the destruction of the Chinese Cultural Revolution in Tibet ${ }^{5}$. The value of the text was readily acknowledged in the preface by Gene Smith, who argued that this "treatise on the various approaches to Buddhist realization focusing upon the methods of Rdzogs-chen by the famed Gnubs-chen Sangs-rgyas-ye-shes, may well prove to be one of the most significant events in Tibetological research during the present decade." ${ }^{6}$ Smith also highlighted the relevance of the text for our understanding of the history of Chan Buddhism in Tibet, since it contained "considerable data about the famed controversy that was resolved at the Council of Lhasa when the Chinese proponents of the [sudden approach] were defeated by the Indian advocates of the [gradual approach]."7

The Lamp's chapter dedicated to the Chan tradition promptly caught the attention of Japanese scholars like Ueyama, ${ }^{8}$ Okimoto, ${ }^{9}$ and Kimura ${ }^{10}$, who, as early as 1976 , published

\footnotetext{
${ }^{5}$ Sangs rgyas ye shes Nupchen Sangye Yeshe (gNnubs chen sangs rgyas ye shes), rNal Byor Mig Gi Bsam Gtan, Or, bSam Gtan Mig Sgron: A Treatise on Bhāvana and Dhyāna and the Relationships between the Various Approaches to Buddhist Contemplative Practice, ed. S. W. Tashigangpa (Leh: smanrtsis shesrig spendzod, 1974). The text was published by S.W. Tashigangpa with the help of Gene Smith and his project as field officer in India for the Library of Congress to fund the printing of Tibetan books under Public Law 480.

${ }^{6}$ Smith, Gene, Preface to the Nupchen Sangye Yeshe (gNnubs chen sangs rgyas ye shes), Rnal Byor Mig Gi Bsam Gtan, Or, Bsam Gtan Mig Sgron: A Treatise on Bhavana and Dhyana and the Relationships between the Various Approaches to Buddhist Contemplative Practice.

${ }^{7}$ Ibid. Preface.

${ }^{8}$ Ueyama mentions in his review of Tibetan Chan manuscripts recovered from Dunhuang how Gene Smith gave a copy of the text to the Japanese scholar Yoshiro Imaeda in 1974 and that he "informed Japanese scholars of its
} 
articles highlighting the connection of this chapter with other Dunhuang manuscripts, like PT116, and the then recently discovered Dunwu dasheng zhengli jue (Ch. 頓悟大乘正理決), a text that also centered on the so-called Samye Debate. In the words of Ueyama, "from these discoveries interest in the transmission of Ch'an to Tibet and the Tibetan Tun-huang documents pertaining to Ch'an escalated rapidly, and these textual discoveries gained recognition as extremely important both as source materials for the study of early Ch'an and as historical data which might clarify the actual circumstances of the early transmission of Buddhism to Tibet." ${ }^{11}$ As relevant as this early research was, it was circumscribed to the importance of the Lamp for our understanding of early Chinese Chan, the history of Chan in Tibet, particularly around the so-called Samye Debate, and as evidence to search for an "explanation of the Buddhist tantric doctrines, such as Rdzogs chen and Mahāyoga, and their fusion with Tibetan Ch'an."12

In 1983 Guenther, in his "'Meditation' Trends in Early Tibet," made the first attempt at exploring the central theme of the Lamp, the various Buddhist approaches to contemplation. While the article clearly follows some of the early Japanese interest in the Lamp as an historical

existence." Daishun Ueyama, "The Study of Tibetan Ch'an Manuscripts Recovered from Tun-Huang: A Review of the Field and Its Prospects," in Early Ch'an in China and Tibet, ed. Whalen Lai and Lewis R. Lancaster, vol. 5, Berkeley Buddhist Studies Series (Berkeley: Lancaster Publications, 1983), 346 n. 7.

${ }^{9}$ See Okimoto, Katsumi 沖本克己.“Bsamyas no shuron (1), Pelliot 116 ni tsuite bsam yas の宗論(J), Pelliot 116 について[TheReligious Debate at Bsam yas (1); Pelliot 116]." Nihon chibeto gakkai kaiha 日本西蔵事曾曾報 21(March 1975): 5-8, and Katsumi Okimoto, "bSam Yas No Shuron (2): Tonko Chibetto Bunken Ni Okeru Shozenji," [The Religious Debate of bSam yas 920, The Various Ch'an Masters in the Tibetan Documents from Dunhuang] Nihon Chibetto Gakkai Kaihō 22 (March 1976): 4-8, which compares PT116, the blon po bka'i thang yig, and the Lamp and, in particular, the names of Chinese Chan masters found in each of the texts; and Katsumi Okimoto, “Chibetto Yaku Ninyū Shigyō Ron Ni Tsuite チベット訳二人四行論について [Concerning the Tibetan Translation of the Erh-ju Ssu-hsing Lun]," Nihon Indogaku Bukkyō Kenkyū 24, no. 2 (March 1976): 992999, in which Okimoto claims that many of the Chan masters found in the Blon po bka'i thang yig and the Lamp are copied from Bodhidharma's Treatise of the Two Entrances and Four Practices (Ch. 二人四行說).

${ }^{10}$ Ryūtoku Kimura, "Tonkō Shutsudi Chibetto Bun Shahon Stein 709 [The Tun-Huang Tibetan Manuscript Stein 709]," Nihon Chibetto Gakkai Kaihō 22 (March 1976): 11-13.

${ }^{11}$ Daishun Ueyama, "The Study of Tibetan Ch'an Manuscripts Recovered from Tun-huang: A Review of the Field and Its Prospects," in Early Ch'an in China and Tibet, vol. 5, Berkeley Buddhist Studies Series (Berkeley: Lancaster Publications, 1983), p. 328.

${ }^{12}$ Ibid., p. 344. 
source for our study of the Samye Debate, ${ }^{13}$ and the Gradual vs. Sudden controversy in Tibet, his main aim was to offer a phenomenological interpretation of Nupchen's overview of the different approaches to meditation (Tib. bsam gtan) as found in Tibet during the early introduction of Buddhism in Tibet. It was not until the publication in 1988 of Samten Karmay's groundbreaking study, The Great Perfection, that we find a substantial examination of the text. Karmay understood the centrality of Nupchen's Lamp for our understanding of the intellectual developments that had taken place after the collapse of the Tibetan Empire, as well as Nupchen's relevance in the establishment of the Great Perfection by the tenth century as "a well-established philosophical doctrine,"14 that was not simply a Tibetan reinterpretation of Chinese Chan.

Following in Karmay's footsteps, scholars like Germano ${ }^{15}$, Meinert, van Schaik ${ }^{16}$, and Dalton $^{17}$, have used the Lamp to further explore the origins of the Great Perfection and its complex relationship to other Buddhist traditions, like Chan ${ }^{18}$ and Mahāyoga, ${ }^{19}$ as well as to

\footnotetext{
${ }^{13}$ On the first page of the article, Guenther argues for the need to question the historicity of the Samye debate, writing that "additional support for [doubting the historicity of the Debate] as well as for the fact that the alleged victor, Kamalaśíla, did not make such an impact on the intellectual life as is claimed by later [Indian] protagonists [...] is provided by Gnubs-chen Sang-rgyas ye śes." In Herbert V. Guenther's “"Meditation' Trends in Early Tibet," in Early Ch'an in China and Tibet, Berkeley Buddhist Studies Series (Berkeley, Ca.: Asian Humanities Press, 1983), p. 351.

${ }^{14}$ Samten Gyaltsen Karmay, The Great Perfection (rDzogs Chen): A Philosophical and Meditative Teaching of Tibetan Buddhism (Leiden - New York: E.J. Brill, 1988), 12. Although he interestingly adds, “...nevertheless [the great perfection] always remained a side development of the mainstream of tantric Buddhism in the period." ${ }^{15}$ David Germano, "Architecture and Absence in the Secret Tantric History of rDzogs Chen," The Journal of the International Association of Buddhist Studies 17, no. 2 (1994): 203-335; ibid.; David Germano, Mysticism and Rhetoric in the Great Perfection (rDzogs Chen) (Unpublished Manuscript, 2009).

${ }^{16}$ Van Schaik, Sam. "The Early Days of the Great Perfection." Journal of the International Association of Buddhist Studies 27, no. 1 (2004): 165-206. See also van Schaik's "The Resolution of the Simultaneous and Gradual Approaches to the Great Perfection in the Klong Chen Snying Thig." In Religion and Secular Culture in Tibet (Proceedings of the Ninth Seminar of the International Association for Tibetan Studies, edited by Henk Blezer, 30920. Leiden: EJ Brill, 2002, and van Schaik's “Dzogchen, Chan and the Question of Influence," Revue d'Etudes Tibétaines 24 (October 2012): 5-20.

${ }^{17}$ Dalton, Jacob. "The Development of Perfection: The Interiorization of Buddhist Ritual in the Eighth and Ninth Centuries." Journal of Indian Philosophy 32, no. 1 (2004): 1-30. See also Dalton's "Rethinking Tibet's Dark Age: Demons, Tantras, and the Formation of Tibetan Buddhism." 2008, and Dalton and van Schaik's "Lighting the Lamp: The Structure of the Bsam Gtan Mig Sgron." Acta Orientalia 64 (2003): 153-75.

${ }^{18}$ Carmen Meinert, "Chinesische Chan- Und Tibetische rDzogs Chen-Lehre: Eine Komparatistische Untersuchung Im Lichte Des Philosophischen Heilskonzeptes 'Nicht-Vorstellen' Anhand Der Dunhuang-Dokumente Des Chinesischen Chan-Meister Wolun Und Des Werkes bSam Gtan Mig Sgron Des Tibetischen Gelehrten gNubs Chen
} 
dispel traditional notions about the "Dark Age," showing how Tibetans were still actively importing, translating, and interpreting Buddhist works during this era.

Dalton and van Schaik's contributions are particularly significant. In 2003 they published a translation of chapter 3 of the $L a m p,{ }^{20}$ in which they analyzed the overall structure of the text. Dalton is only one of the few scholars who have also studied Nupchen's other great surviving work, the Armor Against Darkness (Tib. Mun pa'i go cha), a commentary on the main text of the Anuyoga tradition, the Sütra of the Gathered Intentions (Tib. dGongs pa 'dus pa'i mdo). He has also published the only scholarly study of the recently re-discovered autobiography of Nupchen, The Testament of Nup (Tib. gNubs kyi bka' shog chen mo). ${ }^{21}$ His recent book, The Taming of the Demons, dedicates a chapter to Nupchen, and uses his work as evidence of the relevant and creative Buddhist work that was being produced in Tibet during the so-called Dark Age. ${ }^{22}$

Sangs Rgyas Ye Shes" (Rheinischen Friedrich-Wilhelms-Universität, 2004). See also Meinert's "Chinese Chan and Tibetan Rdzogs Chen: Preliminary Remarks on Two Tibetan Dunhuang Manuscripts." In Religion and Secular Culture in Tibet, edited by H. Blezer, 289-307. Leiden: Brill, 2002, and Meinert's "The Conjunction of Chinese Chan and Tibetan Rdzogs Chen Thought: Reflections on the Tibetan Dunhuang Manuscripts Iol Tib J 689-1 and Pt 699." In Contributions to the Cultural History of Early Tibet, edited by Matthew T. Kapstein and Brandon Dotson, 239-301. Leiden/Boston: Brill, 2007.

${ }^{19}$ Jacob Dalton and Sam van Schaik, "Where Chan and Tantra Meet: Buddhist Syncretism in Dunhuang," in The Silk Road: Trade,Travel, War and Faith (London: British Library Press, 2004), 61-71.

${ }^{20}$ Jacob Dalton and Sam van Schaik, "Lighting the Lamp: The Structure of the Bsam Gtan Mig Sgron," Acta Orientalia 64 (2003): 153-75. That same year Meinert also published an article in which she "proposed to understand [the doxographical classification of the Lamp] through the fourfold correct practice as it is also taught in the Āryāvikalpapraveśanāmadhāraṇī." See Meinert's "Structural Analysis of the bSam Gtan Mig Sgron: A Comparison of the Fourfold Correct Practice in the Āryāvikalpapraveśanāmadhāraṇī and the Contents of the Four Main Chapters of the bSam Gtan Mig Sgron," Journal of the International Association of Buddhist Studies 26, no. 1 (2003): 175-95. Dalton also published an article in which he situated Nupchen's Lamp in the context of previous doxographical works in India and Tibet. In Jacob Dalton's "A Crisis of Doxography: How Tibetans Organized Tantra During the 8th-12th Centuries," Journal of the International Association of Buddhist Studies 28, no. 1 (2005): $115-81$.

${ }^{21}$ Jacob Dalton, "Preliminary Remarks on a Newly Discovered Biography of Gnubs Chen Sangs Rgyas Ye Shes," ed. Andrew Quintman and Benjamin Bogin (Somerville, MA: Wisdom Publications, forthcoming).

${ }^{22}$ See chapter 2 of Jacob Paul Dalton's The Taming of the Demons: Violence and Liberation in Tibetan Buddhism (New Haven: Yale University Press, 2011). 
Additionally, two Italian scholars have recently done some very important work on the Lamp: Baroetto ${ }^{23}$ has done a critical edition and a translation of chapter 7, dedicated to the Great Perfection, and Donati ${ }^{24}$ has recently finished a doctoral dissertation that includes a diplomatic edition of the text, as well as an impressive first attempt at translating the text, although her work offers little in the way of interpretation. ${ }^{25}$ Dylan Esler, a graduate student at the Université Catholique de Louvain, is working on a critical edition of the text for his dissertation and has published several articles on Nupchen. ${ }^{26}$ Tibetans also seem to have a renewed interest in this text, as shown in the publication of a recent commentary on the text by Khenchen Palden Sherab Rinpoche ${ }^{27}$.

\footnotetext{
${ }^{23}$ Baroetto, Giuseppe. La Dottrina dell' atiyoga nel bsam gtan mig sgron di gnubs sangs rgyas ye shes, selfpublished at lulu.com, 2010.

${ }^{24}$ Donati, Valeria. "The Lamp Is Burning Bright. Gnoseological Approaches and Soteriological Perspectives in Gnubs Chen Sangs Rgyas Ye She's Masterpiece." Università degli Studi di Napoli 2007.

${ }^{25}$ The dissertation is barely one hundred pages.

${ }^{26}$ Dylan Esler, "The Exposition of Atiyoga in Nubs-Chen Sangs-Rgyas Ye-Shes' bSam-Gtan Mig-Sgron," Revue d'Etudes Tibétaines 24, Studies in the Sems sde tradition of rDzogs chen, Ed. Jean-Luc Achard (October 2012): 81136.

${ }^{27}$ Gnubs chen sangs rgyas ye shes kyi bsam gtan mig sgron le'u rnams kyi spyi bshad mdor bsdus shes rab mig 'byed (Opening the Eyes of Wisdom, A Commentary on Sangyé Yeshé's Lamp of the Eye of Contemplation).
} 


\section{Contributions to scholarship}

I believe that my research on Nupchen's Lamp can contribute to our understanding of this remarkable figure, his work, as well as of the historical period in which he lived by focusing on five different areas:

1) Reexamining the life of Nupchen: This dissertation includes a study of the largest biographical account of the life of Nupchen found in the Tibetan historical record, the recently rediscovered Testament of Nup (Tib. gNubs kyi bka'shog chen mo). While we need to be careful in our methodological approach to a text that, although presented as an autobiography, was probably written centuries after the death of Nupchen, the Testament offers very important clues as to how the Tibetan tradition, and in particular the Nyingma School, saw this figure and the historical period in which he lived.

2) Reconsidering the Tibetan Dark Age: My research is part of a recent trend in Tibetan Studies that is re-evaluating the process of assimilation of Buddhism in Tibet and, in particular, the role played by the Dark Age in this process. Tibetan historians have traditionally viewed Tibet's Dark Age as one of political and cultural decline, following the collapse of the Tibetan empire. ${ }^{28}$ The Lamp clearly demonstrates that Buddhism had not simply disappeared from Tibet, as later sources want us to believe. Its institutions had obviously suffered, and patronage for the introduction and translation of new texts from other parts of Asia had suffered greatly, but Nupchen's text reveals a significant amount of Buddhist activity during this period. A key aspect for this reassessment is the reconstruction, at least from Nupchen's perspective, of the intellectual and textual world that he inhabited,

\footnotetext{
${ }^{28}$ An example of this type of perception of the Dark Age found in popular traditional sources can be found in Sakya Sonam Gyaltsen's $14^{\text {th }}$ century The Clear Mirror: "King Langdarma launched the suppression of the Dharma in the Iron-female-bird Year (901), and as the embers of the Teaching were also retrieved in an Iron-female-bird Year, it is said that the Dharma disappeared from U and Tsang for nine calendrical cycles," p. 271.
} 
which is possible to a great extent because his treatise is highly intertextual, containing close to 800 quotations from almost 200 different texts, many of which are no longer extant. This makes the Lamp the single most important source available to us for our understanding of the intellectual and textual world of the period.

3) The introduction and assimilation of Buddhism in Tibet: the Lamp is the most detailed account of the diversity of Buddhist traditions introduced in Tibet (from India, Central Asia, and China) in the $7^{\text {th }}$ through $10^{\text {th }}$ centuries. Nupchen's text can help us reconsider historical depictions (traditional and contemporary alike) that present Buddhism in Tibet as, mainly, an Indian import. The Lamp undermines this traditional Tibetan narrative by showing how traditions were being introduced from all parts of Asia (India, China, Central Asia), allowing us to view Tibet during this era as a fertile ground for competing ideas from very different parts of Asia (again, India, China, Central Asia), as well as the beginning of a Tibetanspecific appropriation and reinterpretation of the Buddhist path ${ }^{29}$. The understanding of a Buddhist world that did not limit itself to India, but that was part of the social and religious fabric of Asia, may help us to better contextualize the textual world described in the Lamp, and also help us broaden the historical framework by which we study early Tibetan history and the introduction of Buddhism in Tibet. This approach would not challenge the enormous influence that the Indian Buddhist tradition played on Tibet, but would offer an alternative model in which Tibet was at the center of a more complex Buddhist network and where teachers, texts, and teachings came from many different venues.

4) A study of the role of Nupchen and the Lamp in the emergence and construction of the Great Perfection tradition as an independent tradition: As I have

\footnotetext{
${ }^{29}$ Kapstein, Ibid, p. 70.
} 
mentioned, scholars, such as Karmay, Germano, Meinert, Dalton and van Schaik, have studied the complex relationship of the Great Perfection tradition with Chinese Chan and Mahāyoga. In this dissertation, though, I want to focus on the specific role that a figure like Nupchen and, in particular, the Lamp had in extricating the Great Perfection from its doctrinal, social, and intellectual relations to those Buddhist traditions in order to create a distinctive and separate tradition. I believe this way of reading our text will help us by problematizing Nupchen's narrative, by looking at it not as an inevitable, inner-driven, theological Buddhist interpretation of the tradition, but by looking at it in a very specific social and historical context, and especially as an attempt to construct a worldview that translated the needs of a new, evolving culture.

\section{5) I also want my dissertation to contribute to our understanding of the Buddhist} intellectual landscape in Asia at the turn of the first millennium. Nupchen's Lamp offers a unique overview and analysis of some of the most important Buddhist doctrinal debates that were taking place in Asia during this period, such as the doctrinal tensions between the gradual vs. sudden approaches to enlightenment, represented by the Indian and the Chinese traditions respectively, and the ethical issues raised by the transgressive but enormously popular ritual and meditative practices of the Indian tantric tradition, with its pervasive use of violent and sexual language and imagery. While the perspective of Nupchen on these debates is uniquely Tibetan and quite partisan (he is an advocate of the Tibetan Great Perfection tradition), there is no doubt that a study of his discussion of the doctrines and textual sources of the various Asian Buddhist traditions will be an important contribution to our knowledge of the intellectual history of Buddhism during this period. 


\section{Methodology}

\section{Textual Analysis}

In the study of any text, but in particular in the case of a text that is over a thousand years old and with an obscure recension history, it is of paramount importance to begin any serious research with a formal textual analysis of the text. As Martin West has said about Greek and Latin works:

[T] extual criticism is not the be-all and end-all of classical scholarship, which is the study of a civilization. But it is an indispensable part of it. By far the greater part of our knowledge of that civilization comes to us from what the ancients wrote. In almost all cases those writings have survived, if they have survived at all, only in copies many stages removed from the originals, copies of which not a single one is free from error. Often errors are so great that it is no longer possible to tell what the author meant to say. It follows that anyone who wants to make serious use of ancient texts must pay attention to the uncertainties of the transmission [...] if he is not interested in the authenticity and dependability of the details, he may be a true lover of beauty, but he is not a serious student of antiquity.",30

My dissertation is not a philological project per se (Donati's and Esler's dissertations are more focused on that approach to the Lamp), but, as Jan Nattier argues in her study of the Inquiry of Urga (Skt. Ugrapariprcchā-sütra) in A Few Good $\mathrm{Men}^{31}$, "we must first consider several methodological issues involved in using scriptural sources to reconstruct social history."32 The second chapter of this dissertation will address important textual concerns, including the obscure recension history of the text, as a foundation for my main goal, which is an exploration of the intellectual history of the Dark Age period in Tibet.

\footnotetext{
${ }^{30}$ West, M. L. Textual Criticism and Editorial Technique Applicable to Greek and Latin Texts. Stuttgart: B. G. Teubner, 1973, p. 7.

${ }^{31}$ Jan. Nattier, A Few Good Men: the Bodhisattva Path According to the Inquiry of Ugra (Ugrapariprcchā), Studies in the Buddhist Traditions (Honolulu: University of Hawai'i Press, 2003).

${ }^{32}$ Ibid., p. 48.
} 


\section{Historical Analysis}

The Lamp is a unique text that stands alone, like a beacon of light, in a period that has been mainly portrayed as an era of darkness. Its contents reveal a rich and creative Buddhist world that has been largely ignored by the later Tibetan tradition and even modern scholars. But why has it been ignored? A short answer is that Nupchen's description of Buddhism during this period challenges and even contradicts most traditional Tibetan accounts. Traditional Tibetan historical works, like the influential $14^{\text {th }}$ century The Clear Mirror, by Sakya Sonam Gyaltsen, portray the Dark Age as an era of cultural decline. ${ }^{33}$ This traditional view is still quite pervasive in contemporary scholarship, as we can see in Davison's influential Tibetan Renaissance, published in 2005, which studies the period following the Dark Age, which he defines as “...one of the most remarkable achievements in human history: the rebirth and reformation of Tibetan culture approximately a century after the catastrophic collapse and fragmentation of the Tibetan Empire in the mid ninth century." ${ }^{34}$ Davidson's entire argument for a Tibetan Renaissance hinges on the existence of a previous period of crisis, a Dark Age, from which Tibetan culture could reemerge from its ashes. I argue that the Lamp is key textual evidence demonstrating that the Dark Age is not accurately describing a historical reality, but functions, using Keith Jenkins notion of history ${ }^{35}$, as a construct, a historical narrative that serves a very particular political, social, and intellectual purpose. In this case, the notion of a Dark Age has been used by traditional Tibetan historiography as a label that helped obscure and even attack the developments of this period (particularly the Great Perfection tradition, which has been labeled by later Tibetan schools as a Tibetan corruption without legitimate Indian origins), but also to

\footnotetext{
33 "King Langdarma launched the suppression of the Dharma in the Iron-female-bird Year (901), and as the embers of the Teaching were also retrieved in an Iron-female-bird Year, it is said that the Dharma disappeared from U and Tsang for nine calendrical cycles," p. 271 (1996).

${ }^{34}$ Davidson, ibid., p. ix.

${ }^{35}$ Keith Jenkins and Alun Munslow, Re-Thinking History (New York: Routledge, 2003).
} 
legitimize the centers of political and intellectual power that emerged after the $10^{\text {th }}$ century in Tibet. When we consider Jenkins' approach to the study of history, we can see the Lamp not as an oddity to be disregarded, but as a challenge to the traditional narrative that needs to be taken seriously.

\section{Intellectual History}

In his Tsung-mi and the Sinification of Buddhism, Peter Gregory argues that his study of the 9th century Chinese scholar Zongmi is:

...not only important for understanding some of the major developments within the Chinese Buddhist world of the late T'ang but also for bringing into focus some of the recurring themes in Chinese intellectual history that are important for understanding the complex process by which Buddhism accommodated itself to Chinese cultural values at the same time that it thereby transformed those values. An examination of the life and thought of Tsung-mi therefore offers a pivotal vantage point for understanding how the Chinese adapted Buddhism to their own religious and philosophical concerns as well as clarifying the ways in which Buddhism expanded the realms of discourse in which those traditions were conceived. ${ }^{36}$

I think Gregory's project in his study of Zongmi is equally valid for my study of Nupchen.

One of my arguments is that the Lamp shows how Buddhism was being transformed to adapt to Tibetan sensibilities, and the literary genre of doxography (as in Zongmi's case) was perfect to organize the wealth of Buddhist traditions imported into Tibet, as well as accommodating new ones. I intend to explore with my study of Nupchen and the Lamp the intellectual world in which this text was possible. What are Nupchen's influences? How does he understand them? In order to answer some of these questions, I will discuss the Lamp together with some of the most important textual references of the period in order to explore the intellectual world inhabited by Nupchen.

\footnotetext{
${ }^{36}$ Peter N. Gregory, Tsung-mi and the Sinification of Buddhism, vol. 16 (Honolulu: University of Hawai'i Press, 2002), p. 20.
} 


\section{Overview of this Dissertation}

This study of Nupchen's Lamp for the Eye in Contemplation is divided into five separate chapters and a conclusion. The first chapter explores the historical context in which Nupchen lived, the so-called Age of Fragmentation, or Dark Age, and challenges traditional assumptions about the period. The chapter also offers an overview of Nupchen's life, using the largest and oldest biographical account of Nupchen available to us, the recently rediscovered biography, The Testament of Nup (Tib. bKa'shog chen mo). The goal of the chapter is to reconsider Nupchen's life and the historical period in which he lived in order to create a more complex and nuanced framework in which to situate and explore the Lamp in the ensuing chapters.

Chapter two examines the Lamp as a text from three very different perspectives: as a physical object, as a literary genre, and as an intertext. As a physical object, I examine the obscure recension history and reception of the text from its production in the 10th century by Nupchen, until it resurfaced in 1974 and was republished in India. From a literary perspective, I discuss Nupchen's use of the Buddhist doxographical (or classification of views) genre to organize the variety of Buddhist traditions that had made their way into Tibet until the 10th century, as well as a tool to construct the necessary intellectual boundaries that allowed the Great Perfection tradition to claim its status as a new, separate Buddhist tradition. From the perspective of the Lamp's deep intertextual nature, we will explore how Nupchen uses hundreds of sources from many different Buddhist traditions not only to present their particular views and practices, but also to manipulate them in order to strengthen his general argument that situates the Great Perfection as the ultimate and superior Buddhist system. 
Chapter three offers an overview of the first three chapters of the Lamp, in which Nupchen discusses the preliminaries that any practitioner needs to consider before entering into retreat (chapter 1 of the Lamp), the different contemplative methods used by each of the traditions discussed in the text (chapter two), and their different understandings of nonconceptuality (Skt. avikalpa; Tib. mi rtog pa). Because non-conceptuality is a central notion shared by all Buddhist traditions discussed in the text, it offers a focus for Nupchen to compare the traditions, as well as to hierarchically organize them.

Chapter four discusses chapters four and five of the Lamp, in which Nupchen introduces, respectively, the Indian Gradual and the Chinese Sudden traditions. The chapter will explore the historical and intellectual background of those traditions, focusing on some of the central figures responsible for their introduction into Tibet (Śāntarakṣita and Kamalaśîla in the case of the Gradual, and Hashang Mahāyāna in the case of the Sudden), as well as Nupchen's presentation and comparison of both traditions in the text.

Chapter five will follow a very similar structure to chapter four, examining Nupchen's discussion, in chapters six and seven of the Lamp, of the Mahāyoga and Atiyoga traditions. The chapter discusses the historical and intellectual background of the Mahāyoga tradition in Tibet, paying particular attention to the role of the 9th century Tibetan scholar, Pelyang, as well as Nupchen's interpretation of the tradition in the Lamp. The chapter concludes with a discussion of the emergence of the Great Perfection out of some of the doctrinal and contemplative developments of Mahāyoga (already insinuated in Pelyang's works), as well as Nupchen's presentation of the tradition in the Lamp.

Finally, in the conclusion, I will discuss the role of Nupchen and, in particular, of the Lamp in the construction of the early Great Perfection identity as a new and separate Buddhist 
vehicle. With the help of the scholar, Jonathan Smith, ${ }^{37}$ I will argue the key role that the doxographical genre played, with its use of comparison and classification, not only in organizing the variety of Buddhist traditions that made their way into Tibet during the $7^{\text {th }}$ to $10^{\text {th }}$ centuries, but also in creating artificial boundaries that articulated and reflected historical and social needs, more than doctrinal and contemplative differences.

${ }^{37}$ I am aware that Smith uses the concepts of comparisson and classification in the modern context of the study of religion, but I think that his ideas are useful to see Nupchen's project of comparisson and classification under a new light. 


\section{Chapter 1 - A Light in the Darkness: Nup Sangyé Yeshé and the Tibetan}

\section{Dark Age}

\section{Intro}

This chapter offers an introduction to the historical period in which the 10th century Tibetan scholar, Nupchen Sangyé Yeshé, lived, as well as a discussion of his life. The main goal of the chapter is to introduce the general framework in which our discussion of Nupchen's Lamp for the Eye in Contemplation in the following chapter can be understood in the context of the historical and intellectual world in which it was produced. In order to do that, I have divided the chapter into three different parts. In the first part, I offer an overview of the historical period in which Nupchen lived, the so-called Age of Fragmentation or Dark Age (842-986 CE). I argue, following recent research by scholars like Germano, Dalton, and van Schaik, the need to reconsider negative presentations of the period as seen in traditional scholarship (Tibetan and Western alike!). While the Dark Age may have been a period of intense social, political, and intellectual upheaval, the life and works of Nupchen also show that his was a period where new and innovative Buddhist texts and doctrines were being imported, translated, and also produced in Tibet. This more complex and nuanced presentation of the Tibetan Dark Age will help us to better frame, in the second part of this chapter, the rich and adventurous life of Nupchen. My account of his life, based mainly on the recently rediscovered, purported autobiography, Testament of Nup, will present a figure deeply engaged in the intellectual Buddhist world in the 9th-10th centuries, traveling to India, Nepal, and Central Asia, learning from a wide variety of teachers, collecting and translating texts, and composing commentaries and treatises on some of the most cutting edge Buddhist literature of the period, such as that of the Anuyoga and Atiyoga traditions. As we will see, he was also a unique witness to the political events that unraveled 
after the collapse of the Empire in the mid-9th century. In the third and final section, I offer an overview of Nupchen's surviving texts, which will help us situate the Lamp in the broader context of his intellectual work.

\section{Methodological Considerations}

I should make clear before we proceed, though, that the goal of the chapter is not to offer a definitive historical account of the period, or even of the life of Nupchen. The methodological approach taken in this chapter (and througout this dissertation) when reading historical sources does not have as a goal, as philosopher Hayden White felicitously phrased it, "to get the story straight." For White, "those historians who draw a firm line between history and philosophy of history fail to recognise that every historical discourse contains within it a full-blown, if only implicit, philosophy of history." ${ }^{, 38}$ In the specific context of Tibetan studies I think Kapstein, in his The Tibetan Assimilation of Buddhism, offers a very productive example of this very approach, acknowledging that the line "between history and philosophy of history" is, indeed, very difficult to maintain, and that, in the end, "the scholar [...] must in the end be a myth maker, spinning tales of reason, truth, and history, in virtue of which the actions, arts, sciences, and, myths of persons elsewhere and elsewhen may become somehow more intelligible for us than they would have been otherwise." ${ }^{39}$ My goal in this chapter is, then, to read the historical

\footnotetext{
${ }^{38}$ And he added: "The principal difference between history and philosphy of history is that the latter brings the conceptual apparatus to the surface of the text, while history proper (As it is called) buries it in the interior of the narrative, where it serves as a hidden or implicit shaping device." Hayden V., 1928- White, Tropics of Discourse: Essays in Cultural Criticism (Baltimore: Johns Hopkins University Press, 1985). pp. 126-27.

${ }^{39}$ Matthew Kapstein, The Tibetan Assimilation of Buddhism: Conversion, Contestation, and Memory (Oxford; New York: Oxford University Press, 2000), p. 143. Although, as he adds, "not all myths are equal: some succeed relatively better than others in the task of making the foreign intelligible to us, and thereby opening our own world of discourse to voices previously unheard" (p. 4). Wedemeyer, in his recent study of the early Tantric Buddhism in India has taken a very similar methodological approach: "Historiography of whatever sort—etiological or narrative - always involves making sense of its object [...] Human beings seek to understand - to make sense oftheir world. It is precisely the purpose of historiography to take a set of data and lend it meaning and coherence, Historiography is always an act of making sense insofar as it brings order and (consequently) meaning to events [...] It is impossible for a proper history not to interpret its subject-not to make it into something- to transform isolated
} 
materials about the Dark Age and about Nupchen, and explore how the sources weave narratives that serve particular political and intellectual discourses that have shaped (and, I argue, obscured), in Tibetan and Western scholarship alike, the role that the Dark Age and Nupchen played in the Tibetan Assimilation of Buddhism. ${ }^{40}$

events through an act of imaginative creation into a process that can be grasped by the reader as a coherent object of understanding." In Christian K. Wedemeyer, Making Sense of Tantric Buddhism: History, Semiology, and Transgression in the Indian Traditions, South Asia across the Disciplines (New York: Columbia University Press, 2013).

${ }^{40}$ Wedemeyer's Making Sense of Tantric Buddhism offers a recent effort of mantaining that balance between history and the various methodologies we use to write it and to interpret it. He presents his methodological approach (following philosopher Robin Collingwood) as one that "never simply thinks about an object [but] always, while thinking about any object, thinks also about its own thought about that object." In Wedemeyer, Making Sense of Tantric Buddhism, p. 8. 


\section{Part 1 - Reconsidering the Dark Age}

In his study of Nupchen's newly discovered biography, The Testament of Nup (Tib. gNubs kyi bka' shog chen mo) ${ }^{41}$, Dalton introduces one of the main challenges faced by scholars when studying this complex figure:

In many ways, Nupchen is the very embodiment of Tibet's age of fragmentation [...] However one thinks about this controversial period in Tibetan history, so will one think of Nupchen. If it was an era of absolute corruption, when the flame of the dharma was extinguished in Tibet, then Nupchen represents a prime example of a Tibetan misled by demons and an unhealthy obsession with the tantras and tantric violence. If, conversely, it was a time when at least some strands of the "early dispensation" (snga dar) Buddhist tradition (and especially those non-monastic strands) managed to survive, then he is a holy man and a brave protector of the faith, who faced down the forces of darkness almost single-handedly. ${ }^{42}$

This tension regarding Nupchen can be easily found in traditional Tibetan literature. The depiction of Nupchen as a Tibetan "misled by demons and an unhealthy obsession with the tantras and tantric violence" is found mainly in Sarma literature (Tib. gSar ma), the new schools of Buddhism that attempted to start anew during the so-called Second Dissemination of Buddhism (Tib. phyi dar bstan pa), and appears as early as the end of the $10^{\text {th }}$ century with figures like Lama Yeshe Ö (Tib. bLa ma ye shes 'od) and his nephew Podrang Zhiba Ö (Tib. Pho drang zhiba 'od). ${ }^{43}$ Lama Yeshe Ö (959-1040 CE), ${ }^{44}$ as part of his project to reform Buddhist

\footnotetext{
${ }^{41}$ gNubs chen sangs rgyas ye shes, Sangs rgyas ye shes rin po che'i lo rgyus gnubs kyi bka' shog chen mo (vol. 42 of the bKa' ma shin tu rgyas pa) (Chengdu: kaH thog mkhan po 'jam dbyangs, 1999).

${ }^{42}$ Dalton, "Preliminary Remarks on a Newly Discovered Biography of Gnubs Chen Sangs Rgyas Ye Shes." p. 2. Bold is mine.

${ }^{43}$ Regarding these two figures, see the classic articles by Karmay: "The Ordinance of 1Ha Bla-ma Ye-She-'Od," and "An Open Letter to Pho-brang Zhi-ba-'od," in Samten Gyaltsen Karmay, The Arrow and the Spindle: Studies in History, Myths, Rituals and Beliefs in Tibet (Kathmandu: Mandala Book Point, 1998). Karmay recently published a new article on Yeshe O in Samten Gyaltsen Karmay's "A Recently Discovered Rnam Thar of Lha Bla Ma Ye She's 'od," in Tibet after Empire: Culture, Society and Religion between 850-1000 (Lumbini: LIRI, 2013). Regarding Yeshe O, also see Laxman S. Thakur, "A Tibetan Inscription by $1 \mathrm{Ha}$ Bla-Ma Ye-Shes-'Od from dKor (sPu) Rediscovered," Journal of the Royal Asiatic Society 4, no. 3 (November 1, 1994): 369-75. and Omacanda Hāṇ̦ā, Buddhist Western Himalaya: A Politico-Religious History (Indus Publishing, 2001).
} 
practices in Tibet that culminated with the invitation and subsequent arrival of Atīśa (Skt. Atīśa Dīpamkara Śrijñāna, CE 980-1054) to Tibet in $1040,{ }^{45}$ attacked the widespread use of violent and sexual tantric texts and practices that had spread and become popular in the post-Imperial period:

You tantrists, who live in villages, have no connection with these Three Ways [Śrāvakayāna, Pratyekabuddhayāna, and Bodhisattvayāna] and yet claim "we follow the Mahāyāna" without observing the rules of the Mahāyāna, you say "we are Mahāyānist." This is like a beggar saying that he is king [...] As "sexual rite" [Tib. sbyor ba] has become popular the different classes of people are mixed [...] As the ritual of the corpse [Tib. dur mchod] has become popular the making of offerings in cemeteries is abandoned. As the ritual of sacrifice has become popular it happens that people get "delivered" [Tib. 'grol ba] alive.'

Lama Yeshe Ö particularly attacks the emergence during this period of what he calls "the false doctrine of Dzogchen [which] views are mistaken." ${ }^{\text {47 }}$ That Nupchen was considered an important representative of this group of tantric practitioners who were followers of the Great Perfection becomes obvious in the proclamation of Yeshe Ö's nephew, Podrang Zhiba Ö (1016-1111 CE), ${ }^{48}$ in which some of Nupchen's texts, like the Lamp for the Eye in Contemplation, ${ }^{49}$ a collection of tantric texts under the title rGyud kyi rgyal po drug, and some of his commentaries on Semde tantras, like the Rig pa' $i$ nyi $m a$ (a commentary on the Nam $\left.m k h a^{\prime} c h e\right)^{50}$, are dismissed as part of

\footnotetext{
${ }^{44}$ For more on this figure, see the following two works by Karmay: The Arrow and the Spindle: Studies in History, Myths, Rituals and Beliefs in Tibet, pp. 3-16. Karmay, "A Recently Discovered Rnam Thar of Lha Bla Ma Ye She's 'od.” Also see Thakur, “A Tibetan Inscription by $1 \mathrm{Ha}$ Bla-Ma Ye-Shes-'Od from dKor (sPu) Rediscovered."

${ }^{45}$ See Alaka Chattopadhyaya, 982-1054. Atīśa, and Lama Chimpa, Atīśa and Tibet: Life and Works of Dīpamkara Śrij̄ñanna in Relation to the History and Religion of Tibet (Delhi: Motilal Banarsidass, 1981). Hubert Decleer, "Atisha's Journey to Tibet," in Religions of Tibet in Practice, ed. Donald S. Lopez (Princeton University Press, Princeton, N.J.) and David Seyfort Ruegg, The Literature of the Madhyamaka School of Philosophy in India, (Wiesbaden: Harrassowitz, 1981).

${ }^{46}$ Karmay, The Arrow and the Spindle: Studies in History, Myths, Rituals and Beliefs in Tibet, pp. 12-13.

${ }^{47}$ Ibid., p. 10.

${ }^{48}$ See Ibid., pp. 17-40.

${ }^{49}$ The actual Tibetan name referenced in the text is the rNal 'byor mig gi sgron ma. Since one of the titles of the Lamp is the rNal 'byor mig gi bsam gtan, scholars like Karmay seems to suggest that this may be a reference to the Lamp.

${ }^{50}$ For this work see section three of this chapter.
} 
a list of texts "composed in the guise of the word of the Buddha [claiming] to be of Indian origin," which, in fact, were "produced by Tibetans," and therefore "one can hardly accept them [...] since they may be the path leading into evil rebirths." ${ }^{, 51}$

On the other hand, it will be scholars belonging to the Nyingma tradition (Tib. rnying $m a$ ), who rooted themselves in the Buddhism that developed during the Tibetan Empire and that survived during the Era of Fragmentation, or Dark Age, the ones who will defend Nupchen as a beacon of light in an otherwise dark and difficult period. For the Nyingma, Nupchen almost singlehandedly preserved the teachings imported during the Tibetan Empire and protected them during the difficult times of the Dark Age. The $18^{\text {th }}$-century Nyingma scholar, Guru Tashi (Tib. Gu ru bkra shis), in his Religious History ${ }^{52}$ describes Nupchen as a brave protector of the Buddha's teachings who embraced wrathful practices in order to stop the evil King Langdarma from destroying Buddhism in Tibet:

"At the time when king Langdarma was destroying the teachings of the Buddha [Nupchen] scared this evil king. The king asked him: "What powers do you have?" and Sangyé Yeshé replied: "Look at the power of my mantra!" and [Nupchen] raised his index finger towards the sky and, on the tip of his finger there was a black iron scorpion [the size] of a nine story building. This vision frightened the king and he said: "I will not challenge this precious mantrin! [I will allow you to] practice your dharma!" Then

\footnotetext{
${ }^{51}$ Samten Gyaltsen Karmay, The Arrow and the Spindle: Studies in History, Myths, Rituals and Beliefs in Tibet (Kathmandu: Mandala Book Point, 1998), p. 31 and pp. 37-38. The $11^{\text {th }}$-century scholar, Gö Khukpa Lhetsé's (Tib. 'Gos khug pa lhas btsas), in his Refutation of False Mantra (Tib. sngags log sun 'byin gyi skor) also accuses Nupchen of composing tantras in Tibet while claming to be of Indian origin. See Jacob Paul Dalton, The Taming of the Demons: Violence and Liberation in Tibetan Buddhism (New Haven: Yale University Press, 2011). On p. 8 Dalton translates this relevant passage from Gö Khukpa Lhetsé attacking Nupchen: "Because of Nup Sangyé Rinchen, sources appeared in India. Some really astonishing teachings were composed. The five and the eighteen mantra-teachings, as well as The Great Mental Arising, are all false and corrupt teachings made up by Tibetans... Also made up by Sangyé Rinpoché are [The Tantra of] The Peaceful and Wrathful Deities, the greater and lesser Planet Tantras of the Rahula Cycle, [The Tantra of] The Ice-Faced One, and so forth."

${ }^{52}$ See Tashi Guru, Gu Bkra 'i Chos 'Byung, ed. Rdo-rje-rgyal-po (Beijing: Krung-go'i bod-kyi shes-rig dpe-skrunkhang, 1990). In chapter 3, the section "The Old Tantra Translations Teachings of Gnyags, Gnubs, and Zur" (pp. 242-321) there is an important, although rather late, biography of Nupchen. For Guru Tashi's Religious History see Dan Martin's “A Brief Political History of Tibet by Gu-Ru Bkra-Shis,” in Tibetan History and Language: Studies Dedicated to Uray Géza on His Seventieth Birthday, ed. Uray, 1921- Géza and Ernst Steinkellner, vol. Heft 26, Wiener Studien Zur Tibetologie Und Buddhismuskunde; Heft 26 (Wien: Arbeitskreis für Tibetische und Buddhistische Studien, Universität Wien, 1991), 329-51.
} 
[Nupchen] said: "Look again at my power!" He pointed his index finger towards a rock, and a lighting bolt destroyed it into pieces. Then, the terrified king said: "I will not harm your followers!" It is clear that due to Sangyé Yeshé's kindness the mantrins with white robes and long hair were not harmed and, in general, [this was of] great benefit to the teachings of the Buddha." 53

Tibetan depictions of Nupchen, then, seem to be inextricably bound to Tibetan feelings about the historical period in which he lived. Since one of the main goals of this dissertation is to offer a more nuanced and complex portrait of the life and works of Nup Sangyé Yeshé , it is seems essential, then, that we begin this project by examining the historical period in which he lived, the Era of Fragmentation or Dark Age.

\section{Periodization and the construction of history}

In his article, "Some Reflections on the Periodization of Tibetan History," Bryan Cuevas explores the various periodization schemes found in Tibetan histories, as well as in western histories of Tibet. For Cuevas, periodization is a key tool in the study of history, since:

"History is always expressed as a narrative, a story about the past. To write a story out of the events of the past, historians must give those events a coherent meaning and plot those meaningful events as chapters in a larger narrative [...] Historiography [...] presupposes that history by necessity, whether we prefer this or not, is always written in chapters. Periodization - the breaking-up of the past into chapters, or "periods" - is one necessary way historians make sense of the past and also write history."

\footnotetext{
${ }^{53}$ Bold is mine. The Tibetan is "khyad par du rgyal po glang dar mas sangs rgyas kyi bstan pa bshig pa'i dus slob dpon 'dis rgyal po sdig can skrag par mdzad del rgyal pos khyod la nus pa ci yod zer bas ngas sngags tsam bzlas pa'i nus pa 'di la gzigs shig ces sdigs mdzub gnam du phyar bas sdigs mdzub kyi steng na lcags kyi sdig pa nag po g.yag po tsam dgu brtsegs su 'dug pa mthong bas rgyal po skrag ste dkon mchog sngags pa'i sku la mi bsdo'o chos mdzod cig zer/ da dung nus pa 'di la gzigs shing zer nas sdigs mdzub kyis thog phab ste pha ri'i brag la bsnun pas tshal bar song/der rgyal po 'jigs shing skrag nas khyed 'khor bcas la gnod pa mi byed do zer nas btang stel sngags 'chang gos dkar lcang lo can rnams la gnod pa ma byung na khong gi drin du mngon te sangs rgyas kyi bstan pa spyi la'ang phan pa cher byung ngo." In Guru Tashi, Gu Bkra'i Chos 'Byung, p. 167.

${ }^{54}$ Bryan Cuevas, "Some Reflections on the Periodization of Tibetan History," Revue d'Etudes Tibétaines, no. 10 (April 2006): 44-55, p.44.
} 
The historical period in which Nupchen lived has been traditionally labeled as the Dark Age, the Era of Fragmentation (Tib. sil bu'i dus), the Era of the Decline of the Teachings (Tib. bstan pa' $i$ bsnubs lugs), and the Intermediate Period (Tib. bstan pa bar dar). In most historical sources ${ }^{55}$, this period begins in $842 \mathrm{CE}$ with the death of Emperor Langdarma (Tib. gLang dar ma), ${ }^{56}$ marking the beginning of the end of the Tibetan Empire, and it ends in $986 \mathrm{CE}$, the date of the already mentioned Proclamation of Lama Yeshe Ö, that rejected the religious developments that had taken place in Tibet during the post-Empire period and attempted a reform of Buddhist practices in Tibet, a project that culminated with the invitation of Atiśa to Tibet in 1040, ${ }^{57}$ although, as we will see, these dates vary according to sources and to the different understandings of the period. ${ }^{58}$

A challenge that we face when studying this particular period of Tibetan history is that, as the historian Ludmilla Jordanova argues,

...ideas about periods and the terms in which they are expressed, are largely inherited from earlier generations, and these shape the most fundamental assumptions we have, not just about how the past is to be divided up, but about its interpretation. This inheritance is unfortunate because conventionalized period terms seem to hamper fresh thinking; through periodization particular views of history are naturalized, so that it is difficult to bring them up for critical scrutiny. ${ }^{59}$

\footnotetext{
${ }^{55}$ For a discussion on periodization in Tibetan history, see also Jacob Paul Dalton's The Taming of the Demons: Violence and Liberation in Tibetan Buddhism (New Haven: Yale University Press, 2011).

${ }^{56}$ His actual name was U Dumten (Tib. 'U'i dum brtan). On this polemic historical figure see Zuihō Yamaguchi, "The Fiction of King Dar-Ma's Persecution of Buddhism," in Du Dunhuang Au Japon: Études Chinoises et Bouddhiques Offertes À Michel Soymié (Geneva: Droz, 1996), 231-258.

${ }^{57}$ On the invitation of Atiśa to Tibet see Alaka Chattopadhyaya, Atīśa and Tibet: Life and Works of Dippamkara Śījñāna in Relation to the History and Religion of Tibet (Delhi: Motilal Banarsidass, 1981) and Decleer, "Atisha's Journey to Tibet."

${ }^{58}$ For some of the different dates for the period, see Dalton: "More strictly speaking, we may follow the dates 843 986 C.E., from the collapse of the Pugyal dynasty to the distribution of Yeshe Ö's bka' shog chen mo. Regarding the former date [mid-ninth century to the late tenth], see Yamaguchi 1996, 252, where he dates the "break up"of the kingdom of Tufan by reference to Chinese Tangshu. Regarding the latter date, see Vitali 1996, 185. Another turning point was the return of the "ten men" from the northeast, and the subsequent revival of monastic Buddhism. Dromtönpa suggests a date for this event of 978 (see Vitali 1990, 62 n.1), though Khepa Deu seems to suggest 988 (Mkhas pa lde'us mdzad pa'I rgya bod kyi chos 'byung rgyas pa, 394), in Dalton, The Taming of the Demons : Violence and Liberation in Tibetan Buddhism, p. 226 n. 3.

${ }^{59}$ L. J. Jordanova, History in Practice (London: Arnold, 2000), p. 106. Italics are mine.
} 
Critical scrutiny of the use of these historical labels, then, is important if we want to look at the period anew. ${ }^{60}$ Most discussions about the period use these labels uncritically and, in some cases, interchangably, paying little attention to the consequences that their use has on our perception and understanding of the period. Let's briefly explore the meaning and use of each of these labels and how each of them offers a slightly different perspective, and brings its own interpretative connotations to this historical period.

\section{The Dark Age}

The most common label used to describe the collapse of the Tibetan Empire and its immediate aftermath is that of the "Dark Age." This is, strictly speaking, an etic term not really found in Tibetan sources until very recently. ${ }^{61}$ As Philip Denwod has pointed out,

...the term 'Dark Age' in relation to Tibet has been coined by analogy with the European Dark Ages. Both periods are 'dark' in two dimensions. Firstly, they are historically dark: much less is, or was known about them than about their respective preceding and following periods, for reasons to do with the presumed breakdown of literacy and historical tradition. Secondly, to certain insiders, they were interludes of spiritual darkness when great religious traditions were temporarily in eclipse. ${ }^{62}$

\footnotetext{
${ }^{60}$ In his article on periodization in Tibetan history, Cuevas argues for the same idea: "even though Tibetanists continue to generate and repeat various divisions of time whenever writing about Tibet [they] rarely, if ever, take up the question of periodization. For whatever reason, few have been willing to openly consider this question or acknowledge that the persistent articulation and interpretation of the periods of Tibetan history, which have generally been accepted uncritically, may still be in need of reassessment." In Cuevas, "Some Reflections on the Periodization of Tibetan History”, p. 45.

${ }^{61}$ Snellgrove uses the term Dark Age, although he qualifies it by saying "dark simply because so little is known about it." In David L. Snellgrove, Indo-Tibetan Buddhism: Indian Buddhists and Their Tibetan Successors / (Boston: 1987), p. 464. Kapstein devotes a section to this period with the title "Literacy and Learning in the Dark Age" in his The Tibetan Assimialtion of Buddhism Kapstein, The Tibetan Assimilation of Buddhism: Conversion, Contestation, and Memory, pp. 10-17.

${ }^{62}$ Philip Denwood, “Tibetan Arts and the Tibetan 'Dark Age,' 842-996 CE,' Journal of Inner Asian Art Archaeology 5 (2010), p.1. A classic definition of the European Dark Ages can be found in Manchester's A World Lit only by Fire: "The densest of the medieval centuries - the six hundred years between, roughly, A.D. 400 and A.D. 1000 - are still widely known as the Dark Ages [...] Very little is clear about that dim era. Intellectual life had vanished from [...] Indeed, throughout the Middle Ages, which lasted some seven centuries after Charlemagne, literacy was scorned [...] Nevertheless, if value judgments are made, it is undeniable that most of what is known about the period is unlovely. After the extant fragments have been fitted together, the portrait which emerges is a
} 
While the use of the term and its success in contemporary scholarship may have to do with its historical similarities to the events of the European Medieval Period, it is important to point out that Tibetan themselves use images of darkness, if not the actual "Dark Age" label itself, to describe the period. A classic example of the use of darkness to describe the period can be found in the Pillar Testament:

Then in three generations a king with the name of a beast of burden will come [i.e. Langdarma]. The excellent dharma will fade entirely. The teachings will decline and degenerate. In that age, all the peoples of Tibet who will be led by that king will end up going to the hells of unending torments. For a little over a hundred years the sounds of the excellent dharma will not be pronounced. The land of Tibet will become shrouded in darkness. For five generations it will remain like that. Then after several generations, the slight embers of the excellent dharma will be rekindled in this snowy kingdom ${ }^{63}$

This prophetic use of images of darkness to describe the period, as Germano has pointed out, "unquestionably plays off the eschatological language of eons of darkness (Tib. mun pa' $i$ bskal pa) and eons of light (Tib. 'od kyi bskal pa), which refer to the respective absence and presence of Buddhas in any given cosmic age." ${ }^{64}$ The notion of a Dark Age evokes an era of decline and danger for Buddhism and, by extension, for the spiritual well-being of all Tibetans.

melange of incessant warfare, corruption, lawlessness, obsession with strange myths, and an almost impenetrable mindlessness," (pp. 3-5).

${ }^{63}$ From the Pillar Testament (Tib. bKa' chems ka khol ma 275.6-15). Translation from Dalton, The Taming of the Demons: Violence and Liberation in Tibetan Buddhism, p.7. Davidson uses the same quote (with a slightly different translation) to open his chapter on the Dark Age in his Tibetan Renaissance (p. 61). The Pillar Testament (Tib. $b K a^{\prime}$ chems ka khol $\mathrm{ma}$ ) is considered a treasure text (Tib. gter ma) composed by King Sontsen Gampo (Tib. Srong btsan sgam po) in the 7th century and discovered by Atiśa in the 11th century. It is one of the earliest examples of treasure literature in Tibet. On this text see Roger R. Van der Kuijp, "Tibetan Historiography," in Tibetan Literature: Studies in Genre, ed. Jose Cabezon and Roger Jackson (Ithaca, N.Y.: Snow Lion, 1996). Also see A Vostrikov, Tibetan Historical Literature ([Calcutta: Indian Studies Past \& Present, 1970).

${ }^{64}$ David Germano, The Secret Tibetan History of Buddhist Tantra in the Great Perfection (Unpublished Manuscript, 2009). The image of darkness is also intimately linked with the dissapearance of the monastic community from Central Tibet. The famous return of the "Eastern Vinaya Monks" in 978 (see n. 14) is traditionally labelled as "rekindling the embers of the teachings" (Tib. bstan pa'i me ro gsol ba), playing on that image of Buddhism as brigning light to the Tibetan plateau. 
Buddhism had civilized Tibetans during the era of the Empire, and had provided Tibet with enormous cultural capital that raised its profile from a barely related group of nomadic, barbaric tribes $^{65}$ to a civilized nation, on par with the cultures of India and China, the rightful inheritors of Buddhist culture. ${ }^{66}$ It is for that reason that the period, according to Dalton, acquired a largely (negative) symbolic role "as an increasingly darkened age, the period came to play a more symbolic role in the Tibetan imagination, as a fundamental time of demonic corruption and rampant violence to which Tibetans were forever in danger of reverting. "67 From this perspective, Tibetans were not only losing Buddhism during this period, but also the spiritual and cultural essence of the new Tibetan identity forged during the Empire.

What makes this term useful in our description of the period is that it captures certain anxieties about the survival and development of Buddhism that are reflected in the work and life of Nupchen, so while we need to be careful with the connotations it carries with it, it does help

\footnotetext{
${ }^{65}$ This perception of Tibetans as brutal, barbaric tribes can be seen in their description, by other nations, as the "red faced" people. Nupchen himself uses this appellation in the closing section of the Lamp when he describes Tibet as "this borderland kingdom, [land] of the red-faced barbarians" (Tib. mtha' khob kyi rgyal khams / bod srin po gdong dmar gyi yul, Lamp 494.3.). Snellgrove also describes how the Khotanese would likewise describe Tibetans in the same way: "The ambivalent attitude of the people of Khotan to their Tibetan conquerors finds expression in several texts concerning Khotan that are even available in the Tibetan canon, being included there since they take the form of religious prophecies, either attributed to Śăkyamuni himself or to an Arhat named Samghavardhana. The several references to the Tibetan invaders nicknamed the "Red Faces," describe them sometimes as its actual defenders. This presumably represents the gradual change in Tibetan attitudes to the conquered people. Thus in one such prophetic statement Sakyamuni commits Khotan into the hands of the gods Vaiśravana and Samjaya (the chief of a yakșa host) with these words: "I continually commit the Land of Li to your protection. When the Red Faces seize the country, destroying and burning the monasteries, temples and great stüpas with the perverse aspiration of destroying my religion, then two armies will very soon be at war with one another."' In David L. Snellgrove, IndoTibetan Buddhism: Indian Buddhists and Their Tibetan Successors (Boston [New York]: Shambhala, 1987), 351. Italics are mine. Kapstein also discusses this appellative as used by Khotanese and Chinese in Matthew Kapstein, The Tibetan Assimilation of Buddhism (Oxford; New York: Oxford University Press, 2000), 41. For a recent discussion on this topic see Sam Van Schaik's "Red Faced Barbarians, Benign Despots and Drunken Masters: Khotan as a Mirror to Tibet," in Religions on the Silk Road, ed. Max Deeg (Lumbini: Lumbini International Research Institute, forthcoming) and Sam Van Schaik's “The Red-Faced Men I: Warriors with Painted Faces,” Early Tibet, accessed May 4, 2014, http://earlytibet.com/2007/09/18/red-faced-men/.

${ }^{66}$ For this image of Tibet as the inheritors of Indian Buddhism, see D.S Ruegg's "On the Historiography and Doxography of the 'Great Debate of bSam Yas," in Tibetan Studies: Proceedings of the 5th Seminar of the International Associaton for Tibetan Studies (Narika 1989) (Tokyo: Naritisan Shinshoji, 1992). and Ruegg, The Literature of the Madhyamaka School of Philosophy in India.

${ }^{67}$ Dalton, The Taming of the Demons: Violence and Liberation in Tibetan Buddhism, p. 6.
} 
us focus on the religious life of the period and not only in the political state of Tibet, as is the case with labels like the "Era of Fragmentation."

\section{The Intermediate Period}

Another term used to describe the period is the "Intermediate Period" (Tib. bstan pa bar dar), which marks the divide between the two periods used to traditionally describe the dissemination of Buddhism in Tibet, the Earlier Dissemination (Tib. bstan pa snga dar), and the Later Dissemination (Tib. bstan pa phyi dar). ${ }^{68}$ The dates of the intermediate period correspond to those of the Dark Age, and both labels denote a concern with the situation of decline of Buddhism in Tibet, although the label "intermediate" seems to suggest that nothing really remarkable happened during the period or simply implies a desire to erase this era from the history of Tibet, while the "Dark Age," acknowledges the historical relevance of the period (even if only to describe it in negative terms), implying a sense of decline and danger for the tradition. In the case of the Intermediate Period there is a clear reference to a vacuum, an intermission on the process of bringing Buddhism to Tibet. ${ }^{69}$

\section{The Era of fragmentation}

The fact that the Dark Age label, although evoking powerful images to describe the period, is mainly an etic category imposed on Tibetan historiography has made modern scholars

\footnotetext{
${ }^{68}$ The 13th century Tibetan scholar Rig pa'i ral gri uses this periodization scheme in his Flower Ornament of the Teachings of the Buddha (Tib. Thub pa'i bstan pa rgyan gyi me tog).

${ }^{69}$ See also discussion of this historical label in Kurtis R. Schaeffer and Leonard W. J. van der Kuijp, An Early Tibetan Survey of Buddhist Literature: The Bstan Pa Rgyas Pa Rgyan Gyi Nyi 'Od of Bcom Ldan Ral Gri, vol. v. 64, Harvard Oriental Series (Cambridge, Mass.: Harvard University Press, 2009), 61-62.
} 
wary of its use, proposing instead the Tibetan term "Era of Fragmentation" (Tib. sil bu'i dus). This term perfectly describes the political state of affairs after the collapse of the Empire, and recently, scholars like Davidson, ${ }^{70}$ Dalton, and van Schaik, ${ }^{71}$ even with some ambivalence (or even using those two labels interchangeably), have advocated its use, since it is an emic term used in Tibetan historiography. Dalton reflects on this problem and questions whether "it is appropriate to call Tibet's age of fragmentation a "dark age" at all [...]," although he decides to use "the more common indigenous phrase, 'age of fragmentation." Dalton still defends the use of the "dark age" label as a "surprisingly instructive tool," due to its thematic connections to the European Dark Ages, as well as due to the fact that Tibetans, as we have already mentioned, use images and metaphors of darkness to describe the period. ${ }^{72}$

This dissertation also advocates the use of the label Dark Age, although for slightly different reasons. It seems to me that the Dark Age and the Era of Fragmentation, although overlapping, do not describe the exact same period. The Era of Fragmentation is used to describe the period that goes from the death of Langdarma in 841 to the rise of the Sakya government in the 13th century, while the Dark Age is really contained between the dates described at the beginning of this section (842-986 CE), and it also offers a frame for the historical and intellectual period in which Nupchen Sangyé Yeshé lived. Both periods overlap, but they bring different implications to our study of Nupchen. The Dark Age, I would argue, is more relevant

\footnotetext{
${ }^{70}$ See Davidson's ch. 2 in his Tibetan Renaissance.

71 'Often, western accounts of Tibet borrow the term 'dark age' from European history to characterize this period in Tibet. Yet, while historical sources are indeed sparse for Tibet in the tenth century, this age was not entirely dark. Although revolutions or civil wars were by all accounts common during this time, careful attention to historical sources and manuscript shows that there was in fact a great deal of political and religious activity in Tibet's small kingdoms and clan holdings. The traditional name for the era in Tibetan histories, the 'period of fragmentation' (silbü dü), seems a more appropriate appellation." In Sam Van Schaik, "The Sweet Sage and the Four Yogas: A Lost Mahāyoga Treatise from Dunhuang," Journal of the International Association of Tibetan Studies 4 (2008): 1-67.

${ }^{72}$ Dalton, The Taming of the Demons : Violence and Liberation in Tibetan Buddhism. Dalton uses the term since it "is a particularly revealing term," for the topic of his book: violence in Tibetan Buddhism. However, "that said, the present study prefers the more emic term 'age of fragmentation," page 8.
} 
since we are focusing on the intellectual decline, while the Era of Fragmentation refers to the political situation, less relevant for our present study.

\section{The End of an Era: The Collapse of the Tibetan Empire}

Our understanding of this period has been hampered by two important factors. The first is the lack of substantial sources, while the second is the construction of a strong narrative in Tibetan historiography that hides, more than illuminates, the historical events that took place during this period. Let's examine those two factors.

\section{Lack of Sources}

One of the problems we face when studying the Dark Age period is the lack of written sources. ${ }^{73}$ Writing during the Empire period was an institutional affair, ${ }^{74}$ and the collapse of the Empire and, subsequently, of the monastic institutions supported by the state meant that most of the writing that was produced during the post-imperial period severely declined or was lost in the chaos that ensued. The sources that have survived, as Davidson points out, are

...mainly a later and incomplete mixture of royal lineage, history of the Dharma, and hagiography texts [...]The age is seen as dark and fragmented, with meager evidence of positive activity. Although we have several lists of the imperial descendants' names, there is little evidence of their activities or interests for several decades beyond their presumed lineal maintenance and self-preservation. Later literature alludes to the existence of temples from the royal dynastic period in various states of disrepair, but the condition of the Tibetan people as a whole is uncertain. Lineage lists for the Sakyapa and Nyingma traditions trace individuals back through this period, but with a few notable exceptions, they remain only names, without verification or even hagiographical

\footnotetext{
73 "As there are very few contemporary records we can say very little exactly what went on during this long period." In Samten Gyaltsen Karmay, The Great Perfection (rDzogs Chen) : A Philosophical and Meditative Teaching of Tibetan Buddhism (Leiden; Boston: Brill, 2007), p. 9.

${ }^{74}$ On the invention of writing and its role during the Empire see Sam van Schaik, "A New Look at the Invention of the Tibetan Script," in Old Tibetan Documents Monograph Series, ed. Yoshiro Imaeda and Matthew Kapstein, vol. III (Tokyo: Tokyo University of Foreign Studies, 2011), 45-96.: “...the initial impetus for the development of writing, and the spehere within which writing operated in Tibet, was bureaucratic," (p. 52).
} 
narratives. The almost complete lack of post-dynastic royal inscriptions, the absence of chronologically confident textual materials, and the lack of almost any concrete references to Central Tibet in Chinese histories of the period all obscure the condition of Ü-Tsang.",75

We have to be careful when assessing the events described in some of our most important historical sources for the period, such as Nyangrel's Religious history (Tib. Chos 'byung me thog snying po sbrang rtsi'i bcud), and the two Deu histories (Tib. mKhas pa lde'u and lde'u jo sras), since these were written centuries later, and had clear agendas in their portrayal of the events that took place during that period. ${ }^{76}$

The collapse of the state sponsored monastic form of Buddhism in the post-Imperial period, together with the lack of substantial written sources helped develop a narrative in traditional Tibetan sources (continued in most modern scholarship) in which Buddhism during this period almost disappeared. ${ }^{77}$ But, as Kapstein explored in his Tibetan Assimilation of Buddhism:

Deeper reflection on the available evidence suggests that Tibetan Buddhism, once established under the empire, never really vanished. Though the period in question was a sort of Tibetan "dark age," it is clear that, as was the case for its counterpart in Europe, even in the darkness the light was never entirely extinguished. One sign that Tibetan remained alive as a literary language during this time, primarily in surviving (and perhaps even growing) Buddhist circles, is that the literary Tibetan that develops after the tenth

\footnotetext{
${ }^{75}$ Ronald M. Davidson, Tibetan Renaissance: Tantric Buddhism in the Rebirth of Tibetan Culture (New York: Columbia University Press, 2005). See also Yamaguchi: "The traditional histories of ancient Tibet contain much that has been fabricated because of the dearth of available historical materials subsequent to the eleventh century, while historical works dating from the fourteenth century and later contain revisions that were strongly influenced by the rGya yig tshang, a translation of Chinese historical sources," in Yamaguchi, "The Fiction of King Dar-Ma's Persecution of Buddhism," p. 231.

${ }^{76}$ For a discussion on early historical sources see Leonard W.J. van der Kuijp, "Dating the Two Lde'u Chronicles of Buddhism in India and Tibet," Etudes Asiatiques : Revue de La Société Suisse - Asie 46 (1992); Dan Martin, Tibetan Histories: A Bibliography of Tibetan-Language Historical Works (London: Serindia, 1997).

77 Traditional accounts of early post-imperial Tibetan history, repeated throughout later Tibetan historical writing, maintain that, following a persecution of Buddhism that was supposed to have occurred at the order of the emperor Lang Darma, and in the wake of his assassination, probably in 842, Buddhist activity in Tibet virtually ground to a halt, not to be revived for perhaps a hundred years [...]" in Kapstein, The Tibetan Assimilation of Buddhism:

Conversion, Contestation, and Memory, p. 10.
} 
century is to a great degree derived from what had earlier been a language of scriptural translation. At the same time, the archaic literary Tibetan known from Dunhuang, the old royal inscriptions, and other early sources, gradually falls out of use, becoming increasingly obscure to later generations of Tibetans. Thus, it seems plausible that following the collapse of the dynasty, as the archaic language used by the civil and military administration became obsolete and a literate culture was preserved largely among Tibet's Buddhists, Buddhist usage gradually emerged as the standard, even in writing about subjects such as history that had previously been written in the language employed by the state bureaucracy. Some such development would have contributed to the iconizing of Buddhism and its originally Indian context as the paradigms of learned (that is, literate) and prestigious culture. The persistence of Tibetan literacy to a degree that permitted knowledge of sophisticated Buddhist texts to be preserved, including some knowledge of Tibetan-Sanskrit lexicography, must certainly count as prima facie evidence that Tibet's dark age was not nearly so bleak as the traditional historiography would have us suppose. Several other considerations support this same conclusion."78

The recent works of scholars like Dalton and van Schaik on the Tibetan Dunhuang manuscripts are also making us reconsider the notion that there is a lack of sources for our understanding of the period, and their numerous articles and recent books are rewriting the history of the Tibetan Dark Age: ${ }^{79}$

Over the past century it commonly has been assumed that the Tibetan manuscripts [in the Dunhuang Library] must date from the Tibetan occupation of Dunhuang 9c. 786-848 C.E), when the Pugyal Empire was at the height of its power. In recent years, however, it has become increasingly clear that a large portion of the collection in fact dates from the tenth century, and this is particularly true of those items relating to esoteric, or "tantric," Buddhism. This means that the Tibetan manuscripts from Dunhuang may reflect, in part, the kinds of religious concerns that characterized the Tibetan age of fragmentation. The fact that so many of the tantric manuscripts in particular date to the $10^{\text {th }}$ century itself may be taken as an indication of the increased popularity of the tantras among Tibetans of the $10^{\text {th }}$ century. Today the esoteric Dunhuang materials remain a surprisingly

\footnotetext{
${ }^{78}$ Kapstein, The Tibetan Assimilation of Buddhism: Conversion, Contestation, and Memory, pp. 10-11.

${ }^{79}$ Sam van Schaik, "The Early Days of the Great Perfection," Journal of the International Association of Buddhist Studies 27, no. 1 (2004): 165-206; Jacob Paul Dalton and Sam van Schaik, Tibetan Tantric Manuscripts from Dunhuang : A Descriptive Catalogue of the Stein Collection at the British Library (Leiden ; Boston: Brill, 2006); Sam van Schaik and Jacob Dalton, "Where Chan and Tantra Meet: Buddhist Syncretism in Dunhuang," in The Silk Road: Trade, Travel, War and Faith (London: British Library Press, 2004), 61-71; Dalton, The Taming of the Demons: Violence and Liberation in Tibetan Buddhism.
} 
untapped resource, due in part to the difficulty of gaining access to the collection and to a prejudice among scholars of the early twentieth century against all things tantric. ${ }^{80}$

\section{Description of the Dark Age}

Before we offer a reexamination/reinterpretation of the Dark Age, we need to ask ourselves, what do we know about this historical period? And, what made it so "dark," and so "fragmented"? ${ }^{81}$ For all the emphasis found in later Tibetan sources on the precarious position of Buddhism during the Dark Age, one of the paradoxes of the period is, as Davidson points out, "that some forms of the religion were complicit in unraveling the empire in the ninth century." 82 The Empire, through prominent figures like the Kings Sontsen Gampo and Trisong Detsen had played a crucial role in the establishment of Buddhism as the religion of Tibet, which culminated with the establishment of Buddhism as the official state religion in $792,{ }^{83}$ and supported the construction of temples, monasteries, and the translation of Buddhist scriptures through the creation of an imperial scriptoria. ${ }^{84}$ While there have been periodical waves of resistance to the new religion instigated by some of the noble families still supportive of old Tibetan religious

\footnotetext{
${ }^{80}$ Jacob Paul Dalton, The Taming of the Demons: Violence and Liberation in Tibetan Buddhism (New Haven: Yale University Press, 2011), p. 8.

${ }^{81}$ For an extensive account on the period see O rgyan Nor brang, The Garland of White Crystals [Bod Sil Bu'i Byung Ba Brjod Pa Shel Dkar Phreng Ba] (Lhasa: Bod ljongs mi dmangs dpe skrun khang, 1991). In English see Luciano Petech, "The Disintegration of the Tibetan Kingdom," in Tibetan Studies: Proceedings of the 6th Seminar of the International Association for Tibetan Studies, Fagernes, 1992, ed. Per Kværne, Occasional Papers (Instituttet for Sammenlignende Kulturforskning); 1. (Oslo: Institute for Comparative Research in Human Culture, 1994), 649659. Roberto Vitali, The Kingdoms of Gu.Ge Pu.Hrang: According to Mnga'.Ris Rgyal.Rabs by Gu.Ge Mkhan.Chen Ngag.Dbang Grags.Pa, 2nd edition (Serindia Publications, 1997). Davidson, Tibetan Renaissance: Tantric

Buddhism in the Rebirth of Tibetan Culture. Dalton, The Taming of the Demons: Violence and Liberation in Tibetan Buddhism.

${ }^{82}$ Davidson, Tibetan Renaissance: Tantric Buddhism in the Rebirth of Tibetan Culture.

${ }^{83}$ For a recent assesment of the relation between religion and politics during the Tibetan Empire, see Michael L. Walter's Buddhism and Empire: The Political and Religious Culture of Early Tibet (Brill Academic Publishers, 2009).

${ }^{84}$ On the Imperial Scriptoria see Sam van Schaik's “Oral Teachings and Written Texts: Transmission and Transformation in Dunhuang," in Contributions to the Cultural History of Early Tibet, (Leiden: EJ Brill, 2007), 183-208.
} 
rituals and practices, Buddhism had gained a strong foothold in the Land of Snows by the time of King Ralpachen (Tib. Ral pa can, 806-838 CE).

The generous patronage of King Ralpachen towards the Buddhist tradition seemed to have arrived at a period in which the economic and military power of Tibet in Central Asia was waning, and his strong support of Buddhism, which included the construction of state supported temples and monastic institutions, the financial support of imperial translation bureaus, and the creation of catalogues for the royal libraries, ${ }^{85}$ became "a recipe for deficit spending and bureaucratic jealousy." 86

After the death of Ralpachen, ${ }^{87}$ the last of the Dharma Kings of the Tibetan Empire period $^{88}$ he was succeeded by his brother Darma Udum-tsen (Tib. Dar ma u dum btsan, CE 803842), known in later Tibetan traditional sources as King Langdarma. ${ }^{89}$ Traditional sources depict

\footnotetext{
${ }^{85}$ On the creation and the contents of these catalogues see Georgios Halkias, "Tibetan Buddhism Registered: Imperial Archives from the Palace-Temple of 'Phang-Thang," The Eastern Buddhist XXXVI, no. 1 and 2 (2004): 46-105. in the administration, while others have argued that he died after he became sick. For the first explanation see W. D., Shakabpa, Tibet, a Political History, (New Haven,: Yale University Press, 1967). For the last explanation, see Hugh Richardson's “Khri Gtsug-Lde-Brtsan's Illness," Bulletin of the School of Oriental and African Studies, no. 44 (1981): 351-52.

${ }^{88}$ Sontsen Gampo, Trisong Detsen, and Ralpacan are traditionally known as the Three Dharma Kings (Tib. chos rgyal) or the Three Ancestral Kings (Tib. mes dbon rnam gsum).

${ }^{89}$ On this controversial figure, see Yamaguchi: "In regard to the epithet 'Glang' that appears prefixed to King Darma's name in sources dating only from the elenventh century and later, I had earlier considered it to derive from the year of his birth, in which case he would have been born in the year of the ox (809) mentioned in the gloss in the rGyal rabs gsal ba'i me long. But since this form of his name prefixed with "Glang" is also used in early sources that give the year of his birth as 803 , it is probably advisable to retract my earlier interpretation linking it to the year of his birth and to follow the explanation given in the mKhas pa'i dga' ston in regarding it as a derogatory nickname alluding to his "oxenlike build." In Yamaguchi's "The Fiction of King Dar-Ma's Persecution of Buddhism," p. 254." See also van Schaik's discussion of this issue in his EarlyTibet blog posts: The Decline of Buddhism I: Was Lang Darma a Buddhist? http://earlytibet.com/2008/02/28/lang-darma/, and in The Decline of Buddhism II: Did Lang Darma Persecute Buddhism in http://earlytibet.com/2008/03/13/did-lang-darma-persecute-buddhism/. Regarding his name, van Schaik says in the last post: "Glang Dar ma is a nickname, and is not found in any of the pre-11th century documents (though he is known as Khri or Lha sras Dar ma). The king's proper name was U'i dun/dum brtan, a rather unusual name which is confirmed by the Dunhuang manuscripts. As for the nickname Glang ('ox'), there are two possibilities, both found in Tibetan histories: (i) that it refers to the year of his birth, the ox year 809, or (ii) that it refers to his ox-like build. Since some of the earliest sources that use the name Glang for the king give his birthdate as 803 (not a year of the ox), Yamaguchi decided that the second option must be the correct one. As for
} 
Langarma as a demonic character who "was fond of wine, enjoyed hunting, and had a taste for women; he was cruel and perverse, and lacked generosity; the disorder of the state did nothing but increase." ${ }^{90} \mathrm{He}$ is also blamed for the persecution of Buddhism during his reign, although the details about the causes and motivations behind it are not completely clear and some scholars, like Yamaguchi and Davidson, have argued that the issue may be more complex, and offer an alternative vision of Langdarma, presenting him, at least initially, as a supporter of Buddhism ${ }^{91}$ and a reformist that tried to redress some of the socio-political and economic imbalances that were crippling the state due to its increasing support of Buddhism as the state religion. ${ }^{92}$

It is worth pointing out that, whatever Langdarma's motivations, Buddhism was facing persecution not only in Tibet, but also in China. Tang Emperor Wuzong (Ch. 唐武宗, 814-846 CE) waged a campaign against Buddhism that started in 841 (the same exact year as Langdarma's), and which culminated with the official suppresion of the religion in 845 . The persecution only ended in 846 with Wuzong's death. The causes for this suppression have been explained as a combination of anti-Buddhist sentiment stoked by followers of indigenous Chinese traditions who were jealous of Buddhism's influence in the Chinese court, and the

Dar ma, we do find it in several Dunhuang manuscripts from the imperial period with the meaning of dharma or dharma text. According to Yamaguchi it can also mean 'youth' but I haven't seen this meaning attested in the Dunhuang texts." The fact that the name Lang Darma is mentioned in an interlinear note in Nupchen's Lamp for the Eye in Contemplation, could mean that the name has an earlier origin, or that the interlinear notes were written not by Nupchen himself but by one of members of his lineage.See discussion on this important issue in chapter two of this dissertation.

${ }^{90}$ Description of Langdarma found in the Tang Annals as translated by Pelliot in his Histoire Ancienne du Tibet (p. 133). In Dalton's The Taming of the Demons: Violence and Liberation in Tibetan Buddhism, p. 47.

${ }^{91}$ An argument for the initial support of King Langdarma to Buddhism can be found in Yamaguchi's "The Fiction of King Dar-Ma's Persecution of Buddhism." His arguments have been criticized by Scherrer-Schaub in Cristina Scherrer-Schaub's "Prière Pour Un Apostat: Fragments D'histoire Tibétaine," Cahiers d'Extrême-Asie 11 (1999): 217-46. For a review of the argument between Yamaguchi and Scherrer-Schaub, see Dalton's The Taming of the Demons: Violence and Liberation in Tibetan Buddhism, p. 227, n. 12.

92 Davidson: “... although Darma may have been possessed by a demon from the monks' perspective, in fact his 'suppression' was most likely an attempt to redress large capital expenditures on behalf of both the military and the clergy, faced as he was with a dwindling resource base and a declining sense of imperial authority and beset by challeneges from both the pro-Buddhist and anti-Buddhist clans," in Davidson's Tibetan Renaissance: Tantric Buddhism in the Rebirth of Tibetan Culture, p. 66. 
drainage of tax revenue from the state caused by the swelling numbers of monastic communities sponsored by the government. ${ }^{93}$

Whatever the causes, though, what really matters to us were the consequences of these tensions. Dalton agrees with James Robson's insight as to how the parallel persecution of Buddhism in China and Tibet around the same time "came to shape the Buddhist traditions of the two regions. James Robson has argued that the Huichang persecution of 844-845, combined with the Anlushan (755-763) and the Huangchao (875-884) rebellions were the catalysts for the rise of regional Buddhist movements that were no longer dependent on imperial patronage but instead forged alliances with local rulers." 94

In the case of Tibet, the collapse of the Empire allowed the introduction of tantric texts, rituals and practices that had been forbidden during the previous decades. But we can also interpret the emergence and rise of the Great Perfection tradition during this period, with its emphasis on negative rhetoric and its rejection (at least on paper) of institutions, rituals, and

\footnotetext{
${ }^{93}$ The famous 9th century Confucian thinker Hanyu personified the leading opposition of Confucianism to Buddhism in China. As Valerie Hansen has written, "Hanyu [...] argued that the tax-exempt Buddhist establishment was draining the resources of the state and many concurred with him. Throughout the ninth century, the state had struggled with the problem of diminishing tax returns," in Valerie Hansen's The Open Empire: A History of China to 1600 (New York: Norton, 2000). As we can see, this is a very similar arguement to the one use during Ralpachen's reign to criticize the effect of Buddhism on the Imperial treasury. See also Davidson: "Any critical assessment, though, of Darma's, campaign against the clergy should be considered in light of the other anti-Buddhist campaign in contemporary Asia, the suppression of Buddhism under the Wuzong emperor. This Tang emperor's disfavor with the clergy also began in 841-the same time as Darma's persecution was inaugurated- and Wuzong's concluded with the full-fledged suppression of the religion in 845 and 846, ending only with Wuzong's death in 846. Evidently, both these suppressions resulted from the combination of falling revenues from Buddhist-controlled estates, the decline of head taxes through the expansion of Buddhist ordination certificates, the erosion of aristocratic authority in the face of the Buddhist public persona, and the excessive expenditures on Buddhist ritual and monastic activities. In addition, in Tibet, the empire was not growing but static with a very large army and a paucity of new resources," in Davidson's Tibetan Renaissance: Tantric Buddhism in the Rebirth of Tibetan Culture. Dalton makes a similar argument: "As several scholars have noted, it is surely relevant that during precisely the same period, China experienced its own anti-Buddhist crackdown, the worst in its history, when Emperor Wuzong (r. 841/842-845) ordered the closure of virtually all Buddhist monasteries in the empire. Scholars attribute this crackdown to a combination of causes, from the financial drain caused by the monasteries, to the Daoist leanings of the emperor and long-standing Confucian suspicions about the foreign religion," in Dalton's The Taming of the Demons: Violence and Liberation in Tibetan Buddhism.

${ }^{94}$ Dalton, The Taming of the Demons: Violence and Liberation in Tibetan Buddhism, 228, n. 24.
} 
complex (if not all) contemplative practices, parallel the rise of Chan in China during the same period, with a similar rhetoric. Both traditions were particularly well positioned for the new social and political environment and thrived in the empty space left by the collapse of traditions that were more dependent of institutional support.

The death of Langdarma in $842 \mathrm{CE}$ opened a battle for succession between the son of his junior queen, Namde Osung (Tib. gNam lde 'Od srung ), and the son of his older queen, Tride Yumten (Tib. Khri lde yum brtan). The rivalry between the two successors intensified clan tensions ${ }^{95}$ in Tibet, with the Dro clan supporting Osung and the Ba clan supporting Yumten. The tensions forced the division of the Empire, with Osung and his followers controlling Central Tibet below the Tsangpo River and Yumten controlling Central Tibet above the Tsangpo River.

\footnotetext{
${ }^{95}$ On clan politics in early Tibet, Walter has this to say: "Tibet's military successes often resulted in quick expansions - and contractions - of its empire. This meant that the alliances between btsan-pos and clans must have undergone constant torques. Clan hierarchies of the Mgar, Dba's, Myang, Mchims, Tshe-pong, Bro, Mnon, etc., would have watched as their ranks became thinly stretched, with the court requiring more and more personnel and advisors, who at first came almost exclusively from them. This pressure, increasing as time and the amount of occupied area went on, was almost certainly an element in Khri Srong Lde Brtsan's decision to turn away from, or to augment this system, by relying more and more on Sanghas. It is no coincidence that this change occurred at the time the Tibetan Empire reached its greatest geographical expansion. Monks provided additional manpower and thus took some pressure off this system. This was an excellent motivation for establishing Sanghas as official representatives of the Imperium. The inherent inflexibility of local clan politics would have been another cause for the lack of development of a professional administrative class of literati in the Imperium, such as had developed in China long before. The Sangha would have been seen as an institution to fill that role. Such dynamics must also have affected the politico-religious orientation of clan hierarchs to the btsan-pos. In its early period, the oft-cited annual and triennial 'rites of renewal', the oath-taking rituals that bound the btsan-pos and clan leaders, provided the btsan-pos with their manpower." In Michael L. Walter's Buddhism and Empire: The Political and Religious Culture of Early Tibet (Leiden: Brill,, 2009), 25. See also van Schaik, "Tibetan Chan IV: The Great Debate," Early Tibet, accessed May 6, 2014, http://earlytibet.com/2010/03/31/tibetan-chan-iv/.: "We know of the court intrigues regarding the introduction of Buddhism, Padmasambhava, Yeshe Tsogyal, Vairotsana and his exile by Queen Tshe Pongza and allied ministers and his return as well as other dramas and that the tensions in the new court of the unified panTibetan king were great and very delicate. So delicate that they just exploded not long after. Basically the warring clans shifted their quarrels from the battlefields onto a political dimension. Various ideological matters, Bon or variants of Buddhism and personalities, served as thinly disguised fronts. Of course with the introduction of Sarma schools later, this ideological front for power-plays and conflicts was repeated over the centuries as we know. So we have to take any narrative specially that early which suspiciously evolves over time and even has precious hints of clan motivations with a pinch of salt."
} 
The increasing military and political decline of Tibet during this period was punctuated by a series of rebellions (Tib. kheng $\log$ ). ${ }^{96}$ The first one took place around 845 (the sources are not clear on this date), following the initial chaos of the death of Langdarma and the tension over his successor, and had as one of the main consequences the loss of Tibetan control over Dunhuang, that reverted to Chinese control. The second rebellion occurred in 904, and will be explored later in more detail, since Nupchen played a small role and lost between two and four of his sons (depending on the sources) during its time. ${ }^{97}$ The third rebellion, which started in 905 and lasted until 910, witnessed the death of both royal candidates, Osung and Yumten, ${ }^{98}$ and the short and ill-fated inheritance of the empire by the son of Osung, Pel Khortsen (Tib. dPal 'khor btsan) who died in 910.

The rebellions and the constant problem of succession plagued the rest of the period, although in the midst of this picture of political fragmentation and instability we can also find the seeds of later centers of power that will be essential for the resurgence of Buddhism in Tibet during the Tibetan Renaissance. The descendants of Pel Khortsen, for example, following the

\footnotetext{
${ }^{96}$ On how to translate this term, see the interesting discussion in van Schaik's post "The Decline of Buddhism V: A Prayer for the Dark Age," in http://earlytibet.com/2009/06/12/decline-of-buddhism-v/. For an account of these rebellions, see Vitali's The Kingdoms of Gu.Ge Pu.Hrang. See also Roberto Vitali's "The Role of Clan Power in the Establishment of Religion (from the Kheng Log of the 9-10 Century to the Instances of the dByil of La Stod and gNyos of Kha Rag)," The Relationship between Religion and State (chos Srid Zung 'brel) in Traditional Tibet, 2004. Finally, see Davidson's Tibetan Renaissance: Tantric Buddhism in the Rebirth of Tibetan Culture.

${ }^{97}$ For a traditional account of this rebellion, see mKhas pa lde'u, pp. 321-22, and Vitali's The Kingdoms of Gu. Ge Pu.Hrang.

${ }^{98}$ Vitali proposes 905 as a possible date in ibid., p. 542, n. 923. The date for Yumten is not clear in the sources, although it is clear that he died during the third rebellion. For this period, see Guntram Hazod's "The Nine Royal Heirlooms" in Civilization at the Foot of Mount Sham-Po: The Royal House of 1Ha Bug-Pa-Can and the History of g.Ya'-Bzang ; ed. Gyalbo Tsering, Beiträge Zur Kultur- Und Geistesgeschichte Asiens; Nr. 36 (Wien: Verlag der Österreichischen Akademie der Wissenschaften, 2000); Guntram Hazod, "The Yum-Brtan Lineage," in Civilization at the Foot of Mount Sham-Po: The Royal House of 1Ha Bug-Pa-Can and the History of g. Ya'-Bzang;, ed. Gyalbo Tsering, Beiträge Zur Kultur- Und Geistesgeschichte Asiens ; Nr. 36 (Wien: Verlag der Österreichischen Akademie der Wissenschaften, 2000).
} 
death of their father, fled to Western Tibet where the elder son, Trih Kyide Nyimagun, will become the ancestor of the rulers of the Kingdom of Guge Purang. ${ }^{99}$

The picture painted by traditional Tibetan sources is, then, quite troubling, and shows a country imploding, fragmented, and with important internal divisions that affected Buddhism in many ways. Davidson offers a good "picture" of the feelings that many Tibetans had about the period, using the following quote from the lDe'u jo sras:

With the pent up evil of these troubled times, one exalted person would commit crimes against another exalted person. The edifice of nobility was occluded with the revolt of the Öbar vassals. A mother was unable to confide in her son; there was no agreement between advisor and minister, or father and uncle. The king's minister Nyak Tokpo was robbed and killed, and corpses seemed to rise from the barren snow ${ }^{100}$

This description of events is clearly bleak. Tibet went from being a military, political and economic force in Asia to being a fragmented, troubled, and in danger of losing the political and cultural prestige gained during the Empire, but that this doesn't mean though that there was no Buddhism during the period, or that the Buddhist developments that took place during this period were not relevant. This dissertation argues that they were. Maybe this was not an intensively creative and radically transformational period of Buddhism in Tibet, since most of the developments were born out of the dire historical context and not out of some particularly creative zeitgeist, such as during the Empire or the Tibetan Renaissance. However, what this dissertation wants to argue is that the transformation that Buddhism underwent during this period is relevant and worth studying, and it will have implications for the fate of Buddhism in Tibet in the ensuing centuries. In fact, we could make an analogy between the Tibetan Dark Age and the

\footnotetext{
${ }^{99}$ See Davidson's Tibetan Renaissance: Tantric Buddhism in the Rebirth of Tibetan Culture, p. 69. For a detailed history of this kingdom, see Roberto Vitali, The Kingdoms of Gu-Ge Pu-Hrang: According to Mgna'-Ris Rgyal Rabs by Gu-Ge Mkhan-Chen Ngag-Dbang-Grags Pa (Dharamsala, India: Tho-lin dpal dpe med lhun gyis grub pa'i gtsug lag khan lo 1000 'khor ba'i rjes dran mdzad sgo'i go sgrig tshogs chun gis dpar skrun źus, 1996).

${ }^{100}$ Davidson, Tibetan Renaissance: Tantric Buddhism in the Rebirth of Tibetan Culture, 71.
} 
Chinese invasion of Tibet (and its consequences) in the 20th century. Tibet in the 20th century has gone through a serious period of political, social, and religious upheaval, with most of its main religions institutions dismanteled or seriously disrupted. It would be an error, though, to assume that during the past sixty years nothing of relevance has happened within Tibetan Buddhism. In fact, it has been clearly the opposite, with Buddhism having to adapt and transform to new, challenging conditions in order to survive.

One aspect that it is relevant to the Dark Age is the fact that Buddhism unshackle itself from the control of the government. During the Imperial period the government controlled the scriptures that were translated, as well as the rituals and practices deemed acceptable. Now there was no central authority controlling what was deemed acceptable as Buddhism and what was not and Tibetans were able to experiment for over a hundred years away from the controlling eyes of any form of centralized power (or centralized monastic institutions). 


\section{History as Narrative: the Creation of the Dark Age}

While the historical facts described above are not totally clear and they are open to interpretation, it is obvious that, in the mind of Tibetans, this period stands in stark contrast to the period that preceded it, the Tibetan Empire (618-842 CE). If the Tibetan Empire were a period in which Tibet emerged as a great economic and military power in Central Asia, the Dark Age saw its catastrophic political and social collapse. If the Empire witnessed a cultural and religious transformation through the introduction of Buddhism in the $7^{\text {th }}$ century and its final adoption as the official religion of the Empire in 792, the Dark Age witnessed the destruction of most of the temples and monastic institutions founded during the previous period and the almost complete disappearance of the religion in Tibet. If the Empire was a period of great religious kings that were strong patrons of the new religion, like Sontsen Gampo, Trisong Detsen, and Ralpacen, the Dark Age was filled with evil kings (Langarma), and warring, competing factions (Osung and Yumten).

This portrayal of the Dark Age as an era of decline has also been perpetuated by Western scholars. Davidson, in his excellent study of the period that followed the Dark Age, the Tibetan Renaissance, claims that this period of Tibetan history was so unique and such a key for the Tibetan assimilation of Buddhism since "Tibet eventually displaced India itself as the perceived source for ideal Buddhist study and practice, becoming the goal of devout Buddhist pilgrims from much of Eurasia, and the reference point for all viable esoteric Buddhism." ${ }^{101}$ For Davidson, the Renaissance was a period in which anything and everything was possible, in which Tibetans imported, developed, reinterpreted and imagined all forms of Buddhism that competed for public

\footnotetext{
${ }^{101}$ Davidson, Ronald M. Tibetan Renaissance: Tantric Buddhism in the Rebirth of Tibetan Culture. New York: Columbia University Press, 2005, p. ix.
} 
favor and patronage. Some succeeded, while many did not, ${ }^{102}$ and, in most cases, the path to success (and failure) was never as straightforward as later sources want us to believe. But in order to make the Tibetan Renaissance all the more unique, Davidson has to present the previous period, the Dark Age, as a period that witnessed "the catastrophic collapse and fragmentation of the Tibetan Empire in the mid ninth century"103 in which the "consistent decay of social mores depict an all too familiar process of a culture self-destructing." ${ }^{104} \mathrm{He}$ wants to oppose the darkness of the period of fragmentation to the light of the Renaissance - destruction vs. creation. But Davidson, like many other historians, is not simply describing history, but also prescribing it, constructing it from a very particular ideological perspective. ${ }^{105}$

If we want to reassess our understanding of the Dark Age period, it would serve us well to also reconsider the way in which we approach traditional Tibetan historical sources. Here the methodological approach defended by the post-modern historian Keith Jenkins may help us reframe the debate regarding the Dark Age. Jenkins understands

...that history is not the same as the past. That history is always for someone. That history has always a purpose. That history is always about power. That history is never innocent but always ideological (and not in the sense of political bias, but moral judgments about right and wrong and how the individual historian thinks the world works). ${ }^{106}$

In this dissertation, following Jenkins' warning for historians, I argue that the Tibetan Renaissance, the Tibetan Empire, the Dark Age, or any historical period for that matter, are not

\footnotetext{
${ }^{102}$ An example of this can be found in Dan Martin, "The Star King and the Four Children of Pehar: Popular Religious Movements of Eleventh- to Twelfth-Century Tibet," Acta Orientalia 49, no. 1-2 (1996): 171-95.

${ }^{103}$ Davidson, Ibid. p. ix.

${ }^{104}$ Davidson, Ibid. p. 83.

${ }^{105}$ See my methodological discussion at the beginning of this chapter.

${ }^{106}$ This is the way Munslow describes Jenkins' notion of history in the preface, Jenkins, p. xiii. Davidson is an example of a classic historian who does not really follow this post-modern approach to history. Kapstein, on the other hand, dedicates two full chapters of his Tibetan Assimilation of Buddhism (chapters 4 and 5) using an approach closer to Jenkins' in his study of Tibetan history.
} 
historical realities, but historical narratives that serve particular political, social, and intellectual purposes. This does not mean that we need to negate the events that occurred during the period (the collapse of the Empire, the challenges faced by Buddhism during the period), but that we need to read those Tibetan histories as historical narratives that are interpreting the historical events of the period and integrating them into a larger narrative that will articulate a particular vision / interpretation of the period, serving particular political or intellectual agendas. So while Nyingmas and Sarmas may agree that the collapse of the Empire severely affected the development of Buddhism in Tibet, both traditions have different takes regarding the legitimacy of the Buddhism that did survive and developed during the Dark Age. 
Nupchen, the Dark Age, and the Tibetan Assimilation of Buddhism: A Reassesment

In her book The Open Road, Hansen argues that negative depictions of the decades that followed the collapse of the Tang dynasty in 907 are directly related to the tendency by historians to see Chinese history through the dynastic model:

By focusing too much on events at court, the model of the dynastic cycle assumes that nothing much happened between dynasties. Traditional court historians tended to describe these interludes as periods of chaos and disunity that ended only when the country was reunified by force of arms. If we were to look at the twentieth century through the lens of a traditional court historian, we would characterize the period from the 1911 fall of the last dynasty to the end of the twentieth century as a period of chaos and disunity because China and Taiwan are separated political entities. But, as was so often the case in the past, chaos and disunity have brought forth vitality and innovation [...] The idea that Chinese civilization attained its greatest heights only during times of unity should therefore be regarded with skepticism until more consideration is given to the forgotten, yet vigorous, interludes between dynasties. This book reexamined prevailing assumptions about the benefits of unity, if only to light a candle in the darkness. $^{107}$

A similar understanding is starting to emerge within the Tibetan studies field, and the works of a few scholars are focusing on the relevance of this "interemediate periods," such as the Dark Age, offering a more complex and nuanced view of the period. The works of Nupchen, particularly the Lamp, are playing a very important role in this reassesment.

While, [as we have seen], there is no doubt that the Dark Age was a period of social and political upheaval that had dramatic consequences for the standing of Buddhism in Tibet, particularly regarding the survival of monastic institutions, recent scholarship is reassessing traditional negative views of the period.

\footnotetext{
${ }^{107}$ In Valerie Hansen, The Open Empire: A History of China to 1600 (New York: Norton, 2000). Italics and bold are mine.
} 
Karmay, in his study of the origins of the Great Perfection, was one of the first scholars to use Nupchen's Lamp, as well as some of the Tibetan manuscripts found in the Dunhuang Library cave, in order to offer a more positive assessment of the period:

After the assassination of Glang Dar-ma, Tibetan history enters into its darkest period. It stretches from 842 to about 1000 . Yet the political, religious and cultural developments that began during this period would seem to have made a large contribution to the Tibetan Buddhist cultural "Renaissance" which emerged again from the beginning of the eleventh century. ${ }^{108}$

Kapstein, in his The Tibetan Assimilation of Buddhism, calls the period "one of the great puzzles in the study of Tibetan history," and questions traditional Tibetan accounts, especially by the Sarma schools that claimed that "Buddhist activity in Tibet virtually ground to a halt, not to be revived for perhaps a hundred years." ${ }^{109}$ Kapstein claims that one sign of clear Buddhist activity during the period can be inferred by the fact that the literary Tibetan that emerged after the $10^{\text {th }}$ century is mainly a continuation of what had been the language of scriptural translation. For Kapstein, the survival of Tibetan literacy after the collapse of the Empire, which disrupted imperial patronage for Buddhist institutions "to a degree that permitted knowledge of sophisticated Buddhist texts to be preserved, including some knowledge of Tibetan-Sanskrit lexicography, must certainly count as prima facie evidence that Tibet's dark age was not nearly so bleak as the traditional historiography would have us suppose. $" 110$ This reconsideration of the Dark Age was continued by Germano, who explored the relevance of this period for the emergence of the Great Perfection tradition:

\footnotetext{
${ }^{108}$ Karmay, The Great Perfection (rDzogs Chen): A Philosophical and Meditative Teaching of Tibetan Buddhism, p. 9.

${ }^{109}$ Kapstein, The Tibetan Assimilation of Buddhism: Conversion, Contestation, and Memory, p. 10.

${ }^{110}$ Kapstein, p. 11.
} 
I will instead argue that the period was the locus not only of continuing transmissions from outside Tibet, but also that its social decentralization masked a critically important period of Tibetan assimilation of Buddhism. This assimilation not only involved the popularization of Buddhism, but I also think it likely that a considerable amount of new literature was produced reflecting a number of creative tantric lineages amongst protoNyingma communities. ${ }^{111}$

Dalton $^{112}$ and van Schaik ${ }^{113}$ have also contributed enormously to our understanding of the period through their extensive study of the Tibetan Dunhuang manuscripts. In his recent study of violence in Tibetan Buddhism, Dalton offers one of the most positive descriptions of the period, arguing, "[This] era was in fact marked by an eruption of religious creativity. The innovations that emerged during these crucial years were subsequently denied their historical importance by later historians, dismissed as the heretical distortions of ignorant Tibetans under the influence of demons."114

\section{Bringing Some Light to the Dark Age}

This dissertation with its study of the work of Nupchen Sangyé Yeshé , and in particular of his doxographical treatise, the Lamp for the Eye in Contemplation, wants to contribute to this process of reassessment of the Dark Age by focusing on three general areas.

\footnotetext{
${ }_{111}$ Germano, unpublished manuscript: The Secret Tibetan History of Buddhist Tantra in the Great Perfection, p. 75. ${ }^{112}$ Dalton's inaugural Khyentse Foundation lecture had the title "Rethinking Tibet's Dark Age: Demons, Tantras, and the Formation of Tibetan Buddhism." For more details on this lecture see http://buddhiststudies.berkeley.edu/webcasts/.

113 "That the fragmentation of the previous political and religious establishments did not stop the development of Buddhism in Tibet is shown by the strong evidence for a vibrant Buddhist community in one of the fragmented segments of tenth-century Tibetan culture: the Tibetans of the Hexi corridor. This region joins the northeastern end of the Tibetan cultural area, now known as A mdo, with the western limit of the Chinese cultural sphere. Passing through it were a number of the trans-Asian trade routes popularly known today as the Silk Road. After the fall of the Tibetan Empire in the mid-ninth century, there was indeed a fragmentation of Tibetan power in the Hexi corridor. Yet the small Tibetan kingdoms and principalities that established themselves in the region were surprisingly robust, establishing diplomatic relations with the short-lived Chinese dynasties of the tenth century and subsequently with the Song dynasty. The historical records also indicate the growing importance of Buddhist monks in the political events of this period," in van Schaik 2008, p. 2.

${ }^{114}$ Dalton, The Taming of the Demons: Violence and Liberation in Tibetan Buddhism, p. 5.
} 
First, Nupchen's Lamp can help us question the lack of important and creative Buddhist activity during the period. Even if we consider Nupchen's life and work an exception and not the norm, a beacon of light during an era of darkness, a close reading of Nupchen's hundreds of sources (quite a few not extant today) show that Buddhism was actively imported, translated, and commented upon during this period. The Lamp shows the enormous diversity of Mahāyoga works that were being imported and translated after the collapse of the Empire. It also underscores the importance of the Anuyoga ideology in Nupchen's understadnding of tantra (as we will see, the Sütra of the Gathered Intentions, a key Anuyoga text, forms the backbone of Nupchen's articulation of the tantric view in the Lamp, including the Mahā, Anu, and Atiyoga traditions). Finally, the Lamp is our earliest witness to a Great Perfection tradition that asserts itself as an independent Buddhist vehicle.

Second, the life and works of Nupchen (at least what we know about him from later sources) show how Buddhism was being imported into Tibet from a wide variety of places besides India. As we will discuss in more detail in other parts of the paper, the Lamp makes a clear point about the relevance, at least until the Dark Age period, of Chinese Chan in Tibet, something that has been confirmed by Japanese researchers ${ }^{115}$ and scholars like van Schaik, with his study of the Dunhuang manuscripts. ${ }^{116}$ Another sign of the geographic diversity of the Buddhism that was being imported into Tibet can be found in another work written by Nupchen, the Armour Against Darkness, which was a commentary on a text, The Sutra of the Gathered

\footnotetext{
115 See Uyaema, Daishun: "The Study of Tibetan Ch'an Manuscripts Recovered from Tun-Huang: A Review of the Field and Its Prospects." In Early Ch'an in China and Tibet, edited by Whalen Lai and Lewis R. Lancaster. Berkeley: Asian Humanities Press, 1983.

${ }^{116}$ This is also something that we can see in some of the Dunhuang manuscripts, like in PT 996: "Après avoir 'diagnostoqué' les sūtra dont le Sens est certain, ayant accordé sa proper méditation avec les àgama et les upadeśa des conseillers religieux, ayant attaint la source des commentaries sur le Sens certain de sūtra du Grand Véhicule et le Sens de ces āgama et upadeśa des penseurs Maitres du Dhyāna du Tibet, de la Chine et de l'Inde." In Lalou, Marcelle. "Document Tibétain Sur L'expansion Du Dhyāna Chinois." Journal Asiatique 231, (1939): 502-23, bold and underlining are mine.
} 
Intentions, that was supposed to have been translated from Burushaski into Tibetan. ${ }^{117}$ As we can see, then, Nupchen can be of help in pointing out a more regionally diverse introduction of Buddhism in Tibet. ${ }^{118}$

Finally, the Lamp is the earliest text that defines the Great Perfection tradition as an independent vehicle, and offers a unique window into not only the early history of this tradition, but also of the mechanisms by which tradition is created. As we will see (in chapter 2), the use of the doxographical genre on the part of Nupchen is key in the process of articulating the Great Perfection as a separate vehicle in opposition to other Buddhist traditions.

\footnotetext{
${ }^{117}$ For this issue see Dalton's Appendix 1 of his dissertation.

${ }^{118}$ Kapstein also seems to agree with the need to reconsider this issue: "Tibetan Buddhism has often been presented, by both Tibetans and non-Tibetan students of Tibetan culture, as the product of a strict and literal transmission of Indian Buddhism, an almost invariant preservation of a perennial tradition [...] Despite the powerful and enduring role of Indian Buddhist sources and precedents, however, it is clear that this view alone is far too simple. "Indian Buddhism" itself was not at all monolithic, and India imparted many and varied influences to Tibet, which the Tibetan themselves received and transformed in many and varied ways. Moreover [...] not all of the Buddhism the Tibetans transmitted came from India." Kapstein, Ibid., p. 70. Also Kapstein offers a good example of what this history looks like with his analysis of the very tenuous (but still existent) traces of Korean Buddhism in Tibetan Buddhism. Kapstein argues that his academic exercise "serves as an illustration of Tibet's participation in the international culture of Buddhism, and, at the same time, of the assimilation and transmission in Tibet of materials made available through such participation" (p. 69). At the end of the same chapter Kapstein argues, "Turning now to the history of Tibetan Buddhism in particular, we must understand that [these] examples taken up in this chapter would have to be multiplied a thousand fold to do justice to the full range of texts and teaching traditions that variously became interwoven or opposed to one another in the fabric of Tibetan thought, from about the eighth through the thirteenth centuries [...] The full complexity of such connections, moreover, must be considered in relation to the full panoply of Tibetan individuals, lineages, and institutions that identified themselves with, rejected, or ignored specific materials that became available through the varied processes of cultural transmission." In Kapstein, Ibid. p. 84. Broughton makes a similar point: "The Tibetan Ch'an manuscripts serve to remind us how much, particularly during the Tibetan occupation period, the religion of Tun-huang was the religion of the Silk Road and therefore how it must be approached as part of a continuum extending across the Western Region to such distant places as the city-state of Kucha. One of the characteristics of the Buddhism of this continuum was a receptivity to both Indian and Chinese currents. This was a truly eclectic environment, so it should come as no surprise that its Buddhism was not purely Chinese.” In Broughton, Jeffrey L. The Bodhidharma Anthology the Earliest Records of Zen. Berkeley, Calif.: University of California Press, 1999, p. 99.
} 


\section{Part 2 - The Unusually Long Life of Nupchen Sangyé Yeshé : Calendrical Issues,}

\section{Lack of Sources, and Turning a Problem into an Opportunity.}

"In regard to the time of the appearance of this Sangs-rgyas ye shes, some say that he lived in the time of Khri-song lde-btsan, some say that he lived in the time of Ral-pa-can, and again some say that he lived in the time of Khri bKra-shis brtsegs-pa-dpal."

Blue Annals $^{119}$

One of the first problems we face when studying the life of Nup Sangyé Yeshé is the uncertainty surrounding his dates. Some traditional Tibetan sources consider him to have lived between $772-884,{ }^{120}$ making him a contemporary of King Trisong Detsen (Tib. Khri srong lde btsan) and identifying him as one of the twenty five direct disciples of Padmasambhava, while others place him between 832-962, confronting King Langdarma (Tib. Glang dar ma) for his opposition to Buddhism and a witness to the collapse of the Empire. ${ }^{121}$

The problematic nature of his dates is something also acknowledged in Tibetan historiographical writing. In the $15^{\text {th }}$ century, Go Lotsawa (Tib. 'Gos lo tsa ba) already acknowledged the confusion surrounding Nupchen's dates, as it is clear in the quote that opens this section, although he seems to be inclined to situate him in the latter part of the $9^{\text {th }}$ century and the beginning of the $10^{\text {th }}$ by saying, "[I]t seems it would be correct to say that having been

\footnotetext{
${ }^{119}$ Gos Lo-tsā-ba Gźon-nu-dpal and George Roerich, The Blue Annals (Delhi: Motilal Banarsidass, 1976 ), p. 108.

${ }^{120}$ Like the $16^{\text {th }}$ century Nges don 'brug sgra by Blo gros rgyal mtshan, p. 278 or the $18^{\text {th }}$ century rGyud 'bum rtogs brjod by 'Gyur med tshe dbang mchog grub, dGe rtse sprul sku. See Karmay, The Great Perfection (rDzogs Chen): A Philosophical and Meditative Teaching of Tibetan Buddhism, p. 100, n. 89.

${ }^{121}$ Khetsun Sangpo uses this later date in his mkhas btsun bzang po, Biographical Dictionary of Tibet and Tibetan Buddhism (rgya Bod Mkhas Grub Rim Byon Gyi Rnam Thar Phyogs Bsgrigs), 12 vols. (Library of Tibetan Works and Archives, 1973), vol. 3, pp. 136-155. Dudjom Rinpoche uses similar dates in his The Nyingma School of Tibetan Buddhism: Its Fundamentals and History (Boston: Wisdom Publications, 2002), p. 607. Vitali points out how bSod nams don grub in his sNga 'gyur rnying ma'i bljod pa "goes to the extent of attributing the improbable dates $770-883$ to him (p.79 line 22-p.80 line 2: "gNubs chen 'di mi yul du bzhugs/ chu stag spyi lo 883 lor rang.bzhin rdzogs pa chen po'i lam las lhun grub 'od kyi phung por mya ngan 'das so"), in Vitali, The Kingdoms of Gu.Ge Pu.Hrang, p. 546, n. 932.
} 
born in the reign of king Ral pa can, he lived until the time of Khri bKra shis brtsegs-pa-dpal." 122 In the $18^{\text {th }}$ century, Guru Tashi (Tib. Gu ru bkra shis) repeats, almost verbatim, in his Religious History the Blue Annals assessment on Nupchen dates. ${ }^{123}$

The Testament of Nup, which Guru Tashi quotes in his assesment of Nupchen's dates, offers the following account of Nupchen's birth, as well as a date:

A sandalwood tree grew in the middle of the ancestral charnel ground of Grag Riboche. This generated much amazement [so] the tree was shown to a Chinese monk [who was] invited from Samye monastery [in] Drakmar. [The Chinese monk was also] amazed and said: "In the lineage of Nup Selwa Changchub, an excellent son, an emanation, will certainly be born in the first spring month of the wood male rat year. ${ }^{124}$

The wood male rat year could be, according to the sixty year cycle Tibetan calendar, and on what we know of Nupchen's life, either 784 or 844. Modern scholarship has glossed over this issue by either using one specific date from the various Tibetan sources (Snellgrove, in his Indo-Tibetan

122 'Gos Lo-tsā-ba Gźon-nu-dpal and tr. George Roerich, The Blue Annals, 2nd ed. (Delhi: Motilal Banarsidass, 1976), p. 108.

${ }^{123}$ Donati quotes this passage in her dissertation: "[Regarding] gNubs chen Sangs rgyas Ye shes['dates], some state that he was born between Khri stong IDe'u btsan and Khri bKra shis brTsegs pa dPal; some state that, born during Ral pa can's reign, he lived until Khri bKra shis brTsegs pa's reign; other state that an earlier Sangs rgyas Ye shes was born during Khri srong 1De'u btsan's reign, while a later one was born during Ral pa can's reign. Nevertheless, it is stated in the Extensive Ordinance: 'This is the precept that the Indian scholar Vimalamitra, the abbot from Oddiyana Padmasambhava, the Nepalese scholar Vasudhara and the Tibetan scholar Jñanakumara bestowed upon me'; so it is unquestionable that he was born during Khri srong IDe'u btsan's reign." The Tibetan is: "gnubs chen sangs rgyas ye shes rin po che 'di/ btsan po khri srong lde'u btsan nas/ khri bkra shis rtsegs pa dpal gyi bar ci rigs par byung bar 'dod pa dang yang ral pa can gyi dus su byung nas/ khri bkra shis brtsegs pa'i bar bzhugs par 'dod pa dang/yang snga ma btsan po khri srong lde'u btsan dang/ phyi ma ral pa can gyi dus na byung ngo zhes gtan tshigs sna tshogs yod de bka' shog rgya bo cher/ rgya gar mkhas pa bi ma la mi tra dang/ o rgyan mkhan po padma 'byung gnas dang/ bal po'i mkhas pa ba su d+ha ra dang/ bod kyi mkhas pa dz+nyA na ku mA ras/ bdag la gnang ba'i man ngag 'di rnams yin/zhes pas btsan po khri srong gi dus na byung bar rtsod pa med la/ ku tshe'i tshe brgya dang bcu gsum la gtan tshigs bsgrigs nas byon pa'i dus phyir bsring ba dang/rus gnubs dang/yul sgrags la gzugs brnyan gnyis par bcos pas snga phyi gnyis par byung ste de dag la snying po med do." In Gu ru bkra shis, Gu Ru Bkra Shis Chos "Byung (bsTan Pa"i Snying Po Gsang Chen Snga "Gyur Nges Don Zab Mo"i Chos Kyi Byung Ba Gsal Bar Byed Pa'i Legs Mkhas Pa Dga' Byed Ngo Mtshar Gtam Gyi Rol Mtsho), W20916 ed. (Beijing: Krung go'i bod kyi shes rig dpe skrun khang, 1990), p. 246. In Valeria Donati's "The Lamp Is Burning Bright. Gnoseological Approaches and Soteriological Perspectives in gNubs Chen Sangs Rgyas Ye She's Masterpiece" (Università degli Studi di Napoli, 2007), 4-5.

${ }^{124}$ Testament $2 \mathrm{a}-2 \mathrm{~b}$ “/dur gyi dkyil du tsan+dan sdong bo skyes/_/ngo mtshar skyes nas brag dmar bsam yas nas/_/rgya nag ha shang spyan drangs tsan dan sdong po bstan/_/kho yang ngo mtshar skyes nas 'di skad gsungs/_gsal ba byang chub snubs kyi che rgyud la/_/lo yi dang po shing pho byi ba'i lo/_zla ba'i dang po dpyid zla ra ba la/_/sras kyi dam pa sprul pa'i sku gcig 'khrungs par nges/" 
Buddhism, offers 772 as his birth date, ${ }^{125}$ while Ruegg ${ }^{126}$ places him in the $8^{\text {th }}$ century as a disciple of Padmasambhava), or by simply acknowledging the ambiguity of the dates found in the traditional sources. In his groundbreaking study of the early Great Perfection tradition, Karmay seems to follow the Blue Annals and limits himself to acknowledging the difficulty of the issue ("the dates of this personage are surrounded by total confusion as far as the rNying ma pa chronology is concerned"). ${ }^{127}$

Dudjom Rinpoche, in his Nyingma School of Tibetan Buddhism offered one of the first serious attempts at solving the conundrum posed by Nupchen's dates, and after making "an accurate calculation following the chronology of the Kālacakra Tantra," he offers 832-943 as possible dates. ${ }^{128}$

${ }^{125}$ David L Snellgrove, Indo-Tibetan Buddhism: Indian Buddhists and Their Tibetan Successors (Boston: 1987), p. 464.

${ }^{126}$ David Seyfort Ruegg, Buddha-Nature, Mind and the Problem of Gradualism in a Comparative Perspective: On the Transmission and Reception of Buddhism in India and Tibet (New Delhi: Heritage, 1992), p. 66 n. 129.

${ }^{127}$ Karmay states in full,"The dates of this personage are surrounded by total confusion as far as the rNying ma pa chronology is concerned. While one version places his birth as early as 772 A.D. and so making him a direct disciple of Padmasambhava, another version puts him in the reign of Khri bKra-shis brtsegs-pa-dpal, hence around the late tenth century A.D." For the earlier dates his source is the Nges don 'brug sgra, by Blo gros rgyal mtshan, while he uses the Blue Annals for the later one. Karmay, The Great Perfection (rDzogs Chen): A Philosophical and Meditative Teaching of Tibetan Buddhism, p. 66, n. 129.

${ }^{128}$ Dudjom offers as Nupchen's date of birth the water (instead of the wood) male rat year, which would sitaute Nupchen in either 778 or 832, depending on the calendrical cycle chosen. He choose 832. Dudjom's complete explanation for his calculation is as follows: "[T] here was a prophecy that [Nupchen] would be born two thousand years after the Teacher's nirvana, this was an approximation, for it was close to two thousand years. If we make an accurate calculation, following the chronology of the Kālacakra Tantra, which is well known today, Nup was born one thousand seven hundred and thirteen years after the Teacher's nirvana. This is because it is calculated from the iron dragon year of the Teacher's passing $(881 \mathrm{BC}) .72 \mathrm{~S}$ Twenty-eight years later, in the earth monkey year (853 $\mathrm{BC}$ ), the secret mantra texts fell onto the roof of the palace of King [a. One thousand six hundred and eighty-five years after that in the water mouse year 832, Nup was born. This same water mouse year was the forty-third year of King Trhisong, who had been born in the iron horse year 790; and it was the sixth after the ordination of the "seven men who were tested", which had occurred in the fire sheep year 827. In the earth tiger year 858, when Nupcen was in his twenty-seventh year, King Trhisong died. Eighty-five years later, in the water tiger year 943, Nupcen passed away. Therefore, it is clear that he lived for about thirty-seven years after the persecution of the teaching by Langdarma. Nup passed away in his one hundred and eleventh year in the district of Khyonmi. Finally, he entered nirvana in a mass of light, spontaneously accomplished by means of the path of the natural Great Perfection," in Dudjom Rinpoche, Dorje Gyurme, and Matthew Kapstein, The Nyingma School of Tibetan Buddhism: Its Fundamentals and History (Boston, Mass.: Wisdom Publications, 2002), pp. 613-14..For the history of Tibetan calendrical systems see Dieter Schuh, Untersuchungen Zur Geschichte Der Tibetischen Kalenderrechnung (Wiesbaden: F. Steiner, 1973). 
While this is the first serious attempt found in historical sources to try to solve this issue, these dates still maintain for Nupchen an unusually long life of 112 years. Vitali, in his 1996 study The Kingdom of Gu Ge Pu hrang, argues that the "exceptionally long life" attributed to Nupchen that "makes him a contemporary of Guru Padma and [King] Khri srong lde brtsan," are simply "a pious fabrication to increase his prestige," 129 and offers a new, and quite convincing, attempt at dating Nupchen. He offers as a more accurate date of birth for Nupchen the year 844, basing his calculations on the fact that various sources, like the lDe'u chos 'byung, Nyangrel's and Guru Tashi's Religious Histories, and Pema Tinley's biography, relate Nupchen's connection with the second of the three revolts (Tib. kheng log) that took place after the collapse of the Empire. Pema Tinley and Guru Tashi (as well as the Testament of Nup, the probable source for later accounts of Nupchen's life, and of which Vitali had no access at the time of writing his book) mention that Nupchen was sixty one years old when the rebellion started, and we know that the second rebellion took place in 904 . Therefore, according to Vitali:

gNubs chen was obviously born in the wood rat year of the previous rab byung to be sixty-one in the following wood rat year, when the second kheng.log broke out. The literature, including this biography, makes him a contemporary of Guru Padma and Khri.srong Ide.btsan. This is a pious fabrication to increase his prestige. Were he to have been born in a wood rat year during the 8th century to be contemporary with Guru Padma, he could have not been sixty-one in the wood rat year of the second kheng.log, as this took place during dPal.'khor.btsan's reign. Hence, he was born in wood rat 844 , and, when he was sixty-one in wood rat 904, the second kheng.log broke out. ${ }^{130}$

Vitali's efforts at dating Nupchen, while still problematic, ${ }^{131}$ are quite convincing and

have been widely accepted in modern scholarship on Nupchen. Dalton, ${ }^{132}$ in most of his research

\footnotetext{
${ }^{129}$ Vitali, The Kingdoms of Gu.Ge Pu.Hrang, p. 546. Also see David Germano's "The Seven Descents and the Nature of sNga' 'Gyur: The 'history' of rNying Ma Tantras," in The Many Canons of Tibetan Buddhism: Piats 2000: Tibetan Studies: Proceedings of the Ninth Seminar of the International Association for Tibetan Studies (Leiden: Brill, 2000).

${ }^{130}$ Vitali, The Kingdoms of Gu.Ge Pu.Hrang.

${ }^{131}$ Vitali relies heavily for his proposed date of 844 on the fact that two sources, Padma Tinley and Guru Tashi, mention in their accounts that Nupchen was sixty-one when the second rebellion of 904 broke out. Vitali does not acknowledge the possibility, as I believe, that Guru Tashi either used Padma Tinley's biography or that both used the earlier gNubs chen bka' shog chen mo for this assertion. Although, as Dalton acknowledges, the bka' shog chen
} 
on the subject, agrees with Vitali, as do Donati and Esler in their studies of Nupchen. ${ }^{133}$ The most important contribution of Vitali and also of Dalton ${ }^{134}$ is, if not solving what is probably an unsolvable issue, at least placing Nupchen in a more focused historical period, anchoring him at the end of the Empire and, particularly, in the difficult years of the Dark Age.

The resurfacing of the Testament of Nup allows us to confirm Vitali's dating of Nupchen as the most probable. The biography makes references to important years in the life of Nupchen, like the date of birth (844 CE, the wood male rat year; Tib. shing pho byi ba), the year he turned thirteen (857 CE, the male rat year; Tib. pho byi $b a$ ), or the year he turned sixty one (904 CE, the rat year; Tib. byi lo). Those Tibetans years only would add up if we follow Vitali's suggestion

mo may have some autobiographical parts written by Nupchen himself, the work is certainly of later composition, probably a late $13^{\text {th }}$ or late $14^{\text {th }}$ century composition, which makes any dating in it not highly reliable. Vitali also avoids addressing why he focused on such dates, when Padma Tinley offers other dates for his birth, death, etc. that would complicate his general conclusion of an 844 birth date.

${ }^{132}$ Dalton has also addressed the issue of Nupchen's dates to conclude that, although they are still problematic, the ones proposed by Vitali "fit well with the evidence such as it is." "Nupchen's dates have been the cause of some debate. Karmay 1988: 99-103 and Vitali 1996: 546-7 provide good discussions of some of the key sources. Against the common view within the tradition that Nupchen was a student of Padmasambhava and therefore born in the eighth century, Karmay concludes that Nupchen's Lamp for the Eyes (Bsam gtan mig sgron) should be dated to the late tenth century. Vitali, however, arrives at somewhat earlier dates, with a birth date of 844 C.E., which in turn would give an early tenth-century date for the Lamp for the Eyes. Vitali calculates his date on the basis of Padma Trinlé's seventeenth-century biography, which (as we shall see) is largely based on the Gyawoché that is the subject of the present article. While none of the available sources are terribly reliable, Vitali's dates fit well with the evidence such as it is." (Bold is mine), in Dalton, "Preliminary Remarks on a Newly Discovered Biography of Gnubs Chen Sangs Rgyas Ye Shes," p. 1, n. 1.

${ }^{133}$ Donati, "The Lamp Is Burning Bright. Gnoseological Approaches and Soteriological Perspectives in gNubs Chen Sangs Rgyas Ye She's Masterpiece," p. 2. . Esler just published an article while I am completing my dissertation that also agrees with Vitali's dates for Nupchen, in Dylan Esler, "On the Life of gNubs-Chen Sangs-Rgyas YeShes," Revue d'Etudes Tibétaines, no. 29 (April 2014): 5-27.

${ }^{134}$ Although Kapstein has this to say about Dalton's dating of Nupchen in his Taming of the Demons: "One point that I found troubling was Dalton's treatment of the difficulties of dating and establishing the provenance of certain materials with which he is concerned. Dalton is not careless in this regard—he is appropriately cautious overall-but he occasionally prefers to accept a plausible but uncertain solution without making clear the degree of uncertainty. Most important in this respect, and crucial for some of Dalton's arguments, are the problems surrounding the Mdo dgongs pa 'dus pa (Mdo hereafter), its Tibetan promulgator Bsnubs Sangs-rgyas-ye-shes, and the large commentary attributed to him, entitled Mun pa'i go cha. Dalton proposes a ninth-century dating for the Mdo, and late ninth century for Bsnubs. The late ninth-century date accords with the later legends of Bsnubs, which affirm him to have been active during the period following the fall of the Tibetan empire. It is also consistent with the contents of the other major work attributed to him, the Bsam gtan mig sgron, whose discussions of Chinese Chan sources closely resemble those found in the Tibetan Dunhuang documents. The history of the $M d o$, however, remains deeply puzzling. Although we cannot exclude the possibility that it existed (at least in some form) as early as the ninth century, it may well be a later composition," in Matthew Kapstein, "The Taming of the Demons: Violence and Liberation in Tibetan Buddhism by Jacob P. Dalton (review)," Harvard Journal of Asiatic Studies 73, no. 1 (2013): $177-84$. 
that Nupchen did, in fact, live through the second revolt, which would mean that he was sixtyone in 904 , and was born in 844 , and not 777 or 884 , as some traditional sources suggest.

This still does not clarify some of the references in the text, like the reference to the Chinese monk (Hashang Mahāyāna?), or to Padmasambhava, which should makes us wary of declaring victory and forgetting that the bka' shog, while trying to place Nupchen in a particular historical period (at least from the use of dates) also felt compelled to insert him in earlier historical developments of the introduction of Buddhism in Tibet, during the glory days of the Empire.

The problem of dating Nupchen can be attributed to three particular issues: the change of calendrical system in the early $11^{\text {th }}$ century, the lack of contemporary sources, and the fact that the later Nyingma tradition used the confusion around his dates to transform Nupchen into a liminal figure, a bridge between the early (Tib. bstan pa snga dar) and the later diffusion (Tib. bstan pa phyi dar) of Buddhism in Tibet.

\section{1) The adoption of the Kālachakra calendrical system and the problem with}

Imperial dates: One important issue regarding early Tibetan dates can be also explained by the adoption of the Kālachakra sixty year cycle that started in 1027 , which conflicted with the early twelve year cycle used during the Empire. As Petech has stated regarding this issue:

The grounds for this chaos [regarding Imperial dates] are twofold. Firstly, all the dates in that early period were expressed in the twelve-years cycle, as it was the rule in the documents of the monarchy. The addition of the names of the five "elements", i.e. the conversion into the sexagenary cycle starting in 1027 was an uncertain process and the cause of many mistakes, partly due to the historians themselves and partly through the repeated copying. Usually in a date referring to this period the only sure component is the 
animal; the "element" is often doubtful and sometimes demonstrably incorrect. In the second place $[\ldots]$ even the dates of the duocenary cycle are conflicting ${ }^{135}$

Kapstein and Dorje addressed this issue in the specific context of Nupchen's dates, offering an explanation for the discrepancy between the two traditional set of dates offered for Nupchen:

There are many discrepancies in the dating of the imperial period of Tibetan history which come to light when the various available sources are compared. One of the problems centers on whether Songtsen Gampo died in 649/50 as stated by Chinese and early Tibetan sources (Tun Huang, Tang Annals), or whether he lived until 718 as claimed by some Tibetan sources (cf. Dudjom Rinpoche, rgyal-rabs, pp. 137ff). In addition, Tibetan historians disagree as to the length of time that elapsed between Langdarma's persecution and the restoration of Buddhism in Central Tibet. Nupcen's birth according to the tradition which asserts Songtsen Gampo's longevity and a late date for the Langdarma persecution would be February 832, whereas the dating based, on the early annals would place his birth in 772 (chu-pho-byi 10). Our present History assumes that the dates associated with the life of Nupcen [832-943] follow the former tradition ${ }^{136}$

2) The lack of contemporary sources. The second obvious issue affecting our assessment of Nupchen's dates is the scarcity of contemporary sources. Most of our biographical accounts of Nupchen's life were written decades if not centuries after his death. We have some references in early literature like Nyangrel Nyima Ozer's Religious History and Podrang Zhiba Ö’s Proclamation, but the more detailed accounts about his life, like the two 1 De'u histories, and the probably $14^{\text {th }}$ century Testament of Nup (Tib. Sangs rgyas ye shes rin po che'i lo rgyus gnubs kyi bka' shog

\footnotetext{
${ }^{135}$ Luciano Petech, "The Disintegration of the Tibetan Kingdom," in Tibetan Studies: Proceedings of the 6th Seminar of the International Association for Tibetan Studies, Fagernes, 1992, ed. Per Kværne, Occasional Papers (Instituttet for Sammenlignende Kulturforskning); 1. (Oslo: Institute for Comparative Research in Human Culture, 1994), 649-59, p. 653.

${ }^{136}$ In Dudjom 'Jigs-bral-ye-śes-rdo-rje Bdud-'joms et al., The Nyingma School of Tibetan Buddhism: Its Fundamentals and History (Boston, Mass.: Wisdom Publications, 2002), pp. 54-55 of notes.
} 
chen $m o$ ), ${ }^{137}$ or the $17^{\text {th }}$ century biography written by Pema Tinley (Tib. Rigs 'dzin chen po padma 'phrin las), 'Dus pa mdo dbang gi bla ma brgyud pa'i rnam thar ngo mtshar dad pa'i phreng ba (an Account of the Transmission Lineage of the Initiation of the 'Dus pa mdo Tantra Written in 1681 at rDo rje brag by the Second Rigs 'dzin chen po padma 'phrin las), were written much later.

3) Nupchen as a liminal figure. Finally, the confusion surrounding Nupchen's dates, while explainable within the previous two issues (change of calendrical system in the $11^{\text {th }}$ century and the lack of contemporary sources), has also been used by Nyingmapa scholars in particular to transform Nupchen into a liminal figure, a bridge between the glorious era of the Tibetan Empire, through his association with King Trisong Detsen, Padmasambhava, Hashang Mahāyāna, and Kamalaśīla, and the second diffusion of Buddhism in Tibet that began in the began in the late $10^{\text {th }}$ century. ${ }^{138} \mathrm{He}$, alone, became a beacon of light, protecting and carrying the teachings during a period that came to be depicted as one of social and political upheaval and intellectual darkness. Nupchen, particularly for the Nyingma Kama (Tib. bka' $m a$ ) tradition, has become the "historical" missing link that the Nyingmas needed to legitimize the great numbers of teachings that surfaced during the Dark Age period with no clear Indian (i.e. Sanskrit) reference.

\footnotetext{
${ }^{137}$ See Dalton, "Preliminary Remarks on a Newly Discovered Biography of Gnubs Chen Sangs Rgyas Ye Shes" for a possible date for this text.

${ }^{138}$ A good example of the transformation of Nupchen into a liminal figure can be found in his inclusion as one of the "descents" (Tib. babs bdun) in some of the Nyingma histories. The notion of "descents" helped the Nyingma tradition articulate "lineal transmissions [...] in Tibet that attempt[ed] to anchor their own teachings" origins in foreign Buddhist countries (India above all)." See David Germano, "The Seven Descents and the Nature of sNga' 'Gyur: The 'history' of rNying Ma Tantras," in The Many Canons of Tibetan Buddhism: Piats 2000 : Tibetan Studies : Proceedings of the Ninth Seminar of the International Association for Tibetan Studies (Leiden: Brill, 2000), p 252.
} 


\section{Autobiography, Biography, and Hagiography: Some Methodological Considerations}

As I have pointed out, there are a few sources describing the life and career of Nup Sangyé Yeshé . The first obstacle for the scholar, though, is what to do with them, how to approach them. Schaeffer pointed out in his study of Saraha: "Past focus in the historicity of Saraha has ignored the nature of literature from which it has drawn, for this literature is overwhelmingly hagiographic in orientation, and neither biographical in the modem sense nor historically motivated." ${ }^{139}$ This is also applicable to most of the scholarly effort to understand the life and works of Nupchen. This presentation of the life of Nupchen will not try to solve the tension between historical facts and hagiographical accounts. As Roesler argued in Lives Lived, Lives Imagined: Biography in the Buddhist Traditions, biographies in the various Buddhist traditions are "intended not to render facts about life, but a different and somehow more essential truth about a person," and that there is no contradiction between a "life lived" as opposed to the "life imagined," since "a life is always and necessarily imagined, whether somebody is thinking and writing about the life of another person or about his or her own life."140

Our outline of the life of Nupchen in this section then, is not particularly interested in discussing the historicity of the life of Nupchen, but the way in which the Tibetan tradition has imagined his life, as well as the "truths" (more than specific historical facts) that we can learn from it. This is not to say that I do not believe in the historical reality of Nupchen, but even if we

\footnotetext{
${ }^{139}$ Kurtis Schaeffer, Dreaming the Great Brahmin Tibetan Traditions of the Buddhist Poet-Saint Saraha (New York: Oxford University Press, 2005), p. 14. In his dissertation it is on pp. 17-18. He quotes de Certeau to make this argument: "It is impossible to consider hagiography solely in terms of its 'authenticity' or 'historical value': this would be equivalent to submitting a literary genre to the laws of another genre -historiography- and to dismantling a proper type of discourse only in order to engage its contrary," (de Certeau 1990), p. 270 .

${ }^{140}$ Linda Covill, Ulrike Roesler, and Sarah Shaw, Lives Lived, Lives Imagined: Biography in the Buddhist Traditions (Boston [Oxford]: Wisdom Publications; In collaboration with the Oxford Centre for Buddhist Studies, 2010).
} 
had a better record of his dates and some of the key events of his life, those facts would still not give as the "real Nupchen." It is interesting to see how traditional Tibetan scholars, as well as contemporary scholarship, has attempted to "put together" the various accounts of his life, like they were pieces of an incomplete puzzle. But, like Humpty Dumpty, the life of Nupchen cannot be "put back together again." Each piece of his life as found in the various accounts is not simply a piece of the puzzle, but a new interpretation of his life, sometimes simply trying to make sense of the obvious contradictions found in our historical record (as the issue of his dates has already shown), sometimes transforming Nupchen in order to insert him into a new particular lineage, or a contemplative or ritual tradition.

What I am interested in this section, particularly in the portrayal of his life as founded in the Testament of Nup, is to see what Tibetan perceptions of his life are. What can this particular portrayal tell us about Tibetan depictions of the historical period in which he lived? And what can it tell us about the emergence of the Great Perfection tradition? Further, it can also offer interesting clues regarding the period in which the purported biography was also written.

As Roesler argues:

Thus life stories have various purposes and contain various types of truth. This, however, does not mean that the question of historicity is altogether out of place. It does make a difference whether a life story deals with a historical person like a Burmese or Tibetan teacher who has been involved in the politics of his or her time, or with legends like the one about the Buddha's brother Nanda visiting the nymphs in heaven [...] Questions about historicity may be inappropriate if they are considered to be the sole purpose of studying biographies, but this should not lead to a general verdict on asking them. It is possible and legitimate to ask whether certain details in a biography are corroborated by other sources. $^{141}$

$\overline{141 \text { (Covill, Roesler, and Shaw 2010) }}$, p.4. 


\section{The Biography}

As I have mentioned earlier, we have a few narrative accounts of the life of Nupchen, with the 17 th century account by Pema Tinley ${ }^{142}$ being the most extensive. Recently, though, a purportedly autobiography under the title The Great Testament of Nup: The Story of Sangyé Yeshé (Tib. Sang rgyas ye shes rin po che'i lo rgyus gnubs kyi bka' shog chen mo ${ }^{143}$ has resurfaced in the Extremely Extensive Spoken Teachings (Tib. bKa' ma shin tu rgyas pa). ${ }^{144}$ Dalton has already offered some relevant preliminary insights on the text and its possible origins. ${ }^{145}$ Dalton argues that the text, although claiming to be an autobiography (there are constant references to the first person, using the personal pronouns $n g a, b d a g$, etc.), probably is not, and he suggests that it was most likely written between the 11 th-14th century by a member of the early Zurs, the inheritors of Nupchen's teachings. ${ }^{146}$

\section{Birth and the Unexpected Role of a Chinese Monk}

The text begins with an account of Nupchen's miraculous birth, something not unusual in traditional Buddhist biographies:

[My] homeland [land of birth] is Drak Yangdzom. [As for my] lineage and family name, [I am] the son of the great lord of Nup. [The name of] my father was Selwa Changchub

\footnotetext{
${ }^{142}$ Rigs 'dzin chen po padma 'phrin las, “'Dus Pa Mdo Dbang Gi Bla Ma Brgyud Pa'i Rnam Thar Ngo Mtshar Dad Pa'i Phreng Ba (Biographies for the Lamas of the Sūtra Initiation Lineage Written in 1681 at rDo Rje Brag by the Second Rigs 'Dzin Chen Po Padma 'Phrin Las),' in bKa' Ma Mdo Dbang Gi Bla Ma Rgyud Pa'i Rnam Thar, vol. 37 (Leh: Smanrtsis Shesrig Spendzod, 1972). Donati translated his short biography of Nupchen in her dissertation, in Donati, "The Lamp Is Burning Bright. Gnoseological Approaches and Soteriological Perspectives in gNubs Chen Sangs Rgyas Ye She's Masterpiece," pp. 7-19.

${ }^{143}$ Nupchen Sangye Yeshe (gNnubs chen sangs rgyas ye shes), Sangs Rgyas Ye Shes Rin Po Che'i Lo Rgyus Gnubs Kyi Bka'Shog Chen Mo (vol. 42 of the Bka'Ma Shin Tu Rgyas Pa). Karma Delek, during a personal conversation with me on June 25, 2013, mentioned that the original manuscript of this biography was found in the monastery of Chab mdo 'jo mda' zhan rmug sangs dgon, in Chamdo province, in Chamdo (Kham region). According to Karma Delek, the manuscript was in ume script and had a lot of mispellings, a problem that was compounded by the numerous mispellings made by the person who transcribed the text.

${ }^{144}$ See TBRC W25983.

${ }^{145}$ Dalton, "Preliminary Remarks on a Newly Discovered Biography of Gnubs Chen Sangs Rgyas Ye Shes."

${ }^{146}$ On the Early Zurs, such as Zurpoche, Zurchung, see Ibid. pp. 7-24. He also discusses at length the possible role of the 11th century treasure revealer Gya Zhangtrom Dorjé Öbar (Tib. Rgya Zhang khrom Rdo rje 'od 'bar) in the possible authorship of the text.
} 
Nup. [The name of] my mother was Chinmo Tashitsho. A sandalwood tree grew [was born?] in the middle of the ancestral charnel ground of Grag Riboche. This generated much amazement [so] the tree was shown to a Chinese monk [who was] invited from Samye monastery [in] Drakmar. [This also] amazed him [produced amazement in him] [and he] said: "In the lineage of Nup Selwa Changchub, a pure son, an emanation, will certainly be born in the first spring month of the wood male rat year [...] At the time of his birth [this emanation body] should be wrapped in white scarfs and laid down [should be laid down] between the sun and the shade. He is to be fed [the medicines of] the three whites [i.e. milk, butter, and curd], and the three sweets [i.e. sugar, honey, and molasses]. In order to repel any life threats, first, [the following ceremonies will have to be performed] four times a month, [the first], the $8^{\text {th }}, 15^{\text {th }}$, the $30^{\text {th }}$ of the each [lunar] month: life-long ceremonies, readings of the Buddha's words, [you should also] make as many tsa tsas as possible for those who obtain life OR life affirmation rituals [srog 'dod], and make as many as possible tsa tsas as possible, and ganacakras, and large scale alms giving should be performed. His parents [should] always keep the [religious] vows and [respect] the law." Having said this, the Chinese monk was filled with wonder. ${ }^{147}$

There are two important pieces of information here that should give us some pause when considering the historicity of the text. On the one hand, we have the date of birth of Nupchen, the “wood male rat year" which, if we follow Vitali's dating of Nupchen, corresponds to $844 \mathrm{CE}{ }^{148}$ On the other hand, we have the presence of a Chinese monk ${ }^{149}$ from Samye Monastery playing a very important role in prophesizing the birth of Nupchen. In traditional Tibetan historical accounts, the presence of Chinese monks in Samye is attested until the so-called Samye Debate, which supposedly took place in 792-794, and in which Indian and Chinese monks debated their

\footnotetext{
${ }^{147}$ Testament 1b-2a: “/skyes pa'i pha yul sgrags kyi yang rdzong na/_/rus dang ming du smos pa rje chen snubs kyi bu/___pha ru smos pa gsal ba byang chub snubs/_ma ru smos pa 'phyiMms mo bkra shis mtsho/_pha mes dur sa sgrags kyi ri bo che/_/dur gyi dkyil du tsan+dan sdong bo skyes/_/ngo mtshar skyes nas brag dmar bsam yas nas/_/rgya nag ha shang spyan drangs tsan dan sdong po bstan/_/kho yang ngo mtshar skyes nas 'di skad gsungs/_gsal ba byang chub snubs kyi che rgyud la/_lo yi dang po shing pho byi ba'i lo/_zla ba'i dang po dpyid zla ra ba la/_/sras kyi dam pa sprul pa'i sku gcig 'khrungs par nges/_sprul pa'i sku des 'khrungs pa'i dus na yang /_/dar dkar khud du dril la nyi grib mtshams su snyol/_dkar gsum zas dang mngar gsum sman gyi gsos/_sprul pa'i sku de phyir la bzlog srid pas/_/sngon tshe chog rgyal ba'i bka' rnams sgrogs/_/srog 'dod grub tshad gyis la tsha tsha ci mang thob/_nya stong tshes brgyad la sogs dus bzhi ru/_tshogs kyi 'khōor lo sbyin pa rgya chen thongs/_pha mas khrims la rtag tu sdom pa bsrungs/_/de skad gsungs nas ha shang ngo mtshar skyes/."

${ }^{148}$ The date 844 is also one of the possibilities according to the traditional Tibetan calendar. See Dung dkar. Blo bzang 'phrin las, Dung Dkar Tshig Mdzod Chen Mo (Beijing: Krung-go'i Bod rig pa'i dpe skrun khang, 2002).

${ }^{149}$ This monk could be Hashang Mahāyāna, but since the term Hashang refers to any Chinese monk, the reference is too vague to confirm. The biography does later mention Hashang Mahāyāna, specifically, as one of Nupchen's teachers.
} 
doctrinal positions in front of Emperor Trisong Detsen (reign 755-797 CE). Since, according to traditional sources, the Chinese side lost the debate, Chinese monks had to leave Tibet. The reference to a Chinese monk would imply that Nupchen's birth took place much earlier, probably a full calendrical cycle earlier (Tib. rab byung), placing his birth in 784 . This would make the encounter with a Chinese monk feasible, although I agree with scholars like Germano and Vitali, who argue that situating Nupchen at such an early date has more to do with the reinvention by the Nyingma tradition of Nupchen as a liminal figure, as someone who was connected to the glory days of the Empire, but who was also essential in the translation and transmission of the new, cutting edge tantric teachings. The appearence of several references to Chinese monks (particularly Hashang Mahāyāna) in Nupchen's biography, as well as his extensive discussion of the Chan tradition in the Lamp, should at least give us some pause in our acceptance of traditional accounts of what happen to the Chan tradition in China and the historicity of the socalled Samye Debate. ${ }^{150}$

\section{Early Education in Tibet}

The narrative continues with an account of Nupchen's early education under the Tibetan teacher, Odren Pelgyi Zhönu, ${ }^{151}$ and the Nepalese master, Vasudhara. ${ }^{152}$ Both of these masters are considered to be disciples of Nyak Jñānakumāra (Tib. gNyags dznyāna kumāra), one of the main lineage holders of the distant lineage of the transmitted precepts (Tib. ring brgyud bka' ma) that includes Nupchen, and the Zur family. ${ }^{153}$

\footnotetext{
${ }^{150}$ I will discuss this issue in chapter 4 of this dissertation.

${ }^{151}$ See Dudjom Rinpoche's The Nyingma School of Tibetan Buddhism: Its Fundamentals and History, p. 604-607.

152 See Ibid., p. 489.

${ }^{153}$ He also played a very important role in the transmission of the trilogy of the Sütra of the Gathered Intentions, the Magical Net, and the Mind Tantras (Tib. mDo sgyu sems gsum), the main tantras of the Mahāyoga, Anuyoga, and Atiyoga traditions, respectively. See Ibid.
} 
We do not have many references regarding his monastic education. Pema Tinley's biography says that Nupchen was ordained by Sāntarakșita, but the fact that he is also said to have had children ( 4 or 6 , depending on the sources) seems to indicate that, while he took vows, he was part of a lay ordained lineage, very much like contemporary Ngagpa (Tib. sngags pa) communities, as many members of the Nyingma tradition are today. ${ }^{154}$

When I reached seven years of age, I became a student of Odran Pelgyi Zhonu, whom I studied with learned fluently (byang bar) reading, writing, and astrology (divination).

At the age of nine, at the glorious [monastery of] Samye arrived Vasudhara [a teacher] from India. [At this time] Vasudhara turned the wheel for three years, due to the king's great power. ${ }^{155}$ Then, I offered [Vasudhara] approximately three $\operatorname{srangs}^{156}$ of gold [i.e. 300 grams] and stayed in his presence for three years. Having successively completed the empowerments and transmissions, I was taught the precepts [samaya] and [received] purification rites. ${ }^{157}$

\footnotetext{
154 Tarthang Tulku makes an interesting reference to Nupchen's being a member of the white sangha (vs. red sangha): "During King Ral-pa-can's reign, there were two types of Sangha, the Red Sangha and the White Sangha. The Red Sangha were fully ordained monks who wore red robes in formal assemblies; the White Sangha were generally yogis or householders who wore white robes in formal assembly and often had long hair. Most of the disciples of Padmasambhava were members of the family-clan lineage of the White Sangha. This trend toward full participation in Dharma practice by the lay community has remained a strong theme within the rNying-ma school, in accord with the teaching that spiritual excellence and exemplary compassion can be practiced in all times and circumstances." In Tarthang Tulku's “Lineage of the Diamond Light," Crystal Mirror Series. V (1991), pp. 227-228. This could help explain the type of religious community Nupchen belonged to, although one of the most difficult aspects of studying Nupchen and the period in which he lived is our lack of information regarding the social context in which scholars like Nupchen studied and practiced. For a contemporary study of Ngagpa communities and their relationship with monastic communities see Antonio Terrone's "Householders and Monks: A Study of Treasure Revealers and Their Role in Religious Revival in Contemporary Eastern Tibet," in Buddhism Beyond the Monastery: Tantric Practices and Their Performers in Tibet and the Himalayas (Leiden: Brill, 2009), 73-109, http://search.lib.virginia.edu/catalog/u5616216.

${ }^{155}$ Thanks to Prof. Jake Dalton for his suggestion on the translation of this passage.

${ }^{156}$ Duff's Illuminator Dictionary defines Srangs as: "A standard measure of weight which is equal to ten sho. There were fifty srang in a tam. The srang was also used as a basis unit of currency. Originally it was a certain weight of gold or silver, but later became minted as coins and later still as paper money. The system ceased when the Chinese Communists took over Tibet in 1959."

${ }^{157}$ Testament 3a: “/lo bdun lon nas dpal gyi gzhon nu'o bran gyi/_phyag phyir 'breng nas yig rtsis byang bar bslabs/_lo dgu lon nas dpal gyi bsam yas /su/_rgya gar yul nas ba su d+ha ra byon/_rgyal po mnga' thang che bas lo gsum chos kyi 'khor lo bskor/_/de nas bdag gis ba su d+ha ra la/_gser srang gsum tsam phul nas lo gsum spyan sngar bsdad/_/dbang lung rim pa rdzogs nas dam tshig khrus lung bshad/,” pp. 696.5-697.3.
} 


\section{The Seven Trips to India and Nepal}

At the age of twelve, after three years of teaching in Tibet, Vasudhara decides to return to Nepal, and encourages Nupchen to go to India and Nepal to meet various teachers. ${ }^{158}$ Thus began a series of seven trips (although the timeline is not completely clear in the text) in which the biography describes Nupchen's dedication at the feet of a wide variety of teachers belonging to various Buddhist traditions, like Rombu Guhya Deva Candra, Śrī Siṃha (Tib. shri sing ha), Padamsambhava, the famous Indian master Kamalaśîla, as well as his counterpart in the Samye debate, the Chinese monk Hashang Mahāyāna. As the scholar John McRae pointed out in the context of Chan lineages, though: "[L]ineage assertions are as wrong as they are strong,"159 and I would argue that the same applies to our text, with the biography anchoring Nupchen to as many Buddhist lineages and schools as possible, transforming Nupchen into a symbolic figure for the period, one that allowed the later Nyingma tradition to establish much needed continuity between the Tibetan Empire and the Tibetan Renaissance. ${ }^{160}$

\section{Return to Tibet and the Collapse of the Empire}

In the year 901, at the age of sixty one, Nupchen returned to Tibet, which was, at the time, in the midst of the second of three uprisings that followed the collapse of the Empire. In this period, we find, probably, the most famous episode connected to his life. Due to the political and social unstability in Central Tibet, Nupchen and some of his followers are forced to move from place to place until they finally settled in a fortress in Nyemo (in Central Tibet). A contingent of

\footnotetext{
${ }^{158}$ Although other accounts, like the one in the 1De'u Chos byung, argue that Nupchen began traveling in search of teachers since he was dissatisfied with existing lineages in Tibet. See mkhas pa lde'u, Rgya Bod Kyi Chos Byung, 13 th century.

${ }^{159}$ John R. McRae, Seeing through Zen: Encounter, Transformation, and Genealogy in Chinese Chan Buddhism (Berkeley: University of California Press, 2003).

${ }^{160}$ This section also includes an extensive account of the teachings that Nupchen received during these various trips. I will refer to them briefly in my overview of Nupchen's works, but due to their length and nature (mainly ritual texts), it is beyond the scope of this dissertation to discuss them in full and requires further investigation.
} 
soldiers surrounded the fortress and threatened to kill Nupchen and the rest of his followers.

Nupchen, then, through a ritual invocation, kills all of the soldiers:

Then, [when] I reached sixty one years of age, in the year of the year of the rat (901), which befell in (was) my obstacle [year], the second (i.e. middle) uprising took place. [Since] I could not stay in Grags, I fled to Nupyul valley. In Chen, the three Buddhist clans of Zhang, Chung, and Tshur hosted me, [but] since I could not stay there either, I went to the fortress of Nyemo. [There,] Rogban Kyab took care of my household possessions and Nyangmé Jampel (Tib. Myang sman 'jam dpal) became my personal assistant. Then, when the rebel army surrounded the place, Tibetan monks sought refuge inside the fortress, Then, on the side of the mountain of the fortress of Nyemo, I saw many soldiers discussing [how] they were going to kill the Tibetan monks, until there were no Buddhist monks [left]. Then, [I] the little Tibetan monk [...] went to the top of the castle, [and said to the army]: "Listen to me, rebel [soldiers]! Gods and Demons of the World be my witness! In order to nurture the nectar of the Excellent Teachings, I have travelled the whole world from the time I was thirteen years old. I went to India and Nepal seven times, [where] I tirelessly served many scholars.

I have offered tormas and offerings to those deities holding a promise [to protect Buddhism]. I have practiced Dharma and worshiped the deities. I have meditated on the thought of enlightenment for the sake of [all] beings without making any distinction between myself and others. I escaped but it was useless, since [the revolts] followed me, as if the revolts were happening because of me! I [hope that] all of the vidyādhara, their consorts, the protectors of the oceanic holy dharma, and all of the powerful yakșas of Tibet come to assist me. If you go away, [those deities] will not commit any crime or revenge.

Having said this, I folded my robe three times. Then [I] cried and, when I stopped crying, all the witnesses to my promise [the deities] appeared in front of me and said: "With our strength and power, we could lift mountains, empty the oceans, and although we could have offered you our strength and power, because of the ripening of your karma (actions) of your previous lives, until now, we could not help you. Now, do you want us to destroy the world? What do you want us to do?" Then, taking out a wooden kilaya from my robe I gather them by using the life mantra of the gods, demons and those bound by the samayas, and I said (the mantra) "ma ra ya phat" while (I faced) the mountain. The mountain started to catch fire, and the rebel army burned and was destroyed in an instant.

In order to purify [myself] from this sin [sinful action], I composed the Lamp for the Eye in Contemplation for the benefit of future generations. Then, although the rebellion was pacified, I suffered poverty for three years, I went to the [Grags] Yangdzong where I accomplished the siddhis. I was invited by the powerful Divine son [i.e. the King], to establish the Dharma teaching in the Bodhi temple in Samye. Afterwards, I went [back] to Nupyul Valley [after] passing through "Drogang." 161

\footnotetext{
${ }^{161}$ Testament 20a-21b: “/dur gyi dkyil du tsan+dan sdong bo skyes/_/ngo mtshar skyes nas brag dmar bsam yas nas/_/rgya nag ha shang spyan drangs tsan dan sdong po bstan/_/kho yang ngo mtshar skyes nas 'di skad gsungs/_gsal ba byang chub snubs kyi che rgyud la/_lo yi dang po shing pho byi ba'i lo/_zla ba'i dang po dpyid zla
} 
I would argue that this incident, found also in Pema Tinley's biography, would later be transformed into the famous encounter between Nupchen and Emperor Langdarma. This incident is mentioned in passing in Pema Tinley's biography, but it is described at length in Dudjom Rinpoche's History of the Nyingma School:

During the reign of King Ralpacen, Nup had been in the habit of travelling between India and Tibet. On the other hand, when King Langdarma persecuted the teaching, he asked Nup, "What power do you have?" Nup replied, "Behold this power of mine, which comes from the recitation of a mere mantra!" With his index finger he pointed to the sky, and the king saw a black iron scorpion as large as a yak, sitting nine storeys above Nup's pointed finger. The king was terrified and said, "By all that is precious, I will not harm this mantrin. Go practise your doctrine!" Then Nup said, "Behold this power yet again!" And with his index finger he hurled a thunderbolt, which pierced the rock on the mountain opposite and smashed it to pieces. Now the king was extremely terrified and afraid. He said to Nup, "I will harm neither you, nor your attendants." And then he dismissed him. Thus it was by Nup's kindness that the mantra adepts who wore the white robe and long, braided hair were unharmed [during Langdarma's persecution?]." Nup could not endure the supression of the teaching by Langdarma, so, having collected many razor-sharp, wrathful mantras, he resolved to bring him to an end by means of the

ra ba la/_/sras kyi dam pa sprul pa'i sku gcig 'khrungs par nges/[...]de nas drug cu re gcig byi lo la/_bdag gi kag la babs nas kheng log bar pa byung /_sgrags su ma chags gnubs yul rong du bros/_chen la zhang chung tshur ban gsum/_rus gsum ban des nye nas byas/_der yang ma chags snye mo bye mkhar bzung / yul khyim rdzas cha rog ban skyabs pas bsdus/_nye gnas phyag tshang myang sman 'jam dpal byas/_de nas bod ban bye mkhar nang na mchis pa la/_kheng po'i dmag mis rtsa skor chu skor bcug_/de nas snye mo bye mkhar ri logs la/_kheng po'i dmag mi gros bye- mang po rnams /_/bod ban bsod pa'i 'dun gros byed pa mthong /_bod ban mi bzhag mtha' ru skyugs pa go_/de nas ban chung thugs log mkhar rtsir phyin/_kheng po gros byed thams cad tshur nyon cig_/snang srid lha 'dre thams cad gzu dang dpang /_bdag ni dam chos bdud rtsi lta bu mtsho skyong phyir/_bcu gsum lon nas 'dzam gling khyab par khyams/_rgya dang bal po'i yul du lan bdun phyin/_mkhas pa rnams la zhabs tog rgyun ma chad/ /dam can rnams la gtor tshogs rgyun ma chad/___las su chos byas don du lha gnyer nas/_bdag dang gzhan gyi don du ma phye bar/_'gro ba'i don du byang chub sems bsgom nas/_bros kyang ma nyan bdag gi phyir 'breng zhing /_bdag la 'di 'dra'i khengs log byed pa 'di/_/dam chos rgya mtsho skyong ba thams cad dang /_rig 'dzin lcam dral rtsal can thams cad dang /_/bod khams gnód sbyin mthu chen thams cad kun/_ma nyes ma lan bdag la ra mda' log_/ces pa brjod nas chos gos lan gsum brdabs/_de skad gsung nas spyan chab gsil ba yis/_/rang gi dam can la sogs gong gi gzu dpang rnams/_spyan chab tshar re bedag gi mdun du byon/_/bdag cag rnams kyi mthu rtsal 'di 'dra ste/_ri bo spang gis 'degs nus rgya mtsho'i hub 'debs nus/_de lta bu yi mthu dang rtsal bdog kyang /_'di ni slob dpon nyid kyi tshe rabs snga ma yi/_las kyi rnam par smin pa'i tshan brdol nas/_[_ ] sngon chad bdag cag rnams kyis grogs ma bgyis/_da ni 'jig rten rlag par bgyi'am ji ltar bgyi/_zhes gsungs so/_de nas chos gos kyi cha nas seng ldang gi phur pa zhig bton nas/_gnod sbyin dang dam can rnams kyi srog sngags kyis btab nas dril zhing /_ri pha gi ma ra ya phaT/_ces brjod pas/_ri la me 'bar nas kheng log byed pa'i dmag dpung rnams thul gyis tshig nas lan gcig rlag bar byas so/_/de'i sdig sbyong gi don du bsam gtan spyan sgron nyams dang bstun nas phyi rabs don du mdzad do/_de nas kheng log zhi yang lo gsum bar du dbul zhing 'phongs nas/_yang rdzong nang na dngos grub sgrub cing mchis pa la/_lha sras mnga' thang che ba spyan drangs chos btsugs nas/_/bsam yas byang chub gling du chos kyi 'khor lo bskor/_slad nas yang 'brog sgang 'grim gnubs yul rong du byon/"' 
compassionate application of sorcery. But when the evil king was "liberated" by Lhalung Pelgi Dorje, Nup concealed the wrathful mantras as treasures, lest they be misused. ${ }^{162}$

In brief, when the doctrine was persecuted by Langdarma all the dialectical seminaries were destroyed, but the hermitages of the mantra tradition survived somewhat in mountainous ravines, caves, and so forth. For that reason, and in accord with the promise which Langdarma himself made to Nupchen, the mantrins were never harmed at all. During those times a multitude of excellent awareness-holders, who had mastery over the two accomplishments, continued to maintain the teaching of the three inner classes of tantra. Their number included Nyangben Tingdzin Zangpo, Ngenlam Cangcup Gyeltsen, most of the eight glorious disciples of Nyak Jñānakumāra, Nupcen and his disciples, Rok Śākya Jungne, and Deshek Zurpoche. ${ }^{163}$

There are various possible explanations for this transmutation of the story. The autobiography of Nupchen offered as the specific date for the incident 904 (Tibetan year of the wood male rat), which later historians could have placed in the previous calendrical cycle, situating the incident in 844, which, while making it still impossible to meet with Langdarma, who died in 841, would still bring him closer to his reign. As we have seen, though, the vagueness of Nupchen's dates, combined with the efforts of the later Nyingma tradition to transform Nupchen into a liminal figure between the Empire and the Tibetan Renaissance could also help explain the transmutation of this incident from an encounter with some nameless leader of a faceless army into a face-off between Nupchen and King Langdarma, transforming Nupchen into a hero, the savior of the Buddhist tradition during this period of upheaval.

Here we also see the complicated relationship between Buddhism and violence. ${ }^{164}$ Cantwell's study of ritual killing, particulalry in the context of the Vajrakilaya textual cycle, is of

\footnotetext{
162 Dudjom Rinpoche, The Nyingma School of Tibetan Buddhism: Its Fundamentals and History. p. 612

163 'Jigs-bral-ye-śes-rdo-rje Bdud-'joms et al., The Nyingma School of Tibetan Buddhism : Its Fundamentals and History (Boston, Mass.: Wisdom Publications, 2002), p. 918.

${ }^{164}$ On this topic see the excellent study by Dalton: The Taming of the Demons: Violence and Liberation in Tibetan Buddhism.
} 
particular importance to situate Nupchen's actions in context, a great practitioner of this ritual

cycle himself:

In the rNying-ma tradition, sgrol-ba/bsgral-ba in which liberation occurs through ritual killing [...] Its imagery is central to Mahāyoga deity practice [...] Dudjom Rinpoche's history of the rNying-ma-pa contains references to lamas practicing sgrol-ba on human victims, with no attempt to gloss over the implications." "For example, Dudjom Rinpoche (1991: 601-605) describes how Nyak Jñānakumāra (gNyags dznyāna kumāra), plagued by people obstructing his practice, learns the rite of sgrol-ba from Vimalamitra, and proceeds to kill and liberate his enemies, in some cases, along with their kin. In 'liberating' his own brother, he develops Great Compassion through understanding the indestructible nature of anger. Similar stories [...] of Nupchen Sangyé Yeshé , who burns and destroys an entire army, and terrifies King Glang dar-ma, follow. Dudjom Rinpoche [...] identifies the black magician who taught Mi-la-ras-pa enabling him to kill his uncle's family, as Lharje Hūmcung, a succesor of Nup's lineage ${ }^{165}$

\section{Disciples and Legacy}

The final part of the biography is dedicated to establishing Nupchen's lineage and legacy.

This section can be seen in the context of efforts by the Nyingma tradition holders to establish the legitimacy and continuity of its teachings, particularly those known as the Oral Precepts of the Distant Lineage (Tib. $b K a^{\prime} m a$ ), carrying them uninterruptedly from the Dark Age period all the way into the early renaissance. In Dudjom's history of the Nyingma tradition, Nupchen is one of only three figures responsible for the transmission of this teachings, and the only one mentioned from the Dark Age period:

Now, I should explain in particular the way in which the trilogy of the Sutra of the Gathered Intentions, the Magical Net, and the Mental Class have come down to us. These teachings are common to all [the Nyingmapa lineages] and have perpetuated, without decline, the river of the transmitted precepts, the "distant lineage" mentioned above. It is said that, in [Tibet], the land of snow mountains, the teaching of the vehicle of

\footnotetext{
${ }^{165}$ Cathy Cantwell, “To Meditate upon Consciousness as Vajra: Ritual 'Killing and Liberation' in the rNying-Ma-Pa Tradition," in Tibetan Studies: Proceedings of the 7th Seminar of the International Association for Tibetan Studies, pp. 107-108 n. 5, 1997. It is important to point out that all of the practitioners mentioned in this quote are connected one way or the other to Nupchen: Vimalamitra and Nyak Jñānakumāra as teachers, and Lharje Hūṃcung as a member of his lineage.
} 
indestructible reality according to the Ancient Translation School "fell first to Nyak, fell to Nup during the intermediate period, and fell to Zur in the end." 166

In the following passage, we find Nupchen at the end of his life talking to his five main disciples and offering them some last advice on how to preseve the integrity of the teachings while encouraging them to spread the teachings throughout Tibet. Those disciples are Yonten Gyamtso, who may have been Nupchen's biological son, Legpa Gronme, Yeshe Wangchuk, Yeshé Wangchuk, and Lonje Phagspa.

In order to seriously protect the Buddha's teachings, and to praise the Three Jewels, I taught for seven years according to the textual tradition of the holy dharma to [my] four [main disciples], Yonten Gyamtso, with whom I have a karmic connection, the extremely faithful Legpa'i Gronme, my excellent friend Yeshe Wangchuk, and the greatly dilligent and generous Lonje Phagspa. [All of them] have established in their hearts an equal commitment [to the teachings]. I sent Yonten Gyamtso to Mangyul seven times, [and I said to him]: even if it is not suitable to teach these wrathful tantric teachings, the discovered treasure of Brahma says "Beings who have a steady intellect, who have faith, and who are generous and would not regret to give up even their life, (to those), if they want to learn the wrathful tantras, [you should] teach them." Because of this, I entrusted the one hundred and seven uncommon sādhanā to Yonten Gyamtso. To Legpa Gronme I entrusted, for his protection, the harmful wrathful mantras, and the protection against hail. To the excellent friend Yeshe Wangchuk, I entrusted him with the practices of Black Goddess, and the practices of the Flesh-eater Black Goddess. To the greatly powerful and generous Lonje Phagpa, I entrusted him with the practices of the Samantabhadri, and the seven wrathful mantras of Yamāntaka. Furthermore, if the [four] faithful sons who have promised [to teach] future generations do not understand the origin of [the students], their karma, their lineage, etc., if they have small faith, or a degenerating commitment, or they do not have commitments [at all], and they spread the secret [teachings, they are], bad people. [To those people,] [...] even if you carelessly teach one word of these quintessential instructions, [...] the assembly of the dākinīs of the female Yama, and others [...] will immediately bring obstacles to your life and, in your next life, you will be reborn in the torturing hell. ${ }^{167}$

\footnotetext{
${ }^{166}$ Dudjom Rinpoche, The Nyingma School of Tibetan Buddhism: Its Fundamentals and History, p. 599. Bold is mine.

${ }^{167}$ Testament of Nup 22a-23a: "sangs rgyas bstan pa gnyan po bsrung bar bya ba dang /_dkon mchog /dbu 'phang bstod par_bya ba'i phyir/__ las kyi 'brel ba'i yon tan rgya mtsho dang /_/dad pa che ba'i legs pa'i sgron ma dang /_grogs mchog dam pa ye shes dbang phyug dang /_/rtsol shugs gtod phod che ba'i blon rje 'phags pa bzhi/_dam tshig nyams pa_snying la 'jog pa 'dra nas su/_dam chos gzhung bzhin bka' la brten te lo bdun bar du bshad/_/yon tan rgyal_mtsho mang yul lan bdun btab____drag sngags chos 'di bstan par mi 'os kyang /_tshangs pa'i yang gter
} 
The passage ends with a powerful message delivered to Yonten Gyamtso, but that has in mind

the larger audience of future students of his teachings:

So future generations will have [nothing] to fear I say this: from Garab Dorje on down, all the empowerments and the secret instructions of all of the scholars and siddhas who have a relationship with Tibet have come uninterrupted all the way to me. I am the Owner of the Secret Instructions. I protect and bless all of the Secret Instructions. I have seen the Sugatas of the three times, the Dharmapālas, and the guardian [of the teachings, and] if you [all] contradict my warning [mentioned above of teaching to those who are not qualified], a punishment will come [to you]. I have gathered with difficulty the general meaning of the the tantras, the scriptures, and the quintessential instructions, and I taught them across Tibet. When excellent individuals practice these teachings, the signs [of realization] will emerge. [But if] people of weak disposition and lower intellect [practice those teachings], they will condemn the Buddha's teachings. Again, yogis of future generations, hold onto the symbolic mudra of the Spoken Transmissions and do not lose the precepts of the quintessential instructions and empowerments! ${ }^{168}$

"Listen to my last testament (wish) Yonten Gyamtso! To you I entrust you with leading (my) disciples as (their) keeper. As for rituals, I entrust you with the four complete initiations, as for meditative practices (bsgom pa), I entrust you with the āgamas (oral transmission) of the contemplative practices and of àgamas (oral transmission for) the mind. As for siddhis, I entrust you the wrathful manifestation of Manjusri. To you, excellent son (main student), I entrust you many sadhana scriptures. As for black magic, I entrust you with the all completed (perfected) wrathful mantras, as for guardian (of the

gzhung las_'di ltar brda/_/skyes bu blo rtsal brtan zhing dad pa mos pa pa dang /_lus dang srog kyang mi 'phang gtod phod na/_/de dang 'brel ba 'dod na drag sngags bshad/_/ces 'byung bas/_de phyir bdag gis yon tan rgya mtsho la/_/sgrub lugs mi mthun brgya dang rtsa bdun gtad de bzhäg_bdud kyi drag sngags ser ba dbab bsrud_gnyis/_legs pa'i sgron ma'i btsas su bdag gis bzhag/_grogs mchog dam ba ye shes dbang phyug la/_/lha mo nag mo mi_ sring sgrub pa dang /_/sha za nag mo'i sgrub pa gtad de bzhag_/shugs gtong che ba'i blon rje 'phags pa la/_sa la pa tra kun tu bzang mo'i sgrub pa dang /_gshin rje'i drag sngags bdun pa gtad de bzhag_de yang phyi rabs dang du len pa'i bu tsha rnams kyis kyang /_rang gi rigs sam rgyud las ma rtogs pa/_/dad pa chung zhing dam tshig nyams pa dang /_/dam med gsang rdol byed pa'i mi nag la/_/don 'dir bkod pa'i man ngag lta sgom dang /_sgrub dang sgrub thabs man ngag las rgyud mtha' dag dang /_/snying la gtad pa'i man ngag drag sngags mtha' dag dang /_man ngag bla rdol tshig gcig bstan gyur na/_'jig rten 'di na tshe srog dbang byed pa'i/_/ma gshin rdo rje mkha' 'gro'i tshogs rnams dang /_de la sogs pa dam can gsod byed 'khor tsogs kyis/_tshe yi bar gcod myur du byas nas /ni|_'jig rten phyi ma mnar med dmyal bar skye/" Dudjom Rinpoche offers a brief account of the life of Nupchen's disciples on pp. 607-616.

${ }^{168}$ Testament of Nup 24a: "bdag gis de skad smras pas phyi rabs mi 'jigs te/_/dga' rab rdo rje man chad bod 'brel pa'i/_/mkhas shing grub pa thob pa'i dbang dang man ngag dang /_/bdag la rgyun ma chad de man ngag bdag po lags/_/man ngag kun la byin rlabs 'tsho skyong byed pa yang /_/dus gsum bde gshegs chos skyong bsrung ma bdag gis mthong /_kun la smras shig spel na gong ltar bka' chad 'ong /_/spyi don bsdus pa'i rgyud lung man ngag gsum/_dka' ba nyams su blangs nas bod khams yongs la bstan/_/skyes bu dam pa rnams kyi sgrubs na rtags 'byung yang /_nyams chung blo dman rnams kyis sangs rgyas chos la smad/_/da yang phyi rabs dang du len pa'i rnal 'byor rnams/_bka' brgyud rtags kyi phyag rgya su 'dzin pa/_/man ngag dbang gi bka' rtags sho ra re/" Dalton offers a slightly different translation in Dalton, "Preliminary Remarks on a Newly Discovered Biography of Gnubs Chen Sangs Rgyas Ye Shes," 5-6. 
teaching), I entrust you with the Lord of Dakinis. As for propagation (dissemination), I entrust you with all of the royal tantras. I entrust you, Yonten Gyamtso, with my final testament! Do not use your rosary as a bracelet! Use it to keep track (count) the recitation of your mantras. When meditating, do not act idle, and make offerings frequently (continuously). (When you) experience hardships (in your practice) become the vajracārya. Within the holy (community) of vajra brothers and sisters, the samaya is declining. If you don't listen to this, you will destroy you self-awareness." Then, once again, [I], the little Tibetan monk when [I] was practicing meditation (meditating) at the Bamboo Grove, realizing the ultimate meaning and clarifying reality itself. Practicing (meditating on) the (various) methods of contemplation (practice), the signs of accomplishment emerged. (These accomplishements) were not the result of lying down, sleeping, or not thinking. Because of my faith and my effort, which blaze like a fire, they emerge like many magical powers (displays) as a symbol of my clarity. Many worldly gods and demons assembled and empower me (initiated me) as the lord of the quintessential instructions. Many Dakinis who naturally accomplished primordial wisdom, to me, and to the future generations of students of my lineage, promise to possess us and to help us. ${ }^{169}$

It seems clear that the biography, if not written by Nupchen himself, which we have

already seen seems doubtful, was probably written by someone close to him, probably a student of Khulung Yonten Gyamtso, who figures prominently as the main disciple at the end of the text. Dalton has insinuated that the biography may have been written by a member of the Gya clan, the 11 th century treasure discoverer, Gya Zhangtrom Dorjé Öbar (Tib. rGya zhang khrom rdo rje 'od 'bar), ${ }^{170}$ an obscure figure known for his involvement in Vajrakīlaya practice and presented in Dudjom's history as one of the "small-minded treasure-finders who did not reveal the doctrines in their pure form [but] indulged in favouritism and flattery and did not achieve much of benefit for living creatures. By propagating malign mantras before all else Gya Zhangtrom obstructed the welfare of living creatures." ${ }^{171}$ Leaving aside his reputation, his involvement

\footnotetext{
${ }^{169}$ Testament of Nup 25a-25b: "bdag gi kha chems nyon cig yon tan rgyu mtsho kwa ye/_/khyod la gnyer gtad slob ma 'dren pa gtad/_/las su gtad do dbang bzhi rdzogs pa gtad/_/bsgom pa gtad do sgom lung sems lung gtad/_/sgrub pa gtad do 'jam dpal gshin rje gtad/_/sgrub yig mang du bu mchog khyod la gtad/_/mthu ru gtad do drag sngags kun rdzogs gtad/___bsrung ma gtad do mkha' 'gro dbang phyug gtad/_/spel ba gtad do rgyud rgyal mtha' dag gtad/_bdag gi kha chems gtad do yon tan rgya mtsho kwa ye/_'phreng bas lag brgyan ma byed 'dzab bsnyen rims las drongs/_sgom sgrub dus las ma g.yel mchod pa rgyun du gtong /_/dka' ba nyams su longs la rdo rje slob dpon khur/_/grogs mched dam pa'i nang du dam tshig nyams par mchi'o/_/de la mi nyan rang rig phung du tho/_"

${ }^{170}$ See Dalton, "Preliminary Remarks on a Newly Discovered Biography of Gnubs Chen Sangs Rgyas Ye Shes."

${ }^{171}$ Dudjom Rinpoche, The Nyingma School of Tibetan Buddhism: Its Fundamentals and History, p. 765.
} 
would explain the emphasis on ritual practice in the Testament, and in particular with

Vajrakilaya ritual. It would also explain the strange appearance of references to treasure texts in the biography of a practitioner who became known as a central figure in the transmission of the distant lineage of the Oral Precepts.

Do not disseminate to all the secret teachings and the oral instructions (or the oral instructions of the secret mantra). I have concealed [these teachings] as a mind treasure (as a treasure into my mind). Do not complain Yonten Gyamtso! In order to hide [these teachings] as treasure, I called an artisan from Thoseli, in Nepal, and while he was working on a dark grey Rhinoceros hide [skin as a container for the treasures] ${ }^{172}$

More research needs to be done in order to establish the possible authorship of the

\section{Testament.}

\footnotetext{
${ }^{172}$ Testament 25a4-25a6: “/de rnams kun gyis ma spel gsang sngags bka' gdams rnams/_bdag rang rgyud la gter du spas nas bzhag pa yin/_de la khyod ma 'khang zhig yon tan rgya mtsho kwa ye/_de nas gter du sba bar dgongs nas/_bal po'i yul nas tho se lo'i gzo bo bkug_/bse sgrom smug po brdung zhing mchis pa la/_/mal gro'i yul na klu yi rgyal po des/_dpag tu med pa'i 'khor dang bcas nas byon." This is an interesting aspect of the biography in which Nupchen seems to reveal how he plays a key role in the manufacture of treasures.
} 


\section{Part 3 - Nupchen's Works}

This dissertation is dedicated to Nupchen's Lamp for the Eye in Contemplation, a work that will be extensively discussed in the following chapters and that has already received some attention by a number of scholars. ${ }^{173}$ The rest of Nupchen's writing corpus, though, has been severely understudied or simply ignored. The reasons for this are various, although they are closely link to the problems that plagued the Dark Age period in general. First, many of Nupchen's writings, like many of the textual sources from the period, have not survived. Later sources mention titles by him, such as the Disputant's Sword which Cuts through Difficulties (Tib. $d K a^{\prime}$ gcod smra ba'i mtshon cha) and the Commentary on the Realisation of the EightyChapter Magical Net (Tib. sGyu 'phrul brgyad cu pa'i mngon rtogs 'grel), ${ }^{174}$ but neither of them seem to have survived. There is, though, some hope that some of those works may resurface in the near future. During a 2013 field research trip to Tibet, I was able to talk to Karma Delek, the head of the Peltsek Reseach Center on Tibetan Language and Ancient Texts (Tib. dpal brtsegs bod yig dpe rnying zhib 'jug khang) in Lhasa, and one of the main Tibetan scholars who have studied the figure of Nupchen Sangyé Yeshé. He is also one of the main scholars responsible for the compilation and preservation of many ancient Tibetan texts, such as the Nyingma collection, The Extremely Extensive Spoken Teachings (Tib. bKa' ma shin tu rgyas pa). During our conversation, he revealed to me that he had not seen a copy of the Commentary on the Realisation of the Eighty-Chapter Magical Net, but that a copy of the Disputant's Sword which Cuts through Difficulties could be found in the Potala library, although he had doubts that the text was, indeed, by Nupchen. He also mentioned a text, the The Fortress of the View of the

\footnotetext{
${ }^{173}$ See review of scholarship on the Lamp for the Eye in Contemplation in the introduction of this dissertation.

${ }^{174}$ Dudjom Rinpoche, The Nyingma School of Tibetan Buddhism: Its Fundamentals and History, 607-617.
} 
Quintaessential Instructions (Tib. Man ngag blta ba'i rdzong 'phrang), ${ }^{175}$ which is cited in the catalogue of Nyingma texts in the Potala Palace, ${ }^{176}$ but for which I have not been able to found any other reference. Karma Delek claimed to have obtained it from the Potala library and that he suspects was written by Nupchen. ${ }^{177}$ Karma Delek also mentioned the existance of some texts written by Nupchen in the monastery of Nyémo Jékhar (Tib. Nye mo bye mkhar; now bye mkhar chos sde dgon), the location where Nupchen supposedly killed a rebel army during the second rebellion (Tib. kheng log) in the 10th century, as described in his biography, the Testament of Nup (Tib. gnubs kyi bka' shog chen mo) and already discussed in the previous section of this chapter. Karma Delek reported how there were many old manuscripts there, and some of them were by Nupchen himself, although mostly incomplete. During my visit to the monastery, I was astonished to see the number of manuscripts sitting there. There are, literally, hundreds of them (I was told that there are around a hundred bundles, all of them containing several texts).

\footnotetext{
${ }^{175}$ Karma Delek was quite conviced that this text was written by Nupchen. He described it as quite long, but with some parts missing. The only reference I have found to this scripture is on a list of Great Perfection scriptures connected to Vairocana and transmitted to the Tibetan teacher rGyal mo gYu sgra snying Po: "According to this tradition, rDzogs chen scriptures are divided into four categories: the external teachings (phyi skor), the internal teachings (nang skor), the secret teachings (gsang skor) and the treasure cave (ke'u tshang skor) teachings. The external teachings include nine series: rgyud sde, sems sde, klong sde, bam po'i skor, mdo lung, rdzogs chen ma bu'i skor, man ngag rdzong 'phrang gi skor, man ngag snyan brgyud kyi skor, man ngag bsam btan gyi skor. The internal teachings include six series: bram ze'i skor, rig pa'i skor, gab pa'i skor, rmad du byung ba'i skor, snying po'i skor, rdzogs chen lde mig gi skor. The secret teachings include nine series not listed here. The treasure cave teachings include six series: 'phrul gzhi zab mo skor, rin po che rgyas pa'i skor, nyi ma'i 'khor lo zab mo skor, rgyal po'i bla gter zab mo skar, za 'og ber khyim zab mo skor, rgyud pa tha ma zab mo skor." Bold is mine. Namkhai Norbu based his list on the long chen chos 'byung, pp. 292-298. In Namkhai Norbu, The Supreme Force. The Fundamental Tantra of Dzogchen Semde Nujed Gyalpo (Snow Lion Publications, 1999).

${ }^{176}$ Rnying ma gsung 'bum dkar chag, 1992 (catalogue of the rnying ma texts contained in the Potala library), p. 145.

${ }^{177}$ Private conversation that took place in Lhasa on 04/11/2013. During that same conversation he, in fact, mentioned that he had seen and had in his possession other texts (close to twenty) written by Nupchen and his main disciples, although at that time he was not able to give me a copy of the texts. Some of them are on sems sde, tantra, etc. He said he would give me a list of the texts in a couple of months or so, although I am still not sure why getting the list of texts would take this long. He mentioned the many problems he has with the government regarding the sharing of texts. When I asked him how come he knows those texts are there but, sometimes, he does not have them, he said that the people working at the Potala sometimes do not know anything about the texts, so they call him, then he asks to see the text so he can tell them who wrote it, how it should be classified, etc. That's how he has some of those texts. He also mentioned issues of copyright, the fact that he can not share those texts because of copyright issues, but that he wants to publish them by 2014 and then he can share them with everyone.He mentioned that, among the texts in the Potala there are some by gNubs khu lung pa yon tan rgya mtsho, one of his main students, probably his son.
} 
Unfortunately, I was only able to quickly inspect a couple of bundles (for maybe twenty minutes)

before the local security forces got wind of my visit and asked me to leave the premises. ${ }^{178}$

Second, the texts that survived, like many of the Buddhist texts produced during the period, were attacked during the Sarma period as forgeries produced by Tibetans with no legitimate Indian origins. We have already seen this in the attacks of Yeshe Ö and Podrang Zhiba Ö. These attacks, combined with the perception of Nupchen, by some of the Sarma schools, as a skilled practitioner of the dark arts seemed to have affected his standing for the later Tibetan tradition. $^{179}$

The third and last section of this chapter will offer an overview of what we know of the rest of Nupchen's corpus. This will help us situate the Lamp not only in Nupchen's particular historical context, but also in the context of his varied writings, showing the richness and complexity of Nupchen's intellectual life, which covered a wide range of Buddhist intellectual traditions, rituals, and contemplative practices.

\footnotetext{
${ }^{178}$ I was able to send a few of the pictures I took of the manuscripts to Sam van Schaik, the scholar in charge of the Tibetan manuscripts at the British Library, and to Jake Dalton. This is van Schaik's personal evaluation of the manuscripts after having seen the pictures in a personal communication on 06/07/2013: "It looks like a real mixed bag of manuscripts (literally!). The ones in the bag, and the ones on the yellow cloth are mostly in cursive dpe yig and printed dbu can that are most likely to be from the last 300 years or so. As Jake mentioned, the ones on the red table could be older. The one with red and black ink that Jake mentioned as the commentary on the Madhyantavibhaga is written in a style comparable with the Dunhuang manuscripts, and combined with the older orthography, means this manuscript could *in theory* go back as far as the 10th century (though not earlier as there are no reverse gi-gu). It is also interesting that the page has half-circles at the bottom. This means they were cut down from larger folios that would have been made for expensive sutra manuscripts. There is also a hole in the middle of the circle, which is another indicator of an early date. Since these pages are blank on the back, they were probably double-thickness paper that has come apart (similarly, the Dunhuang large sutra manuscripts were made with double-thickness paper). The other page that could be from an early manuscript is the one on brownish paper, half folded over. The one that is rolled up must be 13th century or later because of the khyug style writing in the interlinear commentary, and the one to the far right looks like a printed page, so probably 15 th century or later." Further, in the summer of 2013, Prof. Hildergard Diemberger, from Cambridge, who has done some work on this particular monastery in the past, told me that there is a catalogue of the texts found in the monastery. I am currently trying to get my hands on it. If it is true that there are some texts by Nupchen in the monastery, a future study of this catalogue (although, most importantly, of the texts themselves) should allow us to have a more complete picture of Nupchen's corpus and a better understanding of the Tibetan Dark Age.

${ }^{179}$ For this image of Nupchen, see Dalton's "Preliminary Remarks on a Newly Discovered Biography of Gnubs Chen Sangs Rgyas Ye Shes.”
} 
The Armor Against Darkness (Tib. Mun pa'i go cha)

The most important and influential work written by Nupchen besides the Lamp is the Armor Against Darkness (Skt. Samāja vidyā satra, Tib. dGongs pa 'dus pa'i mdo), a commentary on the Sütra of the Gathered Intentions (Tib. dGongs pa'i 'dus pa'i mdo), ${ }^{180}$ the root text of the Anuyoga tradition. It could be argued that while the Lamp is Nupchen's most relevant work for our understanding of the historical, doctrinal, and textual developments that were taking place in Tibet from the very early introduction of Buddhism in Tibet all the way to the Dark Age, it had very little influence on the philosophical and doctrinal developments that took place within the Nyingma tradition after the Dark Age period. On the other hand, the Armor Against Darkness had a strong influence on Nyingmapa doctrine and ritual all the way up to the present. ${ }^{181}$ Dalton, who has studied this text extensively, describes the Sütra as a:

[c]omprehensive system for organizing all the Buddhist teachings that had arrived in Tibet. It wove together the day's most popular myths, doxographical schemes, rituals, and doctrines into a single, elaborate structure. [...]The Sütra stood out from this crowd with its breadth of vision. It sought to integrate and organize all the other tantras, weaving them into a single tantric cosmos, and this was how Gnubs chen presented it in his commentary, the Mun pa'i go cha ('Armor Against Darkness'). ${ }^{182}$ Emerging when it did, the Sütra presents us with an important window onto the rush of tantric innovations that ran from the eighth through eleventh centuries. Tantra in eleventh century Tibet was different in many respects from tantra before the dark period, and the Sütra offers a

\footnotetext{
${ }^{180}$ Sütra of the Gathered Intentions: Sangs Rgyas Thams Cad Icyi Dgongs Pa 'Dus Pa'i Mdo Chen Po. Full Title: De Bzhin Gshegs Pa Thams Cad Kyi Thugs Gsang Ba'i Ye Shes; Don Gyi Snying Po Rdo Rje Bkod Pa'i Rgyud; Rnal 'Byor Grub Pa'i Lung; Kun 'Dus Rig Pa'i Mdo; Theg Pa Chen Po Mngon Par Rtogs Pa; Chos Kyi Rnam Grangs Rnam Par Bkod Pa Zhes Bya Ba'i Mdo., vol. 16, Rnying Ma'i Rgyud 'Bum, n.d.

${ }^{181}$ Dalton offers a detailed description of the history of the Sutra and the relevance of Nupchen's commentary in the context of Nyingma history in his dissertation: "The Armor appeared to have been destroyed after the Dzungar invasions destroyed Mindroling and Dorje Drak in 1718. The Armor, though, was "re-discovered" in the early 20th century (1919) by Kah thog Si tu Chos kyi Rgya mtsho (1880-1925) in the libray of Tashi Lumpo, spearheding a revival of the Sutra itself, as well as a new commentary by Khenpo Nuden (Tib. mKhan po nus ldan)." See Dalton's chapter "Reviving the Mun pa'i go cha” in his dissertation Jacob Dalton, "The Uses of the dGongs Pos 'Dus Pa'i Mdo in the Development of the rNying Ma School of Tibetan Buddhism" (University of Michigan, 2002). ${ }^{182}$ In Jacob Dalton's “The Uses of the dGongs Pos 'Dus Pa'i Mdo in the Development of the rNying Ma School of Tibetan Buddhism” (University of Michigan, 2002).
} 
glimpse of these tantric developments in the transition from the earlier yoga and mahāyoga to the later anuttarayoga tantras. ${ }^{183}$

In this respect, the Armor played a very similar role to the Lamp for the Eye in Contemplation in attempting to organize the wide variety of Buddhist practices and rituals that made their way into Tibet since the beginning of the introduction of the religion into Tibet in the 7 th century, all the way up until Nupchen's time in the 10th century. While the Armor, though, was focused on tantric rituals and doctrines as mainly prescribed in the Sütra of the Gathered Intentions and therefore, as prescribed by the Anuyoga tradition, the Lamp explored a wider range of Buddhist contemplative literature that included the Indian gradual approach and the Chinese Chan tradition, while focusing on the emergent Great Perfection tradition and its literature (Tib. sems sde).

According to the Pema Tinley's Biographies for the lamas of the Sütra Initiation Lineage, ${ }^{184}$ a history of the transmission of the Sütra of the Gathered Intentions, Nupchen did not

${ }^{183}$ Dalton adds "The Sütra used a number of strategies in constructing its new tantric universe. It was the locus classicus for the hierarchical classification scheme of the nine vehicles (theg pa dgu) that eventually gained wide acceptance in Tibetan Buddhism, especially within the Rnying-ma school [...] It reinterpreted in tantric terms some of the most well-known doctrines in Mahāyāna Buddhism, such as the five paths and the ten levels of the prajñāpāramitā, and the eight consciousnesses of Yogacara thought. But perhaps most successful were its extensive myths explaining the origin of the tantric teachings. The Sütra wove together many of the most popular myths of the day, using a new exegetical apparatus that organized tantra into three "transmissions" (brgyud pa gsum). The result was an entire tantric universe, with defined places for all that had come before in tantra. This tantric universe was tied to the earlier Buddhist sūtras at numerous points," pp. 51-52 of his dissertation.

${ }^{184}$ Padma 'Phrin las, “'Dus Pa Mdo Dbang Gi Bla Ma Brgyud Pa'i Rnam Thar Ngo Mtshar Dad Pa'i Phreng Ba (An Account of the Transmission Lineage of the Initiation of the 'Dus Pa Mdo Tantra Written in 1681 at rDo Rje Brag by the Second Rigs 'Dzin Chen Po Padma 'Phrin Las)." Dalton also argues that Nupchen himself may have writen the Sūtra: "Given that Gnubs-chen was the main Tibetan holder of the lineage, we must also consider the possibility that Gnubs-chen himself wrote the entire sutra, perhaps with Che Btsan-skye to help with the Burushaski parts and Dharmabodhi playing a largely inspirational role. However, Gnubs-chen does not say he was involved in the translation effort, and there would be no reason to deny it if he had been. In fact, Gnubs-chen was remarkable in his day for his honesty in admitting his hand in numerous works, including his Mun pa'i go cha, Bsam gtan mig sgron and many shorter texts. To my knowledge, no other Tibetans were fixing their names to their compositions this early. In short, while it must remain provisional, the "written for export" picture outlined above seems the best choice." In Dalton, "The Uses of the dGongs Pos 'Dus Pa'i Mdo in the Development of the rNying Ma School of Tibetan Buddhism," p. 275, n. 21. 
only write a commentary of the text, but was directly involved in the translation of the Sütra itself and the dissemination of the practices and rituals associated with it in Tibet.

According to what it has been stated at length in the Great Testament [of Nup] as well as in the account of the [transmission] of the Sütra of the Gathered Intentions, in Nepal [Nupchen] requested to his teacher Vasudhara the empowerment of the Sütra and [Vasudhara] responded: "Request them to Abbot Chos rgyal sKyong!" [...] At a certain point the Abbot Chos rgyal sKyong went to Bru sha; the Bru sha Abbot Che btsan bKyes was the translator for Dhanarakrita, otherwise known as Sakya Sen ge or O rgyan chen po [Padmasambhava], and Dharmabodhi; as there was little devotion among the people towards the translator of Sütra [of the Gathered Intentions], they gave up [the translation] and went back to India; he [Chos rgyal sKyong] instructed the Bru sha Abbot [Che btsan bKyes], Vasudhara, Jñanakumara, gTsug lag dPal ge and Sangs rgyas Ye shes, and the latter attended on the Abbot from Bru sha and obtained teachings when the Abbot from Bru sha was working on the translations of [the teachings he was bestowed with] into Bru sha language following Dhanarakrita's advice. ${ }^{185}$

Dudjom Rinpoche argues in his History of the Nyingma Tradition that the date of the encounter between Nupchen and Che bTsan skyes took place in 885 C.E., making Nupchen 41 years old at the time of the translation. Although we need to take these dates with a healthy dose of skepticism, it seems that Nupchen wrote the Lamp after his translation of the Sütra and the composition of its commentary, the Armor Against Darkness. Traditional dates would support this, since he is supposed to have written the Lamp in the immediate years after 904, at the age of 61, in order to compensate for his negative actions during the second rebellion, which took place in 904. The fact that the Sütra is the most cited text in the Lamp, and that passages from the Lamp are very similar to those of the Armor, also support the claim that Nupchen wrote the Lamp after he had composed the Armor Against Darkness. ${ }^{186}$

\footnotetext{
${ }^{185}$ Donati, "The Lamp Is Burning Bright. Gnoseological Approaches and Soteriological Perspectives in gNubs Chen Sangs Rgyas Ye She's Masterpiece," pp. 8-9.

${ }^{186}$ This is what Dalton has to say about this issue: "The famous Tibetan exegete, Gnubs-chen Sangs rgyas Ye-shes studied directly under the translator, Che Btsan-skyes, and composed the most influential commentary on the Sütra, the Mun pa'i go cha. Dudjom Rinpoche suggests that Gnubs-chen, on the advice of his Nepalese teacher, Vasudhara, went to meet Che Btsan-skyes around 885 C.E. Gnubs-chen would have been about forty-one years old at that time.
} 
What the Armor and the Lamp clearly reveal is the breadth of Nupchen's knowledge of the Buddhist doctrinal, contemplative, and ritual developments that were taking place in Asia during his lifetime. These two texts also demonstrate Nupchen's ability to synthesize and structure a broad variety of ideas into a clear and original framework, helping to articulate a unique vision for Buddhism in Tibet. If the Lamp is a dry, traditional doxography, with a focus on the differences between different Buddhist contemplative traditions, the Armor weaves together philosophical, and ritual narratives in order to offer a cohesive presentation of the richness and variety of Buddhism in Tibet. The Lamp and the Armor also offer classifications of Buddhist doctrine, although while the Armor includes what would become the more standard ninefold classification of Buddhist vehicles, the Lamp offers only four.

An interesting aspect of the autobiography of Nupchen is that neither the Sütra nor its commentary, the Armor Against Darkness, are mentioned in the text (the Lamp is mentioned only once). This is strange if we consider that most of Nupchen's legacy is tied up in his holding and transmission of the Anuyoga tradition and, in particular, of the Sütra of the Gathered Intentions. An explanation of this could be, as Dalton has already argued, that this supposed

The ultimate source for Dudjom's 885 date is uncertain, but roughly the same time is arrived at through another means: We can say with some confidence that Gnubs-chen composed his Mun pa'i go cha some years before his other renowned work, the Bsam gtan mig sgron. This is stated in his biography and is corroborated by the regular citations of the Sütra (under the alternate title of Rnal 'byor sgrub pa'i lung) throughout his Bsam gtan mig sgron (where it is, in fact, cited more than any other work). According to his biography, Gnubs-chen composed his Bsam gtan mig sgron in order to purify the bad karma he accumulated in the second revolt (khengs log), dated by Vitali at 904. Thus we can assume that Gnubs-chen was focusing his attentions on the Sütra during the period just prior to the turn of the tenth century, which makes the Sütra's translation date of 885, or slightly earlier, look quite accurate." In Dalton, "The Uses of the dGongs Pos 'Dus Pa'i Mdo in the Development of the rNying Ma School of Tibetan Buddhism," pp. 266-67. 
autobiography was not written by him, but by someone who was not particularly interested in the Sūtra and its legacy, and was more concerned with the transmission of texts and practices related to the Mahāyoga tradition and the Great Perfection. On the other hand, Pema Tinley's biography of Nupchen is mainly concerned with the legitimacy of the Sütra and the figure of Nupchen is key for the narrative of the transmission of the text from India all the way to Tibet. 
Great Perfection Literature Commentaries: the Rig pa'i nyi ma and the rTse mo 'byung rgyal 'grel $b a$

The Lamp shows Nupchen's clear commitment to the Great Perfection tradition in Tibet and, in particular, to the main corpus of Great Perfection texts that were emerging in Tibet during that period, the so-called 18 Semde Tantras, which Nupchen discusses at length in the Lamp. Two commentaries to two particular texts of that canon have survived, which may have been composed by Nupchen, the Sun of Yogic Awareness (Tib. rNal 'byor rig pa'i nyi ma), a commentary of the Nam mkha' che and the Commentary on the Victorious Emergence of the Peak (Tib. rTse mo 'byung rgyal 'grel ba). These Semde texts were singled out during the earlier Sarma developments as particularly problematic and, as in the case of Phobrang Zhiba Ö's proclamation, as forgeries, pretending to be of Indian origin, written by Tibetans.

The Sun of Yogic Awareness is located in the bKa' ma shin tu rgyas pa and, as Wilkinson points out, the text's colophon "does not explicitly state that gNubs chen [...] is its author.",187 Authorship of the text can only be inferred indirectly, and our strongest evidence is Phodrang Zhiba Ö's proclamation, in which the text is attributed to Nupchen. Wilkinson's evidence does not go beyond that reference, and his acknowledgment that "this is an intuitive statement I make, based on 27 years of familiarity with the bSam gtan mig sgron." ${ }^{188}$ Although I agree with him that the text's discussion of the Nam kha' che resonates with his writing in the Lamp, its attribution is far from certain. In fact, Dudjom Rinpoche attributes the text to the master, Vajrahāsya (Tib. rDo rje bzhad pa): ${ }^{189}$

\footnotetext{
${ }^{187}$ Christopher Wilkinson, “The Mi Nub Rgyal Mtshan Nam Mkha' Che," Revue d'Etudes Tibétaines 24 (October 2012): 21-80, p. 34.

${ }^{188}$ A teacher in the lineage transmission of the Mahāyoga teachings in Tibet, Ibid., p. 34. Dudjom offers a brief biography of his life on pp. 466-67.

${ }^{189}$ Nupchen mentions Vajrahāsya as one of the two main masters (the other one is Vilāsavajra) that exemplified the Mahāyoga gradual approach. See chapter 5 of this dissertation.
} 
The master [Sukha the "Zombie", one of the names of the emanation Garap Dorje.] empowered the master Vajrahāsya in Uttarasara Forest, and explained the tantras to him. He, too, obtained supreme accomplishment by the path of supreme bliss. He composed a treatise entitled the Sun of Yogic Awareness (rnal-byor rig-pa'i nyi-ma), which systematically explains the profound path of the Sütra Which Gathers All Intentions. On the bank of the Indus River, in the country of Gajane, he empowered the master Prabhāhasti and explained the tantras to him. 190

Guru Tashi also mentions the Sun of Yogic Awareness in close connection with other of Nupchen's works, which reinforces the notion that this text, at least for the Tibetan tradition, was written by Nupchen. ${ }^{191}$

The second text, the Commentary on the Victorious Emergence of the Peak (Tib. rTse mo 'byung rgyal 'grel ba) ${ }^{192}$ is also a commentary on another of the thirteen Semde tantras, translated by Vimalamitra. The colophon attributes the text to Nupchen, ${ }^{193}$ but little has been written about him, and its authorship is, at this point, questionable.

\section{Ritual Texts}

As we have seen in his biography, Nupchen, or at least the Nupchen portrayed in the Tibetan tradition, was strongly interested in ritual practices and, in fact, over one third of Nupchen's autobiography consists of lists of ritual teachings he received (and later transmitted himself) during his trips to India and Nepal. Most of those practices involve wrathful deities, like

\footnotetext{
${ }^{190}$ Dudjom Rinpoche, The Nyingma School of Tibetan Buddhism: Its Fundamentals and History, p. 488., although this maybe a different text, since it specifially refers to the Sütra of the Gathered Intentions. Eva Dargye, in her The Rise of Esoteric Buddhism in Tibet, misread these passages and attributes the text to Garab Dorje instead of to Vajrahāsya. See Eva K. Dargyay, The Rise of Esoteric Buddhism in Tibet (Delhi: Motilal Banarsidass, 1977), p. 40. ${ }^{191}$ Guru Tashi mentions a list of texts belonging to the Rong system (Tib. Rongs lugs) under the name of Great Texts of Meditation (Tib. sgom yig chen mo). The texts are: 1) Rnal 'byor Rig pa'i Nyi ma; 2) Bsam gtan Mig gi Sgron ma; 3) Bsam gtan Snying gi Nyi ma; 4) Brdar sha; 5) Gzer bu; 6) Zhu lan; 7) Khung gdab; and 8) Rdo rje sems dpa'i Zhu lan.

${ }^{192}$ Sangs rgyas ye she's $r$ Tse mo byung rgyal 'grel pa In bka' ma shin tu rgyas pa (kaH thog). TBRC W25983. 103: 181 - 232. [chengdu]: [kaH thog mkhan po 'jam dbyangs], [1999].

193 The colophon to the text reads "yang dbang gter gnubs sangs rgyas ye shes rin po che gyis/ rtse mo byung rgyal gyi 'grel pa rdzogs so."
} 
Vajrakilaya. This affinity of Nupchen for wrathful practices should not surprise us, particularly since one of the most famous episodes connected to Nupchen's life is his confrontation with a rebel army during the second rebellion in 904 which, as I have already argued, I believe was later transformed into a confrontation between Nupchen and King Langdarma to raise the stature of Nupchen during the Dark Age period as a champion and protector of the Buddhist tradition during those difficult times.

There is an interesting connection between Nupchen's fondness for wrathful rituals and the life of one of the most important figures in Tibetan religious history, the famous yogi Milarepa. As is well known in the Tibetan tradition, Milarepa killed many members of his family in an act of revenge during a family celebration by summoning a hail storm that collapsed the room of the house in which the celebration was taking place, killing thirty five people. According to Dan Martin, Milarepa's teacher in the dark arts was part of Nupchen's lineage:

Available biographies of Milarepa give different forms for the name of the magic teacher. In the Blue Annals, he is called Doctor Hūm-chung. By Padma Dkar-po he is called Doctor Ye-shes-gzungs of Gtsang-rong. Most often, he is called Doctor Gnubs-chung, but frequently he is said to be Gnubs Khu-Iung-pa or even Gnubs Khu-Iung-pa Yon-tanrgya-mtsho. He is a well known figure in Nyingma history. In order to reach a more positive identification of this teacher, however, it will be necessary to resort to a study of lineages. Gnubs Khu-Iung-pa belonged to an important lineage for the oral tradition (bka'-ma) of the Nyingma which transmitted the Guhyagarbha and other teachings. The following reconstruction of information supplied by Padma Dkar-po (p. 387) and the Blue Annals (pp. 108-109) will be important for this discussion, since it supplies a rough chronology and many of the persons involved will reappear later on [...] This doesn't help narrow our choices. That he is called Gnubs-chung only lends credence to the idea that it really was Gnubs Khu-Iung-pa since he was the most important successor of Gnubs-chen and, generally speaking, the 'lesser' master of a tradition follows on the heels of the 'greater'. If it is true that Gnubs-chen Sangs-rgyas-ye-shes died in 962 A. D., it is improbable that his disciple could have been a contemporary of Milarepa (1040-1123). Also, if the Blue Annals is correct when it says that Milarepa was age thirty-eight at the time of his first meeting with Marpa, then the date of the magic teacher's death could not be before 1078 A. D. ${ }^{194}$

\footnotetext{
${ }^{194}$ Dan Martin, “The Early Education of Milarepa," The Journal of the Tibet Society 2 (1982): 52-76.
} 
Another very important ritual text that is attributed to Nupchen and that is commonly used by all Tibetan Buddhist traditions (it is probably Nupchen's most widely used text) ${ }^{195}$ is the Golden Libation for the Eight Classes (Tib. sDe brgyad gser skyems). This ritual text is devoted to the eight types of non-human beings ${ }^{196}$ to whom the practioner makes offerings of alcohol. ${ }^{197}$

\section{Works Attributed to Nupchen}

There are a series of texts traditionally attributed to Nupchen, as translator or as its main author, that can be found when searching through the different catalogues of Nyingma works, or that are mentioned in the various biographical accounts written about him. Dudjom, for example, mentions the Gnubs chen 'da ka'i zhal chems lung rdo rje bkod pa'i gdams pa gnang ba, although this seems to be a mChog gyur gLing pa treasure. ${ }^{198}$ Then there is also the Transmitted Instructions of the Indestructible Array (Tib. gNubs chen 'da' ka'i zhal chems lung rdor je), which Nupchen mentiones in the Final Testament, but which I have not been able to locate. Dalton also mentions the Zab pa'i chos drug, "a teaching Nupchen is said have received from

\footnotetext{
${ }^{195}$ See T.C. Gyatso, "The Doctrine of the Incense Homa," The Mikkyo Bunka (Quarterly Reports on Esoteric Buddhism) 128, no. December (1979): 109-89.

196 There are different lists describing the eight types of deities. The Great Tibetan Dictionary (Tib. Tshig mdzod chen mo) lists thems as: 1) Gods (Tib. lha); 2) Nagas (Tib. klu); 3) Yakrhas (Tib. gnod sbyin); 4) gandharva (Tib. dri za); 5) Asura (Tib. lha ma yin); 6) Garuda (Tib. nam mkha' lding); 7) Kinnara (Tib. mi'am ci); and 8) Mahoraga (Tib. lto 'phye chen po).

${ }^{197}$ The text is also used in rituals to prevent hail and, presumably, also to invoke it, a theme that connects the text with the famous story of Milarepa in which supposedly he learned from a disciple of Nupchen how to invoke hail to kill members of his family. On the tradition of hail preventing rituals, see Dorje Dondrup's "Hail Prevention Rituals and Ritual Practitioners in Northeast Amdo," Asian Highlands Perspectives, no. 21 (2012): 71-111. On the connection between Milarepa and Nupchen see Martin, "The Early Education of Milarepa."

${ }^{198}$ In TBRC it is listed as a work by mchog gyur gLing pa: "bkod-pa'i gdams-pa gnang-ba. Disc. Mchog-gyur dechen gling-pa, Collected works of mchog gling Vols. 22-3. Rinchen gter mdzod Vol. 86, pp. 1-171. [847]”
} 
four of his teachers, as explained by the Fifth Dalai Lama (Gangga'i chu rgyun: vol. 3, 21.23), ${ }^{, 199}$ but I have not been able to consult this text.

\section{Conclusion}

In this chapter, I have argued for a reassesment of the Tibetan Dark Age, one that acknowledges the challenging political and intellectual environment of the period, as described in many traditional Tibetan literary sources, but that also recognizes the wealth of Buddhist activity that took place in Tibet during this period, away from the traditional institutional structures that had crumbled after the collapse of the Empire. Nupchen's life is a reflection of the complexity of the period, in which the collapse of the religious institutions forced intellectuals to travel to India, Nepal, and Central Asia in order to study. We can see this in Nupchen's role in Tibet in importing, translating, and writing commentaries for some of the latest and most cutting edge Buddhist developments of the time, mainly the Anuyoga and Atiyoga traditions.

\footnotetext{
${ }^{199}$ Dalton also adds, "Fortunately, a manuscript copy of this work has been preserved by the Nepal-German Manuscript Preservation Project (role AT52/12). The prophecy cited by the Fifth Dalai Lama in the present context appears on f. 2a.6-3b.2, so it is quite possibly the same work. This and some other manuscripts from the same preservation project relating to Nupchen have come into my possession just as the present article is going into production, so a study of their significance vis-à-vis the Gyawoché must await my forthcoming and more detailed study and translation." In Dalton's "Preliminary Remarks on a Newly Discovered Biography of Gnubs Chen Sangs Rgyas Ye Shes."
} 


\section{Chapter 2 - The Lamp for the Eye in Contemplation: Text and Contexts}

\section{Introduction}

The first chapter of this dissertation has explored the life of Nup Sangyé Yeshé and the tumultuous historical period in which he lived, the Tibetan Dark Age. This second chapter will focus on Nupchen's most famous text, the Lamp for the Eye in Contemplation (Tib. bSam gtan mig sgron), to which this dissertation is dedicated. This chapter will explore the text by approaching it from three different perspectives: as a physical object, as a literary genre, and as an inter-textual blueprint to Buddhism in 10th century Tibet. In order to do that, I have divided the chapter into three different parts. The first part will explore the obscure recension history of the text, from its production in the early 10th century, to its re-discovery and publication in 1974. This section will also try to shed some light on certain confusion surrounding the nature of the various editions that have survived of the text. The second part will explore the Lamp in the context of the literary genre to which it belongs, that of the Buddhist doxography, or classification of views. The main argument of this section is that Nupchen uses this specific Buddhist literary genre not only to reflect and organize the various Buddhist traditions that existed in Tibet during his lifetime, but also to impose a particular view of the Buddhist path, one that situated the new and emerging Great Perfection at the top. Finally, in the third part of this chapter I will explore the deep intertextual nature of the Lamp. Nupchen's text includes hundreds of quotes from a wide variety of Buddhist traditions, which makes it the most important source, together with the cache of Tibetan manuscripts in the Dunhuang Library Cave, for our understanding of the textual and intellectual world of 10th century Tibet. 
PART 1 - The Obscure Recension History of the Lamp for the Eye in Contemplation and the

\section{Search for the Mysterious Lost Manuscript}

In the study of any text, but, in particular, in the case of a text that is over a thousand years old, it is of paramount importance to begin any serious research with an examination of the recension history of the text. As Martin West has said about Greek and Latin works:

[T] extual criticism is not the be-all and end-all of classical scholarship, which is the study of a civilization. But it is an indispensable part of it. By far the greater part of our knowledge of that civilization comes to us from what the ancients wrote. In almost all cases those writings have survived, if they have survived at all, only in copies many stages removed from the originals, copies of which not a single one is free from error. Often errors are so great that it is no longer possible to tell what the author meant to say. It follows that anyone who wants to make serious use of ancient texts must pay attention to the uncertainties of the transmission [...] if he is not interested in the authenticity and dependability of the details, he may be a true lover of beauty, but he is not a serious student of antiquity."200

While my dissertation is not a philological project per $s e^{201}$, the first part of this chapter is dedicated to the historical vicissitudes of the text. I will discuss the reception history of the text, as well as what we know of its obscure recension history. An important goal of the chapter is to correct some of the confusion regarding the recension history of the text, particularly as presented in the recent critical work on the Lamp by Donati and Esler. This section will also argue that the interlinear notes found throughout the text were not the work of Nupchen, but of an immediate disciple/s or early member of the Great Perfection tradition. As we will see, these interlinear notes offer important clues as to the early reception of the text and its manipulation in order to reflect early developments of the Great Perfection.

\footnotetext{
${ }^{200}$ West, M. L. Textual Criticism and Editorial Technique Applicable to Greek and Latin Texts. Stuttgart: B. G. Teubner, 1973, p. 7.

${ }^{201}$ Donati offers a diplomatic edition of the text in her dissertation. Dylan Esler's forthcoming dissertation includes a critical edition of the text, which will be a very much needed addition to our philological understanding of the text. At this moment, though, I have only been able to read Esler's "Introductory Remarks" in which he discusses the recension history of the text.
} 
Recension History and Editions of the Lamp for the Eye in Contemplation

There are four different editions of the Lamp for the Eye in Contemplation. Below, I offer a brief description of each of them, including an image of the first page of each edition:

Leh edition $-1974^{202}$

The Leh edition (from now on, Leh), the earliest one available, was published in 1974, and according to the preface written by Gene Smith, it was "reproduced from a manuscript made presumably from an Eastern Tibetan print by 'Khor-gdong gter sprul 'chi-med rig-'dzin.,"203

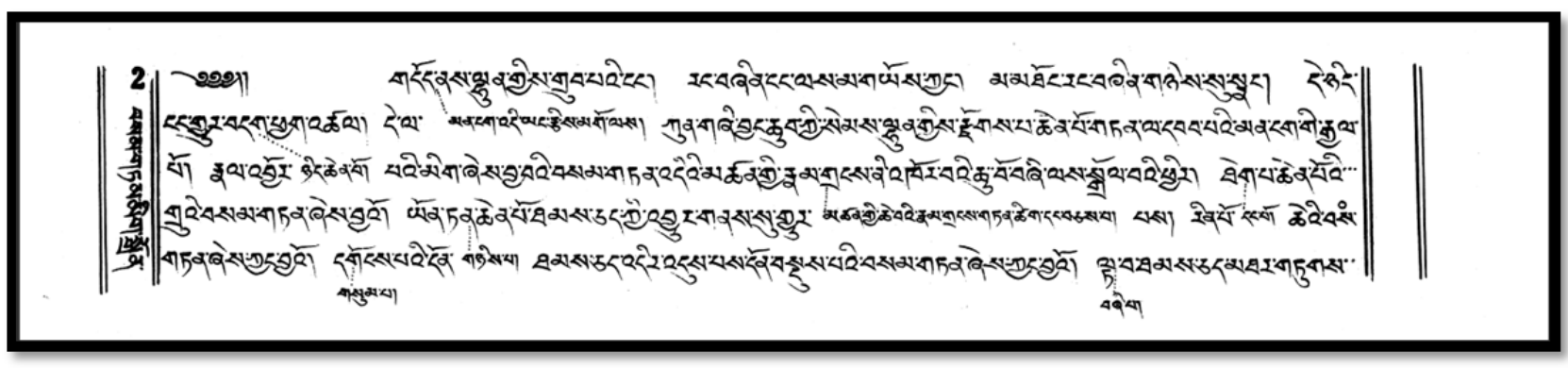

\footnotetext{
${ }^{202}$ Sangs rgyas ye shes, Gnubs chen. Rnal Byor Mig Gi Bsam Gtan, Or, Bsam Gtan Mig Sgron: A Treatise on Bhavana and Dhyana and the Relationships between the Various Approaches to Buddhist Contemplative Practice (Leh: smanrtsis shesrig spendzod, 1974).

${ }^{203}$ The full description of the text as given by Gene Smith in his preface to the Leh edition is interesting in and of itself: "The text here is a legible, though not elegant, copy of a block print from eastern Tibet. The text was xylographed through the efforts of a student of the 'Jam-dbyangs Mkhyen-brtse and 'Jam-mgon Kong-sprul tradition. The colophon to the blocks is signed by one 'Jam-dbyangs Blo-gros-rgya-mtsho, a teacher connected to Kah-thog. The blocks were prepared on the basis of a manuscript which had belonged to the great Rnying-ma-pa scholar Smin-gling Lo-Chen Dharma-shri (1654-1718). This manuscript, in turn, was based on a manuscript from the library of the famed Jo-nang Rje-btsun Tāranātha (b. 1575). The text belonging to Smin-gling Lo-chen was defective according to the editor of the block print edition," in Ibid. It is interesting that Smith did not recognize the author of the colophon as the famous 'Jam-dbyangs mkhyen-brte chos-kyi blo-gros. Khordong Tertrül Chime Rikdzin (Tib. 'Khor gdong gter sprul 'Chi med rig 'dzin, 1922-2002) was the head of Khordong Monastery in Tibet (in the Kham region). Between 1954 and 1987 he was the head of the Department for Indo-Tibetan studies at the Visvabharati University at Santiniketan in West Bengal, India. He was responsible for the edition of many Tibetan texts published by Gene Smith through the Library of Congress's Tibetan Text Publication Project of the United States Public Law 480 (PL480).
} 
Volume 104 of the 120 Volume Collection of the Extremely Extensive Oral Teachings $1999^{204}$

The second edition, published in volume 104 in the 120 volume collection of the Extremely Extensive Spoken Teachings (Tib. bKa' ma shin tu rgyas pa) was an initiative of Khenpo Munsel $^{205}$ in order to celebrate the reopening of Katok Monastery (Tib. Kah thog) in 1999. The work was carried out by Khenpo Jamyang ${ }^{206}$ with the help of Karma Delek. As Esler conveys in his critical analysis of the various editions, though, and as it can be easily recognized looking at the first page of both editions as seen in this section, the edition found in the 120 collection "is useless for text-critical purposes, as it is merely a photostatic reproduction of [the Leh edition from 1974], with a few typographical amendments to make all the interlinear glosses fit into the Tibetan page format." ${ }^{207}$

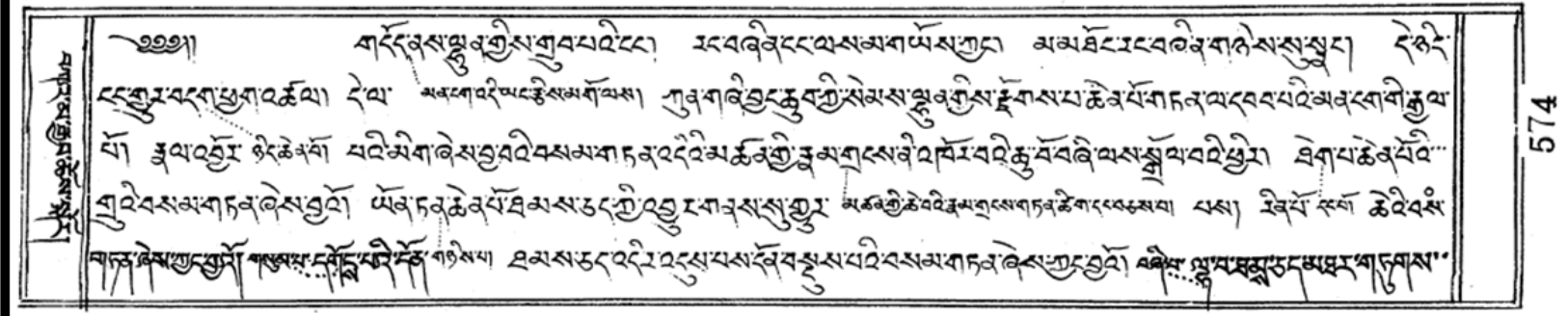

\footnotetext{
${ }^{204}$ Sangs rgyas ye shes, Gnubs chen. Bsam Gtan Mig Sgron 120, vol. 104, 120 vols. (Chengdu: kaH thog mkhan po 'jam dbyangs, 1999). My discussion of the various editions of the Extremely Extensive Oral Teachings has benefited from various conversations with Michael Sheehy, head of Literary Research at TBRC. He also wrote an overview of the various editions of this collection in their site http://about.tbrc.org/the-nyingma-kama-collections/

${ }^{205}$ Khenpo Munsel (Tib. mkhan po mun sel) 1916-1994. For a short biography see http://treasuryoflives.org/biographies/view/Khenpo-Munsel/9929

${ }^{206}$ Khenpo Jamyang (Tib. mkhan chen 'jam dbyangs rgyal mtshan). For a biography of him see http://treasuryoflives.org/biographies/view/Jamyang-Gyeltsen/8536

${ }^{207}$ Esler, Dylan "Critical Edition: Introductory Remarks," in Unpublished Dissertation, Forthcoming, 323-330, p. 325 .
} 
Volume 97 of the 110 Volume Collection of the Extremely Extensive Oral Teachings $2000 / 2001^{208}$

The edition published in volume 97 of the Extremely Extensive Spoken Teachings (Tib. bKa' ma shin tu rgyas pa) in 110 volumes (Chengdu 110) is, according to Esler, a xylographic reprint of a Tibetan block-print. ${ }^{209}$ For Esler and Donati, Leh and Chengdu 110 are independent witnesses of an older version of the text. ${ }^{210}$

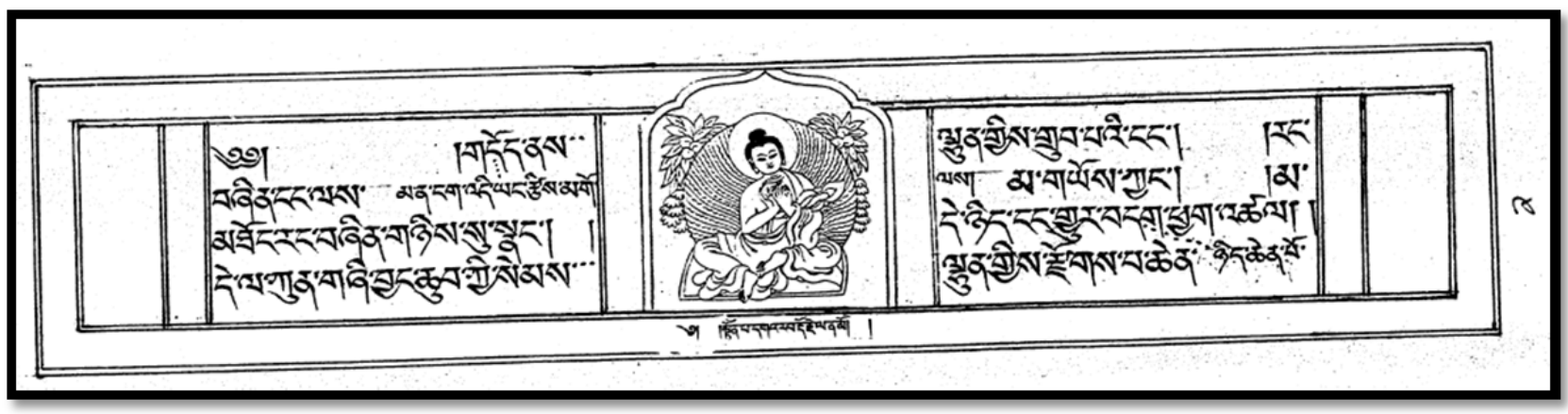

\footnotetext{
${ }^{208}$ Sangs rgyas ye shes, Gnubs chen. Bsam Gtan Mig Sgron 110, vol. 97, 110 vols. (Chengdu: kaH thog mkhan po 'jam dbyangs, 1990s). The TBRC site does not give a date for this collection. In a personal communication with Michael Sheehy, Head of Literary Research at TBRC, he mentioned that "the 110 vols. edition was actually the initial collection that Karma Delek put together, but it was published about a year after Khenpo Jamyang's edition [in 1999]. The Katok edition was made rather hurriedly for the ceremony at Katok Monastery and was printed in a small batch. Zenkar Rinpoche and Karma Delek took out all of what was considered non-bka' ma texts from that Katok edition and printed the 110 vols. edition sometime in 2000/2001." Personal e-mail 3/11/2014.

${ }^{209}$ See Esler, "Critical Edition: Introductory Remarks," p. 326. Michael Sheehy, from TBRC, also helped me get a clear picture of the differences between the 120 and the 110 editions: "Zenkar Rinpoche and Karma Delek took out all of what was considered non-bka' ma texts from that Katok edition in 120 volumes, and printed the 110 vols. edition sometime in 2000/2001." Personal e-mail 3/11/2014.

${ }^{210}$ Both also seem to prioritize Chengdu 110, since they consider it a more reliable witness. Donati, for example, says: "giving [sic] the strong connections between the personages mentioned in the colophons and those involved in the redaction of the rNying ma bka' ma shin tu rgyas pa, I have decided to rely on the bKa' ma edition rather than on Leh.”), p. viii. See also Esler Ibid., p. 325.
} 
Volume 104 of the 133 Volume Collection of the Extremely Extensive Oral Teachings $2009^{211}$

The final and most recent edition of the text, the one found in volume 104 of the 133 volume edition of the Extremely Extensive Spoken Teachings is an electronic version also based on the Leh edition, making it also irrelevant for a philological study of the origins of the text. ${ }^{212}$

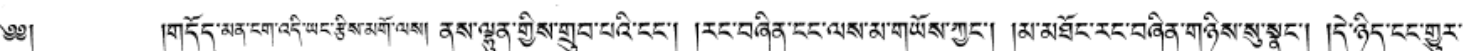

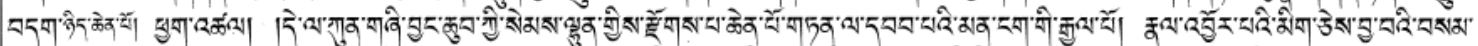

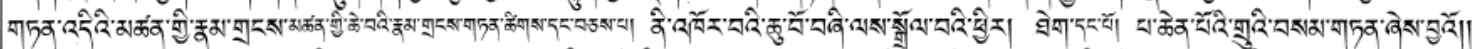

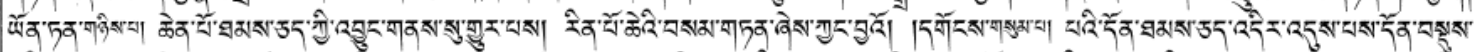

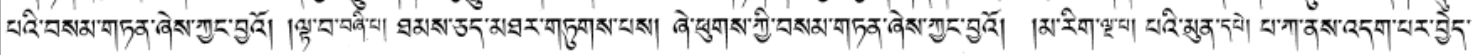

We have then, two editions, Leh and Chengdu 110, that are, as regard to content, essentially the same, but that include enough differences (particularly concerning spelling, as well as the content and position of the interlinear notes) that seem to warrant a close comparative analysis of the two editions. ${ }^{213}$ These textual differences have been explored in a diplomatic edition prepared by Donati, ${ }^{214}$ and a critical edition prepared by Esler. ${ }^{215}$ In both cases, Chengu 110 has been given preference since both scholars consider it a more reliable witness of the text. In order to have a better sense of the recension history of the text and, in particular, of the

\footnotetext{
${ }^{211}$ Sangs rgyas ye shes, Gnubs chen. Bsam Gtan Mig Sgron 133, vol. 104, 133 vols. (Chengdu, 2009).

212 The edition found in the 133 volume collection, not mentioned by Esler in his analysis of the various editions of the text, is an electronic version of the text that was included in this, at the moment, largest edition of the Extremely Extensive Spoken Teachings published in 2009. Karma Delek, also responsible for this latest edition, told me in a personal communication that all of the texts in this latest collection are plagued with errors, since there was not enough funding to thoroughly review and edit all of the texts.

${ }^{213}$ In this regard, Donati made a diplomatic edition of the text in her dissertation, and Esler has opted for a critical edition of the text in his unpublished dissertation. See Valeria Donati's "The Lamp Is Burning Bright. Gnoseological Approaches and Soteriological Perspectives in Gnubs Chen Sangs Rgyas Ye Shes' Masterpiece" (Università degli Studi di Napoli L'Orientale, 2006). Donati makes a mistake in the attribution of the version of the Lamp for the Eye in Contemplation that she is using for her diplomatic edition, citing the one in the 120 (which in fact is a reproduction of the one published in Leh), instead of the one found in the 110 .

214 Ibid.

${ }^{215}$ Esler's dissertation work is still in progress.
} 
relation between the Leh and the Chengdu 110 editions, the most logical place to start is the colophon of the text, which is identical in both editions.

The colophon was written by Jamyang Lodrö Gyamtso (Tib. 'Jam-dbyangs blo-gros rgya-mtsho ${ }^{216}$, 1893-1959) of Katok monastery, a reincarnation of Jamyang Khyentse Wangpo (Tib. 'Jam dbyangs mkhyen brtse'i dbang po, 1820-1892), both very important figures in the non-sectarian movement (Tib. ris med) that swept Eastern Tibet in the 19th century and was extremely influential in the revival of the Kama literature (Tib. bka' ma) in the Nyingma tradition. According to the colophon, Jamyang Lodrö Gyamtso prepared the edition of the text in order to fulfill the enlightened activities of his previous incarnation, Jamyang Khyentse Wangpo, who is described in the colophon as "the last student of the Gyalba Kah-thog Chenpo (Tib. rgyal ba kaH thog pa chen po). ${ }^{217}$ Jamyang Khyentse Chokyi Lodro worked on this edition under the guidance of Sechen Khenchen Pema Namgyal (Tib. Ze chen mkhan chen padma rnam rgyal, 1871-1926), ${ }^{218}$ and Dorje Changwang Pema (Tib. rDo rje 'chang dbang padma bi dza ya.) ${ }^{219}$ The project was sponsored by one Gelek Gyatso (Tib. dGe legs rgya mtsho). The colophon, finally, traces the original source for the Jamyang Khyentse Chökyi Lodrö (Tib. 'Jam dbyangs mkhyen brte chos kyi blo gros) edition to a text belonging to Minling Lochen Dharmaśrī (Tib. sMin gling lo chen Dharmaśrī, 1654-1718) which was, itself, based on a text belonging to Tāranātha (15751634).

\footnotetext{
${ }^{216} \mathrm{He}$ is most famously known as 'Jam-dbyangs mkhyen-brte chos-kyi blo-gros.

${ }^{217}$ I am unclear as to who this title refers to. Donati identifies this figure as sMin-gling lo-chen Dharmaśrī, although this attribution is dubious, since he was affiliated with Mindroling Monastery, and not with Kah-thog. Esler identifies him with Kah-thog Dri-med zhing-skyong (1899-1939). He was the Fourth Drime Zhingkyong (Tib. Drimed zhing-skyong)

${ }^{218}$ He was the fourth Shechen Gyaltsab (Tib. Ze chen rgyal tshab), one of the main teachers of Jamyang Khyentse Chökyi Lodrö.

${ }^{219}$ This may refer to Khenchen Kunzang Pelden (Tib. mKhan chen kun bzang dpal ldan), 1862-1943, who was a student of Jamyang Khentse Wangpo and a teacher to his reincarnation, Jamyang Khyentse Choki Lodro. For a biographical account, see http://www.treasuryoflives.org/biographies/view/Kunzang-Pelden/9593
} 
The colophon, then, traces the oldest extant version of the text, on which the present ones are based, to the famous Jonangpa teacher Tāranātha. There are some references to the Lamp in earlier historical sources (the earliest one probably found in the proclamation of Podrang Zhiba Ö in the early 11th century), but they are not of much help tracing the manuscript history of the work from its presumed composition in the $10^{\text {th }}$ century to the time of Târanātha in the $17^{\text {th }}$ century. Furthermore, we have no manuscript witnesses to help us trace its history from the $17^{\text {th }}$ to the $20^{\text {th }}$ century. Most importantly, we do not have the immediate source (manuscript or blockprint) for the Leh and the Chengdu 110 editions.

These issues have been tackled by Esler in his critical edition of the text, in which he offers the following possible stemma of the text, establishing the relationship between Leh and Chengdu 110 as follows: 
To summarize the above, we may depict the relationship of the two editions to their hyperarchetypes in the following stemma:

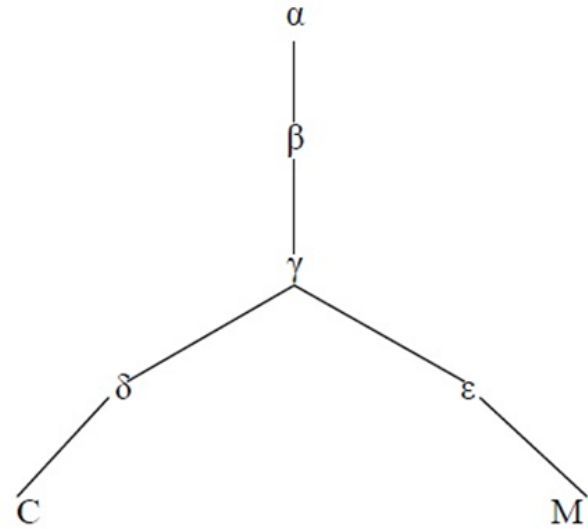

$\alpha \quad$ Tāranātha (1575-1634) manuscript

$\beta \quad$ sMin-gling lo-chen Dharmaśrī (1654-1718) manuscript

$\gamma \quad$ 'Jam-dbyangs mkhyen-brte chos-kyi blo-gros (1893-1959) block-print (Kah-thog)

$\delta \quad$ Calcutta manuscript

$\varepsilon \quad$ Kah-thog block-print

C Chhimed Rigdzin Rinpoche edition

M mKhan-po Mun-sel edition

${ }^{220}$ I want to thank Dylan Esler, of the Institut Orientaliste at the Universite Catholique de Louvain for sharing his research with me. This stemma is from Dylan's "Introductory remarks" to his critical edition and translation of the Lamp. Esler is still working on his research and these results may not be final. 
Lodro in Katok, which was based on a manuscript belonging to Minling Lochen Dharmaśrī ${ }^{221}(\beta)$, and this one, in turn, was based on a manuscript belonging to Tāranātha. While Esler's philological work is remarkable and seems to explain some of the differences between the Leh and the Chengdu-110 edition, the fact that there are no witnesses of either of the editions ( $\delta$ or $\varepsilon$ ) in his stemma make it difficult to corroborate.

\section{The Leh edition}

Esler, following an account by Khenpo Palden Sherab (1938-2010), offers an interesting account that may shed some light on the manuscript on which the Leh edition from 1974 is based:

[The Leh edition] appears to have been copied on the basis of a manuscript which Chhimed Rigdzin Rinpoche found in the library in Calcutta $(\delta)$, this manuscript itself being a copy of $\gamma$. This rather vague mention of a library in Calcutta could refer to the library of Visva-Bharati University, Santiniketan, where Chhimed Rigdzin Rinpoche was professor, to the library of Calcutta University or to the library of the Asiatic Society. Indeed, according to Lopon P. Ogyan Tanzin, who was working under Chhimed Rigdzin Rinpoche at that time, Dr. Anukul Chandra Banerjee (Calcutta University) frequently helped Rinpoche to take out books on loan from Calcutta University as well as from the Asiatic Society. In March 2011, I was able, thanks to Prof. Mihir Kumar Chakrabarti (General Secretary, Asiatic Society) and Dr. Bandana Mukherjee (Manuscript Librarian, Asiatic Society), to consult the catalogues of non-canonical Tibetan manuscripts held at the Asiatic Society prepared by Dr. Archana Ray. There is no mention of the bSam-gtan mig-sgron therein, and I was assured that all the manuscripts held have been catalogued. Later, in August-September 2012, I was granted permission by Tulku Ugen Chencho Lama, the son and principal regent of Chhimed Rigdzin Rinpoche, to carefully look through his father's personal collection held in the library of the Khordong Byangter Monastery near Siliguri. I used this opportunity to prepare a catalogue of the Tibetan texts kept in that library, but unfortunately, the manuscript $\delta$ is not found there either. It still remains to be seen whether the manuscript can be located in Calcutta University or Visva-Bharati ${ }^{222}$

\footnotetext{
${ }^{221} \mathrm{He}$ was the younger brother of the famous treasure finder (Tib. gter ton), Terdak Lingpa (1646-1714). One of his main teachers was Pema Tinley, responsible for one of the most famous biographies of Nupchen, as we saw in chapter 1 of this dissertation. Lochen Dharmasri is, then, closely connected to the mdo rgyud sems gsum which connects him back to the Zur lineage and to Nupchen himself.

${ }^{222}$ See Esler's “Critical Edition: Introductory Remarks,” p. 324.
} 
Bringing Light into the Darkness: An Intellectual History of Tibet's Dark Age (842-978 CE) Manuel Lopez Ph.D. Dissertation - University of Virginia 


\section{The Chengdu Edition and the mysterious block-print}

According to Esler, the Chengdu edition is a "xylographic reprint of a Tibetan block-print $\varepsilon$ itself prepared on the basis of $\Upsilon$." This account, though, leaves us with a lost manuscript somewhere in India, and two different sets of unallocated block-prints somewhere in Tibet. While this is very possible, particularly after the dramatic consequences that the Cultural Revolution wrought Tibet in all aspects of material culture, it still seems rather strange that none of these sources for the current editions have been located.

A conversation with Karma Delek, who was involved in the elaboration of the three different editions of the Extremely Extensive Oral Teachings in April of 2013, shed some light on this issue. According to Karma Delek, the Chengdu edition is, in fact, based on the Leh edition, which he collected during a trip to India and Nepal during the '90s in search of Tibetan texts, and after some editing, used as the base for all of the Tibetan editions. This version of events, unfortunately, seems to dismantle Esler's analysis of the recension history of the text, and current preference among Nupchen scholars for the Chengdu edition instead of the Leh version. Although I had no reason to doubt Karma Delek, there was still the question of how the Leh version could be the source for the Chengdu edition, since the Chengdu edition is based on a block-print. The answer was offered to me by Michael Sheehy at TBRC, who wrote a short study of the history of the various editions of the Extremely Extensive Oral Teachings for the TBRC site. $^{223}$ According to Sheehy, although the Chengdu edition looks like a xylographic edition based on a block-print is, in fact, a manuscript. A careful analysis of the edition shows that the final result could not be the product of a block-print.

\footnotetext{
${ }^{223}$ See "The Nyingma Kama Collections" by Michael Sheehy in http://about.tbrc.org/the-nyingma-kama-collections/
} 
This also raises the doubt that there was ever a block-print for the Lamp for the Eye in Contemplation. A careful reading of the colophon does not actually mention a block-print, ${ }^{224}$ but only the preparation of an edition of the text. In fact, most of the texts found in the Kama edition circulated in the form of manuscripts. These texts never had the appeal, until the late 19th century, with the emergence of the non-sectarian movement (Tib. ris med), that the Treasure tradition had for the Nyingma school, and never warranted the enormous expense of producing block-prints. In fact, the Kama collection is a very recent literary creation (at least in its current size) with the first edition published by Dudjom Rinpoche in 1982.

This, though, leaves us with the mystery of the original manuscript in which the Leh, and therefore all other editions, are based. During my attempts to locate the manuscript, Karma Delek suggested that I contact Sechen Gompa, in Nepal, where he had heard the original manuscript in the form of a scroll (not in the traditional pecha format) was first found among the estate of the late Dilgo Khyentse Rinpoche (1910-1991). This story was confirmed by Matthieu Ricard, a close disciple of Dilgo Khyentse and a resident at Sechen Monastery since the late '70s, who mentioned that "there was a special, unknown manuscript that a lama brought through some years ago. ${ }^{225}$ It was written on a scroll, not in pecha format, just a rolled up scroll with the entire

\footnotetext{
${ }^{224}$ I think the notion of a block-print began with the first description of the text offered by Gene Smith in his preface to the 1974 Leh edition, in which he describes the text as follows: "[t] copy of a block print from eastern Tibet. The text was xylographed through the efforts of a student of the 'Jam-dbyangs Mkhyen-brtse and 'Jam-mgon Kong-sprul tradition. The colophon to the blocks is signed by one 'Jam-dbyangs Blo-gros-rgya-mtsho, a teacher connected to Kah-thog. The blocks were prepared on the basis of a manuscript which had belonged to the great Rnying-ma-pa scholar Smin-gling Lo-Chen Dharma-shri (1654-1718). This manuscript, in turn, was based on a manuscript from the library of the famed Jo-nang Rje-btsun Tāranātha (b. 1575). The text belonging to Smin-gling Lo-chen was defective according to the editor of the block print edition." In Gnubs chen's Rnal Byor Mig Gi Bsam Gtan, Or, Bsam Gtan Mig Sgron: A Treatise on Bhavana and Dhyana and the Relationships between the Various Approaches to Buddhist Contemplative Practice, Preface. Bold is mine.

${ }^{225}$ The connection between Ricard and Dilgo Khyentse is outlined in Jean François Revel and Matthieu Ricard's The Monk and the Philosopher: A Father and Son Discuss the Meaning of Life (New York: Schocken Books, 1999).
} 
Lamp for the Eye in Contemplation on it." ${ }^{226}$ Although the idea of the Lamp having been written in a scroll is quite improbable (the size of the text would make the task almost impossible), the mention of this anecdote would seem to indicate that a very old version of the text, which was not at Sechen Monastery anymore and had probably made its way to India, where it probably became the source for the version copied by Chimmi Rigzin and published in Leh in 1974. Locating the original manuscript would definitely settle some of our current problems with the recension history of the text, particularly if the manuscript is in the form of an old scroll, but it seems clear to me that any attempts of creating a diplomatic or a critical edition are undermined by the fact that all versions are based on the Leh edition of 1974. Locating the manuscript would also help solve some of the riddles posed by the many mistakes in the Leh manuscript, probably caused by a hurried copyist ${ }^{227}$ that Karma Delek and the other editors of the text attempted to correct in the following editions without ever being able to consult the original.

\footnotetext{
${ }^{226}$ I want to thank my colleague, Dominic Di Zinno, for asking Matthieu Ricard this question during his field research period in Nepal in 2012. Personal e-mail 11/25/2012.

${ }^{227}$ On the copyist of the manuscript, see Esler's "Critical Edition: Introductory Remarks."
} 


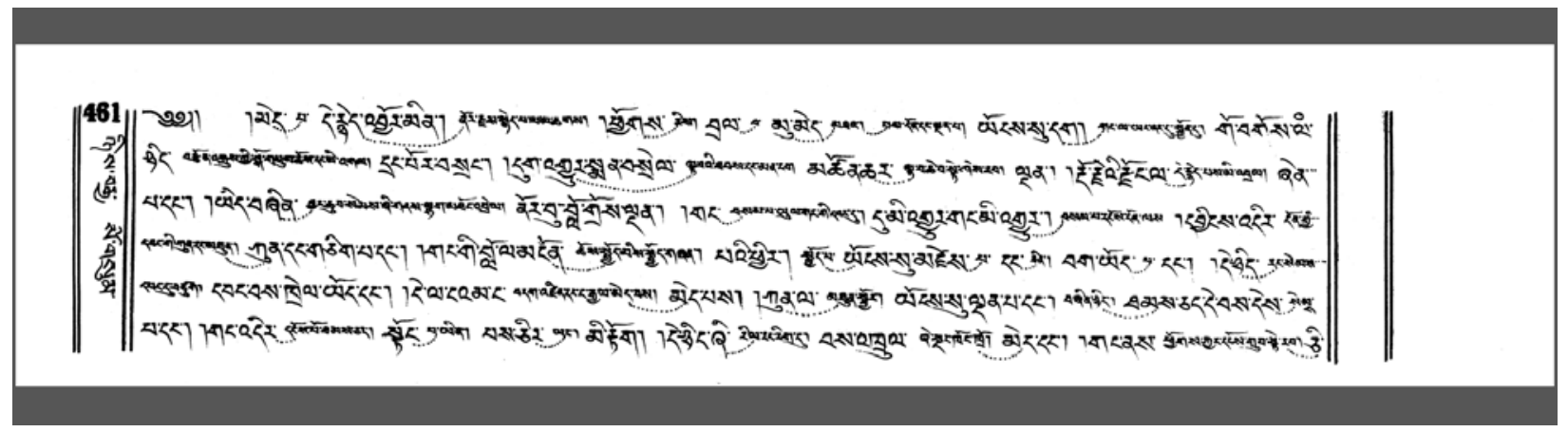

Interlinear notes on a page of the Lamp

Since the textual transmission of the Lamp, as we have seen in the early section of this chapter, is quite obscure, with no manuscript witnesses of the text from its creation in the 10th century until its recent publication in 1974 (the bulk of the information regarding the transmission history of the text comes from its colophon, and the mysterious manuscript witness to the Leh edition cannot be found), we have to be very careful assuming that the text was written in its entirety by Nupchen, and that it has not been heavily edited over the centuries. ${ }^{228}$

There are several clues that can help us feel comfortable with stating that Nupchen is the author of the Lamp. First, we have the colophon attribution. Although we always have to be careful with taking at face value colophon attributions, this is a first step in identifying possible authorship. The colophon, in this case, is pretty clear: "The Contemplation of the Eye of Yoga,

\footnotetext{
${ }^{228}$ The colophon offers an interesting fact that also brings some light to the vicissitudes that the physical text may have endured over the centuries. The colophon says that "folio one hundred is missing, but the meaning [of the text] is complete," (Tib. shog bu brgya pa de grangs yig ma tshang 'dug kyang don la tshang yod). Donati translated the passage, I believe erroneously, as meaning that the text "lacks one hundred pages," in Donati, "The Lamp Is Burning Bright. Gnoseological Approaches and Soteriological Perspectives in Gnubs Chen Sangs Rgyas Ye Shes' Masterpiece,” p. 495. Karma Delek conveyed during a private conversation $(04 / 11 / 2014)$ that the most probable meaning is that folio one hundred was not numbered.
} 
also known as The Lamp for the Eye in Contemplation, by Nupchen Sangyé Yeshé ."229 Second, we also have a few important self-references within the body of the text, as well as in the interlinear notes, that reinforces the sense that Nupchen is the author of the text. ${ }^{230}$ An example of this can be found in the dedication chapter, situated just before the final colophon, in which Nupchen declares:

I, the beggar, Sangs rgyas Ye shes Rinpoche, the little monk from gNubs, I have studied with many scholars from different countries, including many scholars from India, the Nepalese king, Vasudhara, and the translator from Brusha Che btsan skyes [among others]. I served and pleased those scholars, and [since they were delighted] they granted me authorization [to study with them]. I opened the door of the treasure of their minds, and I completely understood and obtained the meaning of the [Sütra of the Gathered] Intentions, the King of the Quintessential Precepts, and I myself became a King of Quintessential Precepts. ${ }^{231}$

As Germano has argued, ${ }^{232}$ one of the aspects that made Nupchen such a unique individual is that he was one of the first Tibetans to claim authorship of his own texts, instead of simply pretending to use the name of a famous Indian teacher to legitimize his writings.

\footnotetext{
${ }^{229}$ Gnubs chen's Rnal Byor Mig Gi Bsam Gtan, Or, Bsam Gtan Mig Sgron: A Treatise on Bhavana and Dhyana and the Relationships between the Various Approaches to Buddhist Contemplative Practice, 508.

${ }^{230}$ There are two different instances in the text in which Nupchen refers to himself as "I, the little monk." "ban chung rang gi 'dod byang kyang yin," 375.6 and "ban chung rang gi 'dod phyi nang gi chos thams cad rang byung gi ye dshes su thag chod pa la," 419.2.

${ }_{231}$ The Tibetan text says: "bdag sprang po gnubs ban sangs rgyas ye shes (498.1) rin po ches // rgya gar gyi mkhas pa paNDita mang po dang / bal po'i rgyal po ba su dh'a ra dang / gru zhwa'i yul gyi lo ts'a ba che btsan skyes la sogs pa rgyal khams so so'i (498.2) mkhas pa mang po'i zhal brims te // mnyes pa phul bas paNDita rnams dgyes pa skyes te gnang ba thob pas / thugs kyi mdzod sgo phye nas / man ngag gi rgyal po (498.3) dgongs don mthar gtugs pa bdag gis thob ste / bdag man ngag gi rgyal por gyur to" in Gnubs chen's Rnal Byor Mig Gi Bsam Gtan, Or, Bsam Gtan Mig Sgron: A Treatise on Bhavana and Dhyana and the Relationships between the Various Approaches to Buddhist Contemplative Practice, 497.6-498.3.

${ }^{232}$ This is what Germano says on this matter: "Gnubs is a liminal figure since he translated new texts into Tibetan, yet he lived during the dark period after the other figures in question, and is prominent within subsequent Tibetan lineages. He is also prominent for producing significant texts in the Snga 'gyur tradition which he acknowledged composing himself, an authorial acknowledgement rarely echoed outside a few individuals such as Rongzom prior to the 14 century. His importance led Mkhas pa ldeu to present him as the 10th and final descent of tantra that formed the basis of the later Rnying ma transmissions." In Germano, "The Seven Descents and the Nature of sNga' 'Gyur: The 'history' of rNying Ma Tantras," 252.
} 
Third, as we have mentioned before, the Lamp is also attributed to Nupchen as early as the 11 th century by scholars like Podrang Zhiba Ö. Fourth, there are many similarities in content and tone between the Lamp and Nupchen's other major surviving work, the Armor Against Darkness (Tib. Mun pa'i go cha). All of this, then, can help us assert with a certain degree of confidence that Nupchen is the author of the Lamp for the Eye in Contemplation.

At the same time, though, the copious interlinear notes found in the text offer evidence of some heavy editing during the early decades or centuries after its composition, offering some clues as to its early reception history among the early Nyingma and Great Perfection followers.

All currently extant manuscripts of the Lamp are interspersed with the same interlinear annotations. ${ }^{233}$ These annotations expand ideas discussed within the text, offer some insight on obscure passages, and correct textual problems (sometimes a misquoted sutra), but also create textual problems of their own (misattributing a sutra, for example). ${ }^{234}$

Karmay, in his pioneer study of the early Great Perfection, and the first serious study of the Lamp, was already skeptical regarding Nupchen's authorship of the interlinear notes, particularly since they seem to include a few anachronisms, like the use of the name "Langdarma" to refer to King Ü Dumten (Tib. 'U'i dum brtan). ${ }^{235}$ Meinert ${ }^{236}$ and Esler ${ }^{237}$ have offered other

\footnotetext{
${ }^{233}$ Tib. mchan bu or mchan 'grel

${ }^{234}$ On p. 38 of the Leh edition an interlinear note attributes a quote to the Perfection of Wisdom Sūtras when, indeed, it is from the Ratnakūta Sutra.

${ }^{235}$ As Yamaguchi already argued, the use of the derogative name "Langdarma" cannot be found in any of the manuscripts of the Dunhuang cave, which probably indicates a late Dark Age or early Tibetan Renaissance period for the composition of the interlinear notes..

${ }^{236}$ Meinert offers as an example the following grammatical point: "Der Begriff bdag im Grundtext ist in einer Anmerkung durch nyid chen po als bdag nyid chen po ,große Wesenheit' erweitert. Allerdings ist diese Erklärung an dieser Stelle irreführend. Denn der Grundtext liefert in der Lesung bdag phyag 'tshal bereits den traditionellen Vers der Verehrung des Verfassers (rtsom pa po'i mchod brjod), so daß bdag phyag 'tshal als ,ich verehre' zu übersetzen ist. Die Ergänzung in der Anmerkung ist grammatisch nicht schlüssig. Denn hätte die Bedeutung ausgedrückt werden wollen ,Verehrung eben diesem Zustand, der zur großen Wesenheit geworden ist‘, müßte die grammatisch korrekte Version folgendermaßen lauten: /bdag nyid chen po'i ngnag du gyur pa de la bdag phyag 'tshal/. Zumindest diese erste Anmerkung stammt somit ganz eindeutig nicht aus der Feder gNubs chen Sangs rgyas ye shes selbst, sondern ist als eine spätere Hinzufügung zu verstehen.” In Carmen Meinert, "Chinesische Chan- Und
} 
convincing historical and grammatical arguments that seem to confirm Karmay's early suspicions regarding the authorship of the notes, attributing them to close disciples, or to the later Tibetan tradition. $^{238}$

I agree with the prevalent assessment of the interlinear notes being written not by Nupchen, but by some close disciples or early custodians of Nupchen's tradition (probably, early members of the Zur tradition). In this section, though, I would like to focus not simply on the authorship of the notes, but on how these notes offer important clues regarding the early reception of the text, as well as important clues regarding the early stages of the emergence of the Great Perfection tradition in Tibet.

Tibetische rDzogs Chen-Lehre: Eine Komparatistische Untersuchung Im Lichte Des Philosophischen Heilskonzeptes 'Nicht-Vorstellen' Anhand Der Dunhuang-Dokumente Des Chinesischen Chan-Meister Wolun Und Des Werkes bSam Gtan Mig Sgron Des Tibetischen Gelehrten gNubs Chen Sangs Rgyas Ye Shes" (Rheinischen Friedrich-Wilhelms-Universität, 2004), p. 238 n. 599.

${ }^{237}$ Esler in particular offers interesting insights on the nature and possible origin of this interlinear notes: "One of the glosses in particular (C 15.4) gives a hint about the date of composition of the bSam-gtan mig-sgron, since it alludes to Glang-dar-ma's religious persecution: 'At the time of Glang-dar-ma, because of the obstacles which came towards the venerable Ye-shes dbang-po, the lineage of the instructors of dialectics declined.' This gloss occurs in the context of the advice to obtain the lineages of the various approaches (Chapter I, §5.2), where it is explained that the Tibetan branch of the lineage of the simultaneous approach (which had belonged to the [Tibetan] emperor and monks) had declined by gNubs-chen's time. One of the problems with this gloss concerns Ye-shes dbang-po, who is presumably identical to dBa' Ye-shes dbang-po, the first abbot of bSam-yas and successor of Śantarakșita; however, $\mathrm{dBa}^{\prime}$ Ye-shes dbang-po (whose secular name was dBa' gSal-snang) is generally believed to have passed away before the death of Khri-srong lde'u-btsan in $797 \mathrm{CE}$, thus far predating Glang-dar-ma (r. 836-842 CE). A further question arises as to why Ye-shes dbang-po, who is generally referred to as a master of the gradualist approach, should be mentioned in the context of the decline of the simultaneous approach. Of course, the term 'dialectics' (mtshan-nyid; Skt. lakșana), which is found in the expression 'vehicle of dialectics' (mtshan-nyid-kyi theg-pa; Skt. lakșanayāna), can be said to refer to the sütra vehicle in general, and hence to englobe both the gradualist and simultaneous approaches. Nonetheless, it is clear from the context that it is the decline of the simultaneous approach that is being referred to. The impression one gains from all these factors is that the text (or, at the very least, this gloss) was written quite some time after the events here alluded to. That is why Ye-shes dbang-po is wrongly made a contemporary of Glang-dar-ma, and perhaps also why his death is associated with the decline of the simultaneous approach. Furthermore, the very mention of the sobriquet Glang-dar-ma seems odd, since this nickname is not found in the Dunhuang documents; this would point to the fact that the bSam-gtan mig-sgron's glosses are insertions by a later hand. It is likely that these glosses were written down by a disciple of the author, probably an immediate one. Indeed, several indications point to the fact that the glosses incorporate fragments of an oral commentary to the text." In Esler, "The Exposition of Atiyoga in Nubs-Chen Sangs-Rgyas Ye-Shes' bSam-Gtan Mig-Sgron," 129.

${ }^{238}$ van Schaik is one of the few scholars who offers some appealing arguments in favor of Nupchen being the author of the interlinear notes. See Sam van Schaik's "The Early Days of the Great Perfection," Journal of the International Association of Buddhist Studies 27, no. 1 (2004): 165-206, p. 197. 
Editing the Lamp - The Creative Assimilation of Buddhism in Tibet:

\section{The Nine Views, Indian Teachers, and Legitimizing the Great Perfection}

If we accept that the interlinear notes may not have been written by Nupchen, we can interpret them as offering important clues for our understanding of a Great Perfection tradition that in the Lamp can be seen at its very early stages. The interlinear notes contribute to a picture of a text that is witness to and participant in the emergence of a new tradition, the Great Perfection, that is trying to differentiate itself from other Buddhist contemplative traditions, while arguing for its legitimacy, as well as the continuity of its doctrines and practices with established Buddhist teachings.

The interlinear notes, while found throughout the text, become particularly copious in the Mahāyoga and, in particular, in the Atiyoga chapter. The use of the interlinear notes is quite inconsistent since they do not simply operate as an auto commentary (as they do in some of the works of Sakya Pandita, for example). Sometimes the notes clarify an obscure passage, correct a grammatical error, or attribute a quotation to an otherwise unnamed textual source (although sometimes the interlinear notes also make mistakes, like misattributing a quotation to the wrong text). If the interlinear notes were written by Nupchen himself, we should read the Lamp more as a work-in-progress by the author, a not very polished text that Nupchen may have used more as a teaching manual than as a polished treatise presenting the views of the Atiyoga tradition.

We see this process at work in Nupchen's presentation of the so-called Great Perfection Nine Views (Tib. 1ta ba, pp. 316-403). The presentation of the Nine Views is probably one of the key sections of the chapter dedicated to the Great Perfection, which will be discussed later in Ch. 
5, in which Nupchen developed a systematic approach to nine different contemplative approaches within the Great Perfection tradition. While the body of the text leaves the names of those teachers nameless, referring only to these views as being connected to different "spiritual friends," 239 the interlinear notes add a series of mainly Indian names (with a few Tibetans, Nupchen included) to the various views that would establish these teachings as of Indian origin, trying to dispel any notion that the Great Perfection tradition was simply a Tibetan concoction.

1- The view [which is] free from doubt - Vimalamitra and the Mahārāja of Oḍ̣iyāna; (Tib. Bi ma mi tra and O rgyan ma h'a ra tsa)

2- The view of the Great State of Spontaneity - Garab Dorje (Tib. dGa' rab rdo rje)

3- The view of the Great Self - Vairocana (Tib. Be ro tsa na)

4- The view of the Self-arising Primordial Wisdom - Gelongma Kungama (Tib. dGe slong ma kun dga' ma)

5- The view which is free from activity - Buddhagupta (Tib. 'Bu ta kug ta)

6- The view of the Great Bliss - Kukkarāja and Śrī Siṃha (Tib. Ku ku ra tsa and Shi ri sing ha)

7- The view of Non-duality of the Supreme Mahāyoga - (Tib. jam dang la bshes gnyen)

8- The view of the Great Nature of the Seminal Essence - (Tib. Sras thu bo ra' tsa ha ta)

9- The view of the actual ground of all phenomena - Garab Dorje and King Dahenatalo (Tib. dGa' rab rdo rje and rGyal po 'da' ha na ta pho)

Although most of these names are famous as key lineage holders for the later Great Perfection tradition, their addition to the text as interlinear notes seems to undermine the notion that Nupchen himself wrote them. Van Schaik has addressed this addition of particular names in the interlinear notes to each of the Atiyoga views as a way by which Nupchen was transforming authored treatises into scripture, only to then acknowledge the connection between individual

\footnotetext{
${ }^{239}$ Lamp 315: “de ni sbyir gcig las kyang med / bsam las kyang 'das na / re zhig dge ba'i bshes gnyen gyi bzhed gzhung 'ga' 'dir bstan te"
} 
doctrines to their masters in a subtle footnote. ${ }^{240}$ While this may be a possibility, each of these views included quotations of many different scriptures, most of them part of the Semde literature or the Sütra of the Gathered Intentions, which would undermine or weaken the argument, since Nupchen draws from the wide corpus of Atiyoga literature to present each view, and not from an individual source that could be connected to an individual teacher. I think that the addition of the names, linking them to specific views, is a mechanism to legitimate those teachings, giving them an 'accepted' Indian origin, or linking them to a respectable Tibetan translator. Bernard Faure discusses the creation of the patriarchal tradition in Chinese Chan as "a product of people on the margins, the result of their desire to become the party of the orthodoxy. It is not a sign of

${ }^{240}$ van Schaik's complete argument is here: "The almost total lack of authorial attribution in the Atiyoga section of the STMG suggests that gNubs chen himself may have been complicit in the activity of transforming authored texts into scripture. In fact, names of teachers are mentioned quite frequently in the Atiyoga chapter, though mainly in the interlinear notes to the text. These were apparently written by gNubs chen, unless his references to himself in the notes are a later falsification. ${ }^{90}$ The teachers are associated with different approaches to teaching the Great Perfection, rather than with specific texts [...] The attribution of different approaches to the Great Perfection to these figures, itself suggests that they may have been responsible for some literary production, and that these names themselves were originally been [sic] the authorial names attached to the Great Perfection texts that gNubs chen quotes. The appearance of Buddhagupta's name in ITJ 597 may be an example of a continuing tradition in which the authorial names were still attached to the texts, which as "statements" (lung) were accepted to be the writings of named teachers. The appearance of these names the interlinear notes of STMG as the exponents of particular approaches to the Great Perfection may have been gNubs chen's strategy for acknowledging their contributions after stripping their names from the texts they created. Due to the paucity of sources, it is perhaps impossible to determine whether gNubs chen was repeating a received tradition or himself attempting to found a tradition. There is however, reason to believe that gNubs chen was attempting to define a tradition around the names Great Perfection and Atiyoga. Firstly, as we have seen, gNubs chen's works are the earliest reliably dateable instance that we see Atiyoga being defined explicitly as a vehicle (theg $\mathrm{pa}$ ). If gNubs chen was involved in early attempts to establish a tradition, then to give the tradition vehicle status would have been highly desirable. Furthermore, the great range of texts quoted in the Atiyoga section of STMG suggests that gNubs chen may have been drawing these texts together, to make them all part of a group under the label of Atiyoga, where they were previously disparate texts from a number of lineages. The texts themselves, while sharing numerous resemblances, are by no means a homogeneous group. gNubs chen may well have faced the same difficulty that confronts us when examining our Dunhuang texts: while the texts bear certain resemblances to what we know in the later tradition as the Great Perfection, they are also quite different from each other. gNubs chen's enumeration of different approaches to the view of Atiyoga suggests an attempt to unify as a whole a somewhat disparate group of teachings. His bringing together of the texts in the Atiyoga chapter of the STMG can itself be seen as an act of imposing a coherence and unity upon the texts. Yet the differences between his chapter and the accepted texts of the later tradition, such as his inclusion of the dGongs pa 'dus pa 'i mdo and several other texts that do not form part of later canons, and the conspicuous absence of the Kun byed rgyal po 'i mdo, suggest a movement still in development, one that has yet to achieve a stable canon. Thus even if gNubs chen was not the first to gather together these texts and categorize them as belonging to a vehicle of their own, he was certainly one of the earliest to do so." In Sam van Schaik's "The Early Days of the Great Perfection," Journal of the International Association of Buddhist Studies 27, no. 1 (2004): 165-206, pp. 197-199. 
richness in the tradition, but rather of the lack in it." ${ }^{241}$ The same could be said of the Tibetan Great Perfection, a tradition that wanted and needed to be recognized within the later framework of the Buddhist tradition. And an acceptable lineage would allow them to move from the "margins" to a respected, orthodox position. We see a similar process in the Mahāyoga chapter, with the inclusion of the names of particular teachers attached to specific tantric views. ${ }^{242}$
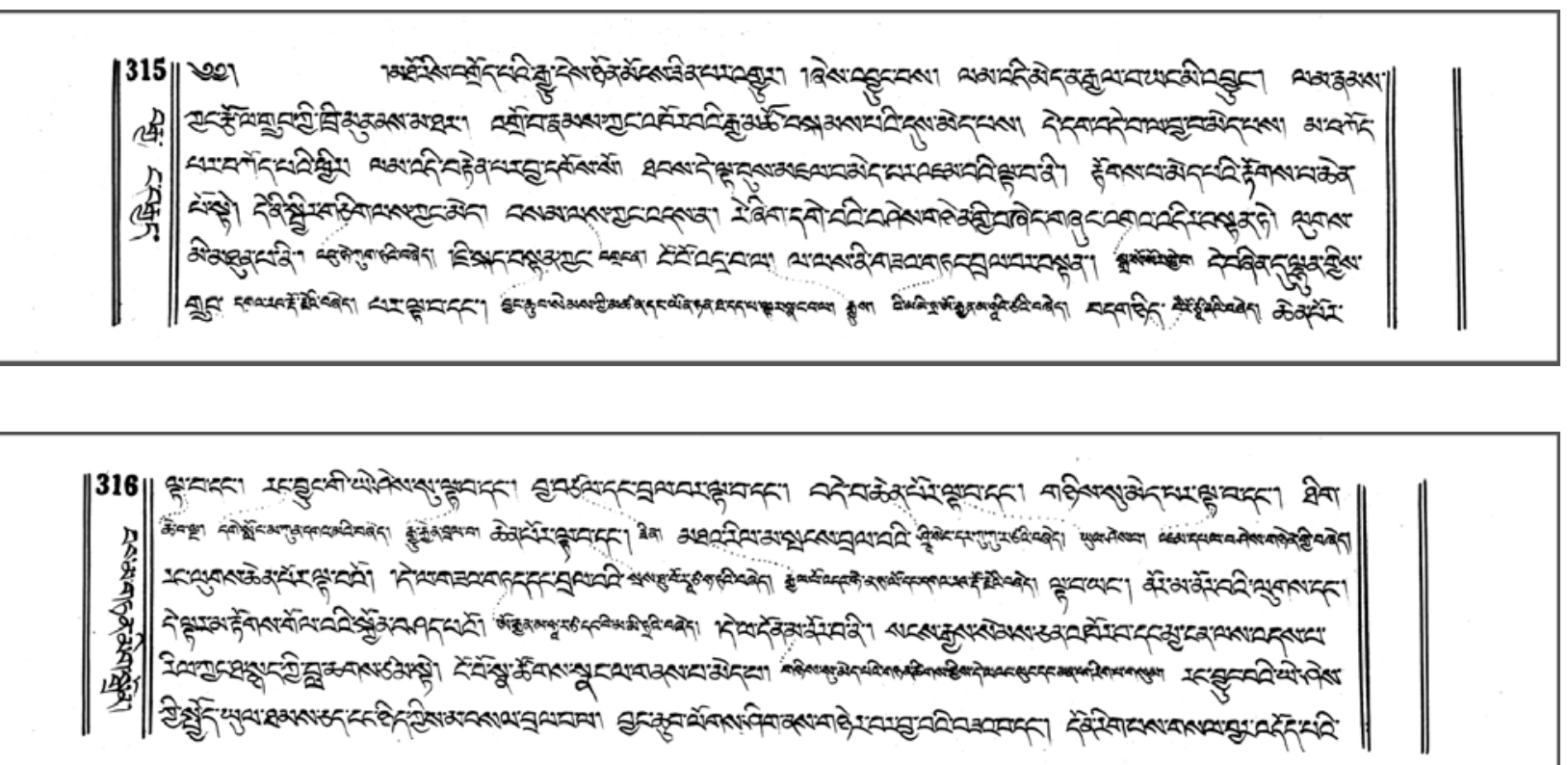

Introduction to the Nine Views with the names of the Masters in the interlinear notes

In addition, the last chapter dedicated to the Great Perfection tradition is the most heavily edited, to the point that some pages are difficult to read, which seems to indicate that the text was edited to include some of the later developments within the tradition after Nupchen's passing.

\footnotetext{
${ }^{241}$ Bernard Faure, The Will to Orthodoxy: A Critical Genealogy of Northern Chan Buddhism (Stanford, Calif:: Stanford University Press, 1997), p. 9. McRae made a similar analysis of the nature of lineages in his Seeing Through Zen.

${ }^{242}$ I think that the addition of teachers attached to specific views in the Mahāyoga and Atiyoga chapters also show the intimate connection that Nupchen and his students had with both traditions, with some names like Padmasambhava appearing in both chapters. Both traditions were also in need of legitimacy since they were both attacked as Tibetan creations during the 10th century by the Modernists, or Sarma schools.
} 
The interlinear notes do not seem to reflect developments past the 11th century, since they focus on the early Great Perfection tradition as reflected in the Semde literature, without including texts like the All Sovereign King (Tib. Kun byed rgyal po) or Seminal Heart literature (Tib. sNying thig). The notes, then, can be read as reflecting the early reception of the text. They highlight the parts that needed clarification, those that were particularly under attack by other traditions, etc. 


\title{
PART 2 - A Text in Context: Buddhist Hermeneutics, Doxographies, and Order and
}

\author{
Creativity in the Lamp for the Eye in Contemplation
}

In the second part of this chapter, I want to discuss The Lamp for the Eye in

Contemplation in the context of the literary genre to which it belongs, a doctrinal classification

(classification of views) or doxography. The term doxography was coined by the German

classical scholar, Hermann Alexander Diels, to describe the work of classical historians that

included discussions of Greek and Roman philosophers of the past. ${ }^{243}$ Modern Buddhist scholars

have adopted this term to describe a similar genre within the Buddhist tradition named siddhānta

in Sanskrit, panjiao in Chinese (Ch. 判教), and grub mtha' in Tibetan. ${ }^{244}$

\footnotetext{
${ }^{243}$ See Leonid Zhmud, "Revising Doxography: Hermann Diels and His Critics," Philologus, no. 145 (2001): 21943.

${ }^{244}$ I would like to add, though, an important terminological clarification. Following most of the scholarship on this subject, this essay will use the term doxography in order to describe these Buddhist systems of doctrinal classification. Doxography means etymologically to "write the views," and its origins are attributed to the Greek tradition. The term describes a literary genre in which views of past philosophical systems are organized, usually, in some sort of historical fashion. The use of this term in the context of Indian, Tibetan, and Chinese classification of views, quickly shows though, that the term does not always describe accurately the nature and goals of these texts. In India the term used for this genre of literature is siddhānta, in Chinese panjiao (Ch. 判教), and in Tibetan they are called grub-mtha'. In both cases the meaning generally refers to the description of systems of practice (of realization, literally). There are some general similarities among these Buddhist terms, but there are also some differences. In some of the early classifications (especially in the Indian ones) the main goal was not to classify hierarchically, but to argue specific doctrinal or philosophical views. That is why some scholars are proposing that the term summa may be more accurate to describe the siddhānta or grub mtha' literature (see Ferran Mestanza, "La Première Somme Philosophique Du Bouddhisme Tibétain. Origines Littéraires, Philosophiques et Mythologiques Des 'Neuf Étatpes de La Voie' (theg Pa Rim Pa Dgu)," Revue d'Etudes Tibétaines 8 (2005), p. 85. To clarify these issues is beyond the scope of this dissertation, but it is important to point out that we need to be careful when using western terminology to describe Buddhist categories, since they bring with them unintended meanings to the object of our study. Another issue related to the use of the term doxography is the problem of determining what counts as one. In most of the scholarship reviewed, we find that the study of classificatory Buddhist systems usually begins with the earliest one that has survived, Bhāviveka's Madhyamakahrdayakārikāh. But what about the classification of Buddhist systems found in the Samdhinirmocana Sütra? This sūtra presents a hierarchical classification, in the form of the Three Turnings of the Wheel, and it is also polemical, arguing the superiority of Yogācāra over other Buddhist teachings. The point here is not to deconstruct the notion of doxography (or siddhānta, or grub mtha') to the point that they are not useful anymore. The goal is just to make us aware of the constructed nature of these terms, and the fact that we need to be aware of the fluidity of the category (in any of the languages relevant to us) as it was used differently in different historical contexts. Dalton also makes an interesting point when he says that another important difference between western doxographies and Indian ones is that "whereas the former are generally philosophical works and restrict themselves to the views held by each school, the tantric classification systems of India [...] are largely
} 
In his study of the role of doxographies in the process of assimilation of Buddhism in China, Peter Gregory offers a good summary of the function that this particular literary genre has served in the history of Buddhism. For Gregory, doctrinal classifications served very specific "hermeneutical, sectarian, and soteriological purposes. That is, it organized into a coherent and internally consistent doctrinal framework the diverse corpus of [Buddhist] sacred scriptures [...]; it legitimized the claims of different [Buddhist] traditions to represent the supreme, orthodox, or most relevant teaching of the Buddha; and it provided a map of the Buddhist path."245

A quick overview of the history of Buddhist doxographies in India, China, as well as Tibet, will help us to better understand the contents of the Lamp, as well as Nupchen's goals when writing it. The main argument of this section is to show how Nupchen was using the doxographical genre not only to passively organize the various forms of Buddhism that were imported into Tibet during his time, but also to actively and creatively engage in the construction of a unique Tibetan Buddhist view, shows that Nupchen was a deeply innovative thinker working within a very traditional framework.

\section{Doxographies: Solving a Buddhist Hermeneutical Problem}

The importance of the doxographical genre within the Buddhist tradition cannot be underestimated since it responded to a very important hermeneutical problem at the core of the

concerned with differences in ritual practice." See Ibid. and Jacob Dalton, "A Crisis of Doxography: How Tibetans Organized Tantra During the 8th-12th Centuries," Journal of the International Association of Buddhist Studies 28, no. 1 (2005): 115-81, p. 119. Additionally, for important studies of the doxographical genre in Buddhism, see Jeffrey Hopkins's “The Tibetan Genre of Doxography: Structuring a Worldview," in Tibetan Literature: Studies in Genre, ed. Roger R. Jackson, Geshe Lhundup Sopa, and José Ignacio Cabezón, Studies in Indo-Tibetan Buddhism (Ithaca, N.Y.: Snow Lion, 1996). Chanju Mun, The History of Doctrinal Classification in Chinese Buddhism: A Study of the Panjiao Systems (Lanham (Md.): University Press of America, 2006). Gregory, Tsung-Mi and the Sinification of Buddhism. Helmut Eimer, "The Classification of Buddhist Tantras," Wiener Zeitschrift Für Die Kunde Südasiens: Vienna Journal of South Asian Studies 36 (1993): 221-28.

${ }^{245}$ Peter N. Gregory, Tsung-Mi and the Sinification of Buddhism, vol. 16 (Honolulu: University of Hawai'i Press, 2002), p. 115. 
diversity (of texts, of rituals, of practices) of Buddhism. ${ }^{246}$ This problem is clearly expressed in this poignant scene in the Mahāparanibbanasutta, in which the Buddhist community is witness to the imminent death of the Buddha:

Then [the Buddha] addresses the venerable Ānanda: "It may be, Ānanda, that some of you will think. 'The word of the Teacher is a thing of the past; we have now no Teacher.' But that, Ānanda, is not the correct view. The Doctrine and the Discipline, Ānanda, which I have taught and enjoined upon you, is to be your teacher when I am gone."

Mahāparanibbanasutta $60^{247}$

For over forty years, the Buddha had created a community that relied on him not only as their teacher, as the transmitter of the truth he had discovered under the Bodhi tree, but also as its interpreter. Whenever there was a doubt about the possible meaning of his teachings, the community could always address him, and the Buddha could offer a definitive answer that settled any existing doubts. After his death, though, the community, as the Mahāparanibbanasutta makes clear, is not only sad about the departure of their teacher, but they are also deeply worried about how to preserve the meaning of his words and, most importantly, how to retrieve it. While the language of his teachings may have appeared, at times, equivocal, the Buddha always could guarantee the stability of its meaning.

The moment described in the above quote also signals, as Donald Lopez has argued, the very beginning of Buddhist hermeneutics, since, as he pointed out, "those who are not yet enlightened must interpret." 248 On the one hand, the Buddha ensures in the

\footnotetext{
${ }^{246}$ Gregory begins his chapter on doctrinal classification by saying, "[D]octrinal classification [...] has often been said to be the hallmark of Chinese Buddhism.” In Ibid., p. 93.

${ }^{247}$ Warren, Henry Clarke. Buddhism in Translations. Vol. 3, Harvard Oriental Series; 3. Cambridge, Mass.: Harvard University, 1896, p. 107.

${ }^{248}$ Donald S. Lopez, Buddhist Hermeneutics, vol. 6, Studies in East Asian Buddhism; (Honolulu: University of Hawaii Press, 1988), p. 9. He also adds "these last instructions of the Buddha before his passage into Nirvānna attempt to address the dilemma of a religious community upon the death of its founder. Where, in his absence, shall authority reside? The Buddha instructs Ânanda that it is his teachings that shall be the teacher. But what, exactly,
} 
Mahāparanibbanasutta the continuity of his teachings, since "the teaching [...] is to be your teacher." On the other hand, he also opens the door to interpretation since he does not explain what this statement exactly means. This tension is very important in understanding the development of Buddhism over the next 2,500 years, particularly the way in which it has allowed the tradition to preserve a certain degree of unity within an astonishing degree of doctrinal, soteriological, and ritual diversity.

The notion that the teaching is the teacher allows the later Buddhist tradition a great degree of freedom to determine what the teachings of the Buddha are. At the same time, Buddhists over the centuries had to develop a series of interpretation strategies that have allowed the tradition to rein in that plurality of understandings under the umbrella (even if this was a rhetorical one) of the unity of all of the teachings of the Buddha.

This is not the place to discuss some of the mechanisms that the Buddhist tradition developed in order to solve this hermeneutical tension ${ }^{249}$, but I want to highlight in this section the important role that doxographies played in articulating key differences between various Buddhist traditions, integrating different doctrines, rituals, and practices within a cohesive system, while organizing those differences hierarchically in order to establish the superiority of certain doctrinal developments versus competing or old ones.

was his teaching and what does it mean for the teaching to be the teacher? It was the contemplation of these questions that led to what can be called Buddhist hermeneutics," Lopez, p. 1.

${ }^{249}$ Some of the most important hermeneutic strategies developed by Buddhism to solve this tension are: 1) a fluid view of the concept of doctrine (Skt. Buddhavacana); 2) the notion of an open canon, which allowed for the constant emergence of new Buddhist interpretations that could be incorporated under the umbrella of an existing corpus of teachings; and 3) the understanding of truth as contextual (Skt. upāya), which allowed the tradition to reconcile apparently contradictory teachings under the idea that the Buddha taught different things to different people at different times in history, depending on their capabilities. For a discussion on this topic see Ibid. 
As I hope this section will also show, the various functions of the doxographical genre are a reflection of its simultaneous descriptive and prescriptive nature. On the one hand, we can examine these texts and trace the evolution of Buddhism in India, China, as well as Tibet. Doxographies then, can be seen as describing a historical process. At the same time, and bringing back Jenkins' understanding of history, we can see doxographies as a narrative written with clear agendas by various competing Buddhist groups that were attempting not only to organize (sometimes contradictory) ritual and doctrinal systems, but also to impose, prescribing a particular doctrinal or sectarian point of view. Doxographies were, from this perspective, tools to create an ideological reality. Being able to see where these two aspects intersect, as well as when they differ, is one of the important roles in our scholarly research of these texts.

\section{Indian precedents}

In India, doxographies were originally used as an intellectual tool to define Buddhist positions against non-Buddhist traditions. The emergence, over time, of discrepancies in the interpretation of certain Buddhist ideas, forced doxographies to eventually incorporate various intra-sectarian doctrinal issues. In the earlier form, doxographies were articulated around the discussion of particular doctrinal or philosophical views in which the Buddhist view always prevailed against non-Buddhist positions. When Buddhist doxographies shifted to discussions of mainly different Buddhist philosophical views (with non-Buddhist traditions being peripheral to the main argument of the text or not even included), we see a shift in the genre to a hierarchical organization of those diverse philosophical positions. Doxographies, as a literary genre, offer 
Buddhism a structure in which diversity could be interpreted and organized, arguing for the unity of the Buddhist path, while allowing space for new and diverse interpretation.

For reasons of space, I will only refer to the most important examples of the doxographical genre in India, mainly those of Bhāvaviveka, Śāntarakṣita, Buddhaguhya, and Vilāsavajra, which will give us a sense of the evolution of late Indian tantra and the attempts to organize new ritual and systems of practice into cohesive, clearly organized, hierarchical schemes. $^{250}$

\section{Bhāvaviveka (500-570 CE)}

Bhāvaviveka's Madhyamakahṛdayakārikā $h^{251}$ with its auto-commentary, the Tarkajvālā, is traditionally considered by scholars to be the earliest extant Indian Buddhist doxography (although, as we will see, there were earlier Buddhist doxographies in China). He is believed to have been influenced by Indian scholar and grammarian, Bhartṛhari. ${ }^{252}$ The Madhyamakahṛdayakārikāḥ offers a detailed discussion of the most important schools of thought, Buddhist as well as non-Buddhist, influential during Bhāviveka's time:

- chapter 4 is an analysis of the determination of reality according to the Śāvakas

- chapter 5 is an analysis of the determination of reality according to the Yogācārins

- chapter 6 is an analysis of the determination of reality according to the Sāmkhya

- chapter 7 is an analysis of the determination of reality according to the Vaiśeșika

\footnotetext{
${ }^{250}$ For a thorough analysis of the doxographical genre, particularly in the Indian and Tibetan contexts, see the excellent article by Dalton: "A Crisis of Doxography: How Tibetans Organized Tantra During the 8th-12th Centuries."

${ }^{251}$ His work has been translated: Bhāvaviveka. Bhāviveka and His Buddhist Opponents: [Chapters 4 and 5 of Bhāviveka's Madhyamakahrdayakārikah with Tarkajvāla Commentary. Edited by Malcolm David Eckel. Cambridge, Mass.: Dept. of Sanskrit and Indian Studies, Harvard University, 2008.

${ }^{252}$ See Dalton, "A Crisis of Doxography: How Tibetans Organized Tantra During the 8th-12th Centuries," p. 119. His source is Wilhelm Halbfass's India and Europe: An Essay in Understanding (Albany, N.Y.: State University of New York Press, 1988), p. 268.
} 
- chapter 8 is an analysis of the determination of reality according to the Vedānta

- chapter 9 is an analysis of the determination of reality according to the Mīmāmssā

The structure of the work does not follow the hierarchical organization that will be common in later doxographical systems. Bhāvaviveka seems more concerned with arguing specific doctrinal points against non-Buddhist traditions than in ranking those traditions hierarchically. Nonetheless, we already find in the Madhyamakahṛayakārikāḥ vigorous internal Buddhist debate between the Svātantrikas, of which Bhāvaviveka is considered one of the earliest proponents, and the Prāsangikas whose position was defended by Buddhapālita. ${ }^{253}$

Although later Buddhist doxographies will differ in content as well as in structure, there is no doubt that we find in Bhāvaviveka the foundation for a new way of thinking within the Buddhist tradition. Doxographies will be used, from then on, to argue within the Buddhist tradition in the same way that had been used in the past to argue against the doctrinal issues of other religious traditions. Buddhism will gradually become more concerned about the internal structure and importance of its own teachings than in arguing against other traditions. ${ }^{254}$

Śāntarakṣita 705-762 CE

Śāntarakșita's Tattvasangraha ${ }^{255}$ and his own auto commentary, the Tarkajvālā, can be considered one of the earlier (if not the earliest) Indian doxographical systems to make it onto the Tibetan plateau. Śāntarakșita was, after all, the first abbot of Samye monastery and had a very

\footnotetext{
${ }^{253}$ I am aware that some of these categories were created only retrospectively, but this dissertation is not the place to discuss this issue. For further information about this issue, see Hopkins' Emptiness Yoga.

${ }^{254}$ Dalton has this to say about the influence of Bhāviveka: “... at first the doxographic paradigm was resisted by many within Buddhism, but it was part of a deep and irresistible trend that was sweeping through Indian thought; by the seventh century Candrakīrti could have argued against doxography, but only on its own terms." In Dalton, "A Crisis of Doxography: How Tibetans Organized Tantra During the 8th-12th Centuries," p. 119.

${ }^{255}$ Śāntarakșita. The Tattvasangraha of Śantarakșita, with the Commentary of Kamalaśíla. Edited by Kamalaśíla and Ganganatha Jha. Baroda: Oriental institute, 1937.
} 
important role in the introduction of the monastic and, by extension, scholastic Buddhist tradition into Tibet. Śāntarakșita's work, especially as transmitted into Tibet by his main disciple, Kamalaśîla, ${ }^{256}$ will be enormously influential to Nupchen, especially in his understanding of what he labeled as the Gradual vehicle in the Lamp. Ruegg offers the following description of Śāntarakșita’s classification:

- Chapters 1-3: discussion of the Sāmphya prakṛti and theory of causation. It also discusses the concept of God.

- Chapter 4: Examination of the doctrine of a world endowed with own being.

- Chapter 5: Examination of the theory of śabdabrahman.

- Chapter 6: Examination of the theory of purușa.

- Chapter 7: Śāntarakșita's examines the views of Nyāya, Mīmāṃsā, Sāṃkhya, Jainas, and the aupaniṣadikas, as well as the Buddhist Vātsīputrīya's pudgala ideas.

- Chapter 8: Analysis of the doctrines of permanent and stable entities.

- Chapter 9: Karma and the result of actions.

- Chapter 10: The six categories (padārtha) of substance (dravya).

- Chapter 11: Quality (guña).

- Chapter 12: Karman (action).

- Chapter 13: The Universal (sāmānya). ${ }^{257}$

Śāntarakșita’s Tattvasañgraha, following Bhāvaviveka’s Madhyamakahṛayakārikāḥ, does not offer a hierarchical classification of philosophical views, but presents an overview of important philosophical concepts and the way they were understood by various Buddhist, as well

\footnotetext{
${ }^{256}$ Kamalaśîla (740-795), Śāntarakṣita's most important student, wrote an important commentary to Śāntarakșita’s Tattvasangraha, although this did not add any important doctrinal changes to Śāntarakșita's text. He became a relevant figure in Tibetan history due to his role in the so-called Samye debate in which the gradualist tradition, represented by his teacher Sanntarakșita, had to defend his views against the sudden approach, represented by Chan and defended by the monk known as Hashang Mahāyāna. Some important sources for the debate are: Demiéville, Paul. Le Concile De Lhasa. Paris: Impr. nationale de France, 1952; Tucci, Giuseppe. Minor Buddhist Texts II. 2 vols. Vol. 2, Serie Orientale Roma V. 9. Roma: Instituto italiano per il Medio ed Estremo Oriente (IsMEO), 1956; Faber, Flemming. "The Council of Tibet According to the Sba Bzhed." Acta Orientalia 47 (1986): 33-61. On the issue of the Samye Debate, see chapter 4 of this dissertation.

${ }^{257}$ Ruegg, The Literature of the Madhyamaka School of Philosophy in India, 7:88.
} 
as non-Buddhist schools, like the Nyāya, Mīmāṃsā , Sāṃkhya, Jainas, and the aupaniṣadikas, as well as of some Buddhist traditions like the Vātsīputrīya.

In retrospect, we can see the Tattvasangraha as part of a transitional period in the history of Buddhism. Śāntarakșita’s Tattvasañgraha reflects a Buddhism in which external debates still overshadow internal Buddhist tensions. It is also important to point out the lack of any meaningful discussion of tantric systems, especially since these systems are thriving during this period and will become the center of any doxographical discussion in the upcoming decades.

Buddhaguhya (8th century)

Buddhaguhya's doxographical classifications can be found in his two commentaries to the Mahāvairocana-abhisambodhi Tantra ${ }^{258}$ and are structured around a twofold system that differentiated between Mahāyāna and tantric teachings. He also included a division within the tantric teachings between Kriyā and Yoga Tantras. His scheme then looks as follows:

- The teachings of the Mahāyāna, focused on the practice of the perfections (pāramitā);

- The teachings of Tantra, focused on mantra recitation;

a. Kriyā: focused on outward practice or "objective supports";

b. Yoga Tantras: focused on inward techniques or on the "practice of the profound and vast." 259

With Buddhaguhya we clearly see that Buddhist doxographical classifications are taking a new direction from the one we have seen in the works of Bhāvaviveka and Śāntarakșita. We see this in five main areas. First, Buddhaguhya's writings are not as concerned in arguing against

\footnotetext{
${ }^{258}$ Hodge, Stephen. The Mahā-Vairocana-Abhisambodhi Tantra: With Buddhaguhya's Commentary. London; New York: Routledge Curzon, 2003.

${ }^{259}$ See Dalton, “A Crisis of Doxography: How Tibetans Organized Tantra During the 8th-12th Centuries,” p. 122.
} 
non-Buddhist views as in trying to make sense of the enormous variety of new Buddhist teachings being produced during his time. Second, he also proposes a clear separation between Mahāyāna teachings and the new cycles of tantric teachings being produced in India. Third, he is one of the earlier Buddhist scholars, whose focus is mainly on tantra, making all other previous Buddhist teachings merely introductory or peripheral to the new tantric cycles. Fourth, we can also see a change of attention from doctrine to ritual. Even if we argue for the profound doctrinal relevance of these new ritual vehicles, the new classification will pay attention to ritual aspects in order to organize them. Fifth, Buddhaguhya classifies the new tantras around a dichotomy that will become very important in later tantric thought: external vs. internal tantras. This dichotomy, in which "exterior" practices are inferior to "interior" ones, will help organize new tantras in a hierarchical way. In a very different context this inward vs. outward categorization found an echo in the earlier denigration by the Mahāyāna of the Theravada tradition, using the label Hinayāna, or inferior vehicle to refer to it. The use of these categories in order to articulate ideas can be very powerful since they affect the way we look at those earlier teachings. There is no doubt that earlier Buddhist practitioners did not consider their early practices and rituals as merely outwards and were, probably, a complete soteriological path of their own. ${ }^{260}$

\section{Vilāsavajra}

The $8^{\text {th }}$ century Indian Master Vilāsavajra proposed new, additional layers to the ones proposed by Buddhaguhya. Vilāsavajra wrote commentaries to the Chanting the Names of Mañjusri (Skt. Mañjuśrīnāmasamgīti, Tib. jam dpal mtshan brjod) and the Guhyagarbha Tantra, in which he offered two different classifications. The one in the Mañjuśrinnāmasamgīti adds an

\footnotetext{
${ }^{260}$ See discussion on Buddhaguhya's Margavyūha's in the introduction to José Ignacio Cabezon, The Buddha's Doctrine and the Nine Vehicles: Rog Bande Sherab's Lamp of the Teachings (New York: Oxford University Press, 2013). Thanks to Prof. Jake Dalton for suggesting to me this reference.
} 
intermediate category, Caryā, between the ones of Kriyā and Yoga found in Buddhaguhya's commentary to the Mahāvairocana-abhisambodhi. ${ }^{261}$ This classification looks as follows:

1. Kriyā

2. Caryā

3. Yoga

However, it is the classification in his commentary to the Guhyagarbha tantra (Tib. spar khabs) that deserves special attention, since it has some characteristics that will be very influential for later Tibetan thought. In fact, Vilāsavajra will be one of the main references, together with the $9^{\text {th }}$ century Tibetan scholar, Pelyang (see chapter 4 of this dissertation), informing Nupchen's understanding of the Mahāyoga tradition. As we can see in the following list, this doxography is more inclusive and quite different from the more simple one offered in the Mañjuśrīnāmasamgīti:

1. No realization: apathetic (tib. ma rtogs: phyal ba)

2. Wrong realization: nihilists and eternalists (tib. log par rtogs: rtag chad gnyis)

3. Partial realization (tib. phyogs rtogs)

a. Śrāvakas (tib. nyan thos pa)

b. Pratyekabuddhas (tib. ran sangs rgyas)

c. Vijñānavādins (tib. rnam par rig pa)

4. Misrealization of the genuine: Madhyāmika (tib. yang dag nyid ma rtogs: dbu ma)

5. Discipline: Kriyā (tib. 'dul ba)

6. Intention: Yoga (tib. rnal 'byor)

7. Secret: Mahāyoga (tib. gsang ba: rnal 'byor chen po)

8. Natural secret meaning: Atiyoga (tib. rang bzhin gsang ba'i don: a ti yo ga) ${ }^{262}$

There are several important aspects in this new classification. First, although Vilāsavajra includes some non-Buddhist vehicles, their inclusion is clearly not as relevant as in Bhāvaviveka or Śāntarakșita’s systems. They seemed to simply be included in order to add legitimacy to the later Buddhist systems. Second, we can see the new relevance of the Mahāyoga system, with

${ }^{261}$ Dalton, “A Crisis of Doxography: How Tibetans Organized Tantra During the 8th-12th Centuries.” pp. 124-5

262 Ibid., p. 130. 
which the Guhyagarbha was first associated. The Guhyagarbha and, especially, its $13^{\text {th }}$ chapter will be highly influential in the development of later tantric systems. Third, we see the emergence of the Great Perfection. Although Vilāsavajra discusses Atiyoga as separate from Mahāyoga, Dalton thinks that "in practical terms [Atiyoga] is still dependent on it."263 Atiyoga seems to be a separate ritual moment that emerges from Mahāyoga, but not a different vehicle with its separate textual tradition and contemplative practices as we will see later with Nupchen. Fourth, we also see something that will be very relevant for the later Sarma traditions, mainly, the organization of these tantric vehicles around gender categories: "the male tantras focused primarily on method, the female tantras focusing on wisdom, [plus a category of] neuter tantras." ${ }^{264}$ Fifth, the fact that we can find two different classification systems in Vilāsavajra's writings (something we will also see in Nupchen's corpus) can point to certain fluidity in the use of these categories during this period, but we can also see how tantra is taking shape in a way that will be clearly recognizable to the later Tibetan tradition.

As we can see, doxographies fulfilled a variety of functions in India. Early on they were used mainly to argue doctrinal Buddhist positions against non-Buddhist views. Later on, it became an important genre for intra-sectarian polemical discussions, as well as a vehicle in which to organize and classify the new tantric ritual developments of the $8^{\text {th }}$ and $9^{\text {th }}$ centuries.

\footnotetext{
${ }^{263}$ Ibid., p. 130. Van Schaik adds that Vilāsavajra "does not give any special precedence to the term $r d z o g s c h e n$, and does not employ it in any specific technical sense." In van Schaik, "The Early Days of the Great Perfection," 2004, p. 170.

${ }^{264}$ Dalton, “A Crisis of Doxography: How Tibetans Organized Tantra During the 8th-12th Centuries,” p. 128.
} 


\section{Chinese precedents}

Tibetan doxographies, due to their interest in Tantric systems, followed Indian models for the most part, but the unusual fourfold classification found in Nupchen's Lamp has made some scholars suggest a possible Chinese influence. ${ }^{265}$ Buddhism in China has a long history of doxographical classifications, or panjiao (Ch. 判教). In fact, Chinese classification systems are slightly older than the ones found in India. Doxographies became so important for Buddhism in China that some scholars, like Peter Gregory, have argued that "doctrinal classification has often been said to be the hallmark of Chinese Buddhism." 266 One of the reasons to explain the importance of classification systems in China is the fact that they helped make sense of and organize the wide range of Buddhist teachings that were being imported into the country (just as they did in Tibet). As we have seen in the Indian case, doxographies could be used to roughly chart the historical development of the Buddhist tradition while, at the same time, conceptually organizing the various doctrinal claims (sometimes at odds with each other) found within the tradition.

While in India and Tibet, classification systems were organized around doctrinal or ritual issues (especially with the development of tantra), a distinctive characteristic of classification systems in China was that they "were usually arranged around narratives of the Buddha's life, often with the aim of promoting a particular text over all others." ${ }^{267}$ Obviously, in India and

\footnotetext{
${ }^{265}$ See Dalton and van Schaik, "Lighting the Lamp: The Structure of the Bsam Gtan Mig Sgron," 2003.

${ }^{266} \mathrm{He}$ also adds: "Although this judgment is surely one-sided -ignoring as it does many rich areas of more 'popular' developments- it is certainly no exaggeration when applied to Chinese Buddhist scholastic writing. Doctrinal classification is one of the most striking features of Chinese Buddhist scholasticism, and it is impossible to understand how medieval Chinese Buddhist scholars thought without understanding panjiao." In Gregory, Tsung-Mi and the Sinification of Buddhism, p. 93.

${ }^{267}$ Dalton, “A Crisis of Doxography: How Tibetans Organized Tantra During the 8th-12th Centuries,” p. 116.
} 
Tibet, texts or cycles of texts were important in doxographical classifications, but, at least rhetorically, they were not at the center of these doctrinal battles. I will include a brief discussion of two of the Chinese scholars, Huiguan 慧觀 and Chegwan 諦觀, whose doxographies could be seen as having some similarities to the one composed by Nupchen.

Huiguan 慧觀 (d. 453)

Although there are some earlier doxographical classification systems in China prior to the one presented by Huiguan, ${ }^{268}$ scholars seem to agree that his system was one of the first to articulate a unique and influential Chinese way of organizing the Buddhist teachings that was particularly influential for the later tradition. ${ }^{269}$

One of the distinctive characteristics of Huiguan's system is that he proposes a division of the Buddhist teachings between sudden, which correspond to the Huayan Sütra (Skt. Avatamsaka Sütra), and gradual teachings, which he divides into five different periods, each one associated with a particular textual tradition. The final classification looks as follows ${ }^{270}$ (from Gregory 111-112):

- Sudden - Huayan

- Gradual

o The Three vehicles (as described in the Lotus Sūtra ) were taught separately by the Buddha

- The Four Noble Truths to the Śrāvakas

- Interdependent Origination to the Pratyekabuddhas

- The Six Perfections to the bodhisattvas.

o The Buddha taught the common teaching to the Three vehicles, mainly, the Perfection of Wisdom

\footnotetext{
${ }^{268}$ Chanju Mun's History of Doctrinal Classification in Chinese Buddhism offers a thorough overview of the panjiao system in China.

${ }_{269}$ Gregory, Tsung-Mi and the Sinification of Buddhism, p. 111.

${ }^{270}$ Ibid., pp. 111-112.
} 
o In the third period, the Buddha made clear the inferiority of the teachings of the Srāvakas and elevated the teachings of the bodhisattvas. This is mainly found in the Vimalakirti Sūtra.

1. During this period, the three vehicles were subsumed under one vehicle. This teaching was presented in the Lotus Sūtra .

2. The final period, as presented in the Nirvana Sūtra, taught the eternality of the Buddha.

Huiguan is considered to be the first one to establish the polemical notions of gradual and sudden as classification categories to organize the various Buddhist teachings, ${ }^{271}$ a reflection of a debate that will be part of the Buddhist intellectual life in China in the following centuries. One of the aspects that makes a discussion of Huiguan's classification relevant to this dissertation is that we will see how this tension between sudden and gradual also plays a central role in Nupchen's Lamp. In the Lamp we do not only see a clear distinction between the Indian gradual and the Chinese sudden systems, but even within Mahāyoga there is a distinction between gradual and sudden approaches.

Chegwan 諦觀 (d. 971)

The $10^{\text {th }}$ century classification developed by the Korean monk Chegwan was not particularly influential in the Chinese tradition, but it is important that we briefly discuss it here, since it has been mentioned as a possible direct influence on Nupchen's Lamp. ${ }^{272}$ Chegwan, as well as Nupchen, offers a fourfold scheme that includes, in the two lower levels, the Gradual and the Sudden, while the two upper levels includes what he calls Secret and Indeterminate. Here is how the two systems compare:

\footnotetext{
${ }^{271}$ Gregory 2002, p. 113.

272 Dalton and van Schaik, p. 116 and Chappell, pp. 60-61.
} 


\begin{tabular}{|l|l|l|}
\hline & Chegwan & Nupchen \\
\hline 4 & Indeterminate & Atiyoga (Great Perfection) \\
\hline 3 & Secret & Mahāyoga \\
\hline 2 & Sudden & Sudden \\
\hline 1 & Gradual & Gradual \\
\hline
\end{tabular}

Although there are important differences in their understandings of each of those categories, what it is relevant to us is the possible formal borrowing of them by Nupchen. This would explain the obvious difference of the Lamp's classification when compared with late Indian systems, which, as we saw, were more concerned with tantric developments than with doctrinal and philosophical issues. The fourfold doctrinal system and the centrality of the tension between sudden and gradual approaches may indicate a certain amount of Chinese influence in the work. The inclusion of Chinese Chan as one of the Buddhist traditions discussed in the Lamp definitely indicates that Nupchen was quite familiar with the Chinese Buddhist tradition. 


\section{Early Tibetan Classifications}

It is now time to look at some of the early Tibetan classification systems that preceded the Lamp and that show the way Tibetans were assimilating and reinterpreting late India tantric developments before Nupchen composed his doxography. For the most part, Tibetans will follow Indian doxographical models concerned with late Indian tantric developments, like the ones by Buddhaguhya and Vilāsavajra. Nupchen was also very much part of this process of assimilation of late Indian tantric Buddhism (as shown in his doctrinal classification included in the Armor Against Darkness), but he was also an exception, and proposed in the Lamp an alternative classification system that did not follow its Indian precedents and had more in common with Chinese panjiao systems.

One of the main differences between the Tibetan and the Indian approaches to the doxographical genre is that, while Indian systems were more concerned with organizing and classifying new tantric ritual developments, Tibetans were more interested in doctrinal issues. ${ }^{273}$ This may have to do with the foreign nature of Buddhism in Tibet. Another important aspect of the early Tibetan doxographies is that they show Buddhism in Tibet in a process of creative transformation, before the Nyingma and the Sarma schools settled for standard nine and four vehicle systems, respectively, of the later centuries.

In this section I will discuss two early precedents to Nupchen's Lamp, Padmasambhava's Garland of the Views of the Secret Instructions (Tib. Man ngag lta ba'i phreng ba) and Pelyang's Lamp for the Mind (Tib. thugs kyi sgron ma). ${ }^{274}$ The first one is important for its

\footnotetext{
${ }^{273}$ Dalton, “A Crisis of Doxography: How Tibetans Organized Tantra During the 8th-12th Centuries," p. 116.

${ }^{274}$ There are other doxographies, both from the 8th century:Yeshe De's (Tib. Ye shes sde) Differentiating the Views (Tib. lTa ba'i khyad par) and Kawa Peltsek's (Tib. sKa ba dpal brtsegs) Esoteric Instructions of the Stages of the View (Tib. lTa ba'i khyad pa'i man ngag) that I will not be discussing here for lack of space and because they are less relevant for my argument. For Yeshe De's text, see David Seyfort Ruegg's "Le ITa-Ba 'i Khyad par de Ye-
} 
connection to the early developments of the Great Perfection tradition as a separate vehicle, an important aspect of Nupchen's Lamp. The second one will be one of the main sources for Nupchen's understanding of the Mahāyoga tradition. Nupchen quotes from both of them repeatedly in the Lamp.

\section{Padmasambhava's Garland of the Views of the Esoteric Instructions (Tib. Man ngag lta ba' $i$} phreng ba)

The importance of the Garland of the Views of the Esoteric Instructions (the Garland from now on) for our understanding of the early development of Buddhism in Tibet has been extensively discussed by many scholars. ${ }^{275}$ This text is important for a variety of reasons: 1) it is considered to be one of the earliest Tibetan doxographies; ${ }^{276}$ 2) its seven vehicle classification is a clear Tibetan precedent to the nine vehicle system later adopted by the Nyingma tradition; and 3) the Garland is also seen as very influential in the formation of the early Great Perfection tradition, first as part of a third ritual moment following the generation and perfection stages of

Shes-Sde," Journal Asiatique, 1981, 207-29. Van Schaik also has argued that Kawa Peltsek's text may not be by him and of later composition, making it irrelevant for our discussion. See van Schaik's "The Early Days of the Great Perfection," 2004, 188.

${ }^{275}$ Karmay 1987, Dalton 2005, Germano in two of his forthcoming manuscripts, The Secret Tibetan History of Buddhist Tantra in the Great Perfection and Mysticism and Rhetoric in the Great Perfection.

${ }^{276}$ Dalton claims that the text is "our earlier extant text entirely devoted to setting forth a tantric classification system." In Dalton's “A Crisis of Doxography: How Tibetans Organized Tantra During the 8th-12th Centuries," p. 132. According to Dalton, there is substantial evidence for the attribution of the text to Padmasambhava: "All indications point to the reliability of the attribution of the Man ngag lta ba'phreng ba to Padmasambhava: The text clearly predates Gnubs chen sangs rgyas ye shes (late ninth/early tenth century), who quotes it (Bsam gtan mig sgron, 207.3-6), and it reflects a stage of tantric development we would expect to see in the late eighth century. The eleventh century Rong zom chos kyi bzang po wrote a commentary on it attributing it to Padmasambhava, and the Sba bzhed claims Padmasambhava wrote it while visiting central Tibet. Moreover, it seems that Padmasambhava composed at least one other Mahāyoga commentary while in Tibet. The Dunhuang manuscript 1TJ321 is a complete and lengthy commentary to the Thabs kyi zhags pa (Q.416) that is clearly attributed to the master." In Jacob Dalton's "A Crisis of Doxography: How Tibetans Organized Tantra During the 8th-12th Centuries," Journal of the International Association of Buddhist Studies 28, no. 1 (2005): 115-81, p. 132, n. 41. Ruegg (p. 86) thinks that the first Tibetan doxography is the ITa ba khyad par and Takahashi, in her dissertation, proposes Pelyang's Lamp of the Mind. 
contemplative practice, as proposed by later Mahāyoga systems, and later as its own independent vehicle. The fact that the text is quoted in Nupchen's Lamp testifies to its old pedigree.

The Garland shares with Vilāsavajra's sPar khab the fact that both are a commentary of the $13^{\text {th }}$ chapter of the Guhyagarbha tantra. This complex and obscure chapter proved to be very fertile ground for the development of tantric thought and lead to the early speculations that would be the seeds for the Great Perfection. The text offers a sevenfold classification that, as we can see, follows earlier India developments, as discussed in our previous section. The Garland divides all Buddhist views into three main vehicles, the Sūtra, the Outward Tantra, and the Inner Tantra:

\section{Sūtra}

1. śrāvaka

2. Pratyekabuddha

3. Bodhisattva

\section{Outward Tantra}

4. Kriyā

5. Upāya

6. Yoga

\section{Inward Tantra}

7. Mahāyoga
a. Generation
b. Perfection
c. Great Perfection ${ }^{277}$

Here, as we saw in the late Indian tradition developments, Yoga Tantra is pushed into the Outward Tantra, showing that during this period the system is still very much at play, with newer developments rapidly pushing aside (or outside, or lower, depending on the image the text wants

\footnotetext{
${ }^{277}$ Ibid., p. 133. The Garland also offers, following earlier Indian models, a discussion of earlier Indian systems, as well as "erroneous views" (phyin ci log gi lta ba): Non-believers (phyal ba); Materialists (rgyang 'phren); Nihilists ( mur thug pa). See Mestanza's "La Première Somme Philosophique Du Bouddhisme Tibétain. Origines Littéraires, Philosophiques et Mythologiques Des ‘Neuf Étatpes de La Voie’ (theg Pa Rim Pa Dgu),”p. 87.
} 
to present) older ones. What we find here, though, is not yet a system of separate vehicles, but a blueprint for a gradual, integrated system of meditation that outlines the different stages of contemplative practice. The Great Perfection tradition during this period is still part of a broader system of ritual practice and contemplation ${ }^{278}$.

Pelyang's Lamp for the Mind (Tib. Thugs kyi sgron ma; late $8^{\text {th }}$ early $9^{\text {th }}$ centuries $)^{279}$

Pelyang's doxographical system also shows clear Indian precedents (particularly Buddhaguya), although, unlike the Garland, his main concern is the Mahāyoga tradition. As we have said, it is very difficult to know if this classification is earlier or later than the Garland, but, nonetheless, an examination of these two texts, which were probably composed very close in time, shows that Tantra is undergoing a very creative period, with new developments continuously emerging and with various classification systems trying to articulate them in some sort of cohesive way.

Pelyang's Lamp for the Mind, probably the first Tibetan-authored doxographical system that has survived, includes, again, non-Buddhist as well as Buddhist philosophical views:

1. Gods and humans

2. śrāvakas

3. Pratyekabuddhas

4. Bodhisattvass

5. Tantras

a. Kriyā

b. Upaya

c. Yoga

\footnotetext{
${ }^{278}$ In Ibid., p. 88.

${ }^{279}$ For an excellent study of Pelyang's life and works, see Kammie Takahashi's“'Lamps for the Mind: Illumination and Innovation in dPal Dbyangs's Mahayoga" (University of Virginia, 2009).
} 


\section{d. Mahāyoga}

We can see also some Chinese influence in Pelyang's system in his inclusion of a vehicle of Gods and humans, which is common in many early Chinese doxographies. ${ }^{280}$ Dalton also points out the fact that, while the Garland had mainly a ritual focus, following Indian models, Pelyang's focus is doctrinal, showing a new Tibetan sensibility that seems to pave the way for the philosophical approach of Nupchen's Lamp. ${ }^{281}$

We can see Pelyang's influence on Nupchen's Lamp on two different levels. On a more general one, Nupchen's Lamp shows the doctrinal concern of Pelyang in his presentation of the four different vehicles and, in fact, he has no interest in the ritual aspects of the various traditions he discusses. A more direct influence can be seen in Nupchen's particular presentation of the Mahāyoga tradition, which is strongly influenced by Pelyang's works, and which he cites at different times in the Lamp. Nupchen, just like Pelyang, will avoid, for the most part, any discussion of the sexual or violent rhetoric of the tradition and focus on its more philosophical aspects.

\footnotetext{
${ }^{280}$ In Dalton's “A Crisis of Doxography: How Tibetans Organized Tantra During the 8th-12th Centuries,” p. 137 and Gregory's Tsung-Mi and the Sinification of Buddhism.

${ }^{281}$ Takahashi agrees with this portrayal of Pelyang's classification: "The first half of the Lamp of the Mind is a Buddhist doxographical presentation of non-Buddhist and Buddhist systems, refuted or criticized in the standard hierarchical progression of lower to higher systems, ending with a summation of the highest system. In this light Pelyang's work is nothing out of the ordinary. However, while most Indian Buddhist tantric doxography centers on distinctions in the rituals of the various tantras, Pelyang's Lamp of the Mind hardly mentions ritual. The distinctions that concern Pelyang are exclusively related to view; he does not comment on the role of ritual in distinguishing whether a system is effective. Furthermore, although later Tibetan doxography resembles Pelyang's Lamp of the Mind in relying upon view and perspective rather than practice or ritual for their rankings, it appears that Pelyang's Lamp of the Mind is among the first, and perhaps the oldest, extant Tibetan doxography to do so. Once again, Pelyang appears to have been an innovator among Tibetans in this field," Takahashi, p. 104.
} 
This overview of early Indian, Chinese, and Tibetan doxographies show how Buddhist doxographies were conservative tools, since they tried to preserve the unity of the Buddhist tradition in the face of astonishing, and, sometimes, contradictory views, while, at the same time, offering a vast amount of room for creativity and innovation, as new ritual and doctrinal systems would be added to the older ones.

The goal of this section is to situate Nupchen's Lamp in the context of previous Buddhist doxographical classifications and use the text as an example of how Tibetans, from the very early stages of the introduction of Buddhism into Tibet, were not passively receiving an imported tradition, but actively and creatively developing indigenous interpretations of the Buddhist path.

The way in which Nupchen engages the Buddhist doxographical tradition can be clearly seen not simply in the Lamp, but also in his other major surviving work, the Armor Against Darkness (Tib. Mun pa'i go cha). This commentary on the Sutra of the Gathered Intentions, a key Anuyoga text, clearly engages the previous Indian classifications of these ritual and contemplative systems as elaborated by Buddhaguhya and Vilāsavajra in India, and the Garland in Tibet. Nupchen, though, will argue for a nine vehicle classification that includes the Great Perfection (as Atiyoga) as a separate vehicle, something that neither of the previous systems had proposed.

1. Śrāvaka

2. Pratyekabuddha

3. Bodhisattva

4. Kriyā

5. Upaya

6. Yoga

7. Mahāyoga 
8. Anuyoga

9. Atiyoga 282

In fact, van Schaik has argued that Nupchen's doctrinal classification in the Armor Against Darkness may be the first instance of a the nine vehicle system found in Tibet. ${ }^{283}$ As Dalton points out, the Garland and Pelyang's text "divide their highest class of Mahāyoga into three 'techniques' (Tib. tshul) or 'stages' (Tib. rim) of development, perfection, and great perfection. In the writings of Nupchen, these three stages are enshrined as thee separate classes." ${ }^{284}$ What is unique of Nupchen's classificatory system in the Armor is that it shows that he is part of a contemplative and textual movement in Tibet that is arguing for the unique nature of the Great Perfection, a movement that wants to separate the Great Perfection from the earlier tantric ritual and contemplative stages, transforming it into its own vehicle. In the case of the Armor, though, Nupchen seems to tackle the Great Perfection within the specific context of Indian Buddhism.

${ }^{282}$ Dalton 2005, p. 140.

${ }^{283}$ van Schaik argues that he may have been the first one to use the nine vehicle system: "Although as we saw above there are certain Dunhuang texts that appear to be early instances of the nine-vehicle system, none of these actually refers to Atiyoga as a vehicle. The closest they come to such a definition is to include Atiyoga as one in a series of "statements" (lung). Therefore, gNubs chen remains the earliest known exponent of the nine vehicles, as vehicles per se. This places the first appearance of Atiyoga as a vehicle within gNubs chen's lifetime, in the late ninth and early tenth centuries. ${ }^{63}$ We should note here that there is a text attributed to sKa ba dPal brt-segs in the bsTan 'gyur, entitled The Instructions / Teachings on the Stages of the View (ITa ba rim pa' $i$ man ngag or ITa ba rim pa'i bshad pa). ${ }^{64}$ This text refers to Mahayoga, Anuyoga and Atiyoga as vehicles, and describes the general approach of Atiyoga in some detail. Though unlikely, it is possible that Mahayoga, Anuyoga and Atiyoga were designated vehicles in a late eighth century text, but not again until the early tenth century. However, I am inclined to doubt the attribution of this text to dPal brtsegs and therefore its status as an eighth-century text. gNubs chen quotes dPal brtsegs several times in STMG, but these passages, including one that mentions Atiyoga, are not from the ITa ba rim pa'i man ngag. ${ }^{65}$ One would not expect gNubs chen to overlook a source from a well-known author which offered a venerable tradition for his assertion that Atiyoga was a vehicle. Furthermore, as Karmay has noticed, Bu ston, though including this text in the bsTan 'gyur along with the other texts attributed to dPal brtsegs, was inclined to doubt its authenticity." In van Schaik's "The Early Days of the Great Perfection," 2004. p. 188. Germano suggests that the nine vehicle doctrinal classification may be a Tibetan indigenous interpretation of the Buddhist path that is based on the Tibetan myth of the nine rung ladder that connects heaven and earth. In David Germano's Mysticism and Rhetoric in the Great Perfection (rDzogs Chen) (Unpublished Manuscript, 2009). For the Tibetan indigenous myth, see Samten Gyaltsen Karmay's The Arrow and the Spindle: Studies in History, Myths, Rituals and Beliefs in Tibet (Kathmandu: Mandala Book Point, 1998), p. 252.

${ }^{284}$ Dalton's “A Crisis of Doxography: How Tibetans Organized Tantra During the 8th-12th Centuries,” p. 140. 
The Lamp for the Eye in Contemplation offers an alternative and more unusual doxographical fourfold classification, at least in the Tibetan context, that seems to have a broader focus, being concerned not only with Indian tantric developments, but also with Buddhist contemplative systems across Asia, as the inclusion of Chinese Chan proves. The Lamp organizes the various forms of Buddhism that made their way into Tibet during Nupchen's time (again, the $10^{\text {th }}$ century) into four basic approaches to meditation. The four different meditational systems are discussed individually and in detail in chapters 4 to 7 , and they are the Indian gradual approach; the Chinese sudden approach, Mahāyoga (Tib. rNal 'byor chen po); and Atiyoga, or the Great Perfection (Tib. rDzogs pa chen po). For Nupchen, a) on the one hand, all of these systems share something in common, in this case an understanding of some form of nonconceptual meditation (Skt. avikalpa, Tib. mi rtog pa, which allows him to compare them; and b) on the other hand, their different understanding of non-conceptuality is what allows him to rank them $^{285}$ :

1. Gradual approach (Tib. tsen men rim gyis 'jug pa) - not conceptualizing appearances (Tib. snang ba mi rtog pa), which describes the traditional Mahāyāna textual and scholastic tradition coming mainly from India;

2. Instantaneous approach (Tib. ston mun cig car 'jug pa) - not conceptualizing nonappearances (Tib. mi snang ba mi rtog pa). Represented by Chinese Chan;

\footnotetext{
${ }^{285}$ On the role of non-conceptuality as an organizing principle in the Lamp see my discussion in chapter three of this dissertation. Jake Dalton, in his article, "A Crisis of Doxography," traced some of the early historical developments of the doxographical tradition in India as well as in Tibet all the way up to Nupchen, arguing that while in India the focus of doxographies were the organization of the constant ritual innovation within the tantric material, in Tibet, while this was also a concern, the focus shifted to doctrinal differences. This point becomes obvious in the Lamp, in which Nupchen constructs his doxography around the understanding that different Buddhist traditions have of the notion of non-conceptuality (Tib. mi rtog pa), which allows him to position the Great Perfection away from ritual or contemplative contexts and engage the other traditions in the intellectual arena.
} 
3. Mahāyoga (Tib. rnal 'byor pa chen po) - not conceptualizing non duality (Tib. gnyis su med pa'i mi rtog pa). which represents the new tantric developments that had become popular during this period all across Asia, starting in the $7^{\text {th }}-8^{\text {th }}$ century; and

4. Atiyoga (rdzogs pa chen po) - not conceptualizing [which is] spontaneously present (lhun gyis grub pa'i mi rtog pa), Nupchen identifies himself with this tradition, which also explains why he situates it at the top of his classification.

The origins of this fourfold classification is not completely clear. As we have seen, the Indian doxographical tradition, at least as was being interpreted in Tibet, was heading towards the classical nine vehicle classification, one that is already acknowledged by Nupchen in his Armor Against Darkness. As we have seen, Dalton and van Schaik suggest for a possible Chinese influence, ${ }^{286}$ while Meinert argues for the concrete influence of the fourfold correct practice of the Aryāvikalpapraveśanāmadhārani ${ }^{287}$ a text that Nupchen himself quotes in the Lamp. The origin or possible influence of other doctrinal systems in Nupchen's classification will be discussed in chapter three of this dissertation, but here I just want to point out that when compared with the classification found in the Armor Against Darkness, it becomes clear that Tibetans, and Nupchen in particular, are actively trying to understand the enormous variety of Buddhist teachings that were making their way into Tibet during his era and proposing different systems that allowed them to incorporate their own interpretations of the Buddhist path.

\footnotetext{
${ }^{286}$ See Dalton and van Schaik, "Lighting the Lamp: The Structure of the Bsam Gtan Mig Sgron,” 2003.

${ }^{287}$ Meinert, "Structural Analysis of the bSam Gtan Mig Sgron: A Comparison of the Fourfold Correct Practice in the Āryāvikalpapraveśanāmadhāraṇ̄ and the Contents of the Four Main Chapters of the bSam Gtan Mig Sgron,” 2003.
} 
At the same time, and as Gregory points out in the context of Chinese doxographies, doctrinal classifications can be used to assert sectarian boundaries and the superiority of certain Buddhist traditions over others, in this case that of the Great Perfection. We could argue that Nupchen's Lamp seems to be defining certain boundaries (although maybe not sectarian ones) between different Buddhist communities (Indian monastic Buddhism as represented by the Gradual tradition, Chinese Chan communities following the Sudden Approach, Indian noncelibate tantric systems followers of Mahāyoga, and a new emerging movement that may have had Indian or Central Asian origins, but that, as defined by Nupchen, reflects a Tibetan Buddhist interpretation of the Buddhist path. Our lack of knowledge of the social context in which the Great Perfection emerged makes it very difficult to assess the self-perception of Great Perfection practitioners and their relationship with other Buddhist traditions, but if the life and work of Nupchen (at least what we know of him) is any indication, those boundaries expressed in doctrinal classification may be more reflective of doctrinal differences than of social realities, since Nupchen seemed to have been very adept at Mahāyoga, Anuyoga, as well as of Great Perfection practices and rituals.

\section{Why is Anuyoga not a Separate Vehicle in the Lamp?}

An interesting side note in this discussion of the doxographical classification presented by Nupchen in the Lamp has to do with the status of Anuyoga, which appears as a separate vehicle in his other major and earlier text, the Armor Against Darkness, but it does not deserve its own category in the Lamp. This is particularly strange since Nupchen was a key figure for the introduction of Anuyoga in Tibet, and played a key role in the translation of its main scripture, 
the Sütra of the Gathered Intentions, and maybe even its composition, ${ }^{288}$ as well as in its early interpretation, as the massive commentary the Armor Against Darkness shows. It is also particularly strange since Nupchen does mention the Anuyoga tradition several times in the text.

I think that there are two different ways we can approach this omission. The first one would be to suggest being extremely careful when considering Nupchen's works as presenting a rigid division between these Buddhist traditions. In the case of the Mahā, Anu, and Atiyoga categories, this is particularly important, since some of the characteristics of Mahāyoga described in the Lamp became central to Anuyoga (particularly its more antinomian set of practices), and the boundaries between Anuyoga and Atiyoga were particularly fluid, especially if we take into account that Nupchen seems to consider the Sütra of the Gathered Intentions, which became a central text for the Anuyoga tradition, a Great Perfection text in the Lamp. The fact that the Sütra of the Gathered Intentions is the most quoted text in the Lamp in the Mahāyoga and Atiyoga chapters, more than any of their scriptural canons, highlights the fluidity between these categories during this period, something that Nupchen seems to be negotiating differently in his various works. The status of the Sütra of the Gathered Intentions and its fluidity with all tantric traditions is something that Dalton discussed in his study of the text:

The later Tibetan tradition classified the Sütra under anuyoga, which leads one to wonder how the Sütra viewed its own position in relation to the triad of maha-anu-ati. After extensive searching, nowhere does the Sütra agree with its later exegetes that it is a work of anuyoga. It definitely considers itself "secret mantra," but this seems to include all three vehicles of mahāyoga, anuyoga, and atiyoga. The original purpose of the Sütra was not to set forth the vehicle of anuyoga, but to create a complete system of doctrines, myths, and rituals to explain all the tantric vehicles, and the highest three especially. ${ }^{289}$

\footnotetext{
${ }^{288}$ See Appendix 1 in Jacob Dalton's "The Uses of the dGongs Pos 'Dus Pa'i Mdo in the Development of the rNying Ma School of Tibetan Buddhism” (University of Michigan, 2002).

${ }^{289}$ Ibid., 318.
} 
I also believe that the different doxographical categories as found in the Armor and the Lamp do not represent a contradiction, but instead reflect the fluidity that Nupchen is trying to understand and negotiate. In the case of the Armor, Nupchen is more interested in articulating a Tibetan vision for the tantric teachings as they mainly came from India and other parts of Central Asia. In the Lamp, he is more concerned with articulating the main differences of contemplative practices in Buddhist systems all across Asia, integrating new Tibetan developments within that vision.

In this section of the chapter, I have discussed the historical and doctrinal context of doxographies in India, China and Tibet up to Nupchen's Lamp in order to show how first, the doxographical genre became one of the main tools for Buddhist philosophical argumentation not only against non-Buddhist traditions, but also among various Buddhist philosophical views. Second, I have shown that Tibetans were using doxographies as a very effective tool to organize the wide variety of teachings that were being introduced in Tibet during this period. Finally, I demonstrated how Tibetans, and Nupchen in particular, were using the doxographical genre not only to passively organize the various forms of Buddhism that were being imported into Tibet, but were actively and creatively engaging in the construction of a unique Tibetan Buddhist view. Nupchen's use of doxographies to organize various Buddhist traditions, while, at the same time, arguing for the superiority of the new and emergent Great Perfection shows how he was a deeply innovative thinker working within a very traditional framework 


\section{Part 3 - A World of Texts: The Lamp for the Eye in Contemplation and the Textual \\ World of the Dark Age Period.}

Any text is a new tissue of past citations. Bits of code, formulae, rhythmic models, fragments of social languages, etc., pass into the text and are redistributed within it, for there is always language before and around the text. Intertextuality, the condition of any text whatsoever, cannot, of course, be reduced to a problem of sources or influences; the intertext is a general field of anonymous formulae whose origin can scarcely ever be located; of unconscious or automatic quotations, given without quotation marks.

Barthes, Theory of the Text ${ }^{290}$

One of the most relevant qualities of the Lamp for the Eye in Contemplation for the modern researcher is the amount of textual sources used by Nupchen to discuss the various Buddhist contemplative traditions included in the text. The Lamp includes hundreds of quotes from over a hundred different texts, some of them no longer extant. Nupchen's encyclopedic knowledge (from a Buddhist perspective) and passion for books can be seen in his suggestion that all practitioners should bring to their retreat with them a well assorted collection of books:

Regarding the harmonious Dharma [books that you should take with you to a retreat]: Kamalaśīla['s Bhāvanākrama], [Hashang] Mahāyāna texts on contemplation, those of the profound Inner Yoga; the kLong drug, the bZhi phrugs (whose commentary are like the primordial meaning), the six Tantras of Suchness, and the twenty or eighteen minor [texts of the] Mind. ${ }^{291}$

If in the first part of this chapter I have looked at the life of the Lamp as a physical text, exploring its complex recension history, and in the second part I have explored the Lamp from the perspective of its literary genre, now I want to highlight its deep intertextual nature by using Daniel Boyarin's use of intertextuality in Midrash literature in order to highlight the effects that

\footnotetext{
${ }^{290}$ Roland Barthes, Image, Music, Text (New York: Hill and Wang, 1977), 39.

${ }^{291}$ Lamp 33.3-33.5.
} 
constant quotation has on the manipulation of meaning of the texts quoted, and in the creation of a new meaning by inserting those texts into a new context.

\section{Intertextuality}

As I have mentioned, the Lamp is highly intertextual, with Nupchen constantly quoting from many different texts. The notion of intertextuality as defined by several scholars like Kristeva, Foucault, or Boyarin will help me problematize further the nature of Nupchen's text under a new set of assumptions borrowed from literary criticism. Boyarin understands intertextuality as having three main meanings:

The first is that the text is always made up of a mosaic of conscious and unconscious citation of earlier discourse. The second is that texts may be dialogical in nature contesting their own assertions as an essential part of the structure of their discourse [...] The third is that there are cultural codes, again either conscious or unconscious, which both constrain and allow the production (not creation) of new texts within the culture; these codes may be identified with the ideology of the culture, which is made up of the assumptions that people in the culture immediately make about what may or may not be true and possible, about what is natural in nature and history. ${ }^{292}$

Although Boyarin sides with the theorists that claim that all texts are by nature inherently intertextual, it would not take long for any reader of The Lamp for the Eye in Contemplation to realize how it is especially true of this text. An example from almost any page of the text illustrates this mosaic-like nature "of conscious and unconscious citations of earlier discourse" that articulates Nupchen's text:

\footnotetext{
${ }^{292}$ Daniel Boyarin, Intertextuality and the Reading of Midrash (Bloomington: Indiana University Press, 1990$), 12$.
} 

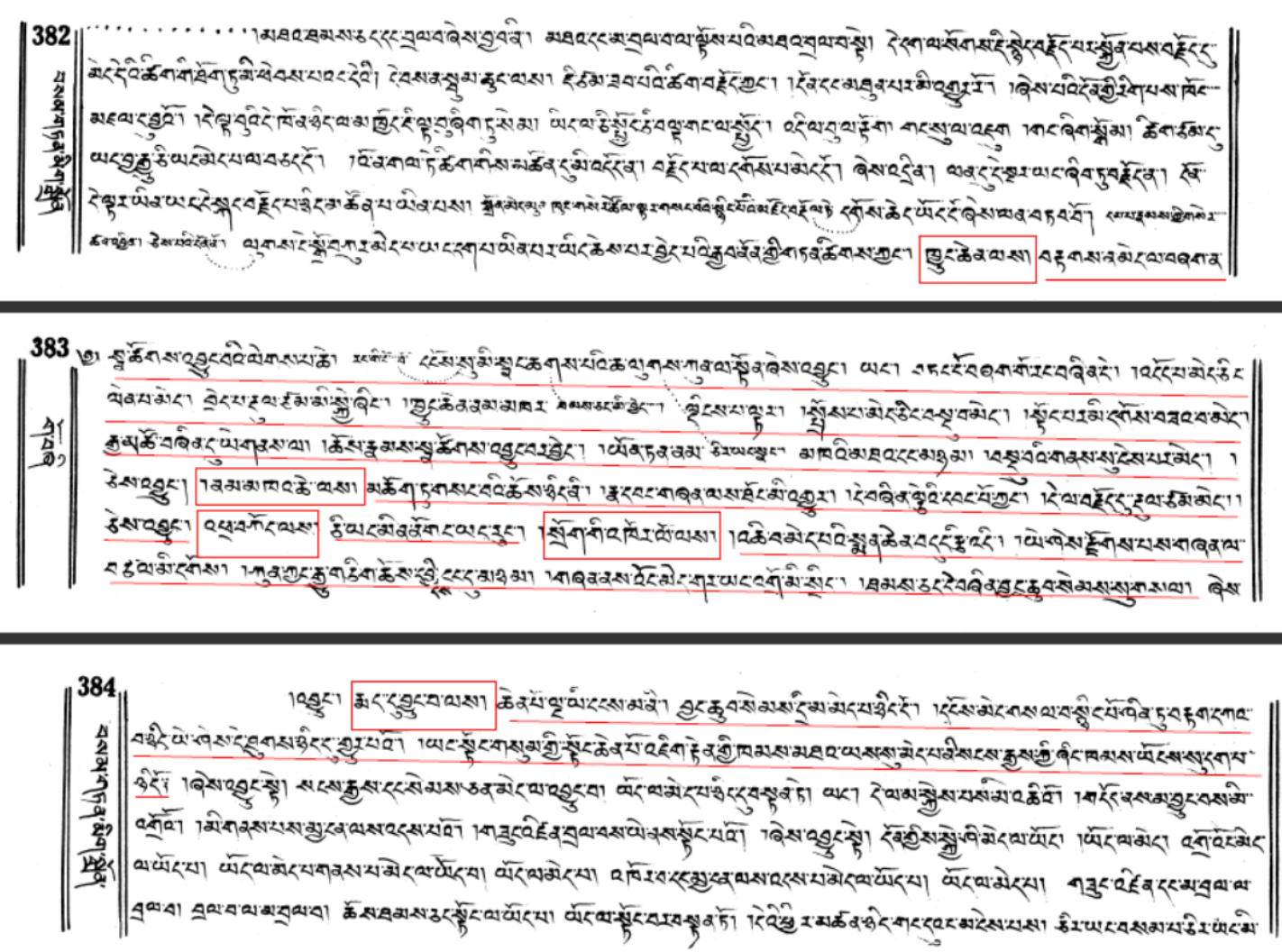

Pages from chapter 7 of the Lamp. The red boxes indicate a text, while the underline text indicates the actual quotation from the text.

As we can see in the images above, Nupchen's commentary of the different Buddhist meditational systems is built as a commentary to dozens of texts from each of these traditions that are constantly quoted, sometimes at great length, throughout its pages. Here, Boyarin's insights, with the help of Julia Kristeva, about the role of quotation in Midrash as a technique that helps preserve as well as transform the tradition are quite relevant:

As Julia Kristeva has written, 'every text builds itself as a mosaic of quotations, every text is absorption and transformation of another text.' By absorbing and transforming, the textual system both establishes continuity with the past and renews itself for the future. The simultaneous rejection and preservation of tradition in Midrash is shown in the allpervasive quotation which forms its very warp and woof. ${ }^{293}$

${ }^{293}$ Daniel Boyarin, Intertextuality and the Reading of Midrash (Bloomington: Indiana University Press, 1990), 22. 
In the Lamp, the continuation with the past is established by including and legitimizing the views (i.e. texts) of the four different Buddhist vehicles: Indian Gradual, Chinese Sudden, Mahāyoga, Atiyoga or Great Perfection. Each of them is assigned a place in Nupchen's Buddhist worldview. At the same time, there is a manipulation of the meaning of each tradition's principal texts by extracting them from their original contexts and inserting them into a new framework, in which the original answers and explanations to Buddhist questions and problems become insufficient since the new overarching structure is putting forward new questions and problems to which only the new tradition, in this case the Great Perfection, has all the answers. ${ }^{294}$

The second understanding of intertextuality is related to the claim that all texts are dialogical in nature, in the sense that "every text cannot but record the traces of its contentions and doubling of earlier discourses." On the surface, The Lamp for the Eye in Contemplation would seem to defy this understanding of intertextuality. While it would seem obvious for the contents of the text that Nupchen understands the Buddhist tradition, and by this I mean its texts, as dialogical (they contain different interpretations, sometimes quite antagonical, like in the case of the Gradual vs. Sudden positions), he is trying to articulate these tensions into a monological discourse. What allows him to do that is to rewrite the whole Buddhist tradition as the constant reinterpretation of the "non-conceptual" (Skt. avikalpa, Tib. mi rtog pa) nature of the Buddha's experience. For Boyarin, though, this is just a literary technique that cannot hide the intrinsic dialogical nature of any text.

The final understanding of intertextuality implies that there are "cultural codes, again either conscious or unconscious, which both constrain and allow the production (not creation) of new texts within the culture." In the context of Midrash, Boyarin argues that one source for the

\footnotetext{
${ }^{294}$ See examples of this manipulation of meaning in chapter 4 of this dissertation.
} 
production of new texts is the intertextual nature of the canon, which is gapped and dialogical with the midrash filling in the gaps. In this sense the production of texts is a hermeneutical necessity put forward by the canon itself. The second impetus for the production of texts, though, and the one relevant in this third understanding of intertextuality, comes from "the ideological intertextual code of rabbinic culture." Midrash is for Boyarin "not [...] a reflex of that ideology but a dialogue with the biblical text conditioned and allowed by that ideology." In the context of the Lamp, this context of intertextuality, opens the door for a more social, cultural understanding of the text that takes us beyond pure scholastics and would frame Nupchen's work in the crossroads of a culture that it is trying to appropriate a foreign religion while, at the same time, reinterpreting it within the shifting parameters of a socially, politically, and ideologically evolving culture. This can also be connected to J.Z. Smith's understanding of religion, which draws heavily on Durkheim and a more social interpretation of religion when he says,

The world is not a given, it is not simply "there." We constitute it by acts of interpretation. We constitute it by activities of speech and memory and judgment. It is by activities of speech and memory and judgment. It is by an act of human will, through projects of language and history, through words and memory, that we fabricate the world and ourselves. ${ }^{295}$

I believe this way of reading our text helps us by problematizing further Nupchen's narrative, by looking at it not as an inevitable, inner-driven, theological Buddhist interpretation of the tradition, but by looking at it in a very specific social and historical context, and especially as an attempt to construct a worldview that translated the needs of a new, evolving culture.

295 Jonathan Z. Smith, On Teaching Religion: Essays by Jonathan Z. Smith (New York: Oxford University Press, 2013), 125. 


\section{Conclusion}

This second chapter has discussed the Lamp from three different perspectives. As a physical text, we have explored the obscure recension history of the text as well as attempted to correct some of the current misunderstanding regarding the various editions that have survived of the Lamp. From the perspective of its literary genre, we have seen used doxographies to organize the diversity of Buddhist systems that had been imported into Tibet from all parts of Asia up to the 10th century, as well as to argue for the superiority of the new an emerging Great Perfection. Finally, from the point of view of its rich intertextual nature, we have seen how Nupchen is constructing a Buddhist doctrinal reality out of quotations from a wide variety of Buddhist scriptures while, at the same time, the new context in which these texts are quoted, ie. the Lamp, allow him to manipulate and transform their meaning in order to support the superiority of the tradition to which he belongs, the Great Perfection.

\section{Chapter 3 - Putting Meditation in Context: Practical Advice, Contemplative}

\section{Techniques, and the Final Goal.}

\section{Introduction}

This chapter focuses on chapters 1 through 3 of the Lamp for the Eye in Contemplation, in which Nupchen offers a general overview of some important topics essential for the success of a meditation retreat: What is the ideal place to meditate? What are the best contemplative techniques? How do you choose the teacher, consort, and the servant who will help you during your retreat? Although Nupchen offers a unique Tibetan approach to these issues, the topics discussed in these first three chapters of the Lamp are quite common in Buddhist meditation manuals. The most famous in the early Buddhist tradition is, probably, the 5th century treatise, 
Visuddhimagga, ${ }^{296}$ in which Buddhaghoșa offers a detailed discussion of all aspects related to meditation, from the ideal characteristics of the retreat location to an elaboration on the subtleties of contemplative practice. Surprisingly, though, this treatise was never translated into Tibetan, although a text that Buddhaghoșa used as a reference in the composition of the Visuddhimagga, Upatissa's Vimuktimārga, was translated into Tibetan in the 9th century by Vidyākaraprabha and Peltseg. ${ }^{297}$ In the Chinese context, Zhiyi's 6th century Rituals for the Lotus Samadhi Repentance (Ch. 法華三昧懺儀; Fahua sanmei chanyi), which offers a detailed discussion of the rituals and practices to be performed during a three week retreat focused on the Lotus Sūtra, and Zongmi's 9th century Manual for the Cultivation and Realization of the Scripture of Perfect Enlightenment Retreat (Ch. 圆觉经道场修证义; Yuan jue jing daochang xiuzheng yi), a text that offers "the prescriptions for an 80 to 120 day retreat centered around the liturgical recitation of the Scripture of Perfect Enlightenment (Ch. 圓覺經)" ${ }^{298}$ represent good examples of Chinese meditation manuals written prior to Nupchen's Lamp.

\footnotetext{
${ }^{296}$ Buddhaghosa, Henry Clarke, ed Warren, and Dharmananda Kosambi, Visuddhimagga of Buddhaghosācariya, vol. 41, Harvard Oriental Series (Cambridge: Harvard University Press, 1950).

297 "The Treatise on the Path to Liberation was compiled by the arahant Upatișya/Upatissa, while its translation into Chinese was undertaken by Saṃghapāla, Saṃghavarman or Saṃghabhara (僧伽婆羅), active in the early sixth century [...] The text can be found in the Derge edition no. 306 or in the Peking edition no. 972 under the title Rnam par grol ba'i lam las sbyangs pa'i yon tan bstan pa zhes bya ba, corresponding to Vimuktimärga-dhutaguna-nirdeśa in Sanskrit. The translation of this extract, which describes the ascetic practices, is attributed to Vidyākaraprabha, who was active in the ninth century. The Tibetan text has been edited by Sasaki 1958 and Bapat 1964. Bapat 1944 (cf. also Bapat 1964: XV) notes that in some editions of the Tibetan canon the Vimuktimārga-dhutaguna-nirdeśa contains a spurious passage with some sütra quotations from otherwise unrelated works, probably the result of a copyist's error who may have inadvertently taken over material from the Sütrasamuccaya. Extracts from the Vimuktimārga can also be found in the Samskrtāsamskrta-viniścaya, a compendium of tenets of various schools that has similarly been preserved in Tibetan.” In Anālayo, “The Treatise on the Path to Liberation (解脫道論) and the Visuddhimagga," Fuyan Buddhist Studies 4 (2009): 1-15, pp. 2-3. From TBRC: rnam grol lam las sbyangs pa'i yon tan bstan pa" In bka' 'gyur/(li thang). TBRC W4CZ7445. 72: 384 - 402.

${ }^{298}$ Peter N. Gregory, "Tsung-Mi's Perfect Enlightenment Retreat: Ch'an Ritual During the T'ang Dynasty," Cahiers d'Extrême-Asie 7, no. 1 (1993): 115-47.Gregory also points out the connection between the Tsungmi and Zhiyi's texts: "Tsung-mi's discussion of preparatory practices (in the first fascicle) and ritual procedures (in the second fascicle) draws heavily from Chih-i's Fa-hua san-mei ch'an-i (T. $\left.n^{\circ} 1941\right)$, which offers detailed prescriptions for the performance of the three-week Lotus Samâdhi Repentance."
} 
I am not claiming here a direct influence of these works on Nupchen's Lamp (in fact, he does not quote any of these sources), but I think it is important to frame Nupchen's discussion in these first three chapters within the larger context of Buddhist discussions of various aspects important for the success of a meditation retreat. While each text reflects the very specific historical, cultural, and intellectual contexts in which they were written, all of them also reveal a continuity regarding some essential topics shared by all Buddhist traditions, such as the importance of an ideal place to practice, the importance of a strong commitment to practice, the role of the teacher, etc. Nupchen's exploration of these questions in the first three chapters of the Lamp (chapters 1-3) allow him to create the framework in which he will discuss each of the particular Buddhist traditions in the subsequent four chapters (chapters 4-7).

This chapter is divided into four parts. The first one explores chapter 1 of the Lamp, in which Nupchen offers advice for those who want to engage in meditation (how to choose the ideal place, the importance of a strong commitment to practice, how to avoid distractions, etc.). The second part focuses on chapter 2, where Nupchen offers a general overview of the contemplative techniques employed by each of the four traditions discussed in the text (Gradual, Sudden, Mahāyoga, and Atiyoga). The third part focuses on chapter 3 of the Lamp, in which Nupchen discusses what he considers to be the common element shared by all Buddhist contemplative traditions discussed in the text, i.e. the understanding of the Buddha's realization as being "non-conceptual" (Skt. avikalpa, Tib. rnam par mi rtog pa). This discussion is a key moment in the text since the centrality of this concept allows Nupchen to compare the four different traditions, while the differences in how they are interpreted will allow Nupchen to rank (organize) them. This section will also explore the possible influence of The Supreme Dharani of Entering into Non-Conceptuality (Skt. Āryāvikalpapraveśa-dhāraṇī; Tib. 'Phags pa rnam par mi 
rtog par 'jug pa zhes bya ba'i gzungs) on the structure of the Lamp. These first three chapters are very comparative in nature, and offer a taste of Nupchen's hermeneutical approach (and struggle) throughout the text, i.e. Nupchen's constant efforts asserting the unity of the Buddhist tradition regarding various aspects of Buddhist contemplation, while, at the same time, acknowledging the vast differences in how they are interpreted. I will address this tension at the core of Nupchen's classification in the fourth and final section of the chapter, where I will argue that Nupchen's Lamp reveals the contested nature of meditation in the Buddhist tradition, and uses that same contested nature in order to establish the Great Perfection as a new and separate Buddhist vehicle (Tib. theg pa) within the continuum of the Buddhist tradition. 


\section{PART 1 - Getting Ready for a Meditation Retreat: Searching for the Ideal Place,}

\section{Making a Commitment, and Removing Desires and Sorrows.}

\section{Chapter one of the Lamp offers a general overview of some of the issues any practitioner}

needs to take into account before going into retreat, such as the importance of a suitable location

for a retreat and the need of a strong commitment, as well as some advice on how to deal with

temptations and regrets while in retreat. ${ }^{299}$

Where to Meditate: Sacred Geography and the Importance of the Retreat Location

Nupchen begins his discussion of some of the issues a practitioner needs to consider

before entering retreat by discussing the importance of a suitable retreat location: "If you want to

attain the status of the Great Liberation, first, you need to search for a place [to practice]."300

\footnotetext{
${ }^{299}$ To begin a discussion regarding contemplative practices, particularly in the context of a retreat, with a consideration of the need and the importance of some basic preliminaries is quite common in Buddhist literature. The 19th century Tibetan scholar, Jamgon Kongtrul, offers in his Retreat Manual an example of a later and more systematic discussion of some of these preliminaries issues using the notion of the "eight basic resolutions" that a practitioner should take to heart before entering retreat: "In order to practice [meditation] in retreat, you must first [prepare] a proper foundation by ensuring that your intention [to meditate wholeheartedly] is irreversible." He, then, quotes the Ratnaküta Sütra in order to remind the practitioner of the eight basic resolutions that a committed meditator needs to reflect upon before a retreat: "'Kasyapa, if a fully ordained person plans to enter a hermitage [to meditate], he or she should formulate eight resolutions. What are they? He or she should resolve, "I completely renounce this body of mine. I dedicate my life completely [to this effort]. I reject any honors given to me. I renounce all attachment and desire. I will stay in a mountain retreat like a mountain goat [...]. I will stay there nourished by the instructions for spiritual life. I will not nourish myself with the obscuring emotions." These are the eight resolutions. Fully ordained persons who wish to enter a hermitage should remain there sustained by them. In brief, you should put all worldly concerns behind you and enter the retreat with the sincere intention to attain unsurpassable great awakening."' In Jamgon Kongtrul's Jamgon Kongtrul's Retreat Manual (Ithaca, N.Y.: Snow Lion, 1994). The Bhāvanākramas also have a brief discusion regarding these preliminary topics: "Now if it is asked what are the prerequisites of tranquility, they are: 1) living in an agreeable place; 2) having few desires; 3) being content; 4) abandonment of many involvements; 5) very pure moral conduct; 6) complete abandonment of thoughts connected with desires and so forth." In the second Bhāvanākrama, in Martin Adam's Meditation and the Concept of Insight in Kamalaśilla's Bhāvanākramas, PhD Dissertation (Montreal: McGill University, 2002), p. 191. Vimalamitra's Rim gyis 'jug pa'i sgom don also includes a brief discussion on this topic: "What are the prerequisites which produce quiescence? Dwelling in a suitable place, less desire for worldly objects and contentment, abandoning negative activity, right morality, and eliminating discursive thoughts such as attachment and so forth, are all prerequisites to developing quiescence.” In Vimalamitra's The Stages of Meditation, trans. Lozang Jamspal (Ladakh: Ladakhratnashridpika, 2000), p. 10.

${ }^{300}$ Lamp 5.6 "thar pa chen po'i go 'phang thob par 'dod pas / dang por gnas btsal te." Buddhaghoșa's Visuddhimagga includes a very similar discussion of these issues. For Buddhaghoșa, the ideal retreat place is the one "that has the five factors beginning with 'not too far from and not too near to' the alms resort is called favourable. For this is said by the Blessed One: "And how has a lodging five factors, bhikkhus? Here, bhikkhus, (1) a lodging is not too far, not
} 
Nupchen uses the Tibetan term gnas to refer to the location where the retreat should take place. This term is usually translated as "place," or "abode," and in religious contexts as "holy place," or "power place." Toni Huber defines gnas as "the abodes of [...] deities and spirits," and considers these places as "extraordinary because they are 'consecrated' or 'empowered' and [...] they involve specific relationships between them and persons $[. .$.$] by way of practices such as$ pilgrimage." ${ }^{301}$ In the Lamp, the "extraordinary" nature of the places discussed by Nupchen is defined by three main factors: their connection with important events in the life of the historical Buddha, their identification with Tantric sites developed by Indian Esoteric Buddhism, and their association with famous Buddhist saints.

For Nupchen, each of the Buddhist traditions discussed in the text has a different understanding of what a suitable location for meditation is. The Gradual and the Sudden traditions, which he groups together under the label "Causal Vehicle” (Tib. rgyu'i theg pa) ${ }^{302}$, suggest locations that are connected to the life of the historical Buddha:

As for the system of the Great Causal Vehicle (Tib. rgyu'i theg pa chen po), it is said in many texts that if you want to achieve the [goals of meditation], you need to search for auspicious places that have been previously [visited by] the Buddha such as the Vajra

too near, and has a path for going and coming. (2) It is little frequented by day with little sound and few voices by night. (3) There is little contact with gadflies, flies, wind, burning [sun] and creeping things. (4) One who lives in that lodging easily obtains robes, alms food, lodging, and the requisite of medicine as cure for the sick. (5) In that lodging there are elder bhikkhus living who are learned, versed in the scriptures, observers of the Dhamma, observers of the Vinaya, observers of the Codes, and when from time to time one asks them questions, 'How is this, venerable sir? What is the meaning of this?' then those venerable ones reveal the unrevealed, explain the unexplained, and remove doubt about the many things that raise doubts. This, bhikkhus, is how a lodging has five factors." These are the details for the clause, "After that he should avoid a monastery unfavourable to the development of concentration and go to live in one that is favourable." In Buddhaghosa, The Path of Purification: Visuddhimagga, trans. Bhikkhu Nanamoli (Seattle: Pariyatti Publishing, 2003), p. 120.

${ }^{301}$ Huber, "Putting the Gnas Back Into Gnas-Khor: Rethinking Tibetan Pilgrimage Practice," p. i.

${ }^{302}$ Nupchen here follows a traditional distinction between the vehicle of the cause (Tib. rgyu'i theg pa), which includes the Vehicle of the Hearers (Skt. Srāvakayāna; Tib. nyan thos kyi theg pa), the Vehicle of the Solitary Buddhas (Skt. Pratyekabuddhayāna; Tib. rang rgyal theg pa), the Vehicle of the Bodhisattva (Skt. Bodhisattvayāna; Tib. byang chub sems dpa'i theg pa), and the Vehicle of the Result (Tib. 'bras bu'i theg pa), which refers to all tantric or esoteric vehicles. In this chapter Nupchen also uses the label Vehicle of the Inner Yoga (Tib. rnal 'byor nang pa'i theg pa) to refer to the tantric vehicle. See Dudjom Rinpoche's The Nyingma School of Tibetan Buddhism: Its Fundamentals and History (Boston, Mass.: Wisdom Publications, 2002), pp. 23-39. 
Seat [Bodhgaya Tib. rdo rje'i gdan] (a place greatly blessed), Vulture Peak Mountain [Skt. Rājagṛha; Tib. bya rgod phung po] (an auspicious place for siddhas), and the Purple Willows of Khotan [Tib. Li yul]. ${ }^{303}$

The first two places mentioned by Nupchen are well known in Buddhist history: Bodhgaya is the location where the Buddha Śăkyamuni is understood to have achieved enlightenment, while Vulture Peak Mountain is the place where it is traditionally considered that the Buddha performed the Second Turning of the Wheel ${ }^{304}$ and began teaching the Perfection of Wisdom Sūtras. The mention of the "Purple Willows of Khotan" is more unusual, since it is not included as one of the places visited by the Buddha in classical sources. ${ }^{305}$ As van Schaik has pointed out, though, Khotanese sources "do indeed tell of the Buddha visiting Khotan," "306 and the fact that Nupchen accepts that fact can be seen as a small but important acknowledgement of the influence of Khotanese Buddhism during the early introduction of Buddhism in Tibet. ${ }^{307}$ We can

${ }^{303}$ Lamp 5.6-6.2 "bzhin du bor te / thar pa chen po'i go 'phang thob par 'dod pas / dang por gnas btsal te / de la gnas kyi ngo bo ji ltar btsal zhen / rgyu'i theg pa chen po'i lugs kyis kyang sngon ston pas zhabs kyis bcags pa'i rdo rje'i $<$ gnas byin che ba /> gdan dang / bya < grub pa thob pa'i gnas bkra shis pa /> rgod phung po'i ri dang / li yul lcang ra smug po la stsogs pa bkra shis pa'i gnas dag bya ba grub par byed pas btsal lo"

${ }^{304}$ In the Princeton Dictionary of Buddhism (p. 670) the Three Turnings of the Wheel of the Law (Skt. Dhammacakra pravartana; Tib. chos 'khor rim pa) are listed as: I. the dharma wheel of the four noble truths (Skt. catuh satyadharmacakra; Tib. bden pa bzhi'i chos 'khor); 2. the dharma wheel of the absence of defining characteristics (Skt. alakșanadharmacakra; Tib. mshan nyid med pa'i chos 'khor); and 3. the dharma wheel of thorough delineations (Skt. suvibhaktadharmacakra/pravicayadharmacakra; Tib. legs par rnam par phye ba'i chos 'khor).

${ }^{305}$ For a discussion of the various lists of sites associated with the Buddha, see chapter one of Toni Huber, The Holy Land Reborn: Pilgrimage and the Tibetan Reinvention of Buddhist India (Chicago: University of Chicago Press, 2008).

${ }^{306}$ Sam Van Schaik, "Red Faced Barbarians, Benign Despots and Drunken Masters: Khotan as a Mirror to Tibet," in Religions on the Silk Road, ed. Max Deeg (Lumbini: Lumbini International Research Institute, forthcoming), p. 2.

${ }^{307}$ For a discussion of the history of Buddhism in Khotan see David L. Snellgrove's Indo-Tibetan Buddhism: Indian Buddhists and Their Tibetan Successors (Boston [New York]: Shambhala, 1987). It is also interesting that of the four mentions of Khotan in Dudjom Rinpoche's History of Nyingma, three of them are connected to discussions of the Great Perfection. One in particular, in which Dudjom recounts the life of the 14th century Nyingmapa scholar, Longchenpa, is significant since it reproduces the sequence found in Nupchen's text by citing together Vulture Peak Mountain and Khotan: "When Longcenpa went to Lhasa and saw the image of Lord Śăkyamuni Buddha, a ray of light emanated from the circle of hair between the eyebrows of the image, and vanished between his own, whereupon he remembered his previous life as a scholar at Vulture Peak and in Khotan." In Dudjom Rinpoche's The Nyingma School of Tibetan Buddhism: Its Fundamentals and History (Boston, Mass.: Wisdom Publications, 2002), p. 590. Van Schaik also mentions how in one version, the Buddha flies over to Khotan "from Vulture's Peak." (p. 2) The fact that there seems to be a consistent connection, at least in some Nyingma sources between Vulture Peak 
also read the addition of Khotan in this section of the text in the context of what Toni Huber calls the "shifting terrain of the Buddha." For Huber, western scholars have "engaged upon a specific quest to locate the 'original' sites of the Buddha in India. ${ }^{308}$ In doing so, they sought to map out and anchor their fantasy of a pure 'golden age' of ancient Buddhism upon the Indian topography. ${ }^{309}$ He argues, instead, that there are different lists of sacred sites associated with the life of the historical Buddha and that these different lists are not simply anomalies, but evidence of the contested nature of these sacred sites, as well as a creative response to different historical, social, and geographical needs as Buddhism evolved and spread throughout Asia, which, in this case, include regions like Khotan and Tibet. ${ }^{310}$

Nupchen, then, proceeds to describe an alternative sacred geography, as depicted in Buddhist tantric literature, in which the practitioner can find suitable places to meditate. He

Mountain and Khotan, may indicate that some of the Khotanese Buddhist scriptures had an important influence in the early understanding of Buddhist sacred geography in Tibet. Although van Schaik humorously adds, using Huber as a source, "[L]ater, when the real location of Khotan had largely been forgotten in Tibet, the Shady Willow Grove came to be identified with one of the tantric holy sites known as pitha - pilgrimage sites in India associated with parts of the body. The place associated with Khotan was Grihadevatā, a problematic site unlocateable in India. On the divine body, Gṛhadevatā represented the anus, a rather ignominious place for the Willow Grove to end up," p. 1, n. 2. See also note 19 in this chapter.

${ }^{308}$ The Mahāparinirvāna Sütra is considered to be the classical reference for the four main Buddhist sites: "Ananda, there are four places the sight of which should arouse emotion in the faithful. What are they? "Here the Tathagata was born" is the first. "Here the Tathagata attained supreme enlightenment" is the second. "Here the Tathagata set in motion the Wheel of Dhamma" is the third. "Here the Tathagata attained the Nibanna-element without remainder" is the fourth. And, Ananda, the faithful monks and nuns, male and female lay-followers will visit those places." In Maurice Walshe's The Long Discourses of the Buddha: A Translation of the Digha Nikaya, The Teachings of the Buddha (Boston: Wisdom Publications, 1995). The places are Lumbini, in Nepal, as the site of the birth of the Buddha; Bodhgaya, the site of enlightenment; Deer Park, the location of the first teaching; and Kushinagar, as the place where the Buddha died. The last three places are all in North-India.

${ }^{309}$ In Toni Huber's The Holy Land Reborn: Pilgrimage \& the Tibetan Reinvention of Buddhist India / (Chicago: University of Chicago Press, 2008), pp. 16-17. A good example of this "fantasy of a pure golden age of ancient Buddhism" can be found in a discussion by Snellgrove of Khotanese sources that describe the visit of the Buddha to Khotan as "apocryphal traditions envisage him travelling as far as Sri Lanka in the South and even to the city of Khotan in Central Asia, but no such extravagances occur in early sources." In David L. Snellgrove's Indo-Tibetan Buddhism: Indian Buddhists and Their Tibetan Successors (Boston [New York]: Shambhala, 1987), p. 9. Italics are mine.

${ }^{310}$ Huber adds: "I would not deny that certain individual sites in India do have an ancient history of repeated, albeit often rather discontinuous, use and significance for Buddhists. However [...] it quickly becomes clear that we can no longer afford to simply consider them as a known, fixed, and long-established singular tradition, or one which might always serve as a ready and reliable reference point," p. 17. 
divides those places according to what is described in tantric scriptures, and according to what

can be found in the biographies of famous tantric practitioners:

According to the Vehicle of the Esoteric Yoga, there are [two types of locations for a retreat]: those [described] in the scriptures and tantras, and those [described] in auspicious histories. Many scriptures [suggest] searching for an excellent [location] in all cardinal directions, in forests, and great mountains. The top of the mountain should be [auspiciously] shaped like the Precious Mudra of the Tathāgata, or a lotus, a crossed vajra, a wheel, etc. These shapes have the perfect qualities for a [retreat place]. Many scriptures and tantras [also suggest] to search for pleasant [places] with auspicious birds, and melodious sounds [...] According to the auspicious histories, [you should practice in] places where, previously, many male and female scholars from Indian and Tibet achieved realization, [or in such places as] the eight charnel grounds, ${ }^{311}$ [which correspond to the five limbs, the upper, lower, and the inner organs of the Liberated Rudra $]^{312}$ the ten dwelling sites of Heruka, ${ }^{313}$ the Asura cave, ${ }^{314}$ the virtuous location of Chimpu, ${ }^{315}$ the

\footnotetext{
311 The Eight Charnel Grounds (Skt. așțamahāśmāśāna; Wyl. dur khrod chen po brgyad), according to Dudjom’s History, are "The Most Fierce (gtum-drag), Dense Thicket (tshang-tshing 'khrigs-pa), Dense Blaze (bar 'khrigs-pa), Endowed with Skeletons (keng-rus-can), Cool Forest, (bsil-bu tshal, Skt. Sitavana), Black Darkness (mun-pa nagpo), Resonant with "Kilikili" (ki-li ki-lir sgra-sgrog-pa) and Wild Cries of "Ha-ha" (ha-har-god-pa)." See Dudjom Rinpoche's The Nyingma School of Tibetan Buddhism: Its Fundamentals and History, Section 2, p. 157. Toni Huber discusses the importance of these sites in the context of the pit tha cult in Tibet: "Another important sub-division of sites in the pittha cult is that of the eight cemeteries (așta-śmaśāna). These Indian charnel grounds, well known to Tantric ascetics, were sites frequented for the purpose of performing certain meditations and rites. Symbollically they are represented as part of the vajrakāya [i.e. the complete network of twenty-four pittha sites] around the perimeter of the Samvara mandala [as found in the Cakrasamvara Tantra]." In Toni Huber, "Where Exactly Are Cāritra, Devikoța and Himavat? A Sacred Geography Controversy and the Development of Tantric Buddhist Pilgrimage Sites in Tibet," Kailash 16, no. 3 and 4 (1990): 121-64, p. 124.

${ }^{312}$ Here, in the form of an interlinear commentary, we see a clear reference to the correspondance of the outer macrocosm of specific geographic locations with the inner microcosm of the practitioner, in which the eight cemeteries are mapped out as different parts of the body. In the words of Huber: "The role of the twenty-four (or in some schemes thirty-six) Tantric sites classed as pịtha, kṣetra, chandoha, and so forth, as fully developed in the anuttarayoga-tantras is now clearly understood as being related primarily to the internal practice of yoga. In this yoga the logic of the vajra-kāya and the 'body mandala' systems is directed towards the experience of unity referred to as dạkiālasamvara in the Tantras. But the pịtha, etc., were also sites in the world considered to be presided over by certain deities in the 'geographical vajra- kāya', and as such places of gathering for an exclusive coterie of yoginīs and yoginis who followed specific Tantric practice. These were especially those who had reached the carya or 'action' phase of the Completion stage (sampannakrama) of the anuttarayoga-tantras." In Huber, "Where Exactly Are Cāritra, Devikoța, and Himavat? A Sacred Geography Controversy and the Development of Tantric Buddhist Pilgrimage Sites in Tibet," $p$. 123-24.

${ }^{313}$ The interlinear note makes clear that by Heruka the text is referring to Rudra (Tib. $r u$ dra). The connection between the myth of Rudra and the pitha cult in Tibet is discussed by Huber: "It is undoubted that the three holy mountains dedicated to Samvara, and other associated sacred places, were established at important pre-Buddhist sites which were the preserves of Tibetan autochthonous deities and their cults [...] The primary narratives which account for the conversion of these Tibetan holy places are now becoming more familiar to us: i.) The Buddhaisation 'drama' of the subjugation of Rudra/Maheśvara by Vajradhara/Cakrasamvara at the twenty-four pițha sites of the vajrakāya, and ii.) the dramas of Lama-isation which followed depicting the contests of magic at individual Tibetan locations when yogins, such as Mi-la Ras-pa and gTsang-pa rGya-ras, 'opened' these regions as sites of Tibetan Buddhist pilgramage by conquering local spirit forces, 'binding them by oath' into the services of Buddhism. These two themes are widely employed in the Tibetan pilgrimage literature." In Ibid., pp. 123-24. For the importance of the myth or Rudra in the development of tantra and of tantric geography see Jacob Dalton's "The Uses
} 
Tiger and the Lion valleys, the caves in Lhodrak Karchu, ${ }^{316}$ the Gabu Pass, Mount Tise [Kailash] and the shore of Lake Manasarovar, ${ }^{317}$ Tiger Valley, etc. ${ }^{318}$

of the dGongs Pos 'Dus Pa'i Mdo in the Development of the rNying Ma School of Tibetan Buddhism" (University of Michigan, 2002). Dalton's book, The Taming of the Demons, includes a complete translation of the Rudra myth.

${ }^{314}$ In the Princeton Dictionary of Buddhism the Asura Cave is described as a "cave south of the Kathmandu Valley in Nepal where Padmasambhava is said to have meditated and conquered the twelve bstan ma (tenma) goddesses. It is an important pilgrimage place, considered sacred by Tibetan and Newar Buddhists as well as Hindus, and the site of several Tibetan monasteries. According to the writings of one Tibetan lama, the fourth Khams sprul (Khamtrul) Rin po che, the cave may take its name from a small passage at its rear that is purported to lead to the realm of the Asuras." Prof. Jake Dalton, though, pointed out to me that there were multiple Asura caves, and that the reference in the Lamp may not be referring to the one in Nepal.

${ }^{315}$ Chimpu is the mountain behind Samye monastery and became one of the most important retreat places in Tibet. The Blue Annals has a very interesting section that highlights the importance of Chimpu during the early introduction of Buddhism in Tibet, and also offers another possible influence of Khotanese Buddhism during this early period: "In a later period, a minister of khri lde gtsug brtan discovered an inscribed copper plate in a rocky ravine at 'chims phu, on which were inscribed the words of king srong btsan: 'My nephew bearing my name with the addition of the word "lde", will spread the Doctrine of the Buddha' Khri lde gtsug brtan thinking that 'this lde must be me', built several vihāras, including that of brag dmar mgrin bzangs. He invited (Buddhist) priests who had been expelled from Li yul (Khotan), and many Buddhist monks (Ho-shang) from China. Though the king honoured the Doctrine, the Tibetans did not accept ordination," in Gos Lo-tsā-ba Gźon-nu-dpal and George Roerich, The Blue Annals (Delhi: Motilal Banarsidass, 1976), p. 40. Bold is mine.

${ }^{316}$ This is one of the sacred spots associated with Padmasambhava. It is situated in the southern Tibet in the border with Bhutan. In fact, there is a close connection among the Tibetan places listed here and what will become known as the Eight Solitary Places of Realization of Padmasambhava, which Dowman lists as (he translates gnas as "power-place") the five main sites of Guru Rinpoche: "1) Drak Yongdzong, Power-place of the Guru's Body, 2) Samye Chimpu, Power-place of the Guru's Speech, 3) Lhodrak Karchu, Power-place of the Guru's Mind, 4) Yarlung Shetak , Power-place of the Guru's Qualities, 4) Monka Nering Senge Dzong, Power-place of the Guru's Action," plus "6) Drakmar Yamalung, 7) Monka Sridzong, and 8) Paro Taktsang Puk." See Keith Dowman, The PowerPlaces of Central Tibet: The Pilgrim's Guide (London; New York: Routledge \& Kegan Paul, 1988), 289-290.

${ }^{317}$ The Princeton Dictionary of Buddhism offers a definition of Mount Kailash that makes important references to its connection to the myth of Rudra and the tantric geography of the pitha sites: "The Sanskrit name for one of the most important sacred mountains in Asia, generally referred to in English as Kailash or Mount Kailash. It is 21,778 $\mathrm{ft}$. high and is located in southwestern Tibet, not far from the current borders of India and Nepal. Lake Manasarovar is located eighteen miles to the southeast; these two sites have long been places of pilgrimage for Buddhists, Hindus, Jains, and followers of Tibetan Bon, some of whom have regarded the striking dome-shaped peak as Mount Sumeru. The mountain is particularly important in Tibetan Buddhism, where it is called Gangs dkar Ti se ('White Snow Mountain Ti se') or simply Gangs rin po che ('Precious Snow Mountain') [...] The mountain came to take on numerous tantric associations beginning in the eleventh century. According to a popular story, the yogin Mi la ras $p a$ won control of the mountain for the Buddhists by defeating a rival Bon priest, Na ro bon chung, in a contest of miracles. The mountain later became an important meditation site for the followers of Mi la ras pa [...] Both Śákyamuni Buddha and Padmasambhava are said to have visited Kailāsa. One of the most important associations of Mount Kailāsa is with the Cakrasamvvara Tantra, which names twenty-four sacred lands (pịtha) as potent locations for tantric practice. The Cakrasamvara literature recounts how long ago these twenty-four lands came under the control of Maheśvara (Śiva) in the form of Rudra Bhairava. The buddha Vajradhara, in the wrathful form of a Heruka deity, subdued Bhairava, transforming each of the twenty-four sites into a Mandala of the deity Cakrasamvara and his retinue. In Tibetan literature, Mount Kailāsa came to be identified with one of the twenty-four sites, the one called Himavat or Himālaya ('The Snowy,' or 'The Snow Mountain'); this was one of several important transpositions of sacred locations in India onto Tibetan sites," p. 1245. 
The tantras Nupchen is referring here are the Yoginitantras, such as the Cakrasamvara and the Hevajra tantra cycles, among others. According to Huber, the introduction of this corpus of tantric literature to Tibet made "Tibetan students of Tantra first acquainted with a network of Indian holy places which were totally novel for them. Indeed, these same holy places were unprecedented in the history of Buddhism itself. This unique Buddhist category of holy place was that of the pitha, literally meaning a 'seat' or 'footstool,' or also a 'raised altar' or 'mound.",319

For Huber, this new sacred geography became important in Tibet for two main reasons. The first one is that it opened up a new sacred landscape, with a new "definition and location from the pilgrimage sites of the ancient Buddhist holy land in the Middle Ganges region, which the Tibetans had already come to know and accept. [This was] an important factor in their development of a new and far more extensive, subcontinental vision of India as Buddhist holy ground." The second reason was related to the unique ontological nature of these new tantric sites since they were also reflected within the interior of the practitioner's body:

[These] external cult sites (bāhyapīṭha) of specialized pilgrimage which also had an internal (nāḍisthāna) equivalent within the yogin's body during meditational practices [...] Both external geographical sites and internal subtle locations (cakra or nāḍī) within the practitioner's body, and both are described as being 'seats of revelation' and 'places of concentration.' The Buddhist Yoginitantras discuss the pițtha as the 'abodes'-or né in

\footnotetext{
${ }^{318}$ Lamp 6.2 - 7.3: “"rnal 'byor nang pa'i theg pa'i gzhung gis kyang / gzhung dang rgyud kyi ldan pa dang / lo rgyus shis pa ste / gzhung dang ldan pa ni phyogs mtshams kyi sgros legs pa dang / snag dang ldan pa dang / ri lhun stug pa / ri'i dbyibs dang bar snang gi dbyibs de bzhin gshegs pa'i phyag rgya rin po che dang padmo dang / rdo rje rgya gram dang / 'khor lo la sogs pa spangs pa phun sum tshogs pa'i gzugs 'dra ba dang / bkra shis bya dang / snyan pa'i sgra ldan yid 'ong bcal bar rgyud gzhung du ma las bka' stsal to [...] lo rgyus shis pa yang sngar smos pa dang / rgya bod kyi mkhas pa pho mo mang po grub pa thob pa'i gnas <bgrangs kyis mi tshugs so / > dur khrod brgyad <ru dra bsgral ba'i yan lag lnga khog pa stod smad nang khrol lo $/>$ dang / a $<$ rdo rje gdan gyi rga ba na $/>$ su ra'i brag dang / mchims < bod kyi grub pa thob pa'i gnas / > phu'i dge gnas dang / stag dang seng ge lung dang / lho brag mkhar chu'i brag dang / ga bu'i rong dang / gangs ti se ma pham gyi 'gram dang / stag < ga yas ru /> lung la sogs pa de lta bu la bya'o."

${ }^{319}$ Huber, The Holy Land Reborn: Pilgrimage and the Tibetan Reinvention of Buddhist India, p. 86.
} 
Tibetan-of initiatory goddesses known as dakini and yogini who are ritually associated with and thought to be emanations of the principal Tantric deity who is the object of the meditation rite (sādhana). ${ }^{320}$

This unique dual characteristicof the pith ha sites allowed Tibetans to insert the physical landscape of Tibet within the larger network of Buddhist sacred sites. The importance of these sites is, as Huber argues, “...not only because of their long-standing popularity as pilgrimage venues and the large numbers of individual pilgrims involved in visits to them, but also because of what the Tibetan literary and oral sources concerning them can tell us about the processes which A.W. Macdonald has recently referred to as 'Budhha-isation' and 'Lama-isation' that is, the 'conversion' of Tibetan culture to a Vajrayana Buddhist one." ${ }^{321}$ Nupchen's discussion of sacred sites illustrates this transition from classical sites visited by the Buddha as found in early sources, to the later locations developed by Indian Buddhist tantra to, finally, new Tibetan sites like Chimpu or Lhodrak Karchu that signal the early steps of what Huber has called the process of reinvention of Tibet as a Buddhist Holy Land. ${ }^{322}$

\footnotetext{
${ }^{320}$ Huber, The Holy Land Reborn: Pilgrimage \& the Tibetan Reinvention of Buddhist India, p. 87. He also adds, "Morover, as if to place emphasis upon the external function and understanding of such sites, in Classical Tibetan religious language the term pịtha was translated as né (gnas), meaning 'dwelling/abode' or 'place' (from the Sanskrit sthāna), that is, the above or place of a deity or of enlightened being. It thus became synonymous with the more general term- also né (gnas)- that was used universally from about the eleventh century onward for the conventional concept of a 'holy place' of pilgrimage in Tibetan Buddhism," p. 88.

${ }^{321}$ Huber, "Where Exactly Are Cāritra, Devikoța, and Himavat? A Sacred Geography Controversy and the Development of Tantric Buddhist Pilgrimage Sites in Tibet," p. 122. He also adds: "Over the last millenium a major Buddhist pilgrimage network has developed in Tibet and Tibetan areas of the Himalaya. It is based upon the Pitha traditions found in the influential anuttarayoga-tantra cycles of Cakrasamvara, and related traditions such as the Hevajra, Vajraḍāka, Dākārṇava, and so forth," p. 121.

${ }^{322}$ He adds "Tibetan acquisition of the pit tha cult was also an important factor in their development of a new and far more extensive, subcontinental vision of India as Buddhist holy ground. Morover, the thorough appropriation of this Indian scheme as sacred geography contributed to the alternative creation of a new type of Tantric Buddhist geography in Tibet itself." In Huber's The Holy Land Reborn: Pilgrimage and the Tibetan Reinvention of Buddhist India, p. 86. Also see Jamgon Kongtrul's Jamgon Kongtrul's Retreat Manual. For a discussion of Tibetan interpretations of the dual nature of this tantric sacred places as physical locations, as well as locations within our body, pp. 41-74.
} 
Selecting a location with a strong connection to the Buddha, famous Buddhist saints, or according to tantric sacred geography, will have, according to Nupchen, very important benefits for the practitioner, who will develop "the ability to have great endurance, joyous and constant meditative experiences, and obstacles will not emerge. ${ }^{323}$

But Nupchen also has very mundane considerations in mind. As described in many Buddhist stories, ${ }^{324}$ a retreat can be a very powerful time for the spiritual development of the practitioner, but it is also fraught with danger. ${ }^{325}$ Nupchen addresses these concerns when stating some of the challenges that can affect the practitioner if the wrong place is chosen:

How do we examine the problems of the location? If the temperature of the location is not moderate [either too cold or too hot, you] will get sick. [There are problems caused] by poisonous snakes, evil local deities, and the life obstacles sent by gods and ghosts. [There are problems caused] by the difficulties of searching for goods [to support you during your retreat], and by having many unpleasant experiences. Extreme darkness can affect your mood, and extreme brightness, the barking of dogs, the loud voices of humans, and the sound of the river, can distract your mind [...] Obstacles will [also be created] by evil kings and ministers [...] It is important to eliminate those [obstacles] ${ }^{326}$

\footnotetext{
${ }^{323}$ Lamp 7.4-7.5: “de dag tu byas na 'dug sran che ba dang / nyams dga' zhing thag nye ba dang / bar chad mi 'byung ba dang / rang bzhin gyi nus pa dang ldan pa'i phyir ro." Huber begins chapter 4 of his book Holy Land Reborn with a quote from the Samvarodaya Tantra that contains very similar advice: "By resorting to pītha or upa pītha, people can become stainless. Wandering to them and examining their characteristics, one will become wise and free from conceptuality," Samvarodaya-tantra 9:25. He then comments: "Concerning the efficacy and religious benefits of ritual resort to the pitha, some texts stress that the practitioner becomes stainless, wise, and free from delusion, and also that, at these sites and in a state free from fear, special powers or attainments (siddhi) can be quickly obtained." In Huber, The Holy Land Reborn: Pilgrimage and the Tibetan Reinvention of Buddhist India, p. 87.

${ }^{324}$ See, for example, Milarepa's famous encounter with the hunters in Gtsan-smyon He-ru-ka and Andrew Quintman's The Life of Milarepa, Penguin Classics, (New York: Penguin Books, 2010). For a recent account of the worldly struggle that a practitioner has to face during a solitary retreat, see also Ani Tenzin Palmo's biography, $A$ Cave in the Snow.

${ }^{325}$ Buddhaghoșa's Visuddhimagga offers the following list of faults of a retreat place: "Herein, one that is unfavourable has any one of eighteen faults. These are: (1) largeness, (2) newness, (3) dilapidatedness, (4) a nearby road, (5) a pond, (6) [edible] leaves, (7) flowers, (8) fruits, (9) famousness, (10) a nearby city, (11) nearby timber trees, (12) nearby arable fields, (13) presence of incompatible persons, (14) a nearby port of entry, (15) nearness to the border countries, (16) nearness to the frontier of a kingdom, (17) unsuitability, (18) lack of good friends. [119] One with any of these faults is not favourable. He should not live there." In Buddhaghosa, The Path of Purification, p. 113. Buddhaghoșa is describing, though, a monastic setting for meditation, while Nupchen seems to be describing more isolated places.

${ }^{326}$ Lamp 9.4-10.2: "'o na gnas de skyon brtag pa ji lta bu zhe na / sa tsha grang ma snyoms pas nad 'jug pa dang / klu gdug (9.5) pa gnas pa dang / yul lha nag po gnas pa dang / lha 'dre'i rgyu srang du babs pas srog gi bar chad dang / yo byad shin tu btsal dka' ba dang / mchog tu nyams mi dga' (9.6) ba dang / mun gyis chod na khams 'khrug go ha cang snang yal ches pa dang / khyi sgra dang / sgye <nyan pa dang skyo ba dang rgyu 'grul khe tshol byed / > bo grol
} 
The reference to the problems caused by evil kings and ministers in this section is particularly interesting when read in the context of Tibet's history during Nupchen's time. ${ }^{327}$ As we saw in chapter one of this dissertation, the reign of King Langdarma, and the succession problems that emerged after his death, had dramatic implications for the survival of Buddhism in Tibet and, in particular, of its monastic institutions. The famous episode in Nupchen's biography of his confrontation with the rebel army in 904, which, as I have already argued, was later transformed into a direct confrontation between Nupchen and King Langdarma, also reveal the problems that emerge in the delicate intersection of the religious and the political spheres.

After having described the ideal characteristics of the retreat place according to the Causal Vehicle, Nupchen offers a discussion of the Mahāyoga and Atiyoga understanding of a contemplative site. These traditions have a different approach to the understanding of the ideal

ba'i ca co'i sgra dang / chu sgra gnas pa na sems 'phros so [...] /rgyal po gdug pa can dang / blon po gdug pa can gnas na bar chad 'ong ngo / nye na gnyen gyi cha mchus (10.2) gnod par 'gyur te g-yeng ngo / ring na dgra'i 'tshe ba 'ong bas de dag dang ldan pa ni skyon no / dgos pa ni de dag med par bya ba ste." The second Bhāvanākrama has a similar section: "In this regard, five qualities should be recognized in an agreeable place: a) it is convenient on account of food, clothing and so forth being obtained without difficulty; b) it's a good place to live on account of the absence of rough people and enemies; c) it's a healthy spot since it's a place without disease; d) there are happy friendships because one's friends there are moral and of similar perspective; e) it is praiseworthy since it is not crowded with living beings during the day and because there are few sounds at night." In Adam's Meditation and the Concept of Insight in Kamalasíla's Bhāvanākramas, p. 191. Similar to the is the section in Vimalamitra's rim gyis 'jug pa'i sgom don: "The five characteristics of a suitable place for meditation on quiescence are': 1) a place where one can easily find clothes and food; 2) where there is no wicked person or enemy; 3 ) where no contagion exists; 4) where a companion lives who is endowed with morality; and 5) a place where few people gather in the daytime and there is little noise at night." In Vimalamitra, The Stages of Meditation, trans. Lozang Jamspal (Ladakh:

Ladakhratnashridpika, 2000), p. 11. Later, he also quotes the Grhapatyugraparipraccha Sütra to offer more advice about how to select a soliraty place for a retreat: "A solitary dwelling is described in Noble Jewel Cloud [of Dharma]: One should dwell in a place neither too far, nor too close to where one begs food. The place should be where water and land are not polluted, where things are clean and pure, where there is no trouble, but many exquisite trees, flowers, leaves and fruit. There should be a cave with no harmful wild animals about, with ravines and medicinal plants, where there are no obstructions, and where it is easy to move about. It should be a comfortable, peaceful place, where one can be alone." In Ibid., pp. 49-50.

${ }^{327}$ Buddhaghoșa's Visuddhimagga also offers a discussion on this issue: "In one near the frontier of a kingdom there is fear of kings. For perhaps one king attacks that place, thinking, 'It does not submit to my rule,' and the other does likewise, thinking, 'It does not submit to my rule.' A bhikkhu lives there when it is conquered by one king and when it is conquered by the other. Then they suspect him of spying, and they bring about his undoing," p. 113. 
location for meditation, an understanding that is grounded in the dual nature of tantric sacred geography, i.e. as an external place, as well as a physical location in the body of the practitioner:

For the Great Vehicle of Esoteric [Yoga] and Atiyoga, everything [has] the nature of selfaware wisdom, free from all extremes [...] the Universe is intrinsically pure. The Secret Essence Tantra (Tib. gsang ba'i snying po) says "The ten directions of the Universe are primordially isolated," and the rMad du byung ba says "the Universe (i.e. the great thousand third-order thousand world-system), is my own home, my dwelling place, my celestial palace ${ }^{328}$

Since the actual place of practice is the body of the meditator, any physical location is a "pure place" for a retreat. Nupchen, though, ends the section dedicated to the search for the ideal place for meditation by subverting the previous discussion, and presents the Great Perfection approach, in which the practitioner is not attached to the notion of an ideal external location endowed with perfect qualities since, for the Great Perfection practitioner, the actual setting of practice is not an external location or even the body of the practitioner as in the tantric tradition, but the mind of the practitioner:

In the Commentary to the Expanse [Tib. klong 'grel], ${ }^{329}$ Vimalamitra says: "The best understanding is that the place [for a retreat should be] the mind itself. Concentration [Tib. ting nge 'dzin] and Wisdom [Tib. ye shes] are the most excellent locations [for mediation]. Do not search for an isolated hermitage: you will be shackled by the thought of [an ideal] place [for meditation]." [Also, in Vimalamitra's] Oral Instructions [it says]: "If you don't understand the isolation of the mind [as the ideal place for meditation],

\footnotetext{
${ }^{328}$ Lamp 8.2-8.4: theg pa chen po nang ba dang / shin tu rnal 'byor gyi lugs kyis / ril kyang rang rig pa'i ye shes nyid mtha' thams cad dang bral ba [...] stong gsum nyid yang dag pa'i gnas su bka' stsal to / gsang ba'i snying po las / phyogs bcu sto khams ye nas dben / zhes gsungs pa dang / rmad du byung ba las / stong gsum gyi stong chen po'i 'jig rten gyi khams 'di dag nga nyid kyi yul lo /bzhugs gnas so /gzhal yas khang ngo /" ${ }^{329}$ van Schaik thinks that "this is perhaps a commentary to the mTsho klong (Byang chub kyi sems rgya mtsho klong dgu'i rgyud, Tb.69), which is cited twice in the Atiyoga chapter. There is a commentary on the Klong drug rgyud attributed to Vimalamitra in the bKa' ma shin tu rgyas pa (vol.100) but as the root text is one of the Seminal Heart tantras which were not in circulation until the eleventh century at the earliest, this is most unlikely to be the text referred to here." In Sam van Schaik's“The Early Days of the Great Perfection," Journal of the International Association of Buddhist Studies 27, no. 1 (2004): 165-206, p. 196 n. 88.
} 
[your] mind will be like a savage wandering around the universe, or a body in an empty bedroom, like a marmot sleeping in an abandoned cave. ${ }^{330}$

\section{Making a Commitment}

When a place has been chosen, the practitioner has to make a strong commitment (Tib. dam bca') to his or her practice, leaving everything behind (family, possessions), and taking the traditional Bodhisattva vow by which all of the benefits of the practice are dedicated to all sentient beings:

Meditating continuously, without interruption, any individual belonging to a family, has to renounce to close relatives, country, family. With the discipline of a fox [the practitioner should think] "Because I am a great person who searches for the great important hermitage, first, I shall make a commitment. This great ocean of samsara has no end and it is difficult to scape, so be quick! Oh, how pitiful, since there is not enough time to liberate them I shall think of all sentient beings as if they were my children!"331

According to Nupchen, all contemplative traditions acknowledge the relevance of this commitment, but they have different understandings of it. ${ }^{332} \mathrm{He}$ does not go into details about what those differences are, and concludes this section by, again, proposing the superiority of the commitment of the Great Perfection in which the practitioner makes a commitment that has no object, and therefore, there is no danger of attachment to the result of that commitment:

\footnotetext{
${ }^{330}$ Lamp 9.1-9.4: "bi ma la'i klong 'grel las / gnas su sems nyid < dgon pa /> rtogs pa bzang / ting 'dzin ye shes mchog gi gnas / dgon pa'i dben pa mdag mi tshol /gnas kyi rtogs pas bcings par mchi / de nyid <bi ma la $>$ kyi gdams ngag las / sems la dben par ma rtogs na / dgon pa'i dben par sus phyin kyang / sems ni rmu rgod stong khams nyul /lus po nyal khang gnas stong bsrung / spang phug (')phyi ba nyal ba 'dra /zhes gsungs pa'i phyir /"

${ }^{331}$ Lamp 10.5-11.2: "dus < su sgom sgom /> nam zhig brgyu 'ga' las gdung tshab [tshob?] gyi skyes bu su zhig / snag gi gnyen 'dun dang / rgyal srid dang / khyim thabs ni wa'i brtul zhugs kyis spangs nas dgon par don chen po 'tshol ba'i mi chen pos / thog mar dam bca' ste / 'khor ba'i rgya mtsho chen po ni shin tu zad pa med de thar dkar la 'gying skyen <'gyur /> pas 'di dag las thar pa'i dus med pa ni snying re rje shes sems can thams cad bu dang 'dra bar bsam mo/"

${ }^{332}$ Lamp 12.1-12.3: "de la lta ba dang sbyar na / theg pa bzhi car du yang bcad du yod <ton / tsen / mah'a / a ni / sems can ni / don byed pa'i rtog pa mig la mi 'gal dam bca' ba la rtsod pa / $>$ na / ri zhig gtso bo'i dbang du rdzogs pa cen po'i lugs 'dir / bya ba thams cad bral lo zhe na <'dir dam bca' ba mi 'gal lam zhe na / > 'dir dam bca' ba med pa'i don rtogs na dngos po gang la'ang spang blangs med pas skyon gyis mi gos pa dpe na nam mkha' dang 'dra ba'i phyir."
} 
This commitment is not a contradiction [with Atiyoga]. Staying in [retreat] for the sake of yourself and others, [you] need to completely internalize the scriptures of each of the vehicles (i.e. Gradual, Sudden, Mahāyoga, and Atiyoga). Without altering the three doors [of body, speech and mind, you] should use your mind to practice in accordance with the view of the Dharma. Practice without interruption: there is nothing to do, nothing to stop. $^{333}$

The Preliminaries (Tib. sngon du bya ba)

The next aspect to be considered is what Nupchen calls the preliminaries (Tib. sngon $d u$ bya $b a)$. The section begins with a discussion on the importance of listening to and understanding the Buddhist teachings, as well as a brief discussion of the various forms of transmission of these teachings. The importance of language is expressed in an image that reflects on the title of Nupchen's text:

As it is said in many Sūtras, just as, initially, the one who searches for gold in the darkness relies on a lamp, the one who searches for the great meaning in the mind or [practices] meditation needs to rely on the lamp of words and letters. ${ }^{334}$

For Nupchen, "the vehicles of the cause and the result agree [about the importance] of listening [to the teachings] but they disagree regarding their meaning (of the view, meditation, conduct, and the result)." 335

What follows is a brief summary of the different forms of transmissions of the teachings across Buddhist traditions. ${ }^{336}$ From the exoteric approach of the Gradual approach, based on the

\footnotetext{
${ }^{333}$ Lamp 12.5-13.4: "dam du bca' ba'ang 'gal ba ma yin no / de nas bdag gzhan gyi don du gnas der las brtsam pa'ang theg pa so so'i <spyir bstan > mi rtog pa'i gzhung legs par khong du chud pas / sgo gsum bcos slad med par sems kyis chos lta ba dang rjes su mthun pa'i sbyod pa'ang / bya ba med bya ba mi 'gog ma chags par spyod do /"

${ }^{334}$ Lamp 13.3-13.4: "thog mar mun pa'i gser tshol ba na sgron me la brten pa 'dra bar / don chen po sems las btsal ba dang / bsgoms pa yang / tshig dang yi ge'i sgron ma la brten dgos pas / mdo sde dag las mang du yang gsungs"

${ }^{335}$ Lamp 14.6-15.1: "mnyan par bya ba ni / rgyu (15.1) 'bras theg pa kun mthun yang / don <lta sgom spyod pa 'bras bu / $>$ mthun pa ni ma yin no /de las spyir bstan $/>$ khyad par du gdams ngag rna bar brgyud pa'i man ngag thob par bya'o /"

${ }^{336}$ It is quite common in Buddhist contemplative literature to begin the path by listening and obtaining teachings from qualified teachers. In his discussion of contemplative practices in the Yogācārabhūmiśāstra, von Rospatt discusses this practice in the context of laying the foundation of meditation: "[I]n this way, the Bhāvanāmaȳ
} 
Sūtra tradition and the works of Indian scholars like Kamalaśila, ${ }^{337}$ to the patriarch tradition of Chinese Chan that began with the direct transmission of enlightenment by the Buddha to Kaśyapa, a lineage of teachings that was brought to India by Bodhidharma, and to Tibet by Hashang Mahāyāna:

The [teachings] of the Causal Vehicle were transmitted to Kaśyapa by the Bhagavān at the time of his Paranirvāna. Then, the [teachings] were transmitted to China by Bodhidharma and so forth, until it reached the seventh [patriarch] of the lineage, Hashang Mahāyāna. ${ }^{338}$

The followers of the Mahāyoga and the Atiyoga tradition search for the secret instructions (Tib. man ngag) from qualified teachers. ${ }^{339}$ In the case of Mahāyoga, those teachings involve the

Bhūmih [a text included in the main section of the Yogācārabhūmiśāstra] treats particular issues, even when they are not of inmediate relavance to the practice under consideration, because they form the basis in which the practice should be grounded [...] A good example of the foregoing is the repeated emphasis on listening to the holy dharma and receiving oral instructions. Our text refers to this theme already in the first part [...] when it mentions recourse to formal teachings of the Buddha [...] and to personal instruction [...] as a prerequisite needed for cultivating the thrity-seven factors conducive to awakening [...] and realizing the fruits of ascetic practice." In Alexander von Rospatt's "Remarks on the Bhāvanāmaȳ Bhūmih and Its Treatment of Practice," in The Foundation for Yoga Practitioners: The Buddhist Yogācārabhūmi Treatise and Its Adaptation in India, East Asia, and Tibet, ed. Ulrich Timme Kragh, Harvard Oriental Series 75 (Cambridge: Harvard University Press, 2013), 312-29. p. 856.

${ }^{337}$ Lamp 15.4: "ka m'a la shi las rim par bslab pa la sogs pa dag the tshom chod par byas te"

${ }^{338}$ Lamp 15.1-15.3: "de la rgyu'i theg pa bcom ldan 'das sku mya ngan las 'da' kar 'od srungs la gdams ngag phog / de nas dar mo dh'a ra la sogs pa nas / rgya nag por bdun rgyud tha ma ha shang mah'a ya na la thug" The Chan tradition regards Mahākāśyapa as the first of the patriarchs of a direct and uninterrupted transmission from the Buddha Śákyamuni all the way to Bodhidharma, who purportedly brought the teachings to China. Bodhidharma is considered to be the 28th or 29th Indian patriarch, depending on the sources, and the first in China. Karmay points out the interesting fact that "only the Cig car ba tradition in Tibet considers Hva-shang Mahāyāna as the 7th Chinese patriarch." In Samten Gyaltsen Karmay's The Great Perfection (rDzogs Chen): A Philosophical and Meditative Teaching of Tibetan Buddhism (Leiden; Boston: Brill, 2007), p. 93 n. 42. For a classic discussion of the various patriarchs in the Chan tradition and, in particular, the issues involving the succession of the Fifth Patriarch, see Philip B Yampolsky's The Platform Sutra of the Sixth Patriarch; the Text of the Tun-Huang Manuscript with Translation, Introduction, and Notes, Records of Civilization, Sources and Studies, No. 76 (New York: Columbia University Press, 1967). For a more modern discussion, see John R. McRae's Seeing through Zen: Encounter, Transformation, and Genealogy in Chinese Chan Buddhism (Berkeley: University of California Press, 2003). ${ }^{339}$ Here Nupchen makes a distintion between man ngag and gdams ngag. Regarding the distinction between gdams ngag and man ngag, Kapstein has this to say: "The Tibetan terms gdams ngag (Skt. upadeśa) and man ngag (Skt. $\bar{a} m n \bar{a} y a$, but sometimes also upadeśa) refer broadly to speech and writing that offer directives for practice, whether in the general conduct of life or in some specialized field such as medicine, astronomy, politics, yoga or meditation. In any of these areas, they may refer to "esoteric" instructions, i.e., advice not usually found in theoretical textbooks but derived from the hands-on experience of skilled practitioners, and thus intended primarily for those who are actually engaged in the practice of the discipline concerned. Man ngag seems often to connote a higher degree of esotericism than does gdams ngag, particularly where both terms are employed together contrastively, and despite 
"secret teachings of the Samädhi of Great Desire, the secret teachings of the Seminal Essence (Tib. thig le), and the secret teachings of the upper and lower doors." 340 The teachings of the Great Perfection involve the "secret teachings of non-activity," ${ }^{341}$ reflecting the negative rhetoric that will define the tradition during Nupchen's time.

This section offers a good example of Nupchen's writing style in the Lamp. Unlike the Visuddhimagga, a very well organized and structured text in which Buddhaghoșa discusses each of the topics related to meditation in detail, Nupchen is more concerned in the Lamp with establishing some general themes and ideas than in being precise in his discussion of the particular nuances of each of the points with which he is dealing. In this section, for example, we see Nupchen introducing an overview of the various forms of transmission of the teachings for each of the traditions discussed in the book, but he barely mentions the transmission of the gradual tradition, while he does spend some time establishing the lineage of the Chan tradition in Tibet. Also, he does not refer to any particular practice that should be obtained by the practitioner from the gradual and the sudden approaches, but makes some references to practices that should be obtained by the practitioners of Mahāyoga and the Atiyoga traditions. It almost feels as if Nupchen wrote the Lamp in a rush, and as a way to clarify to himself, as well as to his

their essential synonymity." In Matthew Kapstein's "gDams Ngag: Tibetan Technologies of the Self," in Tibetan Literature: Studies in Genre, ed. Lhundup Sopa, José Ignacio Cabezón, and Roger R. Jackson (Ithaca, N.Y: Snow Lion, 1996), p. 275.

${ }^{340}$ Lamp 15.5-15.6: "sngags nang pa la thabs <mah'a /> 'dod chags chen po'i ting nge 'dzin gyi man ngag dang / gdams ngag thig le la sogs te / steng 'og gi sgo'i man ngag dang." Donati points out that the Samādhi of Great Desire is referenced here, but is not discussed in the Mahāyoga chapter. She also points out a discussion on this type of Samādhi in the first chapter of the Guhyasamāja Tantra. In Valeria Donati's "The Lamp Is Burning Bright. Gnoseological Approaches and Soteriological Perspectives in gNubs Chen Sangs Rgyas Ye She's Masterpiece" (Università degli Studi di Napoli, 2007), p. 135, n. 41. Nupchen will discuss the Upper and Lower door practices in the chapter dedicated to the Mahāyoga tradition. The practices related to the upper doors are those connected to the subtle body, while those of the lower doors refer to sexual practices that involve the use of a consort. For a brief discussion of these doors and the practices connected to them, see Dudjom Rinpoche's The Nyingma School of Tibetan Buddhism: Its Fundamentals and History, p. 277, n.268.

${ }^{341}$ Lamp 15.6: "lhag <'bro lha bu rin chen nas bka' ma chad par bzhugs pa /> pa'i rnal 'byor <a ti / > dag la ni / ci la yang bya ba med pa'i man ngag snyan khung brgyud pa thob par bya ba ste." Nupchen will discuss the meaning of non-activity in the chapter dedicated to the Great Perfection. 
followers, some of the major issues surrounding the emergence of the Great Perfection as an independent tradition. But he did not seem to have as a goal to write a systematic treatise about it. $^{342}$ The addition of the interlinear notes also points to this issue, since they have a tendency not only to add information, but also to clarify obscure points on which Nupchen did not elaborate enough. The lack of a systematic approach can also be seen in the fact that although there is a general outline for the text, Nupchen is not always systematic in his approach to it.

Nupchen, then, gives some advice as to some of the activities any practitioner should follow before entering a retreat, such as making tsa-tsa (i.e. a votive statues), building stūpas and temples (and even bridges!), and performing tantric rituals such as fire offerings:

In brief, [the practitioner] should learn the methods of resting [the body], the methods of correcting the mind, the methods of the path of conduct, etc. in order to remove any doubts. [The practitioner] should also strive making votive statues [Tib. tsa tsa], saving the lives of small fish, ${ }^{343}$ building bridges, clearing difficult paths, building stūpas and temples, establishing large communities of ordained monks, reciting vast amounts of sūtras, acting [according to] the Great Wheel of Dharma, being a friend to those in suffering, nourishing those who are sick regardless if they are close to you or not, and being extremely generous. Regarding the great tantric vehicle, [the practitioner] should obtain many levels of empowerment, and open up the maṇalas of realization, performing extensive homa ceremonies, paying respect to monastic communities, being compassionate, establishing meditation centers, etc. ${ }^{344}$

\footnotetext{
${ }^{342}$ In this regard, the Lamp is quite different from the other important work by Nupchen that has survived, the Armor Against Darkness (Tib. Mun pa'i go cha), a large treatise in two volumes offering a lengthy and detailed commentary of the Sütra of the Gathered Intentions (Tib. mDo dgongs pa 'dus pa).

${ }^{343}$ Karmay makes the following remark regarding this particular item of the list: "The term nye' $u$ has two senses: 'small fish' and 'criminal' (Tshe-brtan zhabs-drung, Thon mi'i dgongs rgyan, mTshon sngon 1957). The word nye 'don is an abridged form of nye' $u$ 'don pa, 'to save a criminal from being punished or to save the lives of small fishes from a fisherman on account of the great number.' It has no connotation of 'muttering of formulae.' In Samten Gyaltsen Karmay's The Great Perfection (rDzogs Chen): A Philosophical and Meditative Teaching of Tibetan Buddhism (Leiden - New York: E.J. Brill, 1988), p. 95.

${ }^{344}$ Lamp 16.1-16.5: "mdor bzhag thabs dang / sems bcos thabs dang / spyod lam bya thabs la sogs pa'i the tshom bcad pa dang / s'a tstsha gdab pa dang / nye 'don dang / stong zam dang / lam 'phrang bsal ba dang / mchod rten dang gtsug lag khang bya ba dang / rab tu byung ba'i sde ba chen po bca' ba dang / mdo sde rgya chen po bklag pa dang / chos kyi 'khor lo chen po bya ba dang / sdug bsngal can gyi grogs bya ba dang / nye ring med pa'i nad bag gso ba dang / sbyin pa rgya chen po la sogs pa rlabs ci cher 'bad do / theg pa chen po sngags la ni khyad par du yang / dbang gi rim pa mang po nod pa dang / sgrub pa'i dkyil 'khor mang du zhal phye ba dang / sbyin bsreg rgya chen po bya ba dang / rab tu byung ba'i sde pa yang mohod gnas su bkur ba dang / snying rje khud pa'i zhing du bya ba dang / sgom grwa gzug pa la sogs pa la 'bad par bya'o /"
} 


\section{Eliminating Desire and Overcoming Sorrow}

Nupchen ends the first chapter with a reminder of the importance of removing worldly desires and suggestions on how to avoid worldly regrets and sorrows that may keep the practitioner still attached to the world and away from contemplative practice.

As for avoiding desires, Nupchen suggests, "[The practitioner] should remove all attachments related to food and wealth" and focus on the benefits of meditative practice. This is, obviously, easier said than done, so Nupchen suggests some ideas that will help the practitioner overcome the sorrow that may emerge after spending long periods in the isolated setting of the retreat:

If [the practitioner has] some problems after staying for a long time in the hermitage, [the practitioner] should think of the small aspects of the life in the village and other frivolous entertainment as impermanent, as suffering and extremely distracting, as meaningless and the [source of] many disputes, and as the ferment for many afflictive emotions [...] they make enlightenment a distant [goal]. ${ }^{345}$

The first chapter of the Lamp, then, offers a general overview of some of the practical aspects that a practitioner should consider before entering retreat, from the search of an ideal place, to the establishment of a strong commitment to the practice, as well as offering some advice on how to keep worldly desires at bay while avoiding any possible regrets and sorrows that would keep the practitioner distracted from achieving the goals of the retreat.

\footnotetext{
${ }^{345}$ Lamp 20.5- 21.3: de ltar thams cad la ma chags pa'i yid kyis dgon par yun bsrings te don dpyad do // gal te dgon par yun rings pas dgon pas skyon 'di ltar bsams te // grong dang 'du 'dzi'i mtshan nyid ni chung ngu na // mi rtag pa dang //sdug bsngal ba dang / rab tu 'khrug pa dang / shin tu g.yeng ba dang / don yal ba dang / rtsod pa mang ba dang / rtsod pa'i rtyur 'gyur ba dang / nyon mongs pa'i ru ma slong zhing sog pa dang / nyon mongs 'phel ba dang / [...] byang chub shin tu thag ring ba la sogs par bsam < so so mkhyes pa 'dul ba $/>$ mo //
} 


\section{PART 2 - In Retreat: On Contemplative Methods, Teachers, Consorts, Books, and}

\section{Servants.}

If chapter one deals with some of the main considerations any practitioner needs to take into account before entering into retreat, chapter two deals with some of the issues and challenges the practitioner needs to consider once in retreat, such as the various contemplative methods available to the practitioner, the most important things a practitioner should rely upon while in retreat, and the virtues of meditation as well as the problems that arise from the lack of it.

\section{The Various Contemplative Methods (Tib. thabs)}

In this section, Nupchen offers a general overview of the various contemplative methods practiced by each of the four traditions discussed in the $L a m p .{ }^{346}$ Nupchen makes a distinction between the approaches of the Causal Vehicles (Tib. rgyu'i theg pa, i.e. the Gradual and the Sudden approaches), and those of the Secret Mantra (Tib. sngags pa nang ba, i.e. Mahāyoga and Atiyoga).

The methods of the Gradual approach are those taught for the individuals of "dull qualities,"347 and are based on "the philosophical writings of the Indian Master Kamalaśīla," and the Sūtras of the Provisional Meaning (Skt. neyārthasūtra, Tib. Drang ba don gyi mdo), ${ }^{348}$ whose meaning, Nupchen adds, "are not complete / perfect," since they only partially reflect the

\footnotetext{
${ }^{346}$ Nupchen will offer a detailed discussion of the various contemplative methods in chapters 4 to 7 .

${ }^{347}$ Lamp 23.4-23.5: "rgyu'i theg pa'i lugs kyis kyang dbang po rno rtul gyi bye brag gi gnyis te // rim gyis pa dang / cig car pa'o // drang ba don gyi mdo sde yongs su ma rdzogs pa'i gzhung ngo." While the actual translation of this section does not directly designate the gradual approach for those of dull qualities and the sudden approach for those of sharp qualities, this distinction becomes clear when the whole section is read.

${ }^{348}$ The Princeton Dictionary of Buddhism explains neyārtha as "“provisional,' 'conventional'; one of the two categories (along with nītārtha, 'definitive,' 'absolute') into which the teachings of the sūtras may be classified. The terms neyārtha and nitārtha are among several sets of categories employed in the interpretation of scriptures, providing a means of accounting for statements that appear to contradict what is regarded as the Buddha's final position on a topic. The Indian schools differ on what constitutes a provisional statement, with some holding that any statement by the Buddha that cannot be accepted literally is provisional, with others holding instead that any statement that does not describe the final nature of reality is provisional."
} 
Buddhist truth. The main practice of the Gradual tradition consists of "attaining [a state of] Calm Abiding [in which you can] examine the continuum of [mental activity] and a [state of] Calm Abiding which is easy to be familiarized with."349 The Sudden approach is for those of sharp qualities, and it is based on the teachings of Hashang Mahāyāna, and in the Completely Perfected Sütras (Tib. Yong su rdzogs pa mdo). ${ }^{350}$ The main practice of the Sudden approach focuses on "attaining the familiarization methods which are free of activity into the primordial, unborn, ultimate truth., 351

Here, it is important to point out the identification that Nupchen makes of the teachings of the Gradual approach being linked with those of the Indian scholar, Kamalaśila, and those of the Sudden tradition being linked to those of the Chinese master, Hashang Mahāyāna. As it becomes clear throughout the text, the works of these two scholars, are the main source for Nupchen's understanding of the Gradual and the Sudden traditions, and it also signals how, in the Lamp, Nupchen is mainly interested in the concrete forms of those traditions as they were introduced in Tibet, more than in having an understanding of those traditions as they developed in their land of origin. This is what makes the Lamp unique as an historical document for our understanding of the introduction and assimilation of Buddhism in Tibet during the period, and also makes it so different from other doxographical classifications, including Nupchen's Armor Against Darkness, which were more interested in reflecting Indian Buddhist developments. The Lamp is trying to make sense of the historical but also of the geographic diversity of Buddhist

\footnotetext{
${ }^{349}$ Lamp 25.1-25.2: “tsen min ni thabs zhi gnas rgyud brtags pa dang / goms par <sogs pa /> sla ba'i zhi gnas pa sogs pa dag thob par byed do //"

${ }^{350}$ Lamp 24.5-24.6: “des brgyud pa'i tha ma ha shang mah'a yan gi gzhung cig car 'jug pa ste / yongs su rdzogs pa'i mdo sde'i gzhung ngo //" Here Nupchen uses "yongs su rdzogs pa'i mdo" to refer to the "nges don gyi mdo," or Sūtras of the definitive meaning (Skt.nìtārthasūtra), in clear opposition to the Sütras of the Provisional Meaning. (Skt. neyārthasūtra, Tib. Drang ba don gyi mdo) of the Gradual tradition.

${ }^{351}$ Lamp 25.2-25.3: "ston mun ni thog ma nyid nas don dam pa ma skyes pa $<$ 'o na mongs gang dang gang che ba'i gnyen por byams pa la sogs /> la bya ba med pas / goms pa'i thabs rnams thob par byad kyang / thabs ni yi na gyi de la thabs chen po zhes mi bya'o //"
} 
teachings and practices that were flourishing all across Asia, and that were competing for the attention and the patronage of Tibetans.

The Secret Mantra traditions (Tib. sngags pa nang ba, i.e. Mahāyoga and Atiyoga) use what Nupchen calls the Great Methods (Tib. thabs chen po). These Great Methods can be divided into "those with support" (Tib. rten pa'i thabs) used by the Mahāyoga tradition, and the "methods of non-activity" (Tib. bya ba'i med pa'i thabs) ${ }^{352}$ used by Atiyoga. The methods with support are divided between those that rely on listening and reflecting on the teachings (which Nupchen defines as the outer methods), and the practices that rely on the subtle body, and the use of female consorts (which Nupchen classifies as inner methods): ${ }^{353}$

The Outer Methods which rely on the path of hearing and reflection for the purpose of settling the mind, ${ }^{354}$ and the many texts [which discuss] non-objectification ${ }^{355}$

There are two [types] of Inner Methods: such as the Oral Instructions of the Samädhi which rely on the channels, the lights, and the seminal nuclei, ${ }^{356}$ such as the Four

\footnotetext{
${ }^{352}$ Lamp 25.3-25.4: "thabs chen po gang zhe na // de la'ang gnyis te / rten pa ba'i thabs dang / byed pbyaM? ba med pa'i thams so",

${ }^{353}$ Lamp 25.4-25.5: “de la rten pa'i rnal 'byor chen po'i thabs ni dper na dug nyid dpyad pas sman gyi mchog tu gyur pa ste / (25.5) de'ang phyi dang nang ngo." Kongtrul defines the difference between the "inner" and the "outer" practices as: 'Generally 'outer' (phyi) refers to the first two tantric systems of the fourfold division, that is, action and conduct tantras, because they are mostly concerned with outer physical and verbal practices such as ablution. 'Inner' (nang) refers to yoga and highest yoga tantras because they are concerned primarily with contemplation and interiority. Highest yoga tantra (rnal 'byor bla med or bla med rgyud, Skt. anuttaratantra) is said to be for recipients of the highest faculties. In the Nyingma tradition, highest yoga tantra is represented by mahāyoga, anuyoga, and atiyoga." In Jamgon Kongtrul and Sarah Harding's The Treasury of Knowledge: Book Eight, Part Four: Esoteric Instructions: A Detailed Presentation of the Process of Meditation in Vajrayana (Ithaca, N.Y.: Snow Lion Publications, 2007), p. 370, n. 2.

${ }^{354}$ Jamgon Kontrul defines these two paths as part of the "shes rab gsum: the wisdom or discernment of listening or studying (thos pa), of contemplation or reflection (bsam pa), and of familiarization or meditation (sgom pa). These three lead to the experience of certainty." In Ibid., p. 373, n. 21.

${ }^{355}$ Lamp 25.5-25.6: "phyi ni thos bsam gyi lam nas blo gzhug (bzhugs?) pa'ithabs khyad par can mang po <spyod yul dang bral bas stogs pa dang gis mi skya (skye?) bar /> dang / yi ge la brten pas mi dmigs par bya ba rtams so //de dag gi gzhung yang shis par bya'o /"

${ }^{356}$ The usual representation of the suble body includes a discussion of the rtsa / lung / thig le, or the channels, winds, and the seminal nuclei. What is remarkable in this fragment is that Nupchen substitutes the winds, or lung, for lights (Tib. 'od). Discussion of light as a consequence of the meditative experience will be an important aspect of the later Great Perfection, which will develop an alternative set of light channels (Tib. 'od rtsa) that will be an important component of the Direct Transcendence practices (Tib. thod rgal). For a discussion on the channels, winds, and seminal nuclei, see Kelsang Gyatso's Clear Light of Bliss: Mahamudra in Vajrayana Buddhism (London: Wisdom Publications, 1982), pp. 17-33. For a discussion of the Light Channels see Daniel Scheidegger's "Different
} 
Methods [the Dharmacakra, etc.] of the eight channels (which abide in the secret heart center), and those of the quintessential instructions of the body and the light at the moment of death. ${ }^{357}$ Then there are those that rely on a consort, which depend on the sun and the moon, and in searching for a woman who has all of the characteristics ${ }^{358}$ and, when found, you can gradually complete the outer methods, ${ }^{359}$ abide in the creation [stage].

Finally, the Great Perfection's methods are superior since they are the "methods of non-activity,"

although here Nupchen adds an interesting aside in which he does not completely reject the use

of the Mahāyoga methods, since they can help the practitioner achieve a more stable and

uninterrupted contemplative practice:

Question: Does the Great Perfection rely on the Inner Methods?

Answer: Although it is not the intention of the Great Perfection [to rely on those methods], from time to time [those methods are employed] since they help cut off conceptual [thinking]. ${ }^{360}$

Sets of Light-Channels in the Instruction Series of Rdzogs Chen," Revue d'Etudes Tibétaines 12 (March 2007): 33 36.

${ }^{357}$ Here, he is referring to the lights that appear during the intermediate state or bar do. Dudjom describes this process as part of the Path of Liberation (Tib. grol lam) that follows the practices of the Upper and Lower Doors, which Dudjom includes in the Path of Skilful Means (Tib. thabs lam): "Concerning the paths that are the object of this meditation, the Tantra of the [Secret] Nucleus explains: 'Through their maturation during the sequence of rebirth, The aspects of the entrance are established to be five: Because all that is substantial is intrinsic awareness, Death is [the moment of] the ultimate truth, The intermediate state before life is relative appearance, And the three phases of life are the non-dual truth.' In this way, Mahāyoga perfectly reveals the paths through which the rebirth process including death, the intermediate state and the three phases of life, is immediately purified. Now, the path which corresponds to inner radiance at the moment of death is great emptiness (stong-pa chen-po), the path which corresponds to the intermediate state [after death] is great compassion (snying-rje chen-po), and the paths which correspond to the three phases of life are the single seal (phyag-rgya gcig-pa), the elaborate seal (phyag-rgya sprosbcas) and the attainment of the mandala clusters (tshom-bu tshogs-sgrub), making five in all." In Dudjom Rinpoche's The Nyingma School of Tibetan Buddhism: Its Fundamentals and History, pp. 278-79.

${ }^{358}$ Tib. mi mo mtshan nyid tshang ba. This probably refers to the attributes of the female consort. Nupchen will discuss some of these characteristics in chapter 3 of the Lamp. The Guhyagarbha Tantra offers discussions of six different types of female consorts according to their sexual organs. Longchenpa's Treasury of the Supreme Vehicle (Tib. Theg $m c h o g ~ m d z o d$ ) has five. This is from a handout for a talk given by David Germano on October 16, 2009 at the University of Colorado as part of the "Sex and Texts: Representations of Sexuality in Asian Religious Traditions" conference.

${ }^{359}$ Lamp 25.6- 26.4: "nang gi la yang gnyis te / ting nge 'dzin gyi gdams ngag rtsa dang / 'od dang /thig le la brten pa ni gsang < snying gar > ba'i gnas su rtsa brgyad la bsgom pa'i thabs <chos 'khor la sogs pa / > bzhi dang / sku dang 'od kyyi 'da' ka'i man ngag la sogs pa mang po yod pa ste / de dag rim par rdzogs < <lob dpon la / > shing mnyes pa mchog tu byas la mtshams drag tu bcad la zhu ba dang / phag <las kyi /> rgya la brten pa ni / bla (bza?) ba dang nyi mar ldan pa'i mi mo mtshan nyid tshang ba btsal te / rnyed nas phyi'i rim pa rdzogs / bskyed pa la gnas so /gsang ba'i dbang nod de gong gi < ste sgo'i /> gdams ngag la gnas so //de brten phra ba'i las la 'jug cing brtag go //de brten nas bde ba chen po la 'jug go //

${ }^{360}$ Lamp 27.5.27.6: “'o na rdzogs chen nang pa'i thabs la brten nam zhe na //rdzogs pa chen po'i gzhung gi dgongs pa min na'ang / re zhig de dag nas brgyad pas / rtogs pa mi 'gog pa'i phyir /" 
The acceptance of subtle body practices, particularly those involving complex rituals, visualizations, and even the use of consorts, could be seen as an apparent contradiction within the context of the strong negative rhetoric against any sort of practice in the early Great Perfection, but I would argue that the rhetoric does not really reflect the complex and fluid reality of the Buddhist world of the period (or of any period, for that matter), ${ }^{361}$ in which practitioners would use a wide variety of practices, even if they would reinterpret them from the perspective of their particular tradition. ${ }^{362}$

\footnotetext{
${ }^{361}$ The 14th century Nyingma scholar Longchenpa also allows the possibility for a Great Perfection practitioner to use these tantric practices. In his Treasury of Words and Meanings (Tib. tshig don mdzod) he says: "Furthermore, it is taught that ordinary minor psychic attainments and depth contemplation (which involves the mind's stabilization) can be accomplished on the path in reliance upon the conventional catalytic seminal nuclei, yet the supreme spiritual attainment (the meditative state wherein the Reality Body and primordial gnosis naturally flow) can be made directly manifest only in reliance upon the ultimate seminal nuclei of radiant light. Since along these lines the tradition of the Great Perfection doesn't view the conventional seminal nuclei as an essential part of the spiritual path, it advocates meditation on radiant light in reliance upon the ultimate seminal nuclei. However, some individuals' psychic makeup is such that engaging the conventional seminal nuclei here (in the Great Perfection tradition) becomes necessary. In this sense, the means of meditation on the conventional seminal nuclei, reliance on a sexual consort and so forth are taught simply as kind of special method or "efficacious means" for taking care of those otherwise blocked from the Great Perfection path, so that those people obsessively addicted to the conventional seminal nuclei can circuitously enter (the path of the Great Perfection). Then, subsequently the stage of engaging the ultimate seminal nuclei is taught to such individuals." Translation by Germano from The Tantra of Unimpeded Sound as cited in the fifth chapter of the Treasury of Words and Meanings (p. 258ff). From a handout for a talk given by David Germano on October 16, 2009 at the University of Colorado as part of the "Sex and Texts: Representations of Sexuality in Asian Religious Traditions" conference. Italics are mine.

${ }^{362}$ As for the complex relation and interpenetration of these contemplative traditions during this period in Tibet, see Jacob Dalton and Sam van Schaik's "Where Chan and Tantra Meet: Buddhist Syncretism in Dunhuang," in The Silk Road: Trade,Travel, War and Faith (London: British Library Press, 2004), 61-71. Gregory makes a similar point regarding the tension between rhetoric and practice in Chan in his discussion of Tsungmi's Manual for the Cultivation and Realization of the Scripture of Perfect Enlightenment Retreat (Ch. 圆觉经道场修证义 yuan jue jing daochang xiuzheng yi). He argues, "I suspect that one of the reasons this text has not yet received the scholarly attention it deserves is that it does not fit the generally accepted picture of Ch'an's radical rejection of standard Buddhist practices. Of course there is an abundant literature of detailed ritual prescriptions in later Sung-dynasty (960-1279) Ch'an monastic regulations, but this material is often viewed as symptomatic of the decline of the creative genius and iconoclastic spirit that had animated the supposedly 'pure' Ch'an of the late T'ang, an institutional compromise with wealth and power occasioned by Ch'an's emergence as the dominant form of establishment Buddhism. I would contend, however, that Tsung-mi's ritual manual is especially worthy of study precisely because it directly calls into question one of the most commonly asserted characteristics about the early tradition. In fact, I believe that the study of this text will help relocate Ch'an within the mainstream of Chinese Buddhist monastic practice, which is the proper context in which to evaluate its radical rhetoric," p. 119.
} 
The Four Harmonious Things to Rely On (Tib. mthun po bsten pa bzhi)

This section discusses the four things a practitioner should rely on while on retreat: an experienced friend (i.e. a teacher), a female consort with all of the prescribed charateristics for the inner practices of Mahāyoga, books that are in accordance with your contemplative practice, and a pleasant servant. ${ }^{363}$ With the exception of books, here we have a good summary of the human interactions that are important for a practitioner, at all levels, for the success of a meditation retreat. The teacher offers the practitioner the contemplative techniques and advice necessary for the success of practice; a female consort ${ }^{364}$ allows him to engage in the sexual practices that are part of the tantric path (and that Nupchen has already suggested are also complementary to the Atiyoga approach), while a servant offers very practical support to the practitioner by bringing him food and all sorts of goods necessary to survive a lengthy retreat. In fact, we could even argue how the books referenced by Nupchen connect the practitioner with the teachers of the past, as if the books were able to make them present and become another pillar on which to rely during the long and solitary periods of retreat. Let's examine each of these four important components for the success of a retreat, as discussed by Nupchen.

\footnotetext{
${ }^{363}$ Lamp 30.1-30.2: "de la mthun pa bsten pa <'di lam do chus las / $>$ ni / nyams dang < sdor gnyis med spyod pa'i rgyu /> ldan pa'i grogs bsten pa dang / (30.2) nang pas mtshan dang ldan pa'i phyag rgya bsten pa dang / bsam pa dang mthun pa'i dar ma bsten ba dang / (30.3) yid du 'ong ba'i gyog bsten pa dang bzhi'o //" I have not been able to find a similar discussion centered on this topic of "four harmonious items to rely on," although Donati has noted the similarities of this passage to a discussion in the 9th century scholar, dPal gyi Ye She's Rim pa gnyis pa'i de kho na nyid sgom pa zhes bya ba zhal gyi lung: "The text is a commentary on the Guhyasamaja Tantra and devotes lengthy and detailed discussions of subtle body practices as well as practices involving female consorts. It is plausible that Nupchen could have been familiar with this text since dPal gyi Ye shes is usually considered one of the main teachers of Nupchen and he is mentioned several times in his biography." See Donati's "The Lamp Is Burning Bright. Gnoseological Approaches and Soteriological Perspectives in gNubs Chen Sangs Rgyas Ye She's Masterpiece," pp. 149-150, n. 31 and n. 34.

${ }^{364}$ The reference to the female consort seems to imply that Nupchen's audience is, mainly, male practitioners, although in the section regarding the search for an ideal retreat place, Nupchen does make a clear reference to male and female tantric practitioners: "lo rgyus shis pa yang sngar smos pa dang / rgya bod kyi mkhas pa pho mo mang po grub pa thob pa'i gnas" (Lamp 6.5).
} 


\section{The Teacher}

The first thing to rely on is the teacher, or, as Nupchen explains, "an experienced friend," (Tib. nyams dang ldan pa'i grogs; Skt. Kalyāṇa- mitratā). Nupchen is clearly focusing on the notion of a tantric lama, since he describes the ideal teacher as someone who has "meditation experience, and who has [also] obtained genuine empowerments and secret instructions." 365 Also, all of the quotations from this section are from tantric literature, including Pelyang's Vajrasattva Questions and Answers (Tib. Zhus lan), the Great Perfection text, Dynamism in Action (Tib. rTsal chen sprugs pa), and the Sütra of the Gathered Intentions. Nupchen also addresses a classic trope in Buddhist literature around the difficulties of finding a good teacher, and what a student should do, if a qualified master is not around:

If you search [for a teacher] who has good nature and profound intention, [you] will make no mistake on your path for liberation. If still you do not find a teacher with these [qualities], look for a good friend ${ }^{366}$

\footnotetext{
${ }^{365}$ Lamp 30.3-30.5: "slob dpon dgongs pa'i nyams dang ldan pa // khungs kyi dbang dang man ngag thob pa / mchog tu dgongs pa don dang 'drel bas slob bu nyams drod zin pa / sems 'chos pa la mkhas pa ste /"

${ }^{366}$ Lamp 32.3-32.5: "rang bzhin bzang la dgongs pa zab pa btsal na / thar lam la nor sa med do //de lta bu'i bla ma ma rnyed na / grogs nyams can btsal lo." The Visuddhimagga also addresses this same issue of the lack of a qualified teacher and how to deal with it: "The good friend is one who possesses such special qualities as these: He is revered and dearly loved, And one who speaks and suffers speech; The speech he utters is profound, He does not urge without a reason (A IV 32) and so on. He is wholly solicitous of welfare and partial to progress. Because of the words beginning, 'Ānanda, it is owing to my being a good friend to them that living beings subject to birth are freed from birth' (S I 88), it is only the Fully Enlightened One who possesses all the aspects of the good friend. Since that is so, while he is available only a meditation subject taken in the Blessed One's presence is well taken. But after his final attainment of Nibbána, it is proper to take it from anyone [sic] of the eighty great disciples still living. When they are no more available, one who wants to take a particular meditation subject should take it from someone with cankers destroyed, who has, by means of that particular meditation subject, produced the fourfold and fivefold jhána, and has reached the destruction of cankers by augmenting insight that had that jhána as its proximate cause," p. 94. Italics are mine. The Bhāvanākramas have a similar discussion: "If it is asked what are the prerequisites of insight, they are reliance upon excellent people, searching out learned people, and correct thinking. And what kind of excellent person should be relied upon? A learned person, clear in words, who is possessed of great compassion and able to bear misfortune. Who is the learned person sought? He is one who has honored the definitive and provisional meanings of the twelve scriptural categories of the illustrious One, and listened to them a lot. Thus in the noble Samdhinirmocanasütra it says, "Desiring noble speech, but not listening - this is a hindrance to insight." In the very same sütra it is explained, "Insight arises from the cause which is a very pure vision which (in tum) arises from listening and reflecting." And in the Nārāyanapariprcchā it is said, "One who listens becomes wise. Possessing wisdom, one comes to thoroughly pacify one's afflictions." In Adam's Meditation and the Concept of Insight in Kamalaśìla's Bhāvanākramas, p. 193.
} 


\section{The Consort}

The second element to rely on is a female consort, which, as we have seen, is a key element of the subtle body practices centered on the Lower Door in the Mahāyoga tradition:

The great yogin also relies on a female consort (Tib. phyag rgya ma) that can discriminate the virtues that emerge from the many tantras. Generally, [the female consort] acts at ease, walks with smooth steps, is dignified, has little desire for material objects, has a beautiful body, sweet smell [...] has an acute wisdom, little afflictive emotions [...] has enormous passion, little shame, and she is skilled in the particular methods of union (Tib. sbyor thabs). ${ }^{367}$

Books

The third item is books "that are in agreement with one's contemplative [practice].",368

This little section offers a great overview of some of the texts that Nupchen considers as essential

for each of the traditions:

"Regarding the harmonious Dharma [books that you should take with you to a retreat]: Kamalaśîla ['s Bhāvanākrama], [Hashang] Mahāyāna's texts on contemplation, those of the profound Inner Yoga; the kLong drug, ${ }^{369}$ the bZhi phrugs ${ }^{370}$ (whose commentary are

\footnotetext{
${ }^{367}$ Lamp 32.6-33.3: "rnal 'byor chen po pas // phyag rgya ma bsten pa yang//rgyud gzhung du ma las 'byung ba'i yon tan dang ldan pa'i rigs dbye ba <rdo rje rigs sogs gang yin pa /> dang / spyir spyod pa dal ba //'gyo na gom pa 'jam pa / brjid ldan / < gnyis pa > yul la gtogs 'dod chung zhing bzhin lus yid du 'ong ba / dri zhim pa / ngag brdzun dang khro gtum dang khra ma spangs pa / tshad pa bzlas pas mi skyo ba dang / sems zhi dal des pa //shes rab rno la nyon mongs chung ba / gdung sems che ba / gsang bar mtshan thang ba / chags pa mchog tu che ba / ngo tsha chung ba / sbyor thabs kyi bye brag la mkhas pa bsten no /." For a general discussion on female consorts in the tantric tradition, see Serinity Young's Courtesans and Tantric Consorts: Sexualities in Buddhist Narrative, Iconography and Ritual (Psychology Press, 2004).

${ }^{368}$ The Visuddhimagga instead warns about the danger of reading books since they may distract the practitioner from meditation: "Books means responsibility for the scriptures. That is an impediment only for one who is constantly busy with recitations, etc., but not for others. Here are relevant stories. The Elder Revata, it seems, the Majjhima reciter, went to the Elder Revata, the dweller in Malaya (the Hill Country), and asked him for a meditation subject. The elder asked him, 'How are you in the scriptures, friend?'- 'I am studying the Majjhima [Nikáya], venerable sir.' - "The Majjhima is a hard responsibility, friend. When a man is still learning the First Fifty by heart, he is faced with the Middle Fifty; and when he is still learning that by heart, he is faced with the Last Fifty. How can you take up a meditation subject?' - 'Venerable sir, when I have taken a meditation subject from you, I shall not look at the scriptures again.' He took the meditation subject, and doing no recitation for nineteen years, he reached Arahantship in the twentieth year. He told bhikkhus who came for recitation: 'I have not looked at the scriptures for twenty years, friends, [96] yet I am familiar with them. You may begin.' And from beginning to end he had no hesitation even over a single syllable." In Buddhaghosa., Warren, and Kosambi's Visuddhimagga of Buddhaghosâcariya, pp. 94-95.

${ }^{369}$ This text could be the Kun tu bzang po klong drug pa'i rgyud attributed to Vimalamitra, but, as Karmay pointed out, since the text is not actually quoted in the Lamp, "there is no means of verifying it." He then adds, "Klong-chen rab-'byams uses it as one of the fundamental sources in his works, e.g. Theg mchog mdzod, ff. 190a5, 300a3 et
} 
like the primordial meaning), the Six Tantras of Suchness, ${ }^{371}$ and the twenty or eighteen minor [texts of the] Mind ${ }^{372,373}$

Nupchen, clearly identifies the teachings of the Gradual and the Sudden traditions, respectively, with the figures of Kamalaśîla and Hashang Mahāyāna. As for the texts belonging to the Mahāyoga tradition, it is important to notice that Nupchen is not citing any of the classic tantric sciptures, such as the Guhyagarbha Tantra (Tib. gSang ba'i snying po) and most scholars have had actually problems locating these sources. As for the Great Perfection texts, Nupchen is referering to what will be known in the later Great Perfection traditions as the Eighteen Tantras of the Mind (Tib. sems sde bco brgyad).

passim; Tshig don mdzod ff. 4b2, 5b2, $6 \mathrm{~b} 3$ et passim." In Karmay's The Great Perfection (rDzogs Chen): A Philosophical and Meditative Teaching of Tibetan Buddhism, p. 97, n. 69. van Schaik, though, thinks that this text may be quoted in the Lamp under a slightly different name: "This is perhaps a commentary to the $m$ Tsho klong (Byang chub kyi sems rgya mtsho klong dgu'i rgyud, Tb.69), which is cited twice in the Atiyoga chapter. There is a commentary on the Klong drug rgyud attributed to Vimalamitra in the $b K a^{\prime}$ ma shin tu rgyas pa (vol.100) but as the root text is one of the Seminal Heart tantras which were not in circulation until the eleventh century at the earliest, this is most unlikely to be the text referred to here." In van Schaik's "The Early Days of the Great Perfection," p. 196.

${ }^{370}$ This is another text that I have not been able to identify. Karmay found a reference to this text in Longchenpa's gNas lugs mdzod, f. 72a "lta sgom spyod 'bras bzhi phrugs cig lhun grub tu 'byung ste/-View, contemplation, conduct and the result, the four will come naturally and simultaneously." In Karmay's The Great Perfection (rDzogs Chen): A Philosophical and Meditative Teaching of Tibetan Buddhism, p. 97, n. 70.

${ }^{371}$ Donati thinks that this commentary may "refer to the Three Outer Tantras of Kriyāyoga, Upayoga and Yoga and the Three Inner Tantras of Mahāyoga, Anuyoga and Atiyoga. This conjecture is confirmed by one passage I found in dPa' bo gtsug lag's $m$ Khas $p^{\prime} i$ dga' ston, vol. Tha, ff. 37b6-38a1; this passage, quoting a commentary to the Guhyagarbhatantra written by rGyal ba g.Yung, relates that the teachings of the Three Outer Tantras of Kriyayoga, Upayoga and Yoga and of the Three Inner Tantras of Mahayoga, Anuyoga and Atiyoga are the same as the [six kinds of] teachings regarding Thusness (de kho na nyid ston pa rnams dang don gcig go zhes rgyal ba g.yung bzhed to)." In Donati's "The Lamp Is Burning Bright. Gnoseological Approaches and Soteriological Perspectives in gNubs Chen Sangs Rgyas Ye She's Masterpiece,” p. 151 n. 36. Pawo Rinpoche's mKhas pa'i dga' ston also offers a list of old Tibetan texts that include a title of the same name by the translators Peltseg and Chokro Lu Gyaltsen: "dpal brtsegs dang klu'i rgyal mtshan gyi brgal lan bzhi phrugs" in dpa' bo gtsug lag phreng ba Pawo Tsuklak Trengwa, $A$ Scholar's Feast (chos “Byung Mkhas Pa”i Dga' Ston), TBRC W7499, n.d., Vol. 1, p. 402.

372 This is a clear reference to the early Great Perfection group of texts that will be later known as the Eighteen Tantras of the Mind Series (Tib. sems sde bco brgyad). As Kapstein points out, though, the inclusion of these texts as part of the treefold classification of the sde gsum (sems sde, klong sde, and mang ngag gi sde) "appears to originate in the tantras of the latter category and is unknown to the other systems of Rdzogs-chen. A single reference to the threefold classification in the rnam-thar of Khyung-po rnal-'byor (written c. 1140) may be the earliest reference outside the tantras themselves, and perhaps reflects later editorial intervention." In Matthew Kapstein's "The Sun of the Heart and the Bai Rgyud 'bum," Revue d'Études Tibétaines, no. 15 (2008): 275-88, p. 283 , n. 25. ${ }^{373}$ mthun < gsum pa /> pa'i dar ma ni / ka m'a la shi la dang / (33.4) mah'a yan gyi bsam gtan dang / rnal 'byor nang pa'i zab pa'i phyogs rnams dang / lhag pa'i rnal 'byor pas / klong drug dang / bzhi phrugs < gis ba 'gyel te ka don lta bu /> dang / (33.5) de kho na nyid kyi rgyud drug dang / sems phran nyi shu'am bco brgyad la sogs pa bsten no / 


\section{The Servant}

Finally, Nupchen discusses the importance of a good servant, who will help the practitioner procure all necessary food and other goods to subsist during the duration of the retreat:

As for the servant, you need to be aware of the distance of the [retreat] place. If [the place] is far, because there is the possibility of getting sick, [the practitioner] is allowed to have a second one (i.e. a separate one). If [the place] is close [the practitioner should only have] one. Vasudhara, the King of Nepal, also said: "[the servant] should be clean, have great endurance, be affectionate, speak little, be sincere and act calm [...][The servant] should not be weak, or cricital, or talk too much, be lazy or fearful, or not affectionate or like to gossip."374

In this section, Nupchen presents the retreat as, mainly, a solitary practice (with the exception of the occasional company of a female consort or the visit of a servant). There are no discussions of group rituals or activities as we find them in other retreat manuals, such as in Buddhaghoșa's Visuddhimagga, or Zongmi's Manual for the Cultivation and Realization of the Scripture of

\footnotetext{
${ }^{374}$ Lamp 33.5-34.2: “<'zhi pa /> g-yog bsten pa'ang / gnas thag ring thung dang sbyar te / ring na nad kyi bar chad 'byung srid pas zung du yang rung ngo /nye na gcig go / (ba su dh'a ra) de yang / kho brdib nogs thub pa sron che / brtse gdung ldan la smra ba nyung // gsong des zhi la bya ba bzo // brtson ldan kha ska shin tu'ang gces //srang (sran?) chung 'phyo dga' gtam mang dang // brtson med 'gabs lci nogs chung dang // sder ma snying ring kha sla can // bsten na bar chad 'byung ba'i rgyu // ldum ra'i dug bzhin rtsa nas dbyung // ces bal po'i rgyal po ba su dh'a ra gsungs so //" Von Rospatt has commented on the role of serving monks in his "Remarks on the Bhāvanāmayī Bhūmih and Its Treatment of Practice," observing the long history of servants within the Buddhist monastic tradition: "In the Vinaya-literature, the Mahāyānasūtras, and other related materials, the serving monks appear under the titles of 'caretaker' (vaiyāvṛtyakara), 'steward'(upadhivārika), and 'overseer' (karmadāna), etc. [...] Though it is difficult to define the tasks of such 'serving monks' [...] the affairs they were concerned with in general were such matters as the assignment of sleeping mats or cells, etc., and the distribution of food, robes, and other articles, which had been donated to the samgha to serve the members of the pravrajito bodhisattvah group, such as Dharmatcachers (dharmakathika), Vinaya-masters (vinayadhara), Sūtra-masters (sūtradhara), [...] and so forth. The pravrajito bodhisattvah monks, i.e., the served monks, may essentially be divided into two sub-groups, namely, the scholastic monks (dharmakathika, vinayadhara, sūtradhara, [...] etc,) and the ascetic monks (āraṇyaka, pāmsukūIika, paindapātika, etc.). In this way [...] the monastic activities of the Buddhist clergy mentioned above may be understood as consisting of three aspects: (1) meditation, (2) study, and (3) service. In an extensive list of sentient beings found in the Yogācārabhūmi [...], these activities would respectively be equivalent to those of the "striver for abandonment' (prahānika), the 'reciter'(svādhyāyakāraka), and the 'caretaker' vaiyāvṛtyakara)." In Ibid.
} 
Perfect Enlightenment Retreat, which were written with a monastic audience in mind. Even in later Tibetan literature on contemplative practices, such as the famous 19th century Retreat Manual, written by Jamgon Kongtrul, includes lengthy and detailed discussions of the importance of the rules and practices that regulate the success of a group retreat.

\section{Defeating Obstacles During Retreat and the Virtues of Meditation}

In the final section of the chapter, Nupchen offers some warnings regarding the obstacles the practitioner may face during the retreat that may affect the practice, as well as an exaltation of the virtues of meditation. The problems (i.e. defects - Tib. skyon) a practitioner may face during a retreat can be solved with the use of certain rituals, as well as with the use of some medicines:

As for the methods to reverse the [adverse] conditions [during a retreat], the Tantra of the Great $\operatorname{Nectar}^{375}$ [mentions] the dagger to revert hostile forces and obstacles, the fragant resin [Tib. gu gul], ${ }^{376}$ mustard seeds, ${ }^{377}$ etc. [Also] the many [different] medicines to revert sickness and the [various] medicine treatises, [...] and the class of mantras [to avoid] sickness. ${ }^{378}$

Here we have one of the few references to the rituals a practitioner may engage in during the retreat. Unlike in later retreat texts, such as the one by 19th century scholar, Jamgon Kontrul, Nupchen barely makes references to the ritual practices that the yogi should practice during the

\footnotetext{
${ }^{375}$ bdud rtsi chen po chos nyid gsang ba'i rgyud is a Mahāyoga Tantra in the rnying ma rgyud 'bum (gting skyes). TBRC W21518. 26: 501 - 550. Thimphu: dingo khyentse rimpoche, 1975-1975.

${ }^{376}$ Incense burned during some ritual practices.

${ }^{377}$ One of the Eight Auspicious substances (Tib. bkra shis rdzas brgyad). Tony Duff's Illuminator dictionary points out that "It is widely used in secret mantra ritual as a means of scaring off enemies and obstructors [dgra bgegs] because it has a design on its surface which is considered to resemble a weapon."

${ }^{378}$ Lamp 34.3-34.5: "rkyen bzlog pa'i thabs ni // bdud rtsi chen po'i rgyung bzhin / dgra bgegs bzlog pa'i phur bu dang / gu gul dang / lungs dkar la sogs pa dang / nad bzlog pa'i sman mang po dang / sman yig dpyad yi ga dang / sbra ba dang / gtsags dang / nad gzhi la ba'i rigs sngags khyad par can btsal zhing tshags bya'o // bar chad kyi sho gam pa bzlog pa'i go mtshon yang tshags bya'o"
} 
retreat. Here, though, we get a glimpse of some of those practices, particularly those that centered on the Vajrakillaya cycle. Cantwell writes that the Kĭlaya rituals use ritual killing (Tib. sgrol ba), particularly of "hostile forces and obstacles (Tib. dgra bgegs)", as a form of liberation. ${ }^{379}$ In the context of meditation, though, "where the object to be killed and liberated is specified simply as dgra bgegs the symbolism has the same significance: dgra bgegs are also equated with the three poisons. The bgegs - 'obstacles' — are distractions arising in meditation, while dgra are the 'hostile forces' preventing liberation [...] The object of 'vajra wrath' in ritual killing is 'discursive thought' (which creates the process) of labelling: the city of ego projections (of) subject and object." The use of Kīlaya rituals are not new to Nupchen, who famously used them to kill the rebel army, as we saw in our discussion of his autobiography, and is an important part of his iconography (see image below). ${ }^{380}$ The importance of ritual and, in particular, violent forms of ritual may not be a highlight of the Lamp, but, as we saw in our discussion of his biography, was a central element of the life and practice of all yogis, even for those of the Great Perfection who had a tendency to use negative rhetoric to dismiss any sort of activity or practice.

\footnotetext{
${ }^{379}$ Cathy Cantwell, "To Meditate upon Consciousness as Vajra: Ritual 'Killing and Liberation' in the rNying-Ma-Pa Tradition." In Tibetan Studies: Proceedings of the 7th Seminar of the International Association for Tibetan Studies, 1997, pp. 108-109.

380 "Then, taking out a wooden dagger from my robe, I gather [the protector gods] by using the life mantra of the gods, demons and those bound by the samayas. Then, I said (the mantra) "ma ra ya phat" while (facing) the mountain. The mountain started to catch fire, and the rebel army was burned and destroyed in an instant. In order to purify (myself) from this sin, I composed the Lamp for the Eye in Contemplation for the benefit of future generations. Then, although the rebellion was pacified, I suffered poverty for three years." "/de nas chos gos kyi cha nas seng ldang gi phur pa zhig bton nas/gnod sbyin dang dam can rnams kyi srog sngags kyis btab nas dril zhing /ri pha gi ma ra ya phaT/_ces brjod pas/ri la me 'bar nas kheng log byed pa'i dmag dpung rnams thul gyis tshig nas lan gcig rlag bar byas so/_/de'i sdig sbyong gi don du bsam gtan spyan sgron nyams dang bstun nas phyi rabs don du mdzad do/ de nas kheng log zhi yang lo gsum bar du dbul zhing 'phongs nas/" In gNubs chen sangs rgyas ye shes's Sangs Rgyas Ye Shes Rin Po Che'i Lo Rgyus Gnubs Kyi Bka' Shog Chen Mo (vol. 42 of the Bka' Ma Shin Tu Rgyas $\mathrm{Pa}$ ) (Chengdu: kaH thog mkhan po 'jam dbyangs, 1999), f. 22b. The image from this page is from Nupchen's biography in the Treasury of Lives $\mathrm{http}$ //www.treasuryoflives.org/biographies/view/Nubchen-Sanggye-Yeshe/4626
} 


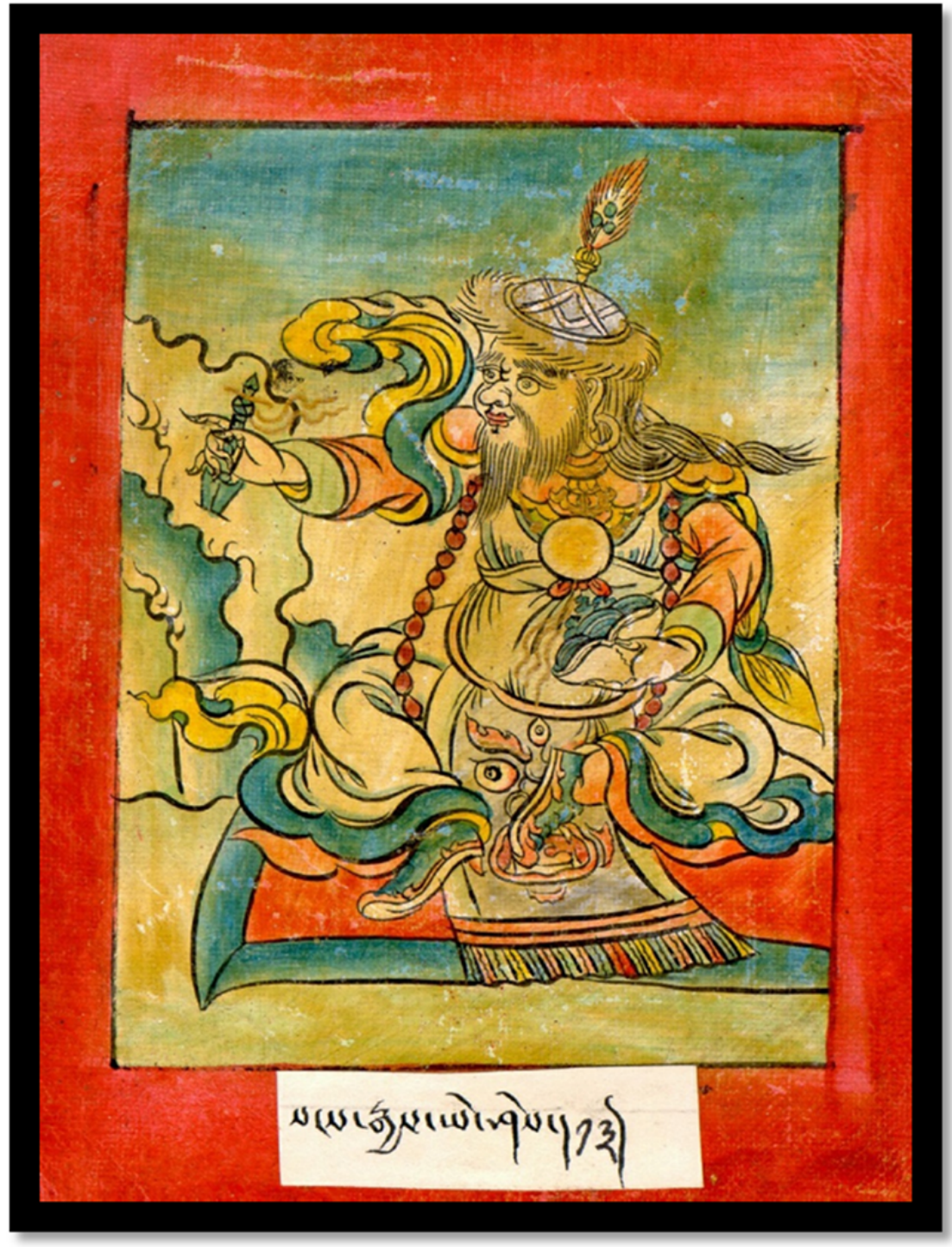

Painting of Nupchen. Source:

http://www.treasuryoflives.org/biographies/view/Nubchen-Sanggye-Yeshe/4626 
The chapter ends with an exaltation of the virtues (Tib. yon tan) of meditation, quoting from a variety of scriptures (mainly the Sütra of the Gathered Intentions, but also the Guhyagarbha Tantra, and the Mahāratnakūta Sūtra). As usual, though, Nupchen argues for the superiority of the Great Perfection approach, undermining the approaches of all other traditions by using the negative rhetoric of Atiyoga:

The Yoga Accomplishment Scripture (i.e. the Sütra of the Gathered Intentions) [says that the practitioner], through the yoga of non-activity, does not have to build stūpas, or read books, or make efigies, or perform hand mūdras and recitations [since they are all] obstructions. [The practitioner] should not do the postures of the yogic practices. ${ }^{381}$

Here we see, again, the use of the negative rhetoric of the Great Perfection to undermine all of the techniques and apporaches of other contemplative traditions. The negative rhetoric seems to function as a linguistic tool to wipe out the assertions of all other traditions, leaving an empty space in which the Great Perfection can insert itself within the overall Buddhist tradition.

${ }^{381}$ Lamp 45.1-45.5: "rnal 'byor grub pa'i lung las / bya ba med pa'i rnal 'byor pas // mchod rten dag gi las mi bya // glegs bam bklag par mi bya zhing // gzugs brnyan brtsam pa'i las mi bya // lag gi phyag rgya mi bya zhing // ngag gi bzlas pa de la sgrib // rnal 'byor lus kyis phyag mi bya // nnyed dang bkun sti lta ma yin // khe phyir ma yin grogs pyir min // ci phyir phyi rol g-yeng ba dang // shin tu g-yeng ba yin pa'i phyir // de la nye ba ma yin pas // lus 'di rnam par gnas par bya'o" 


\section{PART 3 - The Essence of Meditation: Non-Conceptualization}

In a section dedicated to taxonomy and comparison in the chapter "When the Chips are Down" of his book, Relating Religion, Jonathan Z. Smith explains how his early interests in botany and fascination with taxonomy led him directly to a concern with comparison. For Smith, “[p]ut simply, taxonomy seemed a comparative enterprise which sought similarity across obvious individual variations and which asserted significant difference even in the face of apparent resemblances." ${ }^{382}$ For Smith, comparison and classification are inseparable since "comparison is never a matter of identity. Comparison requires the acceptance of difference as the grounds of its being interesting, and a methodical manipulation of that difference to achieve some cognitive end. ${ }^{, 383}$

Smith's remarks will help us frame Nupchen's goal in chapter 3 of the Lamp, in which he compares and classifies the four Buddhist contemplative systems discussed in the text (i.e. Gradual, Sudden, Mahāyoga, and Atiyoga). Nupchen's classification implicitly acknowledges the "acceptance of difference" since, in his view (i.e. in the Buddhist view), there is place for diversity of interpretations of the Buddhist path. At the same time, Nupchen also engages in a "methodological manipulation of that difference in order to achieve a cognitive end"; in this case, to establish a hierarchy and to impose the superiority of the Great Perfection over other Buddhist traditions.

In terms of the structure of the text, chapter 3 is, without a doubt, the most important in Nupchen's Lamp. ${ }^{384}$ If chapters 1 and 2 offer a general introduction to the practice of meditation

\footnotetext{
382 Jonathan Z. Smith, Relating Religion: Essays in the Study of Religion (Chicago: University of Chicago Press, 2004), p. 20.

${ }^{383}$ Ibid., p. 20. Italics are mine.

${ }^{384}$ It is also the most studied chapter of the Lamp. See Herbert V. Guenther, “"Meditation' Trends in Early Tibet," in Early Ch'an in China and Tibet, Berkeley Buddhist Studies Series (Berkeley, Ca.: Asian Humanities Press, 1983),
} 
and chapters 4 through 7 are a detailed and individualized discussion of each of the four contemplative traditions, chapter 3 reveals the methodological rationale behind the structure of the whole text. As Dalton and van Schaik have argued, chapter 3 is "a microcosm of the text as a whole." 385

\section{The Avikalpapraveśa-dhāraṇī and "Non-conceptuality" in Tibet}

In chapter 3 of the Lamp, Nupchen, in a very systematic way, describes the methodology behind the classification that will unfold in the following chapters. For Nupchen, all Buddhist systems share something in common, which will allow him to compare and, at the same time, rank them, as their different understandings (or should we say Nupchen's interpretation of their understanding) of that which they have in common is what gives him the ability to position them. What they have in common is their acceptance of the notion of "non-conceptuality" (Skt. avikalpa; Tib. mi rtog pa) as the defining characteristic of the Buddha's enlightened experience. What sets them apart is how they approach that state (their contemplative methods; Tib. thabs), and how each tradition understands it (their philosophical views; Tib. lta ba).

Although from its very early stages Buddhism had considered the Buddha's experience of enlightenment as being a non-conceptual, non-discursive, direct experience of the nature of reality, the emphasis on identifying non-conceptuality as the defining charateristic of Buddhahood seems to have taken hold within the Indian Siddha movement. ${ }^{386}$ The notion of

351-66. See also Jacob Dalton and Sam van Schaik's "Lighting the Lamp: The Structure of the Bsam Gtan Mig Sgron," Acta Orientalia 64 (2003): 153-75. See finally Carmen Meinert's "Structural Analysis of the bSam Gtan Mig Sgron: A Comparison of the Fourfold Correct Practice in the Āryāvikalpapraveśanāmadhāraṇ̄ and the Contents of the Four Main Chapters of the bSam Gtan Mig Sgron," Journal of the International Association of Buddhist Studies 26, no. 1 (2003): 175-95.

${ }^{385}$ In Dalton and van Schaik's “Lighting the Lamp: The Structure of the Bsam Gtan Mig Sgron,” p. 157.

${ }^{386}$ Higgins, in his discussion, "On the development of the non-mentation (amanasikāra) in Indo-Tibetan Buddhism," a concept that is closely connected to the notion of non-conceptuality, argues, "The first widespread use of amanasikāra ('non-mentation') as a specific description of Buddhahood occurs within the Indian Siddha movement, although the term is not unknown in the Pali canon. The term and its Apabhramśa variant amanasiāra are associated 
"non-conceptuality" played a very important role in many of the philosophical debates about the nature of enlightenment during the period of the early introduction of Buddhism in Tibet. It was at the heart of the so-called Samye Debate, as we will see in the next chapter. A text that played a key role in the introduction of this concept into Tibet was The Supreme Dharani of Entering into Non-Conceptuality (Skt. Āryāvikalpapraveśa-dhāraṇ̄; Tib. 'Phags pa rnam par mi rtog par 'jug pa zhes bya ba'i gzungs). ${ }^{387}$ Ueyama and Meinert argue the very important role that this scripture played in the dissemination of Buddhism from Central Asia into Tibet. ${ }^{388}$ Its importance can also be seen in the influence that the text had on the thought of some of the most important figures of Tibetan Buddhism during its early stages of introduction onto the Tibetan plateau, such as the Indian scholar, Kamalaśîla, who wrote a commentary on this scripture (Tib. Phags pa rnam par mi rtog par 'jug pa zhes bya ba'i gzungs kyi rgya cher 'grel pa), ${ }^{389}$ and the Chinese monk, Hashang Mahāyāna. ${ }^{390}$ The Dunhuang manuscript, Pelliot tibétain 116 (PT 116), a text that reflects Nupchen's understanding of the Chan tradition, also quotes the text.

in particular with the mystical songs (dohā or vajragīti) of Saraha, the most famous of the early Siddhas, and a cycle of texts attributed to his commentator Maitrīpāda (aka Maitrīpa, b. 1007 or 1010) referred to in Tibet as the Yid la mi byed pa'i chos skor or "The Cycle of Teachings on Non-mentation." See David Higgins' "On the Development of the Non-Mentation (amanasikāra) Doctrine in Indo-Tibetan Buddhism," Journal of the International Association of Buddhist Studies 29, no. 2 (January 21, 2009): 255-303.

${ }^{387}$ On this article see Daishun Ueyama, Jeffrey Broughton, and Kenneth Eastman's “The Avikalpapraveśa-Dhāraṇī: The Dhāraṇi of Entering Non-Discrimination," BBK, 1983, 32-42. Also see Carmen Meinert's "Structural Analysis of the bSam Gtan Mig Sgron: A Comparison of the Fourfold Correct Practice in the Āryāvikalpapraveśanāmadhāraṇī and the Contents of the Four Main Chapters of the bSam Gtan Mig Sgron,” Journal of the International Association of Buddhist Studies 26, no. 1 (2003): 175-95.

${ }^{388}$ Meinert, "Structural Analysis of the bSam Gtan Mig Sgron: A Comparison of the Fourfold Correct Practice in the Āryāvikalpapraveśanāmadhāraņī and the Contents of the Four Main Chapters of the bSam Gtan Mig Sgron,” p. 177, and Ueyama, Broughton, and Eastman,"The Avikalpapraveśa-Dhāraņī: The Dharani of Entering Non-

Discrimination," p. 35.

389 "rnam par mi rtog par 'jug pa'i gzungs kyi rgya cher 'grel pa/." In bstan 'gyur (co ne). TBRC W1GS66030. 116: 249 - 294. [co ne dgon chen]: [co ne], [1926].

${ }^{390}$ There is also the attribution to Vimalamitra of the cig car 'jug pa rnam par mi rtog pa'i bsgom don on the issue of non-conceptuality, although the attribution of this text is still a matter of debate. On this issue see David Germano's "The Seven Descents and the Nature of sNga' 'Gyur: The 'history' of rNying Ma Tantras," in The Many Canons of Tibetan Buddhism: Piats 2000: Tibetan Studies: Proceedings of the Ninth Seminar of the International Association for Tibetan Studies (Leiden: Brill, 2000). Also see Flemming Faber's "Vimalamitra—One or Two?," Studies in Central and East Asian Religions 2 (1989): 19-26. 
In the scripture ${ }^{391}$ the historical Buddha is teaching the importance of entering into the non-conceptual (Tib. rnam par mi rtog pa) state to an assembly of bodhisattvas, and teaches a fourfold, gradual approach to achieve it in which the practitioner cuts off the marks (Tib. spong ba) of conceptual thinking (Tib. rtog pa) by not engaging in whatever thoughts appear in the mind (Tib. mngon du gyur pa dag yid la mi byes pas). ${ }^{392}$ The four different stages that will lead the practitioner to the state of non-conceptuality are: 1) perception (Tib. dmigs pa), 2) nonperception (Tib. mi dmigs pa), 3) non-perception of perception (Tib. dmigs pa mi dmigs pa), and 4) perception of non-perception (Tib. mi dmigs pa dmigs pa). Meinert describes these four stages as follows:

In the first step of "perception" one cognizes all dharmas as the manifestation of "mere cognition" (rig pa tsam), that is, all dharmas are an expression of one's own mind [...] In the second step one cognizes "non-perception" of objects, to which the ordinary apprehension generally adheres [...] In the following step of "non-perception of perception" one trains oneself in the non-perception of the perception that "mere cognition" is non-existent. Since cognition is not possible without an object, cognition itself is also impossible [...] In the final step of "perception of non-perception" one perceives neither an apprehending subject not an apprehensible object. As subject and object are not of separate natures, non-duality may be realized. ${ }^{393}$

The relevance of the Āryāvikalpapraveśa-dhāraṇi and, in particular, the importance of the notion of non-conceptuality as the essence of the enlightenment experience can be seen in the arguments of the two factions of the Samye Debate. Hashang Mahāyāna, the defender of the Chinese Chan approach, argued for a complete suppression of all mental activity in order to

\footnotetext{
${ }^{391}$ What follows is a summary of the text as described in Ueyama and Meinert.

${ }^{392}$ Ueyama, Broughton, and Eastman's “The Avikalpapraveśa-Dhāranīi: The Dharani of Entering NonDiscrimination," p. 35.

${ }^{393}$ Meinert, "Structural Analysis of the bSam Gtan Mig Sgron: A Comparison of the Fourfold Correct Practice in the Āryāvikalpapraveśanāmadhāraṇī and the Contents of the Four Main Chapters of the bSam Gtan Mig Sgron,” pp. 182-183.
} 
reach this non-conceptual state. ${ }^{394}$ Kamalaśîla, on the other hand, in his commentary to the Aryāvikalpapraveśa-dhāraṇi, as well as in various references in his Bhāvanākramas, argued against Mahāyāna's position since non-conceptuality in the Āryāvikalpapraveśa-dhāraṇī did not simply imply a complete suppression of all thoughts, or even a negative view of mental processes, as the Chinese master argued, but a gradual process in which conceptual thoughts play a role in gradually entering into a final non-conceptual state. ${ }^{395}$

This is not the place to discuss the nuances of this debate, although we will return to it briefly again in the next chapter. Here, suffice to say that the Aryāvikalpapraveśa-dhāraṇi and its notion of non-conceptuality had a very important role during the introduction of Buddhism in Tibet, influenced some of the most important philosophical debates of the period and, as we will see, its fourfold path was probably the main influence for Nupchen's fourfold doxographical classification in the Lamp.

\footnotetext{
${ }^{394}$ Ueyama argues that Hashang Mahäyāna's interpretation of non-coneptuality "took as the basic cause of birthand-death the fact that thoughts (想 xiang) grasp external objects, that is, that mental impulses arise. He held that awakening consists of cutting off the thoughts which are the cause of delusion and entering into no-examining / nothought (Ch. 不思不观). In Ueyama, Broughton, and Eastman's “The Avikalpapraveśa-Dhāranīi: The Dharani of Entering Non-Discrimination," p. 36.

${ }^{395}$ Ueyama argues that Kamalaśíla "held that to deny all thoughts (manasikāra) is to deny even the correct examining or investigation (pratyavekșā $=$ so sor rtog pa) which is necessary for arriving at non-discriminative wisdom, that is, awakening. His criticism was that subsuming the conditions for becoming a Buddha under insight alone neglects the good practices of upāya and contradicts the Mahāyanna." Ibid., p. 36. Higgins writes in his discussion of the related issue of mentation (manasikära) vs. non-mentation (amanasikära) in the Samye debate that Kamalaśîla's critique of Hashang Mahāyāna (although the Chinese master is not mentioned in the text, scholars agree that he is the recipient of Kamalaśila's criticism) "is that amanasikära does not imply the suppression or cessation of mental activity but rather its progressive refinement through the gradual elimination of subjective distortions [...] Thus, Kamalaśîla singles out mistaking amanasikāra for the absolute non-existence of manasikāra as the major misinterpretation of this concept, a point he further clarifies in his Nirvikalpapraveśadhārañi-țika [...]Conceptual meditation, in other words, is a necessary condition for non-conceptual realization.” In Higgins' “On the Development of the Non-Mentation (amanasikāra) Doctrine in Indo-Tibetan Buddhism," pp. 258-59. As we will see, in the following chapter, Gomez has defended a more nuanced understanding of Mahāyāna's positions that do include what some may call an acceptance of the gradual approach. See Luis Gomez's "The Direct and Gradual Approaches of Zen Master Mahāyāna," in Studies in Ch'an and Hua-Yen, ed. Robert M. Gimello and Peter N. Gregory (Honolulu: University of Hawaii Press, 1983).
} 
Non-Conceptuality and the Fourfold Structure of the Lamp for the Eye in Contemplation

As we saw during our discussion of the doxographical genre in Tibet in the previous chapter, Nupchen's classification in the Lamp is unusual for offering a fourfold scheme when the trend, particularly for the doxographical systems that originated in India, was towards a nine vehicle system that was able to accommodate all the new ritual and contemplative tantric innovations of the 8th and 9th centuries. ${ }^{396}$ Although the origin of Nupchen's fourfold classification scheme is still not completely clear, it seems to me that Meinert makes the strongest case when suggesting that Nupchen used the fourfold scheme of the Arryāvikalpapraveśa-dhāraṇi as a model for the one used in the Lamp. ${ }^{397}$ There is no direct acknowledgement by Nupchen of the direct influence of the Aryāvikalpapraveśa-dhāraṇi on the structure of the Lamp, but the importance of the text in the introduction of the concept of nonconceptuality in Tibet, its influence in shaping some of the main arguments in the Samye Debate, the fact that Nupchen is familiar with it, and quotes it in his text (including chapter 3), and, finally, the similarities between the fourfold schemes in both texts, ${ }^{398}$ seem to strongly suggest an influence of the text on Nupchen's classification in the Lamp. ${ }^{399}$

\footnotetext{
${ }^{396}$ This is, in fact, the doxographical approach used by Nupchen in his Armor Against Darkness (Tib. mun pa'i go cha).

${ }^{397}$ See Meinert's "Structural Analysis of the bSam Gtan Mig Sgron: A Comparison of the Fourfold Correct Practice in the Āryāvikalpapraveśanāmadhāranī and the Contents of the Four Main Chapters of the bSam Gtan Mig Sgron.” Dalton and van Schaik suggest a possible Chinese influence since scholars like the Korean scholar, Chegwan (d. 971), taught “'four methods of conversion' (hua-i): gradual (chien), sudden (tun), secret (pi mi), and indeterminate (pu-ting)."In Dalton and van Schaik's "Lighting the Lamp: The Structure of the Bsam Gtan Mig Sgron,” Ibid. p. 156.

${ }^{398}$ Non-conceptuality also plays a very important role in a text quoted by Nupchen in the Lamp, Vimalamitra's Stages of the Path: "One who wishes to dispel obscuration and quickly achieve omniscience should concentrate on achieving quiescence and insight, thereby generating the altruistic mind. I, like, a blind person, cannot demonstrate this, but relying on the words of Buddha and other scriptures, I will explain it. By right cultivation of quiescence and insight, nonconceptual intuition arises. Through the arising of this [nonconceptuality], one can abandon all obscurations and attain omniscience that is the result of the longtime practice of quiescence and insight. Therefore, one should strive for quiescence and insight. If one dwells in the state of nonconceptualization, one can see the reality of all things. It is certain that the purification of all obscuration and the achievement of omniscience is dependent upon causes; therefore, one should contemplate nonconceptualization. As one who reaches the top of a lofty mountain can see almost all the surrounding places, similarly, one who dwells in the state of
} 
Nupchen structures the Lamp around the notion of "non-conceptuality" and identifies each of the different contemplative systems he discusses in the text with a different and increasingly more subtle and refined understanding of that concept, with the gradual tradition at the bottom, and Atiyoga, or the Great Perfection, at the top: ${ }^{400}$ The Gradual tradition's goal is the non-conceptualization of appearances (Tib. snang ba mi rtog pa), the one of the Sudden approach is the non-conceptualization of non-appearances (Tib. mi snang ba mi rtog pa), the Mahāyoga tradition attempts the non-conceptualization of non-duality (Tib. gnyis su med pa'i mi rtog pa), and the Great Perfection tradition's, or Atiyoga, goal is the non-conceptualization which is spontaneously present (Tib. lhun gyis grub pa'i mi rtog pa). Let's explore how Nupchen explains each of these approaches to non-conceptuality.

\section{The Gradual Approach and "Non-conceptualizing Appearances" (Tib. snang ba mi rtog pa)}

Nupchen uses the Aryāvikalpapraveśa-dhäraṇi in order to describe methods of the Gradual approach:

As for the "tsen men" 401 Gradual approach, when [the practitioner] gradually abandons the four characteristics [which are] conceptualizing the nature, (conceptualizing the antidote, conceptualizing suchness, and conceptualizing the attainment), [the practitioner] enter into the non-conceptual [state]. The Dhäraṇi of Non-Conceptuality (i.e. Avikalpapraveśa-dhāraṇi) says: "The people who want the wish-fulfilling jewels must use their minds to excavate under the extremely solid rock in order to see them. [So when people excavate] under these rocks they [find] the three precious stones: silver, gold, and

nonconceptualization can see, all things without obstacle or impediment. Therefore, one should contemplate on quiescence and insight.” In Vimalamitra's The Stages of Meditation, p. 1.

${ }^{399}$ Although this point needs further research. As Dalton and van Schaik suggest, Nupchen seems to use the Avikalpapraveśa-dhārañi to structure the Gradual chapter, and not simply the whole text. See Jacob Dalton and Sam van Schaik, "Lighting the Lamp: The Structure of the Bsam Gtan Mig Sgron," Acta Orientalia 64 (2003): 159 n. 10.

${ }^{400}$ In this same chapter, Nupchen sketches an alternative threefold non-conceptual classification that does not develop in the text. For a brief discussion of this alternative system, see Dalton and van Schaik's "Lighting the Lamp: The Structure of the Bsam Gtan Mig Sgron."

${ }^{401}$ It is interesting to point out that Nupchen uses the Tibetan (rim gyis), as well as the Chinese term (tsen men), to designate the Gradual approach. For the Sudden school he uses both languages (Tib. cig car; Ch. ton mun). 
emeralds. Under these four very firm rocks, all of them excavate [some more] and obtain the wish-fulfilling jewel, which emerges as the perfection of everything for the sake of self and others. [Similarly those who want to reach] the non-conceptual [state] they should free themselves from the four conceptualizations: conceptualizing the nature, conceptualizing the antidote, conceptualizing suchness, and conceptualizing the attainment. If [the practitioner] meditates about suchness without creating existents (Tib. yod pa) [the practitioner] will accomplish the three characteristics." They gradually meditate on the three gates of emptiness itself, (Tib. stong pa nyid), without signs (Tib. mtshan ma med pa), and without aspirations (Tib. smon pa med pa), and they also meditate [using the techniques] of Śamatha and Vipassana ${ }^{402}$

As we have seen briefly, Kamalaśîla argued the importance of mental processes (Skt. manasikāra; Tib. yid la byed pa) and conceptual thinking (Skt. vikalpa; Tib. rtog pa) as the starting point of the meditation path. In this tradition, then, we see a gradual abandonment of the conceptualizations. $^{403}$

\section{The Sudden Approach - Non-conceptualizing non-appearances (Tib. mi snang ba mi rtog}

In the words of Nupchen, the practitioners of the Sudden approach:

\footnotetext{
${ }^{402}$ Lamp 55.6-57.1: de la tsan med rim gyis 'jug pa ni / rang bzhin (56.1) la rtogs pa'i mtshan ma la sogs ba $<$ dang gnyin po rtog pa dang / de kho na nyid la shrtogs pa dang / thob pa la rtog pa dang / > bzhi rim gyis spangs nas / mi rtog pa la 'jug pa ste / de yang mi rtog pa'i gzungs las / yid bzhin gyi nor bu rin po (56.2) che 'dod pa'i mis brag shin tu rsa zhing 'greg pa'i 'og na yid kyis rkos shig // rin po che 'di lta ste // (56.3) brag de'i 'og na / dngul rin po che dang / gser dang / rdo'i snying po'o // de dag la rin po che'i brag gsum // brag shin tu sra ba dang bzhi'i 'og nas / de yo brkos (56.4) pa dang / yid bzhin nor bu bdag dang gzhan don thams cad rdzogs par 'byung ba 'thob pa de bzhin tu / rnam par mi rtog pa 'dod pas / rang bzhin la rtog pa'i mthan (56.5) ma dang / gnyen po la rtog pa'i mtshan ma dang / de kho na nyid la rtog pa'i mtshon ma dang / thob pa la rtog pa'i mtshan ma de bzhi dang bral bar byas nas / mtshan (56.6) ma gsum po la de kho na yis yod la ma byas par bsgom na 'grub bo // zhes gsungs pas / rim par bsgom pa dang / gzhan stong pa nyid dang / mtshan (57.1) ma med pa dang / smon pa med pa'i sgo gsum rim par bsgom pa dang / zhi gnas lhag mthong la sogs pa bsgrom pa'o //

${ }^{403}$ Nupchen describes it as a process in which the three types of conceptualization are gradually abandoned. These three types of conceptual discrimination (trivikalpa) are described in the Princeton Dictionary of Buddhism as: “(1) Intrinsic discrimination (svabhāvavikalpa), which refers to the initial advertence of thought (vitarka) and the subsequent sustained attention (vicāra) to a perceived object of the six sensory consciousnesses (vijñāna), that is, the discrimination of present objects, as when visual consciousness perceives a visual object. (2) Conceptualizing discrimination (abhinirūpanāvikalpa), which refers to discursive thought on ideas that arise in the sixth mental consciousness when it adverts toward a mental object that is associated with any of the three time periods of past, present, or future. (3) Discrimination involving reflection on past events (anusmaranavikalpa), which refers to discriminative thought involving the memory of past objects."
} 
...enter [into the non-conceptual state] instantaneously. From the beginning, without alternating [methods] they train in the unborn ultimate [...] The entrance gate to the Sudden approach has been explained by many teachers [such as] the Great Master Bodhidharma, who said "Turn in the correct direction and abandon conceptuality. When you remain in wall-gazing and there is no self and other. Common people and noble ones are one and the same. When abiding steady, without moving, from then on, [you] will not go after words and teachings. [You] will abide in the state of the true meaning, where there is no-conceptualization, and no activity. ${ }^{404}$

The superiority of the Sudden over the Gradual is, according to Nupchen, based on the acknowledgment of the superiority of non-conceptuality over conceptuality as the starting point of contemplation. The problem, though, as Guenther pointed out, is that the Sudden approach still "emphasizes the non-thematic [i.e. non-conceptuality] over and against the thematic [i.e. conceptuality] without realizing that experience is made up of both, the thematic and the nonthematic." ${ }^{405}$ Also, Nupchen critizices the Chinese Sudden tradition since, in their efforts to distance themselves from any type of conceptuality (and therefore, separate themselves from the Gradual approach), they seem to have reified the idea of non-conceptuality almost without noticing it. ${ }^{406}$ As Guenther argues, "To speak of something as never having come into existence

\footnotetext{
${ }^{404}$ Lamp 57.1-58.2: "ston mun ni cig car (57.2) 'jug pa ste / dang po nas re mos pa med par don dam pa ma skyes pa nyid la cig car slob te / shes rab kyi pha rol du phyin pa'i mdo las // dang po sems bskyed pa (57.3) nas rnam pa thams cad mkhyen pa nyid la yid bya'o // [...] mkhan <gzhung bstan /> po chen (57.6) po bo dhe dar mo ta ras bshad pa las / yang dag pa la phyogs shing rtogs pa spangs te / lham mer gnas na / bdag kyang med gzhan yang med / ma (58.1) rabs dang 'phags pa mnyam zhing gcig ste / mi 'gyur bar brtan par gnas na / de phan chad yi ge dang bstan pa'i rjes su mi 'brang ngo // 'di ni yang dag (58.2) pa'i don gyi rnal du phab pa rnam par rtog pa med pa / zheng zhing bya ba med pa ste / de ni don la mi 'jug pa'o //"

${ }^{405}$ Guenther, “'Meditation' Trends in Early Tibet,” p. 356.

${ }^{406}$ In the chapter dedicated to the Mahāyoga tradition Nupchen criticizes the Sudden tradition for thinking that their view if "free from activity," but theirs is only a partial understanding of that concept, since it is not grounded in the superior non-dual view of Mahāyoga: "tshe de nyid la dbang bsgyur chen por 'gyur ba dang 'dra ste / ston mun dang (226.6) nga lta bas bya ba dang bral ba skad zer yang / theg pa chen po gnyis su med pa'i de bzhin nyid / mtha' yang ma mthong ste / don dam pa 'ba' zhig la mi stsol du zad de / (227.1) 'jag pa non bgrong pa mthar phyin nas de bzhin gshegs pas dbang bskur nas bzod rdo rje lta bu gnyis med shar nas sngags mthong ba dang / (227.2) de bzhin du da lta blo la brtan par cud zhig 'dug du ma btub kyang / gnyis su med pa rdo rje lta bu'i ye shes la slob pas / tshe 'di nyid la mthar thug pa'i phyir rol kyang (227.3) mi 'byi char yang mi phod de / de ni lta ba'i don gzhi nas khyad par du 'phags pas rgyu'i theg pas thob pa'i byang chub sems dpa' nyid / 'dir dang po sems bskyed pas (227.4) zil gyis gnon
} 
is to have a concept of something, to which we may make attributions. This is precisely to be

back in the thematic aspect of experience, and this the follower of the 'instantaneous' [i.e. Sudden] approach will not admit.",407

\section{Mahāyoga - Non-conceptualization of non-duality (Tib. gnyis su med pa'i mi rtog pa)}

The Mahāyoga tries to break free from this tension between conceptuality and nonconceptuality by embracing the non-dual nature of reality in which those distinctions disappear:

As for inner non-conceptual Thusness, the Mahāyoga tradition [proposes] that all phenomena have the radiance of intrinsic awareness [and therefore], the two truths do not exist, the agent does not act [upon phenomena], and it becomes luminous [naturally]. [All phenomena] is the non-dual sphere of wisdom. The Guyagarbha tantra says, "The object of meditation is not an objext, the activity of meditation is not meditation, therefore, because objects do not exist, there is no object of reference in meditation., ${ }^{, 408}$

But as Guenther argues in his interpretation of Nupchen's presentation of Mahāyoga's approach to non-conceptuality: "It is precisely this attempt to preserve the unitary [i.e. non-dual] character of experience as an interiority in which there is neither a 'within' nor a 'without' that prevents the experience from coming to grips with that spontaneity [of] pure experience. ${ }^{, 409}$ For Guenther, both the Gradual and Sudden traditions have an ontological approach to contemplation in which the practitioner objectifies reality during the practice of meditation. The Mahāyoga tradition is aware of that pitfall and focuses on non-duality, but it its effort to preserve that non-dual nature

par gsungs yang / sems dang po skyes pa nas gnyis su med pa'i don la sems bskyed pas / stobs de las gyur pa ste / zhib tu phyis 'chad (227.5) do /"

407 Guenther, “"Meditation' Trends in Early Tibet,” 1983., p. 357.

${ }^{408}$ Lamp 59.3-59.6: "nang pa'i mi rtog pa de bzhin nyid ni / mah'a yo ga'i gzhung gis / chos thams cad ni rang rig par gsal ba nyid bden pa gnyis med pa / byed pa pos ma byas pa dang / yong gis 'd gsal ba / dbying ye shes gnyis su med pa ste / gsang ba 'dus pa las / dngos po bsgom pa med pa'i dngos // bsgom par bya ba bsgom pa med // de ltar dngos po dngos med pas // bsgom pa dmigs su med pa'o // zhes gsungs pas"

409 Guenther, "“Meditation' Trends in Early Tibet," p. 360. 
of the meditative experience, it does not leave space for the acknowledgement of the spontaneous and dynamic nature of reality.

Atiyoya - Non-conceptualizition [which is] spontaneously present (Tib. lhun gyis grub pa'i mi rtog pa).

Finally, Atiyoga, or the Great Perfection, offers the supreme understanding of nonconceptuality, "non-conceptuality which is spontaneously perfect" (Tib. lhun gyis grub pa'i mi rtog pa):

As for the spontaneous perfected Thusness of Atiyoga, the Supreme Yoga, all appearing and existing phenomena are primordially self-radiant since they remain perfect in the perfectly pure sphere of self-emergent wisdom. As for the cause and the result, which are spontaneously perfected without any need to search [for them], this is the Great Self, where there is no movement, no particles, no names. So what is to meditate in the clear radiance where there is an intrinsic awareness that it is not established, does not wave, it is not tainted, does not settle? What is there to recollect? There is nothing [...] Nonconceptuality is itself a [mere] concept. ${ }^{410}$

Here, the non-dual approach of the Mahāyoga tradition is superceded by an understanding of reality in which everything is spontaneously perfect, and therefore there is no need for any effort or practrice to reach the stage of non-conceptuality.

\footnotetext{
${ }^{410}$ a ti yo ga lhag pa'i rnal 'byor gyi lhun rdzogs de bzhin nyid ni // snang srid gyi chos so cog rang byung gi ye shes rnam par dag pa'i (60.3) klong du sel med par ye nas rang gsal ba la // rgyu dang 'bras bu ril ma btsal bar lhun gyis rdzogs pa ni / bdag nyid chen po pas / de la g-yo rdul ming (60.4) yang med pas / rang rig pa ma bzhag ma g-yos ma bslad ma zhugs par lhan ne lhang nge ye gsal bar ci zhig bsgom / ci zhig dran par byar yod de med / (60.5) med pa'i don de nyid kho na yod / de dang du len pa su zhig ste / ye mi rtog pa chen po la / snang ba bkag pa yang med la / de la rtogs pa med de / mi rtog pa (60.6) nyid kyang bla dwags so // khyung chen las / snang ba rgya mtsho chen po bzhin // mi rtog nam mkha'i mkha' ltar yangs // zhes gsungs so
} 


\section{Comparisson, Classification, and the Creation of Tradition}

The correlation of Nupchen's system with the fourfold presentation of non-conceptuality in the Aryāvikalpapraveśa-dhāraṇī can be seen in the following chart:

Chart 1 - The Lamp for the Eye in Contemplation and the Āryāvikalpapraveśa-dhāraṇ̄

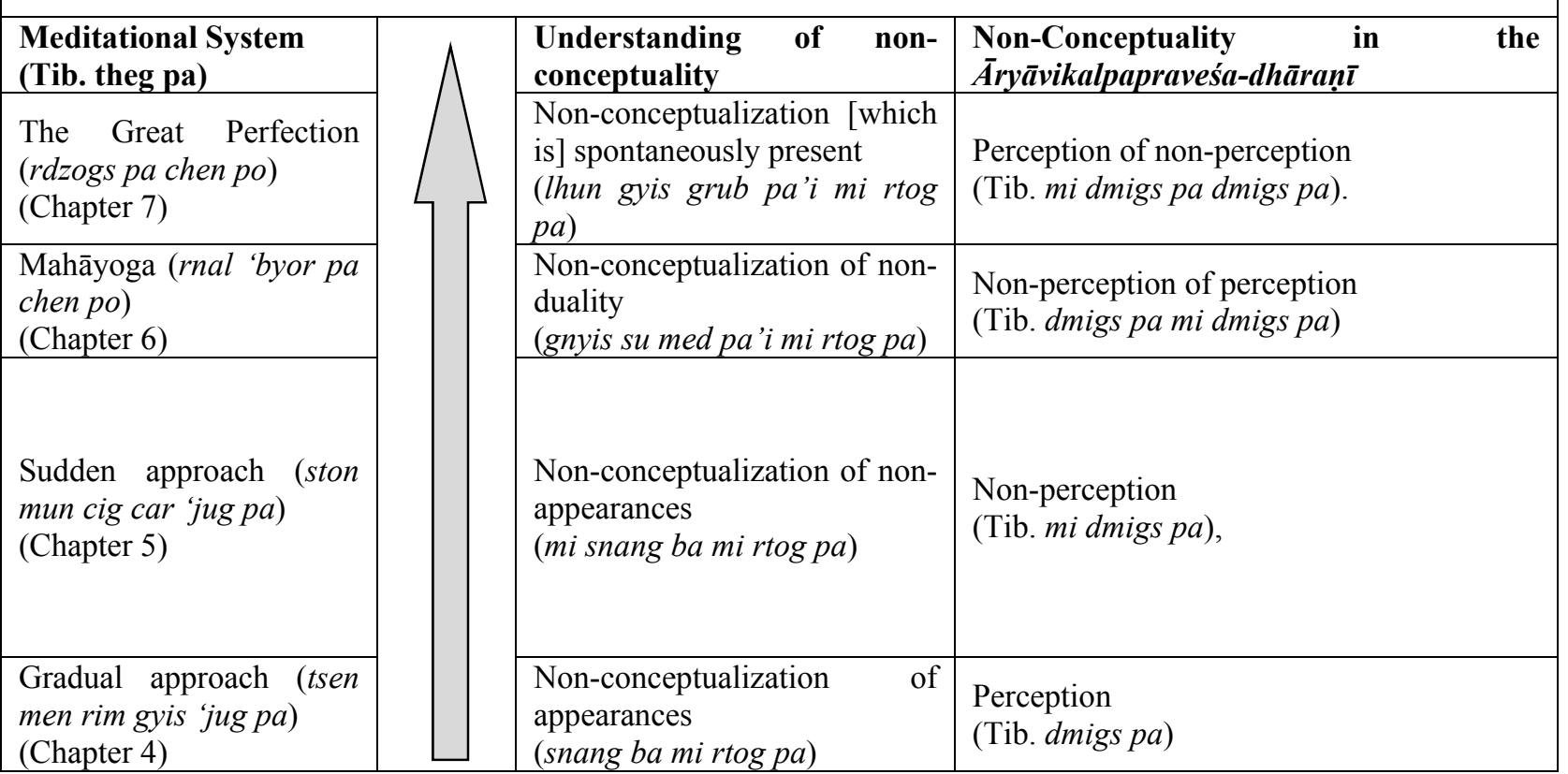

Nupchen clearly indicates that the four traditions articulate a gradual path in which the practitioner could follow in stages the contemplative techniques of each of the traditions in order to achieve the supreme form of non-conceptuality, that of the Atiyoga tradition. He seems to insinuate as much in the text when he claims that:

The differences between these [contemplative systems] are like the rungs of a ladder. Just as a ladder has higher and lower rungs, so are the differences between these four non-conceptualizations [of the Gradual, Sudden, Mahāyoga, and Atiyoga traditions]. ${ }^{411}$

${ }^{411}$ Lamp 60.6-61.1: “de dag gi khyad par skas gyi gdang bu bzhin te / dper na skas gdang la mtho dman yod par dang 'dra ste / mi rtog pa 'di bzhi yang khyad par yod < ston tsen mah'a a ti / $>/ /$." The same notion is repeated in the 
But there is also an important tension at the core of the system. The overall gradual message implied with the image of the ladder resonates with the approach presented in the Áryāvikalpapraveśa-dhāraṇi. The problem, though, emerges when Nupchen attaches each of the stages of non-conceptuality to a different Buddhist contemplative tradition. While all Buddhist traditions as described by Nupchen may share this notion of non-conceptuality, none of those traditions, besides the Great Perfection, to which Nupchen belongs, would agree with Nupchen's portrayal of their understanding of it, and they would, most certainly, not situate themselves in positions of inferiority vis-à-vis other traditions. They are all, from their respective points of view, perfect and complete contemplative systems, and it is only in the context of Nupchen's project that other systems are demoted. This tension is also accentuated by the fact that througout the text Nupchen continuously undermines the idea of a gradual approach to his overall system when he keeps dismissing all of the traditions with the exception of the Great Perfection, criticizing their approaches in each of the chapters.

Here, I would like to bring back Jonathan Smith's ideas in order to address the inherent tension in Nupchen's system (and of all doxographies for that matter). In the first place, Smith can help us understand the constructed nature of Nupchen's classification. For Smith, "Comparisons are not a given, they are the result of thought...comparison does not necessary tell us how things 'are'...like models and metaphors, comparisons tells us how things might be redescribed." ${ }^{412}$ Under this different interpretation of comparison and classification, The Lamp

final colophon of the text in Lamp 500.4: "tsen ston mi dmigs nang pa'i mi rtog de bzhin nyid // lhun rdzogs mi rtog khyad par skas bzhin chud par bya'o //" Bold and italics are mine.

${ }^{412}$ Ibid., pp.23-24. 
for the Eye in Contemplation is not describing Buddhism during Nupchen's time as existing "out there," but offering a model of what Buddhism in Tibet could have been. ${ }^{413}$

Secondly, for Smith, comparisons

...bring differences together within the space of the scholar's mind for the scholar's own intellectual reasons [...] Comparison provides the means by which we're-vision' phenomena as our data in order to solve our theoretical problems. Comparison, as seen from such view, is an active, at times even playful, enterprise of deconstruction and reconstruction which gives the scholar a shifting set of characteristics with which to negotiate the relations between his or her theoretical interests and data stipulated as exemplary. ${ }^{414}$

The notion of non-conceptuality allows Nupchen to bring together these four different traditions "within the space of the scholar's mind for the scholar's own intellectual reasons." These intellectual reasons can be seen as twofold. On the one hand, Nupchen wants to make sense of the variety of Buddhist contemplative systems that had made their way into Tibet up until his own time. On the other hand, he wants to establish the superiority of his own contemplative tradition, the Great Perfection, above all other Buddhist traditions. Comparison and classification, using Smith's terms, offer Nupchen the tools to actively and creatively deconstruct the Buddhist tradition only to put it back together in a new, original way that responds not only to the historical developments of the Buddhist tradition over the centuries, but to the present historical context in which the Buddhist tradition was developing in Tibet.

\footnotetext{
${ }^{413}$ In his unpublished 1996 lecture, "Why Imagine Religion," Smith offers a useful metaphor to understanding the function of Nupchen's text by saying that "maps are structures of transformation, not structures of representation." I am aware that Smith is using the notion of comparisson in the context of the modern study of religion and that this is not what Nupchen, ten centuries earlier and in a very different cultural context, is doing in the Lamp. I simply want to illuminate Nupchen's project of comparisson under a new light by since I believe this is a very useful image to apply to Nupchen's classification, since it really operates as an intellectual map that it is not simply trying to reproduce the Buddhist reality of Nupchen's time, but also to actively transform it.

${ }^{414}$ Jonathan Z. Smith, Relating Religion: Essays in the Study of Religion (Chicago: University of Chicago Press, 2004), 23-24.
} 
Bringing Light into the Darkness: An Intellectual History of Tibet's Dark Age (842-978 CE) Manuel Lopez Ph.D. Dissertation - University of Virginia 


\section{PART 4 - The Problem with Meditation}

Let me conclude this chapter with a brief discussion of the implications that Nupchen's project of comparison and classification of Buddhist contemplative traditions has for our understanding of Buddhist meditation. In “"Meditation' Trends in Early Tibet," Herbert Guenther introduces one of the main issues brought up by Nupchen's Lamp. In Guenther words: "While it will be readily admitted that 'meditation' has always played a major role in what is generically termed Buddhism, what the Buddhists themselves understood by 'meditation' is not so readily apparent." ${ }^{415}$ As Guenther points out, there is no doubt that "meditation" plays an important role in the history of Buddhism from its very early stages. The Buddhist tradition has laid its very own foundations on the transformative meditative experience that Siddharta Gautama, the Buddha, had over 2,500 years ago sitting under the bodhi tree while searching for the ultimate answers to his disillusion with the world and the human condition and that culminated with his experience of enlightenment, in which he claimed to have uncovered the true nature of reality and discovered a path for human salvation. The image of the Buddha, sitting cross-legged in meditation, with one hand touching the ground, "calling the earth as witness" his realization, became one of the most important iconographic images in Buddhist art. At the same time, and as we have already seen in Nupchen's discussion of various Buddhist contemplative traditions, what Buddhists meant (and mean) by "meditation," how to define it, how it should be practiced, and even its final goal, became a constant issue of contention over the centuries. As we saw in our discussion of the Lamp as a doxography, the answer to this question also had crucial implications for Buddhist doctrine and soteriology, since each new Buddhist tradition claims to possess the most effective contemplative technique to replicate that original experience

\footnotetext{
${ }^{415}$ Guenther, "“Meditation’ Trends in Early Tibet,” p. 351.
} 
of the Buddha, while relegating previous or competing traditions to offer only partial, temporary, (and sometimes even wrong) approaches to enlightenment.

I would argue that one way to look at this issue, which could also be a possible answer to Guenther's quandary, is that "meditation," (Tib. bsam gtan; Skt. dhyāna) as a concept as well as a practice functions as a fertile and contested ground which has allowed the Buddhist tradition to assert an important degree of continuity and unity (at least rhetorically) with the teachings of the Buddha and with that primordial contemplative experience of its founder, while, at the same time, that same contested nature opened the door to important discontinuities and diversity, as reflected in the emergence of new Buddhist contemplative traditions and schools of thoughts over the centuries. I am not suggesting here, though, that "meditation," or "meditative experience," is the essence of Buddhism. Robert Sharf has pointed out in his work the dangers of reconstructing the Buddhist tradition through what he considers a western obsession with the notion of experience that he traces back to William James and his The Varieties of Religious Experience. ${ }^{416}$ What I do argue, though, is that "meditation" has functioned as an important marker that has helped define boundaries between various Buddhist traditions. This contested nature, as reflected in the 10th century text, the Lamp for the Eye in Contemplation, also reveals how this continuity and unity of the Buddhist tradition is not simply there, but has to be constantly negotiated and created by individuals like Nupchen through acts of comparison and imagination.

\footnotetext{
${ }^{416}$ Robert H. Sharf, "Buddhist Modernism and the Rhetoric of Meditative Experience," Numen 42, no. 3 (October 1, 1995): 228-83, p. 271.
} 


\section{Conclusion}

In this chapter I have discussed the first three chapters of the Lamp, in which Nupchen offers a general introduction to some of the most important aspects of Buddhist meditation, regardless of the tradition. In the first chapter, Nupchen offers a general introduction to some of the important issues any practitioner needs to take into account before entering a retreat, such as the characteristics of the ideal retreat location, and the need of a strong commitment that will help the practitioner overcome the difficulties and sorrows of a long retreat. The second chapter functions as a brief summary of the contemplative practices of the various contemplative traditions, which he will discuss at length in chapters four through seven. The third chapter includes a key discussion for the structure and organiztion of the text on the non-conceptual nature of meditation (Skt. avikalpa; Tib. rnam par mi rtog pa) and the different approaches of each tradition to this notion. In this chapter I have also had two other goals. The first one has been to present, with the help of scholar Jonathan Smith, the project of comparison and classification of Nupchen's Lamp, not as a description of a reality "out there" in Tibet's 10th century, but as the prescription of a new Buddhist path by Nupchen with a clear goal: to establish the superiority of the Great Perfection over all other Buddhist paths. My second goals was to use Nupchen's discussion of the concept of non-conceptuality to argue that the contested nature of "meditation" (Tib. bsam gtan; Skt. dhyāna), as a practice as well as a concept, has helped Buddhism maintain a great degree of unity (of ideas and practices) while, at the same time, that same contested nature has allowed the Buddhist tradition a great deal of innovation and diversity. 


\section{Chapter 4 - The Indian Gradual vs. the Chinese Sudden Traditions}

\section{Introduction}

This chapter explores chapters 4 and 5 of the Lamp, in which Nupchen discusses, respectively, the Indian Gradual and the Chinese Sudden traditions. The chapter is divided into five sections. The first one will introduce the historical and intellectual background of the Indian Gradual tradition as it was introduced from India into Tibet by scholars such as Śāntarakṣita and Kamalaśîla, followed by a discussion of Nupchen's interpretation of the Gradual tradition in the Lamp. The second part will describe the historical and intellectual background of the Sudden tradition in Tibet, focussing on the role of Hashang Mahāyāna in its introduction, followed by a discussion of Nupchen's interpretation of the Chinese Sudden tradition in the Lamp. Finally, in the third part, I will explore the doctrinal and historical tension between these two sytems that led to the so-called Samye Debate in 792-794 CE. As we will see, the tension between the Gradual and Sudden approaches were not new in the history of Buddhism, ${ }^{417}$ but in the case of Tibet, these doctrinal tensions were heightened by the geographical connections of each of the traditions, India in the case of the Gradual, and China in the case of the Sudden. Both traditions are catergorized in the Lamp as belonging to the Vehicle of the Cause (Tib. rgyu'i theg pa), the Exoteric traditions based on the Buddhist Sūtras, in clear opposition to the Mahāyoga and Atiyoga vehicles, which belong to the Vehicle of the Result (Tib. 'bras bu theg pa), the Esoteric tradition based on the oral precepts (Tib. man ngag) of tantric masters. The fact that both traditions are subsumed under the same umbrella underlines a central tension in their presentation in which the doctrinal and contemplative differences of each of these two traditions is constantly defined in opposition to the other. The chapter concludes by addressing the

\footnotetext{
${ }^{417}$ On this topic see Peter N. Gregory, ed., Sudden and Gradual: Approaches to Enlightenment in Chinese Thought, Studies in East Asian Buddhism (Honolulu: University of Hawaii Press, 1987).
} 
criticism that some contemporary scholars have directed at Nupchen for misinterpreting the Indian and Chinese sources he is using in his presentation of the Gradual and the Sudden traditions.

\section{A Brief Terminological Note}

Nupchen uses the Tibetan term "rim gyis" and its Chinese equivalent 渐门 to refer to the Indian Gradual tradition, and the term “cig car" and its Chinese equivalent 顿门 to refer to the Chinese Sudden or Chan tradition. While the translation of "rim gyis" as gradual describes accurately the Tibetan term, the translation of "cig car" as "sudden" may require a few comments. Stein wrote a detailed discussion on the philological history and meaning of the term "cig car" and advocated for the use of "simultaneous" as a more accurate rendition of the term since it better reflects the "simultaneity of the two planes that are in opposition yet integral (i.e. the absolute and the phenomenal). ${ }^{, 418}$ While I agree with Stein in his historical and philological analysis of the term, I still prefer the use of the term "sudden," since it is broadly used in academic writing and taps into the long history of tension between gradual and sudden approaches in Buddhism.

\footnotetext{
${ }^{418}$ R.A Stein, "Sudden Illumination or Simultaneous Comprehension," in Sudden and Gradual: Approaches to Enlightenment in Chinese Thought, ed. Peter N. Gregory (Honolulu: University of Hawaii Press, 1987), p. 41.
} 


\section{PART 1 - The Indian Gradual Tradition}

\section{Śāntarakșita and the Gradual Tradition in Tibet}

Nupchen makes very clear in the Lamp that the main sources for his understanding of the Gradual tradition are "the philosophical writings of the Indian Master Kamalaśila." 419 Kamalaśîla's Bhāvanākramas are also the only texts of the Gradual tradition recommended by Nupchen as part of the harmonious books to rely upon during a retreat. ${ }^{420}$ The Bhāvanākramas, though, need to be understood in the context of the intellectual work of his main teacher, the Indian scholar, Sāntarakșita (CE 725-788). Śāntarakșita was one of the most important figures during the early introduction of Buddhism in Tibet. He was the abbot of Nālandā, one of the most important monastic institutions in India, and as such, he was invited to Tibet by King Trisong Detsen to build and consecrate the first Tibetan Buddhist monastery, Samye (775-779 CE). ${ }^{421} \mathrm{He}$ became its first abbot, and ordained the first seven Tibetan monks, introducing the Sarvāstivāda monastic lineage into Tibet. ${ }^{422} \mathrm{He}$ also had a very important role in the establishment of the monastic curriculum in the new monastery, and in introducing Tibetans to the logico-epistemological tradition that would so define Tibetan monasticism for centuries. Some of his most important works are the The Ornament of the Middle Way (Skt.

${ }^{419}$ Lamp 23.4-23.5: "rgyu'i theg pa'i lugs kyis kyang dbang po rno rtul gyi bye brag gi gnyis te // rim gyis pa dang / (23.5) cig car pa'o // de la rim gyis pa ni // rgya dkar bo'i slob dpon ka m'a la shi la'i 'dod gzhung ste //"

${ }^{420} \mathrm{See}$ this discussion in chapter three of this dissertation.

${ }^{421}$ The Testament of $B a$ (Tib. dBa' bzhed ) includes the traditional story of the invitation of Śāntarakșita by King Trisong Detsen, the problems and opposition met by Śāntarakșita during the construction of Samye, and the role of the Pdmasambhava in overcoming those obstacles and taming some of the forces that were opposing the introduction of Buddhism in Tibet. See Pasang Wangdu and Hildegard Diemberger, $d B a$ ' Bzhed: The Royal Narrative Concerning the Bringing of the Buddha's Doctrine to Tibet (Verlag der Österreichischen Akademie der Wissenschaften, 2000). See also Dudjom Rinpoche, The Nyingma School of Tibetan Buddhism: Its Fundamentals and History (Boston, Mass.: Wisdom Publications, 2002), pp. 512-521.

${ }^{422}$ For an account of the life of Śāntarakṣita and an overview of his philosophical works, see James Blumenthal, "Śāntarakșita," ed. Edward N. Zalta, The Stanford Encyclopedia of Philosophy, 2014. See also http://plato.stanford.edu/archives/sum2014/entries/saantarak-sita/; James, 1967- Blumenthal, The Ornament of the Middle Way: A Study of the Madhyamaka Thought of Śāntarakșita, 1st USA. (Ithaca: Snow Lion Publications, 2004). For a discussion of Śāntarakșita's thought in the context of the Madhyamaka tradition, see David Seyfort Ruegg's The Literature of the Madhyamaka School of Philosophy in India, vol. 7, 1 (Wiesbaden: Harrassowitz, 1981). 
Madhyamakālamkāra) and his own commentary to the work, The Commentary on The Ornament of the Middle Way (Skt. Madhyamakālamkāravrtti), in which he outlines his synthesis of the Madhyamaka and the Yogācāra traditions. He also wrote the Vipañcitārthāa, a commentary on Dharmakīti's Vädanyāya. Finally, he also wrote the Tattvasamgraha, a very important doxographical work that offered Tibetans one of the earliest and most systematic overviews of the diversity of philosophical systems in India during the period of the early introduction of Buddhism in Tibet. ${ }^{423}$ Historically, though, it seems that the role and importance of Śāntarakṣita quickly became overshadowed in the Tibetan imagination by the powerful narrative of Padmasambhava, which emerged in Tibetan historical accounts, especially in the 12th century, as the central character in the narrative of the the final introduction of Buddhism in Tibet. He helped overcome the obstacles faced by Śāntarakșita in the construction of Samye, and sudbued local resistance to the establishment of Buddhism in Tibet. ${ }^{424}$ Blumenthal, though, reminds us that Śāntarakṣita's influence in later Tibetan thought should not be underestimated:

In affect, Śāntarakșita (and later, his disciple Kamalaśīla) taught Tibetans how to do philosophy. He introduced Tibetans to a plethora of Indian philosophical views, both Buddhist and non-Buddhist, and taught them how to study, critically analyze, and meditate upon these ideas. Several important qualities of Sanntarakșita's thought that were unique to him in India, became a fully integrated modus operandi of philosophy in Tibet including his dynamic engagement with competing philosophical views and his integration of Madhyamaka and logico-epistemological thought. As such his influence impacted the spectrum of Tibetan philosophical literature, from the earliest philosophical doxographies such as Yeshe De's (ca. 8th c.) Distinguishing the Views (lta ba khyad par) to the commentaries and treatises of towering indigenous Tibetan philosophers such as Chaba Chökyi Senge (phwya pa chos kyi seng ge) (1109-1169), Sakya Pandita (sa skya

\footnotetext{
${ }^{423}$ We have already discussed the Tattvasamgraha in some detail in chapter 2 of this dissertation.

${ }^{424}$ For traditional narratives on the role of Padmasambhava, see Wangdu and Diemberger, $d B a$ ' Bzhed; Herbert V. Guenther, The Teachings of Padmasambhava (Brill, 1996); Jacob Dalton, "The Early Development of the Padmasambhava Legend in Tibet," Journal of the American Oriental Society 124, no. 4 (2004): 759-772. The classic Tibetan text with the earliest biography of Padmasambhava is the bka' thang zangs gling ma by Nyangrel Nyima Ozer (Tib. myang ral nyi ma 'od zer). In gter ston brgya rtsa'i rnam thar. TBRC W1PD83972: 277 - 376 . lha sa: bod ljongs mi dmangs dpe skrun khang, 2007. http://tbrc.org/link?RID=O1PD84290|O1PD842902DB75688\$W1PD83972
} 
pandita) (1182-1251), Tsongkhapa (tsong kha pa) (1357-1419) and Mipham Gyatso (mi pham rgya mtsho) (1846-1912). ${ }^{425}$

Śāntarakșita’s main intellectual achievement was the development of what became known as the Yogācāra-Madhyamaka school, ${ }^{426}$ a philosophical system that integrated "the antiessentialism of Nāgārjuna with the logico-epistemological thought of of Dignāga (ca. 6th c.) and Dharmakīrti (ca. 7th c.) along with facets of Yogācāra/Cittamātra thought into one internally consistent, yet fundamentally Madhyamaka system."427 The centrality of scholasticism, the study of scriptures, and formal training in logic and debate is reflected in the following passage from the Testament of Ba: "The Tsen men need to study and acquire expertise in all texts of the doctrine. The whole doctrine has to be understood correctly with reliance upon the three wisdoms (shes rab rnam pa gsum), and the unborn patience (mi skye ba'i bzod pa) can be attained." 428

The core of the Indian Buddhist Madhyamaka (Tib. dbu ma) traditions, particularly as systematized by Nāgārjuna in his Mūlamadhyamakakārikā, was the doctrine of "emptiness" (Skt. śūnyatā; Tib. stong pa nyid) and the notion of the "two truths." The doctrine of "emptiness"

\footnotetext{
${ }^{425}$ Blumenthal, "Śāntarakṣita." Using a theme developed by Kapstein in his The Tibetan Assimilation of Buddhism (pp. 54-56), we could argue that the invitation of Śāntarakșita to Tibet was part of the Imperial project of importing the "charisma of reason," not only for obvious religious reasons, but also for political ones.

${ }^{426}$ The spearheading of the Buddhist logico-epistemological tradition (pramānavāàda) by Dignāga and Dharmakīti, at first in response to Indian thought in the area of philosophy of language and in dialogue with non-Buddhist philosophers, resulted in a tremendous impact on many dimensions of Buddhist philosophical discourse in the middle and late periods of Indian Buddhism. Though its impact could be seen before Sāntarakṣita (in facets of Bhāvaviveka's writings), he was the first major Madhyamaka thinker who was also a commentator on Dharmakirti, a contributor to this discourse, and who attempted to integrate its insights into a Madhyamaka framework. (Both Dignāga and Dharmakīrti are more closely associated with the Mind-Only school). One can witness one dimension of the profound influence Śāntarakṣita had on Tibetan Buddhist thought, even given the differences in the details, when observing this integration of Madhyamaka and pramānavāda thought in towering Tibetan thinkers such as Sakya Pandita and Tsongkhapa among others." Ibid. Bold is mine.

${ }^{427}$ Ibid.

${ }^{428}$ Wangdu and Diemberger, $d B a^{\prime}$ Bzhed, p. 85.
} 
claims that all phenomena (Skt. dharma; Tib. chos) are essentially empty since they always coemerge interdependently (Skt. Pratītyasamutpāda; Tib. rten cing 'brel bar 'byung ba). As Nāgārjuna himself states in the first two stanzas of his Mūlamadhyamakakārikā:

I prostrate to the Perfect Buddha, The best of teachers, who taught that Whatever is dependently arisen 4 is Unceasing, unborn, Annihilated, not permanent, Not coming, not going, Without distinction, without identity And free from conceptual construction ${ }^{429}$

The notion of the "two truths" argues that while all phenomena may ultimately (Skt. paramārthasatya; Tib. don dam bden pa) lack any inherent nature (Skt. svabhāva; Tib. ngo bo), they do exist on a conventional level (Skt. samvrtisatya; Tib. kun rdzob bden pa). The establishment of the two truths allowed the Madhyamaka tradition to avoid what could be considered a nihilistic perspective (the complete denial of reality), by affirming, even if only at a relative level, the nature of our daily and common experience of the world. ${ }^{430}$

Although all Madhyamaka schools will agree in their essentialist position regarding the lack of inherent nature of all phenomena, over the centuries different schools of thought developed according to their different views on how to philosophically establish the reality of the ultimate truth, and how to understand conventional truth. ${ }^{431}$ As for how to philosophically

\footnotetext{
${ }^{429}$ Jay L. Garfield, The Fundamental Wisdom of the Middle Way: Nāgārjuna's Mūlamadhyamakakārikā (New York: Oxford University Press, 1995), p. 2.

${ }^{430}$ On the Two Truths, see Malcolm David Eckel's Jñannagarbha's Commentary on the Distinction between the Two Truths: An Eighth Century Handbook of Madhyamaka Philosophy, SUNY Series in Buddhist Studies (Albany, NY: State University of New York Press, 1987), and Guy Newland's The Two Truths in the Mädhyamika Philosophy of the Ge-Luk-Ba Order of Tibetan Buddhism, Studies in Indo-Tibetan Buddhism (Ithaca, N.Y., USA: Snow Lion Publications, 1992).

${ }^{431}$ For a detailed study, see the classic study by Ruegg: The Literature of the Madhyamaka School of Philosophy in India.
} 
establish the reality of the ultimate truth, two main schools of thought developed different interpretations of Nāgārjuna's ideas: the Sautrāntika and the Prasangika. ${ }^{432}$ The Sautrāntika tradition had as its main intellectual figure, the 6th century scholar, Bhâvaviveka, and it postulated that "it was possible to prove emptiness by logic and independent inference." ${ }^{433}$ The Prasangika school, which had as its main intellectual figures the 5-6th century scholar, Buddhapālita, and the 7th century scholar, Candrakīrti, argued, instead, that "language and logic were yet another kind of obstacle to the attainment of the experience of emptiness [and] their arguments point out to the undesirable consequences (Skt. prasanga) of any view or set of views." $" 434$

Further divisions emerged, mainly within the Sautrāntika tradition, concerning the understanding of conventional truth, particularly around the problem of "whether or not the existence of an external object was to be affirmed from the viewpoint of conventional truth." ${ }^{435}$ The Sautrāntika -Madhyamaka school, with Bhāvaviveka as its main thinker, argued that conventional truth does know the existence of an external object, while the Yogācāra Madhyamaka school of Śāntarakșita and Kamalaśīla, negated that possibility. ${ }^{436}$ Sāntarakșita’s Madhyamakālamkāra is the main work where he outlines his project of synthesizing the ideas of

\footnotetext{
${ }^{432}$ Masamichi Ichigo, "Śāntarakșita 's Madhyamākalaṃkāra," in Studies in the Literature of the Great Vehicle: Three Mahāyāna Buddhist Texts, ed. Luis Gomez and Jonathan A. Silk (Ann Arbor: Centers for South and Southeast Asia, Th, 1999), p. 151. As Ruegg has made clear, "Historians have used the term to designate Buddhapālita's school because it restricted itself to prasanga -type reasoning already used by Nāgārjuna, and the term Svatrāntika to designate Bhāvaviveka's school since it introduced independent (svatantra) inferences into its process of reasoning. The terms Svatrāntika and Prasangika, -which do not seem to be actually attested as the names of the two branches of the Madhyamaka in the Sanskrit sources now accessible to us- correspond respectively to the Tibetan terms Rang rgyud pa and Thal 'gyur ba." In Ruegg's The Literature of the Madhyamaka School of Philosophy in India, p. 58.

${ }^{433}$ Masamichi Ichigo, "Śāntarakșita 's Madhyamākalaṃkāra," p. 152. See also Ruegg, The Literature of the Madhyamaka School of Philosophy in India, pp. 61-67.

${ }^{434}$ Masamichi Ichigo, "Śāntarakșita 's Madhyamākalaṃkāra," p. 152. See also Ruegg, The Literature of the Madhyamaka School of Philosophy in India, pp. 60-61.

${ }^{435}$ Masamichi Ichigo, "Śāntarakṣita ’s Madhyamākalaṃkāra,” p. 152.

${ }^{436}$ Ibid., p. 152. Ruegg, The Literature of the Madhyamaka School of Philosophy in India, 7:87-101.
} 
the Madhyamaka school, affirming the doctrine of emptiness as the ultimate truth, while he accepts Yogācāra notions that assert that phenomena are not of a different nature than consciousness $^{437}$ on a conventional level. But what makes Śāntarakșita’s synthesis unique is not simply his attempt to harmonize what had been seen as diametrically opposed attempts by the Buddhist tradition of understanding the nature of phenomena. For Sāntarakṣita, the Yogācāra view of phenomena functioned as the first step in a path to understanding its ultimate truth. In the words of Blumenthal:

A proper understanding of conventional truths takes a person part of the way towards an understanding of the ultimate. Previous Madhyamaka presentations of conventional truths do not incorporate this practical dimension. For Sāntarakṣita, conventional truths are not completely mistaken. By properly understanding conventional truths (i.e., as a follower of Cittamatra tenets understands the ultimate), one is well on the way to a proper understanding of the ultimate from his Madhyamaka perspective - the most subtle and accurate philosophical presentation of reality. There is a dynamic step at work in Śāntarakșita's presentation of the two truths; first one understands that entities are not of a distinct nature from that of the mind (as Mind-Only proponents claim) and then they progress to realize that nothing exists in and of itself (the Madhyamaka perspective), even the mind. This dynamic engagement with conventional truths is unique among Madhyamaka thinkers and a critical innovation in the thought of Śāntarakșita. ${ }^{438}$

Finally, another important aspect of the role of Sāntarakșita in the introduction of Buddhism in Tibet is that he brought with him a systematic knowledge of the Indian Buddhist tradition. His doxographical work, the Tattvasamgraha, offered Tibetans a clear overview of the richness and variety of Buddhist knowledge in India, of great pedagogical importance during a time when Tibetans were still trying to make sense of the diversity and apparent contradictions

\footnotetext{
${ }^{437}$ Blumenthal, "Śāntarakșita.”

${ }^{438}$ Ibid.
} 
of the various Buddhist paths that were available to them from all parts of Asia during this period. $^{439}$

\section{Kamalaśîla and the Bhāvanākramas}

According to the Testament of $B a$, at the time of his death, Sāntarakșita prophesized the conflict and gave the following instructions to Tibetans:

"In general, wherever Buddhism appears, there is also opposition by non-Buddhist religion. In Tibet, approaching the final 500 years period of the doctrine, there will be no opposition from the non-Buddhists. Buddhists themselves will disagree on the doctrinal point of view and therefore there will be debates. If this occurs, invite my disciple Kamalasitla, dwelling in Nepal, and let him debate. The king shall decide the matter.",440

Kamalaśîla is well known in the Tibetan tradition as one of Śāntarakṣita’s main students, and as his chosen representative to defend the Gradual approach against the Chinese Sudden tradition, represented by Hashang Mahāyāna during the Samye Debate. Kamalaśīla wrote commentaries for some of his teacher's works, such as the Madhyamālaṃāra-panjika (Tib. dbU ma rgyan gyi dka' 'grel), a commentary on the Madhyamālamkāra, and the Tattvasamgraha-panjika, a commentary on Śāntarakșita's Tattvasaṃgraha. He was also a great scholar in his own right, writing works like The Light of the Middle Way (Skt. Madhyamakāloka; Tib. dbU ma snang ba), in which he includes a discussion of the Tathägatagarbha theory, assuring it "a much more prominent place in later Madhyamaka thought than [it] had occupied in the works of the earlier

\footnotetext{
${ }^{439}$ For a more detailed discussion of the Tattvasamgraha see the discussion dedicated to the doxographical genre in chapter two of this dissertation.

${ }^{440}$ Wangdu and Diemberger, $d B a$ ' Bzhed, p. 78. Italics are mine.
} 
Madhyamikas." ${ }^{441}$ His most famous works are the three treatises known as the Bhāvanākramas (Tib. sgom rim).

The Bhāvanākramas have to be understood in the context of this debate between the Indian Gradual and the Chinese Sudden traditions, even though, as many scholars have pointed out, ${ }^{442}$ Kamalaśîla only obliquely mentions his Chinese opponents and their ideas (this takes place in the third Bhāvanākrama). The Bhāvanākramas, then, serve as a "summary" of sorts of Kamalaśîla’s arguments during the debate. ${ }^{443}$ In Ruegg’s words, “Kamalaśîla clearly composed his three treatises for the purpose of refuting what he considered to be serious misconceptions about the Path and establishing the correct philosophical theory and meditational praxis of the Mahāyāna by means of a concise explanations supported by quotations from numerous sūtras." $" 444$

The three Bhāvanākramas overlap in content and are, to a certain extent, quite repetitive (which has made scholars doubt if Kamalaśîla meant them to be a unified work or simply reiterations of similar ideas intended for different audiences, or to be presented in different contexts). ${ }^{445}$ Traditionally, their differences have been explained by arguing that the first Bhāvanākrama explains the Mahāyāna doctrine, the second focuses on meditation, and the third

\footnotetext{
${ }^{441}$ Ruegg, The Literature of the Madhyamaka School of Philosophy in India, 7:95.

${ }^{442}$ One of the earliest studies on the Bhāvanākramas was in Giuseppe Tucci's Minor Buddhist Texts II, vol. 2 (Roma: Istituto italiano per il Medio ed Estremo Oriente (IsMEO), 1956).

${ }^{443}$ Martin Adam, Meditation and the Concept of Insight in Kamalaśila's Bhāvanākramas, $\mathrm{PhD}$ Dissertation (Montreal: McGill University, 2002), p. 6.

${ }^{444}$ Ruegg, The Literature of the Madhyamaka School of Philosophy in India, 7:98-99. Besides the importance of the Bhāvanākramas for our understanding of the doctrinal positions of the Yogācāra - Madhyamaka tradition in Tibet, Ruegg adds in the same page that they also have remarkable philological value: "Since they are among the relatively few later Madhyamaka works extant in Sanskrit, and because they contain important quotations from the Sanskrit texts of Sutras otherwise available only in Chinese and Tibetan translations, the first and the third Bhāvanākramas now constitute our main original documentation for the study of this school toward the end of the eight century."

${ }^{445}$ Adam, Meditation and the Concept of Insight in Kamalaśila's Bhāvanākramas, p. 4. Ruegg, The Literature of the Madhyamaka School of Philosophy in India, 7:98.
} 
one on the results of meditation. ${ }^{446}$ The truth is, though, that the three deal with all of those issues, even if the presentation and emphasis is slightly different. Nupchen, in fact, seems to be borrowing freely from the three of them, as we will see during our discussion of his presentation of the Gradual path in chapter four of the Lamp. As Martin has argued, beyond the specific polemics of the debate reflected in the three treatises (particularly in the third), Kamalaśila is concerned with discussing two issues that he considers key for reaching enlightenment in the Gradual system. The first one is concerned with the relevance of the methods (Tib. thabs) to achieve the final goal, and Kamalaśīla, like other Mahāyāna scholars, emphasizes the importance of compassion and the accumulation of merit (Tib. bsod nams kyi tshogs) through the practice of the six perfections. The second aspect he wants to highlight is the importance of the accumulation of wisdom (Tib. ye shes kyi tshogs) that emerges with "the discernment of reality (Skt. bhūtapratyavekșā; Tib. yang dag par so sor rtog pa)" in the practice of vipaśyanā. ${ }^{447}$

\footnotetext{
${ }^{446}$ Martin explains the source of this traditional distinction between the content of the three Bhāvanākramas: "It is not clear why Kamalaśíla wrote three identically entitled Bhāvanākramas. In this connection Edward Conze describes their contents as follows: "The first explains the doctrine of the Mahayana, the second how it can be meditated upon, and the third what is the result of meditation" (Conze 1975: 177). In making this assertion Conze is following a description contained in one Tibetan record cited in Tucci (1958: 40-41). The account has it that the Tibetan king, [Trisong Detsen], requested these explanations in turn, following Kamalaśîla's pivotal victory in debate over a Chinese Ch'an rival [...] The "doctrine" of Bhk 1 is described as that of the three kinds of wisdom

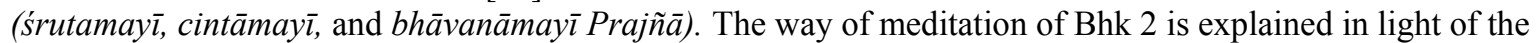
realization that there is only one vehicle; it is the result of this meditation that Bhk 3 is said to explain." In Adam, Meditation and the Concept of Insight in Kamalasíla's Bhāvanākramas, p. 4. A classic depiction of the differences between the three Bhāvanākramas can also be seen in the introduction of the translation of Vimalamitra's Stages of the Path written by Lozang Jamspal: "The King asked Kamalaśila to put into writing the method by which the Dharma of selflessness is ascertained by studying, pondering, and meditation. As a response to this request, Kamalaśîla composed the first Bhāvanākrama and presented a copy to him. The King studied this text and was delighted with its meaning. If one wants to practice Dharma in one single sitting session, how should one do it? In response to this question, Kamalaśîla composed the second Bhāvanākrama. What is the result of this kind of meditation? In response to this he composed the third Bhāvanākrama showing the result of meditation, while also refuting the philosophy of Hvashang. In order to respond to doubts and refutations concerning these three books, he composed Madhyamakāloka (Light of Central Philosophy) demonstrating the bodhisattva view through reasoning and scriptures." In Vimalamitra, The Stages of Meditation, trans. Lozang Jamspal (Ladakh: Ladakhratnashridpika, 2000), p. iii.

${ }^{447}$ Adam, Meditation and the Concept of Insight in Kamalasíla's Bhāvanākramas, p. 9. Gomez also highlights Kamalaśîla's integration of Yogācāra ideology in the Bhāvanākramas: "These three essays borrow extensively from the Yogācāra tradition. The second essay establishes clearly a uniquely Mahāyāna use of the boundless states (āpramānya) as a way to generate the great compassion that will motivate the meditator to seek the awakening of a
} 
Thus one seeking to attain omniscience should train in the triad of compassion, the thought of Awakening and method. When moved by compassion, bodhisattvas will definitely make vows for the sake of rescuing all sentient beings. Then, having removed self-centeredness, they will devotedly apply themselves to the accumulations of merit and knowledge, which are extremely hard work and which are perfected uninterruptedly over a long period of time. Once they have embarked upon it, there can be no doubt that they will thoroughly perfect the accumulations of merit and knowledge. When the accumulations are complete, it will be as if omniscience is contained in the palm of one's hand. $^{448}$

Buddha. The same texts also summarize meditations on emptiness that progress from an abhidharmic analysis of matter, through a Yogācāra analysis of mind and its contents, and culminate in a state of samādhi that is devoid of any conceptual contents (ānimittasamādhi). The latter state is the gateway to the liberating knowledge that is nondual (advayajñāna). "In Luis Gomez's "Meditation," ed. Damien Keown and Charles S. Prebish, Encyclopedia of Buddhism (London; New York: Routledge, 2007), p. 525.

${ }^{448}$ Ibid., 191. 


\section{The Gradual Tradition in the Lamp}

Nupchen begins his discussion of the Gradual tradition with a general overview of the

chapter:

In order to know in this [chapter] the places where [the various traditions] go astray from the perspective of the vehicle of the spontaneous perfection [let's begin] with the first of the four different systems, that of the gradual entrance, (which it blossoms like the malika flower) [named this way] because [the practitioner] meditates on emptiness based on the Sütra system. Also, it is like climbing a mountain step by step. In order to attain the Dharmakāya of the Conqueror [i.e. the Buddha] [the practitioner needs to] gradually train in the Two Truths, and in the [practices of] śamatha and vipaśyanā in order to, one at a time, attain the various [Bodhisattva] bhümis. The Sütra of the Dense Array (Skt. Gaṇdavyūha Sütra; Tib. sTug po bkod pa'i mdo) says:

Just as the most excellent gold, does not seem like gold [when it is mined], but it becomes bright when it is refined and completely clean, so it is with the Storehouse Consciousness (Skt. Alayavijñāna; Tib. kun gzhi rnam par shes pa) which the yogi will always be able to see after having completely practiced the various samādhi of the seven consciousness (Tib. rnam par shes pa). ${ }^{449}$

The opening lines of the chapter make very clear that Nupchen's understanding of the Gradual tradition is that of the Yogācāra-Madhyamaka system as introduced into Tibet by Śāntarakṣita and outlined by Kamalaśîla in his Bhāvanākramas. Here, we see the centrality of Madhyamaka ideas such as the notion of emptiness and the doctrine of the two truths, combined with the

\footnotetext{
${ }^{449}$ Lamp 65.1-65.6: "'dir lhun gyis rdzogs pa'i theg pa'i gol sa shes par bya ba'i phyir / gzhung bzhi bkod pa'i dang po mdo sde stong par bsgom pa la ci'i phyir rim 'jug ces bya < shing tog ma li ka dang 'dra bar / ma gyis smin par 'gyur /> zhe na / yang sngar bstan / 'dir < tsen man rang gzhung /> yang dper / ri bo che la 'jog pa'ang ('dzegs?) gom gcig gom gnyis phyin pas rdol ba dang 'dra bar / rgyal ba'i chos kyi sku bsgrub pa yang / bden pa gnyis dang / zhi gnas lhag mthong la sngar rim par sbyangs nas / je je la sa non par 'gyur ro //de yang stug po bkod pa'i mdo las / de ltar shin tu bzang po'i gser // gser gyi dbyibs na mi snang < bzang po'i ngo bor /> ste // gsal bas shin tu zhib btags na // yongs su sbyangs na snang bar 'gyur//de bzhin kun gzhi rnam par shes //rnam shes bdun dang bcas pa yang // ting nge 'dzin gyis yongs sbyangs pas // rnal 'byor can gyis rtag tu mthong //zhes gsungs pa'i phyir ro //." The Gandhavyuha Sutra, the last chapter of the Avatamsuka Sutra, can be found in D110. Nupchen's quote is slightly different from the one found in the Sutra: “ji ltar shin tu bzang ba'i gser/_/gser gyi dbyings na mi snang ste/_brtsal bas shin tu zhib btags nas/_yongs su sbyangs na snang bar 'gyur/_de bzhin kun gzhi rnam shes pa/_/rnam par shes pa bdun dang bcas/_ting nge 'dzin gyis yongs sbyangs pa'i/_/rnal 'byor can gyis rtag tu mthong"
} 
theory of the eight consciousness of the Yogācāra tradition ${ }^{450}$ hinted at through a quotation from the Gaṇdavyūha Sūtra. ${ }^{451}$

It is important to point out that he does not quote directly from the text in the chapter, although Nupchen himself acknowledges in the Lamp the role that the Bhävanäkramas play in his understanding of the Gradual tradition, ${ }^{452}$ and many of the scriptural references he uses are different from the ones in Kamalaśīla's treatises. Nupchen's chapter, in fact, while covering most of the main themes outlined in the various Bhāvanākramas, it is also informed by the early body

${ }^{450}$ The theory of the Älayavijñanna and the eight types of consciousness is the foundation of Yogācāra thought. The eight consciousnesses are defined in the Princeton Dictionary of Buddhism as "vijñāna. (P. viññāna; T. rnam par shes pa). In Sanskrit, 'consciousness'; a term that technically refers to the six types of sensory consciousness (vijñanna): eye, or visual, consciousness (CAKȘURVIJÑĀNA); ear, or auditory, consciousness (ŚROTRAVIJÑĀNA);

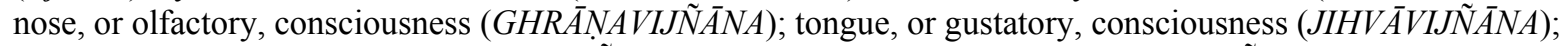

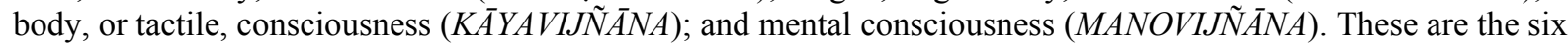
major sources of awareness of the phenomena (DHARMA) of our observable universe. Each of these forms of consciousness is produced in dependence upon three conditions (PRATYAYA): the 'objective-support condition' (ALAMBANAPRATYAYA), the 'predominant condition' (ADHIPATIPRATYAYA), and the 'immediately preceding condition' (SAMANANTARAPRATYAYA). When used with reference to the six forms of consciousness, the term vijñāna refers only to CITTA, or general mentality, and not to the mental concomitants (CAITTA) that accompany mentality. It is also in this sense that vijñanna constitutes the fifth of the five $S K A N D H A s$, while the mental concomitants are instead placed in the fourth aggregate of conditioning factors (SAMSKA $\bar{A} A)$. The six forms of consciousness figure in two important lists in Buddhist epistemology, the twelve sense fields $(\bar{A} Y A T A N A)$ and the eighteen elements $(D H \bar{A} T U)$. With the exception of some strands of the YOGACARA school, six and only six forms of vijñāna are accepted. The Yogācāra school of ASAN்GA posits instead eight forms of vijñāna, adding to the six sensory consciousnesses a seventh afflicted mentality (KLISTTAMANAS), which creates the mistaken conception of a self, and an eighth foundational or storehouse consciousness ( $\bar{A} L A Y A V I J \tilde{N} \bar{A} N A)$." For a detailed discussion on the history and the doctrine of the Ālayavijñāna, see Lambert Schmithausen's Alayavijñanna: On the Origin and the Early Development of a Central Concept of Yogācāra Philosophy (Tokyo: International Institute for Buddist Studies, 1987).

${ }^{451}$ The Gandavyūha Sütra is part of the larger Avatamsaka Sütra and describes the pilgrimage of the young Sudhana in his quest for enlightenment. As Osto has pointed out, one of the interesting aspects of the Gandavyūha is its proto-tantric language and imagery, making it a transitional text between classic Mahāyāna and early tantric literature: "Although a Mahāyāna sūtra, the Gandavyūha clearly contains a number of elements that seem to presage the 'tantric' phase in Indian Buddhism. In particular, the sūtra contains four components worthy of note: elaborate scenes detailing what can best be understood as maṇalas, a soteriology based on absolute faith in the spiritual guides, a strong insinuation of organizational esotericism, and the hint of sexual yoga." In Douglas Osto, "ProtoTantric' Elements in The Gaṇdavyūha Sūtra," Journal of Religious History 33, no. 2 (2009): 168. The Daśabhümika Sütra, which Nupchen also quotes in the text is also part of the Avatamsaka Sütra.The same image of the mind as gold is found in the Bhāvanākramas, although in this case through a quotation from the Samdhinirmocana Sütra: "Also it is said in the noble Samdhinirmocana Sütra, 'Gradually on the highest stages when the mind is thoroughly purified like gold, it directly and completely awakens right up to the point of unsurpassed perfect Awakening." In the third Bhāvanākrama. Translated by Adam in Meditation and the Concept of Insight in Kamalaśila's Bhāvanākramas, p. 227.

${ }^{452}$ See two quotations from the Lamp at the beginning of this chapter that reveal the centrality of the Bhāvanākramas in Nupchen's understanding of the Gradual approach. 
of literature dedicated to meditative practices translated in Tibet during the Imperial period. As I have said before, the Lamp has sections that are close to the Vimuttimagga, ${ }^{453}$ and the Gradual chapter, in particular, has many similarities to the exposition of the Gradual approach as presented in Vimalamitra's The Meaning of the Gradual Approach to Meditation (Tib. Rim gyis 'jug pa'i sgom don), ${ }^{454}$ as well as some of the contemplative treatises on śamatha and vipaśyanā found in the $d b u$ ma section of the Tibetan Tengyur (Tib. bsTan 'gyur). ${ }^{455}$ Further research is needed to discover the connection between this body of literature and Nupchen's discussion of the Gradual, but I believe that the similarities in the exposition of this tradition in these texts indicate that Nupchen was well read in the Gradual tradition literature beyond the Bhāvanākramas.

After this brief overview of the chapter, Nupchen then proceeds, as he will do with each of the traditions included in the Lamp, to discuss the Gradual vehicle, focusing on four main topics: 1) philosophy (Tib. lta ba); contemplative practices (Tib. sgom pa); conduct (Tib. spyod pa); and the results of practice (Tib. 'bras bu).

The Philosophical Views of the Indian Gradual Tradition (Tib. Ita ba)

Nupchen here offers a general introduction to the philosophical foundations of the Gradual tradition, beginning with the centrality of the ideas of emptiness and interdependent origination:

\footnotetext{
${ }^{453}$ See Nupchen's discussion regarding the characteristics of the ideal place to practice and the importance of a teacher in chapter 3 of this dissertation.

${ }^{454}$ Toh. 3938, there is a translation by Lozang Jamspal: Vimalamitra, The Stages of Meditation. We have to be cautious with the attribution of this text to Vimalamitra, since, as Joel Gruber argues, "He is also credited with having compiled the widely disputed, The Meaning of the Sudden Approach to Non-Conceptual Meditation (cig car 'jug pa'i rnam par mi rtog pa'i bsgom don), and The Meaning of the Gradual Approach to Meditation (rim gyis 'jug pa'i bsgom don), though neither is cited, nor appears in Tibetan catalogues before the fourteenth century." In Joel Gruber, "Vimalamitra," The Treasury of Lives, accessed April 30, 2014, http://www.treasuryoflives.org/biographies/view/Vimalamitra/9985.

${ }^{455}$ Particularly those that start in D4366, like the lhag mthog skyes pa'i thabs, or D4374 zhi gnas la 'jug pa'i thabs. Thanks for Prof. Kurtis Schaeffer for the suggestion to examine this body of literature.
} 
Let's examine the philosophical views [of the Gradual approach]. First, the view that [asserts] that by relying on individually discriminating wisdom [Tib. so sor rtog pa'i shes $\mathrm{rab}$ ] the axiom/logical syllogism of interdependent origination [Tib. rten cing 'brel bar 'byung ba'i gtan tshigs] entities cannot be [independently] established. For example, even though the different aspects of a chariot, such as the spokes, the handles, and the wheel appear as the chariot, the essence of the chariot is not in the spokes [or the wheel, etc.]. Likewise, even though entities such as a pillar, a vase, etc. appear through the interdependent origination of causes and conditions, in the ultimate truth, whatever causes and conditions of illusory phenomena cannot be established: it has no aspects, no self, no soul, no being. ${ }^{456}$

After laying out the doctrinal ground, Nupchen reminds the practitioner that the foundation of practice, following the Mahāyāna ideal of the Bodhisattva, should be compassion (Skt. karunā; Tib. snying rje), the first of the Four Immesuarables (Tib. tshad med pa bzhi):

After having ascertained [the meaning] of the various logical axioms [of the tradition], then [the practitioner] first should gradually meditate on the Four Immesurables [Tib. tshad med pa bzhi]. ${ }^{457}$

In the Bhâvanākramas this idea is so important that the three treatises start with this idea of the centrality of compassion as the foundation of practice. In the first Bhāvanākramas, for example, Kamalaśîla states "knowing that compassion alone is the root cause of all the qualities of the Buddha that is cultivated at the very outset." 458

\footnotetext{
${ }^{456}$ Lamp 65.6-66.4: "de la lta bas thag bcad de // dang por lta bas so sor rtogs pa'i shes rab la brten pas rten cing 'brel bar 'byung ba'i gtan tshigs kyis dngos po mi < rang rgyud du /> 'grub ste / dper na shing rta'i rtsibs shing dang sgyogs bu chung dang 'khor lo la sogs pa'i rnam pa shing rtar snang ba bdo tsam na / shing rta'i ngo bo rtsibs shing la yang med / de bzhin du sgyogs bu chung la sogs pa gang la yang med pa ltar / dngos po ka ba bum pa la sogs pa rgyu rkyen rten cing 'brel bar 'byung ba tsogs bdo ba tsam zhig tu snang yang don dam par rgyu rkyen gang la yang dngos po sgyu ma'i chos grub pa med de / rnam pa med pa / bdag med pa / srog med pa / skyes bu med pa'o //"

${ }^{457}$ Lamp 66.4-66.5: "de lta bu la sogs pa'i gtan tshigs rgya che bas thag bcad nas bsgom pa'ang / dang po tshad med pa bzhi la rim gyis bsgom ste"

${ }^{458}$ Adam, Meditation and the Concept of Insight in Kamalaśīla's Bhāvanākramas, p. 171. "de la sangs rgyas kyi chos ma lus pa'i rgyu'i rtsa ba ni snying rje kho na yin par shes par byas la de nyid la thog ma kho nar bsgom mo." Kamalaśîla adds, "Here then, starting from the very outset, the stage of cultivating compassion should be explained. Initially, at the beginning, one cultivates equanimity - thereby clearing away anger and attachment towards any sentient being. Thus even-mindedness should be produced. Thinking, 'All sentient beings desire happiness and do not desire suffering. In beginningless samsāra there is no sentient being who has not been a relative of mine at least
} 
Nupchen continues his exposition by offering a lengthy discussion (Lamp 67.5-75.5) of the doctrine of the Two Truths. As we have pointed out, what made Sāntarakșita and Kamalaśîla's position regarding the Two Truths so unique was their identification of the Madhyamaka understanding of the empty nature of all phenomena with the ultimate truth, while they identified the Yogācāra view of the nature of all phenomena as equal to the nature of the mind with the conventional truth. This particular correlation of the Yogācāra-Madhyamaka system was extremely important since it is through the conventional understanding of Yogācāra and the use of various contemplative methods that the ultimate truth, as put forward by the Madhyamaka, can be understood. ${ }^{459}$ Śantarakșita expressed the importance of the both systems in the path to enlightenment in the following two stanzas of his Madhyamakālamkāra:

a hundred times ... ' -what distinction could there be among them that one could be attached to some and angry at others? Therefore, taking it to heart that one should act with even-mindedness towards all sentient beings, commencing from a position of neutrality, one cultivates even-mindedness towards friends and enemies alike," Martin, p. 182. Regarding the centrality of compassion in the Mahāyāna tradition Beyer argues, "The religious fervor of the Great Vehicle was a major force in renovating the traditional structure of meditation. The concept of the path was extended to include an entire sequence of bodhisattva stages to enlightenment: the foundation of the path became compassion rather than personal virtue, and compassion led inevitably to the awakening of the thought of enlightenment, the vow to achieve Buddhahood for the sake of all beings." In Stephan Beyer's The Buddhist Experience: Sources and Interpretations, Religious Life of Man Series (Encino, Calif.: Dickenson, 1974), p. 99. ${ }^{459}$ Blumenthal describes this as one of the most important consequences of the Yogācāra-Madhyamaka synthesis: "Here we find a particularly important and unique aspect of Sāntarakșita's presentation of the two truths. It is not merely that he incorporates aspects of Mind-Only thinking into his presentation that makes it unique. It is unique because for virtually all of Śāntarakșita's Madhyamaka predecessors in India, the two truths are utilized solely as a vehicle for presenting the ontological status of entities. It is done by way of describing the mode of being for various objects of knowledge (ultimate truths and conventional truths). This common Madhyamaka way of approaching the two truths is present in Śāntarakșita as well, but there is more here. In addition to stating the ultimate truths exist in $x$ way and conventional truths exist in $y$ way, Śantarakșita is also using his presentation of conventional truths as a stepping stone for his readers. A proper understanding of conventional truths takes a person part of the way towards an understanding of the ultimate. Previous Madhyamaka presentations of conventional truths do not incorporate this practical dimension. For Śāntarakșita, conventional truths are not completely mistaken. By properly understanding conventional truths (i.e., as a follower of Cittamatra tenets understands the ultimate), one is well on the way to a proper understanding of the ultimate from his Madhyamaka perspective - the most subtle and accurate philosophical presentation of reality. There is a dynamic step at work in Śāntarakșita's presentation of the two truths; first one understands that entities are not of a distinct nature from that of the mind (as Mind-Only proponents claim) and then they progress to realize that nothing exists in and of itself (the Madhyamaka perspective), even the mind. This dynamic engagement with conventional truths is unique among Madhyamaka thinkers and a critical innovation in the thought of Śāntarakṣita." In Blumenthal's "Śāntarakṣita." 
By relying on the Mind Only (cittamatra, sems tsam pa) [system], know that external entities do not exist. And by relying on this [Madhyamaka] system, know that no self at all exists, even in that [mind].

Therefore, due to holding the reigns of logic as one rides the chariots of the two systems (i.e., Yogacara and Madhyamaka), one attains [the path of] the actual Mahayanist. ${ }^{460}$

As Nupchen makes clear at the end, though, the practitioner should never mistake the

path (Tib. thabs) for the result (Tib. 'bras bu) and, therefore, he asserts the importance of the

ultimate over the conventional truth:

The Perfection of Wisdom Sütras says: "Initially, all phenomena appears due to interdependent origination, and that [phenomena] is naturally devoid of characteristics, and does not emerge of its own accord, you will also observe [how phenomena] gathers through causes and conditions, and that those causes and conditions are inherently empty, and they are also devoid of characteristics, and do not emerge independently. ${ }^{461}$

${ }^{460}$ Blumenthal, The Ornament of the Middle Way, p. 245.

${ }^{461}$ Lamp 75.1-75.3: "yang rten < shes rab pha rol phyin pa las / > (75.2) cing 'brel bar 'byung ba'i chos thams cad gzod ma nyid nas / rang bzhin gyis mtshan ma med pa dang / rang bzhin gyis 'byung ba med par mthong bas / (75.3) rgyu rkyen 'dus par mthong na'ang / rgyu rkyen nyid kyang stong pa dang / mtshan ma med pa dang / 'byung ba med par rab tu shes so //" It is interesting to point out here that whoever wrote the interlinear note here indicating that the quote belonged to the Perfection of Wisdom Sütras made a mistake, since the quote is in the Ratnaküta Sütra (D 50; dkon brtsegs, kha 1b1-70a7 (vol. 40) 'phags pa de bzhin gshegs pa mi 'khrugs pa'i bkod pa zhes bya ba theg pa chen po'i mdo). The actual quote from the Sūtra is: "gzod ma nyid nas stong pa dang / rang bzhin gyis mtshan ma med pa dang / rang bzhin gyis 'byung ba med par mthong bas gzugs la gzugs nyid du mi mthong ste/ tshor ba dang / 'du shes dang / 'du byed dang / rnam par shes pa la yang de bzhin no/ /rnam par shes pa la yang rnam par shes pa nyid du mi mthong pas rnam par shes pa tha dad pa'i rkyen las 'byung ba dang / rnam par shes pa'i mtshan nyid rang bzhin gyis gzod ma nyid nas stong pa dang / rang bzhin gyis mtshan ma med pa dang / rang bzhin gyis 'byung ba med de rgyu rkyen mang por gtogs pa tsam gyin par rab tu rtogs so//rgyu rkyen 'dus par mthong ba na rgyu rkyen nyid kyang stong pa dang / mtshan ma med pa dang / 'byung ba med par rab tu shes so/ /de ltar mthong ba'i tshe mig la mig nyid du mi lta ste/ rna ba dang / sna dang / lce dang / lus dang / yid la yang de bzhin no/ /yid la yang ying nyid du mi mthong bas yid tha dad pa'i rkyen las byung ba dag yid kyi mtshan nyid rang bzhin gyis gzod ma nyid nas stong pa dang / rang bzhin gyis mtshan ma med pa dang / rang bzhin gyis 'byung ba med par rab tu rtogs so/" This is one of several examples in which the interlinear notes misidentify the actual textual source of a quote. Nupchen seems to have followed the 8th century treatise, written by Jñanagarbha, "Commentary on the Distinction Between the Two Truths," (Tib. Bden gnyis rnam 'byed 'grel pa) for his explanation rather than the actual Bhāvanākramas. He mentions the text at the end of the section (although he does not quote from it). 


\section{Contemplative Practices in the Gradual Path (Tib. sgom pa)}

In the Bhāvanākramas, Kamalaśîla describes the core of the Gradual practices as the union of śamatha or Calm Abiding practices (Tib. zhi gnas), and Special Insight or vipaśyanā (Tib. lhag mthong):

Homage to Tara! The Bhāvanākramas is related in brief for those who are beginners in the way of the Mahāyāna sütras. In that context, even if the samādhi of bodhisattvas was taught by the Bhagavān to be limitless (in variety), by way of the (four) Immeasurables and all the rest, nevertheless all samādhis are subsumed under tranquility and insight. Therefore, precisely that path which carries the union of tranquility and insight is related. $^{462}$

Adam, following the work of Paul Griffiths, has interpreted these two types of contemplative processes, as described in the Bhāvanākramas, as focusing on "concentratively enstatic techniques" in the case of śamatha versus "observational analytic techniques" in the case of vipaśyanā. $^{463}$

Before I proceed to outline Nupchen's description of these contemplative techniques, it is important to point out, in this section, that it becomes clear that Nupchen's intention is not to offer a detailed description of the Gradual practices. He assumes the reader is already aware of the various stages of contemplation, and that anyone interested in the details can read a text like the Bhāvanākramas or other sūtras of the Indian tradition that deal with this topic. In fact, as we will see, he seems more interested in the signs and visions that emerge from the practice than in the practices themselves. He then offers only a sketch, a summary that allows him to outline the

\footnotetext{
${ }^{462}$ In the third Bhāvanākrama, in Adam, Meditation and the Concept of Insight in Kamalasíla's Bhāvanākramas, p. 230 .

${ }^{463}$ Adam is borrowing these descriptive categories to describe śamatha and vipaśyanā from Griffiths' unpublished dissertation (1983). See Ibid., p. 54.
} 
important points of the tradition that are important for his general discussion of Buddhist contemplative practices. ${ }^{464}$

Śamatha

Nupchen begins his description of the śamatha practices by focusing, first, on the

position of the body:

Sit comfortably and remain in the cross-legged position of Vairocana. Keep your body straight, as well as you head, without bending it forward. Keep the tip of your tongue touching your palate, and your eyes [should be fixated] on the tip of your nose. Then, gradually, meditate on the Four Immesuareables. ${ }^{465}$

\footnotetext{
${ }^{464}$ The fact that there is an implied audience in this type of literature is also hinted at by Adam in his discussion of the Bhāvanākramas: "Kamalaśīla's conceptions of śamatha and vipaśyanā appear to be based on those set forth in a large number of Mahāyāna sūtras. Those he cites most often in this context are the Samphinirmocana and the Lañkävatära Sütra. The others that are cited more than once in this context are the Ratnamegha, the Samädhiräja, the Ratnaküta. As noted, it is to beginners in such sütra that all three Bhävanākramas are explicitly addressed." in Ibid., p. 54. Bold is mine.

${ }^{465}$ Lamp 75.5-76.1: "de la blo yis don dam pa'i bden pa'i ngang la bsgom zhing 'jug pa gnyis te / sgo nas 'jug < rang gzhung / > pa dang / gzhan $<\log$ rtog dang $>>$ sel ba'i $<$ the tshom gzhan gzhung / sgo nas 'jug pa'o //de la lus stan bde ba la rje btsun rnam par snang mdzad kyi skyil mo krung du 'dug lus ya yo med pa / mgo mi dgye mi dgu ba lce rtse skan la bcar / mig sna rtser phab nas / tshad med pa bzhi la sogs pa rim par bsgom mo //" A very similar definition can be found in the Bhāvanākramas: "Thus squaring his shoulders and keeping his head neither raised nor lowered, nor moving it to one side (or another), he remains erect from the nose right down to the navel. The teeth and lips should be left natural, while the tongue is placed near to the upper teeth. His respirations should not be accompanied by sound, nor move too hurriedly or heavily, but rather should in this manner imperceptibly enter and depart, slowly and effortlessly. In this regard, first of all, at the outset tranquility should be practiced. Tranquility is understood as one's abiding in a state of mind which is thoroughly disciplined and joyful and which is continually and by its own nature fixed inwardly upon the meditation object -- after having calmed one's distractions related to external objects." In the second Bhāvanākrama, translation by Ibid., 195-196. The Princeton Encyclopedia of Buddhism defines the Four Immesuarables as: "Apramāṇa: (P. appammaññā; T. tshad med pa; C. wuliangxin; J. muryōshin; K. muryangsim 無量心). [...] This list is identical to the four 'divine abidings' (BRAHMAVIHĀRA) of loving-kindness (MAITRĪ), compassion (KARUNĀ), empathetic joy (MUDITĀ), and equanimity or impartiality (UPEKȘA $\bar{A}$. When taken as objects of concentration and extended in meditation to all beings without limit, the divine abidings then become 'boundless states' (apramāna). The meditator is taught to take up each of the boundless states in the same way: starting with the first apramāna, for example, filling his mind with loving-kindness, he pervades the world with it, first in one direction, then in a second direction, then a third and a fourth, then above, below, and all around, identifying himself with all beings and remaining free from hatred and ill will. In the same way, he takes up compassion, empathetic joy, and equanimity. These four factors are taken up as objects of meditation to counter the influence of specific unwholesome states of mind: viz., loving-kindness counteracts hostility (VYĀPĀDA); compassion counters harmfulness (VIHIṂSĀ); empathetic joy counters dissatisfaction or envy regarding others' achievements (arati); and equanimity counters both the desire and hostility arising from sensuality (KĀMARĀGA-VYĀPĀDA) and the desire to win the approval of others (anunaya). Of these boundless
} 
Śamatha practices are designed to relax the body and calm the mind, but also to train the practitioner to maintain focused attention on a particular object. This tension at the core of śamatha practice is described by Kamalaśīla in the Bhāvanākramas as:

Tranquility is understood as one's abiding in a state of mind which is thoroughly disciplined and joyful and which is continually and by its own nature fixed inwardly upon the meditation object -- after having calmed one's distractions related to external objects. $^{466}$

Nupchen offers a very similar description of śamatha in the Lamp:

When a person familiarizes with the practice of calm abiding, by obtaining the causes of the practice of calm abiding, its inherent nature (your desire to practice will be so great that your own characteristics will become clear), and its precise definition of its characteristics, the time to practice meditation, the object of perception (during practice), the faults (of practice) and their counteragents, the complete signs and the virtues of meditation, when all of this is reached, then the practitioner has obtained the so-called concentration (Skt. dhyāna; Tib. bSam gtan). The stability of the mind will be that of a mountain Concentration, and until you do not obtain vipaśyanā, this is concentration (Skt. samādhi; Tib. ting nge 'dzin). ${ }^{467}$

Then Nupchen lists the traditional list of challenges the practitioner can face during śamatha (Tib. nyes pa) practice, as well as their antidotes (Tib. spong pa'i gnyen po):

states, the first three are capable of producing the first three of the four DHYĀNAs, or meditative absorptions; the fourth divine abiding is the only one capable of producing the fourth meditative absorption." (page number?)

${ }^{466}$ In the second Bhävanākrama, translation in Ibid., 47.

${ }^{467}$ Lamp 76.4-77.1: "kha cig zhi gnas goms pa dang la byed de la zhi gnas kyi rgyu dang // rang bzhin dang <shin tu sbyangs pa ji ltar 'dod pa rang gi mtshan nyid bzhin du gsal ba'o $/>$ mtshan $<$ sems brtan ri bo dang 'dra zhing $/>$ $<$ ting nge 'dzin / $>$ nyid nges tshig dang / bsgom pa'i dus dang < lhag mthong ma thob tsam na / / dmigs pa dang / nyes pa dang / de'i gnyen po dang / rdzogs pa'i tshad dang / rdzogs pa'i yon tan thob pas bsam gtan ming thob pa'o //de la bsgoms pa'i dus su dmigs pa ni / sems gang la spro ba la bya'o //sku gzugs lta bu la dbye na /" It is interesting, though, that the image of the mountain in the Bhāvanākramas is not associated with Calm Abiding practices, but with Special Insight: "Because of the power of tranquility the mind will not become unsteady with the flurries of thought -- just like a butter-lamp that does not flicker in the wind. Because of insight, it will not be disturbed by others, since all the stains of mistaken views are removed. Thus from the Candrapradīpasūtra: 'Through the power of tranquility one becomes unwavering; Through insight one becomes as if a mountain." In the second Bhāvanākrama, translation by Martin, p. 190. 
As for the defects (of meditation): laziness, forgetting the object of attention, drowsiness and agitation, lack of effort or too much effort. The eight antidotes to eliminate those faults are: faith, aspiration, effort, pliancy, mindfulness, alertness, volition, equanimity. ${ }^{468}$

Finally, Nupchen describes the four different stages of concentration (Skt. dhyāna; Tib. bsam gtan bzhi) that the practitioner will achieve through the familiarization of śamatha. ${ }^{469}$

\section{Vipaśyanā}

The description of vipaśyanā by Griffith as "observational analytical techniques" implies, in the opinion of Martin, "a perceptual element as well as an intellectual element." "470 Śamatha practices have trained the practitioner to "see" phenomena as it really is, and that "seeing" leads to a realization of the ultimate nature of reality. ${ }^{471}$ In other words, śamatha prepares the mind so vipaśyanā can emerge. In the words of Nupchen:

\footnotetext{
${ }^{468}$ Lamp 77.3-77.4: "nyes pa'i skyon ni / le lo dang / dmigs pa brjed pa dang / bying rgod dang / mi rtsol ba dang / rtsol ba'o // de spong pa'i gnyen po ni / 'du byed brgyad de / dad pa dang / 'dun pa dang / rtsol ba dang / shin tu sbyangs pa dang / dran pa dang / shes bzhin dang / sems pa dang / btang snyoms so //" The same list is also included in the Bhāvanākrama: "In brief, there are six (possible) faults for every single samadhi: laziness, loss of the object, laxity, excitement, lack of effort and overexertion. Eight conditions of abandonment should be cultivated as their antidotes, namely: faith, aspiration, exertion, pliancy, mindfulness, clear comprehension, willpower (cetana $\bar{a}$ ) and equanimity." In the first Bhāvanākrama, in Adam, p. 138. The same discussion appears in Vimalamitra's The Meaning of the Gradual Approach to Meditation (Tib. Rim gyis 'jug pa'i sgom don): "In brief, all meditations have six obstructions: laziness, forgetfulness of the object, dullness, restlessness, non-effort and needless effort. As antidotes to these, one should cultivate the eightfold course: faith, aspiration, effort, clarity, mindfulness, observance, awareness and equanimity," in Vimalamitra, The Stages of Meditation, pp. 28-29.

${ }^{469}$ Dudjom Rinpoche offers the following definition of the four meditative concentrations: "The Four Meditative Concentrations (Tib. bsam gtan bzhi, SkI. caturdhyāna. The first is the meditative concentration which possesses both ideas and scrutiny (rtog-pa-dang bcas-shing dpyod-pa-dang bcas-pa'i bsam-gtan dang-po), the second is the meditative concentration which possesses no ideas but scrutiny alone (rtog-pa med-Ia dpyod-pa tsam-dang bcas-pa bsam-gtan gnyis-pa), the third is the meditative concentration of mental action which is devoid of ideas and scrutiny (rtog-pa-dang dpyod-payang-med-payid-la byed-pa bsamgtangsum $\sim \mathrm{pa}$ ) and the fourth is the meditative concentration of mental action which is united with delight (dga'-ba sdud-pa yid-la byed-pa'i bsam-gtan bzhi pal" (Dudjom Rinpoche, The Nyingma School of Tibetan Buddhism: Its Fundamentals and History, p. 124 of the glossary). For a more detailed discussion of the four concentrations in the Tibetan context, see Jamgon Kongtrul's The Treasury of Knowledge. Book One: Myriad Worlds (Ithaca, N.Y.: Snow Lion Publications, 2003), pp. 123-126. For a discussion of the four concentrations in the context of Buddhist history and doctrine, see Rupert Gethin's The Foundations of Buddhism, OPUS (Oxford: Oxford University Press, 1998), pp. 184-186.

${ }^{470}$ Adam, Meditation and the Concept of Insight in Kamalaśila's Bhāvanākramas, p. 49.

${ }^{471}$ Germano, in his definition of the practices of Calm Abiding and Special Insight, argues that the Calm Abiding practices not only settle the body of the mind, but also pave the way for "the acquisition of the ability to see the world in accordance with Buddhist doctrinal analysis of its final reality." What makes Germano's definition interesting and different from that of other scholars is that implies that the result of the Buddhist contemplative
} 
When [the practitioner] is extremely familiarized and endures with [the practice] of Calm abiding, Special Insight will emerge. The mind in Calm abiding should not move, should not be agitated. When it enters the sphere of cognition (Tib. 'du shes klongs su zhugs pas), [vipaśyanā] will emerge strongly. When concentration is perfected, then you should unite [śamatha and vipaśyanā], and this vipaśyanā will be generated through analysis. ${ }^{472}$

\section{Signs and Visions}

Next, we find the longest section in the chapter, which is dedicated to some of the signs and visions that manifest as a result of the successful practice of śamatha and vipaśyanā. These visions are expressed in the one hundred and eight dreams that are found in the Mahäratnaküta Sütra and that Nupchen quotes in their entirety.

What we have here is a very interesting example of interpretation of dreams. In the Western tradition, particularly as established in the classic work of Freud, the Interpretation of Dreams, dreams have meaning, and reveal deep, hidden aspects of the individual, and the role of the psychoanalyst is to interpret their meaning:

There is a psychological technique which makes it possible to interpret dreams, and that on the application of this technique every dream will reveal itself as a psychological structure, full of significance, and one which may be assigned to a specific place in the psychic activities of the waking state. ${ }^{473}$

\footnotetext{
practices is conditioned apriori by their own doctrinal analysis of the world. The full definition is here: "In this way, contemplative calming serves as the meditative basis for the attainment of incisive insight into the nature of reality, specifically into the selflessness of persons and the selflessness of phenomena, realization of which are said to result ultimately in liberation or enlightenment. The practice of calming thus clears a mental space for the acquisition of the ability to see the world in accordance with Buddhist doctrinal analysis of its final reality, while the practice of insight cultivates and deepens that perception with an incisiveness based upon the newly acquired capacity for concentration. The practice of calm abiding is thus roughly equivalent to 'stabilizing meditation,' while the practice of insight meditation is roughly equivalent to 'analytical meditation." In David Germano and Gregory Hillis, "Buddhist Meditation," in Encyclopedia of Religion, ed. Lindsay Jones, 2nd ed. (Detroit: Macmillan Reference USA, 2005), p. 1284.

${ }^{472}$ Lamp 78.6-79.2: "de ltar zhi gnas la shin tu goms nas bzod cig lhag mthong skye ste // zhi gnas kyi sems mi g-yo // mi 'khrug / 'du shes klungs (klongs?) su zhugs pas / shugs kyis kyang skye'o // lhag mthong dpyad pas skyes nas zung du 'brel bar byed pa yang / bsam gtan rdzogs < zhi gnas /> nas byed do //"'

${ }^{473}$ Sigmund Freud, The Interpretation of Dreams (New York: Avon Books, 1965), p. 1.
} 
The dreams described in this section, though, are all the result of a successful practice, and, therefore, their content is filled with Buddhas, and Buddhist imagery and symbolism. In those dreams the practitioner can see the Buddha standing up (dream 11), a stūpa that the practitioner has never seen before (14), a stüpa decorated with precious jewels (15), the Buddha wearing dirty clothes (22), the practitioner can see himself or herself on a mountain (43), have dreams about an earthquake (49), find a text (58), or sees a tree with hanging fruit (77), among others. Some of these dreams reveal challenges and obstacles faced by the practitioner, others reveal progress, but all of them serve a purpose, and are connected with the contemplative practice of the meditator, manifesting the progress, the challenges, and the path ahead for the practitioner. The Mahāratnakūta Sütra offers an interpretation to all of those dreams, and assigns them meaning within the context of the Buddhist cosmology and doctrine. What is interesting here is that, continuing with the synthesis established within the Yogācāra-Madhyamaka tradition, dreams may have no inherent reality (like all phenomena, they are ultimately empty), but from a conventional level they are part of the path. They may be empty, but that does not make them meaningless. More than a Freudian system of interpretation, what we find here is closer to a Jungian understanding of dreams as part of a religious experience. That comparison, as interesting as it is, would take us away from the subject of this dissertation. ${ }^{474}$

\footnotetext{
${ }^{474}$ Jung himself explored the similarities of the idea of the unconscious in the Western tradition and that of the ground in the Tibetan Buddhist tradition (Tib. kun gzhi'i rnam par shes pa; Skt. Álayavijñanna) in several of his works. In his commentary to The Tibetan Book of the Great Liberation, translated by Evans Wentz, Jung has the following to say: "It is also remarkable that our text recognizes the 'potentiality' of the unconscious, as formulated above, by calling the Mind the 'Sole Seed' and the 'Potentiality of Truth'. The matrix-character of the unconscious comes out in the term 'All-Foundation'." In Jung's introduction to W. Y. Evans-Wentz' The Tibetan Book of the Dead (London, New York: Oxford Univ. Press, 1949), p. lviii. Jung was particularly interested in Tibetan literature that dealt with dreams and visions.
} 
The space that Nupchen dedicates to these visions and dreams is remarkable, especially if we take into account that the Bhāvanākramas only mention them briefly, and it does not include a specific reference to any of the one hundred and eight dreams in the Mahäratnakūta Sūtra:

One who has practiced compassion, method and the thought of Awakening in that way will certainly become distinguished at this time. By doing so, he will continually see Buddhas and bodhisattvas in his dreams. He will also dream other good dreams. ${ }^{475}$

In fact, Nupchen spends more time on these dreams and their interpretations than on the actual contemplative practices in the Gradual chapter (14 straight folios in a chapter that is not even 27 folios long). There are various possible answers to this. On the one hand, we can explain this emphasis on dreams and visions of Buddhas in the context of the Mahāyāna practices of "recollection of the Buddha" (Skt. buddhānusmṛti; Tib. sangs rgyas rjes su dran pa;) that attempted to bring back the figure of the absent Buddha of the Hinayana tradition. In fact, the majority of the dreams listed in the Mahāratnakūța Sütra and included by Nupchen in the Lamp contain the presence of the Buddha, or multiple Buddhas, or of a stüpa (a symbolical representation of the body of the Buddha).

As described by Beyer in his "Notes on the Vision Quest in Early Mahāyāna," dreams and visions in early Mahāyāna have three major components: "the technique of visualization, the sense of devotion, and a metaphysical need to explain the soteriological potential of the new contemplative technique." We see this at play in Nupchen's description of Gradual practices, in which dreams and visions are the result of the practice, and they need to be explained in the context of their soteriological importance. Although, as Beyer also points out, the devotion that fueled early recollection of the Buddha practices, which could have led to bhakti movements like

\footnotetext{
${ }^{475}$ In the third Bhāvanākrama, in Adam, Meditation and the Concept of Insight in Kamalaśilla's Bhāvanākramas, p. 234. Italics are mine.
} 
in India, were tempered by the metaphysical doctrine of emptiness at the core of the Mahāyāna

movement:

The wave of visionary theism left its lasting mark on Buddhism as a technique: it is striking how-compared to the Bhagavadgit $\bar{a}$ - the Pure Land texts manage to divorce visualization from devotion: the saving Lord remains impersonal and distant, a power to be tapped by vision and recitation, in a cool and dazzling ecstacy rather than in a genuine encounter of the human with a divine other. Thus the path of Vaidehī and of Dharmākara is a path of training and technical mastery, a progression of visionary and magical skills very much like that of the later Tantric practitioner, and to the same end of utilizing soteriological force through contemplative manipulation. The path of Sadaprarudita is different. In the Prajñāpāramitā texts, the Súnyavādin sūtras, and the Daśabhūmikasūtra we find the possibility of vision combined with a peculiarly Buddhist metaphysics. The metaphysics of the Prajñāpäramitā is in fact the metaphysics of the vision and the dream: a universe of glittering and quicksilver change is precisely one that can only be described as empty. The vision and the dream become the tools to dismantle the hard categories we impose upon reality, to reveal the eternal flowing possibility in which the Bodhisattva lives. The question that issues from Sadaprarudita's samādhi, and the question that becomes the climax of the later version, is "Where do the Buddhas of the vision go?" For Sadāprarudita, in the speculative context of the Prajñaparamitā literature, the visionary quest has become a metaphysical one: in the later version of the tale we can see a hint of the process by which Mahāyna philosophy seeks to free itself from its visionary roots. ${ }^{476}$

We can also see Nupchen's extensive interest in visionary processes, more than in the actual practices of the Gradual tradition, as an early indication of the interest of the Great Perfection in light and visions. The Great Perfection during Nupchen's time is not as photocentric as it will be in the later tradition, particularly with the development of the Seminal Heart tradition (Tib. snying thig) in the 11 th century, ${ }^{477}$ but we see in Nupchen's text, even

\footnotetext{
${ }^{476}$ Stephan Beyer, "Notes on the Vision Quest in Early Mahāyāna," in Prajñāpāramitā and Related Systems: Studies in Honor of Edward Conze, ed. Lewis R. Lancaster, vol. 1, Berkeley Buddhist Studies Series (Berkeley: University of California, 1977), p. 340.

${ }^{477}$ See David Germano's “Architecture and Absence in the Secret Tantric History of rDzogs Chen," The Journal of the International Association of Buddhist Studies 17, no. 2 (1994): 203-335; David Germano, Mysticism and Rhetoric in the Great Perfection (rDzogs Chen) (Unpublished Manuscript, 2009); Sam Van Schaik, Approaching the Great Perfection: Simultaneous and Gradual Approaches to Dzogchen Practice in the Longchen Nyingtig (Boston: Wisdom Publications, 2004).
} 
during his discussion of tantric practice in the Mahāyoga tradition, an emphasis on practices that include the visionary process of the Intermediate State (Tib. bar do). ${ }^{478}$

The Conduct (Tib. spyod pa) and the Result (Tib. 'bras bu)

Nupchen does not dedicate much space to the conduct and the result section in the Gradual chapter, which is more developed in the chapters dedicated to the other Buddhist traditions, and it shows his lack of interest in the Gradual tradition. For conduct, Nupchen briefly mentions the need for the individual to practice the Two Accumulations (Tib. tshogs gnyis). ${ }^{479}$ As for the result, he will refer to it in his discussion of the results when he compares the Gradual and the Sudden traditions at the end of the chapter dedicated to Chinese Chan.

\footnotetext{
${ }^{478}$ See the description of Mahāyoga in chapter 3 of this dissertation.

${ }^{479}$ The Two Accumulations refer to the accumulation of merit (Skt. punya; Tib. bsod nams) and wisdom (Skt. jñāna; Tib. ye shes) that the bodhisattva needs to gather on the path to enlightenment.
} 


\section{PART 2 - The Chinese Sudden Tradition}

\section{The Arrival of Chan in Tibet}

In chapter 2 of the Lamp Nupchen offers a very concise overview of the history of Chan in China and its introduction into Tibet:

As for the Sudden tradition, the lineage of Mahākāśyapa and Master Bodhidharma. Bodhidharma came to the land of Lenkug in China from the East after having crossed the ocean and was received by Emperor. Bodhiharma realized that the Chinese Emperor was not the one who understood [the meaning] of Ultimate Truth. He then left for the castle in Lagchu, where [three Chinese monks] Kashi, Lichi, and Kvanahong, were very jelous of him. Master Lichi poisoned him six times but he did not suceed. After he found a person to whom he transmitted his teachings, he passed away. After being buried, a business man called Un was travelling from China to the Northern region and at the top of Ramating pass, met Master Bodhidharma holding only one show in his hand, and had a very detailed conversation. When he returned to China, he explaind this encounter in detail, and when they went to see the tomb, his body was not there and there was only one shoe. Everybody said "he is a saint!" The teachings of the Sudden approach of Mahāyāna are the last of this lineage, as well as the Sūtras of the perfected meaning. ${ }^{480}$

As we can see in Nupchen's account, his narrative, situating Hashang Mahāyāna as the 7th patriarch, does not correspond with the traditional account of the Chan tradition as found in the Platform Sūtra (Ch. 壇經). This famous scripture of the Chan tradition describes the radical split in the Chan lineage that occurred after the death of the 5th Patriarch, Hongren (Ch. 弘忍), between Shenxiu (Ch. 神秀), who defended a gradual approach to enlightenment, and Huineng (Ch. 惠能), who espoused a sudden approach. These distinctive approaches came to be known as

\footnotetext{
${ }^{480}$ Lamp 23.5-24.4: “cig (23.6) char 'jug pa ni / 'od srungs dang / slob dpon dhar mo ra las brgyud pa ni / bod de dar mo t'a ra ni shar phyogs nas rgya mtsho brgal nas 'ongs te / rgya yul len kug tu (24.1) phyin pa dang / rgya rje se'u yan 'a nga / mkhan po mjal bas / mkhan pos rgya rja'u ni don dam pa go ba ma yin par shes nas / mkhar lag chur byon pas dge sbong kha (24.2) shi dang / li'u ci dang / kwa na hong la sogs pas phrag dog byas te / li cis mkhan po la dug lan snga phyi drug blud pas ma tshugs so // gzhug chos gtad pa'i sa (24.3) rnyed nas rgya yul sku 'das tsul bstan nas / bdur < shi /> ba'ang zin nas / rgya yul nas stod phyogs su tshong pa 'un zhes bya bas phyin pas // ra ma teng gi la ka slob (24.4) dpon bod de dar mo t'a ra dang mjal te / phyag na lha ma ya yang / gcig kyang thogs nas 'dug go //"
} 
the Northern and the Southern schools, repectively. Scholars like John McRae ${ }^{481}$ and Bernard Faure, ${ }^{482}$ among others, have already deconstructed this narrative and argued that this account was a later construction by the Chan tradition that greatly oversimplified their particular doctrinal position in order to favor a particular lineage and set of ideas versus competing ones. ${ }^{483}$

What we find in this brief historical account by Nupchen and in his description of Chan in the Lamp offers a more complex picture of the Chan tradition from the view of the Tibetan plateau, which does not follow neither the Northern nor the Southern schools, ${ }^{484}$ but that of the Baotang lineage, that proclaims Hashang Mahāyāna as the rightful inheritor of the Chan

${ }^{481}$ John R. McRae, The Northern School and the Formation of Early Ch'an Buddhism (Honolulu: University of Hawaii Press, 1986); John R. McRae, Seeing through Zen: Encounter, Transformation, and Genealogy in Chinese Chan Buddhism (Berkeley: University of California Press, 2003).

${ }^{482}$ Bernard Faure, Chan Insights and Oversights: An Epistemological Critique of the Chan Tradition (Princeton, New Jersey: Princeton University Press, 1993); Bernard Faure, The Will to Orthodoxy: A Critical Genealogy of Northern Chan Buddhism (Stanford, Calif.: Stanford University Press, 1997).

${ }^{483}$ McRae is very clear regarding the historicity of the encounter between Shenxiu and Huineng as described in the text: "But there is still more to say about the opening Platform Sütra anecdote itself. The reader might wonder, for example, whether there is any possibility that the events described might have actually happened. Here we can be definitive: there is no such possibility whatsoever, and the account must be accepted as a brilliant and religiously meaningful bit of fiction. How is it possible to be so certain? First of all, Shenxiu studied with Hongren for a few years at the very beginning of the latter's teaching career, so he was nowhere in sight when the events in question are supposed to have occurred. Second, the very notion of selecting an individual successor to serve as "sixth patriarch" would have been inconceivable in the latter years of Hongren's life, since the concept of a Chan "monosuccession" - that there was one and only one orthodox succession of patriarchs - appeared only later, in the teachings of Shenhui. Third, if the matter had been known to Shenhui, who was a master storyteller dedicated to promoting Huineng's identity as sixth patriarch, he certainly would have included it in his writings. We have good evidence to show that in the late 730s Shenhui was ignorant of most of the details of Huineng's life. It is probable, but by no means certain, that Shenhui only thought to contribute to the embellishment of Huineng's life quite late in his own career." In McRae, Seeing through Zen, p. 67.

${ }^{484}$ None of the main teachers of these schools, after the supposed split between the Northern and the Southern schools, are mentioned in the Lamp. Nonetheless, Obata sees traces of Shenhui's thought in Hashang Mahāyāna's works, particularly the Dunwu dasheng zhenglijue. According to Adamek: "Obata Hironobu characterizes the Dunwu dasheng zhenglijue as a unique synthesis that includes concepts reflective of Moheyan's Northern School teachers, Shenhui, and Wuzhu. It does not, however, show any traces of the Southern School polemic against the Northern School. Obata contends that although Moheyan places emphasis on the apparently "Northern School" practice of kanxin (viewing the mind), in fact his interpretation of this practice is more in keeping with the subitism of Shenhui's "jianxing chengfo (see the nature and become a Buddha)." Moreover, Obata argues that although the Dunwu dasheng zhenglijue includes elements of Shenhui's thought, Moheyan's interpretation of "no-thought" appears to be primarily based on Wuzhu's teachings as given in the Lidai fabao ji. The most pointed example of this is the close correspondence between Moheyan's interpretation of nothought (bu si zhe yi bu si 'one is not even thinking that one is not thinking') and Wuzhu's signature phrase, 'At the time of true nothought, no-thought itself is not.' In Wendi Leigh Adamek's The Mystique of Transmission: On an Early Chan History and Its Contexts (New York: Columbia University Press, 2007), p. 8. Nupchen also does not mention some of the contemporary developments that were happening in the Chan tradition in China around the 9th-10th centuries, such as what came to be known the "Five Houses" (Ch. 五家), or the work of Tsungmi (780-841 CE; Ch. 宗密). 
patriarchs tradition. ${ }^{485}$ In her account of the Record of the Dharma Jewel Through Generations, the Lidai fabao ji (Ch. 歷代法寶記), the main account that has survived of the now disappeared

Baotang tradition, Adamek may offer a clue to how this became possible:

The Lidai fabao ji (Ch. 歷代法寶記) fabrication most frequently singled out for criticism is the story that the founder of their school, the Chan master Wuzhu 保唐无住 (714-774), was in possession of the key Chan talisman, the robe of the "first patriarch" Bodhidharma (d. c. 530?). Later we trace the genealogy of works claiming that this robe was given to the sixth patriarch, Huineng 惠能 (638-713), by the fifth patriarch, Hongren 弘忍 (602675). Only in Lidai fabao ji is it claimed that the robe was then given by the empress $\mathrm{Wu}$ Zetian 武则天 (r. 684-705) to a master in the lineage claimed by the Bao Tang school. ${ }^{5}$ However, the Lidai fabao ji comes to an end after Wuzhu's death scene without having cleared up the mystery of the subsequent fate of Bodhidharma's robe and Wuzhu's Dharma. ${ }^{486}$

Various Tibetan documents from Dunhuang, and also here in the Lamp, indicate that Hashang Mahāyāna became the inheritor of the Baotang lineage, at least from the Tibetan perspective. ${ }^{487}$

\footnotetext{
${ }^{485}$ The Chan tradition regards Mahākāśyapa as the first of the patriarchs of a direct and uninterrupted transmission from the Buddha Śákyamuni all the way to Bodhidharma, who purportedly brought the teachings to China.

Bodhidharma is considered to be the 28th or 29th Indian patriarch, depending on the sources, and the first in China. Karmay points out the interesting fact that "only the Cig car ba tradition in Tibet considers Hva-shang Mahāyāna as the 7th Chinese patriarch." In Samten Gyaltsen Karmay's The Great Perfection (rDzogs Chen): A Philosophical and Meditative Teaching of Tibetan Buddhism (Leiden; Boston: Brill, 2007), p. 93, n. 42. For a classic discussion of the various patriarchs in the Chan tradition and, in particular, the issues revolving the succession of the Fifth Patriarch, see Philip B Yampolsky's The Platform Sutra of the Sixth Patriarch; the Text of the Tun-Huang Manuscript with Translation, Introduction, and Notes, Records of Civilization, Sources and Studies, No. 76. (New York: Columbia University Press, 1967). For a more modern discussion, see McRae, Seeing through Zen. For a discussion of the history of the Chan lineage in Tibet, read chapter 5 "From Korea to Tibet" of Matthew Kapstein's The Tibetan Assimilation of Buddhism (Oxford; New York: Oxford University Press, 2000). Meinert also points out: "this sevenfold lineage of Chan Buddhism ending with Hwa shang Mahāyāna has to be seen as a regional phenomenon restricted to the Dunhuang area," in Carmen Meinert, "Chinese Chan and Tibetan Rdzogs Chen: Preliminary Remarks on Two Tibetan Dunhuang Manuscripts," in Religion and Secular Culture in Tibet. Tibetan Studies II (PIATS 2000) (Leiden: Brill, 2002), 241.

${ }^{486}$ Wendi Leigh Adamek, The Mystique of Transmission: On an Early Chan History and Its Contexts (New York: Columbia University Press, 2007), 4. Bold and italics are mine.

${ }^{487}$ Karmay has this to say about this topic: "Many Chan texts consider Mahāyāna the last personage of the sevenfold lineage beginning with Bodhidharma. See, for instance, Pelliot tib. 116 and Pelliot tib. 812. In Pelliot tib. 116, f. 164, 3-4 Bodhidharma is called bdun rgyud kyi dang po (the first of the seven-fold lineage). The text Pelliot tib. 813, $12 \mathrm{~b} 3$ mentions a text entitled mKhan po bdun rgyud kyi mdo. Besides the first five masters (Bodhidharma, Huike, Sengcan, Daoxin, Hongren), the lines of succession vary from school to school. Thus the Northern School gives Shenxiu as Hongren's successor, while the Southern School claims Huineng to be his spiritual heir. Nevertheless, it seems that only the cig car ba school of Tibetan Buddhism gives Mahāyāna as the seventh master of
} 
But this is not the place to elaborate on the history of Chinese Chan, ${ }^{488}$ the complex figure of Bodhidharma, ${ }^{489}$ or the intricacies and contested nature of the Patriach tradition, including the obscure history of the Baotang tradition. ${ }^{490}$ Since the focus of this dissertation is Nupchen's understanding of these contemplative traditions as they were introduced in Tibet, I will focus here, as I did in the section dedicated to the Gradual tradition, on the main sources that Nupchen used to inform his view of the Sudden tradition: the Dunhuang Tibetan Chan manuscripts, paying particular attention to Pelliot Tibétain 116 (PT 116), and to the surviving works of Hashang Mahāyāna.

the lineage. Padma dKar po mentions this Chinese master, but as the twenty-first in the line of succession starting from Kasyapa." In Karmay, The Great Perfection (rDzogs Chen): A Philosophical and Meditative Teaching of Tibetan Buddhism, p. 93.

${ }^{488}$ On this see Heinrich Dumoulin's Zen Buddhism: A History (New York: MacMillan, 1994); Robert M. Gimello and Peter N. Gregory's Studies in Ch'an and Hua-Yen (Honolulu: University of Hawaii Press: Kuroda Institute, 1983); and Faure's The Will to Orthodoxy: A Critical Genealogy of Northern Chan Buddhism.

${ }^{489}$ See Jeffrey Broughton, The Bodhidharma Anthology (Berkeley, Calif.: University of California Press, 1999).

${ }^{490}$ See Adamek for an excellent account of the Baotang tradition, including its introduction into Tibet, as presented in the Lidai fabao ji (Ch. 歷代法寶記), in Adamek's The Mystique of Transmission: On an Early Chan History and Its Contexts. 


\section{The Dunhuang Library Cave and the Tibetan Chan Manuscripts}

The discovery at the beginning of the 20th century of a walled-up library containing thousands of texts that dated from the 4 th to the beginning of the 11 th century, in the cave complex of Mogao, in the Oasis of Dunhuang, in present Gansu province in China, radically transformed our knowledge of the history of Central Asia and, by extension, what we knew about the various Empires that at one point or another controlled this strategically situated oasis, a key enclave on the Silk Road. Among those texts, there were hundred of Tibetan texts and scriptures that attested to the influence that the Tibetan Empire exerted over the area from 781 and that continued for a few decades after the collapse of the Empire in 847/8 and its subsequent lost of influence in the area. ${ }^{491}$

\footnotetext{
${ }^{491}$ The work of scholars like Twitchett, Hansen, and Whitfield offer very good general introductions to the history of the area and its importance for the transmission of ideas along the Silk Road. See Denis Twitchett, "Chinese Social History from the Seventh to the Tenth Centuries. The Tunhuang Documents and Their Implications," Past \& Present, no. 35 (1966): 28-53; Valerie Hansen, The Open Empire: A History of China to 1600, 1st ed. (New York: Norton, 2000); and Susan Whitfield, Life along the Silk Road (Berkeley: University of California Press, 1999). Whitfield includes a very good Further Reading appendix that offers an excellent overview of the bibliography on the history of Dunhuang. For a review of the history of the library cave see Xinjiang Rong and Hansen Valerie, "The Nature of the Dunhuang Library Cave and the Reasons for Its Sealing," Cahiers d'Extrême-Asie 11 (1999): 247-75. While Stein and Pelliot put the theory forward, very early on, that the cave was a depository of sacred waste, Xinjiang Rong reexamined that view and proposed that the library "was not a waste repository but instead a book storehouse of the time, complete with manuscript rolls contained in wrappers as well as various materials awaiting repair from a typical Buddhist library." He also argues that the library was probably sealed before 1006 , “... when the people of Dunhuang heard about the fall of the Buddhist Kingdom of Khotan to the Islamic conquerors from Kashgar and then sought to avoid the destruction that had occurred to Buddhist establishments there." See Aurel Stein, Serindia: Detailed Report of Explorations in Central Asia and Westernmost China Carried out and Described under the Orders of H. M. Indian Government (Oxford: Clarendon press, 1921); Paul Pelliot, "Une Bibliothèque Médiévale Retrouvée Au Kan-Sou," Bulletin de l'École Française D'Extreme Orient 8 (1908): 510-29.Regarding the general contents of the library cave, the best place to start is the review of the manuscripts found in the library cave written by Akira Fujieda, "The Tunhuang Manuscripts: A General Description (Parts $1 \& 2$ ), who travelled to the main cities in which the original contents of the cave are located in the present. For a sample of the complex textual and codological work on the Dunhuang manuscripts, see Jean-Pierre Drège, "Étude Formelle Des Manuscrits de Dunhuang Conservés À Taipei: Datation et Authenticité," Bulletin de l'Ecole Française d'Extrême-Orient 74 (1985): 477-84; Cristina Anna Scherrer-Schaub, "Towards a Methodology for the Study of Old Tibetan Manuscripts: Dunhuang and Tabo," in Tabo Studies II. Manuscripts, Texts, Inscriptions, and the Arts, Serie Orientale Roma (Roma: Istituto italiano per l'Africa e l'Oriente, 1999); Sam van Schaik, "The Tibetan Dunhuang Manuscripts in China," Bulletin of the School of Oriental and African Studies 65, no. 1 (2002): 129-39. The recent work of van Schaik at the British Library has been particularly illuminating regarding the importance of the Tibetan manuscript collection for our understanding of the early history of Buddhism in Tibet and its developments after the collapse of the Empire. Also see the recently published Sam Van Schaik, The Tibetan Chan Manuscripts: A Complete
} 
The French scholar Marcelle Lalou was the first person to recognize the existence of Chan texts among the Tibetan manuscripts with her 1939 article "Document tibétain sur l'expansion du Dhyāna chinois." ${ }^{492}$ In 1952, Demiéville's translation of Pelliot chinois $4646^{493}$ allowed scholars to situate those texts in the historical context of the debate between the Indian Gradual and the Chinese Sudden traditions in the Samye Debate that supposedly took place in Tibet around 792-797 CE. The ensuing decades saw a slow but significant reconstruction of the textual and intellectual world of Chan in Tibet. The nature of the "discovery" of the texts in the early $20^{\text {th }}$ century and the dissemination of the contents of the original cave to places like London, Paris, and St. Petersburg became an obvious challenge to any comprehensive research on the topic, ${ }^{494}$ but the reproduction on microfilm of the Stein collection in 1953-54 by Japanese scholars, ${ }^{495}$ and the publication of various catalogues classifying the various collections, ${ }^{496}$ initiated a new era, which, in the words of Akira Fujieda, allowed scholarship to move in a new, much needed direction:

Descriptive Catalogue of Tibetan Chan Texts in the Dunhuang Manuscript Collections, vol. 1, Papers on Central Asia 41 (Bloomington: Indiana University Press, n.d.).

492 Marcelle Lalou, “Document Tibétain Sur L'expansion Du Dhyāna Chinois,” Journal Asiatique 231 (1939): 50223.

${ }^{493}$ Paul Demiéville, Le Concile de Lhasa (Paris: Impr. nationale de France, 1952).

494 The dislocation of the manuscripts that started with the transfer of an important number of manuscripts by Stein in 1907, and Pelliot in 1908 meant, on the one hand, a remarkable discovery for our knowledge of the history of Central Asia from the $4^{\text {th }}$ to the $11^{\text {th }}$ century (the date of the oldest and newest manuscripts in the cave) but, on the other hand, the dispersion of the texts also made their study, especially during the first decades after their discovery, partial and difficult, with no knowledge of how the texts related to the rest of manuscripts of the other collections. This issue started to be solved with the publication of the catalogues with the contents of the various Dunhuang texts, the reproduction in microfilm of the actual texts that started in the seventies, and in the last few years, with the International Dunhuang Project, the most important project to date and an attempt to make available to scholars and the public alike the contents of the original library cave. One of the earliest catalogues of the Tibetan materials was Lalou, Marcelle, Inventaire Des Manuscrits Tibétains De Touen-Houang Conservés À La Bibliothèque Nationale (Fonds-Pelliot Tibétain), Paris 1939, 1950, and 1961. The International Dunhuang Project (http://idp.bl.uk/) has as its mission statement: "IDP is a ground-breaking international collaboration to make information and images of all manuscripts, paintings, textiles and artefacts from Dunhuang and archaeological sites of the Eastern Silk Road freely available on the Internet and to encourage their use through educational and research programmes." The project is directed by Susan Whitfield at the moment of this writing.

${ }^{495}$ Fujieda, Akira. "The Tunhuang Manuscripts: A General Description (Part I)." Zinbun: Memoirs of the Research Institute for Humanistic Studies 9, (1966): 1-32, p. 1.

${ }^{496}$ Lalou published the first volume of the catalogue of the Tibetan manuscripts in the Pelliot collection in 1939. La Vallée Poussin published the catalogue of the Tibetan manuscripts of the Stein collection in the India Office Library in 1962. See bibliography for details on the rest of the catalogues. 
The "treasure-seeking", which in the first half of this century was the traditional way of studying the fragmentary manuscripts of Tunhuang, must now give way to studies of a new type, that is, to reconstruct the library as a whole, and to find the place of an individual manuscript or a group of manuscripts within this corpus. ${ }^{497}$

The various projects of digitazation of these documents, with the International Dunhuang Project $^{498}$ as the most ambitious and comprehensive among them, has ushered a new era of remarkable progress in our study and understanding of these manuscripts. Japanese academia played a very important role early on, identifying these manuscripts, and situating them in the larger context of the Chinese Chan tradition. What emerged from these early studies was a textual map of the tradition that allowed scholars to attempt the reconstruction of the ideology of Chan in Tibet. ${ }^{499}$

There are some obvious methodological issues we need to consider, though, when examining these manuscripts. First, as Ueyama pointed out, "Central Tibet and Tun-huang are geographically quite remote, and were also culturally distinct [...] Therefore, even though we are able in some instances to verify the historicity of the Tun-huang materials, we are still unable to conclude that all they record is applicable to central Tibet." ${ }^{, 500}$ For this reason, some scholars have put forward the idea of the Dunhuang manuscripts not as representative of the intellectual world of China or Tibet, but of the dynamic world of Central Asia. The second issue, which

\footnotetext{
${ }^{497}$ Fujieda, Ibid., p. 1. The bold and italics are mine.

${ }^{498}$ The International Dunhuang Project at http://idp.bl.uk/

${ }^{499}$ Ueyama wrote a very important overview of the early efforts of Japanese scholars on these manuscripts. An example of the complex textual and philological puzzles faced by these scholars can be seen in the following description of one of Ueyama's articles on Stein tib. 710. Ueyama says: "In this article I discuss the contents of a Tibetan manuscript conserved among the Stein collection, the Lin ka'i mkhan po dang slob ma'i mdo (S. tib. 710), and demonstrate that it is a translation of the Leng chia shih tsu chi $[\ldots]$ a text belonging to the Northern school of Ch'an in China [...] A noteworthy characteristic of this translation is the use of technical terminology that is at variance with the equivalents given in the Mahāvyutpatti [...] Subsequently I infer that this translation was made prior to the standardization of terminology in the Mahāvyutpatti," in Ueyama, Ibid. p. 329.

${ }^{500}$ Uyaema, Daishun. "The Study of Tibetan Ch'an Manuscripts Recovered from Tun-Huang: A Review of the Field and Its Prospects." In Early Ch'an in China and Tibet, edited by Whalen Lai and Lewis R. Lancaster. Berkeley: Lancaster Publications, 1983, p. 342.
} 
Ueyama also warns us about, is that the "Tun-huang manuscripts do not represent a complete collection of contemporary Tibetan literature $[\ldots]$ for this reason, working with these fragmentary materials presents the danger of mistakenly reconstructing the whole of which the remaining literature is but a few scattered parts." ${ }^{, 501}$ In the case of the Tibetan Chan manuscripts, it is especially important to keep this in mind since some scholars are attempting to reconstruct a whole tradition out of very few texts, ${ }^{502}$ with the possibility of a huge margin of error in their evaluations. Nonetheless, the similarities between Nupchen's presentation of the Sudden approach in the Lamp and the contents of many of these Dunhuang manuscripts seem to indicate that they refelct some of the most important developments of Chinese Chan in Tibet during the period.

In the particular context of the Lamp, various scholars have pointed out the similarities between the content of some of the manuscripts and Nupchen's chapter dedicated to the Sudden tradition, indicating that Nupchen could have used these or similar sources for his overview of the Chan tradition. As we will see, PT116 has the most significant correlations in content with the Lamp, ${ }^{503}$ but other manuscripts, such as Or. 2715, PT $3018^{504}$ and IOL TIB J 689-1 ${ }^{505}$, also

\footnotetext{
${ }^{501}$ Ueyama, Ibid, p. 342.

${ }^{502}$ Sam van Schaik, who has been working on these textual collections, has only been able to find around 50 Tibetan Chan manuscripts among the almost 4,000 Tibetan manuscripts in the Dunhuang collections. Personal communication.

${ }^{503}$ Okimoto, "bSam Yas No Shuron (2): Tonko Chibetto Bunken Ni Okeru Shozenji”; Okimoto Katsumi, "Dunhuang Chutu de Zangwen Chanzong Wenxian Neirong (Contents of Tibetan Chan Manuscripts Recovered at Dunhunag)," Guowai Zangxue Yanjiu Shi Wenji (Anthology of Translation on Tibetological Research Undertaken in Foreign Countries), no. 8 (1992): 423-27.

${ }^{504}$ This manuscript includes quotations from the now lost Sems lon. Donati has this to say about this text: "I have not been able to identify this text with certainty. Nevertheless, two of the quotations from the Sems lon found in the STMG correspond to two passages of Pelliot tib. 3018 (which can be found, as well, in Or. 2715 and Beijing Su, 99). As noted by Broughton, 1999, p. 126, n. 62, the manuscript Pelliot. chin. 3018 begins with an unidentified Buddhist text; the sixteenth line of the manuscript has the title Puti damo lun, the Treatise of Bodhidharma. The text here called Sems lon is often referred to as Byang chub sems lon which, in Chinese, would be rendered as Puti xin lun. Though two corresponding passages in both the Chinese and Tibetan versions are not enough, I am brought to think that what originally was called Puti damo lun, the Treatise of Bodhidharma, might have come to be known simply as Puti lun, the Treatise of Enlightement, and then received by many scholars, among whom Sangs rgyas Ye shes, as Puti xin lun, the Treatise of the Mind of Enlightenment. This hypothesis would of course deserve further evidence to
} 
provide possible sources of texts that circulated during the period that Nupchen may have used to write this chapter.

The identification of PT 116 was an important milestone in the study of Tibetan Chan, since the cache of Tibetan Chan manuscripts is fairly small. Its considerable length (124 folios) and its textual diversity (it contains twelve different texts) ${ }^{506}$ makes it among the most relevant manuscripts in the collection. The importance of this manuscript is also reflected in the number of other Tibetan Chan manuscripts that correspond, fully, or in part, to fragments of PT $116,{ }^{507}$ which points to its centrality among the Tibetan Chan texts circulating during the period. Another important aspect of PT 116 is the great variety of texts, Buddhist scriptures, and sayings of Chan masters (including Hashang Mahayana) translated or quoted in the text, which allows modern scholars to analyze the textual and ideological connections of PT116 and Chan in Tibet to other Buddhist textual and intellectual traditions. ${ }^{508}$ Some scholars like Okimoto ${ }^{509}$ also point out the relevance of this text for our understanding of the Chan tradition in Tibet, since it could

be justified and the huge amount of Dunhuang documents in both Chinese and Tibetan dealing with the Chan doctrine would surely require a deeper study. Nevertheless my conjecture could be regarded as the first step towards the identification of this famous, yet still unidentified, text." In Valeria Donati, "The Lamp Is Burning Bright. Gnoseological Approaches and Soteriological Perspectives in gNubs Chen Sangs Rgyas Ye She's Masterpiece” (Università degli Studi di Napoli, 2007), p. 213, n. 2.

${ }^{505}$ Carmen Meinert, "Chinese Chan and Tibetan Rdzogs Chen: Preliminary Remarks on Two Tibetan Dunhuang Manuscripts," in Religion and Secular Culture in Tibet, Tibetan Studies II (PIATS 2000) (Leiden: Brill, 2002), pp. 289-307. Regarding the labelling of the Dunhuang Manuscripts, van Schaik offers this simple explanation: "Almost all the Tibetan manuscripts discovered by Stein are now kept at the British Library. Those which came from the India Office Library are numbered with the prefix IOL Tib, while those from the British Museum's Oriental collections are numbered with the prefix Or." See Sam Van Schaik's "Manuscript Numbers in the Stein Collection," Early Tibet, accessed May 12, 2014, http://earlytibet.com/about/numbers/.The ones with the initials "PT" refer to the Pelliot Tibétain manuscripts at the Bibliothèque Nationale in Paris.

${ }^{506}$ Two detailed descriptions of PT 116 can be found in Ueyama, Ibid, pp. 330-332, and Broughton's "Early Ch'an Schools in Tibet," in Studies in Ch'an and Hua-Yen, edited by Robert M. Gimello and Peter N. Gregory, 1-68 (Honolulu: University of Hawaii Press, 1983), pp. 48-50, fn. 4.

${ }^{507}$ Ueyama observes that PT 21, 118, 813, 817, 821, 822, 823, and Stein tib. 706 and 708 correspond, in part, to the contents of PT 116. In Ueyama, Ibid, p. 330.

${ }^{508}$ The PT 116 includes, among others, translations of the Bhadracaryāprañidharānaja and the Vajracchedikāprajñāparamitāmahāyānsūtra. It also quotes texts like the Lańkāvatārasūtra, the Suvarnapra-bhāsasūta, and the Sandhīnirmocanasūtra.

${ }^{509}$ In Luis Gomez' “The Direct and Gradual Approaches of Zen Master Mahāyāna,” in Studies in Ch'an and HuaYen, ed. Robert M. Gimello and Peter N. Gregory (Honolulu: University of Hawaii Press, 1983), p. 72. 
have been written as a manual for debate, presenting the basic ideas of the Chan tradition, and the main arguments to defend it against competing traditions, just as the Bhâvanākramas did for the Gradual tradition. One section (section VI), for example, contains twenty three questions and answers exploring the Chan position on non-conceptuality (Ch. wu fen bie 无分别; Tib. mi rtog pa), and includes quotations from nineteen Sūtras and commentaries (Ueyama p. 331), which seem to be meant as a pedagodical device to articulate the Chan position for a Tibetan audience through arguments, as well as scriptural authority, against the position of competing traditions, with the Gradual as the most obvious target.

The work of Okimoto ${ }^{510}$ is of particular interest, since he explored in detail the connection between sections of PT116, the Chronicles of the Ministers (Tib. bLon po bka'i thang yig), sections of the Five Chronicles (Tib. $b K a$ ' thang sde lnga), and our very own Lamp for the Eye in Contemplation. Nupchen's presentation of the philosophical view of the Chan tradition according to the saying of various masters follows closely the same list of masters found in PT116. As the table, created by Okimoto, shows below, the correlation between the texts is too close to be mere coincidence, and it shows that Nupchen was using a version of PT116, or a very similar source, in the construction of his description of the philosophical view of the Chan tradition. ${ }^{511}$ We also need to remember that Nupchen is synthesizing the doctrines and practices

\footnotetext{
${ }^{510}$ Okimoto, "bSam Yas No Shuron (2): Tonko Chibetto Bunken Ni Okeru Shozenji." Although the first scholar to discover the connection between these texts was Hironobu Obata. In Daishun Ueyama's "The Study of Tibetan Ch'an Manuscripts Recovered from Tun-Huang: A Review of the Field and Its Prospects," in Early Ch'an in China and Tibet, vol. 5, Berkeley Buddhist Studies Series (Berkeley: Lancaster Publications, 1983), p. 346.

${ }^{511} \mathrm{He}$ also discovered that the source for the Chan masters quoted in the Chan section in the Lamp that were not found in PT116 had been translated from the er ru si xing lun zhang juan zi, which can be found in the Dunhuang manuscripts S 2715, PT 2923, and PT4795. Meinert makes this connection very explicit when she argues that "long passages of quotations are obviously taken from anthologies now available within the corpus of Dunhuang manuscripts, such as PT116. We can thus say that Gnubs' [sic] knowledge of the Cig car ba tradition seems to stand partly on such patch-work materials translated into Tibetan following the Tibetan dominion over Dunhuang in the late eight century." In Carmen Meinert, "Chinese Chan and Tibetan Rdzogs Chen: Preliminary Remarks on Two Tibetan Dunhuang Manuscripts," in Religion and Secular Culture in Tibet, Tibetan Studies II (PIATS 2000) (Leiden: Brill, 2002), p. 48. There are also traces of intertextuality between Vimalamitra's rim gyi 'jug pa sgom don and
} 
of these contemplative traditions, and it would make sense that he would use contemporary works from those traditions that have already summarized the most important ideas of these traditions, such as Kamalaśīla’s Bhāvanākramas or Chan compilations such as PT116.

sections V-VII of PT116. See Harada Satoru, "The Existence of Doctrinal Works of the Sudden School after the bSam Yas Debate (bSam-Yas No Shūron Igo Ni Okeru Tonmonha No Ronsho)," Nihon Chibetto Gakkai Kaihō 22 (1976): 8-10. 


\begin{tabular}{|c|c|c|}
\hline hSam gtan mig sgron & Blon po bkahi thang yig & Pelliot 116 \\
\hline & & pt. VII \\
\hline $\begin{array}{l}\text { bodhedarmotara (57-5) } \\
\text { hdug ba (58-2) }\end{array}$ & $\begin{array}{l}\text { bodhidharmottära (21b1) } \\
\text { hjug du (21b2) }\end{array}$ & $\begin{array}{l}\text { bodedarmatala (164-3) } \\
\text { bu at (165-4) }\end{array}$ \\
\hline beud hdul snyin po (58-3) & bdud hdul snying po (21b3) & $\begin{array}{l}\text { bu cal (165-4) } \\
\text { bdud hdul gyi snying po (166-2) }\end{array}$ \\
\hline $\begin{array}{l}\text { adhanaher }(58-5) \\
38 \text {, arnga wor }(150-3)\end{array}$ & $\begin{array}{l}\text { adhanher (2164) } \\
\text { 36) }\end{array}$ & ardan hver $(167-1)$ \\
\hline \multirow{4}{*}{$\begin{array}{l}\text { 49, hagahlun (168-5) } \\
\text { mhâayan (58-5) }\end{array}$} & 36, arnamtharphyin (26a5) & hgva lun $(167-2)$ \\
\hline & mahäуӓпа (21b4) & mahayan $(167-4)$ \\
\hline & & $\begin{array}{l}\text { Pt. VIII } \\
\text { mahayan (171-1) }\end{array}$ \\
\hline & & $\begin{array}{l}\text { pt. IX } \\
1, b \tilde{u} c u(173-4)\end{array}$ \\
\hline 1, kim hun (119-4) & 1, he han (23a1) & $\begin{array}{l}\text { 1, oul ciu hun }(174-2) \\
\text { 2, kim }\end{array}$ \\
\hline 2, dzing $(120-1)$ & 2, dzing (23a2) & 3 , dzang (175-2) \\
\hline 50, deluu $\lim (173-4)$ & & 4, dehu $\lim (175-4)$ \\
\hline $\begin{array}{l}36, \text { lu }(144-5) \\
44, \text { kyin hu }(161-1)\end{array}$ & & 5, lu $(176-4)$ \\
\hline $\begin{array}{l}\text { 44, kyin hu (161-1) } \\
3 \text {, sbab }(120-2)\end{array}$ & 3, sbab (23a3) & $\begin{array}{l}\text { 6, kim hai }(177-4) \\
\text { 7, pab fran }\end{array}$ \\
\hline \multirow{2}{*}{ 4, mknan po šen śe $(120-3)$} & & $\begin{array}{l}\text { 7, pab svan } \\
\text { 8, par }\end{array}$ \\
\hline & & $\begin{array}{c}\text { 9, dzvahi (179-2) } \\
\text { 10, tshvan gi (179-4) }\end{array}$ \\
\hline \multirow{6}{*}{$\begin{array}{l}\text { 6, thang bzang }(120-5) \\
7 \text {, han sa ci }(121-1)\end{array}$} & 5 , thang bzang (23a5) & $\begin{array}{l}\text { 10, tshvan gi }(179-4) \\
11 \text {, wang }(180-2)\end{array}$ \\
\hline & 6, han ze (23a5) & $\begin{array}{l}\text { 11, wang (180-2) } \\
12 \text {, dzvang za (181-1) }\end{array}$ \\
\hline & & 13 , rgyalhi dge bsnyen (181-3) \\
\hline & & 14, sin hobi $(183-4)$ \\
\hline & & 15, hbyyi lig (186-2) \\
\hline & & 16 , mahayan $(186-4)$ \\
\hline 5, dabu $(120-4)$ & 4, deluu (23a4) & 17, dehu $(187-3)$ \\
\hline 8, a rgya rag (121-2) & 7, ärya rag $(23 a 6)$ & 18, bu cu $(187-4)$ \\
\hline 9 , ka la yan par ma (121-4) & 8, bkat la yan par ma (23b1) & \\
\hline 10, bu cu $(121-5)$ & 9, bu cung (23b1) & \\
\hline 11, mahâyan (122-3) & 10, mahấyâna (23b2) & \\
\hline & 11, kha (23b3) & S. 2715 \\
\hline 13, dzang $(122-6)$ & 12, dzang (23b4) & $"$ \\
\hline 14, yen $(123-2)$ & 13 , yen (23b5) & $"$ \\
\hline 15 , a (123-3) & 14, a (23b6) & " \\
\hline 16 , bo len $(124-6)$ & 15, len (24a1) & $"$ \\
\hline 17, hang (123-2) & 16, hang (24a1) & $"$ \\
\hline 18, kag $(123-4)$ & 17 , kang (24a2) & $"$ \\
\hline 19, si (125-1) & $18, \mathrm{dzi}(24 \mathrm{a} 3)$ & P. 2923 \\
\hline 20 , am $(125-6)$ & & ". \\
\hline 21 , in $(126-1)$ & 19, $\operatorname{kam}(24 a 4)$ & $"$ \\
\hline 22, mkhan po chen po (126-2) & 20, bodhi dharmottara (24a5) & " \\
\hline 23, hyahu gyahu $(126-4)$ & 21, hyau hgyeu (24a5) & " \\
\hline 24, mkhan po si $\operatorname{san}(126-6)$ & 22, gyi (24a6) & \\
\hline 25 , si $(127-4)$ & 23 , ci $(24 \mathrm{~b} 2)$ & P. 2923 , P. 4795 \\
\hline 25, phag do (127-5) & 24, phog rtog (2Ab2) & $"$ \\
\hline 27 , hdzi $(128-1)$ & 25, dze (24b3) & $"$ \\
\hline 28 , yan $(128-2)$ & 26 , yan $(24 b 4)$ & $"$ \\
\hline 29, han $(128-4)$ & 27, han (24b5) & $"$ \\
\hline \multirow{2}{*}{$\begin{array}{l}\text { 30, mkhann po san si } 1(128-6) \\
31 \text {, hye kha }(129-1)\end{array}$} & $\begin{array}{l}28, \text { si (24b6) } \\
29 \text {, he kha }(25 a 1)\end{array}$ & \\
\hline & 29, he kha (25a1) & \\
\hline bSam gtan mig sgron & Blon po bkahi thang yig & Pelliot 116 \\
\hline 32 , lang $(129-3)$ & 30, la (25a2) & \\
\hline 33 , maha $(130-1)$ & $\begin{array}{l}31 \text {, ma (25a2) } \\
32 \text { a mo gzang chu ( } 25 \mathrm{a} 3)\end{array}$ & \\
\hline 34 , mkhan po chen po $(131-2)$ & $\begin{array}{l}\text { 32, a mo gzang chu (25a3) } \\
33 \text {, dharmottära (25a4) }\end{array}$ & \\
\hline 35, ka ba dpal brtsegs (132-2) & 34 , ska ba dpal brtsegs (25a6) & \\
\hline 37 , mahâyan $(145-5)$ & 35 , mahâyỹna $(25 b 3)$ & \\
\hline 39, sna nam yejes dpal $(147-2)$ & & \\
\hline 40, lebu gshon nu snying po (148-2) & & \\
\hline $\begin{array}{l}\text { 41, myang bran dpal }(148-4) \\
42 \text {, hdzin mchog rcyan }(150-4)\end{array}$ & & \\
\hline $\begin{array}{l}\text { 22, hdzin mchog rgyan (150-4) } \\
43 \text {, liku gshon nu snying po (150-4) }\end{array}$ & 1) 38, li shu snying po (26а6) & \\
\hline 45 ye ses dbal $(164-1)$ & 39, dpal dbyangs (27al) & \\
\hline 46, hbah $(164-4)$ & & \\
\hline $\begin{array}{l}\text { 47, mahăyan }(164-6) \\
48 \text {, la }(166-3)\end{array}$ & & \\
\hline $\begin{array}{l}\text { 51, mahâyan }(173-5) \\
52 \text { thig tha nam mhah (180-3) }\end{array}$ & 40 , mahăyảna $(27 \mathrm{a} 2)$ & \\
\hline
\end{tabular}

Okimoto - Correlation between the Lamp for the Eye in Contemplation, the bLon po bka'i thang yig, and Pelliot Tibétain $116^{512}$

${ }^{512}$ Okimoto, "bSam Yas No Shuron (2): Tonko Chibetto Bunken Ni Okeru Shozenji." 
So, as we can see, the multifaceted nature and its rich textual connections puts PT 116 at the center of the Chan world preserved in the Dunhuang manuscripts, and scholars have used it as an anchor to situate the other Tibetan Chan manuscripts, ${ }^{513}$ as well as a portal helping us to see the connections between Tibetan Chan and the rest of the Buddhist world during that period.

Reconstructing the Intellectual World of Chan in Tibet: Master Hashang Mahāyāna and Sudden Enlightenment.

The other important source for our understanding of Nupchen's description of Chan is the surviving works of Hashang Mahāyāna. We do not know much about the details of his life. The first mention of him in the Testament of Ba simply says: "At that time a Chinese hwa shang called Mahāyāna came from China to Tibet and most monks were taught the doctrine [by him]. ${ }^{, 514}$ Demiéville mentions that he was an old and experienced teacher in the Dunhuang area, and that he was invited by the Emperor Trisong Detsen to teach at the court around the time Tibetans took control of the area in $787 .{ }^{515}$ We also know that he was a student of the Baotang lineage, and that his texts reflect the ideas of prominent masters of that lineage, such as Wuxiang (無相 684-762) and Wuzhu (無住 714-774).

The Testament of Nup also offers some interesting clues as to the role that Hashang Mahāyāna played in the narrative of Nupchen's life. The biography includes several references to him. The first one is probably the most vague of them all, since it simply refers to a "Chinese monk" (Tib. rgya nag ha shang) from Samye monastery. The term "hashang" was used to refer to

\footnotetext{
${ }^{513}$ Of the 17 articles reviewed by Ueyama, 10 discuss the role of PT 116 in one way or another.

${ }^{514}$ In Wangdu and Diemberger, $d B a^{\prime}$ Bzhed, p. 76. In a footnote, Diemberger and Wangdu add that "Hwa shang Mahāyāna is reported by the Chinese Dunhuang document PT 4646 as having been summoned by Khri Srong lde bstan from Dunhuang just after this area had been seized by the Tibetans in 787."

${ }^{515}$ Ibid. p. 76. The authors used Demiéville's Le concile de Lhasa as their source.
} 
any Chinese monk in Tibet, so this may not be an explicit reference to Hashang Mahāyāna, but due to the important role played in Nupchen's account, this cannot be discarded. In this first reference, the enigmatic Chinese monk is called when an auspicious event indicates the not-sodistant birth of Nupchen:

A sandalwood tree grew in the middle of the ancestral charnel ground of Drak Riboche. This generated much amazement [so] the tree was shown to a Chinese monk [who was] invited from Samye monastery [in] Drakmar. [This also] amazed him [and he] said: "In the lineage of Nup Selwa Changchub, an excellent son, an emanation, will certainly be born in the first spring month of the wood male rat year. ${ }^{516}$

What is remarkable in this account, leaving aside the possible identification of this mysterious monk with Hashang Mahāyāna, is the fact that a Chinese monk plays such a prominent role in prophesizing the birth of Nupchen.This indicates, from a narrative, if not historical, point of view, the respect and acceptance of the Chinese Buddhist tradition within the biography of Nupchen, which also explains the esteem that he has of the Sudden tradition in the Lamp, situating it above the Indian Gradual school.

The most important reference in the text, this time unequivocally using his name, depicts Hashang Mahāyāna as one of the main teachers of Nupchen. The account is slightly confusing (at least to the present scholar!), since it situtates Hashang Mahāyāna in India, where he gives thirteen silk scrolls with teachings to Rombu Gyuyacandra, who then offers them to Nupchen:

The Emanation of the Chinese [monk] Hashang Mahāyāna was carrying "lali" silk, which is superior to normal silk. [...] 'These thirteen scrolls were given to me by his emanation, and I did not sell them for food or wear them on me [as clothes]. On the silk, there was a title of the (treasure text) by the Sugata [the Buddha]. I wrote [on the silk] Indian

\footnotetext{
${ }^{516}$ Testament of Nup 1a.1-1a.3 "dur gyi dkyil du tsan+dan sdong bo skyes/_/ngo mtshar skyes nas brag dmar bsam yas nas/_/rgya nag ha shang spyan drangs tsan dan sdong po bstan/_/kho yang ngo mtshar skyes nas 'di skad gsungs/_/gsal ba byang chub snubs kyi che rgyud la/_/lo yi dang po shing pho byi ba'i lo/_zla ba'i dang po dpyid zla ra ba la/_/sras kyi dam pa sprul pa'i sku gcig 'khrungs par nges/"
} 
[Sanskrit] and Tibetan texts. These amazing thirteen silk scrolls, I entrust them to you, little Tibetan monk. Hide them as earth treasure.' Having said this, he gave me the thirteen silk scrolls. ${ }^{517}$

In the case of Nupchen's biography, it seems that the inclusion of Hashang Mahāyāna (as well as the one of Kamalaśîla) anchor Nupchen to the period of the Tibetan Empire without taking specific sides. He is an inheritor of all forms of Buddhism during that period: the Gradual, the Sudden, Mahāyoga, and Atiyoga traditions.

If we do not know much about the historical figure of Mahāyāna, we do know a little more about his thought, since some of his works have survived among the Dunhuang Library manuscripts. Luis O. Gómez has done some groundbreaking work on reconstructing the textual legacy of Mahāyāna. His article, "The Direct and Gradual Approaches of Zen Master Mahāyāna: Fragments of the Teachings of Mo-Ho-Yen," ${ }^{, 18}$ using some early Japanese scholarship of the Tibetan Chan manuscripts on Mahāyāna, is an attempt to reconstruct the work and ideas of Hashang Mahāyāna and to explore anew the nature of his Sudden enlightenment approach.

\footnotetext{
${ }^{517}$ Testament of Nup 9b-10a: “/ha shang ma hwa ya na rgya nag sprul pa des/_/dar las khyad 'phags la li dar gyi rigs/_/dar chen bcu gsum khyer nas [...]/rgya gar yul du byon/_/rgya gar rom bu gu h+ya bdag nyid la/_dad pas mos nas dar yug bcu gsum phul/_/bdag la sprul pa'i sku des gnang ba'i dar chen bcu gsum po/_/bdag gi lto ru ma zos rgyab tu ma gyon par/_dar la bde bar gshegs pas kha byang btab/_/rgya dpe bod dpe gnyis su spel nas bris/_ngo mtshar can gyi dar yug bcu gsum 'di/_/bod kyi ban chung khyod la gtad kyi sa yi gter du spos" Dalton offers a slightly different translation, in Jacob Dalton's "Preliminary Remarks on a Newly Discovered Biography of Gnubs Chen Sangs Rgyas Ye Shes," ed. Andrew Quintman and Benjamin Bogin (Somerville, MA: Wisdom Publications, forthcoming), p. 11.

${ }^{518}$ Gómez, Luis O. "The Direct and Gradual Approaches of Zen Master Mahāyāna: Fragments of the Teachings of Mo-Ho-Yen." In Studies in Ch'an and Hua-Yen, edited by Robert M. Gimello and Peter N. Gregory, pp. 69-168. See also Carmen Meinert's "Legend of Cig Car Ba Criticism in Tibet: A List of Six Cig Car Ba Titles in the Chos 'byung Me Tog Snying Po of Nyang Nyi Ma 'od Zer (12th Century)," in Tibetan Buddhist Literature and Praxis. Studies in Its Formative Period 900-1400 (Boston/Leiden: Brill, 2006), pp. 31-54. Honolulu: University of Hawaii Press, 1983.
} 
Gómez identified five possible works among the Tibetan Chan manuscripts ${ }^{519}$ that can be attributed to him well as an author or as containing some of his teachings. All but one are Tibetan manuscripts: ${ }^{520}$

1) Dunwu dasheng zhengli jue (Ch. 顿悟大乘正理决), or Pelliot chinois 4646, which we have already seen repeatedly and which was translated by Demiéville in Le Concile de Lhasa;

2) bSam gtan cig car'jug pa'i sgo (Stein 468, Stein 709, PT 117, PT 813, and sections of PT 116, and PT 812$)^{521}$;

3) bSam gtan gyi snying po (Stein 706, parts of Stein 709, and PT 812);

4) Myi rtog pa’i gzhung (Pelliot 21);

5) mKhan po Ma ha yang is / bSam brtan myi rtog pa'i nang du pha rol tu phyind pa drug dang $/$ bCu 'dus pa bsha pa'i mdo (This is a section from PT 116) ${ }^{522}$.

The image that emerges from a reading of these texts reveals Hashang Mahāyāna as a figure that advocates a sudden approach to enlightenemnt that is not very different from that of other teachers of the Baotang school, like Wuzhu. As Adamek points out, the radical sudden position and the antinomianism of Wuzhu

\footnotetext{
${ }^{519}$ His identification expands the original identifications of Heshang's texts by Okimoto Katsumi. See Ueyama, Ibid. pp. 339-40.

${ }^{520}$ If we look at the sources used by Nupchen, such as PT 116, and the works Mahāyanna, such as the Bsam gtan cig car'jug pa'i sgo, it seems that he is mainly using sources that have been translated into Tibetan in order to inform himself about the doctrines and practices of the Chan tradition. Although there are some terms in the Lamp that are in Chinese, like the phonetic renditions of Gradual (Tib. ton men) and Sudden (Tib. tsen men), and a few other terms interspersed throughtout the text, ${ }^{520}$ it seems that Nupchen mainly relied on Tibetan sources, and that he did not know Chinese, or did not know it well enough to rely heavily on Chinese primary sources.

${ }^{521}$ In fact, Gomez reveals the role that the Lamp has played in putting together these different manuscripts as parts of one single text: "The Bsam-gtan mig sgron thus completes the web of evidence that suggests that Stein 468, Stein 709 , and Pelliot 116, 117, 812, and 813 contain different portions of what was originally a single text, the Bsam-gtan cig-car 'jug-pa'i sgo.” In Gomez' “The Direct and Gradual Approaches of Zen Master Mahāyāna,” p. 76. In the Lamp, this text is quoted also as the sGom lung.

${ }^{522}$ Extracted from Gómez, Ibid, pp. 86-87.
} 
...is firmly grounded in the "no-ground" of subitism, the assertion that moral and formal distinctions belong to the delusory mind that is transcended in no-thought. This view is repeated throughout the Lidai fabao ji, but some of his strongest statements are found in the context of a rather one-sided dialogue with a group of Vinaya masters who come to call. He opens his discussion by questioning them about the meaning of "host and guest," and then proceeds to critique the Vinaya:

The significance of the Vinaya is to regulate and subdue, and the precepts are not blue, yellow, red or white. Not color/desire and not mind, this is the substance of precepts, this is the fundamental nature of beings, fundamentally complete, fundamentally pure. When deluded thoughts are produced, then one "turns away from awakening and adheres to dust," and this is precisely "violating the Vinaya precepts." When deluded thoughts are not produced, then one turns away from dust and adheres to awakening, and this is precisely "fulfilling the Vinaya precepts." When thoughts are not produced, this is precisely Vinayottara; when thoughts are not produced, this is precisely Vinayaviniścaya. When thoughts are not produced, this is precisely destroying all mind-consciousnesses. "If one has views of upholding the precepts then one violates the precepts. Whether 'precepts' or 'not precepts,' the two views are a single characteristic. One who is able to know this is a great Master of the Way." "One sees that the bhikșus who commit grave offenses do not fall into Hell, and sees that those who practice purity do not enter nirvāṇa. If you abide in views like these, this is impartial seeing."

Views like these can be found in a number of eighth-century texts, including Shenhui's works, the arguments of Moheyan in the Dunwu dasheng zhengli jue (Verification of Sudden Awakening in the Mahāyāna) [顿悟大乘正理决 ${ }^{523}$.

The foundation of Mahāyāna's thought is quite similar, and Gomez, acknowledges that the general picture that "we can derive from these fragments does not contradict the generally held view that he esposed a radical sudden enlightenment position (second only to figures such as Shen-hui and Ma-tsu). ${ }^{, 524}$ In his Gate of Entrance into Sudden Contemplation (Tib. bSam gtan cig car'jug pa'i sgo), Mahāyāna offers a very general overview to his thought:

The state of samsāra is merely the result of deluded thoughts (myi bden pa'i 'du ses). Enlightenment is achieved by not grasping at these thoughts and not dwelling on them (ma blans ma chags), by not bringing them to the mind (myi sems), by not inspecting the mind (myi rtog), but by merely being aware (tshor ba) of all thoughts as they arise. ${ }^{525}$

\footnotetext{
${ }^{523}$ In Adamek's The Mystique of Transmission: On an Early Chan History and Its Contexts, pp. $218-219$.

${ }^{524}$ Gomez, "The Direct and Gradual Approaches of Zen Master Mahāyāna,” p. 89.

525 Translation by Gomez, in Ibid., p. 89.
} 
At the center of Mahāyāna's thought we find the notion of non-conceptuality, just as we do in Nupchen's Lamp. His position towards conceptual thought is in clear opposition to that of the Gradual tradition's:

The defect in conceptualization is that it has the power to hinder the original omniscience of all living beings, and thus make them turn about in the endless cycle of the three evil destinies. This is their [the Gradual tradition] defect. It is also taught in the Vajracchedika Sütra that one calls Buddha those who abandon all signs. ${ }^{526}$

As for the methods, Mahāyāna favors the practice of “contemplating the mind” (Ch. 看心 kan xin), which he inherits from masters of the Baotang traditions, such as Wuxiang and Wuzhu, and that can be traced back to the practice of “wall gazing” (Ch. 壁觀 bi guan) and quieting the mind (Ch. 安心 an xin) found in Bodhidharma: ${ }^{527}$

[Gradualist] question: What do you mean when you speak of "contemplating the mind"? Reply: To turn the light [of the mindj towards the mind's source, that is contemplating the mind. (This means that] one does not reflect on or observe (whether thoughts are in movement or not, whether they are pure or not, whether they are empty or not. It is also not to reflect on non-reflection. This is why the Vimalakirti Sütra explains: "Nonobservation is enlightenment." 528

Upon a detailed analysis of these texts, Gómez reaches the conclusion that although Hashang Mahāyāna sustained quite a radical sudden enlightenment position $^{529}$, at the same time

\footnotetext{
526 Ibid., 91.

${ }^{527}$ Carmen Meinert, "The Conjunction of Chinese Chan and Tibetan rDzogs Chen Thought: Reflections on the Tibetan Dunhuang Manuscripts IOL Tib J 689-1 and PT 699," in Contributions to the Cultural History of Early Tibet (extra Volume to Studies in Central and East Asian Religion) (Leiden/Boston: Brill, 2007), pp. $252-53$.

${ }^{528}$ From the Cheng li chueh. Translated by Gomez in Gomez' "The Direct and Gradual Approaches of Zen Master Mahāyāna," p. 93.

529 "The total picture of Mo-ho yen as a 'Dhyana Master' that we can derive from these fragments does not contradict the generally held view that he espoused a radical sudden enlightenment position (second only to figures such as Shen-hui and Matsu)," in Gómez, Ibid, p. 89.
} 
his teachings did not exclude the possibility of a gradual approach. ${ }^{530}$ Gómez' final analysis offers a more complex picture of the figure of Mahāyāna and his teachings, allowing us to see their complexity away from the simplifications found in the polemical texts of the era (either Pelliot chinois 4646 or the Bhāvanākramas), or even in modern scholarship:

Separated from the polemical context of the cheg-li chüeh, it is therefore easier to see, from the internal perspective of the system itself, the dialectical necessities and limitations of a sudden enlightenment position. One is thereby freed from the caricature of Ch'an that both devotees and critics often draw. The inconsistencies and the tensions reveal a real human phenomenon, a religious ideal, and a spiritual practice more conscious of human needs than the rhetoric of a system itself is willing to recognize. ${ }^{531}$

Scholars in general are aware of the dangers of extrapolating the intellectual world of Chan in Tibet (or any intellectual world for that matter) based on a few texts and fragments, but, as Gómez's work shows, with a careful philological and philosophical understanding of the texts, a clearer picture starts to emerge. Nupchen's chapter dedicated to the Chan tradition, even if it was written from a particularly biased perspective, that of the Great Perfection tradition, can play an invaluable role in our efforts to understand the history of Chan not only in Tibet, but also in China.

\footnotetext{
530 "These texts are also a good example of how early Ch'an did not exclude the possibility of (1) rigorous meditational practice, (2) the possibility of a gradual approach, and (3) conceptual schemata to explain the relationship between (1) and (2) and the ineffable, indivisible state of enlightenment." In Gómez, Ibid, p. 69. van Schaik has also devoted some of his research to the teachings of Heshang Moheyan on his site, earlyTibet.com. In his second exploration of Tibetan Chan (out of four at the time of writing this paper), van Schaik, after translating part of IOL Tib J 468, which contains some of Moheyan's teachings, points out: "We can see that Moheyan's teachings were not so radical as they were painted in the later Tibetan tradition. They even seem, dare one say it, quite reasonable..." in van Schaik, "The Teachings of Heshang Moheyan (Tibetan Chan Ii)," on EarlyTibet.com, posted in 2008. In a different posting of the same series (Tibetan Chan III: more teachings of Heshang Moheyan), van Schaik, using quotations from The Lamp for the Eye of Contemplation of gNubs Chen, PT 117, PT 823 and Pelliot chinois 4646, explores the issues of the tensions between the Sudden and Gradual approaches and also concludes that Moheyan's thought seemed to have been accommodating to the Gradual teachings, even as it favored the Sudden approach.

${ }^{531}$ Gómez, Ibid., p. 103.
} 


\section{The Sudden Vehicle in the Lamp}

\section{Intro to the Chapter}

Nupchen begins the Sudden chapter by offering an overview of the tradition:

[Those who practice the methods] of the Sudden approach are like [those] arriving at the summit of Mount Meru. They have the resolve of the view by which they can see everything. The object of comprehension and the subject [who comprehends] are in their real nature, in their primordial unborn [condition]. [The practitioner] understands this principle without seeking anything [...] Nonetheless, you should not avoid relying on a lama and on the Sūtras of the expedient meaning. [Here,] I will explain [the Sudden approach] through reason and scripture. Through [the understanding] of [the Sudden approach's] view, there are three certainties [to be obtained]: 1) the certainty that is free from extremes, since it is free from all activities (this is the essence of the view), 2) the certainty of the non-duality of the ultimate truth (this is the essence of the ultimate truth), and 3) the certainty of the disappointment that results from gathering all of these principles. $^{532}$

Nupchen brings back the image of climbing Mount Meru as a way to describe the path of the Sudden tradition. The use again of this metaphor helps Nupchen sustain the comparison between the Gradual and the Sudden paths (Nupchen will not use this image of the mountain in the Mahāyoga and Atiyoga chapters), and to also make clear their distinctive approaches. The Gradual tradition accepts as its starting point the existential unsatisfactoriness, the suffering (Skt. duhkha; Tib. sdug bsngal) described by the Buddha as one of the marks of existance. It is only from that acceptance that we can move forward towards finding the solution to the problem. That movement from samsāra to nirvāṇa is described as the path we need to follow from the bottom to the top of the mountain. The Chan tradition, on the other hand, while accepting that unsatisfactory nature of life, takes as its starting point the acceptance that it is only an illusion: we are, and we have always been at the top of the mountain, there is no path to walk, no

\footnotetext{
${ }^{532}$ Lamp 118.4-119.1: "ston mun cig car 'jug pa yang // dper ri rgyal rtse mor phyin na kun mthong ba'i tshul gyis lta ba'i thag bcad pa yang / gzhal bya dang 'jal byed gdod nas ma skyes pa'i chos nyid du / don nyid cir yang ma btsal ba nyid kyis go bar 'dod de / don de mthong na ri'i rgyal po ri rab kyi rtser phyin na / ri bran ma bltas gsal ba bzhin go bar bzhed do // 'on kyang bla ma dang nges pa'i mdo sde la mi brten pa ma yin te /"
} 
mountain to climb. Another interesting aspect of this brief introduction is the fact that, as usual in the Chan tradition (and something it shares with the Great Perfection), the radical and antinomian rhetoric is always tempered or toned down, in this case by the line, "Nonetheless, you should not avoid relying on a lama and on the Sūtras of the expedient meaning" (see line in the block quotation above).

As usual, Nupchen loosely structures the chapter into four different sections, articulating the philosophical views (Tib. lta ba), the contemplative practices (Tib. sgom pa), the conduct (Tib. spyod pa), and the results (Tib. 'bras bu) of the Sudden tradition.

The Philosophical View of Chan (Tib. Ita ba)

Nupchen offers a description of the philosophical view of Chan by quoting from the sayings of Chan masters, as well as scripture:

[Here,] I will explain [the Sudden approach] through reason and scripture. Through [the understanding] of [the Sudden approach's] view, there are three certainties [to be obtained]: 1) the certainty that is free from extremes, since it is free from all activities (this is the essence of the view), 2) the certainty that of the non-duality of the ultimate truth (this is the essence of the ultimate truth), and 3) the certainty of the disappointment that results from gathering all of these principle. ${ }^{533}$

\section{Saying of Masters - The Yulu Literature (Ch. 語録)}

The tradition of quoting from masters was codified in the Records of Saying literature (Ch. Yulu 語錄). This was a unique development within the Chinese Buddhist tradition. Early Chan literature followed a more conventional approach using treatises, such as Bodhidharma's

\footnotetext{
${ }^{533}$ Lamp 119.1-119.3: "de nyid kyis rigs pa dang lung gis de ltar ston te / de la lta bas thag bcad pa yang gsum ste / bya ba thams cad <lta ba rang gi ngo bo $>$ dang bral ba la mtha' med par thag bcad pa dang / gnyis su med par $<$ don dam de'i ngo bo /> don dam par gcig par thag bcad pa dang / don der thams cad 'dus pas 'bras bu la re thag med par thag bcad pa'o // de yang rigs pa dang lung gis bshad de/"
} 
Two Entrances and Four Practices (Ch. 二人四行), or scripture, as in the case of the Platform

Sütra. The development of Yulu literature seems to reflect the Chan notion of being a tradition "outside of scriptures" that did not rely on words, but on the direct exchange between master and student. 534

What we have in this section is a list of thirty four masters covering some of the basic principles of the Chan tradition: conceptuality as the root of identity of saṃsāra and nirvāna, the unborn (Tib. mi skyed) condition of phenomena, and an emphasis on non-activity (Tib. mi bya ba). Among the teachers mentioned by Nupchen are, obviously, Bodhidharma, ${ }^{535}$ but most masters seem to be connected to the Baotang school, like Wuzhu or, in the case of the following example, Hashang saṃsāra, the Mahāyāna:

[Master Hoshang] Mahāyāna said: "As for the complete view, wisdom [helps the practitioner] recognize the self-originated and the general characteristics of your own body and mind, the internal and external phenomena [and help him] comprehend that individual characteristics are impermanent and suffering, and the general characteristics are empty and without a self." 536

\footnotetext{
${ }^{534}$ On the emergence of this genre of literature, see Judith A. Berling's "Bringing the Buddha Down to Earth: Notes on the Emergence of 'Yu-Lu' as a Buddhist Genre," History of Religions 27, no. 1 (August 1987): 56; Albert Welter's The Linji Lu and the Creation of Chan Orthodoxy: The Development of Chan's Records of Sayings Literature (Oxford: Oxford University Press, 2008); and Poceski's "Mazu Yulu and the Creation of the Chan Records of Sayings," in The Zen Canon, ed. Steven Heine and Dale S. Wright (Oxford: Oxford University Press, 2004), http://www.oxfordscholarship.com/view/10.1093/0195150678.001.0001/acprof-9780195150674.

${ }^{535}$ Most of his quotes can be found in the textual collection known as the Great Chinese Scripture (Tib. rgya lung chen po), which Nupchen often cites in the Lamp, and that Broughton has translated in his The Bodhidharma Anthology the Earliest Records of Zen. This collection includes Bodhidharma's famous Two Entrances and Four Practices (Ch. 二人四行).

${ }^{536}$ Lamp 122.3-122.4: “mah'a < bcu gcig /> yan gyis bshad pa /yong(s?) lta bas ni phyi nang gi chos bdag gi lus dang sems rang byung dang spyi'i mtshan nyid shes rab kyis so (122.4) sor phye ste / rang gi mtshan nyid ni mi rtag pa dang / sdug bsngal ba dang / spyi'i mtshan nyid ni stong pa dang / bdag med par 'jal bar bgyis nas zhes 'byung ba //"
} 
As we have said in our introduction to this chapter, Nupchen used available compilations of Yulu literature in order to compose this list of citations. That may explain the randomness of it, since, unlike in the Gradual approach, topics and concepts are thrown together without any apparent order and without much context. ${ }^{537}$

\section{Scripture}

Nupchen then proceeds to continue his presentation of the philosophical view of the Chan tradition through a series of scriptural quotes from Sūtras, such as the Ratnakūta Sūtra, Lañkāvatāra, Tathāgatagarbha, and, as in this example, the Vimalakīrti Sūtra, emphasizying the notion of no-effort and no activity central to Chan:

The famous Vimalakīrti Nirdeśa Sūtra says: "Noble Son! Because it is non-contrived, it is the essence of thought; because it is free from effort, it is the essence of endeavor (Tib. sbyor ba); because it understands differences, it is the essence of superior thought; it is the essence of enlightenment." 538

\footnotetext{
${ }^{537}$ Meinert's research has brought some light onto some of the teachers mentioned in this list, like masters Wuzhu and Wolun. See Carmen Meinert's "A Pliable Life: Facts and Fiction about the Figure of the Chinese Meditation Master Wolun," Oriens Extremus 46 (2007): 184-210; Meinert, "Chinese Chan and Tibetan Rdzogs Chen: Preliminary Remarks on Two Tibetan Dunhuang Manuscripts," 2002; Carmen Meinert, "Chinesische Chan- Und Tibetische rDzogs Chen-Lehre: Eine Komparatistische Untersuchung Im Lichte Des Philosophischen Heilskonzeptes 'Nicht-Vorstellen' Anhand Der Dunhuang-Dokumente Des Chinesischen Chan-Meister Wolun Und Des Werkes bSam Gtan Mig Sgron Des Tibetischen Gelehrten gNubs Chen Sangs Rgyas Ye Shes" (Rheinischen Friedrich-Wilhelms-Universität, 2004); Meinert, "Legend of Cig Car Ba Criticism in Tibet: A List of Six Cig Car Ba Titles in the Chos 'byung Me Tog Snying Po of Nyang Nyi Ma 'od Zer (12th Century)."

${ }^{538}$ Lamp 137.3-137.5: “dri ma med par grags pa las / rigs kyi bu byang chub kyi snying po zhes bya ba de ni bcos ma ma yin pa'i phyir bsam pa'i snying po'o / rtsol ba las bsgral ba'i phyir de ni sbyor ba'i snying po'o / khyad par khong du chud pa'i phyir / de ni lhag pa'i bsam pa'i snying po'o //"
} 


\section{Chan Practice (Tib. sgom pa)}

Nupchen begins this section acknowledging the usual Chan rhetoric that dismisses practice: "There is nothing to search in the unborn ultimate truth, this is the essence itself,",539 only to then discuss contemplative practices, which he divides into those that settle the body and those that settle the mind. Donati has pointed out how in this section, unlike in the previous section, in which all of the teachers mentioned but one were Chinese (there is a reference to the famous 8th century translator Kawa Peltsek [Tib. sKa ba dpal brtsegs]), many Tibetan figures, such as Yéshé Pel (Tib. Ye shes dpal) and Leu Zhönu Nyingpo (Tib. Le’u gzhon nu nying po), ${ }^{540}$ are quoted, describing various aspects of the Sudden approach. I believe that this keeps pointing towards the idea that Nupchen was mainly (if not exclusively) using Tibetan sources in his composition of the Lamp.

Through scripture and reasoning, [you should understand that] there is nothing to search in the unborn ultimate truth, this is the essence itself. This is the essence of it, and there is no need to look for other results, the unborn principle is gathered in the Perfection of Wisdom and other [scriptures]. This [principle] is also primordially limitless, and free from view and object of view in the sphere of phenomena. You should first contemplate and internalize these good qualities. If you meditate without understanding them, it is like taking a path without being familiar with it. [First] I will how you how to enter this principle [by teaching you]: 1) The methods for settling the body, and 2) the methods for settling the mind. ${ }^{541}$

\footnotetext{
${ }^{539}$ Lamp 143.5: "sgo nas don dam pa ma skyes pa la btsal du med pa / dngos po 'di nyid yin pa dang /"

${ }^{540}$ Leu Zhönu Nyingpo was the 8th abbot of Samye Monastery. On this figure see Karmay, The Great Perfection (rDzogs Chen) : A Philosophical and Meditative Teaching of Tibetan Buddhism, 2007, 103. See also Brandon Dotson, "Emperor' Mu Rug Btsan and the 'Phang Thang Ma Catalogue," Journal of the International Association of Tibetan Studies, no. 3 (December 2007): 6.

${ }^{541}$ Lamp 143.4-144.2: “de dag la sogs pa rgya cher 'byung ste / lung dang rigs pa'i sgo nas don dam pa ma skyes pa la btsal du med pa / dngos po 'di nyid yin pa dang / 'bras bu gzhan nas btsal mi dgos pa dang / ma skyes pa don du pha rol tu phyin pa la sogs pa kun 'dus pa dang / de nyid kyang ye nas mtha' thams cad dang bral ba dang / chos kyi dbyings la blta ba dang blta bya'i yul bral ba dang de dag gi yon tan la sogs pa sngon du legs par khong du chud nas bsgom pa ste / ma rtogs bsgom pa ni rgyus med lam du zhugs pa ltar gsol ba 'gyur ba'i phyir / don mthong bar bya ba bstan pa'o //de nas don la 'jug pa yang / lus kyi 'dug thabs dang / sems kyi bzhag thabs so //"
} 
The practices to settle the body are quite similar to those we have seen in the Gradual

tradition:

In the meditation treatise of the monk Yéshé Pel, it says: "If you want a of nonconceptual [form of] meditation, sit in a comfortable place with your body straight, looking at your nose, with the tongue touching your palate, sitting firmly with your legs crossed. [This is called] the concentration (Tib. ting nge 'dzin) of the unshakable Great Peace." 542

\section{Methods to settle the mind}

Regarding the methods to settle the mind, Nupchen quotes, among others, Hashang

Mahāyāna in order to describe the Chan practice known as "looking at the mind" (Tib. sems la bltas), ${ }^{543}$ which can be traced back to Bodhidharma and his practices of "quieting the mind" (Ch. 安心 an xin) and “wall gazing” (Ch. 壁觀 bi guan):

In the Meditation Treatise of Hashang Mahāyāna it says: "The person who realizes that this principle is the view gives up any other activity and stays isolated without any distractions, alone and without other people, sitting with legs crossed, body straight. When [the practitioner] looks at his/her own mind (Tib. sems la bltas; Ch. kan xin), there will be no thoughts and you will think of nothing. If a conceptual though moves you should sense this! But how do you recognize [that this is happening]? Do not think if this wavering thought is waving or not, or if it exists or not. Do not think [if this wavering thought] is virtuous or not, or if it is an afflictive emotion, or if it needs to be purified, etc. You should not think [in this way] in regards to all phenomena. If all movements of the mind are perceived this way, they will lack self-nature. This is called the Activity of the Dharma Path. ${ }^{544}$

\footnotetext{
${ }^{542}$ Lamp 144.2-144.4: “dge slong ye shes dpal < dang po /> gyi bsgom lung las / mi g-yo zhi ba chen po'i ting nge 'dzin ni rnam par mi rtog pa bsgom par 'dod pas / stan bde ba la 'dug ste / lus drang por bsrangs nas yin / sna la bltas te / lce rkan la bcar na / skyil mo krung dam por bca' ste 'dug par bya'o //" 543

${ }^{544}$ Lamp 145.5-146.3: “mah'a <gsum pa /> yan gi bsgom lung las / don de lta bu yin par rig pa'i mis bya ba gzhan btang te / gang dben pa 'du 'dzi med pa'i gnas su nga gcig su) mi gnyis par 'dug nas skyil mo krung bcas lus po drang por bsrangs te srod dang tho rangs mi nyal bar bya'o // bsam gtan nyid du 'dug pa'i tshe // nga dag gi sems la bltas na ci yang sems pa med de mi bsam mo // rtog pa'i sems g-yos na tshor bar bya'o // ji ltar tshor bar bya zhe na / g-yos pa'i sems de nyid g-yos pa dang ma g-yos par mi brtag yod pa dang med par yang mi brtag // dge ba dang mi dge bar yang mi brtag // nyon mongs pa dang / rnam par byang bar yang mi brtag pa la sogs ba ste / chos thams cad de lta bur yang mi brtag go // g-yos pa de lta bu tshor na rang med par 'gyur te / chos lam spyod pa zhes bya'o //"
} 
Nupchen then, clarifies what are the main differences between the Sudden and the

Gradual tradition in their approaches to meditation:

As it is has been extensively explained, through the sayings of the Masters (yulu), and through scripture: unlike in the Gradualist tradition, there is no object of perception. In the empty, unborn principle, with its clear nature, there are no thoughts whatsoever, and there is nothing to grasp. Since there is nothing to establish step by step, this is conventionally called settling the mind. If you meditate like this, make offerings to all of the Buddhas, and direct sentient beings to the [path of] enlightenment, your merits will increase your merits. ${ }^{545}$

Here, the practices of śamatha and vipaśyanā play a secondary role to the practice of "looking at the mind," although Nupchen includes a brief discussion on the topic that shows Chan's particular approach to both classic forms of meditation:

This meditation is the union of samatha and vipasana. This [union] shows the essence of meditation, the unborn clear light which recognizes appearances. Vipasana is the clarity which does not grasp the principle, which is unborn and empty. In Samatha [thoughts] do not wave or stand anywhere. This principle, when dual, will be clear at once; the two [samatha and vipasana] will occur simultaneously. When there is no wavering [of the mind], focusing the mind in one point is the essence of meditation. There is no phenomena which is perceived as dual. ${ }^{546}$

As he did in the Gradual chapter, Nupchen also offers an overiew of the Chan approach to the problems that emerge during practice (Tib. skyon) and the antidotes used against them:

\footnotetext{
${ }^{545}$ Lamp 158.4-158.6: “de dag la sogs pa rgya cher bstan pa yang / slob dpon so so'i bzhed pa dang / lung gi don gyis kyang / tsen men ltar dmigs pa ril pa can ma yin par stong pa ma skyes pa'i don la cir yang mi bsam pa de tsam du 'dzin pa med par rang gsal ba la gcig gis gcig la bzhag pa med na'ang tha snyad du blo bzhag ces bstan to // de ltar bsgom na rgyal ba ril mchod pa dang sems can ril byang chub la bkod pa las bsgom pa bsod nams che bar sngar rgyas par bstan"

${ }^{546}$ Lamp 159.6-160.1: “de ltar bsgoms zhi gnas lhag mthong zung du 'brel te / snang ba nyid rig pa ma skyes par rang gsal ba yang bsgoms pa'i ngo bor bstan pa ni / stong pa ma skyes pa'i don 'dzin pa med par gsal ba ni lhag mthong / gang du yang mi g-yo mi ldang ba zhi gnas ste / don 'di gnyis dus gcig tu gsal la mi g-yo bas bsgom (160.1) pa'i ngo bo sems rtse gcig pa zhes kyang bya ste / de la dmigs pa gnyis pa'i chos med do //"
} 
When you meditate like this, generally, three types of meditative experience emerge. ${ }^{547}$ These [can be described as] a strong river [streaming down a mountain], like water flowing down a river, and like the ocean. And [they are also described as] non-static, gentle, and the great stillness. The Gradual approach and all common forms of meditation teach that when [the practitioner] abides in the first and the second (i.e. middle) meditative experiences, due to increasing clinging [to those experiences] the defects of various conceptualizations emerge and it teaches how they should be identified, and how [these conceptualizations work] and the common antidotes [against them]. The Sudden tradition, instead, teaches that there is no need to meditate on each antidote for each conceptualization since [defects] are like gold, or the waves in the ocean. The essence of the defects [that emerge from] conceptualization are just like the unborn essence of phenomena itself of the three times, which, although it may temporarily arise, [there is no need to] reject them, since they self-arise and self-cease. ${ }^{548}$

From the Chan perspective, though, the best antidote is to simply observe thoughts

without being attached to them:

When conceptual defects have been recognized, let them emerge and cease of their own accord. When you meditate for long periods of time, those conceptualizations will decrease, and they also will be softer. The Small Treatise says about conceptualizations: "mind becomes tamed (Tib. gyung), suffering becomes purified, samsara becomes nirvana." $" 549$

\footnotetext{
${ }^{547}$ The three meditative experiences in a tantric context (Tib. nyams gsum) are: bliss (Tib. bde ba), clarity (Tib. gsal $b a$ ), and non-conceptualization (Tib. mi rtog). The three meditative experiences of the Chan practice are very similar to the ones described in Atiyoga as the Four Meditative Experiences (Tib. nyams gzhi), described by Kongtrul as follows: "The sequence of possible experiences is endless and cannot be estimated. However, in terms of the generic manner of arising, first there is the experience of abiding in which the conscious mind remains undivided during the meditation session without pursuing an external object. Second is the experience of unwavering meditative absorption without any conditions such as sinking or agitation. Third is the experience of evenness in which one rests in the sky-like equipoise of the equal flavor of samsara and nirvana. In the subsequent cognition, one integrates the illusory-like nature of all things and obtains the total confidence of fearlessness. Fourth is the experience of spontaneous presence, the absorption that goes beyond meditation sessions and breaks, the falling away of intellect and of phenomena. These "four experiences" (nyams bzhi) of the mind and space paths were posited by the great awareness-holder Garab Dorje."

${ }^{548}$ Lamp 162.1-162.5: "de ltar bsgom pa yang spyir nyams rnam gsum 'byung ste / drag < ri gzar $/>$ dal < chu klung /> gyi chu dang / rgya mtsho lta bu / mi sdod pa dang / dal bzhin pa dang / mi g-yo ba chen po'o // tsen men dang bsgom pa thun mong kun la 'byung ba'i nyams dang po dang / bar pa la gnas pa'i dus su sngon mngon par zhen pa brtas pa'i dbang gis rtog pa'i skyon rnams skye ste byung ba yang / de yang sngon ngos bzung ba dang / des bcos pa thun mong du bstan te / de dag 'dir skyon skyes kyang / tsen men ltar rtog pa re la gnyin po re bsgom mi dgos te / skabs 'dir dper gser gyi rdzas dang / rgya mtsho'i rlabs bzhin / rtog skyon ngo bo nyid dus gsum du chos nyid ma skyes pa'i ngo bo nyid yin pas glo bur 'byung srid na / de nyid mi spong rang 'byung rang zhi ste / de la don chos yod la byed na'ang skyon de /"

${ }^{549}$ Lamp 170.1-170.2: “de ltar rtog skyon nges zin nas / rang byung rang zhir bzhag pas / yun ring du bsgom na / rnam rtog je la nyung zhing snyi bar 'gyur te / rtogs pa ni lung chung nas gsungs pa ltar / sems g.yung du 'gyur zhing sdug bsngal nyid byang chub la / 'khor ba mya ngan las 'das par 'gyur ro //"'
} 


\section{Conduct (Tib. spyod pa)}

As for conduct, the Chan tradition emphasizes carrying meditative practice beyond traditional sitting meditation to all aspects of life:

The Sudden approach teaches how to complete the [two] accumulations [of merit and wisdom] during concentration itself and that you do not need to make any deliberate positive efforts, and since you are able of non-perception [of objects] this is asserted as emptiness. The Sems lon says: "Do not leave your concentration (Tib. ting nge 'dzin) during all the [actions] of the Path of Activity, such as walking, standing, sitting, and sleeping. 550

Nupchen includes a short discussion of the signs that emerge from practice, but it is much shorter (one folio) compared to the one in the Gradual chapter. Here, there is no discussion of visions and dreams and, instead, there is an emphasis on knowledge (Tib. shes pa) that the practitioner will achieve through practice. ${ }^{551}$

\section{The Results of Chan Practice (Tib. 'bras bu)}

The chapter completes the description of the Chan tradition with another brief description of the results of practice, which is described as the "[bhümi of] absolute light (Tib. kun tu 'od) that is through the strength of non-reference (Tib. mi dmigs pa)," although Nupchen does not elaborate much on the topic. ${ }^{552}$

\footnotetext{
${ }^{550}$ Lamp 172.3-172.5: "tshogs ting nge 'dzin nyid la rdzogs par bstan te dkar phyogs ched du rtsol bar mi byed kyang / mi dmigs pas ci nus su bya bas stong pa ni bzhed do / sems lon las / de yang 'gro sdod 'dug nyal spyod lam thams cad du ting nge 'dzin las mi 'bral lo // zhes 'byung /"

${ }^{551}$ de ltar <yon tan /> spyod pa spyad yun ring du byas (177.2) na / rtags ji lta bu zhig 'thob ce na / de ltar bsgom nus na 'jug // gnyid choms pa dang / kha zas med par dbang po gsal ba dang / gang la chags sdang med pa la (177.3) sogs pa mang du 'byung ste / mah'a yan gyi bsam gtan las / de ltar bsam gtan yun bsrings te byas na / bar bar sangs rgyas dang byang chub sems dpa' mang po byung (177.4) bar bar pha rol gyi sems shes pa la sogs pa lnga ma mngon par shes pa snyam byed bar bar padmo chen po'i 'od la sogs te ngo mtshar sna tshogs ci yang mthong ste / de dag (177.5) thams cad rnam par rtog pa la spyod pa yin te / gcig tu bdud yin gyis / de kun la mi bsam zhing chags par mi bya'o //

${ }_{552}$ Lamp 185.1-185.4: “'bras bu dngos ci thob zhe na / kun tu 'od do / mi dmigs pa'i stobs kyis / 'bras bu kun tu 'od thob nas / bsod nams kyi brgyud pa'i rgyu byas pa'i gzugs sku gnyis rang 'char ba ni 'bras sa lu legs pa'i phub sog
} 


\section{The Differences Between the Gradual and the Sudden}

The chapter concludes with a direct comparison between the Gradual and the Sudden approaches. As we have mentioned at the beginning of the chapter, both traditions are catergorized in the Lamp as belonging to the Vehicle of the Cause (Tib. rgyu'i theg pa), the exoteric traditions based on the Buddhist Sūtras, in clear opposition to the Mahāyoga and Atiyoga vehicles, which belong to the Vehicle of the Result (Tib. 'bras bu theg pa), the esoteric tradition based on the oral precepts (Tib. man ngag) of tantric masters. What Nupchen is doing is not only defining the various vehicles in the Lamp on their own terms, but also in relationship with each other, centering those comparisons on the pairs Gradual vs. Sudden, and Mahāyoga vs. Atiyoga ${ }^{553}$ The boundaries between traditions are delineated not only by explaining their unique doctrinal and contemplative traditions, but are also defined in their opposition to each other.

The tension between these two traditions, as Ruegg has explored at length, centers on their different interpretations of the relationship between the Ground (Tib. gzhi) and the Result (Tib. 'bras bu), which is also interrelated to their view of the relationship between the Relative Truth (Tib. kun rdzob bden pa) and Absolute Truth (Tib. don dam bden pa). In other words, in a Mahāyāna world in which all traditions accept the non-dual nature of reality, what is the relationship between Samsāra and Nirvāna $?^{554}$ And how do you get from one to the other? In the Lamp, Nupchen discusses ten main differences between these two vehicles, covering a wide range of topics. Those differences are of: 1) methods (Tib. thabs); 2) systems of entrance (Tib. 'jug lugs); 3) conduct (Tib. spyod pa); 4) Samādhi (Tib. ting nge 'dzin); 5) antidotes for

dang 'dra'o /des don mdzad pa'i tshul ni 'dir yang smon lam dang snying rje las skyes nas don mdzad pa'i tshul nyi zla dang / chu dwangs ba bzhin mdzad do /de dag 'dir rgyas par ma bkod do"'

${ }^{553}$ There are also some importants comparisons between the Sudden approach and the Atiyoga tradition that are briefly addressed in this chapter and articulated at more length in the Atiyoga chapter. We will deal with those comparisons in the following chapter.

${ }^{554}$ David Seyfort Ruegg, Buddha-Nature, Mind and the Problem of Gradualism in a Comparative Perspective: On the Transmission and Reception of Buddhism in India and Tibet (New Delhi: Heritage, 1992), p. 6. 
discursive thoughts (Tib. rnam rtog bcos pa); 6) purification of obscurations (Tib. sgrib pa sbyong ba'i); 7) accomplishments (Tib. bsgrub pa); 8) accumulations (Tib. tshogs pa); 9) comprehension (Tib. rtog pa); and 10) benefit to others (Tib. 'gro don). ${ }^{555}$ Since we have covered some of those topics in our overview of each of the vehicles, I will not discuss them again here, but the most interesting conclusion of the list is that for each one of those differences, Nupchen always considers the Sudden tradition superior to the Gradual, which, for a text written in the 10th century, seems to undermine traditional accounts of the victory of the Gradual over the Sudden tradition in the so-called Samye Debate, as well as the decline of the Chan tradition in Tibet after that event. In the last section of this paper I would like to discuss how the Lamp may help us reconsider traditional accounts of the introduction of Buddhism into Tibet, and of the fate of Chan after the supposed debate in the 9th century.

\footnotetext{
${ }^{555}$ Lamp : "de dag 'dir rgyas par ma bkod (185.4) do / tsen < lus ngag gi rtsol ba las / > men las 'dir khyad par bcu 'phags te / thabs < rtsen men rtsol ba byed / $>$ kyi $<$ ched du bya ba las 'phags te tha phyogs de / $>$ khyad par dang / $<$ ched du dmigs $>>$ 'jug lugs $<$ dmigs su med pas 'jug tu med par shes pas 'phags $>$ kyi khyad par dang / spyod $<$ bya ba med de spyod pa bzhi 'phags / > pa'i <bsgom gsum bya ba mong pas / $>$ khyad par dang / (185.5) ting < dmigs pa rtse gcig / $>$ nge 'dzin < rang rig ma skyes par rang gsal ba mi dmigs pas 'phags $>$ gyi khyad par dang / rnam < rang byung rang zhir bzhag pas 'phags $/>$ rtog $<$ gnyen pos 'chos $>$ (185.6) bcos pa'i khyad par dang / sgrib <ched du ma gsal dag las 'phags / rgyu las 'bras bu la ra $>$ pa sbyong ba'i khyad par dang / bsgrub <rang sems med par rtogs pas 'phags / > pa'i khyad par (186.1) dang / tshogs < bsod nams ni bya ba ched du gsog / $>$ kyi <ting nge gnyis tshogs gnyis rdzogs pas 'phags / $>$ khyad par dang / rtogs $<$ bden gnyis tshul $>>$ pa'i $<$ ril ma skyes ma bslad pa la bdag gzhan yed par rtogs pas 'phags $/>$ khyad par dang / 'gro < lus ngag gi rtsol bas $/>$ don $<$ ting nges kyang 'gro don mang po byed pas 'phags so /> gyi khyad par dang / bcus 'phags so // rnal 'byor (186.2) mig gi bsam gtan gyi skabs 'dir / ston mun dang / rdzogs (186.3) chen <lta spyod kun /> cha 'dra bas gol du dogs pa'i phyir <cung zhig /> rgyas par bkod do //"
} 


\section{The Samye Debate: Reexamining the Introduction of Buddhism in Tibet}

In traditional historical accounts, the tensions and differences between the Gradual and the Sudden traditions came to a head in the so-called Samye Debate. This is not the place to discuss at length the contradictory nature of Tibetan sources regarding this debate, but since the Lamp, a text written in the 10th century, offers an account of the Chan school that contradicts most traditional accounts, it may be worth examining what Nupchen's text can offer to our understanding of this event.

\section{Reconsidering Tibetan History: Demiéville's Le Concile de Lhasa}

The publication in 1952 of Paul Demiéville's Le Concile de Lhasa, a translation of the Chinese Dunhuang manuscript Pelliot chinois $4646^{556}$, was one of the earliest and most important examples of how the contents of the Dunhuang library would force scholars to reexamine our understanding of early Tibetan history in general, and of the early introduction of Buddhism in Tibet in particular. It also helped scholars over the next decades to understand Tibetan Chan manuscripts not just as an anomaly, but in the context of a more complex and contested interpretation of Tibetan history. ${ }^{557}$

\footnotetext{
${ }^{556}$ Demiéville, Paul. Le Concile De Lhasa. Paris: Impr. nationale de France, 1952. The original Chinese title is Dunwu dasheng zhengli jue and it was written by Wang Xi, which Demiéville translated as Préface de la Ratification des Vrais Principles du Grand Véhicule d'Éveil Subit. Demiéville later found other Dunhuang manuscripts that corresponded to Pelliot chinois 4646, like Stein 2647, which he discusses in his "Deux Documents De Touen-Houang Sur Le Dhyâna Chinois," in Essays on the History of Buddhism Presented to Professor Zenryu Tsukamoto / Repr. In Choix D'études Bouddhiques, 1973, Pp. 320-346., 1-27, Kyoto: Nagai Shuppansha, 1961. ${ }^{557}$ As Ueyama pointed out, "The general assumption seems to have been that [the Tibetan Chan manuscripts] were ancillary to the mainstream of Tibetan literature, wherein they exerted little influence and were, therefore, neither equivalent to, nor as valid as, the orthodox Tibetan literary tradition. The first step toward correcting the above notions came in 1952 with the publication of the Tun wu ta ch'eng chen li chüeh [Dunwu dasheng zhengli jue] by Paul Demiéville. This text proved that the Tibetan religious debates, which had been thought to be legendary, did in fact take place." In Uyaema's "The Study of Tibetan Ch'an Manuscripts Recovered from Tun-Huang: A Review of the Field and Its Prospects," in Early Ch'an in China and Tibet, edited by Whalen Lai and Lewis R. Lancaster, Berkeley: Lancaster Publications, 1983, pp. 340-341.
} 
Until the publication of this manuscript, traditional Tibetan history, as transmitted by texts like the $s B a$ bzhed (in its various versions), Nyang Nyi ma 'od zer's Chos 'byung me tog snying po and, most famously, Bu ston's Chos 'byung, had presented the debate as a confrontation between the Indian gradualist school, represented by Śāntarakşita and, most directly, by Kamalaśîla, and the Chinese subitist ${ }^{558}$ school, defended by Heshang Moheyan that was settled by the Emperor Trisong Detsen in what came to be known in western scholarship as the Samye Debate. ${ }^{559}$

Obermiller, in 1931, had translated Bu ston's Chos 'byung, ${ }^{560}$ so this version of traditional Tibetan history was already known by western scholars before the publication of Demiéville's work. The language of Bu ston's text is quite straightforward regarding the tone and the outcome of the debate:

After that ācārya bodhisattva (=Śāntarakşita) said: "Although there will not appear Brahmin heretics in Tibet, there will occur a two-fold division concerning the interpretation of Buddha's doctrine. Because (of this there) will be fighting. At the time the fighting starts invite my disciple Kamalaśîla. Let him enter the fighting! When (this is done) the Buddhist contention will subside [...]

Because the emperor said to practice the method of Saantarakşita all the Ton mun [...] became angry. Each help up a sharp curved knife [...] and said: kill all the gradualists! The king (grew more) unhappy. [...]

\footnotetext{
${ }^{558}$ I am using here the term "subitist" since it is the most common one used in English scholarship to refer to the Chan ideas proposed by Heshang Moheyan and its followers. Stein's "Illumination Subite Ou Saisie Simultanée. Note Sur La Terminologie Chinois Et Tibétaine." Revue de l'histoire des religions 179, no. 1 (1971): 3-30, offers a very interesting analysis of the Chinese (dunwu) and Tibetan terms (cig car) and "[i]t subjects to criticism the usual translation of these two terms, translations that emphasize the sudden or instantaneous nature of this mystical experience. While this essay does not deny that this aspect is inherent to the concept in question, it shows that what is really at issue is the simultaneity of two planes that are in opposition yet integral (i.e. the absolute and the phenomenal)." From the English translation of the article in Stein, R.A. "Sudden Illumination or Simultaneous Comprehension." In Sudden and Gradual: Approaches to Enlightenment in Chinese Thought, edited by Peter N. Gregory, 41-66. Honolulu: University of Hawaii Press, 1987, p. 41.

${ }^{559}$ Originally, Demiéville named it Le Concile De Lhasa in his 1952 book while, Tucci, in Minor Texts II (1956) called it the The Council of bSam yas. Demieville later revised the name to The Council of Tibet in "Recents Travaux Sur Touen-Houang," Toung-Pao 46, no. 3 (1970), since the debate may have been actually a series of discussions that happened in more places than Samye. In later English scholarship (Houston, Ruegg, Kapstein) the most common name is the Debate of Samye or the Samye Debate, which is how I will refer to it here.

${ }^{560}$ Obermiller, Eugéne. History of Buddhism 2vols. Heidelberg: Institut für Buddhismuskunde, 1931-1932.
} 
Thus runs the tradition. Then the emperor ordered that from time on everyone would embrace the system of the Nāgārjuna school. Concerning practice, he ordered everyone to learn the ten religious practices and (the ten) pāramitās. It was not permitted to follow the Chinese method. Hva šang was sent back to China $[\ldots]^{561}$

But Pelliot chinois 4646 offered a very different account of the debate, one, in fact, with a completely different outcome, in which Heshang Moheyan is not only not vanished from Tibet, but the Chan tradition is the winner of the debate and it is ratified as legitimate by the Emperor himself:

Or, dans ce pays du Tibet, l'éventail de la mondanité profane répandait le vent de l'erreur; la doctrine du Buddha n'y était point transmise, l'école du Dhyāna n'y étatit point compromise. C'est alors que notre Saint Roi (bcan-po), ayant tôt planté de bonnes racines, s'éveilla, par le procédé subit, à la vérité, cette nasse, et que, pris de pitié pur son peuple longtemps égaré, il divulgua les arcanes du vrai Véhicule. [...]

En l'année siu, le 15 de la 1re lune, fut enfin promulgué ce grand édit: "La doctrine du Dhyāna qu'enseigne Mahāyāna est un développement parfaitement fondé du texte des sūtra; il n’y a pas la moindre erreur. Que désormais religieux et laïcs soient autorisés à practiquer et à s'exercer selon cette Loi!",562

The implications of Pelliot chinois 4646 were immediately obvious to Tibetan scholars and a "debate on the Debate" rapidly ensued, trying to verify the validity of the document and its implications for our understanding of Tibetan history and the early introduction of Buddhism in Tibet. $^{563}$

\footnotetext{
${ }^{561}$ Provisionally I am using Houston's translation of Bu ston's chos 'byung since I was not able to obtain in time the Obermiller edition of the text (both were checked out). Houston, G. W. Sources for a History of the Bsam Yas Debate, Monumenta Tibetica Historica. Sankt Augustin, Denmark: VGH-Wissenschaftsverlag, 1980, pp. 92-95.

${ }^{562}$ Demiéville, Paul. Le Concile De Lhasa. Paris: Impr. nationale de France, 1952. The first paragraph is from p. 24, the second one from p. 42.

563 The questions raised by Pelliot chinois 4646 were multiple. Some scholars questioned the nature of the debate and even its actual ocurrence. Demieville (pp. 11-14) and Tucci defended its historicity (in one form or another), but Imaeda, Yoshiro. "Documents Tibetains De Touen-Houang Concernant Le Concile Du Tibet." Journal Asiatique 265, (1975): 125-46, and Guenther (following Imaeda) in Guenther, Herbert V. "'Meditation' Trends in Early
} 
In the decades following the publication of Demiéville's work, the identification of new Tibetan Chan manuscripts helped scholars fill the gaps in our own sources of the Samye Debate

Tibet." In Early Ch'an in China and Tibet, edited by Lewis Lancaster and Whalen Lai, 351-66. Berkeley, Ca.: Asian Humanities Press, 1983, seemed to have doubts about it. Guenther thinks that the "debate" was more on the order of a series of discussions, of which there seem to have been at least three" p. 361, ft. 1. At the same time, in the same footnote, Guenther offers quite a dubious reason why the actual debate may not have happened: "It may be pointed out that such early writers as Bsond-nams rtse-mo (1142-1182) in his Chos la 'jug pa'I sgo [...] and Klong-chen rab-"byams-pa (1308-1364) [...] do not mention this event," p. 361, ft. 1. I agree that these two scholars are "early" if we looked at them from the present time, but they are still between 300 and 500 years removed from the supposed event, which would make their omission of it possible for many other reasons. I would find the omission of the event in a text like the $10^{\text {th }}$ century bSam gtan mig sgron by gNubs chen much more compelling evidence for this argument. Demiéville himself seemed to have recognized that the debate may have happened over a few years period and it may had been a series of councils (in Demiéville, Paul. "Recents Travaux Sur Touen-Houang." ToungPao 46, no. 3 (1970): 1-95. Van Schaik talks about "a series of royal consultation and edicts on what was acceptable [...] in the Chan teachings," in van Schaik, Sam. "The Emperor's Chan (Tibetan Chan I)." In Early Tibet.com. Ruegg defends the existence of an actual debate from his reading of the sBa bzhes and the Chos 'byung me tog snying po of Nyang nyi ma 'od zer, in which the terms rtsod pa and gshags are used, in Ruegg, D.S. "On the Historiography and Doxography of the "Great Debate of Bsam Yas." In Tibetan Studies: Proceedings of the 5th Seminar of the International Associaton for Tibetan Studies (Narika 1989), edited by Shoren Ihara. Tokyo: Naritisan Shinshoji, 1992, p. 238. Another interesting issue discussed by scholars was the political vs. religious nature of the debate. Demiéville and Houston seemed to have argued for the importance of the political tensions between Tíbet and China at the time of the events, Houston says "[o]ne of the most important aspects of this debate, which deserves additional study, is the antagonism between China and Tíbet that had been increasing since 670 A.D. The Tibetan emperor Mes ag choms (7-4-755) acted according to the precedent set by Srong bcan sgam po and chose a T'ang princess, Chin-ch'eng as a consort in 710. But, this only caused further complications to the Tibeto-Chinese situation. Through Chin-ch'eng's 'influence the Hva-shang monks [...] again began to play a role at the Tibetan court,"'in Houston, G. W. Sources for a History of the Bsam Yas Debate, Monumenta Tibetica Historica. Sankt Augustin, Denmark: VGH-Wissenschaftsverlag, 1980, p. 2. Ruegg, on the other hand, seems to defend the ideological nature of the debate: "[b]y Demiéville and other scholars the 'Great Debate' has been characterized as a Sino-Indian or an Indo-Chinese controversy. This description could, however lead to a misapprehension as to its nature and purpose, for the discussions were evidently set in train by the Tibetans themselves in order to clarify acute problems of theory and practice that had urgently come to their attention," in p. 239 Ruegg, D.S. "On the Historiography and Doxography of the "Great Debate of Bsam Yas." In Tibetan Studies: Proceedings of the 5th Seminar of the International Associaton for Tibetan Studies (Narika 1989), edited by Shoren Ihara. Tokyo: Naritisan Shinshoji, 1992. Ueyama offers an interesting interpretation of the discrepancies between Pelliot chinois 4646 and the traditional account that had been transmitted to us in various Tibetan sources: "I proposed that there were two debates, one in which Mo-ho-yen was victorious and another one in which he was defeated by Kamalaśila. In addition I had suggested that Ch'an had continued in the geographically remote outpost of Tun-huang even though it had been banished from Tibet proper. In this manner I accepted the separate variant accounts as equally valid and did not critically examine the sources," in Uyaema, Daishun. "The Study of Tibetan Ch'an Manuscripts Recovered from Tun-Huang: A Review of the Field and Its Prospects." In Early Ch'an in China and Tibet, edited by Whalen Lai and Lewis R. Lancaster. Berkeley: Lancaster Publications, 1983. Demiéville's work not only initiated a reconsideration of the fate of the Chan tradition in Tibet, but also of the nature of the gradualist approach defended by Kamalasīla. His Le Concile De Lhasa included a translation by Lamotte of the first of the three Bhāvanākrama of Kamalaśîla from an extant Tibetan version. Obermiller, in "A Sanskrit Ms. From Tibet -- Kamalaśîla Bhāvanākrama." Journal of the Greater Indian Society 2, no. 1 (1935): 1935, published the third Bhāvanākrama from a surviving Sanskrit version, while Tucci, in Minor Texts II, published a version in Sanskrit of the first. Luis O. Gómez has published in Spanish the three Bhāvanākrama in three separe issues of the Spanish journal Diálogos, Revista del Departamento de Filosofia de la Universidad de Puerto Rico (see Bibliography for details). 
from the Chan perspective. Starting in the sixties, ${ }^{564}$ the research of Japanese academics, by scholars like Ueyama, Obata, Kimura, and Imaeda, recognized the value of manuscripts like PT 116 (which we will discuss in more detail in section 4 of the paper), PT 117, PT 812, PT 813, or

Stein tib. 468 , among others, for our knowledge of the circumstances surrounding the debate. ${ }^{565}$ A lot of this early work, though, either had a strong philological bent, ${ }^{566}$ or was consumed with the clarification of various historical facts. ${ }^{567}$

\section{History or Historical Narrative?}

A somewhat different approach to the Samye Debate is the one offered by Ruegg, who argues that Tibetans transformed any traces of this historical event into what he calls a “dehistoricized topos,",568

\footnotetext{
${ }^{564}$ In his review of Japanese scholarship of 1983, Ueyama says the following: "my discovery of the Tibetan translation of the Leng chia shis tsu chi [...] in 1968 [...] enabled Japanese scholars to realize for the first time that Ch'an materials had been preserved among the Tibetan manuscripts from Tun-huang," in Uyaema, Daishun. "The Study of Tibetan Ch'an Manuscripts Recovered from Tun-Huang: A Review of the Field and Its Prospects." In Early Ch'an in China and Tibet, edited by Whalen Lai and Lewis R. Lancaster. Berkeley: Lancaster Publications, 1983, pp. 327-328. In the footnote accompanying this comment (in p. 345) Ueyama acknowledges that "In Europe Tibetan Ch'an was recognized by scholars quite early," and mentions the work of Lalou, Demiéville, Tucci, and Stein.

${ }^{565}$ Ueyama's Uyaema, Daishun. "The Study of Tibetan Ch'an Manuscripts Recovered from Tun-Huang: A Review of the Field and Its Prospects." In Early Ch'an in China and Tibet, edited by Whalen Lai and Lewis R. Lancaster. Berkeley: Lancaster Publications, 1983, offers an excellent overview of his own work as well as the research of other Japanese scholars and it should be a starting point for anyone interested in Japanese scholarship in the subject. ${ }^{566}$ This is the case, especially, of the Japanese scholarship. Without this philological emphasis though, a lot of the later work would have not been possible. Again, see Ueyama's review for a sample of this approach. Fleming's article "A Tibetan Dunhuang Treatise on Simultaneous Enlightenment: The Dmyigs Su Myed Pa Tshul Gcig Pa'i Gzhung." Acta Orientalia 46, (1985): 47-77, is a good example of the interpretation efforts that have been possible by the philological work done by Japanese scholars.

${ }^{567}$ Demiéville's own work, with its lengthy footnotes and philological analysis of terms, and Tucci's painstaking analysis in Minor Texts II of various Tibetan sources in order to establish the date of arrival of Kamalaśila to Tibet or the actual date of the Debate are good examples of that.

568 "It would of course be unrealistic to pretend that the Tibetan historical and doxographical sources at our disposal have given us a full and a perfectly accurate and balanced account of exactly what took place at the 'Great Debate' of bSam yas. The relevant Dunhuang documents in Tibetan, although fairly numerous, are both fragmentary and episodic. (In this respect they differ for example from Wang Hsi's Cheng-li chüeh also recovered from Dunhuang.) And the accounts in the classical Tibetan historical literature [...] are no doubt somewhat formalized and stereotyped to the extent that their authors relate what had become, in part at least, a somewhat dehistoricized topos,"
} 
Accounts found in Tibetan historical literature in fact seem to reflect the Tibetans' attempts either to rediscover their early history or to constitute tradition, or even to do both of these things at the same time. As a consequence, the 'Great Debate' of bSam yas often appears in this literature more as a semi-historical topos than as an historical event, and the Hva šang Mahāyāna as a more or less dehistoricized and emblematic figure standing as it were for a certain typological variety of Buddhism. In connection with the 'Great Debate', bSam yas itself became so to say a 'locus of memory ${ }^{569}$

As Ruegg himself acknowledges, this construction of a "dehistoricized topos" may simply have to do with the fact that Chan, as an independent tradition, gradually vanished from the Tibetan plateau after the collapse of the Empire, and played no significant role during the second dissemination of Buddhism in Tibet starting in the $11^{\text {th }}$ century. However, it may also have to do with an attempt (consciously or unconsciously) to rewrite the early history of Tibet with stronger links to India in order to establish the pedigree of the Buddhist teachings that were being introduced into Tibet during the second dissemination of Buddhism in Tibet, in opposition to the Buddhist traditions that had survived after the collapse of the Empire, during the so-called Dark Ages.

Finally, Kapstein offers an interesting alternative model to the traditional historical approach used to explore the sources of early Tibetan history that could be very useful when studying the various sources related to the Samye Debate, and the seeming contradictions raised by Pelliot chinois 4646 and the Tibetan Chan manuscripts:

[I]t has long been evident that Tibetans historical traditions concerning the first millennium of the common era contain much in the way of self-contradiction, factual inaccuracy, legend, and sheer fancy. While contemporary academic historians of Tibet have generally felt in their charge to get at the facts of the matter to the extent possible, it has sometimes not been sufficiently considered

\footnotetext{
in Ruegg "On the Historiography and Doxography of the "Great Debate of Bsam Yas." In Tibetan Studies:

Proceedings of the 5th Seminar of the International Associaton for Tibetan Studies (Narika 1989), edited by Ihara Shoren. Tokyo: Naritisan Shinshoji, 1992, p. 240.

${ }^{569}$ Ruegg, Ibid. p. 240.
} 
that the apparent inaccuracies, legends and fancies are among the facts of the matter [...] our task is not solely to pick away at what they wrote, for the legends themselves, above and beyond the questions that may be raised concerning the literal veracity of their affirmations and denials, were proposed and became authoritative [...] In short, the Tibetanist must strive to illuminate not only Tibetan history, but Tibetan historiography as well ${ }^{570}$

The discovery of the Tibetan Chan manuscripts in Dunhuang forces us to question not only the accuracy of the historical facts of early Tibetan history, but the way itself in which this history needs to be studied and told. ${ }^{571}$

\section{Broadening the scope of the field}

The work of Matthew Kapstein, especially The Tibetan Assimilation of Buddhism, seems to offer interesting new steps in this direction. In this work, Kapstein questions the Indo-Tibetan model of history, ${ }^{572}$ by which Buddhism was introduced in Tibet exclusively, or for the most part, from India, and replaces it by one in which Central Asia, and other traditions besides Buddhism, also played important roles in the assimilation of Buddhism in Tibet:

Tibetan Buddhism has often been presented, by both Tibetans and non-Tibetan students of Tibetan culture, as the product of a strict and literal transmission of Indian Buddhism, an almost invariant preservation of a perennial tradition c Despite the powerful and enduring role of Indian Buddhist sources and precedents, however, it is clear that this view alone is far too simple. "Indian Buddhism" itself was not at all monolithic, and India imparted many and varied influences to Tibet, which the Tibetan themselves received and transformed in many and varied ways. Moreover [...] not all of the Buddhism the Tibetans transmitted came from India ${ }^{573}$

\footnotetext{
${ }^{570}$ Kapstein, Matthew. The Tibetan Assimilation of Buddhism : Conversion, Contestation, and Memory. Oxford ; New York: Oxford University Press, 2000, p. 38.

${ }^{571}$ Faure does some very interesting work in this respect in the area of the early history of the Chan tradition in China, although, sometimes, his application of postmodern ideas needs to be carefully assessed against the historical evidence. In Faure, Bernard. Chan Insights and Oversights : An Epistemological Critique of the Chan Tradition. Princeton, New Jersey: Princeton University Press, 1993.

${ }^{572}$ A good example of this approach was, the otherwise excellent, Snellgrove, David L. Indo-Tibetan Buddhism: Indian Buddhists and Their Tibetan Successors. Boston [New York]: Shambhala, 1987.

${ }^{573}$ Kapstein, Ibid., p. 70.
} 
It is in this more "open world," in which the following lines of the Tibetan Chan manuscript PT

996 have new significance:

Après avoir 'diagnostoqué' les sūtra dont le Sens est certain, ayant accordé sa proper méditation avec les àgama et les upadeśa des conseillers religieux, ayant attaint la source des commentaries sur le Sens certain de sütra du Grand Véhicule et le Sens de ces àgama et upadeśa des penseurs Maitres du Dhyāna du Tibet, de la Chine et de l'Inde ${ }^{574}$

The perception of a Buddhist world that did not limit itself to India, but that was part of the social and religious fabric of Asia, may help us to better contextualize the contents of the Tibetan Chan manuscripts found in Dunhuang, and the relevance that the Chan tradition has in Nupchen's Lamp helps us broaden the historical frame by which we study early Tibetan history and the introduction of Buddhism in Tibet. ${ }^{575}$ This approach would not challenge the enormous influence that the Indian Buddhist tradition played in Tibet, but offers an alternative model in which Tibet was at the center of a more complex Buddhist network in which teachers, texts, and teachings came from many different venues. ${ }^{576}$

\footnotetext{
${ }^{574}$ Lalou, Marcelle. "Document Tibétain Sur L'expansion Du Dhyāna Chinois." Journal Asiatique 231, (1939): 50223 , bold and underlying are mine.

${ }^{575}$ Kapstein offers a good example of what this history looks like with his analysis of the very tenuous (but still existent) traces of Korean Buddhism in Tibetan Buddhism. Kapstein argues that his academic exercise "serves as an illustration of Tibet's participation in the international culture of Buddhism, and, at the same time, of the assimilation and transmission in Tibet of materials made available through such participation." (p. 69) At the end of the same chapter Kapstein argues that "[t]urning now to the history of Tibetan Buddhism in particular, we must understand that [these] examples taken up in this chapter would have to be multiplied a thousand fold to do justice to the full range of texts and teaching traditions that variously became interwoven or opposed to one another in the fabric of Tibetan thought, from about the eighth through the thirteenth centuries [...] The full complexity of such connections, moreover, must be considered in relation to the full panoply of Tibetan individuals, lineages, ad institutions that identified themselves with, rejected, or ignored specific materials that became available through the varied processes of cultural transmission.” In Kapstein, Ibid.p. 84.

${ }^{576}$ Broughton makes a similar point: "The Tibetan Ch'an manuscripts serve to remind us how much, particularly during the Tibetan occupation period, the religion of Tun-huang was the religion of the Silk Road and therefore how it must be approached as part of a continuum extending across the Western Region to such distant places as the citystate of Kucha. One of the characteristics of the Buddhism of this continuum was a receptivity to both Indian and Chinese currents. This was a truly eclectic environment, so it should come as no surprise that its Buddhism was not purely Chinese." In Broughton, Broughton, Jeffrey L. The Bodhidharma Anthology the Earliest Records of Zen. Berkeley, Calif.: University of California Press, 1999, p. 99.
} 


\section{The Samye Debate in the Lamp for the Eye in Contemplation}

One of the first things a scholar notices when reading the Gradual and Sudden chapters if the

Lamp is that, while there is a clear tension between the two approaches, and Kamalaśila and Hashang Mahāyāna, play prominent roles as the main representatives of these traditions, Nupchen never actually mentions a debate taking place deciding the fate of these schools of thought and practice in Tibet. Nupchen's most obvious, even if still criptic, reference to the fate of the Chan tradition in Tibet takes place in the second chapter, during a brief introduction to the history of the Chan tradition:

Now the precepts of the 'vehicle of cause' were imparted to 'Od-srung (Kaśyapa) by the Bhagavan just before he passed away into Nirvana. The lineage of (that teaching) passed from Dharmottara, etc. reaching Hva-shang Mahayana, the last of the seven successions in China. Then in Tibet where a king and monks possessed the lineage of that teaching it came to be destroyed. (However) one can learn the system of that teaching through the books which exist and (also) learn the gradualist teachings taught by Kamalaśîla. So, now one is obliged to learn them without teachers. ${ }^{577}$

Much has been said about this passage of the Lamp, since it is the only reference in the text that offers a clue to the dissapearance of Chan in Tibet. ${ }^{578}$ As we saw in our analysis on the nature of the interlinear notes in chapter 2 of this dissertation, the use of the name Langdarma to refer to King 'U'i dum brtan seems to indicate that the note was written after the original composition of the text and, therefore is not completely reliable that it reflects Nupchen's explanation regarding the decline of Chan in Tibet dur to Langdarma's intervention. The succintness of the note, and the lack of further references in other textual sources to this turn of events, make it very difficult to confirm its historicity.

\footnotetext{
${ }^{577}$ Karmay, The Great Perfection (rDzogs Chen): A Philosophical and Meditative Teaching of Tibetan Buddhism, 1988, 93-94.

${ }^{578}$ See Ibid., 101-103; Donati, “The Lamp Is Burning Bright. Gnoseological Approaches and Soteriological Perspectives in Gnubs Chen Sangs Rgyas Ye Shes’ Masterpiece,” 135 n. 39.
} 
I do not think, therefore, that the Lamp can offer any definitive answer about the existance of an actual debate, or even about the precise circumstances that resulted in the dissapearance of Chan in Tibet, but I do think that the Lamp offers a more problematic picture of the nature and the history of the tension between these two traditions during their coexistance in Tibet in the 9th century. At the same time, the Lamp also seems to indicate that, by the time Nupchen is writing the Lamp, the Chan tradition stopped playing any meaningful role in Tibet, ${ }^{579}$ but Nupchen still includes it in his doxography since it played such an important intellectual role in the early introduction of Buddhism in Tibet and, I think shape to a certain extent certain philosophical and contemplative approaches of the Great Perfection tradition, particularly around their approach to non-conceptuality. The inclusion of the Chan tradition helps Nupchen place the Great Perfection in the intellectual context from which it came from, and from which it developed.

\footnotetext{
${ }^{579}$ Although the same can be said about the Gradual tradition as it was introduced by Śantarakṣita and Kamalaśīla. The collapse of the monastic institutions, essential for the survival of the highly scholastic Gradual system, certainly affected its survival. The same institutional collapse also allowed the emergence of the Mahāyoga and Atiyoga traditions, in less need of big institutions since they relied in smaller communitites of tantric pracitioners centered around the figure of a charismatic teacher.
} 


\section{Did Nupchen understand the Bhāvanākramas and Hashang Mahāyāna's works?}

Let me conclude this discussion of Nupchen's presentation of the Gradual and Sudden traditions by addressing a few scholar's concerns regargind Nupchen's presentation of these traditions. The Japanese scholar Izumi Miyazaki wrote a series of articles ${ }^{50}$ in which he points out the discrepancies between Kamalaśîla explanations in the Bhāvanākramas of the doctrine of the Two Truths and his explanation of the Four Immesuarables, and the way Nupchen interprets them in the Lamp. Miyazaki, argues that either Nupchen misunderstood the Bhāvanākramas, or he simply understood it in a different way. Carmen Meinert made a similar criticism regarding Nupchen's discussion of Chan, by pointing out that Nupchen may have been unfair to the Chan tradition by misunderstanding very important doctrinal aspects as presented in some of the Dunhuang manuscipts, particularly regarding the concept of the luminosity of the mind, which plays a very important role in the Xiuxin Yaolun (Ch. 修心要論) of Master Wolun:

In contrast to his assessment of Rdzogs chen, Gnubs argues that - though the Cig car ba tradition immediately focuses on the unborn absolute (don dam pa ma skyes pa nyid) - it simply corrupts mind, since there is still involved a concept of the unborn absolute. Moreover, he qualifies its concept of the unborn and empty ground as the perfected reality (yongs su grub pa) of the Yogacāra school. However, in his exposition on the understanding of non-conceptuality in the Cig car ba school, Gnubs does not to my knowledge mention anywhere the aspect of luminosity, but only the emptiness aspect. In the present research, it is not the point to argue whether the light metaphor applied in the Cig car ba text Xiuxin yaolun is comparable to the experience of luminosity as it is described above according to the Rdzogs chen tradition. Nonetheless, it is noteworthy that Gnubs' seemingly positive exposition of the Cig car ba school is actually rather onesided and does not take into account the full implications of Chinese Mediation Buddhism - as it was exemplified by a brief analysis of the Kanxin fa and the Xiuxin yaolun. In this light, Gnubs might even be seen as the first critic in the Cig car ba/Rdzogs chen debate, although in the view of later critics he might have appeared as rather pro Cig car $b a^{581}$

\footnotetext{
${ }^{580}$ Izumi Miyazaki, "The Gradual Chapter of the Bsam Gtan Mig Sgron and the Teaching of Kamalaśila," Journal of Indian and Buddhist Studies 52, no. 2 (March 2004): 899-902.

${ }_{581}$ Meinert, "Legend of Cig Car Ba Criticism in Tibet: A List of Six Cig Car Ba Titles in the Chos 'byung Me Tog Snying Po of Nyang Nyi Ma 'od Zer (12th Century)," 49.
} 
While both criticisms are well argued and should make as wary of taking for granted Nupchen's explanations of those two traditions as fair representations of their philosophical views and contemplative practices, I also think they are missing the point. We need to remember that, while the Lamp is an extremely useful tool to study the textual world of the period, it is not a faithful mirror. It is, instead, a window with a very particular outlook onto that world. The fact that Nupchen is not being faithful to many of the texts he is quoting can be easily explained by pointing out the fact that he is constructing a doxography, a classification of views. A doxography is, after all a hierarchical classification, in which traditions that were originally doctrinally and soteriologically self-sufficient become incorporated into a new system in which they are now only acknowledged as having a partial understanding of, in this case, the Buddhist Path. Nupchen is only interested in describing and understanding the Gradual path from the perspective of the Great Perfection, and it is from that perspective that shapes his understanding and interpretation of the Bhāvanākramas or of Hashang Mahāyāna's thought. 


\section{Conclusion}

This chapter has discussed the intellectual and historical background of the Gradual and Sudden traditions as had been imported by figures like the Indian scholars Śāntarakșita and Kamalaśîla, and the Chinese master Hashang Mahāyāna. I has also offered an overview of Nupchen's interpretations of these traditions as discussed in chapters four and five of the Lamp. One of the main arguments of the chapter has been to highlight the fact that Nupchen is defining these two traditions not only in their own terms, but also in opposition to each other. It is through these oppositions that distinctions can be made, and doctrinal bounderies be constructed. This technique is an important part of the doxographical genre, and will help Nupchen to build in the following chapters a distinctive identity for the new and emergent Great Perfection tradition. The chapter has also what he Lamp can offer to our understanding of the so-called Samye debate, as well as to a more complex picture of the introduction of Buddhism into Tibet, one that broadens the horizons beyond India, and situates Tibet at the center of a complex network of Buddhist systems across Asia that will inform and affect the Tibetan assimilation of Buddhism during the Dark Age period. 


\section{Chapter 5 - The Triumph of Tantra and the Emergence of the Great}

\section{Perfection Tradition in Tibet.}

Intro

As we have seen in the previous chapter, Nupchen defines the Indian Gradual and the Chinese Sudden traditions in relationship to each other. There is a clear and well defined tension in their doctrinal and contemplative approaches, which establishes the bounderies between them, but that same tension reflects the interdependence of both traditions: one cannot be defined without the other. From the perspective of the Tibetan Tantric tradition, that interdependence became defined by subsuming both traditions under labels such as the "Sūtra tradition," or the "Vehicle of the Cause" (Tib. rgyu'i theg pa). These labels would set the Gradual and the Sudden tradition in opposition to the new Tantric traditions that emerged around the 7 th century in India and that became known as the "Vehicle of the Result" (Tib. 'bras bu theg pa), ${ }^{582}$ which in Nupchen's Lamp will include the last two Buddhist systems discussed in the book, the Mahāyoga tradition (Tib. rNal 'byor chen po) and Atiyoga or the Great Perfection (Tib. A ti yo ga; rDzogs pa chen po).

\footnotetext{
${ }^{582}$ Dudjom Rinpoche defines the differences between these two vehicles in the following way: "This [vehicle] which makes the result into the path is superior to the vehicle of the transcendental perfections which makes the cause into the path [...] Therefore, in the vehicle of dialectics [i.e. the vehicle of the cause] mind-as-such is merely perceived as the causal basis of buddhahood. Since it is held that buddhahood is obtained under the condition whereby the two provisions increasingly multiply, and since the purifying doctrines which form the causal basis of nirvana are made into the path, it is called the causal vehicle (rgyu'i theg-pa). Therein, a sequence in which cause precedes result is admitted. According to the vehicle of mantras, on the other hand, mind-as-such abides primordially and intrinsically as the essence of the result, identified in the buddha-bodies and pristine cognitions. Mind-as-such is thereby established as the ground which exists within oneself from the present moment as the object to be attained. It is then established as the path through its functions of bringing about recognition and removing the provisional stains which suddenly arise by means of inducing the perception of just what is, and it is established as the result through its function of actualizing this very ground. Since a sequence in which cause precedes result is not really distinguished therein, it is called the resultant vehicle ('bras-bu'i theg-pa) and the vehicle of indestructible reality (rdo-rje theg-pa)." In Dudjom Rinpoche, The Nyingma School of Tibetan Buddhism: Its Fundamentals and History (Boston: Wisdom Publications, 2002), 243-44.
} 
In his description and discussion of the Mahāyoga and Atiyoga traditions, Nupchen will follow the same template he has used in the previous chapters, describing the philosophical views (Tib. lta $b a$ ), the practices (Tib. sgom $p a$ ), the conduct (Tib. spyod pa), and the soteriological result of the practice (Tib. 'bras bu) of the two traditions. As he did in the previous two chapters, Nupchen will also frequently compare the two tantric traditions, although, in this case what we see is a close relationship between the two systems. As van Schaik, among other scholars, has pointed out "we find both Mahāyoga and Great Perfection being interpreted by Tibetans in the tenth century in very close association with each other," ${ }^{, 583}$ and this probably is, as we will see later in the chapter, because the Great Perfection emerged, in fact, from ritual and contemplative developments of the Mahāyoga system.

This chapter is divided in five parts. In the first part, we will explore the rise of Tantra and, in particular, of Mahāyoga in India as well as its introduction into Tibet. We will pay special attention to the role that the 8th century scholar Pelyang had in articulating a Tibetan understanding of the tradition that will be essential, just as Kamalaśîla in the case of the Gradual tradition and Hashang Mahāyāna in the case of the Sudden, in Nupchen's understanding of the Mahāyoga tradition in the Lamp. The second part will examine Nupchen's presentation of the Mahāyoga tradition, and the way he focuses on the more philosophical aspects of the tradition, downplaying its more controversial and antinomian rhetoric and practices. The third one will explore the emergence of the Atiyoga tradition from certain doctrinal and contemplative developments of Mahāyoga, and will discuss the possible and controversial influence of Chinese Chan on the Great Perfection tradition. The fourth section examines Nupchen's presentation of Atiyoga in the Lamp and his role in articulating a new and distinctive identity for the tradition.

\footnotetext{
${ }^{583}$ Van Schaik, "The Sweet Sage and the Four Yogas: A Lost Mahāyoga Treatise from Dunhuang," 5.
} 
The fifth and final section will discuss the formation of the early canon for the Great Perfection tradition as reflected in the Lamp.

The chapter has two main goals. First, I want to argue that the Mahāyoga and Atiyoga chapters of the Lamp show how Buddhism in Tibet was shifting towards a decentralized tantric model, leaving behind the Imperial attempts at regulating, controling, and censoring what was to be importe, translated, and practiced. The second goal is to show the mechanisms by which Nupchen is constructing a separate identity for the Great Perfection tradition. These involve lenghty philosophical discussions that outline the main differences between Atiyoga and other Buddhist traditions, and the articulation of a new lineage of transmission of teachings and scriptures separate and diferent from those of other traditions. As Faure had argued in the context of the Chinese Chan tradition, although the idea applies perfectly to the context of the Mahāyoga and Atiyoga chapters in the Lamp, lineages are "a product of people on the margins, the result of their desire to become the party of the orthodoxy. It is not a sign of richness in the tradition, but rather of the lack in it." 584

\footnotetext{
${ }^{584}$ Bernard Faure, The Will to Orthodoxy: A Critical Genealogy of Northern Chan Buddhism (Stanford, Calif.: Stanford University Press, 1997), p. 9. McRae made a similar analysis of the nature of lineages in his Seeing Through Zen.
} 


\section{Part 1 - Mahāyoga}

The Emergence of Esoteric Buddhism in India

In his remarkable study of the emergence of tantric Buddhism in India after the collapse of the Gupta Empire in the 6th century, Ronald Davidson argued that Esoteric Buddhism was "a direct Buddhist response to the feudalization of Indian society in the early medieval period, a response that involves the sacralization of much of that period's social world." ${ }^{585}$ His work, although contested by some scholars, ${ }^{586}$ helped situate the emergence of Tantric Buddhism in a very specific historical context, and helped explain the use of sexual and violent rhetoric within the new Buddhist scriptures and ritual systems, a rhetoric that seems to have contradict centuries of Buddhist ideology and practice. ${ }^{587}$

\footnotetext{
${ }^{585}$ Ronald M. Davidson, Indian Esoteric Buddhism : A Social History of the Tantric Movement (Columbia University Press, 2002), 2.

${ }^{586}$ See Wedemeyer or White, in particular for some criticism of Davidson's use of sources. Christian Wedemeyer, "Review of Indian Esoteric Buddhism: A Social History of the Tantric Movement by Ronald Davidson," History of Religions 45, no. 4 (May 2006): 373-76; David Gordon White, "Review of Indian Esoteric Buddhism," Journal of the International Association of Tibetan Studies (JIATS) 1 (October 2005). Wedemeyer, in his recent book Making Sense of Tantric Buddhism, has also criticized the "contruction" of a historical context by scholars in order to explain the violent and sexual rhetoric of tantra (an oblique reference to Davidson). Instead, he prefers to offer "a reading of the antinomian discourses of Tantric Buddhist ritual and scripture, demonstrating that these are neither fully literal nor truly figurative, as has previously been claimed. Applying methods out lined by Roland Barthes to a comprehensive analysis of the Guhyasamāja Tantra, I argue that the transgressions of Tantric ritual and scripture constitute a form of connotative semiotics. In this mode of communication, a complete sign in natural language (in this case, the signifier - signified complex of transgression and ritual pollution) functions as a signifier in a higher order cultural discourse. At this higher, performative level, the signified is the attainment of the goal of advanced Tantric practice: non-dual gnosis (advayajñāna). This approach provides a new lens for appreciating the sophisticated systems of signification functioning in esoteric scripture and ritual, and a rather different framework for representing Tantric antinomianism.” In Wedemeyer, Making Sense of Tantric Buddhism, 12.

${ }^{587}$ Davidson refers to this tension as a consequence of this process of assimilation of the socio-political environment into the doctrinal and ritual discuourse of Buddhism. For Davidson, tantra: "represented a moderately successful reorganization of the various religious communities to encounter and overcome the challenges of the period [...] in the face of such challenges, Indian Buddhists responded by appropriating aspects of the sociopolitical sphere, yet this response embodied a tension new to the Buddhist tradition," In Davidson, Indian Esoteric Buddhism: A Social History of the Tantric Movement, 336. On this particular issue see the recent work of Wedemeyer attempting to address the tension between the rhetoric and the actual practices of Tantric Buddhism. Wedemeyer, Making Sense of Tantric Buddhism.
} 
The new esoteric forms of Buddhism grounded their transgressive and antinomian discourses and practices on a radical understanding of the non-dual nature of reality (Tib. gnyis su med pa; Skt. advaya), a realization that there was ultimately no difference between samsāra and nirvāṇa. This central idea transformed traditional Buddhist notions of ritual purity and pollution and allowed Buddhism to explore the limits of traditionally accepted religious discourse and ritual behaviour. ${ }^{588}$ An example of this can be seen by simply comparing the language of old Buddhist scriptures with that of the new tantric traditions. A Sūtra like the Setting in Motion of the Wheel of Dharma (Skt. Dharmacakra Pravartana Sütra), in which the historical Buddha teaches the doctrine of the Four Noble Truths, would use language to convey ideas in a dialectical but not particularly iconoclastic way:

There are these two extremes that are not to be indulged in by one who has gone forth. Which two? That which is devoted to sensual pleasure with reference to sensual objects: base, vulgar, common, ignoble, unprofitable; and that which is devoted to self-affliction: painful, ignoble, unprofitable. Avoiding both of these extremes, the middle way realized by the Tathagata - producing vision, producing knowledge - leads to calm, to direct knowledge, to self-awakening, to Unbinding. ${ }^{589}$

The new tantric literature, particularly those scriptures belonging to the Mahāyoga and the Anuyoga tradition, would include language that would be clearly agressive and antinomian. In the Hevajra Tantra, a key Mahāyoga text, we find passages such as the following one:

Vajragarbha said: 'What usage and observance should one follow?'

The Lord replied: 'You should slay living-beings.

You should speak lying words.

You should take what is not given.

You should frequent others' wives. ${ }^{590}$

\footnotetext{
${ }^{588}$ Wedemeyer, Making Sense of Tantric Buddhism, 9.

589 "Dhammacakkappavattana Sutta: Setting the Wheel of Dhamma in Motion" (SN 56.11), translated from the Pali by Thanissaro Bhikkhu. Access to Insight (Legacy Edition), 30 November 2013, http://www.accesstoinsight.org/tipitaka/sn/sn56/sn56.011.than.html

${ }^{590}$ David L. Snellgrove, The Hevajra Tantra: A Critical Study (London: Oxford University Press, 1964$), 79$.
} 
While, as Wedemeyer has pointed out, there is a context in which the new rhetoric and language of Mahāyoga needs to be interpreted, Davidson may still have been right when signaling that the Buddhist efforts to internalize and incorporate the socio-political changes that were happening around the tradition into new Buddhist scriptures, doctrines, and practices, "this response embodied a tension new to the Buddhist tradition,"

In the ritual and contemplative domain, the most transgressive and antinomian rhetoric of the new tantric traditions will inform what became to be known as the practices of Union (Tib. sbyor $b a$ ) and Liberation (Tib. sgrol ba), which included sexual and violent ritual practices. ${ }^{592}$ If Davidson has offered a compelling account of the historical events that can help explain the emergence of Esoteric Buddhism, Dalton has offered a parallel account in which the emergence and evolution of this type of tantric practices is explained as a process of interiorization of Buddhist ritual:

the tantras did produce an irreversible change in Buddhist ritual discourse is clear. By the end of the eighth century, the shift was apparent even to those involved. Buddhist authors at the time described what was unfolding as an internalization of ritual performance; in contrast to the earlier 'external' methods of worship, they termed the new techniques the 'internal yogas'. The significance this shift had for Buddhist ritual discourse is attested by the fact that the tantras composed between the late eighth and early tenth centuries form the canonical core of the Tibetan Buddhist tradition to this day ${ }^{593}$

\footnotetext{
${ }^{591}$ Davidson, Indian Esoteric Buddhism: A Social History of the Tantric Movement, 336.

592 On the practices of Union and Liberation see Sam Van Schaik, "A Definition of Mahāyoga: Sources from the Dunhuang Manuscripts," Tantric Studies 1 (2008): 45-88; Cantwell, “To Meditate upon Consciousness as Vajra: Ritual 'Killing and Liberation' in the rNying-Ma-Pa Tradition."

593 Jacob Dalton, "The Development of Perfection: The Interiorization of Buddhist Ritual in the Eighth and Ninth Centuries," Journal of Indian Philosophy 32, no. 1 (2004): 2.
} 
These "earlier "external methods of workship"" to which Dalton is referring are what became known as the Kriyā, Caryā and Yogatantra vehicles. ${ }^{594}$ These traditions were a continuation of the earlier practices of Buddhanusmrti or "recollection of the Buddha" that we already saw briefly in our discussion of the dreams and visions that result from the practice in the Gradual approach. ${ }^{595}$ The goal was to bring to the presence of the practitioner the figure of the absent Buddha. During the second half of the 8th century though, we see how this attempts to generate the image of a Buddha in order to worship him was not enough, and we find already in some Yogatantra scriptures a movement in which the practitioner identifies him or herself with the visualized deity. This will become the starting point of a new series of ritual and contemplative practices in the Mahāyoga tradition that will focus on the interior of this newly sanctified (by being identified with the body of a Buddha) body. If Mahāyāna was an exploration of the wonders of the macrocosm, with its detailed descriptions of multiple universes and Pure Lands, tantra will focus its attention in the microcosm of the human body, developing a rich and complex sacred physiology that went beyond its corporeal characteristics, and grounded itself in what became to be known as the subtle body, formed not of flesh and bones, but of channels, winds and seminal nuclei (Tib. rtsa lung thig le).

\footnotetext{
${ }^{594}$ See chapter two of this dissertation for a discussion of the evolution of the nine vehicle system in the Tibetan tradition. In what became the standard nine vehicle division (Tib. theg pa dgu) of the Nyingma tradition, the various tantric vehicles were divided in the outer tantras (Tib. phyi rgyud), which included kriyatantra, Caryatantra, and Yogatantra, and the inner tantras (Tib. nang rgyud) which included the Mahāyoga, Anuyoga, and Atiyoga traditions. The inner tantras were grouped together in the Sarma traditions under the label Unsurpassable Tantra (Tib. bla na med pa'i rgyud; Skt. Anuttarayoga Tantra). On the evolution of the various clasifications of tantric vehickes in Tibet see my discussion in chapter two of this dissertation. See also Dudjom Rinpoche, The Nyingma School of Tibetan Buddhism: Its Fundamentals and History, 268-274; Jamgon Kongtrul, Systems of Buddhist Tantra. The Treasury of Knowledge Book Six, Part Four. (Ithaca, N.Y.: Snow Lion Publications, c2005.), 89-98.

${ }_{595}$ On this topic see also Paul Harrison, "Buddhānusmṛti in the Pratyutpanna-Buddha-Saṃmukhāvasthita-SamādhiSūtra," Journal of Indian Philosophy 6, no. 1 (September 1978).
} 
The Mahāyoga tradition will articulate a complex system of rituals and practices that will explore this new tantric physiology. These practices were divided into the "path of methods" (Tib. thabs lam) and the "path of liberation" (Tib. sgrol lam). ${ }^{596}$ The "path of methods," focuses on visualization and phyisiological practices that involve the manipulation of the subtle body (also named the practices of the "upper door"), ${ }^{597}$ and the use of a female consort for sexual practices (practices of the "lower door"). ${ }^{598}$ The main goal was the manipulation of the subtle

\footnotetext{
${ }^{596}$ For a detailed explanation of this division see Dudjom Rinpoche, The Nyingma School of Tibetan Buddhism: Its Fundamentals and History, 276-281.

${ }^{597}$ Tib. steng sgo. Jamgon Kongtrul offers a general description of some of the content of the practices of the upper door, which include the practices of the "union of blazing and dripping based on the six chakras (Skt. cakra), generating the pristine awareness of bliss in the four chakras as a progressive training." In Jamgon Kongtrul, The Treasury of Knowledge: Book Eight, Part Four: Esoteric Instructions : A Detailed Presentation of the Process of Meditation in Vajrayana, 71. This practice, also called the "fierce woman" (Tib. gtun mo) reflects the new tantric obsession with the body, and with the interior of the body in particular, as well as the tantric sophistication in the use of this new imagined subtle body in order to transform common physiological experiences (in this case sexual desire) for the purpose of achieving enlightenment. Germano explains this practice as follows: "The most well-known instance of this is the Hail Vajra Tantra's paradigmatic account of the fierce woman (gtum mo; Skt. candāli) practice. In these practices, the sexual nature of these representations of the body's interior is most apparent: it is dominated by the lunar wheel of white semen in the crown, the hot sexual and digestive fire located in the navel wheel, and the central channel which links the two. The praxis itself involves the solar fire blazing up from the abdominal area into the cranial vault, such that the lunar ambrosial semen heats up, melts and begins to drip down through the central channel towards the genitals. In terms of its affective experience, this downward progress through the cakras ignites a cascading series of ever intensifying sensations of orgiastic bliss (graded into "four joys"); the practice can be done in conjunction with actual sexual intercourse or not. The techniques themselves rely primarily on breath manipulation, visualizations of this interior, cultivated tactile sensations of heat and bliss, and postures." In Germano, Mysticism and Rhetoric in the Great Perfection (rDzogs Chen), 2009, 54.

598 Tib. 'og sgo. Kongtrul describes these sexual practices in which a consort is required as follows: "In the practice of the lower door, the descent, retention, reversal, and pervasion of the vital essence from union based on both the "space" [of the female] and the "secret" [of the male] instantly generates the pristine awareness of inseparable blissemptiness." In Jamgon Kongtrul and Harding, The Treasury of Knowledge: Book Eight, Part Four: Esoteric Instructions: A Detailed Presentation of the Process of Meditation in Vajrayana, 72. Germano offers a very interesting explanation of the practices of the upper and the lower door in terms of the central metaphors that govern them, death and sexuality, respectively: "With this network of energy and substance flow patterns in the body, complicated new contemplative systems are articulated that manipulate these flows in ways conducive to the generation of unusual sensations and contemplative states understood to eventually culminate in a reiteration of the enlightenment experience. I think it is useful to differentiate between two different basic paradigms of these interior contemplations focused on this body within a body, though at this point I cannot offer a historical analysis of possibly separate modes of genesis: the death-inspired centering of winds into the central channel and the sexualitydriven manipulation of seminal nuclei up and down that same central channel. In the terms of the latter, we find a highly sexualized paradigm explicitly modeled on sexual sensations (in many cases to the point of explicitly relying on actual sexual intercourse) which focuses on the movement of "nuclei" (semen is their coarser aspect), especially as dripping down from their lunar reservoir at the crown's thousand petalled lotus towards the genitals. The most well known instance of this is the Hail Vajra Tantra's paradigmatic account of the fierce woman (gtum mo; Skt. canda $\bar{a} l i)$ practice. 88 In these practices, the sexual nature of these representations of the body's interior is most
} 
body as well as the use of sexual practices in order to generate increasingly powerful experiences of "bliss" (Tib. dga' ba). ${ }^{599}$ Janet Gyatso, among others, has explored the clear tension at the center of these practices, in which the practitioner embraces an element of human nature (i.e. desire), that the Buddhist tradition has rejected for centuries: ${ }^{600}$

"it is especially the valorization of bliss that becomes emblematic of the tantric project to invert certain threads in earlier Buddhism, most specifically its doctrine that sexual pleasure is inseparable from attachment and suffering and therefore to be avoided through celibacy. In contrast, tantric Buddhists, following a trend already under way in some branches of the Mahāyāna [...] to reject all conceptions of enlightenment that excluded any activity or state of mind, sought enlightenment within desire and attachment rather than without them. In tantra such a path of transgression and inclusion proceeds most (in)famously within sexual bliss. This, ironically, is thought to deliver the practitioner from those very grasping desires. As one saying goes, tantra uses more fire to heal a burn on the body, or more water to flush out water caught in the ear."601

apparent: it is dominated by the lunar wheel of white semen in the crown, the hot sexual and digestive fire located in the navel wheel, and the central channel which links the two. The praxis itself involves the solar fire blazing up from the abdominal area into the cranial vault, such that the lunar ambrosial semen heats up, melts and begins to drip down through the central channel towards the genitals. In terms of its affective experience, this downward progress through the cakras ignites a cascading series of ever intensifying sensations of orgiastic bliss (graded into "four joys"); the practice can be done in conjunction with actual sexual intercourse or not. The techniques themselves rely primarily on breath manipulation, visualizations of this interior, cultivated tactile sensations of heat and bliss, and postures." In Germano,Forthcoming Mysticism and Rhetoric in the Great Perfection (rDzogs Chen), 2009.

${ }^{599}$ This is traditionally defined as the "four joys" (Tib. dga' ba bzhi): joy (Tib. dga' ba), supreme joy (Tib. dga' $m c h o g$ ), extraordinary joy (Tib. khyad dga'), co-emergent joy (Tib. lhan skyes pa'i dga' ba). For a brief explanation see Jamgon Kongtrul, The Treasury of Knowledge: Book Eight, Part Four: Esoteric Instructions : A Detailed Presentation of the Process of Meditation in Vajrayana, $374 \mathrm{n} 32$. On the Four Joys and an explanation of these sexual practices see Kelsang Gyatso, Clear Light of Bliss: Mahāmudrā in Vajrayāna Buddhism (London: Wisdom Publications, 1982); Kelsang Gyatso, Tantric Grounds and Paths: How to Begin, Progress On, and Complete the Vajrayana Path (London: Tharpa, 1994).

${ }^{600}$ Desire is one of the Three poisons (Skt. trivișa; Tib. dug gsum) in the Buddhist tradition: "the three primary afflictions (MŪLAKLEŚA) of sensuality, desire, or greed (RĀGA or LOBHA), hatred or aversion (DVEȘA), and delusion or ignorance (MOHA), regarded as poisons because of the harm they cause to those who ingest them or the way they poison the mind. This same list of three is also known as the three "unwholesome faculties" (AKUŚALAMŪLA), which will fructify as unhappiness in the future and provide the foundation for unfavorable rebirths (APĀYA). In the "wheel of existence" (BHAVACAKRA) that the Buddha is said to have instructed to be painted at the entrances of monasteries, showing the six realms of rebirth (ȘADGATI) as well as the twelve links of dependent origination (PRATİTYASAMUTPĀDA), the three poisons are often depicted at the center of painting, suggesting their role as root causes of cycle of rebirth, with greed represented by a rooster, hatred by a snake, and delusion by a pig in a circle, each biting the tail of the other." In Robert E. Buswell and Donald S Lopez, The Princeton Dictionary of Buddhism (Princeton University Press, 2013).

${ }^{601}$ Janet Gyatso, "Healing Burns with Fire: The Facilitations of Experience in Tibetan Buddhism," Journal of the American Academy of Religion 67, no. 1 (March 1, 1999): 122. 
The "path of liberation" focuses on a philosophical approach represented by various views (Tib. lta ba) that express, mainly in poetic form, an understanding of the nature of phenomena. ${ }^{602}$ What is interesting of the Path of Liberation for our discussion here is the fact that it is divided into "gradual," and "sudden." The sudden approach is "for those of exceptional faculties" and the gradual approach is "for those who practice [...] by stages." ${ }^{\circ 03}$ We have already discussed the tension between the gradual and the sudden approaches in the context of Nupchen's analysis of the Indian and Chinese traditions. Now, we see this tension resurfacing again in the context of the Mahāyoga tradition, signaling that this is a tension central to the Buddhist tradition as a whole (particularly as it moved away from its native India and was adopted in other parts of Asia) that needs to be recontextualized and reinterpreted by each new Buddhist tradition. In the context of the Lamp, the central tension between a gradual and a sudden approach to enlightement allows each new Buddhist tradition to present its particular understanding of the relationship between the Two Truths, between saṃsāra and nirvāṇa, and ultimately, allows each of the traditions to present what they believe is the most appropiate way (i.e. contemplative practices) to bridge the difference between them. There is no doubt that, in the Lamp, the notion of a gradual approach (Tib. rim gyis) to enlightenment implies an inferior approach, and that is why, each of the vehicles from the perspective of the Atiyoga tradition have some shade of gradualism. The tension between gradualism vs. subitism is one of the central philosophical pillars, together with the notion of non-conceptuality that allows Nupchen to define and to differentiate each vehicle, creating clear distinctions and bounderies between them,

\footnotetext{
${ }^{602}$ For a detail explantion of the Path of Liberation see Dudjom Rinpoche, The Nyingma School of Tibetan Buddhism: Its Fundamentals and History, 278. Van Schaik also offers an interesting overview on the distinction between the Path of Methods and the Path of Liberation in Van Schaik, "A Definition of Mahāyoga: Sources from the Dunhuang Manuscripts," 64.

${ }^{603}$ Jamgon Kongtrul, The Treasury of Knowledge: Book Eight, Part Four: Esoteric Instructions : A Detailed Presentation of the Process of Meditation in Vajrayana, 73.
} 
which will allow him to construct an identity for the new and emergent Great Perfection tradition.

The centrality of this tension will not go away though, and it will creep in again in the later Great Perfection, in which each a division between gradual and sudden practices will help create new hierarchies within the Atiyoga tradition. ${ }^{604}$

\section{Becoming the Buddha: the Generation and Perfection Stages of Contemplative Practice}

Within this general doctrinal and ritual framework, the Mahāyoga tradition will also develop a two tier system of practice that will become central for the organization and classification of the various tantric ritual and contemplative traditions, that of the generation or creation stage (Tib. bskyed rim; Skt. utpatti-krama) and that of the perfection stage (Tib. rdzogs rim; Skt. utpanna-krama). In the generation stage, the practitioner visualizes a series of deities and mandalas situating him or herself at the center, ${ }^{605}$ while in the perfection stage, the practitioner identifies him or herself with the central deity of the maṇala and becomes one with it. $^{606}$ Then, the practitioner focuses on the subtle body practices of the upper and lower door of the Path of Methods that we have already discussed above.

The centrality of this two stage ritual and contemplative process would become the foundation that will help articulate the increasingly complex tantric ritual and contemplative

\footnotetext{
${ }^{604}$ On the tension between gradual and sudden practices in the Great Perfection see Van Schaik, Approaching the Great Perfection: Simultaneous and Gradual Approaches to Dzogchen Practice in the Longchen Nyingtig.As for the internal tensions of divisions within theearly Great Perfection tradition see Germano, "Architecture and Absence in the Secret Tantric History of rDzogs Chen."

${ }^{605}$ Kongtrul describes this process in which the practitioner "one emanates mandalas, one emanates clusters [of mandalas], one emanates numbers [of deities], and one emanates faces and arms [of the deities]," in Jamgon Kongtrul, The Treasury of Knowledge: Book Eight, Part Four: Esoteric Instructions : A Detailed Presentation of the Process of Meditation in Vajrayana, 78.

${ }^{606}$ Kongtrul describes the perfection (which he translates as completion) stage in the context of the subtle body practices of Mahāyoga: "In completion phase, drawing energy-mind into the central channel is great emptiness. Meditate on luminous clarity day and night by two ways of placement. Compassion arises from liberation in illusory forms of emptiness. The divine form of melting bliss seals, The single form proliferates, and clusters emanate throughout space. The assembly practice and three mudras are the perpetuating cause Of attaining the nondual k>ya of the path of training." In Ibid., 83. On the history and evolution of the generation and perfection stages in within the tantric tradition see Dalton, "The Development of Perfection: The Interiorization of Buddhist Ritual in the Eighth and Ninth Centuries."
} 
practices that will end up crystalizing in the standard division of the Inner Tantras (Tib. nang rgyud): Mahāyoga, Anuyoga, and Atiyoga. What makes the Lamp a crucial text for our understanding of the creation of these categories is that, during Nupchen's time, they are still in flux, they still have not solidified as they will in the Nyingma tradition after the 11th century. In the Lamp as well as in the Armor Against Darkness, Nupchen is still playing with them, organazing them and clasifying them in different ways in response to different intellectual needs and concerns.

\section{Mahāyoga Literature}

These complex set of ritual and contemplative practices became codified in what became known as the Eighteen Māyājāla Tantras (Tib. sGyu 'phrul 'dra ba'i rgyud sde chen bco brgyad), with the Mañjuśrinnammasamgìti, the Guhyasamāja and, in particular, the Guhyagarbha tantra as some of its most important texts within the canon. ${ }^{607}$ The Guhyagarbha, in particular, will be essential for the Tibetan tradition not only in the development of the Mahāyoga tradition, but also of the Great Perfection, ${ }^{608}$ even though the legitimacy of the text has been a bone of contention within the Tibetan tradition, since it only exists in Tibetan translation, and there is no sanskrit or Chinese translation. ${ }^{609}$ The Guhyagarbha is one of the scriptures most quoted in the text (in fact, it is the first text Nupchen quotes in the Mahāyoga chapter.) The most remarkable aspect of Nupchen's presentation of the Mahāyoga tradition though is that the main source for

\footnotetext{
${ }^{607}$ On the creation of the Mahayoga canon see Kenneth Eastman, "The Eighteen Tantras of the Tattvasamgraha/Māyājāla,” Transactions of the International Conference of Orientalists in Japan 26 (1981): 95-96. For a specifi study of the Guhyagarbha see Gyurme Dorje, "The Guhyagarbhatantra and Its XIVth Century Tibetan Commentary, Phyogs Bcumun Sel” (School of Oriental and African Studies, University of London, 1987). Two recent dissertation from fellow University of Virginia graduates also offer great introductions to the Mahayoga literature Takahashi, "Lamps for the Mind: Illumination and Innovation in dPal Dbyangs's Mahayoga"; DeWitt Garson Garsson, "Penetrating the Secret Essence Tantra: Context and Philosophy in the Mahayoga System of rNying-Ma Tantra" (2004).

${ }^{608}$ On the role of the Guhyagarbha on the emergence of the Great Perfection tradition see my discussion later on the Great Perfection tradition later in this chapter.

${ }^{609}$ Takahashi, "Lamps for the Mind: Illumination and Innovation in dPal Dbyangs's Mahayoga,” 169.
} 
his understanding of the tradition is not any of the particular scriptures belonging to the Mahāyoga canon, but the works of one of the most important figures of the Mahāyoga tradition in Tibet, the 9th century Tibetan scholar Pelyang.

Pelyang's Six Lamps influence on Nupchen's understanding of Mahāyoga

Although tantra was very popular in Tibet from the very early introduction of Buddhism in the Tibetan plateau, the most radical and antinomian forms of the traditions as represented, in particular, by the Mahāyoga tradition were forbidden by the Empire. As quoted in the Mahāvyutpatti (Tib. Bye brag tu rtogs par byed pa chen po), the key lexicographical work used during the Empire to ensure the consistency and fiability of scriptural translation:

"(All lexical work) must be presented to the 'Religious Council' [...] at the Palace and to the 'Editorial Board'. If approved, it can then be added to the dictionary (i.e. Mahāvyutpatti). The tantras are to be kept hidden in accordance with their basic texts. Their contents should not be disclosed to those who are unsuitable to receive them. Recently some tantras were allowed to be translated and practiced, but there were people who, unable to understand the intention behind them, took the literal meaning and practiced them wrongly. It is known that terms have been collected from tantras and then translated into Tibetan, but from now on unless authorised, neither dhāraṇī nor tantras are permitted to be translated and no vocabulary is to be collected from them." 610

The collapse of the Empire meant a de facto (by default!) lift on the ban on the translation of the most antinomian scriptures of esoteric Buddhism, represented at that time by the Mahāyoga tradition. The Lamp, in fact, reflects how Buddhism in post-Imperial Tibet had clearly shifted from an institutional attempt to import and regulate a Mahāyāna, Sūtra centered, heavily

\footnotetext{
${ }^{610}$ Fom the Mahāvyutpatti (tib. sGra sbyor bam po gnyis pa, T Vol. 144, No. 5833), translated by Karmay, The Great Perfection (rDzogs Chen): A Philosophical and Meditative Teaching of Tibetan Buddhism, 1988, 5. Bold is mine.
} 
scholastic form of Buddhism (mainly represented by the Indian Gradual system but that allowed, at least early on, for some forms of Chinese Chan) through a few governemnt supported institutions (i.e. monasteries such as Samye), to a decentralized, tantric, esoteric model. This is not to say that early on Tantric Buddhism was not relevant in Tibet, but as we can see in the Lamp, tantric models and scriptures were tempered by the Imperial emphasis on classic scholastic Indian models that were heavily monastic and focused on the learning of scripture and philosophical debate.

As I have done in previous chapters, here I will not devote much time to a historical analysis of the introduction and development of esoteric Buddhism and, in particular, of the Mahāyoga tradition, in Tibet. ${ }^{611}$ My focus here will be to discuss how this system came to be understood and interpreted by Nupchen. If, for his exposition of the Indian Gradual tradition, Nupchen had relied on the work of Kamalaśilla, and for the Chinese Sudden approach he had used the help of the works of Hashang Mahāyāna, in the case of the Mahāyoga tradition Nupchen relies heavily on the work of the 9th century Tibetan scholar Pelyang (Tib. dPal dbyangs). ${ }^{612}$ His works are cited eleven times in the Mahāyoga chapter, quoted more heavily than any of the eighteen tantras of the Mahāyoga tradition, ${ }^{613}$ and they are only second in importance to the Sütra of the Gathered Intentions, a key Anuyoga text, in informing his views of Mahāyoga doctrine and practice. The prominence of Pelyang's scriptural corpus among the

\footnotetext{
${ }^{611}$ A classic overview of that history can be found in Snellgrove, Indo-Tibetan Buddhism: Indian Buddhists and Their Tibetan Successors, 1987. Van Schaik offers an interesting histical and textual study of the early stages of Mahayoga in Tibet in Van Schaik, "A Definition of Mahāyoga: Sources from the Dunhuang Manuscripts." For a traditional depiction of this history see Dudjom Rinpoche, The Nyingma School of Tibetan Buddhism: Its Fundamentals and History, 531-533.

${ }^{612}$ For an overview of the dates and life of this important figure see Takahashi, "Lamps for the Mind: Illumination and Innovation in dPal Dbyangs's Mahayoga," 28-72.

${ }^{613}$ Takahashi has done a great work uncovering some instances in the chapter in which Nupchen quotes from Pelyang without any attribution.
} 
Dunhuang manuscripts also indicate his relevance in the introduction of Mahāyoga scriptures and their interpretation into Tibet. ${ }^{614}$

Takahashi has done an excellent work discussing the literary corpus of Pelyang, which include the Vajrasattva Questions and Answers (Tib. rDo rje sems dpa'i zhus lan), the Letter (Tib. gCes pa bsdus pa'i 'phrin yig), and a group of texts that became known as the Six Lamps (Tib. sGron ma drug): The Lamp of the Mind (Tib. Thugs kyi sgron ma), The Lamp of the Correct View (Tib. lTa ba yang dag sgron ma), The Lamp Illuminating the Extremes (Tib. mTha'i mun sel sgron ma), The Lamp of Method and Wisdom (Tib. Thabs shes sgron ma), The Lamp of the Method of Meditation (Tib. bsGom thabs kyi sgron ma), and The Lamp of the Precious View (Tib. lTa ba rin chen sgron ma). ${ }^{615}$ One of the most remarkable aspects of Pelyang's works is his nuanced philosophical interpretation of the Mahāyoga tradition. This may have to do with the fact that, as we have already seen, Mahāyoga had been singled out during the Empire as particularly dangerous, and the translation of its texts, rituals, and practices had been banned. Pelyang, must have been particularly aware of the wishes of the government since he became the second abbot of Samye monastery ${ }^{616}$ and, therefore, had an important and prominent institutional role in 9 th century Tibet. At the same time, he must have been aware of the popularity of these scriptures and practices in India, and he seems to have taken an approach to its adoption and interpretation that avoided the most polemic aspects of the tradition (the violent rhetoric and the emphasis on sexual practices) and focused his attention to the unique and

\footnotetext{
${ }^{614}$ As Takahashi has pointed out, Pelyang's relevance for the Tibetan interpretation of Mahāyoga can be seen in the "virtually unrivaled prominence among the Dunhuang texts of his individually-authored Vajrasattva Questions and Answers. Special care obviously was taken with the manuscript copies of that work, and two copies include detailed interlinear commentary, indicating that it was a highly valued text and that further teachings on the text were given and preserved." In Takahashi, "Lamps for the Mind: Illumination and Innovation in dPal Dbyangs's Mahāyoga," 18. ${ }^{615}$ For an overview of Pelyang's corpus see Ibid., 3-4. Although we need to be careful while making such general claims when the Dunhuang Library collection offer only a partial and fragmentary collection of texts from the period, it does seem clear, at least in the Lamp, that Pelyang did have a central role in the introduction of Mahāyoga in Tibet.

${ }^{616}$ See Ibid., 59-63.
} 
sophisticated philosophical approach that Mahāyoga had brought to the Buddhist path. ${ }^{617}$ As we will see in our description of Mahāyoga in the Lamp, Nupchen is very familiar with Pelyang's corpus, quoting from several of his works. This familiarity is explained in traditional accounts by placing Nupchen as one of Pelyang's students. ${ }^{618}$ While we need to be careful reading intellectual lineages as actual historical connections, there is no doubt that Nupchen's tone in his presentation of Mahāyoga, with his emphasis on doctrine and philosophical ideas over ritual and practice, points out to the intellectual indebtness of Nupchen towards Pelyang's works.

The philosophical foundation (Tib. lta ba) of Mahāyoga as presented in Pelyang's corpus is based on the basic non-duality (Tib. gnyis su med pa) of phenomena in which there is no disctinction between saṃsāra and nirvāṇa. ${ }^{619}$ In the Lamp of the Mind Pelyang presents this central idea in the following way:

See that non-duality is ineffable and inconceivable.

Distinct from any concordance with words and sounds, It is said to be a method of exposing wrong views and conduct. That is why it is the Mahāvajrayāna. ${ }^{620}$

\footnotetext{
${ }^{617}$ Although Takahashi believes that Pelyang's particular approach to Mahayoga could be explained due to the possibility that the most transgressive forms of the tradition were developed later. While this might be a possibility, scriptures like the Guhyagarbha already included some of the rhetoric, rituals, and practices that made the tradition problematic for the the Buddhist establishment in Tibet during the Empire. See Ibid., 275. An example of the reinterpretation of the violent rhetoric of Mahayoga in the work of Pelyang can be seen in Takahashi's translation of the Questions and Answers of Vajrasattva, in which he reflects on how the practitioner should understand certain forms of visualization in which wrathful deities step and stand over other deities: "If the Body of a Superior (ārya) is crushed beneath the feet of the wrathful deities, is it contradictory to meditatively cultivate like this? Being that the ultimate is of a single flavor, without high and low / If the mind, which has abandoned conceptual attachment to self and other / Understands all to be skillful means, there is no contradiction, but / Through forcefully acting in the particulars of conceptualization, there is no definitive [realization].” Takahashi's translation p. 314.

${ }^{618}$ Pelyang is not mentioned in Nupchen's autobiography or the Pema Tinley's biography, but they mention that Nupchen had studied under the eight main disciples of Nyak Jñanakumara, and Pelyang was one of them. See Dudjom Rinpoche, The Nyingma School of Tibetan Buddhism: Its Fundamentals and History, 608.

${ }^{619}$ As Pelyang says in his Lamp of the Precious View it is only "Out of an illusory distinction between knowledge and ignorance, Samsāra and nirvana appear as cause and fruit.” Takahashi p. 441.

${ }^{620}$ Takahashi's translation of the Lamp for the Mind in Takahashi, "Lamps for the Mind: Illumination and Innovation in dPal Dbyangs's Mahayoga," 353.
} 
This non-dual approach is also deeply interconected in the Mahāyoga tradition with the notion of non-conceptuality (Tib. mi rtog $p a$ ), since the emergence of a dual world, one in which the individual makes a distinction between self and others, between saṃsāra and nirvāṇa, is the result of language and the use of concepts to define, to articulate our view of the world:

There is no conceptualization of things because there are no 'things'. Subjects are not observable. Objects themselves are non-existent. An explanation of the reasons is not included because desire has been overcome. In the realm of dharma, there are no words or expressions. ${ }^{621}$

The role of non-conceptuality plays such a central role in Pelyang's works that, in the Lamp, he is specifically identified as holding a Mahāyoga philosophical view centered around that concept (Tib. gnyis su med pa'i lta ba). ${ }^{622}$

As I have already mentioned above, Pelyang offers a unique approach to tantric practice, one that does not focus so much on the antinomian and violent rhetoric of Mahāyoga and more on the philosophical foundation that should determine the way the practitioner approaches those practices. In fact, in Pelyang's approach we can clearly see the seeds of the Atiyoga approach to practice, downplaying the importance of physical postures and visualizations:

Thus, sitting cross-legged and straight, All the contrivances regarding the body Arise from direct attachment to conceptions of a body. In the unembodied sky there is no contrivance.

If one knows the body is like an illusion, There is no attachment to the seated position with legs crossed. For anyone abiding via the normal course of life There is no training to be undertaken, nor anything at all to be done. ${ }^{623}$

\footnotetext{
${ }^{621}$ Ibid., 440.

${ }^{622}$ See discussion in the presentation of Nupchen various views of the Mahāyoga tradition in the next section of this chapter.

${ }^{623}$ Pelyang's Lamp of the Method of Meditation. Takahashi's translation p. 436.
} 
This does not mean that Pelyang does not discuss some of the more traditional aspects of Mahāyoga practice, such as the visualization of peaceful and wrathful deities and subtle body practices, he does, but he is not really interested in the mechanics of it. In the Questions and Answers to Vajrasattva he is clearly concerned with his students getting the approach to the practices right, not the actual techniques. There is also a clear absence of a discussion of sexual practices within his works, which allows him to avoid the more controversial aspects of the tradition and focus on what he really values of the Mahāyoga tradition: its unique philosophical reinterpretation of the Buddhist path based on a radical understanding of the non-dual nature of reality, of the sameness (Tib. mnyam pa nyid, another important Mahāyoga concept as we will see later in the chapter) of all phenomena. What we see in Pelyang is the early seeds of the Great Perfection emerging from this philosophical reinterpretation of the rhetoric and the practices of the Mahāyoga tradition. We will explore further this issue during our discussion of Atiyoga in this chapter. $^{624}$

What I find particularly relevant here is that the emergence of this form of what some scholars have called "philosophical Vajrayana" ${ }^{625}$ in Tibet may not be only the result of a

\footnotetext{
${ }^{624}$ At the same time, it is important to see that this philosophical approach represented by Pelyang does not mean a rejection of the ritual apparatus of the Mahayoga tradition. As Dalton has argued: "The tantric interiorization of Buddhist ritual was not a rejection of ritual. Nor was it a psychologization; it did not reduce ritual, 'to the spiritual state of the faithful practioner'. This shift took place in the physical realm. Its beginnings can be traced to the first half of the eighth century, and the ritual technologies it spawned continued to develop through the ninth century. By the end of these two crucial centuries, a new ritual discourse of the bodily interior was in place. The tantric subject had become the site for the entire ritual performance; the body's interior provided the devotee, the altar, the oblations, and the buddha to be worshipped." In Dalton, "The Development of Perfection: The Interiorization of Buddhist Ritual in the Eighth and Ninth Centuries," 1-2.The rhetorical rejection of practice and ritual as we see in the case of Pelyang, and as we will see specially in Nupchen's presentation of Atiyoga does not mean that ritual and practice do not play an important role in the life of the practitioner. As we saw in the case of Nupchen's biography, ritual seems to have played, in fact, a central role in his life, and we can assume that this also true for Pelyang. ${ }^{625}$ Generally, this is how it has been traditionally defined. See Germano and Waldron's definition: "Philosophical Vajrayana: One of the most interesting aspects of the historical development of Tibetan Buddhism is the way in which esoteric ritual, lexicons, motifs, and iconography drawn from Indian Buddhist tantra were utilized to shape an innovative and loosely coordinated philosophical movement. In India, Buddhist esotericism - the "adamantine vehicle" (vajrayāna) - tended to be focused elsewhere than philosophy per se. Its new terminology and ideas were encoded instead in the often radically distinct ritual and yogic systems, elaborate iconographic programs,
} 
symbolic reinterpretation of the rhetoric and practices of the most antinomian practices of Mahāyoga, but the result of a dialogue among various Buddhist traditions on the Tibetan plateau. As some scholars, such as Dalton, van Schaik, and Meinert have pointed out, in Dunhuang we can find several manuscripts that reflect an important amount of syncretism between the various Buddhist traditions coexisting during this period, mainly, Chan, Mahāyoga, and the new and emerging Atiyoga. ${ }^{626}$ During this time the boundaries between these traditions are being created, tested, redrawn, and reinterpreted to respond to new historical, social, and intellectual developments, and figures like Pelyang in the 9th century, and Nupchen in the 10th, played a key role in redefining those bounderies. As we will see in Nupchen's discussion of Mahāyoga in the following section, there are other Mahāyoga figures that shaped his understanding of the tantric tradition, but the influence of Pelyang can be felt in the overall approach of Nupchen not only to his presentation of the Mahāyoga tradition, but on his own understanding of the Great Perfection.

\section{Mahāyoga in the Lamp}

Nupchen begins his presentation of the Mahāyoga tradition by establishing clear boundaries between the two Buddhist vehicles he has already discussed, i.e. the Gradual and the

cosmological narratives, behavioral codes and ethics, and narrative literature in the form of lineal accounts and hagiographies. Thus while Buddhist tantra in India was characterized by striking innovation and radical discontinuity with previous Buddhist norms, its ideological shifts and discursive transformations did not predominantly take the shape of distinctive philosophical discourses and systems. As non-institutional forms of Buddhist tantra emerged in the eighth and ninth centuries with the radical agendas of the yogini tantras, they were rapidly domesticated back into the institutional and scholastic milieu of Buddhist monasteries. This process of domestication involved a process of coding Buddhist scholastic values and concepts back into the shocking rhetoric and imagery of these tantras, interpreting the radical behavioral calls as either metaphorical or as references to inner yogic processes." In David Germano and William S. Waldron, "A Comparison of Ālaya-Vijñāna in Yogācāra and Dzogchen," in Buddhist Thought and Applied Psychological Research: Transcending the Boundaries (New York: RoutledgeCurzon, 2006), p. 50.

${ }^{626}$ Jacob Dalton and Sam Schaik, "Where Chan and Tantra Meet: Buddhist Syncretism in Dunhuang," in The Silk Road: Trade,Travel, War and Faith (London: British Library Press, 2004), pp. 61-71; Carmen Meinert, "Chinese Chan and Tibetan Rdzogs Chen: Preliminary Remarks on Two Tibetan Dunhuang Manuscripts," in Religion and Secular Culture in Tibet. Tibetan Studies II (PIATS 2000) (Leiden: Brill, 2002), pp. 289-307; Carmen Meinert, “The Conjunction of Chinese Chan and Tibetan rDzogs Chen Thought: Reflections on the Tibetan Dunhuang Manuscripts IOL Tib J 689-1 and PT 699," in Contributions to the Cultural History of Early Tibet (extra Volume to Studies in Central and East Asian Religion) (Leiden/Boston: Brill, 2007), pp. 239-301. 
Sudden, and the ones he is going to discuss in the upcoming chapters, i.e. Mahāyoga and Atiyoga.

In the Lamp, the Gradual and the Sudden are exoteric, sūtra traditions based that belong to the Vehicle of the Cause (Tib. rgyu'i theg pa), while Mahāyoga and Atiyoga are esoteric traditions, relying on the secret instructions of teachers (Tib. man ngag), that belong to the Vehicle of the Result (Tib. 'bras bu'i theg pa):

In here, [I] will explain the inner system of the Great Adamantine Vehicle of the Result. All phenomena within samsāra and nirvāṇa are gathered as object and as [our] knowledge [of that object]. When they [manifest] in the world, the object and our knowledge [of that object] emerge merely as outer and inner phenomena [i.e. the object as outer phenomena, and our knowledge of it as inner phenomena]

$[\ldots]$

[In the Inner tradition of Mahāyoga] all phenomena is the self-aware primordial wisdom, and because the characteristics [of all phenomena] are clarified by awareness, it is non-dual, cannot be obscured by anything, all of its characteristics cannot be expressed. Then, because it transcends outer (general?) conventions, it is called "inner" (i.e. esoteric).

$[\ldots]$

Master Madhusādhu said: “'Inner’ [means] gathered inside of the circle of reality," 627

Here, we see how Nupchen's introduction reflects the change of landscape of Buddhim in

Tibet, with a discourse that is moving from the external, exoteric teaching of the previous traditions, to the esoteric discourses of tantra, with an emphasis on interiority and, in particular, with the interior of the human body. ${ }^{628}$ The explosion of cosmological landscapes and Pure Lands that so define the Mahāyāna tradition will be now replaced with a deep exploration of the

\footnotetext{
${ }^{627}$ Lamp 186.5-187.5: “de la 'bras bu rdo rje theg pa chen po nang pa'i lugs 'chad de / 'khor ba dang mya ngan las (186.5) 'das pa'i chos ji snyed pa dang / yul dang / shes pas bsdus pa rnams la / 'jig rten pa'i dus na / yul dang shes pa phyi dang nang gnyis pa'i chos sha dag tu snang (186.6) ngo /[...] chos thams cad rang rig pa'i ye shes rang gi mtshan nyid rig par gsal bas / cis kyang ma bsgrib pa gnyis su med pa la mtshan nyid 'di 'drar brjod du / (187.4) med de / de la phyi rol gyi tha snyad ma spangs bral ba'i phyir nang zhes bya la / don de gzhan min lam pa'i rang rig pa nyid pas / de gnas pa med < tha snyad 'dogs pa'i dbang com /> pa'i tshul gyis gnas / goms par byar (187.5) med pa'i tshul gyis byed pas nang pa zhes bya'o / [...] de yang slob dpon ma dus dus su bshad pa las / nang zhes bya ba ni chos nyid kyi 'khor lo kha nang du 'dus pa'o /"

${ }^{628}$ On this topic, see David Gordon White, The Alchemical Body: Siddha Traditions in Medieval India (Chicago: University of Chicago Press, 1996).
} 
interior of the body, as reflected in the emergence of the complex physiology of the subtle body, with its complex interconnection of channels (Tib. rtsa), winds (Tib. lung), and seminal nuclei (Tib. thig le). What we also see in this chapter is an acknowledgment of the historical transition that Buddhism underwent in Tibet during the 10th century, in which Tibetans fully embraced a tantric model and left behind the exoteric forms of Buddhism that had been supported by the Empire.

\section{The Philosophical View of Mahāyoga (Tib. Ita ba)}

As he has done in previous chapters, Nupchen begins his exposition of Mahāyoga by discussing its main philosophical ideas (Tib. lta ba). He structures this first section of the chapter by presenting the main concepts and doctrines of the tradition, supporting them with the main scriptures from the Mahāyoga textual corpus, and finally he discusses some of the most important Mahāyoga doctrines as presented by relevant teachers. ${ }^{629}$ As in other chapters of the Lamp, the presentation is quite haphazard, which seems to imply that Nupchen has in mind an audience that is very familiar with the ideas and doctrines presented. His goal is never to explain the intricacies of each of these Buddhist traditions. He only explains them to the extent that it is useful to his larger project of comparison and classification and, ultimately, to his effort of proclaiming the superiority of the Great Perfection tradition over all other Buddhist traditions.

${ }^{629}$ Lamp 188.5: "sngar yang bshad pas / sngags kyi gtan tshigs gsum <lung man ngag rig pa / gyis yid ches pa gdeng chud par bya'o /", 


\section{Reason and Scripture}

As we have seen, the first important notion of the Mahāyoga tradition discussed by Nupchen is its emphasis on interiority (Tib. nang ba), which is reflected in the centrality of the body as the focus of the tradition doctrines and practices: "According to many tantric teachers, the system of the Great Yoga (i.e. Mahāyoga) asserts the view that all phenomena is the mandala of the body, speech, and mind. ${ }^{, 630}$ He also emphasizes the importance of the teacher, a crucial figure if one is to receive tantric, esoteric teachings. ${ }^{631}$

In terms of doctrines, Nupchen highlights the idea of non-duality (Tib. gnyis su med pa), ${ }^{632}$ in which there is no difference between the Two Truths, ${ }^{63}$ between saṃsāra and nirvāṇa , ${ }^{634}$ and, ultimately, between a Buddha and all other sentient beings. ${ }^{635}$ Nupchen also points out the impossibility of expressing through language the ultimate nature of reality, which allows him to justify the variety of Mahāyoga views, since they are different attempts at using language in order to convey the ultimate meaning of the tradition:

\footnotetext{
${ }^{630}$ Lamp 189.2-189.3: "de la lta ba'i lugs nyid ji skad brjod kyang don du 'dra yis kyang / tha snyad du mi mthun pa'i bzhed gzhung yang mang bar bzhugs so < sgegs pa'i rdo rje'i bzhed gzhung lung dang rigs pas 'bebs pa 'og kun lang 'gre / / sngogs kyi mkhan po la la dag rnal 'byor chen pa'i lugs kyis / chos thams cad sku gsung thugs kyi <yig 'bru gsum dang dag pa gsum gyis rtogs $>$ dkyil 'khor du lta bar 'dod de." In the interlinear notes, the text also adds that one of the traditions that will be discussed later in the chapter is that of the famous Mahāyoga teacher, Vilāsavajra.

${ }^{631}$ Lamp 188.6-189.1: "don de bla ma don gyi nyams dang Idan pa sgo kun la ma rmongs pa / bslab bya ril kyungs su thug ba la mnyes pa phog par gyis la zhus shig / de yang / 'khor ba'i sdug (189.1) bsngal sel 'dod na / man ngag ldan pa'i slob dpon 'tshol / des ni 'khor ba rcad nas 'don / de la rtag tu gus pa gyis/"

${ }^{632}$ chos thams cad rang rig pa'i ye shes rang gi mtshan nyid rig par gsal bas / cis kyang ma bsgrib pa gnyis su med pa la mtshan nyid 'di 'drar brjod du / (187.4) med de /

633 (191.2) As part of a quote from the Sutra of the Gathered Intentions: "bden pa gnyi gar dbyer med pyir/"

${ }^{634}$ 'khor ba dang mya ngan las (186.5) 'das pa'i chos ji snyed pa dang / yul dang / shes pas bsdus pa rnams la / 'jig rten pa'i dus na / yul dang shes pa phyi dang nang gnyis pa'i chos sha dag tu snang (186.6) ngo /

${ }^{635}$ sangs rgyas sems can thams cad dang/(191.5) mchon mar btags pas thams cad kun / gnyis med ngang du gcig pa ste / de bas sku gsung thugs kyi bdag / This is quoted from the Ten Virtues of the logical syllogisms of the esoteric instructions of Master Garab Dorje (Tib. Man ngag gi gtan tshig slob dpon dga' rab rdo rje'i yon tan bcu). Donati mentions that Achard in L'Essence perlée du secret. Recherches philologiques et historiques sur l'origine de la Grande Perfection dans la tradition rNying ma pa (p. $36 \mathrm{n}$. 2) talks about this text. I did not have time to check this reference.
} 
Even though their assertions and scriptures are different (from a conventional point of view), whatever the [various Mahāyoga ] systems express, their meaning is the same. ${ }^{636}$

In terms of scriptures, although Nupchen quotes from several Mahāyoga texts, there is no doubt of the central role that the Guhyagarbha Tantra plays as the main doctrinal and ritual backbone for the tradition in Tibet. It is the first and most quoted Mahāyoga scripture in this section. ${ }^{637}$ Its centrality can be also gauged by the fact that some of the most important teachers mentioned in this chapter (Vilāsavajra, Buddhaguhya, Padmasambhava, and Pelyang) ${ }^{638}$ wrote commentaries on this text. As we will see, the Guhyagarbha Tantra is also central to the emergence of the Great Perfection tradition.

\section{Mahäyoga According to Various Teachers}

The most important part of this section is the one dedicated to the various philosophical views as presented by various teachers. Here Nupchen articulates five different approaches to Mahāyoga that only in the interlinear notes are attributed to renowned teachers of the tradition. These views are:

${ }^{636}$ Lamp 189.2-189.3: “de la lta ba'i lugs nyid ji skad brjod kyang don du 'dra yis kyang / tha snyad du mi mthun pa' 1 bzhed gzhung yang mang bar bzhugs so <sgegs pa'i rdo rje'i bzhed gzhung lung dang rigs pas 'bebs pa 'og kun lang 'gre /> / sngogs kyi mkhan po la la dag rnal 'byor chen pa'i lugs kyis" In the interlinear notes, the text also adds that one of the traditions that will be discussed later in the chapter is that of the famous Mahayoga teacher, Vilāsavajra.

${ }^{637}$ The most quoted scripture in this chapter, as well as in the Atiyoga chapter, is the Sütra of the Gathered Intentions, which, as we will see, is considered by Nupchen as the essence of the tantric tradition, and it includes within it the Mahā, Anu, and Atiyoga traditions.

${ }^{638}$ The 8th century Indian Master Vilāsavajra, also known as Līlāvajra (Tib. sGeg pa rdo rje), wrote the commentary, 'Grel pa spar khab (English translation?). On this commentary, see my discussion in chapter two, as well as Jacob Dalton's “A Crisis of Doxography: How Tibetans Organized Tantra During the 8th-12th Centuries," Journal of the International Association of Buddhist Studies 28, no. 1 (2005): 124-132. See also Takahashi's “Lamps for the Mind: Illumination and Innovation in dPal Dbyangs's Mahāyoga," pp. 191-193. Buddhaguhya wrote the Mārgavyūha. On this text see Ibid., 192. Also see José Ignacio Cabezon's The Buddha's Doctrine and the Nine Vehicles: Rog Bande Sherab's Lamp of the Teachings (New York: Oxford University Press, 2013), pp. 29-30. For Padmasambhava's Garland of Views (Tib. Man ngag lta ba'i phreng pa), see chapter two of this dissertation, as well as Dalton's “A Crisis of Doxography: How Tibetans Organized Tantra During the 8th-12th Centuries," pp. $132-134$. See also Takahashi's “Lamps for the Mind: Illumination and Innovation in dPal Dbyangs's Mahayoga,” pp. 192195. Also see Ferran Mestanza's "La Première Somme Philosophique Du Bouddhisme Tibétain. Origines Littéraires, Philosophiques et Mythologiques Des 'Neuf Étatpes de La Voie' (theg Pa Rim Pa Dgu)," Revue d'Etudes Tibétaines 8 (2005). 
1- The view [which reveals] the identity of all phenomena and the enlightened mind of self-awareness (of Padmasambhava) ${ }^{639}$ (Lamp 193.2-198.2);

2- The view of the non-duality of methods and knowledge (of Buddhaguhya) ${ }^{640}$ (Lamp 198.3-200.6);

3- The view of Mahāyoga as the Great Self (Kawa Peltsek) ${ }^{641}$ (Lamp 200.6-204.4);

4- The view of of non-duality (of Pelyang) ${ }^{642}$ (Lamp 204.4-210.5); and

5- The view of sameness (Padmasambhava and Madhusādhu) ${ }^{643}$ (Lamp 210.5-215.4).

From a doctrinal point of view, these approaches are not radically different, and it seems to be more an issue of tone than of substance. ${ }^{644}$ For the purpose of our discussion, the most important aspect of this section is not the subtle differences between the various views, which reflect the philosophical views we have discussed already at the beginning of this chapter, but the fact that, in the interlinear notes, and not in the body of the text itself, the names of various teachers are attached to each of the views.

\footnotetext{
${ }^{639}$ Lamp 193.4: "rnam pa gcig tu tu < padma 'byung gnas /> chos thams cad rang rig pa byang chub sems su sangs rgyas par blta ba'i gzhung lugs ni"”

${ }^{640}$ Lamp 198.3: "mkhan po < sngags kyam / la la <sangs rgyas gsang ba'i bzhed / $>$ dag rnal 'byor chen po ni thabs dang shes rab gnyis su med par blta ba min no/"

${ }^{641}$ Lamp 200.6: "sngags < ska ba dpal ba trsegs kyis bzhed /> kyi dge bshes kha cig mah'a yo ga'i lta ba bdag nyid chen por lta bar bzhed de /"

${ }^{642}$ Lamp 204.4: "dge ba'i bshes < gnyen dpal dbyangs kyis bzhed > gnyen la la'i zhal nas / mah'a yo ga gnyis su med par lta bar bzhed de"

${ }^{643}$ Lamp 210.5: "dge bshis < $<$ slob dpon padma dang ma dus du'i bzhed /> kha cig ni mah'a yo ga'i lta ba ni mnyam pa nyid du bzhed de"

${ }^{644}$ The one that could require some explanation is the "view of Mahāyoga as the Great Self" of Kawa Peltsek. The use of language that acknowledges the idea of a self, or even a "great self," seems to go against one of the central ideas introduced by the Buddha, that of the lack of a permanent self (Skt. anātman). Ruegg offers an interesting discussion on how some Indian notions, such as the vedantic concept of atman, may have been reintroduced and reinterepreted within the Buddhist tradition: "the parallelism between the Tathaggatagarbha (or its equivalents) and the Vedantic àtman is quite striking and it might even be thought at first sight that a crypto-Vedantic tendency has here come to the surface in Buddhism." In David Seyfort Ruegg's Buddha-Nature, Mind and the Problem of Gradualism in a Comparative Perspective: On the Transmission and Reception of Buddhism in India and Tibet (New Delhi: Heritage, 1992), pp. 19-26.
} 


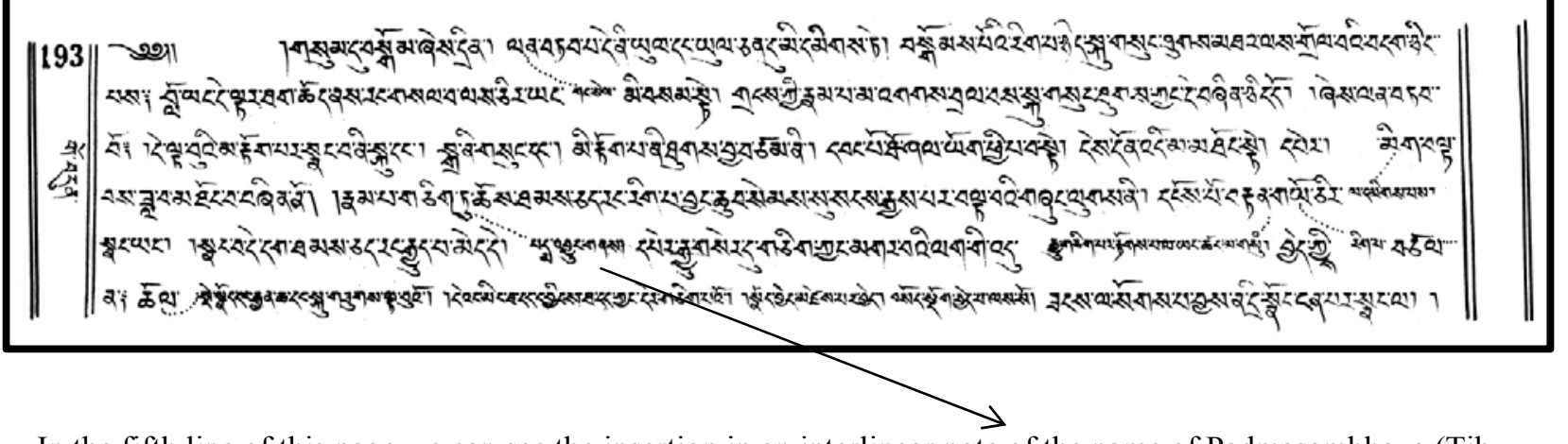

In the fifth line of this page we can see the insertion in an interlinear note of the name of Padmasambhava (Tib. Padma 'byung gnas) as responsible for the "view [which reveals] the identity of all phenomena and the enlightened mind of self-awareness"

As we have seen in chapter two of this dissertation, we need to be careful in our reading of the interlinear notes since they were probably not written by Nupchen himself, but by a close or inmediate disciple. It is only in the Mahāyoga and Atiyoga chapters that we find their respective philosophical views attributed to specific masters in the interlinear notes. In the Gradual and the Sudden chapters, Nupchen had no problem quoting and citing from specific teachers. As I have argued in chapter two of this dissertation, the insertion of specific names attached to particular views can be seen as part of the project of legitimation of the Mahāyoga and Atiyoga traditions in Tibet. As McRae has pointed out in his discussion of the emergence of the Chan tradition, the establishment of lineages: "were polemical tools of self-assertion, not critical evaluations of chronological fact according to some modern concept of historical accuracy. To the extent that any lineage assertion is significant, it is also a misrepresentation; lineage assertions that can be shown to be historically accurate are also inevitably inconsequential as statements of religious identity. ${ }^{645}$ In the Tibetan context, the creation of progressively more complex and detailed lineages for the Mahāyoga and Atiyoga traditions tell us more about the efforts of these traditions to legimitize their new views than about their

${ }^{645}$ John R. McRae, Seeing through Zen: Encounter, Transformation, and Genealogy in Chinese Chan Buddhism (Berkeley: University of California Press, 2003), xix. 
purpoted historicity. In fact, I would argue that the most interesting aspect of this process of insertion of teachers in the interlinear notes of the Mahāyoga and Atiyoga chapters are particularly revealing of the mechanisms by which texts like the Lamp create the fiction of historical narratives for these traditions. This was especially important to both traditions since they were under attack during the Tibetan Renaissance period, accused of having produced scriptures and teachings with no legitimate Indian pedigree.

This is not to say that some of those views had no connection with some of the teachers mentioned in the interlinear notes: the notion of non-duality plays a central role in Pelyang's works, and a text from Master Madhusādhu that has survived in the Dunhuang Library collection shows evidence that the notion of "sameness" (Tib. mnyam nyid) was important in his thought. ${ }^{646}$ But we can also see in early Mahāyoga works, such as Pelyang's Lamp of the Mind, an overview of the main philosophical ideas of Mahāyoga, such as "non-origination" (Tib. ma skyes), "great emptiness" (Tib. stong chen po), "non-appearance” (Tib. snang ba med pa), "nonduality" (Tib. gnyis su med pa), "sameness" (Tib. mnyam nyid), "non-abiding” (Tib. mi gnas pa), “non-objectification" (Tib. mi dmigs pa), "non-conceptuality" (Tib. mi rtog pa), without connecting it to specific teachers. ${ }^{647}$ When examining each view, we also see that Nupchen is arguing them by using a wide variety of Mahāyoga scriptures, and not limiting himself to quoting from the texts written by each of the tantric masters to which those views are attributed. Finally, Nupchen had no qualms before, in the Gradual and Sudden chapters, attributing texts and teaching to various Indian and Chinese figures within the body of the text, so there is no real reason not to do the same in the Mahāyoga and Atiyoga chapters. Van Schaik has argued in the

${ }^{646}$ The text is the Four Yogas and van Schaik recognizes the centrality of this idea, saying, "It is indeed the case that The Four Yogas makes extensive use of the idea of sameness (mnyam nyid), along with synonymous terms like nonduality (gnyis su med), inseparability (dbyer med), and single taste (ro gcig pa)." In Van Schaik's "The Sweet Sage and the Four Yogas: A Lost Mahāyoga Treatise from Dunhuang," p. 8.

${ }^{647}$ See Lamp of the Mind translation by Takahashi, pp. 353-375. 
context of the Atiyoga chapter that the fact that Nupchen is not mentioning the names of teachers connected to those scriptures may suggest that Nupchen "himself may have been complicit in the activity of transforming authored texts into scripture." ${ }^{\circ 48}$ But the fact that Nupchen himself acknowledges that these views are already connected to teachers in the body of the text undermines that argument since what he is doing is not attempting to pass oral teaching for scripture, but to simply avoid mentioning the names of those teachers in the body of the text. We will revisit this issue in our Atiyoga discussion, since in that chapter Nupchen also only include the names of teachers in the interlinear notes, but I would argue that what we find here is an attempt by the later tradition of articulating a clear lineage of teachings and teachers that will connect these problematic doctrines and their scriptures to India. ${ }^{649}$

${ }^{648}$ Sam van Schaik, "The Early Days of the Great Perfection," Journal of the International Association of Buddhist Studies 27, no. 1 (2004): p. 197.

${ }^{649}$ See Dan Martin's "Illusion Web -Locating the Guhyagarbha Tantra in Buddhist Intellectual History," in Silver on Lamps: Tibetan Literary Culture and History (Bloomington: The Tibet Society, 1987); van Schaik's "The Early Days of the Great Perfection"; and van Schaik's "The Sweet Sage and the Four Yogas: A Lost Mahāyoga Treatise from Dunhuang." 


\section{The Contemplative Practices of Mahāyoga (Tib. sgom pa)}

Nupchen structures his presentation of Mahāyoga's contemplative practices around the idea of the "purpose" (Tib. dgos pa), "causes" (Tib. rgyu), and the "divisions" (Tib. dbye ba) between contemplative techniques. The "purpose" refers to the basic goals of the practice, which Nupchen enumerates as two: to achive the unsurpassable result of the practice of Mahāyoga, and to dispel wrong views (of other traditions) and clear away any obscurations. ${ }^{650}$ The "causes" offer an actual, even though brief, description of the various contemplative practices of the tradition, which focus on the subtle body. These are divided into those of the upper door (Tib. steng sgo), and those of the lower door (Tib. 'og sgo). The practices of the upper door, as we have seen, focus on the manipulation of the channels, winds, and seminal nuclei of the subtle body. ${ }^{651}$ In this section, Nupchen is describing what seemed to be early developments of the tantric practice that later became known as "inner heat," or tummo (Tib. gtum mo), which can be interpreted as a form of sublimation of sexual desire in which there is no actual sexual encounter. Then he procedes to describe the practices of the "lower door," (Tib. 'og sgo) in which an actual

\footnotetext{
${ }^{650}$ Lamp 222.2-222.3: "dgos pa ni gnyis te / bla na med <rgyu 'bras $/>$ pa'i 'bras $<$ rgyu 'bras dbyer med pa'ang $/>$ bu bsgrub par bya ba'i sgo nas 'jug pa dang / gzhan log lta <bsam du med pa tha snyad tsam du drang don du / $>$ dang / sgrib pa la (222.3) sogs pa sel ba'i phyir 'jug pa'o /"

${ }^{651}$ Lamp 226.5-223.1: "rten can ni steng 'og gi gnyis te / steng gi sgo la brten pa ni / shi ra $<$ po $>$ tsa kra $<$ 'khor po > bzhi gnas gzhi na gnas pa la / de spyir bsgom ste bsam pa'ang las (222.6) kyi me rlung so so'i thabs mi mthun pa las bskul te / nam <sgo? /> mkha'i ba bzhos la ye shes bdud rtsi phab la bde ba brtag pa dang / de dag so sor rang re? la (223.1) man ngag slob dpon bi ma la dang / 'bu ta kug ta dang / padmo'i gzhung la sogs pa bla ma'i zhal du rag lus so." Kongtrul is more specific about the main distinction between the upper and lower door practices than Nupchen: "When we divide the path of certainty through methods, there are the two approaches of the upper door [of one's own body] and the lower door [of another's body]." He then describes the practices of the lower door as follows: "The meaning of the warming and descent of the vital essence as set forth in these approaches and in the esoteric instruction of energy currents, the root text and commentaries of the Secret Innermost Essence of Vimalamitra, and so on, are found in the oral teachings of the Zur forefathers and the Omniscient Drime Ozer. According to them, training in the union of melting and controlling causes all discursive thought to dissolve into the expanse of nonthought. Enlightenment occurs in the great bliss without reference or limitation." What Nupchen, as well as Kongtru, 1 are describing here is the practice of inner heat or "tummo" (Tib. gtum mo). See Jamgon Kongtrul and Harding, The Treasury of Knowledge: Book Eight, Part Four: Esoteric Instructions: A Detailed Presentation of the Process of Meditation in Vajrayana, pp. 71-72.
} 
consort is used in order to engage in a complex and ritualized sexual encounter in which desire is

transformed into enlightenment:

As for the reliance on [the practices] of the lower gate, as it has been previously explained, [the practitioner] should search for a joyous female consort in accordance with textual [sources]. [Then,] when joyfully offering to the lama, [the practitioner] will gradually perfect the outer and inner [stages], and meditate in the power of transcendent knowledge and pristine awareness, which is the moon, and the great bliss, which is the sun. ${ }^{652}$

What is interesting of this section is how actual little space Nupchen dedicates to these practices, barely one folio, which, when compared with the descriptions of the practices in the Gradual and Sudden chapters, is almost an oddity. These practices are central to the Mahāyoga tradition, and Nupchen has already acknowledged their efficacy by recommending their practice even to the followers of the Great Perfection tradition. ${ }^{653}$ But Nupchen, just as Pelyang, is more interested in the view that informs these practices, in the philosophical framework that articulates

\footnotetext{
${ }^{652}$ Lamp 220.3-220.6: “'og gi sgo la rten pa ni / sngar bshad pa'i shes rab ma gzhung dang mthun pa dkar bas btsal te / bshad pa'i bla ma la mnyas (220.4) phul nas / rim par rdzogs par bya ste phyi nang gi rdzogs pa dang / zla ba can la shes rab ye shes kyi dbang brtag / nyi ma can la bde ba chen po brtag go / de dag goms (220.5) par byas te / 'jig rten pa'i ro dang / 'jig rten las 'das pa'i lam rim gyi ro brtag / de yang dang po shin tu bde ba'i ye shes g-yo ba dang / thob pa dang / 'jug (220.6) brtan nas rjes su 'jug pa'i rnal 'byor thob bo / de nas rten dang bral yang mi nyams pas rten med pa'i / ye shes la 'dris goms su bya'o." Kongtrul, again, can help us with a more explicit explanation of the actual practice that Nupchen only briefly describres, using mainly coded language: "The branch of approach is to first seek a qualified partner, examine the channels, arouse, increase pleasure by following the treatises on desire, and so on. The branch of close approach is encouragement by the mutual exchange of the four signs; delighting in nonduality through the practice of the four mudras (Skt. mudrā) by means of the three perceptions. The branch of attainment is when, having entered into union in this way, the vital energy current moves in the heightened passion, causing the red aspect to descend and the white aspect to melt. As the bodhicitta falls, the four joys arise in sequence. Then the two sexual fluids meet at the tips of the private parts of the male and female. This is the practice of experiencing coemergent pristine awareness with the actual entity [or substance of sexual fluid. The branch of great attainment is when the white and red constituents blend into one and are drawn up through the male's vajra like a spider's thread. As it ascends through the navel, heart, throat, and head chakras the four stable joys of ascent are experienced. Finally, it spreads [throughout the body]." In Ibid., pp. 72-73. The most remarkable aspect of these practices is the fact that they bring to the center stage one of the aspects of human nature that the tradition has been rejecting from the very beginning: desire. In Gyatso, "Healing Burns with Fire," p. 122.

${ }^{653}$ As we saw in chapter three of this dissertation, Nupchen has already addressed this issue: "Question: Does the Great Perfection rely on the Inner Methods? Answer: Although it is not the intention of the Great Perfection [to rely on those methods], from time to time [those methods are employed] since they help cut off conceptual [thinking]." Lamp 27.5.27.6: "'o na rdzogs chen nang pa'i thabs la brten nam zhe na //rdzogs pa chen po'i gzhung gi dgongs pa min na'ang / re zhig de dag nas brgyad pas / rtogs pa mi 'gog pa'i phyir /"
} 
those techniques. What we also see here is how Nupchen is trying to establish the superiority of tantric ideas not in terms of their practices, but in terms of their ideas. If his project of comparison and classification is going to succeed, particularly when the legitimacy and Indian origin of traditions like Mahāyoga and Atiyoga are under suspicion, he cannot simply rely on references to scriptures that may or may not have a Sanskrit original, and on prestigious Indian teachers that may or may have not come to Tibet. Even if those aspects are essential for the legitimacy of the tantric traditions in Tibet, it is by the strength of their ideas that they will impose their particular approaches to the Buddhist path.

\section{The Eternal Problem of the Gradual and Sudden Approaches: the Mahāyoga Take}

Finally, Nupchen discusses the "divisions" (Tib. dbye ba) between contemplative approaches within the Mahāyoga tradition. What we have in this section is the return of a persistent problem for the Buddhist tradition that it needs to address continuosly: the tension between Gradual and Sudden approaches to meditation, which also reflects a central tension within the Buddhist tradition, i.e. the relation between the relative and ultimate truth, between the ground and the result, and, ultimately, between samsāra and nirvāṇa. If in the previous chapters this tension had been represented by the Indian and Chinese approaches, now we find this tension recontextualized within the boundaries of the Mahāyoga tradition. What becomes obvious at this point is that the notions of "gradual" and "sudden" do not only convey distinctive philosophical approaches to contemplation in the Buddhist tradition, but they also become markers to delineate boundaries across traditions. The intrinsic duality that connects these terms has allowed the Buddhist tradition to mantain a sense of continuity within the tradition, while, at the same time, allowing for discontinuities that allowed Buddhism to explore new ideas, develop 
new contemplative techniques, and create new traditions. In the case of the Lamp, we see how each new tradition is superior to the previous one not only because of their superior approach to non-conceptuality, but also because of its more refined understanding of the "sudden" or "simultaneous" nature of enlightenment. This tension will become so central that will help create bounderies even within the tradition, as we will see in the case of Mahāyoga, and later on also within the Atiyoga tradition. ${ }^{654}$

Within the Mahāyoga tradition Nupchen then differentiates between gradual and sudden practices. The gradual practices are divided into "methods to settle the body" (Tib. lus kyi 'dug thabs) and "methods to settle the mind," (Tib. sems kyi bzhag thabs) which the text attributes, in the interlinear notes, to Vilāsavajra and Vajrahāsya. ${ }^{655}$ The methods to settle the body are as follows:

As for the methods to settle the body, when [the practitioner] has understood the real characteristics of self and phenomena, when the time of meditating comes, [the practitioner] should sit on a soft cotton cushion, and, in equipoise, should sit with legs crossed, with a straight spine, and eyes focused on his/her nose. [As it is said] in the Contemplation treatise of Padmasambhava: "Sit on a comfortable cushion, and naturally rest with a clear mind."

Although Nupchen does not make the connection explicit, what we have here is a description of śamatha practices from the perspective of the Mahāyoga tradition. The connection

\footnotetext{
${ }^{654}$ For a study of the tension between gradual and sudden approaches in the Atiyoga tradition, see Van Schaik's Approaching the Great Perfection: Simultaneous and Gradual Approaches to Dzogchen Practice in the Longchen Nyingtig.

${ }^{655}$ Lamp 223.4 "de la rim <slob dpon sgeg pa rdo rje dang rdo rje bzhang pa la sogs pas /> par 'jug pa ni / dang po lus kyi 'dug thabs dang / sems kyi bzhag thabs so /" Bold is mine. Vajrahāsya was an important figure in the lineage of the Mahāyoga tradition, with a central interest in the practices and the transmission of the Guhyasamajja Tantra. On this figure, see Dudjom Rinpoche's The Nyingma School of Tibetan Buddhism: Its Fundamentals and History, pp. 466-467.

${ }^{656}$ Lamp 223.4-224.1: "dang po lus kyi 'dug thabs dang / sems kyi bzhag thabs so / de la (223.5) lus kyi 'dug thabs ni / bdag dang chos kyi mtshan nyid thag chong nas / bsam pa byed pa'i dus su ras bal gyi nang tshas can (223.6) la sogs pa'i stan bdeb la khams bsrangs / cha mnyam ste skyil krung bcad la lus drang bor bsrangs te / mig sna rtse la phab la 'dug go / de yang chen po padma'i bsgom (224.1) lus las / ras stan 'bol ba nang tshad can / khams bsangs lus kyi lugs bzhin 'dug $/$ "
} 
between the "methods to settle the body" and śamatha becomes evident when Nupchen quotes in this section questions thirty-one and thirty-two of Pelyang's Questions and Answers to

\section{Vajrasattva:}

As for what [you] will achieve [in meditation]

Through effort, remain continuosly in meditative equipoise

Then, by gradually mastering the process of familiarization

[You] will acomplish [the result] without effort, spontaneously. ${ }^{657}$

As for the "methods to settle the mind," what we find here is an interesting desciption of some tantric visualizations that the practitioner can use in order to combat distraction and stabilize the mind. ${ }^{658}$ In this section, Nupchen also adresses the fact that when the gradual approach of Mahāyoga is compared to the Chinese Sudden approach, it would seem that the latter one is superior. ${ }^{659}$ But Nupchen argues that the esential non-dual undersanding of reality of the Mahāyoga tradition is superior to the emphasis on the lack of effort, and freedom from any activity (Tib. bya ba dang bral ba), in the approach to practice of the Sudden tradition. ${ }^{660}$ Again we see how the construction of the various tradition in the Lamp is not only an act of definition (of their philosophical views, of their practices, etc.), but it needs to be constantly punctuated by comparisons with the other traditions, helping define the bounderies between the traditions.

\footnotetext{
${ }^{657}$ Lamp 225.2-225.3: "mkhan po dpal dbyangs kyi man ngag las / bsgrub par bya ba gang yin pa de la ni / rtsol bas yang du (225.3) mnyam bzhag ste / goms pa klong du gyur cing khad kyis ni / tsol ba med par lhun gyis grub par 'gyur" The connection with the practice of samatha is made explicit in the previous question (number thirty) of the Questions and Answers of Vajrasattava: "Then, does one not seek a one-pointed calm-abiding type of meditative stabilization? Calm abiding based on nonmistaken realization and / Meditative stabilization [in which] the seals of marks clearly [appear] / Such a meaningful superior path of awakening / Is bound to lead to excellence time and again." Takahashi's translation in her "Lamps for the Mind: Illumination and Innovation in dPal Dbyangs's Mahayoga,"p. 306.

${ }^{658}$ Lamp 224.5-225.2 : "de ltar grims chung zhing dmigs pas / nang gi sems kyi glang po dran pa'i thag pas bcings te / (224.6) dmigs pa'i sngong po la thog na / rtyu ba je nyung je nyung sems je brtan 'gyur te / 'jug sems mi 'grug mi gyo ste shin tu btsal ba med par 'gyur te / dpen (225.1) na yi ge slob pa'i dus na / dang po gral dang ngo bo cho rol du klog ste / gu lja smra ba skad ldab ldib tu 'gyur kyang / yang nas yang du bslabs (225.2) btsal bas / je je la thogs pa med par 'gyur ro /"

${ }^{659}$ Lamp 226.1: “'o na 'di bas ston mun cig car 'jug pa rdos bzang yang bzang ste/”

${ }^{660}$ Lamp 226.5-226.6: "tshe de nyid la dbang bsgyur chen por 'gyur ba dang 'dra ste / ston mun dang (226.6) nga lta bas bya ba dang bral ba skad zer yang / theg pa chen po gnyis su med pa'i de bzhin nyid / mtha' yang ma mthong ste / don dam pa 'ba' zhig la mi stsol du zad de /"
} 
The Sudden approach of Mahāyoga is attributed in the Lamp to Padmasambhava and his Garland of Views (Tib. Man ngag lta ba phreng ba). Here, the practitioner settles the mind naturally in the condition of Thusness "after having understood that all phenomena and Thusness are one, and [the practitioner] self-awareness is also [identical] to Thusness." ${ }^{661}$ What we have here is a gnostic approach to practice in which the realization of the identity of all phenomena is the actual practice. This particular insight of the Mahāyoga tradition will be essential in the development of the Atiyoga tradition, in which this gnostic insight will not be the pinnacle of the tradition, but its very foundation.

As Nupchen has done in previous chapters in his description of other traditions, this section on the contemplative practices of Mahāyoga also include a list of the antidotes against some of the problems that may emerge during practice, as well as a discussion of some of the signs that emerge when the practice is succesful.

The Conduct and the Result (spyod pa and 'bras bu)

The section dedicated to ethics according to the Mahāyoga tradition establishes four different types of conduct:

[As for conduct], you should behave without attachment [to the result of your behavior]. There are four types of conduct: 1) the conduct of the methods of yogic discipline; 2) the conduct free from like and dislike; 3 ) the conduct that is in accordance with the principle; and 4 ) the conduct that is in accordance with others. ${ }^{62}$

\footnotetext{
${ }^{661}$ Lamp 238.6-239.1: "chos thams cad de bzhin nyid yin pa'i don thag chod nas 'jog pa'ang / bdag <chod nyid dang rang gi mtshan nyid du bsgom pa'ang /> gi rig pa'ang de bzhin nyid las ji bzhin pa'i chos nyid la blo ji bzhin pa gyi nar bzhag < tha snyad tsam du / > ste / de bzhin nyid la blo btang ba yang med / don shor ba yang med de / btang snyoms su bya'o /"

${ }^{662}$ Lamp 258.2-258.3 : "spyod pa ci yang ma chogs spyod de / de la spyod pa la yang bzhi ste / brtul zhugs thabs kyi spyod pa dang / chags sdang med pa'i spyod pa dang / don (258.3) gyi rjes su spyod pa dang / mthun 'jug 'tshams pa'i spyod pa'o"
} 
What these four different types of conduct prescribe is basically to avoid making any distinctions between phenomena (postive or negative) since they are all the same due to the non-dual nature of reality, which allows the practitioner to behave in whichever way s/he sees fit, as long as s/he is not attached to the results of those actions.

As for the results, the most distinctive aspects of Mahāyoga are the rejection of the traditional accumulation of merit and wisdom, ${ }^{663}$ and the fact that the result can be achieved in this very lifetime, and not over numerous lifetimes as in the other traditions. ${ }^{664}$

${ }^{663}$ Lamp 268.4-269.1: "rnal 'byor chen po'i (268.5) lugs kyi / tshogs rnam gnyis ma bsags par re bar byed dam mi byed zhe na / tshegs la mi re ste / ci ste zhe na / smon pa dag rgyu la spyad bas rnam par smin (268.6) pa'i 'bras bu sku gsum grub par 'dod pa ni 'dir gol te ma yin no //'dir rang rig pa de bzhin nyid pas / phung po khams skye mched ye nas ye shes (269.1) kyi dkyil 'khor la //"

${ }^{664}$ Lamp 275.4-275.6: “'o na tang 'bras bu de ltar thob pa'i zhus ji tsam na 'grub zhe na / theg pa dman pa dag rnam par smin pa'i dus 'di (275.5) dang / phyi ma dang / man grangs gzhan dang / smin par ma nges la stsogs pa dang / bskal pa grangs med pa gsum na 'grub pa dang / bya ba rdzogs (275.6) pa'i skad cig ma la sogs pa las dang 'dzim pa dang / khyad par du yang las kho na la rag lus par smra ste / de ni shin tu thag ring ngo //" 


\section{The Differences Between Mahāyoga and the Chinese Sudden Tradition}

The chapter ends with a discussion of the main differences between Mahāyoga and the Sudden approach (Tib. “’o na gsang sngags kyi de bzhin nyid dang ston mun la khyad par med do zhes mchi"). Here Nupchen has to address the central tension of all doxographies: establish the continuity of the Buddhist tradition as a whole, asserting that all of them aim for the same goal (i.e. enlightenment), while establishing clear discontinuities between those traditions by asserting important differences. He outlines twelve main differences between these two vehicles:

1) The difference in the generation of Bodhicitta;

2) The difference in the strengh of understanding;

3) The difference of the [philosophical view];

4) The difference of concentration (Skt. samadhi), while in meditative equipoise;

5) The difference in conduct;

6) The difference of modifying the mind when conceptual thoughts emerge;

7) The difference in the collection of the [two] accumulations [of merits and wisdom];

8) The difference on how to purify obscurations;

9) The difference on how to help other sentient beings;

10) The difference on the methods of entrance;

11) The difference on the accomplished result;

12) The difference on the performed enlightened activities. ${ }^{665}$

\footnotetext{
${ }^{665}$ Lamp 279.5-281.1: “'o na gsang sngags kyi de bzhin nyid dang ston mun la khyad par med do zhes (279.5) mchi // mdo sngags kyi theg pa dngos kyang thabs mi mtun du zad kyi / theg pa chen por 'dra mon ces rabs cig mchin / 'di ji ltar lags / zhes (279.6) dris pa dang / lan gsol pa / de ni bden te dus nging sang gis mi sngags kyi gdeng mchung pa dang / mdo sde la lce sbyangs pa'i mun sbrul gyi blo can (280.1) kha cig smra ste / te ni lag <sbrul gyi > 'gro 'o ma 'thung ba ltar mthong ba'i nad du 'gyur ro // nyon cig de'i don rgyas par brzod kyis mi lang na'ang // mdor brda' tsam (280.2) zhig bstan te / mdo sngags kyi theg pa ni shin tu nges don ma nor ba theg pa yang chen po yin pas phyis 'byung ba lnga par 'das pa / rgyal ba mang (280.3) pos lung bstan to // dbu ma gzhung dam pa nyid las / / gsang sngags ni nye la ma mo // zhes bstan pas / khyad par shin tu che ste / de yang re zhig (280.4) 'dir bcu gnyis te / gang zhe na / sems bskyed pa'i khyad par dang / rtogs pa'i stobs kyi khyad par dang / lta ba'i khyad par dang / mnyam par (280.5) bzhag pa'i ting nge 'dzin gyi khyad par dang / spyod pa'i khyad par dang / rnam rtog skyon byung na sems bcos pa'i khyad par dang / tshogs bsog pa'i (280.6) khyad par dang / sgrib pa sbyong ba'i khyad par dang / 'gro don spyod pa'i khyad par dang / 'jug lugs kyi khyad par dang / grub pa'i 'bras bu'i khyad (281.1) par dang / des mdzad pa'i phrin las kyi khyad par ro //" The bold is mine.
} 
In all of those aspects the Mahāyoga tradition is superior to Chan. This section points out the clear hierachical nature of the doxography. The goal of the genre, and of Nupchen when using it, is not simply to define various aspectes of each of the traditions, but to establish a clear, absolute hierarchy between the systems. There is no place for nuances, or for the acceptance of a particular view, or for the practice of one tradition within another. There is an absolute superiority of the Sudden system over the Gradual, and of Mahāyoga over the Sudden. The ultimate purpose of the doxographical genre is to establish (to construct) those bounderies and make them as clear as possible. 


\section{Mystery of its Origins}

A recurring theme when reading scholarship on the early Great Perfection tradition is the issue of its origins: where does the Great Perfection come from? Does it have legitimate Indian origins $?^{666}$ Is it a Buddhist reinterpretation of the Tibetan autochtonous Bon religion? ${ }^{667}$ Is it a copy of Chinese Chan? Is it a natural outgrowth of Mahāyoga? The French scholar Jean-Luc Achard captured the general feelings found in most scholarship when he stated that the "Great Perfection (rDzogs chen) or Atiyoga (Shin tu rnal 'byor) is one of the most fascinating features of Tibetan Buddhism even if our knowledge of its history and principles is rather limited since only a handful of its classical works have been translated into Western languages," adding that "its origins are still lost in the haze of Tibet's ancient history." "668 This section will not attempt to offer an answer to the question of the origins of the Great Perfection. However, since the focus of this dissertation is Nupchen's Lamp, I will discuss some of the scholarship that has looked at the complex relationship of Atiyoga with the Chinese Chan tradition and Indian Mahāyoga, a relationship that Nupchen himself addresses at various times in the text. The goal of this section is, first, to explore the complexity and fluidity of the historical and intellectual world in which the Great Perfection emerged and, second, to discuss the role that Nupchen and the Lamp had in the construction of the early identity of the Great Perfection tradition.

\footnotetext{
${ }^{666}$ Ronald M. Davidson, “Reframing Sahaja: Genre, Representation, Ritual and Lineage,” Journal of Indian Philosophy 30, no. 1 (2002): 43-81.

${ }^{667}$ On this topic, see, among others, Donatella Rossi, The Philosophical View of the Great Perfection in the Tibetan Bon Religion (Ithaca N.Y.: Snow Lion Publications, 1999); Jean-Luc Achard, "The Tibetan Tradition of the Great Perfection," in Northern Buddhism in History, ed. Thapa Shanker (Kathmandu: Vajra Publications, 2008), pp. 185233.

${ }^{668}$ Achard, "The Tibetan Tradition of the Great Perfection," p. 185. Van Schaik has phrased this issue in a similar way when stating, "The origins of the Great Perfection movement, so important in the later Tibetan tradition, have proved very difficult for modern scholarship to establish. The genuinely early texts available to scholars are like the few remaining pieces of what was once a large puzzle. Inquiries into the early history of the Great Perfection have, of necessity, been rather like placing these pieces into an arrangement that merely suggests the larger whole." In van Schaik's "The Early Days of the Great Perfection," p. 165.
} 


\section{The Complex Relationship of Atiyoga with Chan and Mahāyoga}

As Karmay pointed out in his early work on the Great Perfection (which, although outdated, was quite groundbreaking at the time of its publication), "[W]estern writers on Tibetan Buddhism have often viewed [Atiyoga] as a survival of what is known as 'the Sudden Path,' a form of the Ch'an School which was once known in Tibet in the eighth century A.D." ${ }^{669} \mathrm{He}$ argues that this perception derives from the attitude of the Tibetan Buddhist Modernist or Sarma schools, who regarded Atiyoga as a resurrection of the Chan school that was (supposedly) officially banned after the Samye Debate. We can see this Tibetan perspective in comments like the following, by Sakya Pandita:

In the Mahāmudrā of today and in the Rdzogs-chen of the Chinese fashion, "fall from above" and "climb from below" [on the one hand] and "successively" and "simultaneously" [on the other] are only terminological variants. Where meaning is concerned no distinction is made between them. ${ }^{670}$

Karmay argued that this perspective had "transpired" in Western scholarship. His work was published in 1988, and although much research has been done since then, his statement reflects most of the scholarship published prior to its publication. Tucci's early studies on the subject $^{671}$ had much to do with the early perception of the Great Perfection tradition in Western scholarship. His assessment that within Atiyoga "a significant part of the heritage of the Hwa shang's ideas, combined with those of the Siddha, [were] able to come to maturity, be

\footnotetext{
${ }^{669}$ Karmay, Samten Gyaltsen, The Great Perfection (Rdzogs Chen): A Philosophical and Meditative Teaching of Tibetan Buddhism, Leiden-New York: E.J. Brill, 1988, preface p. ix.

${ }^{670}$ Sa skya pan chen, Sdom gsum rab dbye, fol. 25b, Sa skya bka' 'bum ed. (Tokyo, 1968), 5:309, quoted from Stein, R.A.'s "Sudden Illumination or Simultaneous Comprehension," in Sudden and Gradual: Approaches to Enlightenment in Chinese Thought, edited by Peter N. Gregory, pp. 41-66. Honolulu: University of Hawaii Press, 1987, p. 44.

${ }^{671}$ Tucci, Giuseppe, The Religions of Tibet, Berkeley: University of California Press, 1980.
} 
consolidated, and then be transmitted on in further adaptations." ${ }^{672}$ These ideas were pervasive in some of the later scholarship, as seen in Broughton ${ }^{673}$ and Ueyama. ${ }^{674}$ It is fair to say, though, that some of these same scholars were also aware that more research on the subject was needed and that their conclusions were just preliminary. ${ }^{675}$ Tanaka and Robertson ${ }^{676}$ offered a more complex picture on this issue with a more nuanced analysis of some early Tibetan Chan manuscripts (mainly PT 116). In their conclusions, although they acknowledge the necessity of accepting what they consider the neglected influence of Chan on the earliest developments of Buddhism in Tibet, they also believe that there is no strong evidence of the relations between Chan and the Great Perfection tradition. ${ }^{677}$

The complex relation between the early Great Perfection and Chinese Chan took a new direction after the publication in 1988 of Karmay's already mentioned book, The Great

\footnotetext{
${ }^{672}$ Tucci, Ibid., p. 14. Together with the Dzogchen tradition he also adds the Jonangpa as the other of the two
} traditions that inherited Chan ideas. To prove his point, he uses the Five Chronicles (Tib. bka' thang sde lnga) since he thinks it preserved a lot of fragments from the Chan tradition. The use of this text, as we will see, was hardly contested by Tanaka and Robertson.

${ }^{673}$ In his 1983 article, "Early Ch'an Schools in Tibet," Broughton asks, "What became of the Chinese-style ston mun? Certainly, Ch'an was not banished from Bod simply by the wave of a hand, even an imperial hand. There are indications that the eventual Rdzogs-chen response to Ch'an lore was some sort of p'an-chiao or classification of the teachings, to use a Chinese term." From Broughton, Jeffrey's "Early Ch'an Schools in Tibet," in Studies in Ch'an and Hua-Yen, edited by Robert M. Gimello and Peter N. Gregory, Honolulu: University of Hawaii Press, 1983, p. 44. 674،'I now feel that Ch'an may have merged with the Mahāyoga of Rdzogs chen, which was appearing in Tibet at approximately the same time, and continued to be practiced there [...] it is possible that the doctrines of the sudden and gradual schools were synthesized by a third party, the $r d z o g s$ chen school of Tantrism. Ch'an and Mahayoga texts found in association with each other are some indication of this, and it is possible that individuals such as Vimalamitra and Dpal dbyangs were instrumental in such developments," in Ueyama, Ibid. p. 349, fn. 30.

${ }^{675}$ Ueyama himself acknowledges that he does a "very rough estimation," in Ueyama, Ibid., p. 349, fn. 30, and that his ideas should be verified in future research. He also points out the importance of studying a text like the $10^{\text {th }}$ century The Lamp for the Eye of Contemplation, by Nupchen, in order to clarify the origins of the Great Perfection. Tucci also follows his statements on the relations between Chan and Dzogschen with stating the necessity of looking at this picture in the larger context of multiple influences of Buddhism in Tibet, in Tucci, Ibid., p. 15.

${ }^{676}$ Tanaka, Kenneth K., and Raymond E Robertson, "A Ch'an Text from Tun-Huang: Implications for Ch'an Influence on Tibetan Buddhism," in Tibetan Buddhism: Reason and Revelation, edited by Steven D. Goodman and Ronald M. Davidson, Albany: State University of New York Press, 1992, pp. 57-78.

677 "Thus, based on our textual and doctrinal analyses, we believe there is no convincing evidence to support a view such as G. Tucci's that the rDzogs-chen preserves elements originated in Ch'an. While the two traditions do concur on some issues (e.g., 'non-doing'), their fundamental philosophical assumptions are distinct." In Tanaka and Robertson, Ibid. p. 78. Their main argument is that the text used by Tucci in order to prove that relation, the Chronicle of Ministers (Tib. bLon po bka' $i$ thang $y i$ ) in the Five Chronicles (Tib. bKa'thang sdelnga) is not a historically reliable document, since it is partially based on sections of Nupchen's The Lamp for the Eye in Contemplation. 
Perfection. ${ }^{678}$ Karmay offered in his study a more complex picture of the early days of the tradition that involved "[1] certain elements of the cig car ba [Chan] tradition, [2] the sems sde type of teachings [i.e. the early scriptures of Atiyoga] and [3] predominantly tantric doctrines expounded in Tantras such as SNy [i.e. the Guhyagarba Tantra]. ${ }^{, 679}$ With this work, Karmay opened the door to a more complex interpretation of the origins of the Great Perfection that accepted, even as it downplayed, possible Chan influences, and emphasized the role that the Mahāyoga tradition, as well as the early Mind Series scriptures, played in the emergence of Atiyoga. For Karmay, works like Padmasambhava's Garland of Views, a commentary on chapter thirteen of the Guhyagarbha Tantra, a key text for the Mahāyoga tradition in Tibet, show how the Great Perfection emerged on the Tibetan Plateau as an attempt to develop a separate Buddhist vehicle by taking as the central contemplative practice the Perfection Stage (Tib. rdzogs rim), which until that time had been part of the two stage process of meditation within Mahāyoga tradition (the generation stage and the perfection stage). ${ }^{680}$

Germano's work continued Karmay's line of enquiry by defining the early Great Perfection as a continuation of certain themes and practices found in Mahāyoga, even though its early discourse would be constructed as a complete denial of those ideas and practices. This paradox is explained by Germano since this early rhetoric "seems to exist almost purely as a metacritique, a hyper-parasitical discourse which can only thrive by virtue of relationship to its

\footnotetext{
${ }^{678}$ Although Tanaka and Robertson's article is from 1992, the issues they address are very much connected with the early scholarship that tried to see the Chan influences in the early Great Perfection.

${ }^{679}$ Karmay, Ibid., p. 212.

${ }^{680}$ The Garland of Views (Tib. Man ngag lta ba'i phreng ba) is a commentary on the perfection phase practices as described in the Guhyagarbha Tantra. In his opinion, "[b]eing the principal work dealing with the final stage of the process of the rdzogs rim meditation expounded in SNy, it is the original source that gave birth to what is known as the doctrine of rDzogs chen, a syncretic teaching mainly drawn from SNy and tinged with thoughts originating the Sems sde.” In Karmay, Ibid., p. 152. He dedicates great parts of chapter six to that issue. Dalton further explores this relationship in his "The Development of Perfection: The Interiorization of Buddhist Ritual in the Eighth and Ninth Centuries," Journal of Indian Philosophy 32, no. 1 (2004): 1-30.
} 
host, a relationship characterized by negation, derision and dismissal." ${ }^{681}$ A series of younger scholars like Dalton, ${ }^{62}$ van Schaik, ${ }^{683}$ and Meinert ${ }^{684}$ have also continued to research the early days of this tradition by exploring the caché of Tibetan texts found in the Cave Library in Dunhuang, which included many manuscripts that document the early stages of Atiyoga. What has emerged from the study of these manuscripts is a more complex picutre of the interactions between the Buddhist traditions that populated the Tibetan plateau in the 9th and 10th centuries, in which borrowing, synthesis, and syncretism is not seen as negative or derivative, but as part of the creative process by which these traditions were experimenting with ideas, practices and rituals, and being transformed in the process. ${ }^{685}$

Ruegg had already argued for the need of a more complex approach to the study of the early Great Perfection and its connection to the Chan tradition. His study of the Samye Debate tries to change our perspective by asking a different question. The question should not be

\footnotetext{
${ }^{681}$ Germano, Mysticism and Rhetoric in the Great Perfection (rDzogs Chen), p. 17.

${ }^{682}$ See Dalton's "The Development of Perfection: The Interiorization of Buddhist Ritual in the Eighth and Ninth Centuries." This article is an excellent overview of the historical evolution of the various tantric ritual and contemplative traditions, which include the emergence of the Great Perfection out of the Perfection Phase of tantric contemplation.

${ }^{683}$ His article, "The Early Days of the Great Pefection," offers a thorough study of the early terminology used to describe the Great Perfection tradition and its evolution from a particular approach to practice to a fully developed contemplative system with its own set of scriptures. In van Schaik's "The Early Days of the Great Perfection."

684 "Manuscripts recovered in the grottoes of Dunhuang at the beginning of the twentieth century [...] show a variety of religious practices that were in vogue during that time of political anarchy in Tibet. Since there was no central authority to control various religious speculations, different traditions sometimes syncretistically merged owing to doctrinal similarities. This may be seen to some extent in the teachings of Chan and of the Great Perfection." In Meinert, Carmen's "The Conjunction of Chinese Chan and Tibetan Rdzogs Chen Thought: Reflections on the Tibetan Dunhuang Manuscripts Iol Tib J 689-1 and Pt 699," In Contributions to the Cultural History of Early Tibet, edited by Matthew T. Kapstein and Brandon Dotson, pp. 239-301, Leiden/Boston: Brill, 2007, p. 239. Also in Sam van Schaik and Jacob Dalton's "Where Chan and Tantra Meet: Buddhist Syncretism in Dunhuang," in The Silk Road: Trade, Travel, War and Faith, edited by Susan Whitfield, pp. 61-71, London: British Library Press, 2004.

${ }^{685}$ On this topic, see Dalton and Schaik's "Where Chan and Tantra Meet: Buddhist Syncretism in Dunhuang"; Sam van Schaik's "Dzogchen, Chan and the Question of Influence," Revue d'Etudes Tibétaines 24 (October 2012): 5-20; Meinert's "Chinese Chan and Tibetan Rdzogs Chen: Preliminary Remarks on Two Tibetan Dunhuang Manuscripts"; Meinert's "Legend of Cig Car Ba Criticism in Tibet: A List of Six Cig Car Ba Titles in the Chos 'byung Me Tog Snying Po of Nyang Nyi Ma 'od Zer (12th Century)," in Tibetan Buddhist Literature and Praxis: Studies in Its Formative Period, 900-1400 (Boston/Leiden: Brill, 2006), pp. 31-54; and Meinert's "The Conjunction of Chinese Chan and Tibetan rDzogs Chen Thought: Reflections on the Tibetan Dunhuang Manuscripts IOL Tib J 689-1 and PT 699."
} 
focused on if Atiyoga borrowed from Chan, but what are the similarites between these two traditions and how can they be explained, or what he calls "a question of typological affinity as distinct from direct genetic dependence." In his words,

Doctrines that are typologically and structurally related are of course very often linked through direct historical derivation and branching. But, clearly, a pair of doctrines may, in addition, be connected with each other typologically without one having to be directly dependent historically on the other. The question then is: Are the links existing between the teachings ascribed to the Hva šang Mahāyāna and certain currents in rDzogs chen and Phyag chen not only typological and structural but also historical in the sense of direct derivation? Or are these links typological without any direct historical dependence having to be postulated? This is not an easy question to answer. Briefly stated, Sa skya Pandita may have assumed not only typological and structural similarity but also a historical dependence and continuity, and several of his successors appear to have made the same assumption. Klong chen pa (1308-1363), the great rDzogs chen master, on the other hand was evidently prepared to accept a certain typological and structural similarity between rDzogs chen and the teaching of the Hva šang without, apparently, positing any sort of genetic dependence; this is natural for him since, as already noted, his rDzogs chen school has differentiated between its Atiyoga tradition and the cig char ba tradition of the Hva šang (see also the bSam gtan mig sgron). But other rDzogs chen pas/rNying ma pas have emphasized the differences more clearly, just as many bKa' brgyud pas have differentiated between Phyag chen and the teachings of the Hva šang ${ }^{686}$

Ruegg shows that, sometimes, we should be looking for the right question more than the right answer. Kapstein also acknowledges the influences of Chan in the Atiyoga tradition, but, as it is common in his latest work, he attempts to explain this influence in the much larger context of the permanent dialogue among the various Buddhist (and non Buddhist) traditions all across Asia. ${ }^{687}$ The question, then, would not be if Chan influenced Atiyoga (or any other tradition), but by which mechanisms were all of these traditions interacting and influencing each other.

\footnotetext{
${ }^{686}$ Ruegg, D.S., "On the Historiography and Doxography of the 'Great Debate of Bsam Yas," in Tibetan Studies: Proceedings of the 5th Seminar of the International Associaton for Tibetan Studies (Narika 1989), edited by Lhara Shoren, Tokyo: Naritisan Shinshoji, 1992, pp. 243-44.

${ }^{687}$ His chapter, "From Korea to Tibet," in his The Tibetan Assimilation of Buddhism: Conversion, Contestation, and Memory, Oxford; New York: Oxford University Press, 2000, pp. 69-84, is particularly relevant and quite suggestive of what this new understanding of the Buddhist world of the early Tibetan Empire looked like.
} 


\section{The Need for a New Methodological Approach}

Although Karmay and most of the scholars we have discussed have advanced the knowledge we have of the early stages of the Great Perfection tradition, their approach, in general, share a very linear conception of history. As we have seen, this methodology brought important discoveries to the field, but it also has obvious limitations. The most important one is that it creates the illusion that, having all the (missing) pieces, we would be able to reconstruct the final puzzle of the origins of the Great Perfection tradition. The obscurity of the matter is not caused by the methodological approach, but by the lack of sources that, somehow, scholars expect to discover one day (maybe in another Dunhuang cave?), which will solve the problem.

From a methodological perspective, one of the main critics of this historical-linear approach has been the French philosopher Michel Foucault. In some of his most important works, he sees this traditional historical approach arriving at a dead end, since it is based on problematic (and unconscious) assumptions. Mainly, this is because it organizes in a linear form a group of phenomena (or documents) that are dispersed in history (space and time), and allows us to conceive them in an articulate, discursive form. ${ }^{688}$ He tried to avoid this problem by seeing history not as a continuous and organized chronology of events, but as a discontinuous one. Those discontinuities should not be seen as obstacles to be solved by looking for the events that would eventually "fill in the gaps," but as the very nature of history. ${ }^{689}$ The pre-existing forms of historical analysis of phenomena as a linear continuum, he says, do not have to be abandoned,

\footnotetext{
${ }^{688}$ He dedicates chapter 1 of his The Archaeology of Knowledge to this issue. Michel Foucault, The Archaeology of Knowledge, (London: Routledge, 2002), 21-39.

${ }^{689}$ As he says, "In place of the continuous chronology of reason, which was invariably traced back to some inaccessible origin, there have appeared scales that are sometimes very brief, distinct from one another, [...] and which cannot be reduced to the general model of a consciousness that acquires, progresses, and remembers." In Ibid., p. 8.
} 
but should remain "in suspense," $" 690$ and one of the main tasks of the historian is "to show that [those continuities] do not come about of themselves, but are always the result of a construction of the rules of which we must know." In other words, he asks the historian to stop being "innocent" in his/her approach to the material, and to be aware of the historical and intellectual circumstances that "affect" his/her view. With this methodological excursus, it is not our intention to escape to some theoretical "Pure Land," but to point out that most of the early scholarship on the analysis of the Great Perfection did not take into account the context of their particular approaches.

In order to change this traditional approach, Foucault proposed that historians should renounce two pre-conceptions. The first one

...involves a wish that it should never be possible to assign, in the order of discourse, the irruption of a real event; that beyond any apparent beginning, there is always a secret origin -so secret, so fundamental that it can never be quite grasped itself. Thus one is led inevitably, through the naïvety of chronologies, towards an ever-receding point that is never itself present in any history; this point is merely its own void. ${ }^{6}$

Translating this into our field of research it would mean a call-off of the "quest for the origins," or, at least, putting that quest into question. The lost pieces we are looking for would never help us to solve the puzzle of the origins of the Great Perfection, because there is no puzzle. Or, said better, the puzzle is a creation of the tradition itself. ${ }^{692}$ The second thing the historian has to abandon is the idea that

\footnotetext{
${ }^{690}$ Ibid., p. 25.

${ }^{691}$ Ibid., p. 5.

${ }^{692}$ The best example of this approach in the field of Buddhism is the study undertaken by Faure on the Northern Ch'an school (mainly in The Will to Orthodoxy). In this text, he also tries to call the attention to the way traditional scholarship on the origins of the sudden-gradual debate that split the Ch'an school have been "reading" wrongly the sources available on the subject.
} 
...all manifested discourse is secretly based on an 'already-said'; and that this 'already-said' is not merely a phrase that has already been spoken, or a text that has already been written, but a 'never-aid', an incorporeal discourse, a voice as silent as a breath, a writing that is merely the hollow of its own mark. ${ }^{693}$

The implications of this are that historians are always looking "behind" the text to its historical content-context, being the words of the texts mere pointers to a world existing outside of the text. The fact that most scholars look with suspicion upon most of the sources on the Great Perfection does not change the fact that they are trying to separate true from false, comparing the text with the "reality," or what really happened in that remote time. And the judge, the one who can tell us if our analyses are correct, is history. But what Foucault is trying to say is that those texts also create history, that this is not a one way direction, from text to history, but a more complex one where the text produced in a certain moment in history is, inevitably, affecting it.

Some of these methodological concerns have been faced by scholars in the more recent approaches to the "origins" of the Great Perfection. Kapstein, although focusing on the more general issue of the first developments of Buddhism in Tibet, touches on the more specific beginnings of the Great Perfection. There he says,

Not long ago it was widely assumed that it was primarily within the Great Perfection [...] systems of the Nyingmapa and Bön traditions that clear evidence of the continuity of Chan in Tibet was to be found, but it now appears that this is an oversimplification. On the one hand, the Great Perfection is known to involve much more than whatever of its aspects can plausibly be traced back to Chan influence: "Great Perfection" refers to a highly ramified family of systems that are, doctrinally and historically, far too complicated to reduce to a single source or impetus. And on the other hand, it is now clear that the Great Perfection was not alone among the Tibetan meditational traditions in absorbing surviving elements

${ }^{693}$ Foucault, Archaeology of Knowledge, 25.Foucault, Archaeology of Knowledge, p. 25. 
of the Chan teaching; from an early date the Kagyupa proponents of the Mahāmudra [...] adopted certain materials from Chan sources. ${ }^{694}$

Although, as we have said, his research is more focused on the broader issues of the early developments of Buddhism in Tibet, his references to the Great Perfection prove a new orientation. The historical-linear approach, the looking for the "source" (Chan, Mahāyoga, etc...) is not there anymore and it is substituted by a more complex idea of history. That line is transformed in a very subtle network of traditions interconnected in very complex ways: developments of one tradition can affect in the most subtle ways other traditions not related temporally or spatially. The best example is his study of the references of the Korean "Master Kim" in some Tibetan texts. ${ }^{695}$

Moving away from the Chan issue, Germano points out, "Scholarship clearly must thus move beyond an either/or type of framework that posits the Great Perfection as a survival of Chan in Tibet, or disavows any relation whatsoever." ${ }^{696}$ On the other side, most of his works on the topic are clearly interpreting the Great Perfection as being rooted in the philosophical concerns exposed by later Indian Buddhism. In his own words, "A more interesting line of inquiry is to ask how the Great Perfection might have important implications for our re-reading of the history and nature of Indian Buddhism as a tantric tradition offering important

\footnotetext{
${ }^{694}$ Matthew Kapstein, The Tibetan Assimilation of Buddhism (Oxford; New York: Oxford University Press, 2000), p. 75. From a general perspective, it is important to notice that even Tucci saw the complexity of the process: "One must guard against oversimplifying forms of religious experience and doctrinal statements. They do not develop in straight lines [...] The Buddhism entering Tibet came not only from India (by which is to be understood not only India proper, but also its border regions Nepal and Kashmir) but also from present-day Afganistan and Gilgit, from the cities along the caravan routes of Central Asia (then known as the Silk Routes), and from China. Buddhism has never refused to accept, rework and transform the ideas of other peoples. In the territories bordering on Tibet there existed numerous religious forms in a picturesque juxtaposition which favored exchange and reciprocal borrowings," (Tucci, p. 15).

${ }^{695}$ Ibid., 69-84.

${ }^{696}$ Germano, Mysticism and Rhetoric in the Great Perfection (rDzogs Chen), 2009, 16.
} 
hermeneutic and philosophical innovations rather than simple anti-nomian practices, new terminology, or new styles for contemplation." 697

While I agree with the attempts to offer a more complex picture, this dissertation also want to argue for the need to switch the focus of attention from how the text can help us to explain the early history of the Great Perfection to how the history of the tradition is created within the text itself. I do not argue, of course, that the text is creating the tradition alone, or that Nupchen is its architect. Different movements under the rubric of Atiyoga were circulating during his time and, as we will see in our analysis of the Great Perfection chapter, many teachers seem to have been offering different views and practices under this label. ${ }^{698}$ Probably there was a relationship among them that helped to articulate an early self-perception as a separate vehicle, but it is Nupchen who articulates in the Lamp those different views and scriptures of the tradition. He organizes diversity (spatial and temporal) in the unity of a book, and it is that unity that is contested by other groups, and defended and refined by its own followers, over the next centuries. It is that book that comes to us as a document that not only demostrates what happened, but also how it happened. This dissertation is more interested in the in the process of how it happened, because it is not only through reading the text, but also through "de-constructing" it, that we can see what were the mechanisms involved in the creation of the Great Perfection as an independent vehicle.

\footnotetext{
${ }^{697}$ Ibid. 16.

${ }^{698}$ For an overview of all these movements from the $8^{\text {th }}$ to the $14^{\text {th }}$ centuries, see Germano's "David Germano, "The Funerary Transformation of the Great Perfection (Rdzogs Chen)," Journal of the International Association of Tibetan Studies, no. 1 (2005): 1-54.”
} 


\section{The Great Perfection in the Lamp}

The chapter begins with a clear declaration of the intentions of Nupchen's Lamp all along: to declare the superiority of the Atiyoga tradition over all other Buddhist vehicles:

[In this chapter, I] will explain the meaning of Atiyoga, the peak of the supreme vehicle of yoga, the mother of all the conquerors (i.e. Buddhas) [where] all inconceivable phenomena is spontaneously realized without effort. ${ }^{699}$

The chapter, as usual, is divided into four sections: the philosophical view, the contemplative practices, the conduct, and the result. Unlike other chapters, though, this one is clearly as argumentative as it is expositional. Although in other chapters Nupchen has used rhetorical questions to defend or differentiate the positions of other vehicles, this chapter is, from beginning to end, filled with rhetorical questions and answers, a tecnique that Nupchen uses to address any (and all) possible criticism of the Great Perfection tradition and to argue for its superiority. This is not new within the Buddhist tradition, where most Sūtras and Tantras have a dialogical framework in which the Buddha (or a Buddha) responds to an assembly of disciples (or Bodhisattvas). Here, though, the style is quite direct, and it seems to reflect the deep pedagogical nature of the text. It is probable that the text was used by Nupchen as a textbook of sorts in which the general outlines of the new Great Perfection tradition were clearly explained and situated within the general context of the Buddhist tradition.

\footnotetext{
${ }^{699}$ Lamp 290.6-291.3: "de nas theg pa'i mchog rnal 'byor gyi phul yang tog //rgyal ba ril gyi yum a ti yo ga'i don bstan pa ni / mtshan rdzogs chen po zhes bya ste / [...] bsam gyis mi khyab pa'i chos thams cad ma brtsal lhun rdzogs pa'i don"
} 
The section on the view of Atiyoga sets the tone of the chapter by establishing the general view of the tradition through a series of six questions followed by their respective answers. This dialogical device can be conceived within a polemical context, in which Nupchen feels that he needs to defend the doctrine of the Great Perfection even before he outlines its view, but it can also be understood in a pedagogical context, in which he is primarily interested in teaching this view to students who may be more familiar with the other Buddhist traditions discussed in the text. In many ways, the Lamp functions as a textbook, outlining in a very simple, structured way the main characteristics of each of the traditions, comparing them, differentiating them, and finally presenting the superiority of the Great Perfection above all other traditions. The colloquial style of the Lamp, particularly in the final two chapters, also points to the pedagogical nature of the text, which is more interested in conveying ideas than in presenting them in a highly elaborate or scholastic way.

\section{Six Questions}

Nupchen begins by warning the practitioner about holding onto any particular views with a quote from one of the the Atiyoga scriptures, the Wheel of Life (Tib. Srog gi 'khor lo):

The Wheel of Life says: "With nothing to abandon, nothing to accomplish, remain in the condition of the sky / When the three realms are examined, [you realize that] there is neither samsāra not nirvāna/ When you are stuck in a particular position, [then you will not realize the] Tathāgatagarbha. ,700

\footnotetext{
${ }^{700}$ Lamp 292.5-292.6: “srog gi 'khor lo las / ma spangs ma sgrubs nam mkha' ngang du gnas / khams gsum brtags na 'khor ba mya ngan (292.6) med // phyogs char gtses na bde gshesgs snying po min //"
} 
This quote from the Wheel of Life serves as the catalyst for the six questions that will help Nupchen present a general view of the Great Perfection. Those six questions are:

1. [When the Wheel of Life says,] "If one examines the Three Realms" [does that mean that] there is an object of comprehension (gzhal bya) [in the Great Perfection system] $?^{701}$

2. If there is nothing to be examined nor to analyze, [how] is possible to liberate the mind? ${ }^{702}$

3. How is it possible to define the principle [of the Great Perfection] $?^{703}$

4. If all these [other vehicles] are mistaken, which one is unmistaken [about] the principle? ${ }^{704}$

5. What does it mean to view the truth of the pure meaning by the method of noninvestigation? ${ }^{705}$

6. What is the meaning of the Great Perfection, the vehicle free from activity? ${ }^{706}$

What we can see here is how Nupchen tries to address and anticipate possible criticism from other traditions regarding the radical project of deconstruction of the Great Perfection tradition. What do see when there is nothing to see? What do you think when there is nothing to think? What do you do when there is nothing to do? Where do you go where there is no place to go? While, as we have seen, the Great Perfection really emerges from the ritual and contemplative developments of Mahāyoga, its discourse, as seen in these six questions and the rest of the chapter, also shares the negative rhetoric of the Chan tradition, with a discourse that is distrustful of language and all sorts of intellectual conceptualizations. We will not go into detail

\footnotetext{
${ }^{701}$ Lamp 292.6-293.1: “'o na khams gsum brtags na ces pa nyid kyis // 'dir yang gzhal (293.1) bya ni yod dam zhes dris na lan gsol pa

${ }^{702}$ Lamp 295.1-295.2: “'o na cir yang ma brtags ma dpyad na sems grol du btub bam zhe na grol bar byar med pa nyid kyis (295.2) grol ba ste / ci'i phyir zhe na /"

${ }^{703}$ Lamp 295.4-295.5: "'o na don nyid <'dir bstan pa'i tshig /> re (295.5) zhig gang gis mtshon zhe na //"

${ }^{704}$ Lamp 304.6-305.1: “' na de dag (305.1) 'khrul na don ma nor ba de nyid ji lta ba yin ce na"

${ }^{705}$ Lamp 306.2-306.3: “de ltar cir yang ma brtags pa'i thabs kyi yang dag pa'i don gyi bden pa mthong ngo zhes bgyi ba ji lta bu lags /"

${ }^{706}$ Lamp 312.2-312.3: “'o na rdzogs pa <bya ru med na /> chen po bya ba dang bral ba'i theg pa'i don la dgongs (312.3) pa ci yod ces dris na /"
} 
here on how Nupchen answers these questions. ${ }^{707}$ Instead, what is important is to see how these questions allow Nupchen to clear up some of the possible misconceptions about the Great Perfection before laying out nine different philosophical views within the Atiyoga tradition connected to specific masters. This section parallels the one dedicated to the various Mahāyoga views, according to particular teachers. In terms of the construction of the Lamp, we see how the Gradual and Sudden are built in opposition to each other (it is all about the contrast between the views of those two traditions), while the Mahāyoga and Atiyoga chapters are constructed in parallel, with the themes and divisions within each of the traditions clearly mirroring each other.

\section{The Nine Views (Tib. lta ba)}

Nupchen follows those six questions with a discussion of nine different views of Atiyoga, supported by specific teachers of the tradition. The names of the various Atiyoga teachers are well known in narratives of the early transmission of the tradition to Tibet, although the details of their lives are mostly anecdotal. ${ }^{708}$

As in the Mahāyoga chapter, the names of the teachers are only found in interlinear notes. Van Schaik has argued that in the case of the Atiyoga tradition,

[t]he almost total lack of authorial attribution in the Atiyoga section of the [Lamp] suggests that gNubs chen himself may have been complicit in the activity of transforming authored texts into scripture. In fact, names of teachers are mentioned quite frequently in the Atiyoga chapter, though mainly in the interlinear notes to the

\footnotetext{
${ }^{707}$ Karmay offered a discussion on these questions in Samten Gyaltsen Karmay's The Great Perfection (rDzogs Chen): A Philosophical and Meditative Teaching of Tibetan Buddhism (Leiden - New York: E.J. Brill, 1988), pp. 109-119. Esler also offers an overview of this section of the Lamp in his "The Exposition of Atiyoga in Nubs-Chen Sangs-Rgyas Ye-Shes' bSam-Gtan Mig-Sgron," Revue d'Etudes Tibétaines 24, no. Studies in the Sems sde tradition of rDzogs chen, Ed. Jean-Luc Achard (October 2012): 83-85.

${ }^{708}$ Dudjom Rinpoche, The Nyingma School of Tibetan Buddhism: Its Fundamentals and History (Boston: Wisdom Publications, 2002), pp. 530-554. See also the narrative of the transmission of Atiyoga to Tibet found in Ani Jinba Palmo's The Great Image: The Life Story of Vairochana the Translator (Boston: Shambhala, 2004), chapter 8.
} 
text. These were apparently written by gNubs chen, unless his references to himself in the notes are a later falsification. ${ }^{709}$

Although van Schaik's argument is convincing, I beleive that McRae and Faure's warnings to scholars, who make lineage claims historical realities, ${ }^{710}$ should be taken into consideration when interpreting this section of the Lamp. On the one hand, it makes sense that these various teachings were favored by particular teachers, something that the Lamp acknowledges in the interlinear notes. But the presentation of those views is, when all is said and done, remarkably similar, even redundant, which would present each of those teachers as having a very narrow range of view within the tradition. The need to include those names in the interlinear notes may indicate, as in the Mahāyoga chapter, the need to bolster the legitimacy of a tradition in which the role of the teacher and lineages of transmission are key. I am not arguing that this has to be one way or another, but that the answers to the connection between the names and the views may be more complex, one in which some masters may have been known for favoring a particular approach, while other names were simply attached to views as a way to give them legitimacy through establishing an authentic Indian connection. I also think that in the cases of Mahāyoga and Atiyoga, the emergence of a variety of views, and the connection of those views to specific teachers, may be a reflection of the rich religious landscape in Tibet during the 9th and 10th centuries, with competing views and teachers proposing their particular approach to esoteric Buddhism.

Nupchen introduces the different views of Atiyoga arguing that while they may be different, their essence is the same. This is one of the key sections of the chapter, where Nupchen

\footnotetext{
${ }^{709}$ van Schaik, "The Early Days of the Great Perfection," pp. 196-197.

${ }^{710}$ See Bernard Faure's Chan Insights and Oversights: An Epistemological Critique of the Chan Tradition (Princeton, New Jersey: Princeton University Press, 1993); and McRae's Seeing through Zen.
} 
tries to develop a more systematic approach to the different views within the Great Perfection tradition, although he does not forget to make use of strong negative rhetoric in order to express the existence of unique meaning within the tradition: "Generally there is no more than one [view, but] since it is beyond [the scope] of the mind, tentatively various views of different virtuous spiritual friends teach this [teaching].",711

The nine views are:

1- The view [which is] free from doubt (of the Mahārāja of Oḍdiyāna and Vimalamitra) $)^{712}$

This view emphasizes the problematic nature of conceptualizations and language in general as one of the main impediments towards enlightenement: "Buddhas and sentient beings, saṃsāra and sirvāna, all [of these terms] are just conventional concepts. Their various essences, even though they manifest, have no abode."713 When the problematic of language is understood, then the practitioner's mind will not have the need to focus, to grasp onto any particular concept, there will be no object of reference (Tib. dmigs pa) to which the mind will latch, or grasp, and, therefore, the mind will be able to rest in its natural state. ${ }^{714}$

\footnotetext{
${ }^{711}$ SM, 315 [de ni sbyir gcig las kyang med / bsam las kyang 'das na / re zhig dge ba'i bshes gnyen gyi bzhed gzhung ' $g a$ ' 'dir bstan te]

${ }^{712}$ Lamp 316.3-316.4: “de la gza' gtad < o rgyan ma h'a ra tsa dang bi ma mi tra'i bzhed /> dang bral ba'i lta ba yang / nor ma nor ba'i lugs dang / (316.4) de ltar ma rtogs gol ba'i skyon bshad pa'o //." I have translated "gza' gtad" as "doubt" for simplicity here, although the term has more complex connotations. Tony Duff translates the term as "vacillatory focus" or "rationalized uncertainties," and defines it as a "special term which only occurs in the secret mantra vajra vehicle, in Mahāmudra and Great Perfection. It means having a 'gtod so,' a point of focus of the intellect which is one possibility of a pair of opposites which are being argued back and forth internally and which one is thus 'gza,' vacillating over." Duff in the Illuminator Dictionary (electronic source).

${ }^{713}$ Lamp 316.4-316.5: "sangs rgyas sems can 'khor ba dang mya ngan las 'das pa (316.5) ril kyang tha snyad kyi bla chags tsam ste / ngo bo sna tshogs snang la gnas pa med pa/"

${ }^{714}$ Lamp 318.1-318.3: “de ji skad bstan kyang gza' gtad ni (318.2) dmigs pa ste / 'dir bza' gtad med pa mi dmigs pa'i don nyid blo la gnas pa byar med pas / man ngag las / mtshan ma med pa la yang mi gnas (318.3) na / mtshan mar mi gnas smos ci dgos //"
} 
2- The view of the Great State of Spontaneity (of Garab Dorje) ${ }^{715}$

This view focuses on the primordial enlightened nature of all phenomena: "The nature of all the objects of activity of Buddhas and sentient beings is the essence itself. It is enlightened without remainder in the nature of the great state of dharmatā, which is spontaneous with no beginning and no end." ${ }^{, 716}$ Again, there is no difference between samsara and nirvana, but this time the explanation for it is that their essence is spontaneously present (Tib. lhun gyis grub pa). ${ }^{717}$

\section{3- The view of the Great Self (of Vairocana) ${ }^{718}$}

This view is very similar to the one found in the Mahāyoga section, connected to the Tibetan translator, Kawa Peltsek. In the context of Atiyoga, the notion of a Great Self indicates that 'all phenomena that constitutes 'self' and 'others' without exception, and all that manifests as 'I' or 'mine' is unchangeable and uncorrupted. [All phenomena] is primordially clear to the self itself." ${ }^{, 719}$ Nupchen quotes from the Epitome of Teachings, an Atiyoga scripture, to illustrate this idea:

The Epitome of Teachings says:

"Self" exists;

"Other" does not exist;

Because Self and Other are spontaniously present, they [both] exist;

\footnotetext{
${ }^{715}$ Lamp 320.1: “de la lhun <dga' rab rdo rje dang rang bzhin dang bdag nyid chen po'i gran tshogs kyi $>$ gyi grub pa'i ngang chen por ba"

${ }^{716}$ Lamp 320.1-320.3: "sangs rgyas dang / sems can dang / de'i spyod yul ril gyi rang bzhin ni ngo bo nyid na / yong ye gdod ma med pa nas tha ma med par lhun gyis grub pa'i chos nyid ngang chen po'i rang bzhan du lhag ma med par sangs rgyas so //"

${ }^{717}$ Lamp 324.3-324.5: “'khor ba dang mya ngan las 'das pa gnyig lhun gyis grub pa'i ngo bo la / re dogs kyang med par bstan to / rin po che (324.4) kun 'dus las / bkol ba med de kun gyi re skong ba'i // mnyam nyid dang rtogs theg chen 'di dag ni // kun la khyab cing ma rdzogs chos 'ga'ng (324.5) med //"

${ }^{718}$ Lamp 328.5: "de la lhag pa'i rnal 'byor chen po'i lta ba / bdag nyid chen < be ro tsa na'i bzhed / $>$ por lta ba"

${ }^{719}$ Lamp 328.6-329.3: "bdag dang gzhan gyis bsdus pa'i chos ma lus pa dang / bdag dang bdag tu snang ba thams cad / ma bsgyur ma slad par ye nas rang rig pa mi gnas pa'i ye shes kyi bdag nyid du rang gsal ba la bdag nyid chen po zhes bya ba'i tha snyad kyis kyang mi thogs te / yi tshig dang yi ges brjod pa'i tha snyad las 'das so /".
} 
Because [both] are equal in the state of Samantabhadra, "Other" does not exist. ${ }^{720}$

I agree with Esler that, with this type of discourse, Atiyoga is not trying to reintroduce a notion of self (Skt. ätman) within the Buddhist tradition. But as Ruegg has pointed out, some of the language that emphasizes, at least rhetorically, the notion of the self, may be explained by an infiltration of Vedic discourse during the early emergence of Tantra in India. ${ }^{721}$

\section{4- The view of the Self-arising Primordial Wisdom (of the nun Ānanda) ${ }^{722}$}

In this view, "all phenomena, which [is the] gathering of all that is born and that ceases, is from the beginning the self-arising primordial wisdom, free from causes and effects." ${ }^{, 723}$ This is the only view within the Mahāyoga and Atiyoga sections attributed to a female practitioner. Considered one of the teachers of the great Indian master, Padmasambhava, Dudjom Rinpoche describes her particularly colorful teaching style in the following way:

[Padmasambhava,] having received the teaching of the Yogatantra eighteen times, the deities [of those tantras] appeared to him in that very place. Guhyajñānā, the d̦a kinī of pristine cognition, appeared in the form of the nun Ānanda and, at his request for empowerment, she transformed him into the syllable HŪM and then swallowed him. In her stomach he was given the complete outer, inner, and secret empowerments, and was then expelled through her vagina. In this way, the three obscurations were removed. ${ }^{724}$

\footnotetext{
${ }^{720}$ Lamp 329.5: "spyi bcings las / 'dag ni yod do / gzhan ni med do / bdag gzhan chen po lhun gyis grub pas yod do / kun tu bzhang po'i ngang du gcig pas gzhan med de /"

721 "It may therefore come as some surprise to see this view of integral being (Skt. mahätman) discussed in a Buddhist treatise on contemplation. Would this be an attempt to surreptitiously reintroduce the idea of an eternal self? Unequivocally, the answer must be in the negative, since here the term 'integral being' is not reified into an eternally enduring entity." In Esler's “The Exposition of Atiyoga in Nubs-Chen Sangs-Rgyas Ye-Shes' bSam-Gtan MigSgron," p. 91.

${ }^{722}$ Lamp 340.3-340.4: "de la < dge slong ma kun dga' ma'i /> rang byung gi ye shes su lta ba'i (340.4) lugs"

${ }^{723}$ Lamp 340.4-340.5: "skye 'jig < rig pa / > gis < dngos po rang gi lo rgyus kyi gtan tshigs kyis $/>$ bsdud pa'i chos thams cad kyang gdod ma nas rang byung gi ye shes rgyu rkyen ngang gis bral ba'i ngo bor sangs (340.5) rgyas pa'i phyi nang med par nam mkha'i 'od bzhin ye shes chen por rang gsal lo //"

${ }^{724}$ In Dudjom Rinpoche's The Nyingma School of Tibetan Buddhism: Its Fundamentals and History, p. 469.
} 
5- The view which is free from activity (of Buddhagupta) $)^{725}$

This view, explained by Nupchen, following the well-known negative rhetoric of Atiyoga, explains the effortless nature of the Great Perfection. Here we see an example in which the Atiyoga tradition reinterprets Mahāyoga tantric practices of visualization and the manipulation of the subtle body from the Great Perfection perspective. ${ }^{726}$

6- The view of the Great Bliss (of Kukuraja and Śrī Simha) ${ }^{727}$

In this view: "All phenomena, which is the gathering of karma and conflicted emotions, and their result [which is] suffering, if [we] examine the nature of all these actions and afflictions, by leaving them alone, they are non-existent." ${ }^{, 728}$ Nupchen quotes from one of the most important scriptures of the Atiyoga tradition in order to ilustrate this point:

\section{The Great Garuda says:}

"Butchers, prostitutes, and the five deadly sins, they are all complete perfected phenomena. There is nothing other than Great Bliss." 729

7- The view of Non-duality as in the Supreme Mahāyoga (of Mañjuśrīmitra) ${ }^{730}$

This is another view that is also part of the Mahāyoga tradition, although here it is reinterpreted through Atiyoga doctrine and scriptures. The section is mainly a list of fifty-two non-dual principles, such as "When the essence of bodhicitta is examined [you realized that it

\footnotetext{
${ }^{725}$ Lamp 344.4-344.5: "de la bya btsal <'bu ta kug ta'i /> dang bral bar 'dod (344.5) pa'ang 'di ltar bzhed de / lhag $<$ zin pa'i ba tan tshib > pa'i rnal 'byor chen po'i lugs"

${ }^{726}$ Lamp 344.5-345.2: "lhag <zin pa'i ba tan tshib > pa'i rnal 'byor chen po'i lugs kyi / snod kyi 'jig rten ma bcos pa'i gzhal yas khang / bcud kyi 'jig (344.6) rten 'gro drug rang byung rdo rje 'od kyis sangs rgyas / khams gsum sku gsung thugs kyi bdag nyid la / nyon mongs pa (345.1) chos nyid du bskyal btab // sdug bsngal bde ba chen por lhun gyi grub / sgrib pa ye shes su rang 'bar / skye shig yung (345.2) drung tsher gyur / rgas rgud 'pho 'gyur med pa'i ngo bor ye sangs rgyas pa la / de 'phral? du ba tsal du ci yod //"

${ }^{727}$ Lamp 352.1-352.2: "de la bden <ku ku ra tsa dang shi ri sing ha'i /> pa chen por (352.6) lta ba'i lugs"

${ }^{728} \mathrm{SM}, 352$

${ }^{729}$ Lamp 353.2-353.3: "shan pa smad 'tshong mtshams med snga //yongs su rdzogs pa chos kyi rtsi // bde ba che la gzhan med do //"

${ }_{730}$ Lamp 356.5-356.6: "Ihag pa'i rnal 'byor <jam dang la bshes gnyen gyis 'i / > chen po pas // gnyis su med par lta ba ni //"
} 
does not exist]. When [you] think about it, it manifests everywhere. There is non-duality between existence and non-existance.,"731

\section{8- The view of the Great Nature of the Seminal Essence (of Rajāhasti) ${ }^{732}$}

As in the view of the Great Self, here, we find Atiyoga expressing the non-duality of all phenomena by using images or metaphors that indicate unity. In this case, the unity is expressed using the image of the "thigle" (Ti. thig le) or "seminal nuclei," a key element of the subtle body that it is reinterepreted by the Great Perfection $\operatorname{tradition}^{733}$ as having six different aspects: 1) The Seminal Essence of the Expanse (Tib. dbyings kyi thig le); 2) the Seminal Essence of the Completely Pure Expanse (Tib. dbyings rnam dag pa'i thig le); 3) The Seminal Essence of Reality itself (Tib. chos nyid kyi thig le); 4) the Seminal Essence of Primordial Wisdom (Tib. ye shes chen po'i thig le); 5) the Seminal Essence of the All Good (Tib. kun tu bzang po'i thig le); and 6) the Seminal Essence which is spontaneous (Tib. lhun gyi grub pa'i thig le).

\footnotetext{
${ }^{731}$ Lamp 357.1-357.2: "byang chub sems kyi ngo bo kyi ngo bo brtags na med la / bsam na thams cad du snang bas yod pa dang med pa gnyis med /"

${ }^{732}$ Lamp 369.3-369.4: "la < lngas thu gong? tsa nyas sti'i / mtha' dang bral ba'i gtan tshigs rnams /> la dag thig le chen po cig gi rang bzhin du lta ba'i (369.4) lugs ni /"

${ }^{733}$ Kongtrul defines is as: "The vital essences (thig le, bindu/ tilaka) give the body vitality and radiance and are the seeds of great bliss. They are contained within the channels and supported by the winds. The body has both red and white vital essences, the red being predominant in females and the white in males. The principal seat of the white is at the crown of the head; that of the red, at the navel. The vital essences have both refined and residual parts," in Jamgon Kongtrul's Systems of Buddhist Tantra: The Treasury of Knowledge Book Six, Part Four (Ithaca, N.Y.: Snow Lion Publications, 2005), p. 226. Germano offers a definition that emphasizes the creative nature of the seminal nuclei, essential for the reinterpretation of this concept in the Great Perfection tradition: "The term 'seminal nuclei' refers to a wide range of high-energy dimensions both material and non-material, and in its lower order aspects particularly connotes the regenerative fluids, i.e. the father's sperm and the mother's egg. At times they are referred to as 'vibrancy' or 'vibrant quintessence' (Dwangs Ma), 'element' (Khams), or 'enlightened mind' (Byang Chub Sems): 'vibrant quintessence' connotes their extremely subtle and lucent nature as dynamic high-energy potential; 'seminal nuclei' emphasizes their character as creatively organizing generatrixes and in particular their role in sexuality as the source of 'bliss', optimal processes, and the tremendous creativity of conception; 'element' indicates how they are the principal 'element' or 'source' in our body's energetic processes; and 'enlightened mind' emphasizes their crucial role in contemplation, as well as their identity as the high-energy expression of the enlightened nucleus within the heart via which the gnostic intelligence of the Universe continues to in from our body/mind, and which will radiate from within when the dark clouds of alienation have been dispersed." In David Germano, "Poetic Thought, the Intelligent Universe, and the Mystery of Self: The Tantric Synthesis of Rdzogs Chen in Fourteenth Century Tibet" (University of Wisconsin, Madison, 1992), 835.
} 
9- The view of the actual ground of all phenomena (of Garab Dorje, King Dhahenatalo, and Nup Sangyé Yeshé $)^{734}$

Nupchen defines this view as "especially unmistaken," 735 since the "suchness of all things is unfabricated and unadultared, [that is why it is called] Atiyoga, the Great Perfection.",736 There is a clear sense that this last view encompasses or includes all of the others, making them superior to them all. ${ }^{737}$ The superiority of this view is not only indicated by the fact that is the last of the nine, but also by the fact that Nupchen's name is also attached to it.

The section on the views of Atiyoga concludes with another exercise on scholastic gymnastics in which Nupchen emphasizes the fact that the Great Perfection does not dwell on intellectual pursuits:

Therefore, the Atiyoga practitioners do not establish logical syllogisms, they do not engage in fine analysis, do not think, they do not actualize [thoughts], they do not investigate, they do not measure, there is nothing to do, nothing to establish. As for the natural state of suchness [the practitioner of Atiyoga] understands it [without trying to] understand it, finds it without searching it, accomplishes it without [trying to] accomplish it, sees it without looking at it, understands it without [trying to] understand it, obtains it

\footnotetext{
${ }^{734}$ Lamp 375.5-375.6 : "de la chos thams (375.6) cad gzhi ji bzhin <dga' rab rdo rje dang rgyal po 'da' ha na ta pho'i? zhed / ban chung rang gi 'dod byang kyang yin /> par lta ba."

${ }^{735}$ Lamp 375.6: "khyad par du'ang ma nor ba ste"

${ }^{736}$ Lamp 375.6-376.1: "khyad par du'ang ma nor ba ste / de ci'i phyir zhe na / dngos po rnams kyi de kho na nyid kha na ma bcos ma bslad (376.1) pa nyid pas a ti yo ga rdzogs pa chen po'o"

${ }^{737}$ Lamp 376.1-377.5: "de'i mtshan gyi rnams grangs ni yon tan gyi cha las snang ba grangs las 'das so // de kho na nyid (376.2) la dmigs 'dzin med pas / gza' gtad bral zhes bya ba yang grags / de la 'bras bu ril rdzogs pas lhun gyi grub pa zhes bya bar yang (376.3) grags / de kho na sdug bsngal ming med pas bde bchen po zhes bya bar yang grags / gzhan pa'i chos med pas bdag nyid chen por yang (376.4) grags / zla dang spros pa med pas thig le chen por grags / mtha'i chos med pas gnyis su med par yang grags // de nyid du thams cad du (376.5) gsal bas rang rang 'byung ye shes su yang grags / 'bras bu la re ba med pas mi rtsol ba'i phyir / bya rtsol bral ba zhes bya bar yang grags te / (376.6) de dag rtags tha dad kyang ngo bo la tha dad med pas / gcig kyang thams cad yin la / thams cad gcig pas / gzhi ji bzhin pa'i mtshan gyi rnams (377.1) grangs so // de lta bas na ngongs po rnams kyi de kho na nyid rtogs par bya'o // de tshul ji 'zhin zhe na / ye gza' gtad dang bral ba la gza' (377.2) gtad dang bral ba'ang med // ye bdag nyid chen po der lta ba'ang med // ye lhun gyis grub pa la lhun gyis grub par lta ba'ang med // ye gnyis su med pa la (377.3) gnyis su med par lta ba'ang med // ye bya rtsol dang bral ba la / bya rtsol dang bral bar lta ba'ang? med // ye bde ba chen po bde ba chen por lta ba'ang med // ye (377.4) thig le chen por lta ba la / thig le chen por lta ba'ang med // ye rang byung ye shes la / rang byung ye shes su lta ba'ang med pa'i phyir / dngos po rnams kyi de kho (377.5) na nyid ji bzhin pa'i chos la de nyid du'ang mi lta'o //"
} 
without [trying to] obtain it, clarifies it without [trying to] clarify it, and experiences it without [trying to] to experience it. ${ }^{738}$

What is remarkable though is that this exercise on negative rhetoric is followed by a mind-numbing series of lists that elaborate, define, and describe "suchness" (Tib. de kho na nyid) and all its characteristics from the Atiyoga perspective. There is a list of seventeen expressions that shows different aspects of "suchness,"739 a list of the fifty expressions, ${ }^{740}$ eight expressions and fourteen characteristics, ${ }^{741}$ thirty eight characteristics, ${ }^{742}$ and the seventy three characteristics

\footnotetext{
${ }^{738}$ Lamp 379.4-380.1: "de bas na shin tu rnal 'byor pas / gtan tshigs ma btsug // ma gzhig bas ma bsam / mngon du ma byas / ma brtags / ma dpyad / ma gzhal / de ci yang bya ba med par / ma bzhag par bzhag pa / ji bzhin pa de kho na nyid / mi rig par rig / mi rnyed par rnyed / ma bsgrub par grub / ma mthong bar mthong / ma rtogs par rtogs / ma thob par thob / mi gsal bar gsal / ma myong bar myong bar 'gyur ro //"

${ }_{739}$ Lamp 389.4-389.6: "tha snyad bcu bdun las kyang grol bar ston to / gang rag ma las pa / sems la gnas med pa / rten med pa chad pa ma yin / rtag (389.5) pa ma yin / spungs par ma yin / rgyu las ma byung / rkyen gyis ma bskyed / de las ma yin / gzhan las ma yin / de nyid ma yin / gzhan ma yin / rigs med pa / (389.6) rgyud med pa / mi 'po ba / mi snang ba / ngo bo med pa / ji lta ba bzhin du mthong ngo //"

${ }^{740}$ Lamp 389.6-391.5: "rnam pa gcig tu ji bzhin pa de kho na nyid de / tha snyad lnga bcu las grol bar (390.1) ston te / yang dpyad pa thams cad dang bral ba / mtha' dang <yod med rtags chad dang bral ba / / dbus <brtags pa med / $>$ mi dmigs pa / sgro <chad pa med pa / > (390.2) bskur med pa / blang <bzang ngan gnyis med / $>$ dor med pa / rgyu 'bras < ye 'bras bus lam pa'i $>$ las 'das pa / ye $<$ mthas ma reg pa / nas dag pa / ye nas zin <zin pa nyi shu / $>$ pa / (390.3) bya $<$ zin pa'i phyir $>$ ba med pa / rtsol ba med $<$ bya ba med pa'i phyir $>$ pa / bsgrub <bdag nyid chen po pas $>$ tu med pa / brtsom du $<$ ye grub pas 'phral dru / $>$ med pa / gzhan $<$ gdag nyid yin bas rag ma lus pa'i phyir $>$ (390.4) nas mi 'byung ba / gnyen $<$ de nyid la cis kyang zi lam gnon $>$ po med pa / byed <rtsom pa'i / $>$ po med pa / ma $<$ byed pa po med phyir $>>$ byas pa / ma btags $<$ tha snyad bral bas $/>$ pa / bdag < spyod yul bral ba chos dang gang zag / $>$ med pa / (390.5) ma bcos < gzhi ji bzhin pa'i phyir / $>$ pa / ma bslad <le bde ba chen po la log pa / $>$ pa de yin $<$ ril de kho nas / > pa / nges <mi bslu mi 'gyur / > pa / ma nor <nges pa'i phyir $>$ ba / ji (390.6) bzhin < bcos bslad med pa / $>$ pa / ma 'gags <ci lang shar bas / $>$ pa / ma skyes < ngo bo 'di 'drar med pas / pa / mi < dus gsum mi 'gyur bas / $>$ nub pa / mi <mi nub pa'i phyir / > rlag pa / mi snang (391.1) ba <yod med pas grol bas / $>$ ma byung $<$ ma snang ba'i phyir $/>$ ba / ma 'gro ba $<$ skad cig ma'i rgyud du med pas / ye nas $<$ dpal du na bus pa? $>$ gnas pa / kun la $<$ nal de kho na bas $/>$ khyab pa / ming med $<$ brjod pa dang bral bas $/>$ pa / (391.2) mtshan $<$ gzugs med phyir $>$ med pa / gzugs < dbyibs kha dog med pa / $>$ med pa / tha $<$ tshig gilam chad pa'i phyir $/>$ med pa / bltar $<$ shes pa med pa / $>$ med pa / gzung <ngo bo gang du yang snang la ma grub pas $>$ du med (391.3) pa / mtshon $<$ gzung du med pa'i phyir dpe la $/>$ du med pa / dpe $<$ de dang 'dra ba med phyir $/>$ med pa / chod $<$ gzung du $/>$ med pa / brtag $<$ blos $/>$ tu med pa / rtog ge las 'das < spyod pas ye grol / $/$ dpag $<$ blos $/>$ tu (391.4) med pa / bsam $<$ yid la $/>$ du med pa / bsam gyis $<$ bsam pa pos mu mtha' dang mtshan nyid bral $/>$ mi khyab pa / kun gyi 'byung gnas $<$ ril gyi yum pas $>>$ thams cad nas thams cad du (391.5) btang snyoms < spa ba'i dus / phyis kyi dus / rgyan la thun mtshams med /> chen? po / stong <yod med / $>$ pa nyid rig pa rang byung ba kho <ma 'gags rgyu rkyen med par gsal bas phyogs gzhan 'bang ngo $>>$ na'o //"'

${ }^{741}$ thams cad nas thams $<$ dus gnas skabs $>>$ cad du rig hs kyi mtshan $<$ kha? la rdzogs pa $>>$ ma med do / tha $<$ tshig am /> snyad med do / rnam (392.1) pa <ngo bo'i / > med do /yul med <sbyin pa'i / > do / 'jug <'jug par byed pa'i shis pa / $>$ pa med do / sangs rgyas < gung na med pas / $>$ med do / lungs bstan $<$ sangs rgyas med phyir $>$ pa med do / (392.2) nges pa rnyed $<$ don gzhan med pas $/>$ pa med do / thams $<$ dus $/>$ cad nas du byang chub $<$ gnas skabs ye chos sku bas $/>$ pa nyid do / snying <'bras bu nyid pas $/>$ po nyid do / de < ma nor ma bcos $>$ kho na nyid (392.3) do / yang <nges pa'i phyir / > dag pa nyid do / nges pa dam < yang dag pa nyid kyi phyir $>>$ pa nyid de / gzhan ma yin $<$ ril rang rig pa / > pa nyid do / skye ba med < rgyu rkyen bral ba /> pa nyid do / 'gags < cir lta bar snang ba /> (392.4)
} 
of "suchness." ${ }^{743}$ Nupchen pulls all of these lists from the Sütra of the Gathered Intentions, a text

he is very familiar with and of which he has written a lengthy commentary (i.e. the Armor

pa med pa nyid do / de bzhin < ma bcos pa / $>$ nyid do / ma nor < drang po pa / $>$ ba nyid do / chos < phyogs ris med pa / nyid do / chos <mu mtha' med pa / $>$ khyi dbyings nyid do / bsam < bsam pa po'i blo / $>$ gyis mi (392.5) khyab pas bsam du med pa nyid <ma bsam na khyab pa de yin $/>$ do / yang <bskyed du la bzlas pa med pa $/>$ dag pa'i mtha' $<$ ra thug pa / $>$ nyid do /

${ }^{742}$ (392.6) mtshan nyid bcu bzhi dang ldan par yang bstan to // yang de nyid las mtshan nyid dang rang bzhin med pa'o <ngo ba 'di 'drar /cir yang / bdag nyid mi phyed bas > / mi dmigs < rang rig nyid du grub pas /> (393.1) pa'o // goms par byas pa'o // nges par brtags pa'o // yongs <ngon de nyid las ma 'das / $>$ su dpyad pa'o / cir $<$ ji ltar brtags pa ltar / > yang snang ba'o / min <ma nor bar chad mi bsu /> par (393.2) nges pa'o / kun <bams cad pa'i phyir $>$ tu byung ba'o / thams < gang yang la bkol bas $>$ cad 'dus pa'o / yongs < ril 'dus phyir $>$ la khyab pa'o / yongs <cir yang 'byung bas /> gyis skye ba'o / (393.3) rnam < gang yang lhan mi gcig pa / $>$ par dag pa'o // gang $<$ mtshan nyid med pas / > yang ma grub pa'o / khyab pa < par byas pa /> med pa / ma khyab <ril byung thebs pas / > pa med pa / mtho $<$ sangs rgyas sems can dbyer med pa / $>$ (393.4) dman med pa / che < mtho dman med phyir / $>$ chung med pa / bzang $<$ che chung med phyir kyn bzang yul / $>$ ngan med pa / yangs dag $<$ ltos pa med pa $/>$ med pa / rgyu $<$ las mi skye ste snying po nyid pas $/>$ 'bras med pa / (393.5) pho <'i rigs su 'chad pa $/>$ mo med pa / rigs $<$ ctshan bzhi cir yang snang pa / $>$ brgyud med pa / gzugs < dbyings dang kha dog bral ba $/>$ med pa / < las dang rnam par smin pa med pa / ? ma dmigs pa / > phyi dang nang med pa < phyi nang rang rig tu gsal bas / $>$ pa / (393.6) skye $<$ da dpral du / ba med pa / 'pho 'gyur med < gnyin po bral ba / $>$ pa / mun snang < ye shes nyim brdal ba / $>$ med pa / snga phyir $<$ dus gsum rgyud grol ba / $>$ med pa / mtha' dbus med pa < brgyad dang bzhi dang gnyis grol bas $/>/$ (394.1) bdag gzhan $<$ du snang ba sems nyid pas $/>$ med pa / rtsol sgrub med pa <'bras bu gru 'dzin pas / $/$ blang dor <bzang ngan med pas $>$ med pa / ngang gis ma bcos pa $<$ ngang bzhin gtan tshigs byed pas / $/$ (394.2) yong gi 'od gsal < cis kyang ma sgrib pa $/>$ ba / ma bslad $<$ phyin ci log byang chub pas $/>$ pa / ma byung $<$ phro med pa $/>$ ba $/$ ma $<$ ma byung ba yin pas $/>$ skyes pa yin no /

743 bka' stsal pa / byang chub kyi snying po zhes gang la bya / gsol ba / bshes gnyen dam pa / byang chub kyi snying po ni / sangs (394.5) rgyas kun gyi dgongs pa dam pa la bya'o // bka' stsal pa / skyes bu dam pa / dgongs pa dam pa zhes gang la bya / gsol ba / thams cad kyi rang bzhin gang lags pa de kho na nyid do / bka' (394.6) stsal pa / thams cad kyi rang bzhin la gsang sngags zhes bya / gsol ba / thams cad kyi rang bzhin gang lags pa de ni / gang gis kyang ma mthong / mi < mthong du med pas bcad? man chad / rtags / (395.1) spyod <dmigs par byed pa thams? kyi / yul du ma gyur / smrar < rang rig pas dmigs su med phyir / $>$ med pa / brjod $<$ mtshan nyid ma nges pa / $>$ pa las 'das pa / bsam $<$ brjod pa'i lam chad de brjod pa mi thebs $>$ du med pa <yid la byar med pas $>>$ bsam (395.2) gyis mi khyab $<$ mu mtha' med pa'i klong / $>$ pa / brtag par dka' zhing < gting shin tu zang ba / $>$ bstan $<$ gzhan la 'di 'ang zhes $/>$ par dka' ba'i phyir logs so // zhes 'byung / yang bka' stsal pa / snying (395.3) po byang chub ji ltar snang / gsol ba / snying po byang chub ni skad cig kyang snang mi srid lags so / bka' stsal pa / ci gang du yang mi snang ngam / gsol ba / ji ltar bltas pa de ltar (395.4) snang lags so // bka'i stsal pa / de ji ltar yongs su? snang // gsol ba / 'di lta ste / kun $<$ de kho na nyid des / 'di kho na yin par 'dzin / > la khyab pas snang ba med pa lags so / < snying po byang chub de / $>$ (395.5) gang yang ma sbas ma mthong ba lags $<$ kyang lta byar med par ma mthong $/>$ so / ye nas $<$ bdag nyid yin pas / mig gi mi mthong ba 'dra / $>$ ma bral < kyang / $>$ ngo ma shes pa nyid do / brtags < blos $/>$ na ma mthong cir ya (395.6) snang ba nyid < ngo bo 'di 'drar / rtogs ma rtogs pa tha dad du'ang $>$ do / sna tshogs $<$ de ltar ma ba' grol bas yod stong gi $>>$ snang yang dngos po med pa nyid do $/<$ 'khor bar $/>$ bskal bar 'khyams $<$ byang chub sems yin phyir $/>$ kyang stor $<$ ba dang $/>$ bral $<$ ba $/>$ med pa (396.1) nyid do / sna $<$ bag tshogs $/>$ tshogs bgo yang 'gyur ba med $<$ ngo bo de'i dbang pa nyid do / $/ /$ rdul tsam cha med par snang srid khyab pa ni / <ngo bo bzung na / thams cad byang chub sems yin phyir / ngo bo med gnyis kabs ma gyis mi khyab pa mi 'gog /> (396.2) stong pa nyid las / sna tshogs 'byung ba nyid do / dngos gzhi med par cir yang brtags pa nyid < snying po byang chub rang gi / 'di yan bya ba med pa / ming ci btags pa / gud gas 'bras bu la / > do / (396.3) brtsal gnas med par cir bsgrubs 'grub pa <rab 'bring dngos grub tha dan? du /> nyid / gzugs dang mtshan ma med par cir bltas <ma'i ngo bo ma ba ma bral ba ltar $>>$ snang ba nyid $<$ ngo bo shes bya $/>$ do / (396.4) cir yang med par cir rig pa nyid $<$ mtsho dwangs bar skar bzhin $>$ do / khyab brdal 'bu chub gcig < gi mtha'las grol / > mtha' yas par nyid < rang snang $>$ do / kun bral nyag gcig ji ma spangs pa nyid do // phyi dang (396.5) nang med kun tu nang nyid do // mtha' yas byung yang zad pa med pa nyid $<$ de 'byung ba nyid yin phyir ro $/>$ do $/$ ma $<$ ngo bo $/>$ gzung $<$ ming du $/>$ ma btags $<$ thams cad la $/>$ gang du yang chags pa nyid do // gdos < gang dang yang lhan mi gcig pas tha snyad / de gang yang bkol ba ni med? do // ma spang bral bas ril de bzhin nyid kyi phyir / dngos grub dang dbos po'i chos / der gcig pas / tha snyad cing yang dngos po 
Against Darkness). What is remarkable in this section is the extent to which Nupchen is attempting to present the unique view of Atiyoga and its mistrust of language, while, at the same time, he is engaging in a painstaking scholastic exercise of defining it. He attempts to cover all possible linguistic aproaches to what it is, by his own definition, undefinable, inexpressible. It is within that tension that the early Great Perfection seems to thrive and, I would say, struggle. Nupchen is trying to define the new (Atiyoga) with the tools of the old (Mahāyoga, Chan). He is creating a new doctrinal and soteriological space (a new vehicle) within the old landscape of traditional Buddhism. He tries to present the simple doctrine of Atiyoga (i.e. no doctrine, no //> (396.6) pa med par rtag par (397.1) rtag par lhung ba nyid do / 'degs pa < ra byed pa / chos nyid kyis / rad rig 'phyo /> me par mkha' la 'gro ba nyid do / yan < pa'i ril ba ril / > lag med par sa rnams bgrod pa nyid do <'gro 'ong med $/>$ do / gar yang (397.2) ma g-yos kun tu < ril yin phyir $/>$ phyin pa nyid do / bskyed $<$ gro ba med $/>$ pa med par thogs $<$ rang rig pa skad cig la $>>$ med myur ba nyid $<$ thams cad du khyab bo $/>$ do / tha dad du spros kyang $<$ ngo bo $>$ gcig las ma g-yos pa (397.3) nyid do // gcig las ma g-yos <yul la / $>$ sna tshogs $<$ par $>$ snang ba nyid do / thams $<$ snying po byang chub ji bzhin bder $>$ cad du 'jug pas lam nyid $<$ ying yin $/>$ do $/$ gang yang $<$ snod bcud $/>$ ma spangs pas (397.4) 'khor ba nyid $<$ gang yin $/>$ do / ma shes $<$ don nyid $/>$ 'khrul pas sems can no // chu bo bzhi $<$ skye rga na 'bi $>>$ bsgrol ba'i gru nyid $<$ ma bsgral thar pa $/>$ do / rnam par bskyod $<$ sams cad du phyin pa $/>$ pas 'gro ba nyid do / (397.5) dmigs pa med pas byang chub bo // rnam pa sna tshogs < rang rig cir yang /> pas sems nyid do / kun la $<$ shes bya $/>$ mkhas pas shes rab bo $<$ ril gsal bas $/>/$ thams cad gsal $<$ de bzhin nyid du $>$ bas (397.6) bas ting 'dzin no / ma < gang nas kyang $>$ bgrod par phyin $<$ gzhi $/>$ pas gnas nyid do / zla $<$ mgran du bya ba $/>$ med pas rab nyid $<$ chos sku $>$ do / ngo $<$ sku dang ye shes kyi ngo bo $/>$ mtshar bas mchog nyid do / rnam $<$ de dngos po kun la byad bar du / > par 'phags pas phul nyid do / dbang < thob par bya med de de'i $>$ (398.1) dang gnyen po $<$ yang $>$ yod pas bla na med pa nyid do // gting $<$ mtha' $>$ mi rnyed pas dpar $<$ tho 'di 'drar $>$ tu med pas na gsang ba nyid do // 'phrabs mi gsal $<$ ngo bo ba thung dka' ba'i phyir $>$ (398.2) ba nyid $<$ lta ba po la $>$ do // thams cad 'byung $<$ 'khor ba dang mya ngan las 'das $/>$ bas chos so $<$ ngo bo mtha' gang du yang $>/$ mi 'gyur bas de kho na nyid do // go $<$ 'bsgrub bya chos sku gnyis med byeng $/>$ 'phang (398.3) nyid pas byang chub $<$ pa la $>$ sems dpa' $<$ ba shes bu'o $/>$ nyid do / rgyun $<$ rtog rgyun ma spang $>$ song khyab pas < ril la sdums? / > sangs rgyas nyid do / gzhir <chos thams cad 'byung ba'i $>$ gyur pas rca ba nyid do / (398.4) thams cad bskyed $<$ rgyal ba ril dang lam chos $/>$ pas yum nyid do // de la byung bas yab < rgyal ba ril bzhi $>$ nyid do / gdung? brgyud 'dzin < dus gsum du mi nub pa'i rgyal ba'i $>$ bas sras nyid do / rang byung bas dbang (398.5) bdag < sus kyang ma byas te rag ma lus pa / $>$ nyid do / de bzhin nyid pas gdung $<$ rgyud chad pa med phyir rang par gyi /> chen po nyid do / 'da' < de kho na nyid la 're log spyi tshugs gar 'dres kyang 'da' ba med /> bar dka' bas thugs (398.6) dam chen po nyid do / rnam < de kho na nyid dpe ril gzhung $/>$ par 'tsho bas srog nyid do / zad mi <yon tan thams cad du $>$ shes pas gter chen po nyid do //'dod pa grub $<$ lam pa'i $/>$ pas nor nyid do // (399.1) rgyun gyi snying rjes < gro ba'i / $>$ bya ba med pas dran pa nyid do // rnam par brjid $<$ lta bas mi ngoms mi 'gyur /> pas sku nyid do / smra brjod < brjod pa ril lhun kyis grub /> 'byung bas gsung nyid do / thams cad (399.2) mkhyen pas thugs < spyod yul med par rang gsal / > nyid do // 'dod rgyu 'byung bas $<$ gdul bya la bsam pa dang ma thun par / > yon tan nyid do // bya ba byed bas phrin las <mdzad par ma gyur med pas / nyid do / yul la (399.3) 'gro <yul gyi chos ril la son te gnyis med / > bas 'dod pa nyid do / de < de kho na $>$ nyid la spyod pas longs spyod chen po'o <spyod yul med parbdag nyid du / > rgyur gyur pas <thams cad kyi $>$ yo byad chen po'o / dgos (399.4) pa tshang bas tshogs chen po'o / bya $<$ ba dang $>$ rtsol $<$ ba'i rgyu $>>$ med pas don thams cad 'grub pa'o / sna <cir yang bltas pa ltar shar $>>$ tshog 'khrul pas cho 'phrul chn po'o / mtshan <sku'i /> mar byung (399.5) bas phyag rgya $<$ ji snyed du $/>$ nyid do / < gang yang ma rdzogs pa med do $/>$ gzhan nas mi tshol $<$ lam pa'i 'bras bu $>$ bas bsnyen pa nyid do //rang las byung bas nye ba'i bsnyen pa nyid do // snying po nyid pas bsgrub (399.6) pa nyid do // 'dras bu nyid pas bsgrub pa chen po'o // zhes gsungs pa'i don gyis snying po byang chub ji bzhin pa de kho na nyid ni / 'khor ba dang / lam gyi chos dang / 'bras bu dang / (400.1) thams cad du yang rang shar la cir yang gnas pa med par bstan to / 
practice, etc.) using a very complex and redundant discourse. The Lamp, in many ways, shows the growing pains of a new and emerging Buddhist tradition that is trying to define itself. It is mind numbing to comb through the various lists after having presented a view that does not rely on words. Here we can see the constant tension that some Buddhist views such as Chan and Atiyoga have to constantly negotiate, denying language any foundation, only to use language to present their ideas and defend themselves! 


\section{The Great Perfection's Contemplative Practices}

The approach of the Great Perfection to contemplative practice reflects the tradition's philosophical views of naturalness and effortlessness. Nupchen divides this section into the methods to settle the body (Tib. lus kyi bzhag thabs), and methods to settle the mind (Tib. sems kyi 'jug thabs).

The methods to settle the body reject any form of prescribed physical posture. If all the other Buddhist traditions discussed until now accept the importance of sitting with legs crossed, spine straight, eyes focused on the tip of the nose, etc. as the basic preliminaries for meditative practices, in Atiyoga "the body does not have to settle in a contrived position because [the practioner] is free from attachment to the physical body. [In Atiyoga] there are not necessary methods to settle the body." 744 There is not a rejection, per se, of physical postures, but there is a rejection of any attachment to it. ${ }^{745}$

In the methods to settle the mind we see the clear and distinctive gnostic approach that the Great Perfection tradition has towards meditative practice. Here, there are no physical postures, no breathing exercises, no focus on a single point to calm down the mind that will lead to a special insight (Skt. vipaśyanā) into the nature of reality. Instead it is the knowledge, and therefore the clear gnostic bend of the tradition, that there is no actual practice that is the practice itself:

\footnotetext{
${ }^{744}$ Lamp 403.4: "lus bcos la bzhag pa med de / lus 'dzin pa'i 'du shes dang bral ba'i phyir / lus la 'dug thabs nges par bzhag pa med do //"

${ }^{745}$ This section also discusses briefly the position of Atiyoga towards the retreat place, which reinforces the same lack of attachment to the physical location where meditative practice takes place, just as it did with the rejection to any attachment to physical postures to practice. If all physical postures are equally valid for meditation, all places are equally qualified to be retreat places. In a way, what Nupchen is saying is that the world should be our place of practice, and all of our physical activities should be our "postures" of practice. A similar discussion on the different understanding of the retreat place by the various Buddhist traditions already took place in chapter two of the Lamp, which I have discussed in chapter three of this dissertation.
} 
It is (the knowledge iself) that this is the entrance without entrance, and that suchness as it is has no reference point [for the mind to focus on]. Since the self is as clear as the essence of the great non-conceptual [state], the knowlege of the lack of entrance it is held as the entrance itself. ${ }^{746}$

What should be clear though is that Nupchen seems to be prescribing not a complete denial of practice, or of particular contemplative methods, but instead is calling for a rejection of any attachment to practice or methods. This is what, from his perspective, sets the Great Perfection tradition apart from all other traditions, something that he will discuss at length at the end of the chapter.

Nupchen then outlines eight different methods of contemplative practice associated with various Indian and Tibetan teachers. As we have seen several times in the Mahāyoga and the Atiyoga chapters, the original text does not attribute these methods to any particular master, and it simply introduces each one of them with "according to one approach" (Tib. rnam pa gcig tu). It is only in the intelineary notes that the names are attached to each of the views. In fact, most of the methods do not have a name, and are brief poetic descriptions of an approach to practice. All descriptions begin with a quote from one of the scriptures that formed the early canon of the Great Perfection, the so-called Eighteen Texts of the Mind Series (Tib. Sems sde bco brgyad). ${ }^{747}$

\footnotetext{
${ }^{746}$ Lamp 405.6: “sems kyi 'jug thabs ni / 'di 'jug pa med par 'jug pa'o / < shes pa nyid /> de ni ji bzhin pa de kho na nyid de la / gang yang ma dmigs te / bdag nyid mi rtog pa chen po'i ngo bor gsal bas / da 'jug tu med par shes pa nyid zhugs par bzhed do //"

${ }^{747}$ We will discuss this literature in the section, "The Lamp and the Formation of the Great Perfection Literature Canon." in the latter part of the chapter.
} 
The eight methods are:

1. The method of the realization of the expanse of Atiyoga meditation (of Ācārya Selwa Gyal) ${ }^{748}$;

2. The method of resting in quietude (of the nun Ānānda) ${ }^{749}$;

3. The method of the Great Meditation [which allows the pratitioner] to abide in the Great Perfection by settling the mind (of Ācārya Selwa Gyal) ${ }^{750}$;

4. The method which is free from action and by which the practitioner's mind rests in its natural state (of Buddhagupta) ${ }^{751}$;

5. The method that is free from all extreme views (of Mañjuśrīmitra) ${ }^{752}$;

6. The method by which the practitioner settles the mind in meditative equipoise (of Vimalamitra) ${ }^{753}$;

7. The method in which the practitioner is free from any object of meditation (of Vairocana) $)^{754}$;

8. The method of meditation in which the practitioner settles into the sphere of the expanse of the unmistaken principle (of Garab Dorje) ${ }^{755}$.

\section{The Superiority of the Great Perfection Tradition}

After having outlined the various gnostic approaches to practice in the Atiyoga tradition, Nupchen proceeds to differentiate the Atiyoga approach by criticizing all other Buddhist meditative practices. We have seen how this is part of the doxographical genre: a particular Buddhist tradition is not only defined by its own set of doctrines and practices, but by how those views and practices are different from those of other traditions. At the end of each chapter, after

748 (412.3) rnam gcig tu a ti < a tsa rya? gsal ba rgyal gyis bzhed /> yo ga'i bsgom pa klong phol ba ni /

${ }^{749}$ Lamp 412.5-412.6: "rnam gcig tu < dge slong ma kun daga' ma'i bzhed /> lta ba (412.6) a ti yo ga'i sgom mnal du phebs ba ni //." Here I have followed Esler's suggestion of translating (mnal-du phebs-pa) as "settling in quietude," in Esler, "The Exposition of Atiyoga in Nubs-Chen Sangs-Rgyas Ye-Shes' bSam-Gtan Mig-Sgron,” p. 114.

${ }^{750}$ Lamp 413.3-413.4: “yang rnam gcig < gsal ba rgyal gyi bzhed cig / tu rdzogs pa chen po la gnas (413.4) ba'i sgom chen pas blo 'di bzhin du bzhag ste /"

${ }^{751}$ Lamp 414.1: "rnam pa gcig tu / <'bu ta kag ta'i bzhed /> [...] bya ba med pas rang bzhin bzhag pa med par gsal (414.4) na bzhag pa ste thabs dam pa'o"

${ }^{752}$ Lamp 414.4-414.6: "rnam pa gcig <'jam dpal bshes gnyen gyis bzhed $>$ [...] lhun gyis rdzogs pa'i ye shes ji (414.6) bzhin pa ni / phyogs ris thams cad dang bral ba la"

${ }^{753}$ Lamp 415.3-416.3: "rnam gcig < bi ma la mi tra'i bzhed $>>$ tu nam mkha'i rgyal po las / [...] mi rtog / mi len / mi 'dod mi bsgom pa la mi dmigs shing / mi sgom bya ba rang tsam du yang / dmigs pa dang dran bag med par gsal ba ni / blo chos nyid las ma g-yos pas / mnyam par bzhag ces bya'o //

${ }^{754}$ Lamp 416.3-417.2: "rnam gcig < bai ro tsa na'i bzhed /> tu / lhag pa'i rnal 'byor pa rnams blo 'di ltar bzhag ste / [...] bsgom pas bsgom pa'i rtogs 'dzin med la / dmigs pa ma dmigs pa'i rtogs pa'i rtogs 'dzin med pa / goms par bya ba ma 'gags (417.2) bya rgyu med de / de ni thabs mchog tu gyur pa'o //"

${ }^{755}$ Lamp 417.2: "rnam < dga' rab rdo rje'i bzhed /> gcig tu bsgom pa'i don ma nor ba'i klongs dkyil nas bzhag na 'di ltar bzhag ste /" 
having presented the doctrines, contemplative pratices, ethics, and soteriological goals of each tradition, Nupchen has always looked back to also outline their main differences. At the end of the Sudden chapter, Nupchen describes the differences of Chinese Chan with the Indian Gradual system. At the end of the Mahāyoga chapter, Nupchen outlines the differences of that system with the Chinese Sudden approach. Now, in the presentation of what Nupchen considers the final vehicle, he outlines the differences and superiority of the Great Perfection vs. all other Buddhist traditions. What is remarkable, though, is that Nupchen is quite comprehensive, and does not only refer to the previous three vehicles, but points out the problems in the contemplative approach of the Śrāvaka, Pratyekabuddha, Yogācāra, Yogācāra-Mādhyamika, the gradual and sudden approaches, the inner or secret tantras, and Anuyoga.

We also find a final attempt at the end of the chapter to differentiate the Great Perfection tradition. In both sections, Nupchen puts a special emphasis on making clear the differences between the Chinese Chan tradition, Mahāyoga and the Great Perfection, something that Nupchen has also done throughtout the text at various key moments. This reflects the perception problem that the tradition had from its very early beginnings, mainly as a Tibetan version of Chan, or as a development of Mahāyoga. As for the main difference with Chan, Nupchen points out that while the Chinese tradition shares a similar rhetoric to the one used by the Great Perfection, Chan reifies the notion of the unborn ground, the product of a subtle form of conceptualization, as well as not being completely devoid of effort. Mahāyoga and Atiyoga share the same principle, according to Nupchen, but they still practice with effort, which makes it inferior to the Great Perfection. Nupchen also details some other differences with other Buddhist philosophical traditions, but these are not as central to his discussion. 
From the perspective of the foufold structure of Buddhist vehicles created in the Lamp, the inclusion of other Buddhist vehicles, like the Śrāvaka and Pratyekabuddha, and Anuyoga, together with philosophical traditions like Yogācāra and the Yogācāra-Mādhyamika, seems to undermine the framework he has created to insert the Great Perfection as a new Buddhist system. But I think that what Nupchen is acknowledging is that the bounderies between vehicle (Tib. theg pa), doctrine (Tib. lta ba), way of practice (Tib. tshul), etc. is not a rigid and stable one, and that the Buddhist tradition is always playing with those categories in order to articulate new ideas, new practices, new systems. What Nupchen does in this final overview of contemplative practices in Buddhism as a whole is to bring together a broader understanding of the tradition than the one he has discussed so far (he includes vehicles and philosophical systems he has not discussed before) to establish the superiority of the Great Perfection tradition beyond the basic framework proposed in his own text.

The Conduct in Atiyoga (spyod pa)

Once he has done that, he establishes a general code of ethics, of action, for the Atiyoga practitioner. This code of conduct is outlined in four main approaches to acting in the world:

1. The conduct of the great compassion (Tib. thugs rje chen po'i spyod pa);

2. The conduct that is free from effort (Tib. bya brtsal bral bas don dang mthun pa'i spyod pa);

3. The conduct of the great methods (Tib. thabs chen po'i spyod pa); 
4. The conduct which is spontaneoulsy perfected (Tib. lhun gyis rdzogs pa'i spyod pa'o).

What we have here is a general framework in which the philosophical views of the tradition are embedded into an ethical outlook of the world. This is not an ethical view that depends on rules and regulations, such as the ones found in the Vinaya, but on an outlook of the world that makes no distincitions between samsara and nirvana, in which all actions require no effort, in which all behavior is already spontaneously perfected. The ethical perils of such an attitute seem to warrant placing as the first type of conduct one that emphasizes compassion, but also adding a second set of ethical guidelines for to regulate the conduct of the body, speech and mind. This last set skews towards a conservative ethical approach, suggesting that the practitioner remains in a solitary place for practice, restrain from eating excessively, use kind words in his/her interactions with others, mantain mental focus, and stay away from distractions.

\section{The Result of Atiyoga (Tib. 'bras bu)}

Finally, Nupchen describes the soteriological result of Atiyoga practices. As he did in the Mahāyoga chapter, Nupchen uses the experience of the "three warmths" (Tib. drod gsum) to explain the various stages of realization. The experience of warmth, as well as that of bliss (Tib. dga' ba), reflects the Mahāyoga obsession with the body, and what Germano has described as a "move towards felt tactile sensations (especially sexual bliss and sensations of warmth) rather than exclusive reliance on our capacity for vision."756 These experiences of warmth are the

\footnotetext{
${ }^{756}$ The full quote says: "Correspondingly [tantra's sexual symbolism] mark[s] a move towards felt tactile sensations (especially sexual bliss and sensations of warmth) rather than exclusive reliance on our capacity for vision. There is
} 
result of the upper and lower door practices of the Perfection Stage that we have already discussed in this chapter. ${ }^{757}$ The fact that Nupchen uses the experience of warmth to describe the various stages of realization of the Atiyoga tradition indicates the close connection between the Great Perfection and Mahāyoga, something that Nupchen himself seems to acknowledge when he writes: "As for the experiences [of warmth in Atiyoga], they are related to the ones shown in the Mahāyoga [chapter]."758

The various stages of warmth also result in various signs and visions, something that Nupchen has discussed in some detail for each of the other traditions. In the Gradual tradition, for example, we saw how Nupchen quoted from the Mahāratnakūta Sūtra and described a series of one hundred and eight dreams and visions, product of the succesful practice of the practitioner.

thus a shift towards embodiment and processes internal to our body, with sexuality involving intensely tactile felt presences in contrast to vision, the coolest and most metaphysical of our senses. One can thus only fully embody and assimilate these transformations by coming to terms with one's body, a space that somehow resists the influence of the detached image." In Germano, Mysticism and Rhetoric in the Great Perfection (rDzogs Chen), p. 54.

757 Jamgon Kongtrul describes the experiences of warmth as follows: "Kongtrul explains that the pristine awareness of experiential warmth (drod kyi ye shes) is that of a yogin (or yogini) on the tantric path of preparation of the Highest Tantra. Such a yogin has experienced the phase of completion and thus continually engages in the metaphorical pristine awareness. He has acquired proficiency in the states of bliss, clarity, and non-conceptuality, as indicated by the signs of warmth. The pristine awareness at this stage is known as experiential warmth because it serves as a direct cause that leads to the path of seeing. The signs indicating warmth are lesser, middling, and great. The lesser signs are that a yogin is no longer subject to fear, madness, sorrow, pain, or frustration, and cannot be injured; and the middling, that he is not affected by strong desire, hatred, ignorance, or other emotions that arise through the force of major circumstances. The great signs include clairvoyance and other miraculous powers. These signs concord with the stages of warmth, peak, and acceptance explained in the Way of the Perfections. Once the yogin has experienced these signs, if he enhances his realization through the complex, non-elaborated, and simple tantric practices, he will swiftly reach the path of seeing (Commentary on [Rangjung Dorje's] Profound Reality Rumtek, Sikkim: Dharma Charkra Centre, 1981, ff. 155a3-b3). The signs that indicate experiential warmth (drod rtags) are usually understood as those that indicate the yogin's maturity for special tantric practices that accelerate spiritual accomplishment. As taught in the second book of the Hevajra Tantra, Fear, madness, and likewise sorrow and pain, Frustration and injury, Great desire, hatred, and ignorance, do not obscure the adept. In addition, Tibetan masters speak of three degrees of warmth, the best being the understanding of reality; the middling, the leveling of the eight worldly concerns; and the least, the ability to demonstrate magical feats (Kongtrul's Commentary on the Hevajra Tantra, f. 93a1-5).” In Jamgon Kongtrul's Buddhist Ethics (Ithaca: Snow Lion Publications, 1998), p. 494, n. 245.

${ }^{758}$ Lamp 463.1: “nyams ni rnal 'byor mah'a yo ga'i skabs su / bstan pa'i sems du yang rung ngo //.” Meinert and Esler have also noticed this close connection in the presentation of the results of Mahāyoga and Atiyoga practices. See Carmen Meinert's “Chinesische Chan- Und Tibetische rDzogs Chen-Lehre: Eine Komparatistische Untersuchung Im Lichte Des Philosophischen Heilskonzeptes 'Nicht-Vorstellen’ Anhand Der Dunhuang-Dokumente Des Chinesischen Chan-Meister Wolun Und Des Werkes bSam Gtan Mig Sgron Des Tibetischen Gelehrten gNubs Chen Sangs Rgyas Ye Shes" (Rheinischen Friedrich-Wilhelms-Universität, 2004), pp. 278-281. See also Esler's "The Exposition of Atiyoga in Nubs-Chen Sangs-Rgyas Ye-Shes' bSam-Gtan Mig-Sgron,” p. 121. 
In the Atiyoga tradition, we see similar results, but if in the Gradual tradition those visions were mostly of the Buddha or of symbols that represented the Buddha (stūpa, scriptures, etc.), now the visions reflect the central tantric identification of the practitioner with the Buddha and s/he can envision him/herself as a Buddha teaching to other Buddhas, or seeing the whole universe in the palm of his/her hand. The practitioner, concludes Nupchen, should not be attached to any of these visions, since they are all manifestations of suchness and should not be reified or conceptualized. 


\section{The Lamp and the Formation of the Great Perfection Literature Canon}

In this dissertation I have argued already how Nupchen's use of the doxographical genre has helped him create a space for the Great Perfection tradition as a separate vehicle, with its own philosophical views (Tib. lta ba), contemplative practices (Tib. sgom pa), code of conduct (Tib. spyod pa), and soteriological goals (Tib. 'bras bu). In this section I want to discuss how Nupchen articulates those ideas through the use of the emerging new scriptural tradition of the Great Perfection, the so-called Eighteen Texts of the Mind (Tib. sems sde bco brgyad). As we have seen in our description of the Atiyoga chapter, this literature is defined by its poetic bent and its negative rhetoric. This early literature will be subsumed in the 11 th century in the All Sovereign King (Tib. Kun byed rgyal po), with many of these eighteen texts becoming chapters of this larger tantra. But during Nupchen's time, this literature was neither completely defined and codified (as we will see, Nupchen is not clear about the actual number of tantras that are supposed to compose this early canon), nor had this early literature been incorporated yet into a larger tantra. We see this literature, then, in its very early stages. My goal in this chapter is to argue for the role played by Nupchen in offering legitimacy to this new textual tradition by inserting it into the larger framework of Buddhist literature. In the Lamp, Nupchen enhances the prestige and credibility of this literature by using it to argue the superiority of the Great Perfection ideas versus those expressed in the scriptures of other Buddhist traditions. If the tradition emerged from certain ritual and contemplative developments of the Mahāyoga tradition, as we have seen in the introduction to the Great Perfection section of this chapter, and some of its rhetoric and doctrinal points of view may have been influenced by Chan, Nupchen's use of the eighteen texts of the mind allows him to sever that early influence by creating clear doctrinal and scriptural bounderies between Atiyoga and the other traditions. As we will see, different 
scriptures do not only mean different ideas, but a different line of transmission from that of the Gradual, Sudden, and Mahāyoga traditions.

\section{The Story of the Eighteen Texts of the Mind}

Before I discuss the Eighteen Texts of the Mind in the Lamp, let me begin with the traditional account found in the early Great Perfection tradition of its transmission from India to Tibet. The story can be found in one of its earliest and most detailed forms in the Mask of Vairocana (Tib. Bairo'i 'dra 'bag chen mo), ${ }^{759}$ which Karmay summarized in his book, The Great Perfection, and that he dates as a 13 th century text with some parts of it probably older. ${ }^{760}$

In this text, King Trisong Detsen, who in a former life was born in India as a monk called Avadhuti and had practiced Atiyoga, realized that the Great Perfection is a teaching that transcends all other doctrines and that it should be brought to Tibet. In order to do that, he sends two monks to India, Vairocana and Lekdrup (Tib. Legs grub), who, once in India, meet with Master Shri Singha. We have already seen the names of Sri Simha and Vairocana connected to some of the Atiyoga views, but what the Mask of Vairocana offers is a narrative, a story of how these teachings and texts were transmitted from India to Tibet. The encounter between the Indian master Sri Simha and the Tibetan students Vairocana and Lekdrup is described as follows:

Every day they listened to the Secret Mantra teachings based on the result from the later seven scholars and others. Aid every night they listened to Shri Singha's explanations on the pith instructions of the effortless Great Perfection, the heart of the doctrine.

Inside his room Master Shri Singha put a clay pot on top of three big stones and surrounded it with a net. He sat inside the pot and had the opening covered with a big lid

\footnotetext{
759 The text can be found in the last volume of the Bairo'i rgyud 'bum (Leh 1971, Vol. 8, pp. 405-605). The list begins on p. 519.4 .

${ }^{760}$ Karmay, The Great Perfection (rDzogs Chen): A Philosophical and Meditative Teaching of Tibetan Buddhism, p. 18.
} 
on which a pan filled with water was placed. A pipe ran through a hole in the pot and crossed through a cleft in the wall outside of the house. At midnight, Vairotsana and Lekdrub listened outside as Shri Singha whispered the teachings through the tube. They each had on a big deerskin hood, carried loads on their shoulders, held walking sticks, wore their clothes backward, and had put on worn-out pairs of boots the wrong way around. Lekdrub wrote down the teachings in the waning moonlight with white goats' milk, while Vairotsana fully understood them by a mere indication and perfected the doctrine in his mind.

As a sign that the doctrine would come to Tibet, Shri Singha taught Cuckoo of Awareness (Tib. Rig pa'i khu byug)! To express that everything is perfect, he taught Shaking of Great Power (Tib. rTsal chen sprugs pa). To express the meaning of meditation, he taught Six Seminal Nuclei (Tib. thig le drug pa). To express the conclusion of the view and conduct of all the vehicles, he taught Soaring Garuda (Tib. Khyung chen lding ba). To show the superiority of Ati over the other vehicles, he taught the view of NeverWaning Banner (Tib. Mi nub rgyal mtshan). Then he asked, "Noble sons, are you satisfied?" And they answered, "We are overjoyed!"

Then, to show the unity of all philosophical views, he taught Wish-Fulfilling Gem (Tib. Yid bzhin nor bu). To show the greatness of the teachings and instructions, he taught Supreme Lord (Tib. rJe btsan dam pa). To indicate the need to recognize earlier and later flaws and qualities, he taught King of Conduct (Tib. spyi gcod rgyal po). To indicate the need to rely on the three types of knowledge, he taught All-Embodying Jewel (Tib. kun 'dus). These are the four minor teachings.

To indicate that all knowledge should depend on the teachings, he taught Infinite Bliss (Tib. dBe 'byams). To show that the fruition is included in the body, speech, and mind, he taught the Wheel of Life (Tib. srog gi 'khor lo). To indicate the need to depend on example, meaning, and symbol, he explained Commentary on Mind (Tib. yang tig rgyal po) and King of Space (Tib. nam mkha' rgyal po). These are the four medium teachings. Indicating how to help others through the provisional and definitive meaning, he taught Jewel-Studded Bliss (bDe ba 'phra bkod). To indicate the need of distinguishing all vehicles, he taught Universal Bondage (Tib. sPyi chings). To avoid the arising of logical contradictions, he taught Pure Gold on Stone (Tib. rdo la gser zhun = byang chub sems bsgom pa). And because the conduct and the precepts are the yogi's life-force, he taught Spontaneous Summit (Tib. rtse mo byung rgyal). These are the four greater classes.

To check whether a teaching is mistaken or valid, he taught the Marvelous (Tib. rmad du byung ba), and asked, "Are you satisfied with this?" They answered, "We are not satisfied yet. Please give us the tantras and oral instructions that the Buddha taught on these pith instructions!" Upon their request, Shri Singha explained the Eighteen Tantras with the pointing out instructions and asked, "Are you satisfied now?" Lekdrub, because he wanted to impress the king, said, "I am satisfied," and left. On the way (back to Tibet) he was killed by border guards and died at the age of forty-four. ${ }^{761}$

${ }^{761}$ In Palmo, The Great Image. 


\section{The Lists}

In this narrative in the Mask of Vairocana, the Eighteen Texts of the Mind (Tib. sems sde bco brgyad) we already can see the seeds of what became known as the Five Early Translations, attributed to Vairocana, and the Thirteen Later Translations, attributed to Vimalamitra. ${ }^{762}$ This list of texts is pretty standard compared with others found in later Great Perfection literature, although there are important differences. Within the five early translations we find the Six Seminal Nuclei (Tib. Thig le drug pa), taking the place of the Meditation on the Enligtened Mind (Tib. bYang chub sems bsgom pa, here with another common title for this text, the rDo la gser zhun). A common text found in many other lists, the Efficacious Meditation (Tib. bsGom don grub $p a$ ) is missing, but we find a text that does not usually make it onto the lists, the King of Conduct (Tib. sPyi gcod/spyod). The list as presented in the Mask of Vairocana is, then, as follows:

1. The Cuckoo of Awareness (Tib. Rig pa khu byug)

2. Dynamism in Action (Tib. rTsal chen sprugs pa)

3. The Six Seminal Nuclei (Tib. Thig le drug pa)

4. The Soaring Great Khyung (Tib. Khyung chen lding ba)

5. The Never Declining Victory Banner (Tib. Mi nub rgyal mtshan)

\section{Chung ba bzhi - the four small [texts/teachings]}

6. The Wish-fulfilling Gem (Tib. Yid bzhin nor bu)

7. The Sacred and Mighty Lord (Tib. rJe btsan dam pa)

8. The Universally Definitive Perfection (Tib. rDzogs pa spyi gcod (spyod)) here as sPyi gcod rgyal po

9. The All Encapsulating (Tib. Kun 'dus), as Kun 'dus rig pa

'bring po bzhi - the four middle (ones, texts, teachings)

10. The Infinity of Bliss (Tib. bDe 'byam)

\footnotetext{
${ }^{762}$ This division is implicitly stated through the presentation of the first five texts, which are those that later will be known as the Five Early Translations, and the The Four Minor, Medium, and Greater (or Major) works, which will be identified as the Thirteen Later Translations by Vimalamitra. The text will make those divisions explicit later in the text.
} 
11. The Cycle of Vitality (Tib. Srog gi 'khor lo)

12. Sems gi tig

13. The King of the Sky (Tib. Nam mkha' rgyal po)

Che phyogs bzhi - the four great (section)

14. The Inlaid Jewels of Bliss (Tib. bDe ba 'phra bkod)

15. The Epitome (Tib. sPyi chings)

16. Gold Refined from Ore (Tib. rDo la gser zhun, another name for the Byang chub sems (b) sgom pa)

17. The Victorious Emergence of the Peak (Tib. rTse mo byung rgyal)

18. The Marvelous (Tib. rMad du byung ba)

Missing: Efficacious Meditation (sGom don grub pa)

\section{The Problematic Nature of the List of Eighteen Texts of the Mind ${ }^{763}$}

Samten Karmay, who was one of the earlier scholars to study the Mask of Vairocana, in particular, points out an important aspect of the various lists describing the early Great Perfection literature by arguing: "Considerable confusion reigns over this list among the rNying ma pa works. Each claims to have eighteen, but often gives only sixteen or seventeen [...] The titles also vary from one source to another."764

An example of this "confusion" can be easily seen by comparing two different lists found in the works of a single author, the Copper Continent (Tib. bKa' thang zangs gling $\mathrm{ma}$ ), and his Religious History (Tib. chos 'byung me tog snying po sbrang rtsi'i bcud) by the 12th century

\footnotetext{
${ }^{763}$ My work on the various lists of the Eighteen Texts of the Mind is profoundly indebted to the work on this literature by David Germano, particularly in Germano, Mysticism and Rhetoric in the Great Perfection (rDzogs Chen), 90-105 and Appendix One 325-364. I used his early survey of lists of semde literature as the foundation for my own research, which reviewed, corrected, and expanded over the years. This research was also influenced by my research with Prof. Germano, Prof. Kurtis Schaeffer, and fellow graduate student Dominic Di Zinno in the Early Dzokchen Literature Project, and presented a paper on the subject with my own research on the topic entitled "The “Twenty or Eighteen” Texts of the Mind Series: Early Great Perfection Literature in Nupchen Sangyé Yeshé's bSam gtan mig sgron" at the International Association of Tibetan Studies conference that took place in Ulaan Baatar, Mongolia in August 2013.

${ }^{764}$ Karmay, The Great Perfection (rDzogs Chen): A Philosophical and Meditative Teaching of Tibetan Buddhism, pp. 23-24.
} 
Nyingma scholar, Nyangral Nyima Ozer (Tib. Nyang ral nyi ma 'od zer). In both texts the early

Atiyoga canon is called the Eighteen Great Scriptures (Tib. Lung chen po bco brgyad), even though in the Religious History he only mentions seventeen of them. In neither of the lists does he make a clear distinction between early and later translations. The first five texts in both lists are identical and coincide with the Five Early Translations attributed to Vairocana, but there are some differences in the later thirteen attibuted to Vimalamitra. To begin with, Nyangrel's Religious History only lists twelve of them. Neither of the lists includes the Six Seminal Nuclei (Tib. Thig le drug pa), and some of the titles in both lists are unusual. In the Copper Continent we find the The Great Treasure of Variety (Tib. sNa tshogs gter chen kyi lung), and in the Religious History we find Arriving at the Crucial Point (Ti. gNad du gyur ba) and the Great Realization (Tib. rTog chen). These names may be alternative titles for the texts missing in the lists, but they are quite unusual and odd in the Eighteen Texts of the Mind Series.

\section{$\underline{\text { Nyangral Nyima Ozer's List in The Copper Continent }}^{765}$}

1. The Cuckoo of Awareness (Tib. Rig pa khu byug, here as Rig pa khu byug gi lung)

2. Dynamism in Action (Tib. rTsal chen sprugs pa, here as Rig pa rtsal chen gi lung)

3. The Soaring Great Khyung (Tib. Khyung chen lding ba, here as ITa ba khyung chen gi lung)

4. Meditation on the Enlightening Mind (Tib. Byang chub sems sgom pa, here as rDo la gser zhun gi lung)

5. The Never Declining Victory Banner (Tib. Mi nub rgyal mtshan, here as Mi nub pa'i rgyal mtshan nam mkha' che)

6. The Marvelous (Tib. rMad du byung ba, here as Ye shes rmad byung ba'i lung)

7. The Efficacious Meditation (Tib. bsGom don grub pa'i lung)

8. The Sacred and Mighty Lord (Tib. rJe btsan dam pa as rJe btsun dam pa'i lung

9. The Quintessential King (Tib. Yang tig rgyal po, here as sKkye med ti la ka'i lung or the Mi 'gyur thig le tig)

10. The Cycle of Vitality (Tib. Srog gi 'khor lo'i lung)

11. The Wish-fulfilling Gem (Tib. Yid bzhin nor bu'i lung)

12. The All Encapsulating (Tib. Kun 'dus, here as Rin po che kun 'dus kyi lung)

\footnotetext{
${ }^{765}$ In the rin chen gter mdzod chen mo Volume 1 Pages $17-206$.
} 
13. The King of the Sky (Tib. Nam mkha' rgyal po, here as Nam mkha' che ba rgyal po'i lung)

14. The Victorious Emergence of the Peak (Tib. rTse mo byung rgyal gyi lung)

15. The Infinity of Bliss (Tib. bDe ba rab 'byams kyi lung)

16. The Inlaid Jewels of Bliss (Tib. bDe ba 'phra bkod as bDe ba phra bkod kyi lung)

17. The Great Treasure of Variety (as $s N a$ tshogs gter chen kyi lung)

18. The Epitome of Teachings Scripture (as bKa' lung gi spyi chings dang lung)

a. Missing: The Six Seminal Nuclei (Thig le drug pa)

\section{Nyangral Nyima Ozer's list in the Religious History ${ }^{766}$ - Only 17 texts are mentioned}

1. The Cuckoo of Awareness (Tib. Rig pa khu byug, here as Rig pa khu byug gi lung)

2. Dynamism in Action (Tib. rTsal chen sprugs pa, here as Rig pa rTsal chen gi lung)

3. The Soaring Great Khyung (Tib. Khyung chen lding ba, here as ITa ba khyung chen gi lung)

4. Meditation on the Enlightening Mind (Tib. Byang chub sems sgom pa, here as rDo la gser zhun gi lung)

5. The Never Declining Victory Banner (Tib. Mi nub rgyal mtshan, here as Mi nub pa'i rgyal mtshan nam mkha' che)

6. Arriving at the Crux (Tib. gNad du gyur pa)

7. The Sacred and Mighty Lord (Tib. rJe btsan dam pa)

8. The Quintessential King (Tib. Yang ti rgyal po as Yang tig)

9. The Cycle of Vitality (Tib. Srog gi 'khor lo)

10. The Wish-fulfilling Gem (Tib. Yid bzhin nor bu)

11. The All Encapsulating (Tib. Kun 'dus)

12. The King of the Sky (Tib. Nam mkha' rgyal po)

13. The Victorious Emergence of the Peak (Tib. rTse mo byung rgyal)

14. The Infinity of Bliss (Tib. bDe 'byams)

15. The Inlaid Jewels of Bliss (Tib. bDe ba 'phra bkod, here as bDe ba phra bkod)

16. Great Realization (Tib. rTogs chen) ${ }^{767}$

17. The Epitome (Tib. sPyi 'chings, here as Chings)

Missing: The Marvelous (Tib. rMad tu byung ba), The Six Seminal Nuclei (Tib. Thig le $\underline{\text { drug pa) }}$

\footnotetext{
${ }^{766}$ In nyi ma 'od zer, mnga' bdag nyang ral. "chos 'byung me tog snying po sbrang rtsi'i bcud/." In chos 'byung me tog snying po sbrang rtsi'i bcud. TBRC W7972. : 12 - 265. lhasa: bod ljongs mi dbang dpe bskrun khang, 1988, 320321. http://tbrc.org/link?RID=O2DB5786|O2DB57862DB5788\$W7972

${ }^{767}$ According to Germano this could correspond to the bsgom don grub pa, in Germano, Mysticism and Rhetoric in the Great Perfection (rDzogs Chen), 2009, 357.
} 
The Texts

An examination of other lists, like the ones found in both 1Deu's histories and those found in the works of the 14th century Tibetan Nyingma scholar Longchenpa, which go from the 12 th to the 14 th century, reveals that while there is an understanding of the existence of an eighteen text collection, its composition and internal organization is not totally clear. My own study of the Eighteen Texts of the Mind has found further obstacles when trying to retrieve the actual texts from the multiple canonical editions of the Nyingma Gyubum, where they have mainly survived. An examination, for example, of an early redaction of the Nyingma Canon, the Vairo Gyubum, a Nyingma collection that only contains Great Perfection texts (no Mahāyoga or Anuyoga texts), shows that the Eighteen Texts of the Mind is nowhere to be found as a single collection and, in fact, many of the texts are missing. The Vairo Gyubum includes a collection of the Five Earlier Translations (Tib. rDzogs pa chen po snga 'gyur lnga) in Vol.5, but it only contains four of the texts, without the standard Never Declining Banner (Tib. Mi nub rgyal mtshan), although a version of this text can be found in vol. 2 (Bg. 52). In this volume, we also find some versions of the eighteen texts, but without following any specific order. (in Vol. $2 \mathrm{Bg}$ $49-53)^{768}$

It is interesting though that many of the later thirteen translations are not included here, and the ones included are spread across various volumes. In Vol 1 (rTse mo byung rgyal Bg16 and bDe ba 'phra bkod Bg21). Vol. 2 includes two versions of the rMad du byung ba in Bg 43 and Bg 44, but the following ten texts are missing: The Sacred and Mighty Lord (Tib. rJe btsan

\footnotetext{
${ }^{768}$ It is also interesting that in Vol. 1 there is a series of 12 texts that "According to the introductory material to Bg.1, this text appears to be Śrī Singha's (the text reads 司: (Steven Weinberger)" but there are commentaries on some other texts of the snga 'gyur snga.
} 
dam pa), The Wish-fulfilling Gem (Tib. Yid bzhin nor bu), The King of the Sky (Tib. Nam mkha' rgyal po), The Cycle of Vitality (Tib. Srog gi 'khor lo), The Epitome (Tib. sPyi 'chings), The Infinity of Bliss (Tib. bDe 'byams), The Quintessential King (Tib. Yang ti(g) rgyal po, The Six Seminal Nuclei (Tib. Thig le drug pa), Efficacious Meditation (Tib. bsGom don grub pa), The All Encapsulating (Tib. Kun 'dus).

In most of the other Nyingma canonical collections, the absence of these texts is not as dramatic as in this early collection, but we find a similar pattern of inconsistency, with some texts missing, and also some of them scattered in different volumes and not as a single collection, or as part of other texts, mainly in the most important tantra of the sems sde tradition, the Kun byed rgyal po.

\section{The Eighteen Texts of the Mind: Canon as an idea}

Karen Liljenberg has done really valuable work locating some of these "missing," or "lost" texts in some of the editions of the Nyingma Gyubum. In particular, she has identified the Six Seminal Nuclei (Tib. Thig le drug pa), the Epitome (Tib. sPhyi 'chings), the Accomplished Meditation (Tib. bsGom pa don drup) and the Wish-Fulfillying Gem (Tib. Yi bzhin nor bu). The "disappearance" of some of these texts could be explained by the fact that many of the eighteen texts ended up being incorporated into the larger and more popular All Sovereign King (Tib. Kun byed rgyal po), which became the most popular tantra for the early strata of Great Perfection tradition and became known as part of the Mind Series, transforming many of the independent texts into chapters of this tantra. But the lack of consistency among the various lists, and the remarkable differences between some of the texts that bare the same title, may also warrant a 
different approach to our study of this literature. David Gray, in his article, "On the Very Idea of a Tantric Canon," argued:

Perhaps one of the most important and persistent ideas that underlies the tantric traditions of Buddhism is the notion that a complete collection of tantric scriptures [...) or Collection of Tantras (Tantrapițaka), either did exist in the past, and/or continues to exist in an alternate level of reality. This notion was advanced as an important legitimating ideology at the initial stage of the development of tantric traditions and their literature, and it has remained a widespread belief up until the present day." 769

He then adds, "This belief, and the myths that express it, had a significant impact on the ways in which tantric traditions constructed their histories and identities, and on the ways in which they organized and understood their canons of literature."770

I think we see a similar process in the emergence of the early Great Perfection literature, where the differences in the contents of these lists, and the differences in the actual texts, reveals that the strength of the idea of an early corpus of eighteen texts does not reside in its actual content, which as we have seen differs from author to author (sometimes even for the same author) and from period to period, but the strength lies in the "idea" that there is a closed canon transmitted by an Indian figure (i.e. Sri Singha) to his Tibetan disciples. The notion of the eighteen operates as a framework (Gray calls this an "empty signifier") that allows the early Great Perfection tradition to group a nascent but varied corpus of works under one umbrella and distinguish themselves from other Buddhist traditions. In fact, the notion of a canon of eighteen texts in the early Great Perfection tradition offers another clue about the relationship between Atiyoga and Mahāyoga traditions, since Mahāyoga already had a notion of eighteen tantric texts

\footnotetext{
${ }^{769}$ In David Gray, "On the Very Idea of a Tantric Canon: Myth, Politics, and the Formation of the Bka' 'gyur," Journal of the International Association of Tibetan Studies, no. 5 (2009): 1, http://www.thlib.org/?tid=T5690.

${ }^{770}$ Ibid., p. 2.
} 
as the core of its scriptural canon, an idea that Atiyoga may have borrowed for the construction of its own textual identity. ${ }^{771}$

Looking for the "original" texts, then, should not guide us into thinking that we can somehow "recover" the original versions of these texts. As we have seen, the Eighteen Texts of the Mind (as well as the Eighteen Mahāyoga Tantras) operate more as an idea than as a reality. And many of the texts that became standard in the collection were, for the most part, works in progress, an inspiration for later generations of scholars, who rewrote, changed, expanded, and commented on what we should see as a literary genre and not simply a literary canon.

The Eighteen Texts of the Mind in the Lamp for the Eye in Contemplation

To reinforce my argument that the notion of a corpus of eighteen texts operates more as an idea than as an actual reality, let me go back to Nupchen's Lamp, where, I believe, we can see the early stages of formation of this textual corpus. The Lamp is among the earliest witnesses and, definitely, the most extensive early Great perfection work that discusses the Eighteen Texts of the Mind as a corpus. Even though Nupchen is constantly quoting from this group of texts, he only refers to them as a group once, and the reference is quite vague. We find it in chapter 2, when Nupchen is discussing the texts that any practitioner should bring to a retreat:

\footnotetext{
${ }^{771}$ Although in the case of Mahāyoga we find a similar phenomena in which the "idea" of the canon conflicts with its actual reality. Gyurme Dorje has compared various lists of the eighteen Mahāyoga tantras in the works of Tibetan scholars such as Longchenpa, Pawo Tsuklak Trengwa (Tib. dPa' bo Gtsug la phreng ba), and Zhechen Gyeltsap Padma Namgyal (Tib. Zhe chen gyal tshab Padma rnam rgyal), in Gyurme Dorje's The Guhyagarbhatantra and Its XIVth Century Tibetan Commentary, Phyogs Bcumun Sel, Unpublished Ph.D. thesis, School of Oriental and African Studies, 1987, pp. 33-36. Dalton also points out that "other scholars (e.g. Martin 1987: 201 n.14; Garson 2004: 259-264) have noted, variant lists of the eighteen Mahāyoga tantras abound in the writings of later Nyingmapa." In Jacob Dalton's "Preliminary Remarks on a Newly Discovered Biography of Gnubs Chen Sangs Rgyas Ye Shes," ed. Andrew Quintman and Benjamin Bogin (Somerville, MA: Wisdom Publications, forthcoming), p. 12, n. 20.
} 
Regarding the harmonious Dharma [books that you should take with you to a retreat]: Kamalasila['s bhavanakrama], Mahāyāna texts on contemplation, those of the profound Inner Yoga; the kLong drug, the bZhi phrugs (whose commentary are like the primordial meaning), the six Tantras of suchness, and the twenty or eighteen minor [texts of the] Mind. ${ }^{772}$

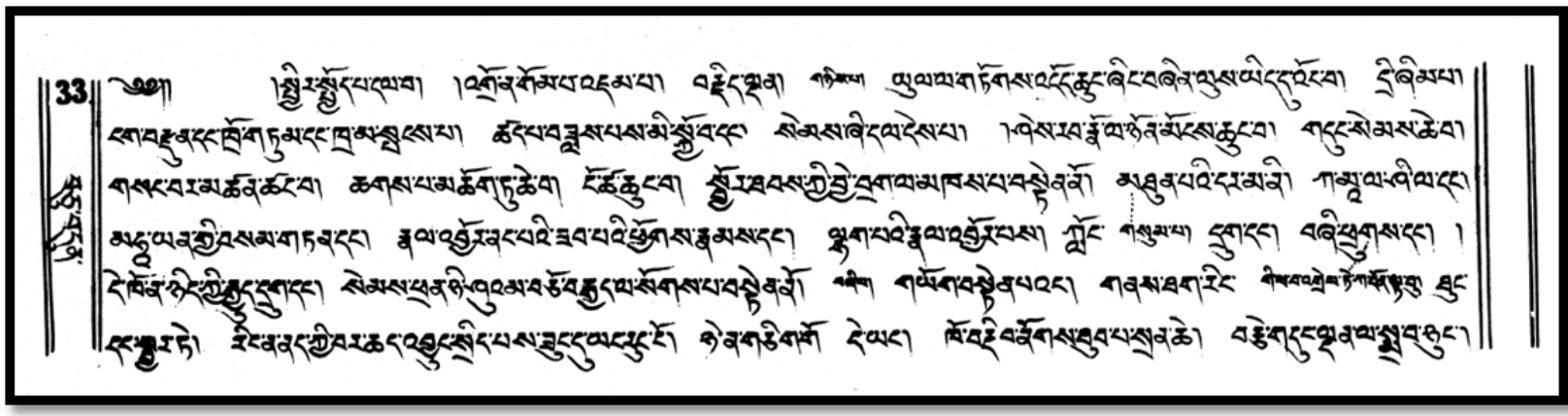

Page of the Lamp in which Nupchen refers to the twenty or eighteen minor [texts of the] Mind

It seems, then, that when Nupchen was writing the Lamp in the 10th century, there was already a nascent sense of a canon for the Great Perfection tradition, but this may have been vaguely defined, since he refers to is as the "twenty or eighteen minor [works] of the mind [series]" (Tib. Sems phran nyi shu'am bco brgya). The Lamp also does not offer a list of the texts, and neither does it offer a division between earlier and later transmissions. There is also no framing narrative for the transmission of the texts, as we saw in the Mask of Vairocana.

A survey of the Lamp, though, shows that most of the texts considered by the later tradition to be part of the early canon are included in it, although the list veers towards twenty more than eighteen, and some of the texts that ended up not making it onto the list, like the Small Hidden Grain (Tib. rGum chung), or the sPhyi bcod, are actually quoted more times than some of the established texts, like the Cuckoo of Awareness (Tib. Rig pa'i khu byug):

\footnotetext{
${ }^{772}$ Lamp 33.3-33.5.
} 


\begin{tabular}{|c|c|}
\hline The Cuckoo of Awareness (Rig pa('i) khu byug) (the title here is khu byug) & 2 \\
\hline 2. Dynamism in Action (rTsal chen sprugs pa) AS bTsal chen sprugs pa & $3 i$ \\
\hline 3. The Soaring Great Khyung (Khyung chen Iding ba) AS Khyung chen Iding ba rgyud and/or Khyung chen & 194 \\
\hline 4. Meditation on the Enlightening Mind (Byang chub sems (b)sgom pa) also with the title here rDo la gser zhun and sems bsgom & $11 ;$ \\
\hline 5. The Never Declining Victory Banner (Mi nub rgyal mtshan) AS nam mkha' che AND nam mkhas che AND rdo rje sems dpa' nam mkha' che & 37. \\
\hline & \\
\hline 6. The Sacred and Mighty Lord (rJe btsan dam pa) & 2 \\
\hline 7. The Wish-fulfilling Gem (Yid bzhin nor bu) & $1 ;$ \\
\hline 8. The Victorious Emergence of the Peak (rTse mo byung rgyal) & $19:$ \\
\hline 9. The Inlaid Jewels of Bliss (bDe ba 'phra bkod) & 7 \\
\hline 10. The King of the Sky (Nam mkha' rgyal po) & 12: \\
\hline 11. The Cycle of Vitality (Srog gi 'khor lo) & 5 \\
\hline 12. The Epitome (sPyi (')chings) AS spyi chings AND sphyi bcangs & $3:$ \\
\hline 13. The Infinity of Bliss (bDe 'byams) & $6 !$ \\
\hline 14. The Quintessential King (Yang ti(g) rgyal po) AS byang chub sems thig & 19 \\
\hline 15. The Marvelous (rMad (du) byung (ba)) & $43:$ \\
\hline 16. The Six Nuclei (Thig le drug pa) & $3:$ \\
\hline 17. Efficacious Meditation ((b)sGom don grub pa) AS don grub & $2 i$ \\
\hline 18. The All Encapsulating (Kun 'dus) AS rin po che kun 'dus rig pa & 154 \\
\hline 19. Supplement 1- The Universally Definitive Perfection (rDzogs pa spyi gcod (spyod)) AS sphyi bcod & $3:$ \\
\hline 20. Supplement 2 - The Small Hidden Grain or Sangyé Bepa's Grain (sBas pa'i rgum chun & $\overrightarrow{5 i}$ \\
\hline
\end{tabular}

\section{The Eighteen Texts of the Mind in the Atiyoga chapter of the Lamp}

What is the Role of this Literature in the Early Development of the Great Perfection?

Nupchen's depiction of the Great Perfection as a separate Buddhist vehicle relies heavily on this early corpus of literature. Nupchen uses these texts, with their particular denials of tantric rhetoric and practice, their poetic bent, their deconstructive approach to discourse, and their emphasis on spontaneity and naturalness to articulate a different approach to Buddhist thought and those of the other Buddhist vehicles (Tib. theg pa) discussed in the Lamp. As Sam van Schaik has pointed out, "The sources for Mahāyoga are not the sources for Atiyoga and vice versa." Nupchen is using the early corpus of the Eighteen Texts of the Mind (what he calls the "Sems phran") to separate the Great Perfection from the other vehicles, showing that their particular philosophical vision is preserved in a different literary corpus, with a different lineage of transmission. 
But even if this is true, there is something that does not quite add up. While these texts play a key role in the articualtion of the Atiyoga view, none of the texts in the corpus is the most mentioned text in the Lamp, not even in the chapter dedicated to the Great Perfection. In particular, this honor goes to the Sütra of the Gathered Intentions (Tib. dGongs pa 'dus pa'i mdo), which is mentioned 99 times. The most mentioned Atiyoga text in the Lamp is the Marvelous (Tib. rMad du byung ba), which is quoted 43 times. In chapter 7, which is dedicated to the Great Perfection, the Marvelous is quoted 41 times. Still, the Sütra of the Gathered Intentions is quoted 45 times and the quotations are much longer. Why would that be? Let me offer here two different possible answers. First, as I have said, I believe that the Lamp presents a Great Perfection tradition in its very early stages, and while the early Atiyoga literature helps Nupchen express a unique vision for the tradition, these texts also lack the philosophical sophistication to articulate and argue their own positions versus those of other Buddhist traditions with more historical pedigree (the rhetoric of denial can only get you so far in an argument!). That is why I believe Nupchen begins his arguments using the Atiyoga canonical literature, but when it comes to refining an argument, uses the Sütra of the Gathered Intentions, which helps him strengthen his case for the Great Perfection as a separate vehicle. An example of this can be seen in Nupchen's discussion of the ninth view of Atiyoga, "the view of the ground of all phenomena as it is" (Tib. chos thams cad gzhi ji bzhin par lta ba), where he argues:

Therefore, the Atiyoga practitioners do not establish logical syllogisms, they do not engage in fine analysis, do not think, they do not actualize [thoughts], they do not investigate, they do not measure, there is nothing to do, nothing to establish. As for the natural state of suchness [the practitioner of Atiyoga] understands it [without trying to] understand it, finds it without searching it, accomplishes it without [trying to] accomplish it, sees it without looking at it, understands it without [trying to] understand it, obtains it 
without [trying to] obtain it, clarifies it without [trying to] clarify it, and experiences it without [trying to] to experience it."

This leads to a discussion of "Suchness" (Tib. de kho na nyid), which starts with a seemingly logical question after Nupchen's presentation of the Atiyoga position regarding any sort of effort and use of language to express or discuss a philosophical concept: "If it is not possible to express it through words then there is no purpose in talking about it?" $" 774$ To this Nupchen responds:

I have already answered this question in detail above [...] but because speaking itself is only an illustration, if the need arises, since this is system completely pure, you can answer the following, using logical reasoning, which reinforces the faith in the system. ${ }^{775}$

Then he proceeds to quote from several Atiyoga sources that poetically reinforce that idea, such as the Great Garuda, the Great Sky, the Marvelous, etc. But at the end of this discussion Nupchen says, "In order to elaborate extensively the meaning of this, it should be explained through logical syllogisms (Tib. de'i don rgyas par bstan pa'i phyir / gtan tshigs kyang 'dir bstan par bya ste)"776 and quotes for eight folios (with annotations) from the Sütra of the Gathered Intentions! He is using a text that is not part of that early canon of the Great Perfection and that, in fact, became the heart of the Anuyoga tradition, in order to articulate a more sophisticated explanation of what "suchness" means from the perspective of the Great Perfection.

\footnotetext{
${ }^{773}$ Lamp 379.4-380.1: “de bas na shin tu rnal 'byor pas / gtan tshigs ma btsug // ma gzhig bas ma bsam / mngon du ma byas / ma brtags / ma dpyad / ma gzhal / de ci yang bya ba med par / ma bzhag par bzhag pa / ji bzhin pa de kho na nyid / mi rig par rig / mi rnyed par rnyed / ma bsgrub par grub / ma mthong bar mthong / ma rtogs par rtogs / ma thob par thob / mi gsal bar gsal / ma myong bar myong bar 'gyur ro //"

${ }^{774}$ Lamp 382.4: "'o na gal te tshig gis mtshon du mi 'dod na / brjod pa la dgos pa med do / zhes 'drin"

${ }^{775}$ Lamp 382.4-382.6: "lan du de sngar yang zhib tu brjod na / don (382.5) de ltar yin yang de skang brjod pa nyid mtshon pa yin pas / dgos < sgron med mun khung gser tshol ltar gsang ba'i snying po'i mdzod brdol te > ched yong ngo zhes lan btab bo / (382.6) lugs < dam pa rnams kyi gser tshan 'byin / ces pa'i don do / > nge sgro bkur med pa yang dag pa yin par yid ches par byed pa'i rgyab non gyi gtan tshigs kyang /"

${ }^{776}$ Lamp 385.2
} 
The eight folios are full of lists, definitions, examples, and expressions, attempting to define what Nupchen just argued was undefinable.

The second possibility for the extensive use of the Sütra of the Gathered Intentions in the Lamp and, in particular, in the Great Perfection chapter is that for Nupchen, I believe, the Sütra does not function as an Anuyoga text, but as a Great Perfection text, articulating some of the Atiyoga ideas and practices from a slightly different perspective. We need to remember that Nupchen had already written a whole commentary on the Sütra, and that he is perfectly aware of the Anuyoga category, which he mentions on several occasions in the Lamp, even if he does not discuss it as a separate vehicle. Dalton offers an answer to this conuncdrum:

The later Tibetan tradition classified the Sütra under anuyoga, which leads one to wonder how the Sütra viewed its own position in relation to the triad of maha-anu-ati. After extensive searching, nowhere does the Sütra agree with its later exegetes that it is a work of anuyoga. It definitely considers itself "secret mantra," but this seems to include all three vehicles of Mahāyoga, anuyoga, and atiyoga. The original purpose of the Sütra was not to set forth the vehicle of anuyoga, but to create a complete system of doctrines, myths, and rituals to explain all the tantric vehicles, and the highest three especially. ${ }^{777}$

This idea seems to be corroborated in the Lamp itself, since the Sütra is also one of the most quoted texts in the Mahāyoga section. The Sütra, then, is not only important for Nupchen as a key textual source for the Atiyoga tradition, but for all tantric vehicles. The importance of the Sütra may also point to the fluidity between traditions during this period, and while Nupchen is attempting to create clear bounderies during these tantric traditions, there is also a clear undercurrent that brings them together, which in this case is represented by the overall view of tantra offered in the Sütra.

\footnotetext{
777 Jacob Dalton, "The Uses of the dGongs Pos 'Dus Pa'i Mdo in the Development of the rNying Ma School of Tibetan Buddhism” (University of Michigan, 2002), p. 318.
} 


\section{Conclusion}

I have argued in this chapter that chapters six and seven of the Lamp, dedicated to the Mahāyoga and Atiyoga traditions, respectively, show the Tibetan transition during the 10th century to a fully tantric, esoteric model. Nupchen's discussion in the Lamp does not only show the doctrinal differences between various Buddhist traditions, but the historical evolution of Buddhism in Tibet. The earlier Imperial attempts to impose and define a certain approach to Buddhism, represented by the Indian Gradual approach, some early Chinese Chan lineages, and a regulated and closely monitored approach to the translation of tantra, failed with the collapse of the Empire, giving way to a decentralized, more organic and chaotic introduction of a series of lineages, teachings and scriptures belonging to the Indian Mahāyoga tradition, as well as to the new and emerging Great Perfection tradition.

In this chapter, I have also argued that Nupchen is not simply describing the transition taking place on the Tibetan plateau, but he is also playing a very active role in shaping these developments, particularly in defining and articulating the Great Perfection tradition as a new and superior vehicle within the larger framework of the Buddhist tradition. 


\section{Conclusion}

\section{The Fate of Nupchen's Lamp for the Eye in Contemplation}

In his pioneering study of the early stages of the Great Perfection, Samten Karmay was one of the first scholars to acknowledge the importance of Nupchen's Lamp for our understanding of the historical and intellectual developments of Buddhism on the Tibetan plateau in the 9 th and 10th centuries. The text, though, does not seem to have had the same importance for the later Tibetan community. In Karmay's own words,

[The Lamp] is not a work that gained any popular esteem even among the later rNying ma pa school. It was a rare work in Tibet itself, not even mentioned in the list of the rare works made by A-khu-chen Shes-rab rgyamtso (1803-1875). ${ }^{778}$

We barely find traces of the transmission of the text in the later tradition, ${ }^{779}$ and there are no available Tibetan commentaries on the text. ${ }^{780}$ There are several possible reasons that can help explain this fate. Karmay argues that this was "perhaps due to the fact that it has accepted the Cig car ba [i.e. Chinese Chan] tradition in Tibet which the Tibetan religious tradition

\footnotetext{
${ }^{778}$ Samten Gyaltsen Karmay, The Great Perfection (rDzogs Chen): A Philosophical and Meditative Teaching of Tibetan Buddhism (Leiden - New York: E.J. Brill, 1988), p. 102.

${ }^{779}$ Karmay offers the following summary of instances in which the Lamp appears in later texts and biographies: "It is mentioned in the $b k a^{\prime}$ 'shog of Pho-brang Zhi-ba-'od (latter half of the eleventh century A.D.). As seen, O-rgyan gling-pa (1329-1367) has used it for writing his BK [Blon po bka' thang]. In his Lo rgyus rin po che'i phreng ba, Klong-chen rab-'byams (1308-1362) records that his master Rig-'dzin Kumaraja listened to the exposition of SM in the presence of Slo-dpon sGom-pa. It is also mentioned in BA [The Blue Annals] among similar types of work described as the great works of meditation of the Rong system (rong lugs kyi sgom yig chen po), and so is in JT ['Jig rten gsum gyi bde skyid pad tshal 'byed pa'I nyin byed] of the Vth Dalai Lama. According to the par byang, the xylographic edition from which the present photoset is produced was based on a manuscript copy which belonged to Taranatha (b. 1575). The well-known historian Ka-thog Rig-'dzin Tshe-dbang nor-bu (1698-1755) also has quoted it in his history of the Ch'an teaching in Tibet." But as he also mentions, it was overall a "rare work in Tibet itself." See Ibid., 102-103.

${ }^{780}$ The only exception is the recent commentary published by the 20th century Tibetan scholar, Khenchen Palden Sherab Rinpoche, entitled Opening the Eyes of Wisdom, A Commentary on Sangyé Yeshés Lamp of the Eye of Contemplation. Its late composition makes it interesting for our understanding of the contemporary Nyingma tradition to the text, but it does not have much value for our understanding of the early historical reception and interpretation of the text. See Palden Sherab, Gnubs Chen Sangs Rgyas Ye Shes Kyi Bsam Gtan Mig Sgron Le'u Rnams Kyi Spyi Bshad Mdor Bsdus Shes Rab Mig "Byed (Opening the Eyes of Wisdom. A Commentary on Sangye Yeshe's Lamp of the Eye of Contemplation) (Boca Raton: Sky Dance, n.d.), http://www.skydancerpress.com/ebook/sungbum/samten.html.
} 
generally regards as officially banned." ${ }^{781}$ As we have seen throughout this dissertation, one of the main attacks towards the Great Perfection tradition was its intellectual similarities with Chinese Chan, so the fact that Nupchen considered Chinese Chan superior to the Indian Gradual tradition probably played a role in the lack of influence of the text in the later tradition. The attacks on the figure of Nupchen by some of the early representatives of the Sarma movement, such as the late 10th century figure, Lama Yeshe Ö, and his 11th century nephew, Podrang Zhiba Ö, ${ }^{782}$ who accused Nupchen of authoring scriptures while claiming an Indian origin for them, probably did not help either with Nupchen's standing and that of his works in the later Tibetan tradition. As Dalton has pointed out, he became a hero to the Nyingma school, which hailed him as a savior of the Buddhist tradition during perilous times, while he was attacked as a charlatan by the Sarma tradition for using the lack of institutional supervision during the period to forge new Buddhist scriptures.

While all of these factors may help explain the little regard for Nupchen's work by the later tradition, I also think another important reason that would help explain this was the fact that the Lamp, and the intellectual work represented in it, became quickly irrelevant under the weight of the historical and doctrinal developments that began to take place in Tibet in the 11th century, during the Tibetan Renaissance. In this new religious environment, there was no place for the Chan tradition, ${ }^{783}$ the Indian Gradual system became thoroughly internalized within the tantric, esoteric model, and the Great Perfection tradition described in the Lamp and represented by the early Mind Series literature (Tib. sems sde) was superseded by a multitude of new Atiyoga movements that moved away from the initial rhetoric of rejection of Mahāyoga practices and

\footnotetext{
${ }^{781}$ Karmay, The Great Perfection (rDzogs Chen): A Philosophical and Meditative Teaching of Tibetan Buddhism, p. 102.

${ }^{782}$ See chapter 1 of this dissertation for a discussion of their attacks on Nupchen.

783 survival traces in Atiyoga and Kagyu NOTE!
} 
were now incorporating them into the Great Perfection tradition. ${ }^{784}$ The Lamp, then, became less of a path to follow (of Buddhist doctrines and practices), and more of a window to a very specific period of the history and intellectual developments of Buddhism in Tibet.

One of the goals of this dissertation, then, has been to offer a view, from the vantage point of the Lamp, of the historical and intellectual world in which it was written. As we have seen, the Lamp is not only one of the few texts that have survived from the period, but also one of the earliest and most important systematic accounts of the various Buddhist schools that had taken hold in Tibet from the time of the introduction of Buddhism during the Tibetan Empire all the way up to this period. The Lamp also offers a more complex account of the introduction of Buddhism in Tibet than the one presented in later Tibetan historiography, which has a tendency to emphasize the Indian origins of the tradition. Nupchen describes a Buddhist tradition arriving in Tibet from India, but also from China and other parts of Central Asia. The Lamp also shows that Buddhism had not simply disappeared from Tibet during the Dark Age period. Some forms of Buddhism suffered greatly, particularly the Gradual and the Sudden approaches. The first one suffered since it depended on the monastic institutions to survive, and these institutions collapsed together with the empire. The reasons for the disappearance of Chan are still unclear, but the Lamp offers a very different picture of the disappearance of the tradition in Tibet to the one presented by later Tibetan historiography, and shows that Chan may have survived longer on the Tibetan plateau than later historiographical accounts want to make us believe. In Nupchen's text, we also see the success of the previously forbidden forms of tantra in the Tibetan plateau, represented by Mahāyoga, and the emergence of the new Atiyoga tradition.

\footnotetext{
${ }^{784}$ On the diversity of traditions that operated under the label of "Atiyoga," see David Germano's "Architecture and Absence in the Secret Tantric History of rDzogs Chen," The Journal of the International Association of Buddhist Studies 17, no. 2 (1994): 203-335.
} 


\section{Nupchen's Lamp, the Construction of the Great Perfection Tradition, and the}

\section{Tibetan Assimilation of Buddhism}

This dissertation has also argued that Nupchen is not simply describing the doctrinal developments that were taken place in Tibet during the early introduction of Buddhism in the Tibetan plateau. As I have discussed in chapter 2 of this dissertation, there is an inherent tension in the doxographical genre between its descriptive and prescriptive nature. On the one hand, we can examine Nupchen's doxography and trace the historical evolution of Buddhism in India, China, as well as Tibet. At the same time, we can (and should) read doxographies as a narrative written with a clear agenda by a particular individual (in this case Nupchen) in an attempt not only to organize (sometimes contradictory) ritual and doctrinal systems, but also to impose and prescribe a particular doctrinal or sectarian point of view (in this case that of the Great Perfection tradition). Doxographies are, from this perspective, tools to create an ideological reality.

An example of Nupchen's role in the construction of an early identity for the Great Perfection tradition can be found in his presentation of the nine views (Tib. lta ba) of the tradition, and the eight methods of practice, which the text connects to a diversity of Indian and Tibetan masters of the period. Even though, as we have seen, the link between those teachers, which only appear in the interlinear notes, may have been added not by Nupchen, but by the later Tibetan tradition, what the text reflects is the richness and diversity of views within the early Great Perfection tradition. An important question to ask, then, is what is the connection between those views and practices that operate under the label of Atiyoga or the Great Perfection tradition. Germano pointed out, "The unitary nature of the label of rdzogs chen [...] obscures the fact that those traditions' contents and practices are often stunningly different, and highly critical of each 
other." 785 This dissertation has argued for the important role played by Nupchen, and the Lamp in particular, in the construction of a unified early identity for the Great Perfection, built out of a diverse group of texts, teachings, and lineages that may have come from India and other parts of central Asia (as the tradition wants to claim), but that were organized and given coherence on the Tibetan plateau by scholars like Nupchen and works like his Lamp for the Eye in Contemplation. As Germano had argued in one of his studies of the literature of the early Great Perfection, these tests were "[r]emarkable for their extreme brevity and lack of any Buddha-narrative frames claiming transcendental origins: they are simply precept texts (man ngag) offering poetic musing on the experiences coming out of perfection phase contemplation [...] but without offering any independent contemplative techniques. ${ }^{, 786}$ It is Nupchen in the Lamp who takes that literature and outlines and organizes its philosophical view (Tib. lta ba), explains its wide variety of contemplative practices (Tib. sgom pa), its code of conduct (Tib. spyod pa), and described the unique (at least from his perspective) soteriological goal (Tib. 'bras bu) in a way that none of the scriptures of the Great Perfection had done until then. But what allowed him to argue for the unique and singular nature of the Atiyoga tradition was not only a description of its doctrine and practices, but the use of the doxographical genre to compare them against other Buddhist views. Comparison and classification, the two essential concepts at the heart of any doxography, offered Nupchen the tools to actively and creatively deconstruct the Buddhist tradition, only to put it back together in a new, original way that responded not only to the historical developments of the Buddhist tradition over the centuries, but also to the historical context in which the Buddhist tradition was developing in Tibet during Nupchen's time.

\footnotetext{
${ }^{785}$ Germano, 2001, p. 5

${ }^{786}$ Germano chapter one, p. 29.
} 
And this brings me to the last point I want to make in this dissertation. There has been a lot of discussion regarding the "mysterious" origins of the Great Perfection tradition, an issue that I have already addressed in chapter 5 of this dissertation. Regardless of the question of origins, what I believe the Lamp makes clear is that by the 10th century Tibetans are not simply interested in importing and translating Buddhism wholesale, but have become fully engaged in the wider conversation that is taking place across Asia about Buddhist doctrine and practice. In the Lamp, we do not only see a presentation of established Buddhist views across the continent, but a Tibetan attempt to present a new and unique approach to the path. Buddhism in the 10th century has become Tibetan Buddhism. 


\section{Bibliography}

\section{Tibetan and Sanskrit Sources}

Kamalaśīla, Bhāvanākrama. Tibetan \& Sanskrit Sgom rim thog mtha' bar gsum bzhugs so / Ka ma la śi las mdzad. Leh, Ladakh: Dpal na lendra'i chos tshogs nas par du bskrun, 2006.

—. Bsgom pa'i rim pa. sDe dge Tibetan Tripitaka bsTan 'gyur. No. 3915 [22a1 41b7], No. 3916 [42al 55b5], No. 3917 [55b6 68b7]. Tokyo: 1979.

\section{—. Madhyamakāloka Madhyamakālokah. Vārāṇasī: Kendrīya Ucca Tibbatī} Sikșāsamsthānam, 2001.

- The Five Bhāvanakrama of Kamalaśĭla and Vimalamitra: a collection of texts on the nature and practice of Buddhist contemplative realization. Gangtok: Gonpo Tsheten, 1977.

Mkhas pa Lde'u, Rgya bod kyi chos 'byung rgyas pa. Lhasa, 1987.

Mkhas btsun bzang po. Biographical Dictionary of Tibet and Tibetan Buddhism (rgya Bod Mkhas Grub Rim Byon Gyi Rnam Thar Phyogs Bsgrigs). 12 vols. Library of Tibetan Works and Archives, 1973.

Gu ru bkra shis. Gu Ru Bkra Shis Chos "Byung (bsTan Pa”i Snying Po Gsang Chen Snga "Gyur Nges Don Zab Mo”'i Chos Kyi Byung Ba Gsal Bar Byed Pa'i Legs Mkhas Pa Dga'Byed Ngo Mtshar Gtam Gyi Rol Mtsho). ed. Beijing: Krung go’i bod kyi shes rig dpe skrun khang, 1990. W20916

'Gyur med tshe dbang mchog grub. Rnying Ma'i Rgyud 'Bum Gyi Dkar Chag. In Gsung 'Bum. gyur Med Tshe Dbang Mchog Grub, TBRC W15098., n.d.

Brgyud pa'i mam thar. Padma 'Phrin las, Rdo rje Brag Rigs 'dzin II. 1972. 'dus pa mdo dbang gi bla rna brgyud pa'i rnam thar ngo mtshar dad pa'i phreng ba. In Bka' ma mdo dbang gi bla ma brgyud pa'i rnam thar and Rig 'dzin ngag gi dbang po'i rnam thar, 1 425. Leh: S. W. Tashigangpa, 1972.

Nyi ma 'od zer, mnga' bdag nyang ral. Bka' Thang Zangs Gling Ma. Vol. 1. Rin Chen Gter Mdzod Chen Mo. New Delhi: Shechen publications, n.d. TBRC W1KG14.

Rnying ma Bka' ma rgyas pa in 58 vol.: a collection of teachings and initiations of the Rnying ma pa tradition passed through continuous and unbroken oral lineages from the ancient masters / completely edited and restructured by H.H. Bdud 'joms Rin po che on the basis of the successive Smin grol gling and Rdzogs chen Rgyal sras redactions. Kalimpong, Dist. Darjeeling, W.B.: Dupjung Lama, 1982

Rnying ma Bka' Ma Shin Tu Rgyas Pa (kaH Thog). 120 vols. kaH thog mkhan po 'jam dbyangs, ed. Chengdu, 1999.

Rnying ma Bka' Ma Shin Tu Rgyas Pa. 133 vols. Chengdu: si khron dpe skrun tshogs pa/ si khron mi rigs dpe skrun khang, 2009. 
rNying ma rgyud 'bum (gting skyes): a collection of treasured tantras translated during the period of the first propagation of Buddhism in Tibet. Thimbu: [s.n.], 36 vol. 19731975.

rNying ma rgyud 'bum (mtshams brag dgon pa'i bris ma). The Mtshams brag manuscript of the Rnying ma rgyud 'bum. Thimphu, Bhutan: National Library, Royal Government of Bhutan, 46 vol. 1982.

Lde'u Jo sras, Lde’u chos 'byung Lhasa., 1987.

Bdud 'joms 'Jigs bral ye shes rdo rje, Rnying ma'i chos 'byung Bdud 'joms chos 'byung. Cheng tu: Si khron mi rigs dpe skrun khang, 1996.

Nor brang, O rgyan. The Garland of White Crystals [Bod Sil Bu'i Byung Ba Brjod Pa Shel Dkar Phreng Ba]. Lhasa: Bod ljongs mi dmangs dpe skrun khang, 1991.

Nupchen Sangye Yeshe (gNnubs chen sangs rgyas ye shes). Bsam Gtan Mig Sgron 110. Vol. 97. 110 vols. Chengdu: kaH thog mkhan po 'jam dbyangs, 1990s.

Bsam Gtan Mig Sgron 120. Vol. 104. 120 vols. Chengdu: kaH thog mkhan po 'jam dbyangs, 1999.

—. Bsam Gtan Mig Sgron 133. Vol. 104. 133 vols. Chengdu, 2009.

.rNal Byor Mig Gi Bsam Gtan, or, bSam Gtan Mig Sgron: a Treatise on Bhāvana and Dhyāna and the Relationships Between the Various Approaches to Buddhist Contemplative Practice. Edited by S. W. Tashigangpa. Leh: smanrtsis shesrig spendzod, 1974.

- Sangs Rgyas Ye Shes Rin Po Che'i Lo Rgyus Gnubs Kyi Bka'Shog Chen Mo (vol. 42 of the Bka' Ma Shin Tu Rgyas Pa). Chengdu: kaH thog mkhan po 'jam dbyangs, 1999.

- gNubs chen Sangs rgyas ye shes $r N a l$ 'byor rig pa'i nyi ma, bKa' ma shin tu rgyas pa (Kạ̣ thog), Vol. 103, pp. 51112.

rtse mo byung rgyal 'grel pa In snga 'gyur bka' ma shin tu rgyas pa/.98: 167 208. chengdu: si khron dpe skrun tshogs pa/ si khron mi rigs dpe skrun khang /, 2009. TBRC W1PD100944.

—. Sde brgyad gser skyems b Zhugs so / s.1. : s.n., 1970?

- Mun pa 'i go cha. Sangs rgyas thams cad dgongs pa 'dus pa mdo'i dka' 'grel mun pa' $i$ go cha lde mig gsal byed mal 'byor nyi ma. In Rnying ma bka' rna rgyas pa, vols. 5051.

Padma 'Phrin las, Rigs 'dzin Chen po. 'Dus Pa Mdo Dbang Gi Bla Ma Brgyud Pa'i Rnam Thar Ngo Mtshar Dad Pa'i Phreng Ba (Biographies for the Lamas of the Sūtra Initiation Lineage Written in 1681 at rDo Rje Brag by the Second Rigs 'Dzin Chen Po Padma 'Phrin Las). In $b K a$ ' Ma Mdo Dbang Gi Bla Ma Rgyud Pa’i Rnam Thar, Vol. 37. Leh: Smanrtsis Shesrig Spendzod, 1972.

Palden Sherab. Gnubs Chen Sangs Rgyas Ye Shes Kyi Bsam Gtan Mig Sgron Le'u Rnams Kyi Spyi Bshad Mdor Bsdus Shes Rab Mig "Byed (Opening the Eyes of Wisdom. A Commentary on Sangye Yeshe”s Lamp of the Eye of Contemplation). Boca Raton: Sky Dance, n.d. 
Pawo Tsuklak Trengwa, dpa' bo gtsug lag phreng ba. A Scholar's Feast (chos “Byung Mkhas Pa”i Dga' Ston). TBRC W7499., n.d.

Blo bzang 'phrin las, Dung dkar. Mkhas dbang Dung dkar Blo bzang 'phrin las mchog gis mdzad pa'i Bod rig pa'i tshig mdzod chen mo shes bya rab gsal Zhes bya ba bZhugs so. Dpar thengs 1. Pe cin: Krung go'i Bod rig pa'i dpe skrun khang; Mtsgo sngon Zhing chen Zhin hwa dpe tshong khang gis bkram, 2002. TBRC ID W26372.

Shākya mchog ldan. Chos la 'jug pa'i sgo. In gsung 'bum/_Shākya mchog ldan. TBRC W00EGS1016899. 24:336 -348. Kathmandu, Nepal: Sachen international, guru lama, 2006.

Sog bzlog pa Blo gros rgyal mtshan, Gsang sngags snga 'gyur la Bod du rtsod pa snga phyir byung ba rnams kyi lan du brjod pa nges don gyi 'brug. Dalhousie: Damchoe Sangpo, 1982. TBRC ID W27914.

Klong Chen Chos 'Byung. Gangs Can Rig Mdzod 17. Lhasa: Bod ljongs bod yig dpe rnying dpe skrun khang, 1991.

\section{Western Language Sources}

Achard, Jean-Luc. "The Tibetan Tradition of the Great Perfection." In Northern Buddhism in History, edited by Thapa Shanker, 185-233. Kathmandu: Vajra Publications, n.d.

Adam, Martin. "Meditation and the Concept of Insight in Kamalaśíla’s Bhāvanākramas." McGill University, 2002.

Adamek, Wendi Leigh. The Mystique of Transmission: On an Early Chan History and Its Contexts. New York: Columbia University Press, 2007.

Ahern, Emily M., Arthur P. ed Wolf, and Society Joint Committee on Contemporary China. Subcommittee on Research on Chinese. Religion and Ritual in Chinese Society. Stanford, Calif.: Stanford University Press, 1974.

Alexander, Jeffrey C., and Philip Smith. The Cambridge Companion to Durkheim. Cambridge: Cambridge University Press, 2005.

Anālayo. “The Treatise on the Path to Liberation (解脫道論) and the Visuddhimagga.” Fuyan Buddhist Studies 4 (2009): 1-15.

Arnold, David, and Stuart H. Blackburn. Telling Lives in India: Biography, Autobiography, and Life History. Bloomington: Indiana University Press, 2004.

Asiatic Society. Catalogue of Tibetan Manuscripts in the Collection of the Asiatic Society. Calcutta: Asiac Society, 1990.

Bacot, Jacques, Frederick William Thomas, and Gustave Charles Toussaint. Documents de Touen-houang Relatifs à l'Histoire Du Tibet. Paris: Libraire Orientaliste Paul Geuthner, 1940.

Baroetto, Giuseppe. La Dottrina dell'Atiyoga Nel bSam Gtan Mig Sgron Di gNubs Chen Sangs 
Rgyas Ye Shes. Edizione Critica Del Settimo Capitolo. 2 vols. Lulu, 2011.

Barrett, T. H. "The Date of the Leng-chia Shih-tzu Chi." Journal of the Royal Asiatic Society (Third Series) 1, no. 02 (1991): 255-59.

Barthes, Roland. Image, Music, Text. New York: Hill and Wang, 1977.

Beckwith, Christopher I., 1945-. The Tibetan Empire in Central Asia: a History of the Struggle for Great Power Among Tibetans, Turks, Arabs, and Chinese During the Early Middle Ages. Princeton, N.J.: Princeton University Press, 1987.

Berling, Judith A. "Bringing the Buddha down to Earth: Notes on the Emergence of 'Yu-lu' as a Buddhist Genre." History of Religions 27, no. 1 (August 1987): 56.

Beyer, Stephan. "Notes on the Vision Quest in Early Mahāyāna." In Prajñāpāramitā and Related Systems: Studies in Honor of Edward Conze, edited by Lewis R. Lancaster, Vol. 1. Berkeley Buddhist Studies Series ; 1. Berkeley: University of California, 1977.

—. The Buddhist Experience: Sources and Interpretations. Encino, Calif.,: Dickenson, 1974.

Bingham, Woodbridge. "Notes on Tun-Huang Manuscripts in Paris and London." The Far Eastern Quarterly 11, no. 1 (1951): 67-70.

Blumenthal, James. “Śāntarakșita.” Edited by Edward N. Zalta. The Stanford Encyclopedia of Philosophy, 2014. http://plato.stanford.edu/archives/sum2014/entries/saantarak-sita/.

- The Ornament of the Middle Way: a Study of the Madhyamaka Thought of Śantarakșita. 1st USA. Ithaca, N.Y.: Snow Lion Publications, 2004.

Boyarin, Daniel. Intertextuality and the Reading of Midrash. Bloomington: Indiana University Press, 1990.

Braun, Willi, and Russell T. McCutcheon, eds. Introducing Religion : Essays in Honor of Jonathan Z. Smith. London; Oakville: Equinox Pub., 2008. http://www.loc.gov/catdir/toc/ecip0720/2007024530.html.

Broughton, Jeffrey. "Early Ch'an Schools in Tibet.” In Studies in Ch'an and Hua-Yen, 1-68. Honolulu: University of Hawaii Press, 1983.

—. The Bodhidharma Anthology. Berkeley, Calif.: University of California Press, 1999.

—. "The Stratigraphy of the Tun-huang Ch'an Manuscripts (Appendix A)." In The Bodhidharma Anthology the Earliest Records of Zen. Berkeley, Calif.: University of California Press, 1999.

Buddhaghoșa. The Path of Purification: Visuddhimagga. Translated by Bhikkhu Nanamoli. Seattle: Pariyatti Publishing, 2003.

- Visuddhimagga of Buddhaghosâcariya; Translated by Henry Clarke Warren and Dharmananda Kosambi. Vol. 41. Harvard Oriental Series. Cambridge,: Harvard University Press, 1950.

Buddhaguhya. The Mahā-Vairocana-Abhisambodhi Tantra: With Buddhaguhya's Commentary. Translated by Stephen Hodge. London ;New York: RoutledgeCurzon, 2003. http://discovery.lib.harvard.edu/?itemid=\%7Clibrary/m/aleph\%7C008059373.

Buswell, Robert E., and Donald S Lopez. The Princeton Dictionary of Buddhism. Princeton 
University Press, 2013.

Cabezon, José Ignacio. The Buddha's Doctrine and the Nine Vehicles: Rog Bande Sherab's Lamp of the Teachings. New York: Oxford University Press, 2013.

Cantwell, Cathy. The Kìlaya Nirvāna Tantra and the Vajra Wrath Tantra: Two Texts from the Ancient Tantra Collection. Wien: Verlag der Österreichischen Akademie der Wissenschaften, 2007.

. "To Meditate Upon Consciousness as Vajra: Ritual 'Killing and Liberation' in the rNying-ma-pa Tradition." In Tibetan Studies, Volume 1: Proceedings of the 7th Seminar of the International Association for Tibetan Studies, Graz, 1995. Wien: Verlag der Österreichischen Akademie der Wissenschaften, 1997.

Cantwell, Cathy, and Robert Mayer. Early Tibetan Documents on Phur Pa from Dunhuang. Vol. 370. Bd. Wien: Verlag der Österreichischen Akademie der Wissenschaften, 2008.

Chappell, David W., Masao Ichishima, and Hawaii Buddhist Translation Seminar of. T'ien-t 'ai Buddhism : an Outline of The Fourfold Teachings = [T'ien-t'ai Ssŭ Chiao I].

Tokyo:[Honolulu]: Daiichi-Shobō ;Distributed by the University Press of Hawaii, 1983.

Chattopadhyaya, Alaka. Atīśa and Tibet: Life and Works of Dīpamkara Śrījñāna in Relation to the History and Religion of Tibet. Delhi: Motilal Banarsidass, 1981.

Chattopadhyaya, Alaka, 982-1054. Atīśa, and Lama Chimpa. Atīśa and Tibet: Life and Works of Dipamkara Śījuñana in Relation to the History and Religion of Tibet. Delhi: Motilal Banarsidass, 1981.

Clauson, Gérard. “Manuscrit Pelliot Tibétain 1283.” Journal Asiatique 245 (1957): 11-24.

Collins, Randall. The Sociology of Philosophies : a Global Theory of Intellectual Change. Cambridge, Mass.: Belknap Press of Harvard University Press, 1998.

Cordier, P. d, and Marcelle Repertoire du Tanjur Lalou. Catalogue Du Fonds Tibétain de La Bibliothèque Nationale. New Delhi: Sharada Rani, 1984.

Covill, Linda, Ulrike Roesler, and Sarah Shaw. Lives Lived, Lives Imagined: Biography in the Buddhist Traditions. Boston :[Oxford]: Wisdom Publications ;In collaboration with the Oxford Centre for Buddhist Studies, 2010.

Cuevas, Bryan. "Some Reflections on the Periodization of Tibetan History." Revue d'Etudes Tibétaines, no. 10 (April 2006): 44-55.

Dalton, Jacob. "A Crisis of Doxography: How Tibetans Organized Tantra During the 8th-12th Centuries." Journal of the International Association of Buddhist Studies 28, no. 1 (2005): $115-81$.

. "Preliminary Remarks on a Newly Discovered Biography of Gnubs Chen Sangs Rgyas Ye Shes.” edited by Andrew Quintman and Benjamin Bogin. Somerville, MA: Wisdom Publications, forthcoming.

_ . "Rethinking Tibet's Dark Age: Demons, Tantras, and the Formation of Tibetan Buddhism," 2008. http://buddhiststudies.berkeley.edu/webcasts/.

. "The Development of Perfection: The Interiorization of Buddhist Ritual in the Eighth and Ninth Centuries.” Journal of Indian Philosophy 32, no. 1 (2004): 1-30. 
—. "The Early Development of the Padmasambhava Legend in Tibet." Journal of the American Oriental Society 124, no. 4 (2004): 759-772.

. "The Uses of the dGongs Pos 'Dus Pa'i Mdo in the Development of the rNying Ma School of Tibetan Buddhism.” University of Michigan, 2002.

Dalton, Jacob, Tom Davis, and Sam van Schaik. "Beyond Anonymity: Paleographic Analyses of the Dunhuang Manuscripts." Journal of the International Association of Tibetan Studies 3 (2007): 1-23.

Dalton, Jacob Paul. The Taming of the Demons: Violence and Liberation in Tibetan Buddhism. New Haven: Yale University Press, 2011.

Dalton, Jacob Paul, and Sam Van Schaik. Tibetan Tantric Manuscripts from Dunhuang : a Descriptive Catalogue of the Stein Collection at the British Library. Leiden ; Boston: Brill, 2006.

Dalton, Jacob, and Sam Schaik. "Where Chan and Tantra Meet: Buddhist Syncretism in Dunhuang." In The Silk Road: Trade,Travel, War and Faith, 61-71. London: British Library Press, 2004.

Dalton, Jacob, and Sam van Schaik. "Lighting the Lamp: The Structure of the Bsam Gtan Mig Sgron." Acta Orientalia 64 (2003): 153-75.

Daoyuan. Original Teachings of Ch'an Buddhism. New York,: Vintage Books, 1971.

Dargyay, Eva K. The Rise of Esoteric Buddhism in Tibet. Delhi: Motilal Banarsidass, 1977.

Davidson, Ronald M. Indian Esoteric Buddhism : a Social History of the Tantric Movement. Columbia University Press, 2002.

_. "Reframing Sahaja: Genre, Representation, Ritual and Lineage." Journal of Indian Philosophy 30, no. 1 (2002): 43-81.

- Tibetan Renaissance: Tantric Buddhism in the Tebirth of Tibetan Culture. New York: Columbia University Press, 2005.

Decleer, Hubert. “Atisha's Journey to Tibet." In Religions of Tibet in Practice, edited by Donald S. Lopez. Princeton, N. J.: Princeton University Press, 1997.

Demiéville, Paul. "Deux Documents de Touen-houang Sur Le Dhyâna Chinois." In Essays on the History of Buddhism Presented to Professor Zenryu Tsukamoto, 1-27. Kyoto: Nagai Shuppansha, 1961.

—. 'L'introduction Au Tibet Du Bouddhisme Sinisé D’apres Les Manuscrits de Touenhouang (Analyse de Récents Travaux Japonais)." In Contributions Aux Etudes Sur Touen-houang, 1-16. Geneve-Paris: Droz, 1979.

_. Le Concile de Lhasa. Paris: Impr. nationale de France, 1952.

—. "Recents Travaux Sur Touen-houang." Toung-Pao 46, no. 3 (1970): 1-95.

Denwood, Philip. “Tibetan Arts and the Tibetan 'Dark Age,' 842-996 CE.” Journal of Inner Asian Art Archaeology 5 (2010).

Diels, Hermann. Doxographi Graeci. Berolini: G. Reimer, 1879. 
Diemberger, Hildegard, and Pasang Wangdu. The Royal Narrative Concerning the Bringing of Buddha's Doctrine to Tibet. Wien: Verlag der Osterreichischen Akademie der Wissenschaften, 2000.

Donati, Valeria. “The Lamp Is Burning Bright. Gnoseological Approaches and Soteriological Perspectives in Gnubs Chen Sangs Rgyas Ye Shes' Masterpiece.” Università degli Studi di Napoli L'Orientale, 2006.

Dorje Dondrup. "Hail Prevention Rituals and Ritual Practitioners in Northeast Amdo," Asian Highlands Perspectives, no. 21 (2012): 71-111.

Dotson, Brandon. “'Emperor' Mu Rug Btsan and the 'Phang Thang Ma Catalogue.” Journal of the International Association of Tibetan Studies, no. 3 (December 2007): 1-25.

Dowman, Keith. The Power-places of Central Tibet: The Pilgrim's Guide. London; New York: Routledge \& Kegan Paul, 1988.

Drège, Jean-Pierre. "Étude Formelle Des Manuscrits de Dunhuang Conservés à Taipei : Datation et Authenticité." Bulletin de l'Ecole Française d'Extrême-Orient 74 (1985): 477-84.

Dudjom Rinpoche. The Nyingma School of Tibetan Buddhism: Its Fundamentals and History. Boston: Wisdom Publications, 2002.

Dumoulin, Heinrich. Zen Buddhism: a History. New York: MacMillan, 1994.

Eastman, Kenneth. "Mahāyoga Texts at Tun-huang." Bulletin of Institute of Buddhist Cultural Studies (Ryukoku University) 22 (1983): 42-60.

—. "The Eighteen Tantras of the Tattvasamgraha/Māyājāla." Transactions of the International Conference of Orientalists in Japan 26 (1981): 95-96.

Eckel, Malcolm David. Bhāviveka and His Buddhist Opponents. Cambridge, Mass: Harvard University, 2008. . Jñanagarbha's Commentary on the Distinction Between the Two Truths: An Eighth Century Handbook of Madhyamaka Philosophy. SUNY Series in Buddhist Studies. Albany, NY: State University of New York Press, 1987.

Eijk, Ph J. van der. Ancient Histories of Medicine : Essays in Medical Doxography and Historiography in Classical Antiquity. Vol. v. 20. Lieden ;Boston: Brill, 1999.

Eimer, Helmut. "The Classification of Buddhist Tantras." Wiener Zeitschrift Für Die Kunde Südasiens = Vienna Journal of South Asian Studies 36 (1993): 221-28.

Esler, Dylan. "Critical Edition: Introductory Remarks," Forthcoming. . "On the Life of gNubs-chen Sangs-rgyas Ye-shes." Revue d'Etudes Tibétaines, no. 29 (April 2014): 5-27.

. "The Exposition of Atiyoga in Nubs-chen Sangs-rgyas Ye-shes' bSam-gtan Mig-sgron." Revue d'Etudes Tibétaines 24, no. Studies in the Sems sde tradition of rDzogs chen, Ed. Jean-Luc Achard (October 2012): 81-136.

. "The Origins and History of rDzogs Chen." The Tibet Journal 30, no. 3 (Autumn 2005): $33-62$.

Faber, Flemming. "A Tibetan Dunhuang Treatise on Simultaneous Enlightenment: The Dmyigs 
Su Myed Pa Tshul Gcig Pa’i Gzhung.” Acta Orientalia 46 (1985): 47-77.

- "The Council of Tibet According to the sBa Bzhed." Acta Orientalia 47 (1986): 33-61.

. "Vimalamitra—One or Two?" Studies in Central and East Asian Religions 2 (1989): 19-26.

Faure, Bernard. Chan Insights and Oversights : an Epistemological Critique of the Chan Tradition. Princeton, New Jersey: Princeton University Press, 1993.

- The Will to Orthodoxy: a Critical Genealogy of Northern Chan Buddhism. Stanford, Calif.: Stanford University Press, 1997.

Foucault, Michel. The Archaeology of Knowledge. London: Routledge, 2002.

Freud, Sigmund. The Interpretation of Dreams. New York: Avon Books, 1965.

Fujieda, Akira. "Major Publications of Professor Fujieda Akira.” Cahiers d'Extrême-Asie 3 (1987): 1-7.

- "The Tunhuang Manuscripts: A General Description (Part I)." Zinbun: Memoirs of the Research Institute for Humanistic Studies 9 (1966): 1-32.

_ . "The Tunhuang Manuscripts: A General Description (Part II)." Zinbun : Memoirs of the Research Institute for Humanistic Studies, Kyoto University 10 (1969): 17-39.

—. "Une Reconstruction de La 'Bibliothèque'de Toen-houang.” Journal Asiatique, no. 269 (1981): 65-68.

Garfield, Jay L. The Fundamental Wisdom of the Middle Way: Nāgārjuna's Mūlamadhyamakakārikā. New York: Oxford University Press, 1995.

Garsson, DeWitt Garson. "Penetrating the Secret Essence Tantra: Context and Philosophy in the Mahayoga System of rNying-ma Tantra.” 2004.

Germano, David. "Architecture and Absence in the Secret Tantric History of rDzogs Chen." The Journal of the International Association of Buddhist Studies 17, no. 2 (1994): 203-335.

. Mysticism and Rhetoric in the Great Perfection (rDzogs Chen). Unpublished Manuscript, 2009.

—. "Poetic Thought, the Intelligent Universe, and the Mystery of Self: The Tantric Synthesis of Rdzogs Chen in Fourteenth Century Tibet." University of Wisconsin, Madison, 1992.

- Prophetic Histories of Buddhas, Dākin̄̄s and Saints in Tibet. Unpublished Manuscript, 2009.

—. "The Funerary Transformation of the Great Perfection (Rdzogs Chen)." Journal of the International Association of Tibetan Studies, no. 1 (2005): 1-54.

- The Secret Tibetan History of Buddhist Tantra in the Great Perfection. Unpublished Manuscript, 2009.

—. "The Seven Descents and the Nature of sNga' 'Gyur: The 'history' of rNying Ma Tantras." In The Many Canons of Tibetan Buddhism: Piats 2000 : Tibetan Studies : Proceedings of the Ninth Seminar of the International Association for Tibetan Studies. 
Leiden: Brill, 2000.

Germano, David, and Gregory Hillis. "Buddhist Meditation.” In Encyclopedia of Religion, edited by Lindsay Jones, 2nd ed. Detroit: Macmillan Reference USA, 2005.

Germano, David, and William S. Waldron. “A Comparison of Ālaya-vijñāna in Yogācāra and Dzogchen." In Buddhist Thought and Applied Psychological Research: Transcending the Boundaries, 33-68. New York: RoutledgeCurzon, 2006.

Gernet, Jacques, and Wu Chi-Yu. Catalogue Des Manuscrits Chinois de Touen-houang, Fonds Pelliot Chinois. Vol. 1. Paris: Bibliothèque nationale, 1970.

Gethin, Rupert. The Foundations of Buddhism. OPUS. Oxford: Oxford University Press, 1998.

Giles, Lionel, and Eric D. Grinstead. Descriptive Catalogue of the Chinese Manuscripts from Tunhuang in the British Museum. London,: British Museum. Dept. of Oriental Printed Books and Manuscripts.,, 1957.

Gimello, Robert M., and Peter N. Gregory. Studies in Ch'an and Hua-Yen. Honolulu: University of Hawaii Press: Kuroda Institute, 1983.

Gómez, Luis O. “El Bhāvanāyogāvatāra.” Estudios de Asia y Africa XIV, no. 1 (1979). . "Indian Materials on the Doctrine of Sudden Enlightenment." In Early Ch'an in China and Tibet, 393-434. Berkeley, Ca.: Asian Humanities Press, 1983.

. "Meditation." Edited by Damien Keown and Charles S. Prebish. Encyclopedia of Buddhism. London; New York: Routledge, 2007.

—. "Primer Tratado Del Cultivo Graduado, Part I (trad. Española Del IBhK)." Diálogos, Revista Del Departamento de Filosofia de La Universidad de Puerto Rico XII, no. 29-30 (1977): 177-224.

. "The Direct and Gradual Approaches of Zen Master Mahāyāna." In Studies in Ch'an and Hua-Yen, edited by Robert M. Gimello and Peter N. Gregory. Honolulu: University of Hawaii Press, 1983.

. "The Direct and Gradual Approaches of Zen Master Mahāyāna: Fragments of the Teachings of Mo-ho-yen.” In Studies in Ch'an and Hua-Yen, 69-168. Honolulu: University of Hawaii Press, 1983.

. "Último Tratado Del Cultivo Graduado (trad. Española Del IIIBhK)." Diálogos, Revista Del Departamento de Filosofia de La Universidad de Puerto Rico VIII, no. 23 (1972): 85-137.

—. "Vimalamitra y La Doctrina Subitista." Estudios de Asia y Africa XVI, no. 2 (1981): 254-72.

Gómez, Luis O., Johnathan Silk, and Jonathan A. Silk. Studies in the Literature of the Great Vehicle: Three Mahāyāna Buddhist Texts. Ann Arbor: Centers for South and Southeast Asia, Th, 1999.

Gordon White, David. "Review of Indian Esoteric Buddhism.” Journal of the International Association of Tibetan Studies (JIATS) 1 (October 2005).

Gos Lo-tsā-ba Gźon-nu-dpal, and George Roerich. The Blue Annals. Delhi: Motilal Banarsidass, 
1976.

Gray, David. "On the Very Idea of a Tantric Canon: Myth, Politics, and the Formation of the Bka' 'gyur." Journal of the International Association of Tibetan Studies, no. 5 (2009). http://www.thlib.org/?tid=T5690.

Gregory, Peter N., ed. Sudden and Gradual: Approaches to Enlightenment in Chinese Thought. Studies in East Asian Buddhism. Honolulu: University of Hawaii Press, 1987.

- Tsung-mi and the Sinification of Buddhism. Vol. 16. Honolulu: University of Hawai' $i$ Press, 2002.

- "Tsung-mi's Perfect Enlightenment Retreat: Ch'an Ritual During the T'ang Dynasty." Cahiers d'Extrême-Asie 7, no. 1 (1993): 115-47.

Gruber, Joel. "Vimalamitra." The Treasury of Lives. Accessed April 30, 2014. http://www.treasuryoflives.org/biographies/view/Vimalamitra/9985.

Guenther, Herbert V. "“Meditation' Trends in Early Tibet." In Early Ch'an in China and Tibet, 351-66. Berkeley Buddhist Studies Series. Berkeley, Ca.: Asian Humanities Press, 1983.

- The Teachings of Padmasambhava. Brill, 1996.

Gyaltsen, Sonam. The Clear Mirror : a Traditional Account of Tibet's Golden Age. Translated by McComas Taylor and Yuthok Choedak. Ithaca, NY: Snow Lion Publications, 1996.

Gyatso, Janet. "Healing Burns with Fire: The Facilitations of Experience in Tibetan Buddhism." Journal of the American Academy of Religion 67, no. 1 (March 1, 1999): 113-47.

Gyatso, T.C. "The Doctrine of the Incense Homa." The Mikkyo Bunka (Quarterly Reports on Esoteric Buddhism) 128, no. December (1979): 109-89.

Gyurme Dorje. "The Guhyagarbhatantra and Its XIVth Century Tibetan Commentary, Phyogs Bcumun Sel.” School of Oriental and African Studies, University of London, 1987.

Hackin, Joseph. Formulaire Sanscrit-tibétain Du Xe Siècle. Paris: Librairie orientaliste Paul Geuthner, 1924.

Halkias, Georgios. "Tibetan Buddhism Registered: Imperial Archives from the Palace-Temple of 'Phang-thang." The Eastern Buddhist XXXVI, no. 1 and 2 (2004): 46-105.

Hāṇ̣̣ā, Omacanda. Buddhist Western Himalaya: A Politico-religious History. Indus Publishing, 2001.

Hansen, Valerie. The Open Empire: a History of China to 1600. New York: Norton, 2000.

—. The Silk Road : a New History. New York: Oxford University Press, 2012.

Harada Satoru. "The Existence of Doctrinal Works of the Sudden School after the bSam Yas Debate (bSam-yas No Shūron Igo Ni Okeru Tonmonha No Ronsho)." Nihon Chibetto Gakkai Kaihō 22 (1976): 8-10.

Harrison, Paul. "Buddhānusmṛti in the Pratyutpanna-Buddha-Saṃmukhāvasthita-Samādhi-Sūtra." Journal of Indian Philosophy 6, no. 1 (September 1978).

Hazod, Guntram. "The Nine Royal Heirlooms." In Civilization at the Foot of Mount Sham-po: The Royal House of $1 \mathrm{Ha}$ Bug-pa-can and the History of g.Ya'-bzang ;, edited by Gyalbo 
Tsering. Beiträge Zur Kultur- Und Geistesgeschichte Asiens; Nr. 36. Wien: Verlag der Österreichischen Akademie der Wissenschaften, 2000.

. "The Yum-brtan Lineage." In Civilization at the Foot of Mount Sham-po: The Royal House of $1 \mathrm{Ha}$ Bug-pa-can and the History of g.Ya'-bzang ;, edited by Gyalbo Tsering. Beiträge Zur Kultur- Und Geistesgeschichte Asiens ; Nr. 36. Wien: Verlag der Österreichischen Akademie der Wissenschaften, 2000.

Higgins, David. "On the Development of the Non-mentation (amanasikāra) Doctrine in IndoTibetan Buddhism." Journal of the International Association of Buddhist Studies 29, no. 2 (January 21, 2009): 255-303.

Hopkins, Jeffrey. Emptiness Yoga: The Middle Way Consequence School. Ithaca, NY: Snow Lion Publications, 1987. . "The Tibetan Genre of Doxography: Structuring a Worldview." In Tibetan Literature : Studies in Genre, edited by Roger R. Jackson, Geshe Lhundup Sopa, and José Ignacio Cabezón, 1st USA. Studies in Indo-Tibetan Buddhism. Ithaca, N.Y.: Snow Lion, 1996.

Houston, G. W. Sources for a History of the bSam Yas Debate. Sankt Augustin, Denmark: VGHWissenschaftsverlag, 1980.

_. "The bSam Yas Debate: According to the rGyal Rabs Gsal Ba'i Me Long." Central Asiatic Journal 18 (1974): 209-16.

Huber, Toni. "Putting the Gnas Back Into Gnas-khor: Rethinking Tibetan Pilgrimage Practice." In Sacred Spaces and Powerful Places in Tibetan Culture: A Collection of Essays, edited by Toni Huber, 77-104. Dharamsala, India: The Library of Tibetan Works and Archives, 1999.

- The Holy Land Reborn: Pilgrimage and the Tibetan Reinvention of Buddhist India. Chicago: University of Chicago Press, 2008.

—. "Where Exactly Are Cāritra, Devikoța, and Himavat? A Sacred Geography Controversy and the Development of Tantric Buddhist Pilgrimage Sites in Tibet." Kailash 16, no. 3 and 4 (1990): 121-64.

Hymes, Robert P. Way and Byway: Taoism, Local Religion, and Models of Divinity in Sung and Modern China. Berkeley: University of California Press, 2002.

Imaeda, Yoshiro. “À Propos Du Manuscrit Pelliot Tibétain 999.” In SŪRYACANDRĀYA : Essays in Honour of Akira Yuyama on the Occasion of His 65th Birthday, edited by P. Harrison and G. Schopen, 87-94. Swisttal-Odendorf: Indica et Tibetica Verlag, 1998.

—. "Chinese Texts on the Tibetan King Glang Dar Ma." Bukkyō-gaku Seminā 74 (January 200AD): 26-38.

—. "Documents Tibetains de Touen-houang Concernant Le Concile Du Tibet." Journal Asiatique 265 (1975): 125-46.

—. "The Provenance and Character of the Dunhuang Documents." Memoirs of the Research Department of The Toyo Bunko 66 (2009): 81-102.

Imaeda, Yoshiro, Ariane Macdonald, Ariane Spanien, Paul Pelliot, Bibliothèque nationale (France), and Mission Paul Pelliot. Choix de Documents Tibétains Conservés à La 
Bibliothèque Nationale: Complété Par Quelques Manuscrits de l'India Office et Du British Museum. Paris: Bibliothèque nationale, 1978.

International Association for Tibetan Studies. Seminar 1992 : Fagernes, Norway), and Per Kværne. Tibetan Studies : Proceedings of the 6th Seminar of the International Association for Tibetan Studies, Fagernes, 1992. Occasional Papers (Instituttet for Sammenlignende Kulturforskning) ; 1. Oslo: Institute for Comparative Research in Human Culture, 1994.

Izumi Miyazaki. "The Gradual Chapter of the Bsam Gtan Mig Sgron and the Teaching of Kamalaśîla.” Journal of Indian and Buddhist Studies 52, no. 2 (March 2004): 899-902.

Jackson, David Paul. Enlightenment by a Single Means: Tibetan Controversies on the "Selfsufficient White Remedy" (dkar Po Chig Thub). Wien: Verlag der Österreichischen Akademie der Wissenschaften, 1994.

Jackson, Roger R., Geshe Lhundup Sopa, and José Ignacio Cabezón. Tibetan Literature : Studies in Genre. 1st USA. Studies in Indo-Tibetan Buddhism. Ithaca, N.Y.: Snow Lion, 1996.

Jamgon Kongtrul. Buddhist Ethics. Ithaca: Snow Lion Publications, 1998.

—. Jamgon Kongtrul's Retreat Manual. Ithaca, N.Y.: Snow Lion, 1994.

- Systems of Buddhist Tantra. The Treasury of Knowledge Book Six, Part Four. Ithaca, N.Y.: Snow Lion Publications, 2005.

—. The Treasury of Knowledge. Book One: Myriad Worlds. Ithaca, N.Y.: Snow Lion Publications, 2003.

- The Treasury of Knowledge: Book Eight, Part Four: Esoteric Instructions : a Detailed Presentation of the Process of Meditation in Vajrayana. Translated by Sarah Harding. Ithaca, N.Y.: Snow Lion Publications, 2007.

Jampa, Samten, and Lobsang Sāstrī. Catalogue of the Library of Tibetan Works and Archives, Manuscript Section. Dharamsala: Library of Tibetan Works \& Archives, 1983.

Jenkins, Keith, and Alun Munslow. Re-thinking History. New York: Routledge, 2003.

Jha, Ganganatha. The Tattvasangraha of Śāntarakșita: With the Commentary of Kamalaślala. Vol. no. 80, 83. Baroda: Oriental institute, 1937.

Jordanova, L. J. History in Practice. London: Arnold, 2000.

Jorgensen, John A. "The Earliest Text of Ch'an Buddhism : the Long Scroll," 2014.

Kapstein, Matthew. Buddhism Between Tibet and China. Boston: Wisdom Publications, 2009. . "gDams Ngag: Tibetan Technologies of the Self." In Tibetan Literature: Studies in Genre, edited by Lhundup Sopa, José Ignacio Cabezón, and Roger R. Jackson. Ithaca, N.Y: Snow Lion, 1996.

—_. "Remarks on the Maṇi bKa'-'bum and the Cult of Āvalokiteśvara in Tibet." In Tibetan Buddhism: Reason and Revelation, edited by Steven D. Goodman and Ronald M. Davidson. SUNY Series in Buddhist Studies. Albany: State University of New York Press, 1992.

- The Presence of Light: Divine Radiance and Religious Experience. Chicago: University 
of Chicago Press, 2004.

. "The Sun of the Heart and the Bai Rgyud 'bum." Revue d'Études Tibétaines, no. 15 (2008): 275-88.

. "The Taming of the Demons: Violence and Liberation in Tibetan Buddhism by Jacob P. Dalton (review)." Harvard Journal of Asiatic Studies 73, no. 1 (2013): 177-84.

- The Tibetan Assimilation of Buddhism. Oxford; New York: Oxford University Press, 2000.

—. The Tibetans. Malden, MA: Blackwell Pub., 2006.

- The Tibetans. Malden, MA: Blackwell Pub., 2006.

Kapstein, Matthew, and Brandon Dotson. Contributions to the Cultural History of Early Tibet. Leiden ; Boston: Brill, 2007.

Kapstein, Matthew, and Sam Van Schaik. Esoteric Buddhism at Dunhuang : Rites and Teachings for This Life and Beyond. Leiden: Brill, 2010.

Karmay, Samten Gyaltsen. “A Recently Discovered Rnam Thar of Lha Bla Ma Ye She's 'od.” In Tibet after Empire: Culture, Society and Religion Between 850-1000. Lumbini: LIRI, 2013.

- The Arrow and the Spindle: Studies in History, Myths, Rituals and Beliefs in Tibet. Kathmandu: Mandala Book Point, 1998.

- The Great Perfection (rDzogs Chen) : a Philosophical and Meditative Teaching of Tibetan Buddhism. Leiden: Brill, 2007.

-. The Great Perfection (rDzogs Chen): a Philosophical and Meditative Teaching of Tibetan Buddhism. Leiden - New York: E.J. Brill, 1988.

Katsumi, Mimaki. "Doxographie Tibetaine et Classifications Indiennes." In Bouddhisme et Cultures Locales. Quelques Cas de Reciproques Adaptations. Actes Du Colloque Francojaponais de Septembre 1991. Paris: Ecole Francaise d'Extreme-Orient, 1991.

Katsumi, Okimoto. "Dunhuang Chutu de Zangwen Chanzong Wenxian Neirong (Contents of Tibetan Chan Manuscripts Recovered at Dunhunag)." Guowai Zangxue Yanjiu Shi Wenji (Anthology of Translation on Tibetological Research Undertaken in Foreign Countries), no. 8 (1992): 423-27.

—. “Tonkō Shutsudo Chibettobun Zenshū Bunken No Kenkyū 沖本克己 (Research on Tibetan Chan Manuscripts Recovered at Dunhuang).” Indogaku Bukkyōgaku Kenkyū (Research on Indian and Buddhist Studies) 28, no. 1 (1969).

Kelsang Gyatso. Clear Light of Bliss: Mahāmudrā in Vajrayāna Buddhism. London: Wisdom Publications, 1982.

- Tantric Grounds and Paths: How to Begin, Progress on, and Complete the Vajrayana Path. London: Tharpa, 1994.

Khetsun Sangpo Rinbochay. Biographical Dictionary of Tibet and Tibetan Buddhism.

Dharamsala, H. P.: Library of Tibetan Works and Archives, Headquarters of H. H. the

Dalai Lama, 1973. 
Kimura, Ryūtoku. "Le Dhyana Chinois Au Tibet Ancien Apres Mahayana.” Journal Asiatique 269 (1981): $184-192$.

. "Tonkō Shutsudi Chibetto Bun Shahon Stein 709 [The Tun-Huang Tibetan Manuscript Stein 709]." Nihon Chibetto Gakkai Kaihō 22 (March 1976): 11-13.

Kuan, hsiu, and Ch i-yü Wu. Trois Poèmes Inédits de Kouan-hiéou. Paris,: Société asiatique, 1960.

Kunsang, Erik Pema. The Lotus-Born: The Life Story of Padmasambhava. Third Edition edition. Hong Kong; Enfield: Rangjung Yeshe Publications, 2004.

La Vallée Poussin, Louis de. Catalogue of the Tibetan Manuscripts from Tun-huang in the India Office Library. London: Published for the Commonwealth Relations Office [by] Oxford University Press, 1962.

- Catalogue of the Tibetan Manuscripts from Tun-huang in the India Office Library. London: Published for the Commonwealth Relations Office [by] Oxford University Press, 1962.

Lalou, Marcelle. Catalogue Du Fonds Tibétain de La Bibliothèque Nationale. Vol. t. 4. Paris: P. Geuthner, 1931.

—_. "Document Tibétain Sur L'expansion Du Dhyāna Chinois.” Journal Asiatique 231 (1939): 502-23.

—. Inventaire Des Manuscrits Tibétains de Touen-houang Conservés à La Bibliothèque Nationale (Fonds-Pelliot Tibétain). Paris, 1939.

—. "Les Textes Bouddhiques Au Temps Du Roi Khri-sron-lde-bcan. Contribution à La Bibliographie Du Kanjur et Du Tanjur.” Journal Asiatique, 1953, 313-54. doi:, dans , 1953, p. .

Lancaster, Lewis R., and Whalen Lai, eds. Early Ch'an in China and Tibet. Vol. 5. Berkeley, Ca.: Asian Humanities Press, 1983.

Liljenberg, Karen. "On the Thig Le Drug Pa and the sPyi Chings, Two of the Thirteen Later Translations of the rDzogs Chen Mind Series." Revue d'Etudes Tibétaines 24, no. October 2012 (n.d.): 137-57.

—. "The Small Hidden Grain by Buddhagupta. Translated from the British Library Dunhuan Manuscript IOL Tib J 594." Http://www.zangthal.co.uk/files.html, n.d.

Lipman, Kennard, and Namkhai Norbu. Dzog Chen and Zen. Nevada City, CA: Blue Dolphin Pub., 1984.

Lopez, Donald S. Buddhist Hermeneutics. Vol. 6. Studies in East Asian Buddhism. Honolulu: University of Hawaii Press, 1988.

- Prisoners of Shangri-La: Tibetan Buddhism and the West. Chicago: University of Chicago Press, 1998.

Mackenzie, Vicki. Cave in the Snow: Tenzin Palmo's Quest for Enlightenment. New York: Bloomsbury :Distributed in the book trade by St. Martin's Press, 1998.

Mair, Victor H. T'ang Transformation Texts : a Study of the Buddhist Contribution to the Rise of 
Vernacular Fiction and Drama in China. Cambridge, Mass.: Council on East Asian Studies Distributed by Harvard University Press, 1989.

Manchester, William. A World Lit Only by Fire: The Medieval Mind and the Renaissance: Portrait of an Age. 1st ed. Boston: Little, Brown, 1992.

Martin, Dan. “A Brief Political History of Tibet by Gu-ru Bkra-shis.” In Tibetan History and Language: Studies Dedicated to Uray Géza on His Seventieth Birthday, edited by Uray, 1921- Géza and Ernst Steinkellner, Heft 26:329-51. Wiener Studien Zur Tibetologie Und Buddhismuskunde; Heft 26. Wien: Arbeitskreis für Tibetische und Buddhistische Studien, Universität Wien, 1991.

- "Illusion Web -Locating the Guhyagarbha Tantra in Buddhist Intellectual History." In Silver on Lamps: Tibetan Literary Culture and History, edited by C.I. Beckwith. Bloomington: The Tibet Society, 1987.

. "Illusion Web: Locating the Guhyagarbha Tantra in Buddhist Intellectual History." In Silver on Lapis: Tibetan Literary Culture and History, edited by Christopher I. Beckwith, 175-220. Bloomington: The Tibet Society, n.d.

. "Lay Religious Movements in 11th- and 12th-Century Tibet: A Survey of Sources." Kailash 18, no. 3-4 (1996): 23-56.

. "The Early Education of Milarepa.” The Journal of the Tibet Society 2 (1982): 52-76.

. "The Star King and the Four Children of Pehar: Popular Religious Movements of Eleventh- to Twelfth-century Tibet." Acta Orientalia 49, no. 1-2 (1996): 171-95.

- Tibetan Histories : a Bibliography of Tibetan-language Historical Works. London: Serindia, 1997.

Masamichi Ichigo. "Śāntarakșita 's Madhyamākalaṃkāra.” In Studies in the Literature of the Great Vehicle: Three Mahayana Buddhist Texts, edited by Luis Gomez and Jonathan A. Silk. Ann Arbor: Centers for South and Southeast Asia, Th, 1999.

McRae, John R. Seeing through Zen : Encounter, Transformation, and Genealogy in Chinese Chan Buddhism. Berkeley: University of California Press, 2003.

- The Northern School and the Formation of Early Ch'an Buddhism. Honolulu: University of Hawaii Press, 1986.

Megill, Allan. Historical Knowledge, Historical Error: a Contemporary Guide to Practice. Chicago: University of Chicago Press, 2007.

Meinert, Carmen. "A Pliable Life: Facts and Fiction About the Figure of the Chinese Meditation Master Wolun.” Oriens Extremus 46 (2007): 184-210.

. "Chinese Chan and Tibetan Rdzogs Chen: Preliminary Remarks on Two Tibetan Dunhuang Manuscripts." In Religion and Secular Culture in Tibet. Tibetan Studies II (PIATS 2000), 289-307. Leiden: Brill, 2002.

. "Chinesische Chan- Und Tibetische rDzogs chen-Lehre: Eine Komparatistische Untersuchung Im Lichte Des Philosophischen Heilskonzeptes 'Nicht-Vorstellen' Anhand Der Dunhuang-Dokumente Des Chinesischen Chan-Meister Wolun Und Des Werkes bSam Gtan Mig Sgron Des Tibetischen Gelehrten gNubs Chen Sangs Rgyas Ye Shes.” 
Rheinischen Friedrich-Wilhelms-Universität, 2004.

. "Legend of Cig Car Ba Criticism in Tibet: a List of Six Cig Car Ba Titles in the Chos 'byung Me Tog Snying Po of Nyang Nyi Ma 'od Zer (12th Century)." In Tibetan Buddhist Literature and Praxis. Studies in Its Formative Period 900-1400, edited by Ronald Davidson and Christian Wedemeyer, 31-54. Boston/Leiden: Brill, 2006.

- "Structural Analysis of the bSam Gtan Mig Sgron: A Comparison of the Fourfold Correct Practice in the Āryāvikalpapraveśanāmadhāraṇi and the Contents of the Four Main Chapters of the bSam Gtan Mig Sgron." Journal of the International Association of Buddhist Studies 26, no. 1 (2003): 175-95.

. "The Conjunction of Chinese Chan and Tibetan rDzogs Chen Thought: Reflections on the Tibetan Dunhuang Manuscripts IOL Tib J 689-1 and PT 699." In Contributions to the Cultural History of Early Tibet (extra Volume to Studies in Central and East Asian Religion), edited by Matthew T. Kapstein and Brandon Dotson, 239-301. Leiden/Boston: Brill, 2007.

Mestanza, Ferran. "La Première Somme Philosophique Du Bouddhisme Tibétain. Origines Littéraires, Philosophiques et Mythologiques Des 'Neuf Étatpes de La Voie' (theg Pa Rim Pa Dgu).” Revue d'Etudes Tibétaines 8 (2005).

Moretti, Franco. “Conjectures on World Literature.” New Left Review, no. 1 (2000): 54-68. - Distant Reading. London: Verso, 2013.

Mun, Chanju. The History of Doctrinal Classification in Chinese Buddhism : a Study of the Panjiao Systems. Lanham: University press of America, 2006.

Nattier, Jan. A Few Good Men: The Bodhisattva Path According to the Inquiry of Urga (Ugrapariprcchā). Studies in the Buddhist Traditions. Honolulu: University of Hawai'i Press, 2003.

Neumaier, Eva K. “The bSam Gtan Mig Sgron and Its Quotations,” 1998.

Newland, Guy. The Two Truths in the Mãdhyamika Philosophy of the Ge-luk-ba Order of Tibetan Buddhism. Studies in Indo-Tibetan Buddhism. Ithaca, N.Y., USA: Snow Lion Publications, 1992.

Norbu, Namkhai. The Supreme Force. The Fundamental Tantra of Dzogchen Semde Nujed Gyalpo. Snow Lion Publications, 1999.

Norbu, Namkhai, and Kennard Lipman. Primordial Experience: An Introduction to rDzogs-chen Meditation. Shambhala, 2001.

Noriaki Hakamaya (袴谷憲. “Serving and Served Monks in the Yogācārabhūmi.” In The Foundation for Yoga Practitioners: The Buddhist Yogācārabhūmi Treatise and Its Adaptation in India, East Asia, and Tibet, edited by Ulrich Timme Kragh, 312-29. Harvard Oriental Series 75. Cambridge: Harvard University Press, 2013.

Obermiller, Eugéne. “A Sanskrit Ms. from Tibet -- Kamalaśīla Bhāvanākrama.” Journal of the Greater Indian Society 2, no. 1 (1935): 1935. . History of Buddhism. Heidelberg: Institut für Buddhismuskunde, 1931. 
Okimoto, Katsumi. "bSam Yas No Shuron (2): Tonko Chibetto Bunken Ni Okeru Shozenji." Nihon Chibetto Gakkai Kaihō 22 (March 1976): 4-8.

. “Chibetto Yaku Ninyū Shigyō Ron Ni Tsuite チベット訳二入四行論について [Concerning the Tibetan Translation of the Erh-ju Ssu-hsing Lun]." Nihon Indogaku Bukkyō Kenkyū 24, no. 2 (March 1976): 992-99.

Onians, Isabelle. Tantric Buddhist Apologetics, or, Antinomianism as a Norm, 2001.

Osto, Douglas. “"Proto-Tantric' Elements in The Gaṇdavyūha Sūtra.” Journal of Religious History 33, no. 2 (2009): 165-77.

Pachow, W. "A Study of the Twenty-two Dialogues on Mahayana Buddhism." The Chinese Culture 20, no. 1 (1979).

Palmo, Ani Jinba. The Great Image: The Life Story of Vairochana the Translator. Boston: Shambhala, 2004.

Pelliot, Paul. Fa Cang Dunhuang Shu Yuan Jing Hua. [Canton?]: Guangdong ren min chu ban she : Guangdong sheng xin hua shu dian jing xiao, 1993.

- Inventaire Sommaire Des Manuscrits et Imprimés Chinois de La Bibliothèque Vaticane (13 Juin-6 Juillet 1922). [Rome,, 1922.

—. "Une Bibliothèque Médiévale Retrouvée Au Kan-sou." Bulletin de l’École Française D'Extreme Orient 8 (1908): 510-29.

Pelliot, Paul, and Jean Pierre Drège. Les Routes de La Région de Turfan Sous Les T'ang ; Suivi de L'histoire et La Géographie Anciennes de l'Asie Centrale Dans Innermost Asia. Paris: Institut des hautes études chinoises du Collège de France, 2002.

Pelliot, Paul, and Robert Gauthiot. Mission Pelliot En Asie Centrale [de 1906 à 1909]. Paris,: P. Geuthner, 1914.

Pelliot, Paul, and Sheng Geng. Boxihe Dunhuang Shi Ku Bi Ji = Grottes de Touen-Houang, Carnet de Notes de Paul Pelliot. Lanzhou: Gansu ren min chu ban she, 2007.

Pelliot, Paul, Sheng Geng, and Jianbin Tang. Boxihe Dunhuang Shi Ku Bi Ji. Lanzhou: Gansu ren min chu ban she, 1993.

Pelliot, Paul, Nicole Vandier-Nicolas, and Monique Maillard. Grottes de Touen-Houang: Carnet de Notes de Paul Pelliot. Inscriptions et Peintures Murales IV: Grottes 112a à 120n. Paris,: College de France, Instituts D’Asie, 1984.

Petech, Luciano. "The Disintegration of the Tibetan Kingdom.” In Tibetan Studies : Proceedings of the 6th Seminar of the International Association for Tibetan Studies, Fagernes, 1992, edited by Per Kværne, 649-59. Occasional Papers (Instituttet for Sammenlignende Kulturforskning). Oslo: Institute for Comparative Research in Human Culture, 1994.

—. "The Disintegration of the Tibetan Kingdom." In Tibetan Studies, edited by Per Kværne. Oslo: The Institute for Comparative Research in Human Culture, 1994.

Poceski, Mario. "Mazu Yulu and the Creation of the Chan Records of Sayings." In The Zen Canon, edited by Steven Heine and Dale S. Wright. Oxford: Oxford University Press, 2004. 
Quintman, Andrew (Andrew H.). The Life of Milarepa. Penguin Classics. New York: Penguin Books, 2010.

Revel, Jean François, and Matthieu Ricard. The Monk and the Philosopher: a Father and Son Discuss the Meaning of Life. New York: Schocken Books, 1999.

Reynolds, Frank, and Donald Capps. The Biographical Process: Studies in the History and Psychology of Religion. Vol. 11. Religion and Reason. The Hague: Mouton, 1976.

Richardson, Hugh. "Khri Gtsug-lde-brtsan's Illnes.” Bulletin of the School of Oriental and African Studies, no. 44 (1981): 351-52.

_. "Political Rivalry and the Great Debate at Bsam-yas." In High Peaks, Pure Earth, 2036. London: Serindia, 1998.

Rong, Xinjiang, and Hansen Valerie. "The Nature of the Dunhuang Library Cave and the Reasons for Its Sealing." Cahiers d'Extrême-Asie 11 (1999): 247-75.

Rossi, Donatella. The Philosophical View of the Great Perfection in the Tibetan Bon Religion. Ithaca N.Y.: Snow Lion Publications, 1999.

Ruegg, David Seyfort. Buddha-nature, Mind and the Problem of Gradualism in a Comparative Perspective : on the Transmission and Reception of Buddhism in India and Tibet. New Delhi: Heritage, 1992.

. "Le ITa-ba ’i Khaydpar de Ye-shes-sde.” Journal Asiatique, 1981, 207-29.

. "On the Historiography and Doxography of the "Great Debate of bSam Yas." In Tibetan Studies: Proceedings of the 5th Seminar of the International Associaton for Tibetan Studies (Narika 1989), edited by Ihara Shoren. Tokyo: Naritisan Shinshoji, 1992.

- The Literature of the Madhyamaka School of Philosophy in India. Vol. 7. 1. Wiesbaden: Harrassowitz, 1981.

Savitsky, Lev S. "Tunhuang Tibetan Manuscripts in the Collection of the Leningrad Institute of Oriental Studies." In Tibetan and Buddhist Studies Commemorating the 200th Anniversary of the Birth of Alexander Csoma de Körös, edited by Louis Ligeti. Budapest: Akadémiai Kiadó, 1984.

Schaeffer, Kurtis R. Dreaming the Great Brahmin: Tibetan Traditions of the Buddhist Poet-Saint Saraha. New York: Oxford University Press, 2005.

Schaeffer, Kurtis R., and Leonard W. J. van der Kuijp. An Early Tibetan Survey of Buddhist Literature: The Bstan Pa Rgyas Pa Rgyan Gyi Nyi 'Od of Bcom Ldan Ral Gri. Vol. v. 64. Harvard Oriental Series. Cambridge, Mass.: Harvard University Press, 2009.

Scheidegger, Daniel. "Different Sets of Light-Channels in the Instruction Series of Rdzogs Chen." Revue d'Etudes Tibétaines 12 (March 2007): 33-36.

Scherrer-Schaub, Cristina. "Prière Pour Un Apostat: Fragments D’histoire Tibétaine." Cahiers d'Extrême-Asie 11 (1999): 217-46.

Scherrer-Schaub, Cristina Anna. "Towards a Methodology for the Study of Old Tibetan Manuscripts: Dunhuang and Tabo." In Tabo Studies II. Manuscripts, Texts, Inscriptions, and the Arts, edited by Cristina Anna Scherrer-Schaub and Ernst Steinkellner. Serie Orientale Roma. Roma: Istituto italiano per l'Africa e l'Oriente, 1999. 
Scherrer-Schaub, Cristina Anna, and Paul M. Harrison. Tabo Studies III : a Catalogue of the Manuscript Collection of Tabo Monastery. Vol. v. 103. Roma: Istituto Italiano per l'Africa e l'Oriente, 2009.

Schmithausen, Lambert. Alayavijñanna: On the Origin and the Early Development of a Central Concept of Yogācāra Philosophy. Tokyo: International Institute for Buddist Studies, 1987.

Schrempf, Mona. "Hwa Shang at the Border: Transformations of History and Reconstructions of Identity in Modern A Mdo." Journal of the International Association of Tibetan Studies 2 (2006): 1-32.

Schuh, Dieter. Untersuchungen Zur Geschichte Der Tibetischen Kalenderrechnung. Wiesbaden: F. Steiner, 1973.

Shakabpa, W. D., 1908-. Tibet, a Political History,. New Haven,: Yale University Press, 1967.

Sharf, Robert H. "Buddhist Modernism and the Rhetoric of Meditative Experience." Numen 42, no. 3 (October 1, 1995): 228-83.

Shaw, Rosalind. "Feminist Anthropology and the Gendering of Religious Studies." In Religion and Gender, edited by Ursula King. Oxford, UK; Cambridge, USA: Blackwell Publishers, 1995.

Smith, Jonathan Z. Drudgery Divine: On the Comparison of Early Christianities and the Religions of Late Antiquity. Chicago: University of Chicago Press, 1990. http://www.loc.gov/catdir/enhancements/fy0609/90038519-b.html http://www.loc.gov/catdir/enhancements/fy0608/90038519-d.html http://www.loc.gov/catdir/enhancements/fy0608/90038519-t.html.

- Imagining Religion: From Babylon to Jonestown. Chicago: University of Chicago Press, 1982. . Map Is Not Territory: Studies in the History of Religions. Leiden: Brill, 1978. . "Narratives into Problems': The College Introductory Course and the Study of Religion." Journal of the American Academy of Religion 56, no. 4 (1988): 727-39.

. On Teaching Religion: Essays by Jonathan Z. Smith. New York: Oxford University Press, 2013.

- Relating Religion: Essays in the Study of Religion. Chicago: University of Chicago Press, 2004. http://www.loc.gov/catdir/description/uchi051/2004045967.html http://www.loc.gov/catdir/enhancements/fy0617/2004045967-b.html http://www.loc.gov/catdir/enhancements/fy0617/2004045967-t.html.

—. To Take Place: Toward Theory in Ritual. Chicago: University of Chicago Press, 1987.

Snellgrove, David L. Indo-Tibetan Buddhism: Indian Buddhists and Their Tibetan Successors. Boston [New York]: Shambhala, 1987.

—. The Hevajra Tantra: A Critical Study. London: Oxford University Press, 1964.

Soymié, Michel. Catalogue Des Manuscrits Chinois de Touen-houang, Fonds Pelliot Chinois. Vol. 3. Paris: Bibliothèque nationale, 1983.

-. Catalogue Des Manuscrits Chinois de Touen-houang, Fonds Pelliot Chinois. Vol. 5. 
Paris: Bibliothèque nationale, 1995.

Soymié, Michel, and Françoise Wang-Toutain. Catalogue Des Manuscrits Chinois de Touenhouang, Fonds Pelliot Chinois. Vol. 4. Paris,: Bibliothèque nationale, 1991.

Stein, Aurel. "Illumination Subite Ou Saisie Simultanée. Note Sur La Terminologie Chinoise et Tibétaine.” Revue de L'histoire Des Religions 179, no. 1 (1971): 3-30.

- Serindia: Detailed Report of Explorations in Central Asia and Westernmost China Carried Out and Described Under the Orders of H. M. Indian Government. Oxford: Clarendon press, 1921.

_. "Sudden Illumination or Simultaneous Comprehension." In Sudden and Gradual: Approaches to Enlightenment in Chinese Thought, edited by Peter N. Gregory, 41-66. Honolulu: University of Hawaii Press, 1987.

—. "Tibetica Antiqua I." Bulletin de l'Ecole Française d'Extrême-Orient 72 (1983): 149_ 236.

- Une Chronique Ancienne de bSam-yas: sBa-bzed, Edition Du Texte Tibetaine et Résumé Francaise. Paris: Bibiotheque de 1'lnstitut des Hautes Etudes chinoises, Textes et Documents., 1961.

Takahashi, Kammie. "Lamps for the Mind: Illumination and Innovation in dPal Dbyangs's Mahayoga." University of Virginia, 2009.

Takeuchi, Tsuguhito, and Sentā Yunesuko Higashi Ajia Bunka Kenkyū. Old Tibetan Manuscripts from East Turkestan in the Stein Collection of the British Library. Vol. 1112. Tokyo, Japan :London: The Centre for East Asian Cultural Studies for Unesco, The Toyo Bunko ;British Library, 1997.

Tanaka, Kenneth K., and Raymond E Robertson. "A Ch'an Text from Tun-huang: Implications for Ch'an Influence on Tibetan Buddhism." In Tibetan Buddhism: Reason and Revelation, edited by Steven D. Goodman and Ronald M. Davidson, 57-78. SUNY Series in Buddhist Studies. Albany: State University of New York Press, 1992.

Tarthang Tulku. Lineage of the Diamond Light. Vol. 5. Crystal Mirror. Berkeley, Ca.: Dharma Publishing, 1991.

Tatz, Mark. "T'ang Dynasty Influences on the Early Spread of Buddhism in Tibet.” Tibet Journal 3, no. 2 (1978): 3-32.

Thakur, Laxman S. “A Tibetan Inscription by lHa Bla-ma Ye-shes-'od from dKor (sPu) Rediscovered." Journal of the Royal Asiatic Society 4, no. 03 (November 1994): 369-75.

Tsuda, Shinichi. "Classification of Tantras in dPal Brtsegs's 1Ta Ba i Rim Pa Bshad Pa and Its Problems." Journal of Indian and Buddhist Studies 13, no. 1 (1965): 397-402.

Tucci, Giuseppe. Minor Buddhist Texts. Parts One and Two. Delhi: Motilal Banarsidass, 1986. . The Religions of Tibet. Berkeley: University of California Press, 1980.

Twitchett, Denis. "Chinese Social History from the Seventh to the Tenth Centuries. The Tunhuang Documents and Their Implications.” Past \& Present, no. 35 (1966): 28-53.

Ueyama, Daishun. “The Study of Tibetan Ch'an Manuscripts Recovered from Tun-huang: A 
Review of the Field and Its Prospects." In Early Ch'an in China and Tibet, edited by Whalen Lai and Lewis R. Lancaster, Vol. 5. Berkeley Buddhist Studies Series. Berkeley: Lancaster Publications, 1983.

Ueyama, Daishun, Jeffrey Broughton, and Kenneth Eastman. “The Avikalpapraveśa-dhāran̄ī: The Dharani of Entering Non-Discrimination." $B B K, 1983,32-42$.

Uray, Géza. "The Old Tibetan Sources of the History of Central Asia up to 751 A.D.: a Survey." In Prolegomena to the Sources on the History of Pre-Islamic Central Asia, edited by J. Harmatta, 275-306. Budapest: Akadémiai Kiadó, 1979.

Van der Kuijp, Leonard. "Dating the Two Lde'u Chronicles of Buddhism in India and Tibet." Etudes Asiatiques: Revue de La Société Suisse - Asie 46 (1992).

"Miscellanea to a Recent Contribution On/to the Bsam-yas Debate." Kailash 11, no. 3-4 (1984): 149-84.

. "Tibetan Historiography." In Tibetan Literature : Studies in Genre, edited by Jose Cabezon and Roger Jackson, 1st USA. Studies in Indo-Tibetan Buddhism. Ithaca, N.Y.: Snow Lion, 1996.

Van Schaik, Sam. "A New Look at the Invention of the Tibetan Script." In Old Tibetan Documents Monograph Series, edited by Yoshiro Imaeda and Matthew Kapstein, III:4596. Tokyo: Tokyo University of Foreign Studies, 2011.

. "Did the Buddha Visit Khotan?" Early Tibet. Accessed March 28, 2014.

http://earlytibet.com/2013/06/07/did-the-buddha-visit-khotan/.

"Manuscript Numbers in the Stein Collection." Early Tibet, n.d. http://earlytibet.com/about/numbers/.

. "More Teachings of Heshang Moheyan (Tibetan Chan III)." Early Tibet, 2008. http://earlytibet.com/2008/06/10/tibetan-chan-iii-more-teachings-of-heshang-moheyan/.

. "Oral Teachings and Written Texts: Transmission and Transformation in Dunhuang." In Contributions to the Cultural History of Early Tibet, , edited by Matthew T. Kapstein and Brandon Dotson, 183-208. Leiden: EJ Brill, 2007.

. "The Early Days of the Great Perfection." Journal of the International Association of Buddhist Studies 27, no. 1 (2004): 165-206.

. "The Emperor's Chan (Tibetan Chan I)." Early Tibet, n.d.

http://earlytibet.com/2007/11/13/tibetan-chan-i-the-emperors-chan/.

. "The Great Debate (Tibetan Chan IV)." Early Tibet, 2010. http://earlytibet.com/2010/03/31/tibetan-chan-iv/.

. "The Great Perfection and the Chinese Monk: rNyingmapa Defences of Hwashang Mahāyāna in the Eighteenth Century." Buddhist Studies Review 20, no. 2 (2003): 189204.

. "The Resolution of the Simultaneous and Gradual Approaches to the Great Perfection in the Klong Chen Snying Thig." In Religion and Secular Culture in Tibet (Proceedings of the Ninth Seminar of the International Association for Tibetan Studies, edited by Henk Blezer, 309-20. Leiden: EJ Brill, 2002. 
. "The Teachings of Heshang Moheyan (Tibetan Chan II)," 2008.

http://earlytibet.com/2008/05/15/tibetan-chan-ii-the-teachings-of-heshang-moheyan/.

. "The Tibetan Dunhuang Manuscripts in China." Bulletin of the School of Oriental and African Studies 65, no. 1 (2002): 129-39.

_. "The Whereabouts of the Tibetan Manuscripts from Dunhuang." earlyTibet.com, n.d. http://earlytibet.com/about/whereabouts/.

Van Schaik, Sam. "A Definition of Mahāyoga: Sources from the Dunhuang Manuscripts." Tantric Studies 1 (2008): 45-88.

- Approaching the Great Perfection: Simultaneous and Gradual Approaches to Dzogchen Practice in the Longchen Nyingtig. Boston: Wisdom Publications, 2004.

- "Dzogchen, Chan and the Question of Influence." Revue d'Etudes Tibétaines 24 (October 2012): 5-20.

. "Manuscript Numbers in the Stein Collection." Early Tibet. Accessed May 12, 2014. http://earlytibet.com/about/numbers/.

—. "Red Faced Barbarians, Benign Despots and Drunken Masters: Khotan as a Mirror to Tibet." In Religions on the Silk Road, edited by Max Deeg. Lumbini: Lumbini International Research Institute, forthcoming.

. "The Limits of Transgression: The Samaya Vows of Mahâyoga." In Esoteric Buddhism at Dunhuang. Rites and Teachings for This Life and Beyond. Leiden: Brill, 2010. . "The Red-faced Men I: Warriors with Painted Faces.” Early Tibet. Accessed May 4, 2014. http://earlytibet.com/2007/09/18/red-faced-men/.

—. "The Sweet Sage and the Four Yogas: A Lost Mahāyoga Treatise from Dunhuang." Journal of the International Association of Tibetan Studies 4 (2008): 1-67.

-. The Tibetan Chan Manuscripts: A Complete Descriptive Catalogue of Tibetan Chan Texts in the Dunhuang Manuscript Collections. Vol. 1. Papers on Central Asia 41. Bloomington: Indiana University Press, n.d.

Van Schaik, Sam, and Jacob Dalton. "Where Chan and Tantra Meet: Buddhist Syncretism in Dunhuang." In The Silk Road: Trade, Travel, War and Faith, 61-71. London: British Library Press, 2004.

Van Schaik, Sam, and Kazushi Iwao. "Fragments of the Testament of Ba from Dunhuang." Journal of the American Oriental Society 128, no. 3 (2008): 477-88.

Vimalamitra. The Stages of Meditation. Translated by Lozang Jamspal. Ladakh: Ladakhratnashridpika, 2000.

Vitali, Roberto. Early Temples of Central Tibet. London: Serindia Publications, 1990. . The Kingdoms of Gu-ge Pu-hrang: According to Mgna'-ris Rgyal Rabs by Gu-ge Mkhan-chen Ngag-dbang-grags Pa. Dharamsala, India: Tho-lin dpal dpe med lhun gyis grub pa'i gtsug lag khan lo 1000 'khor ba'i rjes dran mdzad sgo'i go sgrig tshogs chun gis dpar skrun źus, 1996.

- "The Role of Clan Power in the Establishment of Religion (from the Kheng Log of the 
9-10 Century to the Instances of the dByil of La Stod and gNyos of Kha Rag)." In The Relationship Between Religion and State: (chos Srid Zung 'brel), in Traditional Tibet, edited by Christoph Cuppers. Nepal: Lumbini: Lumbini International Research Institute, n.d.

Von Rospatt, Alexander. "Remarks on the Bhāvanāmaȳ̄ Bhūmiḥ and Its Treatment of Practice." In The Foundation for Yoga Practitioners: The Buddhist Yogācārabhümi Treatise and Its Adaptation in India, East Asia, and Tibet, edited by Ulrich Timme Kragh, 312-29. Harvard Oriental Series 75. Cambridge: Harvard University Press, 2013.

Wallace, Alan. "The Buddhist Tradition of Samatha: Methods for Refining and Examining Consciousness." Journal of Consciousness Studies 6, no. 2-3 (1999): 175-87.

Walshe, Maurice. The Long Discourses of the Buddha: a Translation of the Dìgha Nikāya. The Teachings of the Buddha. Boston: Wisdom Publications, 1995.

Walter, Michael L. Buddhism and Empire: The Political and Religious Culture of Early Tibet. Leiden: Brill,, 2009.

Wangdu, Pasang, and Hildegard Diemberger. $\mathrm{dBa}$ 'Bzhed: The Royal Narrative Concerning the Bringing of the Buddha's Doctrine to Tibet. Verlag der Österreichischen Akademie der Wissenschaften, 2000.

Wedemeyer, Christian. "Review of Indian Esoteric Buddhism: A Social History of the Tantric Movement by Ronald Davidson." History of Religions 45, no. 4 (May 2006): 373-76.

Wedemeyer, Christian K. Making Sense of Tantric Buddhism: History, Semiology, and Transgression in the Indian Traditions. South Asia Across the Disciplines. New York: Columbia University Press, 2013.

Weinberger, Steven. "The Significance of Yoga Tantra and the Compendium of Principles (Tattvasamgraha Tantra) Within Tantric Buddhism in India and Tibet." University of Virginia, 2003.

Welter, Albert. The Linji Lu and the Creation of Chan Orthodoxy: The Development of Chan's Records of Sayings Literature. Oxford: Oxford University Press, 2008.

West, M. L. Textual Criticism and Editorial Technique Applicable to Greek and Latin Texts. Stuttgart: B. G. Teubner, 1973.

White, David Gordon. The Alchemical Body: Siddha Traditions in Medieval India. Chicago: University of Chicago Press, 1996.

White, Hayden. Tropics of Discourse: Essays in Cultural Criticism. Baltimore: Johns Hopkins University Press, 1985.

Whitfield, Susan. Aurel Stein on the Silk Road. Chicago: Serindia Publications, 2004. http:/www.loc.gov/catdir/toc/ecip0415/2004003976.html.

—. Life Along the Silk Road. Berkeley: University of California Press, 1999.

Whitfield, Susan, and Ursula Sims-Williams. The Silk Road: Trade, Travel, War and Faith. Chicago, IL: Serindia Publications, 2004.

Whitfield, Susan, and Frances Wood. Dunhuang and Turfan : Contents and Conservation of Ancient Documents from Central Asia. London: British Library, 1996. 
Wilkinson, Christopher. “The Mi Nub Rgyal Mtshan Nam Mkha' Che.” Revue d'Etudes Tibétaines 24 (October 2012): 21-80.

Yamaguchi, Zuihō. Sutain Shushu Chibetto-go Bunken Kaidai Mokuroku (A Catalogue of the Tibetan Manuscripts Collected by Sir Aurel Stein). Tokyo: The Toyo Bunko, 1977.

_. "The Fiction of King Dar-ma's Persecution of Buddhism." In Du Dunhuang Au Japon: Études Chinoises et Bouddhiques Offertes à Michel Soymié, 231-58. Geneva: Droz, 1996.

Young, Serinity. Courtesans and Tantric Consorts: Sexualities in Buddhist Narrative, Iconography and Ritual. New York and London: Routledge, 2004.

Zhmud, Leonid. "Revising Doxography: Hermann Diels and His Critics." Philologus, no. 145 (2001): 219-43. 